Energy Systems Environmental Restoration Program

\title{
Source Document for Waste Area Groupings at Oak Ridge National Laboratory, Oak Ridge, Tennessee
}

P. L. Osborne

A. J. Kuhaida, Jr.

Date Issued-September 1996

Prepared for

U.S. Department of Energy

Office of Environmental Management under budget and reporting code EW 20

Environmental Management Activities at OAK RIDGE NATIONAL LABORATORY

Oak Ridge, Tennessee 37831-6285

managed by

LOCKHEED MARTIN ENERGY SYSTEMS, INC.

for the

U.S. DEPARTMENT OF ENERGY

under contract DE-AC05-84OR21400 


\section{DISCLAIMER}

Portions of this document may be illegible in electronic image products. Images are produced from the best available original document. 


\section{DISCLAIMER}

This report was prepared as an account of work sponsored by an agency of the United States Government. Neither the United States Government nor any agency thereof, nor any of their employees, makes any warranty, express or implied, or assumes any legal liability or responsibility for the accuracy, completeness, or usefulness of any information, apparatus, product, or process disclosed, or represents that its use would not infringe privately owned rights. Reference herein to any specific commercial product, process, or service by trade name, trademark, manufacturer, or otherwise does not necessarily constitute or imply its endorsement, recommendation, or favoring by the United States Government or any agency thereof. The views and opinions of authors expressed herein do not necessarily state or reflect those of the United States Government or any agency thereof. 


\section{ACKNOWLEDGMENTS}

The authors wish to thank the following people for their contributions to the preparation of this document: D. M. Miller, D. M. Adams, and P. L. Lund. 


\section{PREFACE}

This Source Document for Waste Area Groupings at Oak Ridge National Laboratory, Oak Ridge, Tennessee, ORNL/ER-342, was prepared to facilitate reporting on Environmental Restoration (ER) Program activities at Oak Ridge National Laboratory (ORNL) as specified in the Oak Ridge Reservation (ORR) Federal Facility Agreement established between the U.S. Department of Energy, the U.S. Environmental Protection Agency, and the Tennessee Department of Environment and Conservation.

This work was performed under Work Breakdown Structure 1.4.12.6.3.01, "Program Management Support." This document provides historical and programmatic information necessary for the completion of Comprehensive Environmental Response, Compensation, and Liability Act and other documents developed for and pertaining to ER Program activities at ORNL. Specifically, it contains descriptions of the (1) regulatory requirements for the ORR ER Program, (2) ORR ER Program, (3) ORNL site history and characterization, and (4) history and characterization of Waste Area Groupings 1-20. These descriptions will be used as a project planning tool and resource for the economical and consistent development of future ER Program documents, including Federal Facility Agreement milestone documents. 


\section{CONTENTS}

ACKNOWLEDGMENTS $\ldots \ldots \ldots \ldots \ldots \ldots \ldots \ldots \ldots \ldots \ldots \ldots \ldots$

PREFACE $\ldots \ldots \ldots \ldots \ldots \ldots \ldots \ldots \ldots \ldots \ldots \ldots \ldots \ldots \ldots$

FIGURES $\ldots \ldots \ldots \ldots \ldots \ldots \ldots \ldots \ldots \ldots \ldots \ldots \ldots \ldots \ldots$

TABLES $\ldots \ldots \ldots \ldots \ldots \ldots \ldots \ldots \ldots \ldots \ldots \ldots \ldots \ldots \ldots \ldots \ldots \ldots \ldots \ldots$

ABBREVIATIONS $\ldots \ldots \ldots \ldots \ldots \ldots \ldots \ldots \ldots \ldots \ldots \ldots \ldots \ldots \ldots$

EXECUTIVE SUMMARY $\ldots \ldots \ldots \ldots \ldots \ldots \ldots \ldots \ldots \ldots \ldots \ldots \ldots \ldots$

1. INTRODUCTION ......................... 1-1

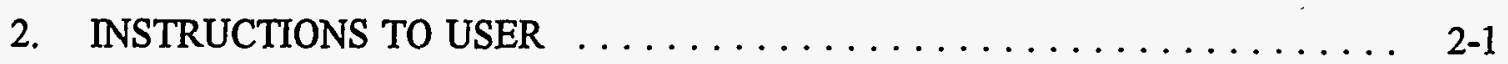

3. REGULATORY INITIATTVE . . . . . . . . . . . . . . $3-1$

3.1 FEDERAL FACILITY AGREEMENT

DESCRIPTION AND GOALS . . . . . . . . . . . . . . . 3-1

3.2 CONSOLIDATION OF REGULATORY INTERACTION . . . . . . . . 3-1

3.2.1 Resource Conservation and Recovery Act

Integration Into CERCLA . . . . . . . . . . . . . 3-1

3.2.2 National Environmental Policy Act

Integration with the CERCLA Process $\ldots \ldots \ldots \ldots \ldots \ldots . . .6$

3.2.3 National Oil and Hazardous Substances Pollution

Contingency Plan Integration with CERCLA . . . . . . . 3-3

3.2.4 National Resource Damage Assessment

Implementation During the CERCLA Process . . . . . . . . . 3-4

3.2.5 Incorporation of ARARs into the CERCLA Process . . . . . . . . 3-4

4. OAK RIDGE RESERVATION ENVIRONMENTAL RESTORATION

PROGRAM DESCRIPTION . . . . . . . . . . . . . . . . . . . . . 4-1

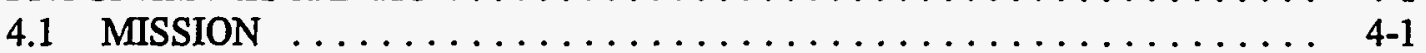

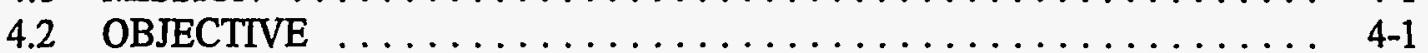

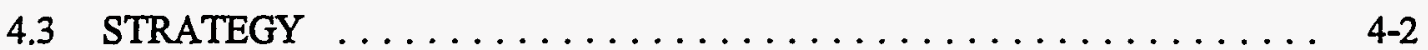

4.4 PROJECT MANAGEMENT $\ldots \ldots \ldots \ldots \ldots \ldots \ldots \ldots \ldots \ldots \ldots$. 4 .2

4.4.1 Roles and Responsibilities . . . . . . . . . . . . . . 4-2

4.4 .2 Contractors $\ldots \ldots \ldots \ldots \ldots \ldots \ldots \ldots \ldots \ldots \ldots . \ldots \ldots$ 4-2

5. HISTORY AND CHARACTERIZATION OF THE ORNL SITE $\ldots \ldots \ldots \ldots \ldots$. . .

5.1 SITE DESCRIPTION AND HISTORY . . . . . . . . . . . . . 5-1

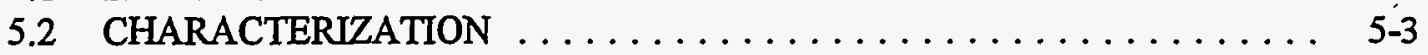

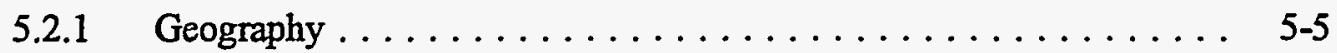

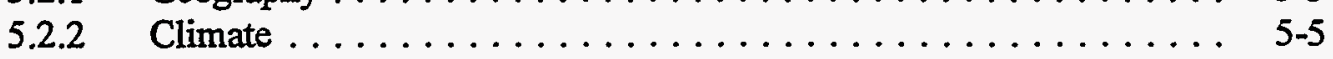

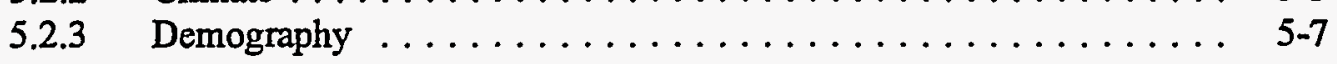

vii 
5.2.4 Geology and Soils $\ldots \ldots \ldots \ldots \ldots \ldots \ldots \ldots \ldots \ldots$ 5-8

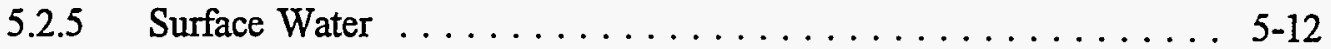

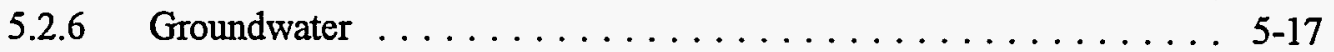

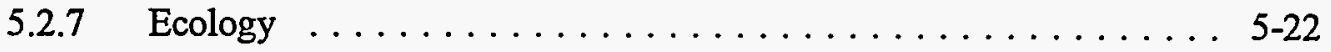

5.3 ACTIVE SITE-WIDE PROJECTS $\ldots \ldots \ldots \ldots \ldots \ldots \ldots \ldots \ldots$. . . . . . . . .

5.3.1 Surface Water Program . . . . . . . . . . . . . . . . . . 5-24

5.3.2 Groundwater Watershed . . . . . . . . . . . . . . . 5-25

5.3.3 White Oak Creek Watershed Project . . . . . . . . . . . . . . 5-27

5.4 ORNL SITE SUMMARY $\ldots \ldots \ldots \ldots \ldots \ldots \ldots \ldots \ldots \ldots \ldots \ldots \ldots$

5.5 REFERENCES . . . . . . . . . . . . . . . . . . . . . . 5-28

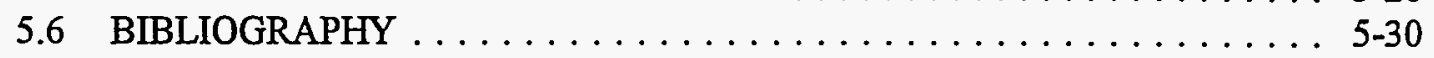

6. HISTORY AND CHARACTERIZATION OF WAG $1 \ldots \ldots \ldots \ldots \ldots$. $\ldots$. $\ldots$

6.1 SITE DESCRIPTION AND HISTORY $\ldots \ldots \ldots \ldots \ldots \ldots \ldots \ldots$ 6 $\ldots \ldots \ldots$

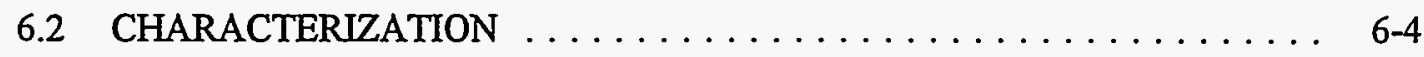

6.2 .1 Geography ...................... 6 .

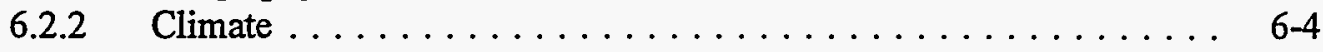

6.2 .3 Demography ...................... 6.4

6.2 .4 Geology and Soils .................... $6-4$

6.2 .5 Surface Water . . . . . . . . . . . . . . . . . . 6-9

6.2 .6 Groundwater . . . . . . . . . . . . . . . . .

6.2 .7 Ecology . . . . . . . . . . . . . . . . . 6-27

6.3 RELEASES AND SITE CONCEPTUAL MODEL . . . . . . . . . . . . 6-27

6.3.1 Site Conceptual Model . . . . . . . . . . . . . . . . . 6-27

6.3.2 Fate and Transport ....................... . 6-29

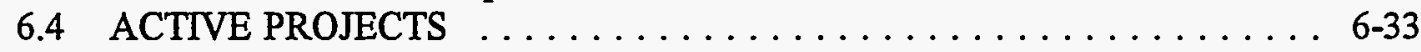

6.4.1 Gunite and Associated Tanks . . . . . . . . . . . . . . 6-33

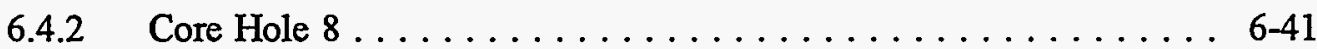

6.4.3 WAG 1 Groundwater Characterization Area . . . . . . . . . . 6-43

6.4 .4 Surface Impoundments $\ldots \ldots \ldots \ldots \ldots \ldots \ldots . \ldots \ldots 67$

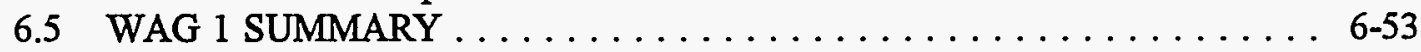

6.6 REFERENCES . . . . . . . . . . . . . . . . . . 6 6-54

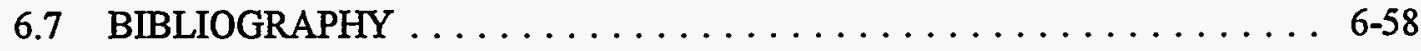

7. HISTORY AND CHARACTERIZATION OF WAG $2 \ldots \ldots \ldots \ldots \ldots \ldots$

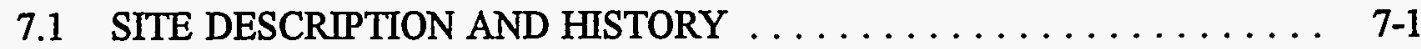

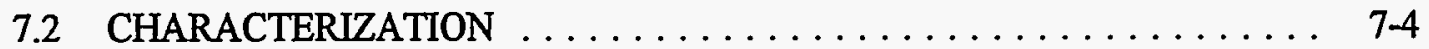

7.2 .1 Geography ...................... 7.4

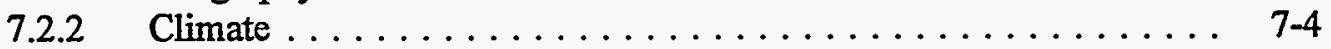

7.2 .3 Demography ..................... 7-5

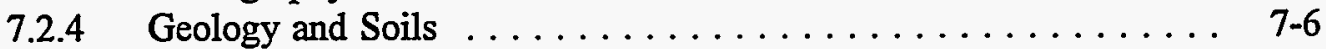

7.2 .5 Surface Water $\ldots \ldots \ldots \ldots \ldots \ldots \ldots \ldots \ldots \ldots \ldots \ldots . \ldots \ldots$

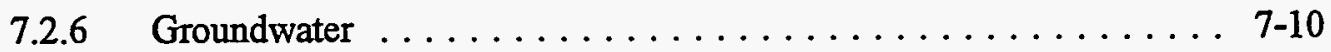

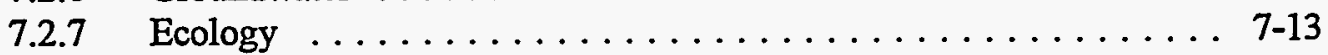

7.3 RELEASES AND SITE CONCEPTUAL MODEL . . . . . . . . . . 7-14

7.3.1 Contaminant Releases to the WOC System . . . . . . . . . . 7-14

7.3.2 Contaminant Releases from the WOC System ... . . . . . . . 7-14

7.3.3 Conceptual Model . . . . . . . . . . . . . . . 7-17

viii 


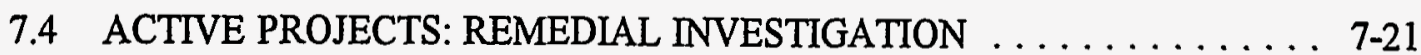

7.4.1 Strategy and Approach of the WAG 2 RI Project ......... 7-21

7.4.2 Consolidation of the WAG $2 \mathrm{RI}$ with the Site Investigations Program ................. 7-22

7.4.3 Initial Studies Conducted by the WAG 2 RI $\ldots \ldots \ldots \ldots \ldots$ 7-22

7.4.4 WAG 2 Phase I Data Quality Objectives Workshop ....... 7-22

7.4.5 Initiation of the ORNL Surface Water Program $\ldots \ldots \ldots \ldots \ldots$ 7-23

7.4.6 Annual Environmental Restoration Monitoring and Assessment Report $\ldots \ldots \ldots \ldots \ldots \ldots \ldots \ldots \ldots$. $7-24$

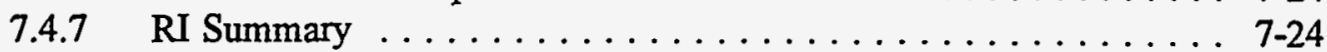

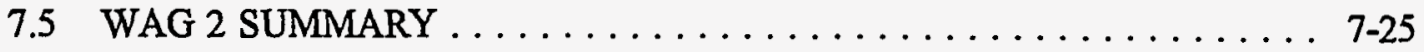

7.6 REFERENCES .......................... $7-26$

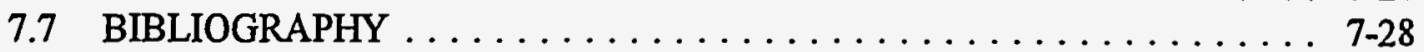

8. DESCRIPTION OF WAG $3 \ldots \ldots \ldots \ldots \ldots \ldots \ldots \ldots \ldots \ldots \ldots \ldots$.

8.1 SITE DESCRIPTION $\ldots \ldots \ldots \ldots \ldots \ldots \ldots \ldots \ldots \ldots \ldots \ldots$ 8-1

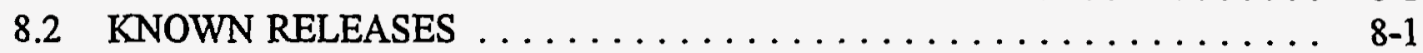

8.3 REGULATORY STATUS $\ldots \ldots \ldots \ldots \ldots \ldots \ldots \ldots \ldots \ldots \ldots$

8.4 REFERENCES . . . . . . . . . . . . . . .

8.5 BIBLIOGRAPHY $\ldots \ldots \ldots \ldots \ldots \ldots \ldots \ldots \ldots \ldots \ldots, 8 \ldots \ldots$

9. HISTORY AND CHARACTERIZATION OF WAG $4 \ldots \ldots \ldots \ldots \ldots \ldots$ 9-1

9.1 SITE DESCRIPTION AND HISTORY $\ldots \ldots \ldots \ldots \ldots \ldots \ldots \ldots$ 9-1

9.1.1 SWMU 4.1-ILLW Pipelines $\ldots \ldots \ldots \ldots \ldots \ldots \ldots \ldots$ 9-1

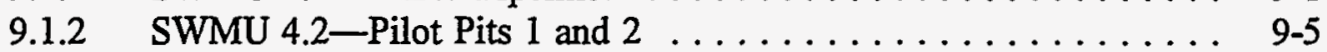

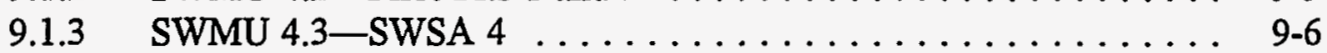

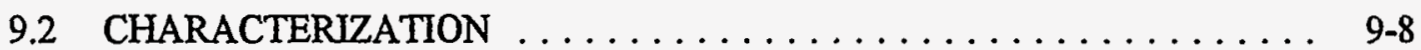

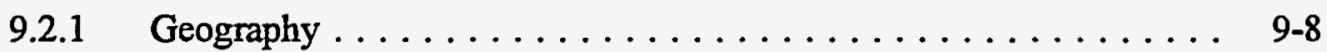

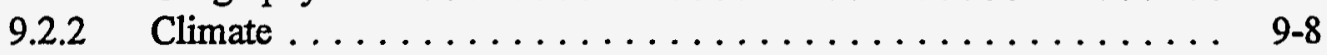

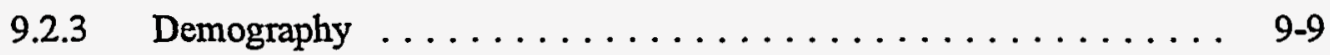

9.2 .4 Geology and Soils $\ldots \ldots \ldots \ldots \ldots \ldots \ldots \ldots \ldots \ldots$ 9-9

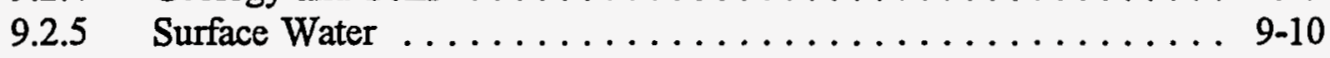

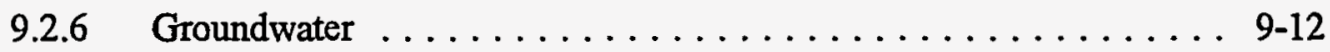

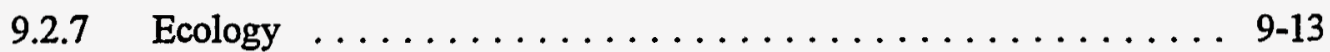

9.3 RELEASES AND SITE CONCEPTUAL MODEL $\ldots \ldots \ldots \ldots \ldots \ldots 9-13$

9.3.1 Known Releases from WAG $4 \ldots \ldots \ldots \ldots \ldots \ldots \ldots \ldots$ 9-13

9.3.2 Site Conceptual Model $\ldots \ldots \ldots \ldots \ldots \ldots \ldots \ldots \ldots . \ldots . \ldots . \ldots .14$

9.4 ACTIVE PROJECTS: SEEPS $\ldots \ldots \ldots \ldots \ldots \ldots \ldots \ldots \ldots \ldots .9 .17$

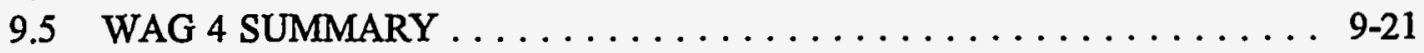

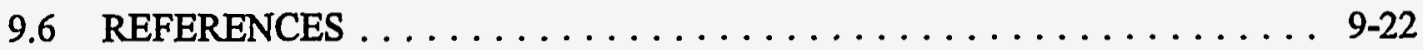

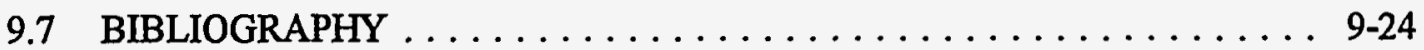

10. HISTORY AND CHARACTERIZATION OF WAG $5 \ldots \ldots \ldots \ldots \ldots \ldots$ 10-1

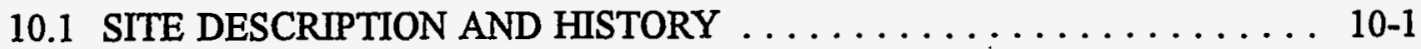

10.1.1 LLW Lines and Leak Sites (SWMU 5.1) . . . . . . . . 10-3

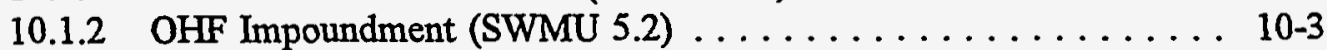

10.1.3 OHF Site Surface Facilities (SWMU 5.3) $\ldots \ldots \ldots \ldots \ldots \ldots$ 10-5

10.1.4 NHF Site Surface Facilities (SWMU 5.4) $\ldots \ldots \ldots \ldots \ldots$ 10-5 
10.1.5 Inactive OHF Waste Storage Tanks (SWMU 5.5a-e) . . . . . . 10-5

10.1.6 Process Waste Sludge Basin (SWMU 5.6) . . . . . . . . . . . 10 10

10.1.7 SWSA 5 South (SWMU 5.7) . . . . . . . . . . . . . 10-6

10.1.8 Active LLW Concentrate Storage Tanks (SWMU 5.8) . . . . . . 10-6

10.1.9 Radioactively Contaminated Waste Oil Storage

Tank 7860A (SWMU 5.9) . . . . . . . . . . . . . . . . 10-8

10.1.10 SWSA 5 North-TRU Waste Storage Area (SWMU 5.10) . . . . 10 10-8

10.1.11 Septic Tank 7831 (SWMU 5.11) . . . . . . . . . . . . . . . . 10-10

10.1.12 NHF Septic Tank 7860 (SWMU 5.12) . . . . . . . . . 10-10

10.1.13 OHF Septic Tank 7853 (SWMU 5.13) . . . . . . . . . . . . 10-10

10.1.14 Old Landfill (at NE Edge of SWSA 5) (SWMU 5.14) . . . . . . 10-10

10.1.15 Active LLLW Slotting Tank T-13 (SWMU 5.15) . . . . . . . . . 10-11

10.1.16 Inactive LLLW Tank T-14 (SWMU 5.16) . . . . . . . . . 10-11

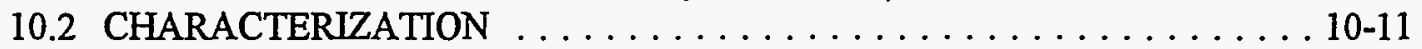

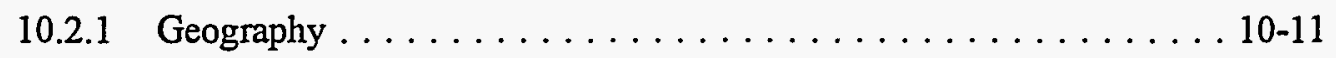

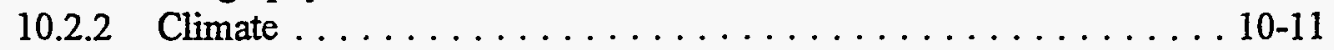

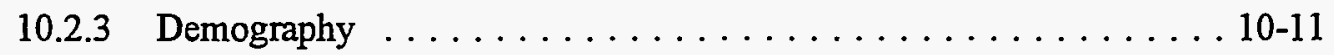

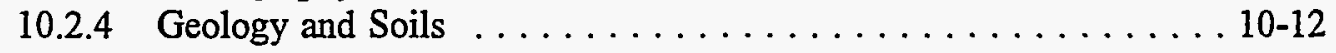

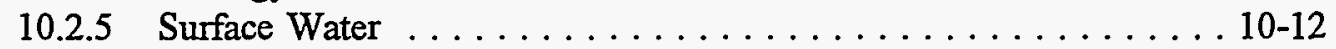

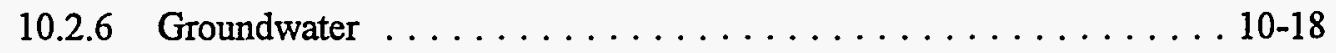

10.2.7 Ecology . . . . . . . . . . . . . . . . . 10-20

10.3 RELEASES AND SITE CONCEPTUAL MODEL . . . . . . . . . 10-20

10.3.1 Releases . . . . . . . . . . . . . . . . . . . . . . 10-20

10.3.2 Site Conceptual Model . . . . . . . . . . . . . . . . 10-21

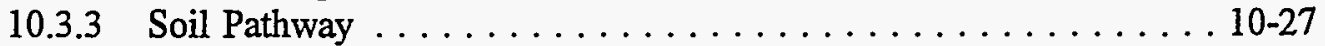

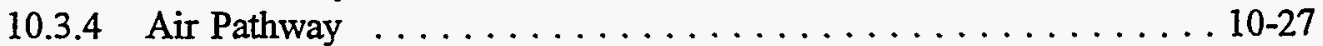

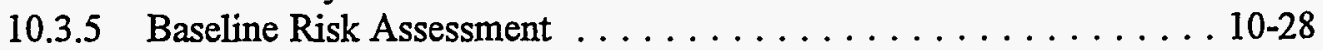

10.4 ACTIVE PROJECTS . . . . . . . . . . . . . . . . . . . . 10-28

10.4.1 Remedial Investigation . . . . . . . . . . . . . . . 10-29

10.4.2 Seeps $\mathrm{C}$ and D Removal Action . . . . . . . . . . . . 10-31

10.4.3 OHF Inactive Tank Contents Removal Project . . . . . . . . 10-32

10.5 WAG 5 SUMMARY . . . . . . . . . . . . . . . . . . . 10-34

10.6 REFERENCES . . . . . . . . . . . . . . . . . . . . . 10-36

10.7 BIBLIOGRAPHY . . . . . . . . . . . . . . . . . . 10-39

11. HISTORY AND CHARACTERIZATION OF WAG $6 \ldots \ldots \ldots \ldots \ldots \ldots$

11.1 SITE DESCRIPTION AND HISTORY $\ldots \ldots \ldots \ldots \ldots \ldots \ldots \ldots \ldots \ldots . \ldots \ldots \ldots$

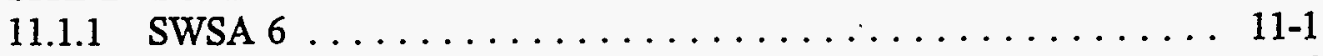

11.1.2 Explosives Detonation Trench ............... 11-6

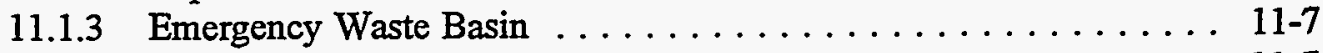

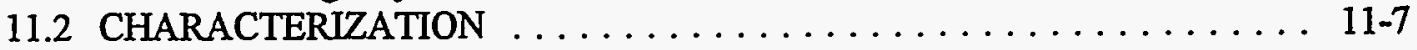

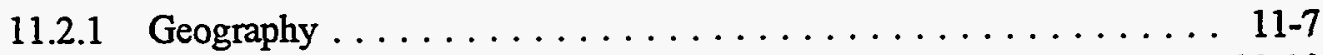

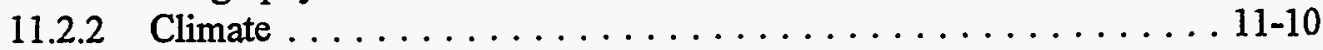

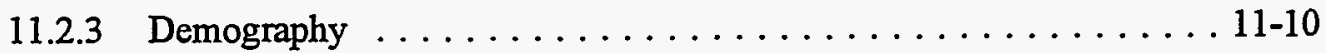

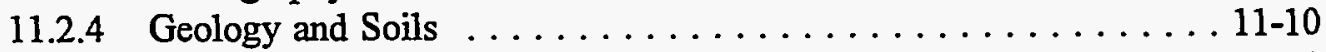

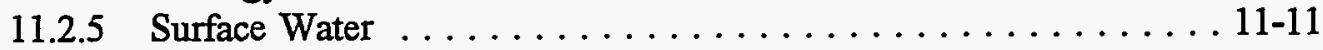

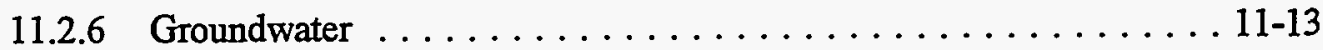

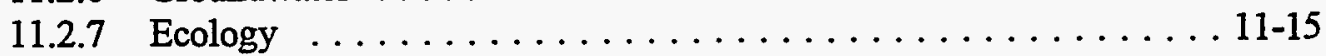


11.3 RELEASES AND SITE CONCEPTUAL MODEL $\ldots \ldots \ldots \ldots \ldots \ldots \ldots$ 11-16

11.3.1 Nature and Extent of Contamination . . . . . . . . . . . . 11-16

11.3.2 Contaminant Fate and Transport . . . . . . . . . . . . . 11-18

11.3.3 Baseline Risk Assessment ... . . . . . . . . . . . . . . 11-18

11.4 ACTIVE PROJECTS . . . . . . . . . . . . . . . . 11-23

11.4.1 Environmental Monitoring Program . . . . . . . . . . . 11-23

11.4.2 Tumulus Disposal Demonstration Project . . . . . . . . . . . 11-24

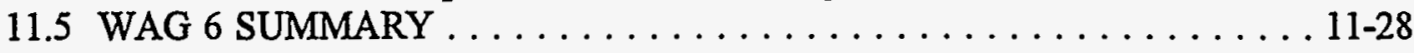

11.6 REFERENCES . . . . . . . . . . . . . . . . . . . . . 11-29

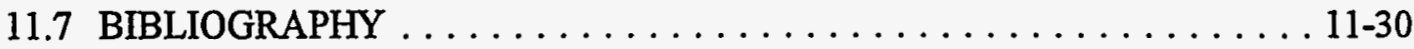

12. HISTORY AND CHARACTERIZATION OF WAG $7 \ldots \ldots \ldots \ldots \ldots \ldots$ 12-1

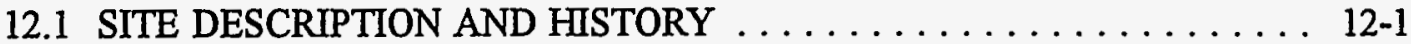

12.1.1 SWMU 7.1-Building 7819 Decontamination Facility . . . . . . . 12-4

12.1.2 SWMU 7.2-Homogeneous Reactor Experiment Fuel Wells . . . . 12-4

12.1.3 SWMU 7.3-Hydrofracture Experimental Site 1

Soil Contamination . . . . . . . . . . . . . . . 12-4

12.1.4 SWMU 7.4a-f-ILLW Line Leak Sites . . . . . . . . . . . . 12-4

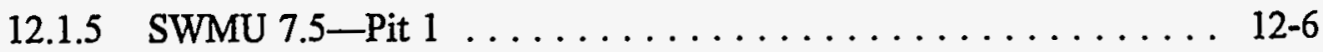

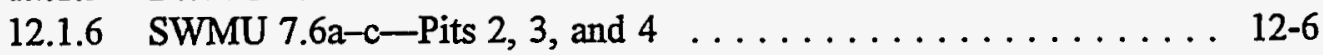

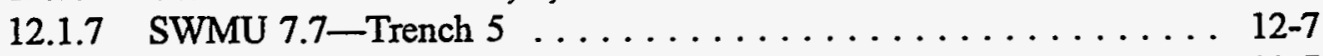

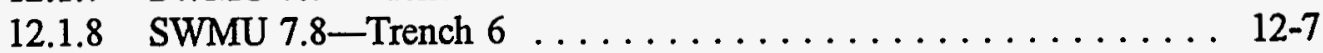

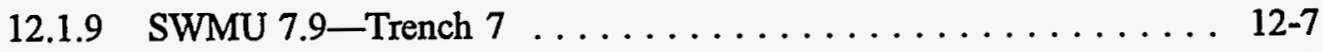

12.1.10 SWMU 7.10a-e-Shielded Transfer Tanks . . . . . . . . . 12-8

12.1.11 SWMU 7.11-Building 7819 Septic Tank . . . . . . . . . 12-8

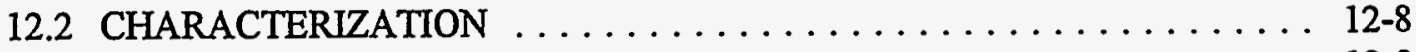

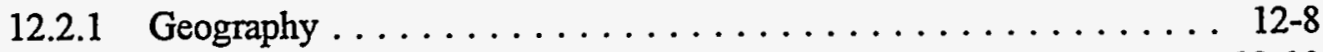

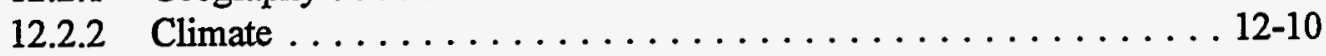

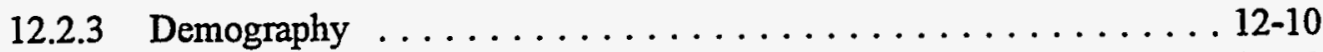

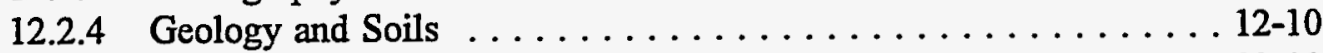

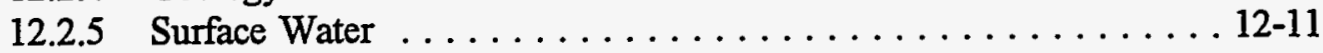

12.2 .6 Groundwater . . . . . . . . . . . . . . . . . . . 12-13

12.2 .7 Ecology . . . . . . . . . . . . . . . . . . . $12-15$

12.3 RELEASES AND SITE CONCEPTUAL MODEL $\ldots \ldots \ldots \ldots \ldots \ldots$ 12-15

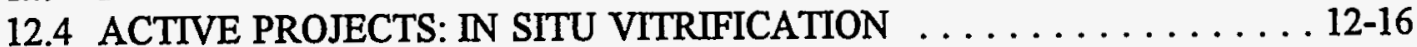

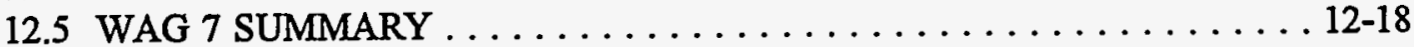

12.6 REFERENCES . . . . . . . . . . . . . . . . . . . . . 12-20

12.7 BIBLIOGRAPHY . . . . . . . . . . . . . . . . . 12-22

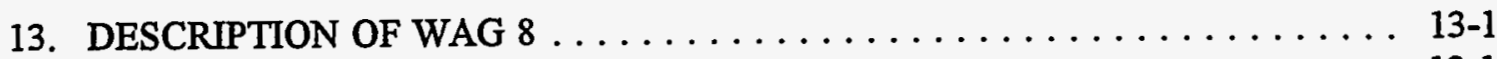

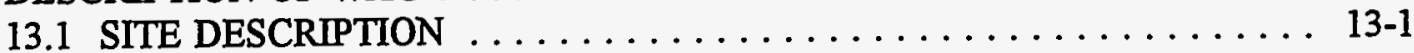

13.2 KNOWN RELEASES . . . . . . . . . . . . . . . . . 13-1

13.3 REGULATORY STATUS . . . . . . . . . . . . . . . . 13-1

13.4 REFERENCES . . . . . . . . . . . . . . . . . . . . 13-4

13.5 BIBLIOGRAPHY . . . . . . . . . . . . . . . 13-4 


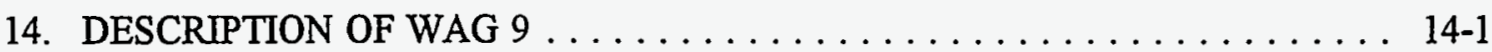

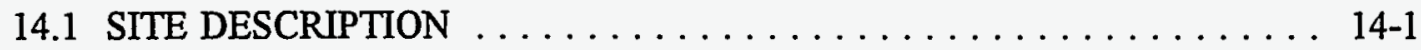

14.2 KNOWN RELEASES . . . . . . . . . . . . . . . . . 14-1

14.3 REGULATORY STATUS . . . . . . . . . . . . . . . . 14-1

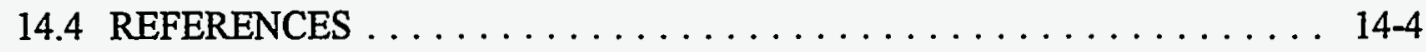

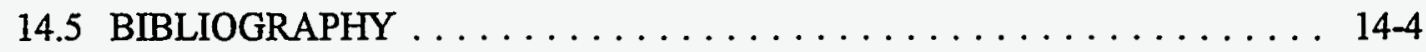

15. HISTORY AND CHARACTERIZATION OF WAG $10 \ldots \ldots \ldots \ldots \ldots \ldots \ldots$

15.1 SITE DESCRIPTION AND HISTORY . . . . . . . . . . . . 15-1

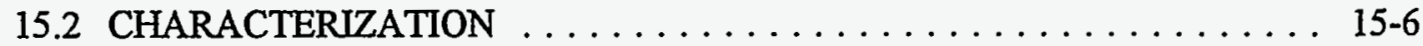

15.2 .1 Geography . . . . . . . . . . . . . . . . 15-6

15.2 .2 Climate . . . . . . . . . . . . . . . . . . 15-7

15.2 .3 Demography . . . . . . . . . . . . . . . 15-7

15.2 .4 Geology . . . . . . . . . . . . . . . . . . . . . . 15-7

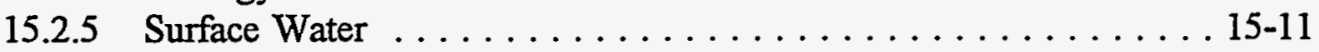

15.2.6 Groundwater . . . . . . . . . . . . . . . . . . . . 15-11

15.2.7 Ecology . . . . . . . . . . . . . . . . . 15-11

15.3 RELEASES AND SITE CONCEPTUAL MODEL . . . . . . . . . . 15-11

15.4 ACTIVE PROJECTS: HYDROFRACTURE WELLS

AND BOREHOLES PLUGGING AND ABANDONMENT . . . . . . 15-12

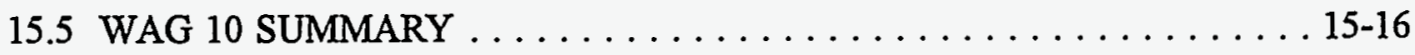

15.6 REFERENCES . . . . . . . . . . . . . . . . . . . 15-17

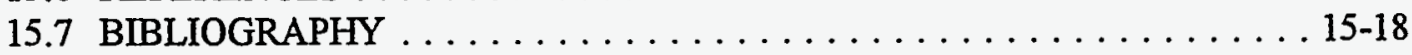

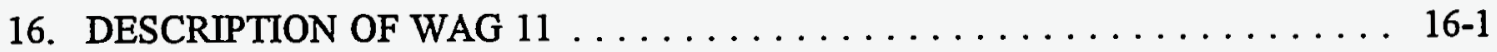

16.1 SITE DESCRIPTION $\ldots \ldots \ldots \ldots \ldots \ldots \ldots \ldots \ldots \ldots \ldots \ldots \ldots$. . . . . . . . . . . . . .

16.2 KNOWN RELEASES . . . . . . . . . . . . . . . . . . . . . 16-1

16.3 REGULATORY STATUS . . . . . . . . . . . . . . . . 16-4

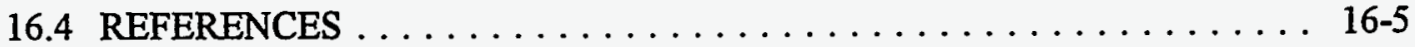

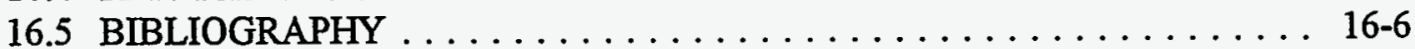

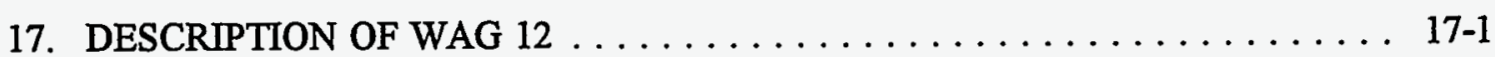

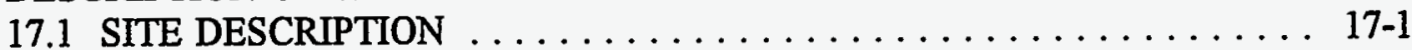

17.2 KNOWN RELEASES . . . . . . . . . . . . . . . . . 17-1

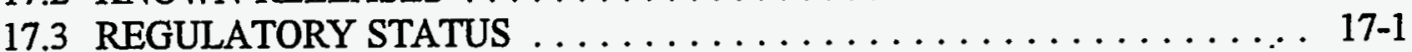

17.4 REFERENCES . . . . . . . . . . . . . . . . . . . 17-4

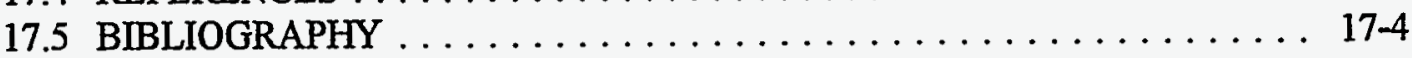

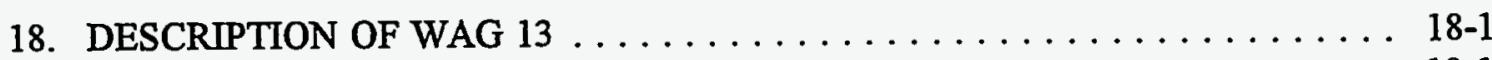

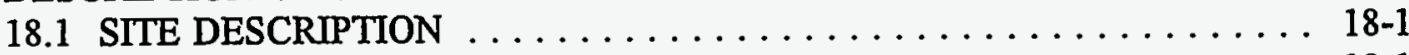

18.2 KNOWN RELEASES . . . . . . . . . . . . . . . . 18-1

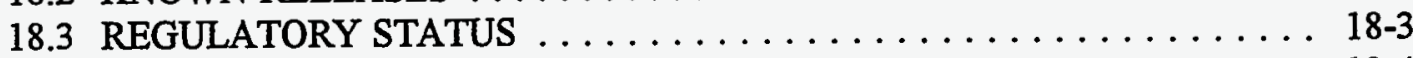

18.4 REFERENCES . . . . . . . . . . . . . . . . . . . . 18-4

18.5 BIBLIOGRAPHY . . . . . . . . . . . . . . . . 18-4

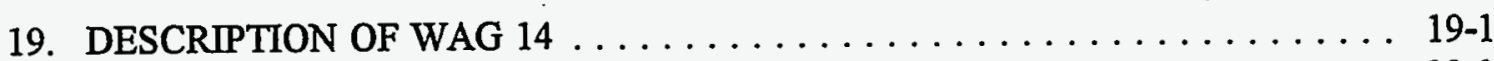

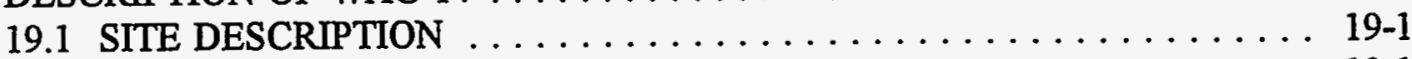

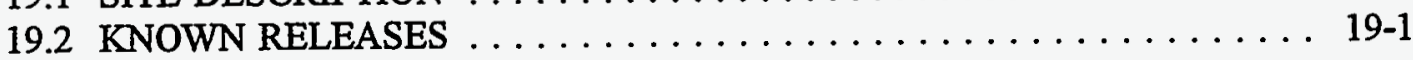




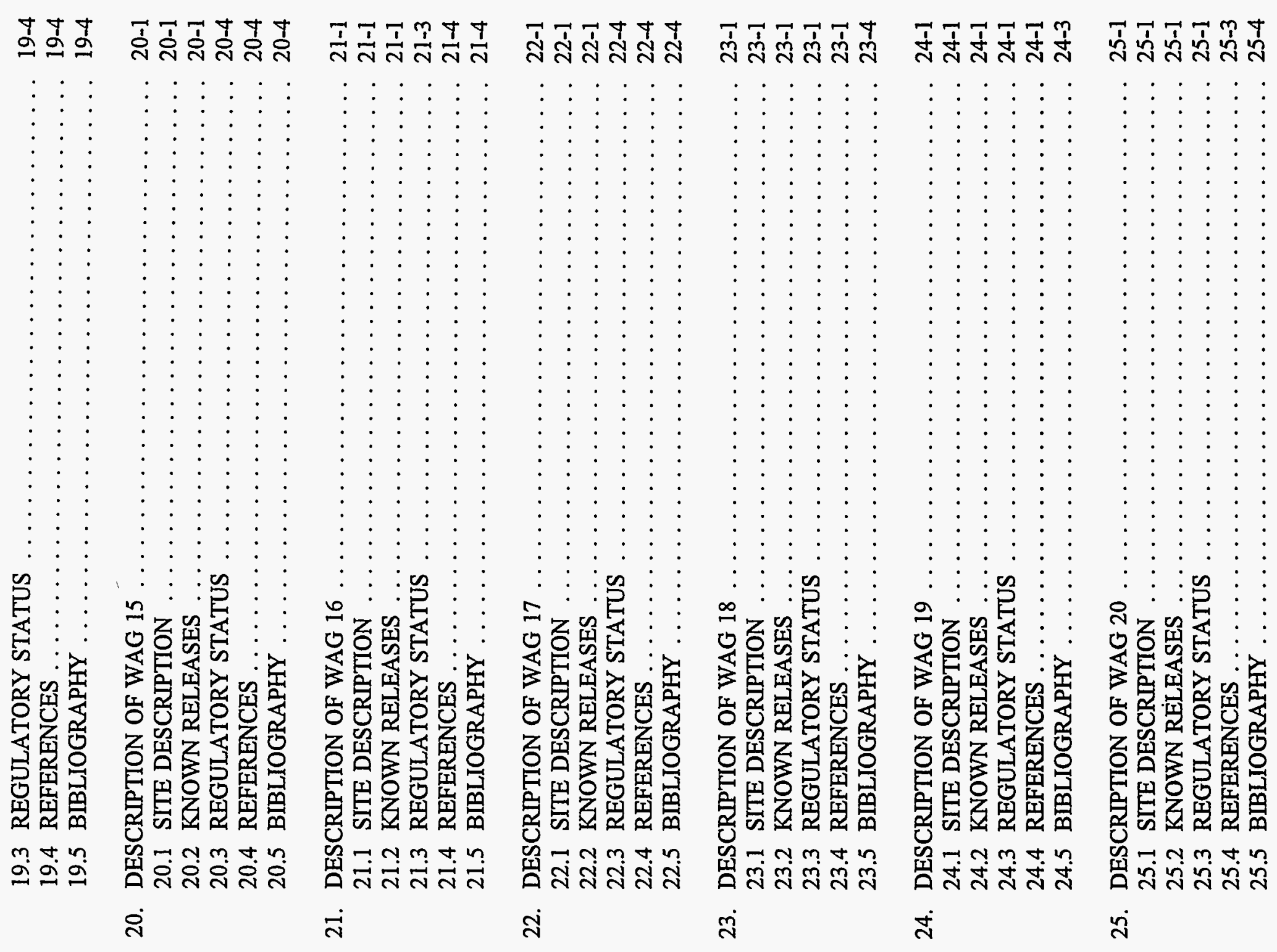




\section{FIGURES}

$5.1 \quad$ Location of Oak Ridge National Laboratory $\ldots \ldots \ldots \ldots \ldots \ldots \ldots \ldots . \ldots . \ldots . \ldots$

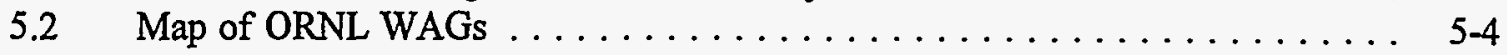

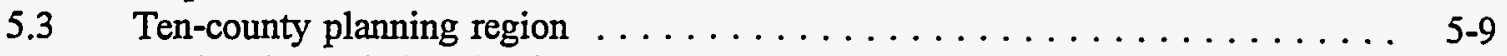

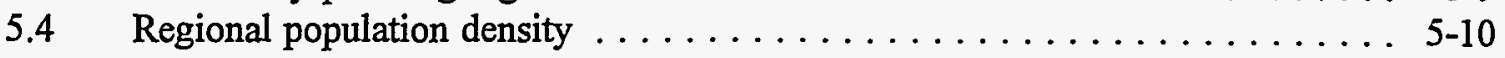

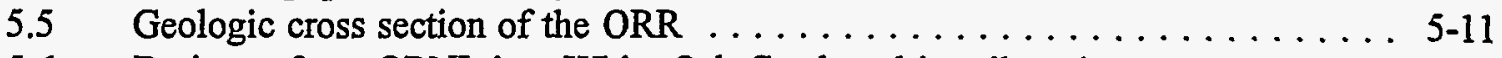

5.6 Drainage from ORNL into White Oak Creek and its tributaries . . . . . . . 5-13

5.7 Conceptual hydrologic model for subsurface flow in shale aquitard at ORR .. 5-15

5.8 Conceptual model for tributaries draining ORNL waste sites . . . . . . . . 5-16

5.9 Schematic vertical relationships of flow zones of the ORR and their

estimated thicknesses . . . . . . . . . . . . . . . . . . . 5-19

5.10 Schematic cross section showing very generalized flow paths, related geochemical evolution, and relative flow rates $\ldots \ldots \ldots \ldots . \ldots \ldots$ 5-21

5.11 Map of the ORNL Groundwater Watershed, which is divided into Bethel Valley and Melton Valley units . . . . . . . . . . . . . 5-26

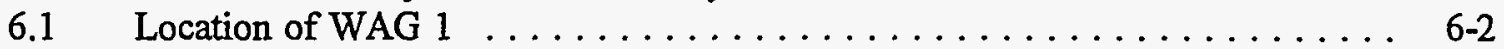

6.2 Geologic cross-section beneath WAG 1 through ORR ............ $6-5$

6.3 Geologic map of the ORNL area . . . . . . . . . . . . . . . . $6-6$

6.4 Geologic cross-section through the main plant area . . . . . . . . . . 6-7

6.5 Surface soil sampling sites within WAG $1 \ldots \ldots \ldots \ldots \ldots \ldots \ldots$

6.6 Location map of ORNL streams . . . . . . . . . . . . . 6-10

6.7 Locations of previous studies and available data of groundwater,

soil, surface water, and sediments . . . . . . . . . . . . .

6.8 Correlation of Stockdale's (1951) unit designations with formal

formation names for Chickamauga Group rocks : . . . . . . . . . . . 6-14

6.9 Overview of radiological contamination in groundwater at WAG $1 \ldots \ldots$. . . 6-19

6.10 Locations of buildings or other facilities associated with groundwater

contamination within WAG $1 \ldots \ldots \ldots \ldots \ldots \ldots . \ldots \ldots$ 6-21

6.11 Locations of $\mathrm{CHO08}$ and Core Hole 8 plume . . . . . . . . . . . . . 6-23

6.12 Locations of contamination in the westem portion of WAG 1

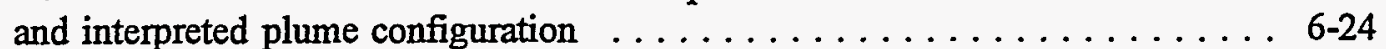

6.13 Facilities in GAAT . . . . . . . . . . . . . . . . . . . . .

6.14 Core Hole 8 plume intercept and transfer system design . . . . . . . . . . 6-42

6.15 Stratabound groundwater flow at WAG $1 \ldots \ldots \ldots \ldots \ldots \ldots . \ldots . \ldots . \ldots 6$

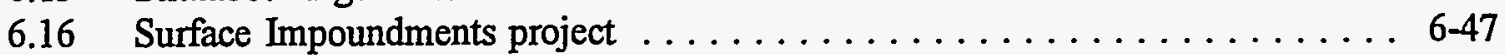

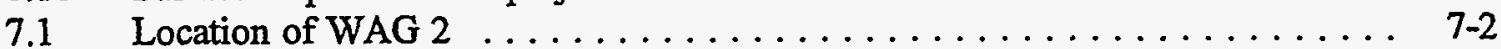

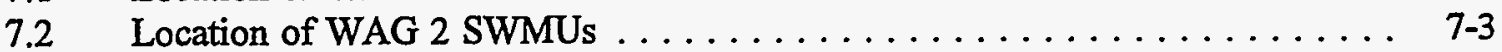

7.3 Map showing the WOC watershed boundaries ............. $7-5$

7.4 Strike-perpendicular geologic cross-section through SWSA 6 and WOL . . . . 7-6

7.5 WOC watershed soils classified according to hydrologic groups (HSGs) $\ldots$. 7.8

7.6 Section showing subsurface zones and direction of groundwater flow ..... $7-11$

7.7 A conceptual model showing differences in the trends and densities of open fractures to explain anisotrophy in the groundwater zone of Melton Valley ... 7-13

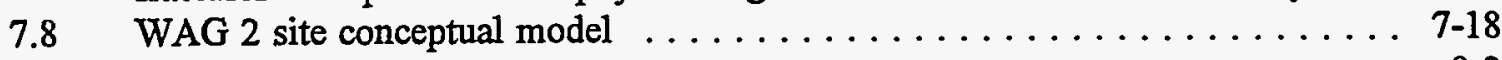

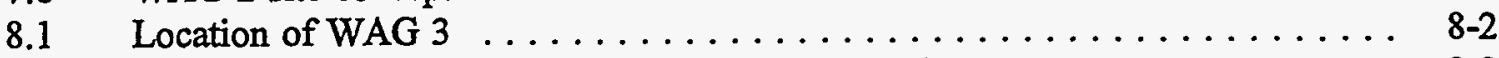

8.2 Location of WAG 3 Solid Waste Management Units .............. 8-3 


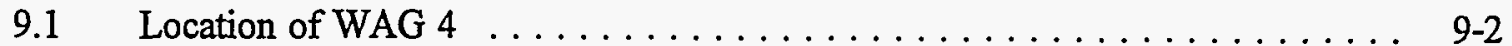

9.2 Location of SWMUs within WAG $4 \ldots \ldots \ldots \ldots \ldots \ldots \ldots \ldots$

9.3 Details of the ILLW transfer pipelines route $\ldots \ldots \ldots \ldots \ldots \ldots \ldots \ldots \ldots$

$9.4 \quad$ SWSA 4 site map . . . . . . . . . . . . . . . . . . . . . . . $9-7$

9.5 Map showing the WOC watershed boundaries . . . . . . . . . . . 9-11

9.6 Seep collection system locations and summary of WAG $4{ }^{90} \mathrm{Sr}$ investigation ... 9-15

9.7 WAG 4 bathtubbing trench conceptual model . . . . . . . . . . . 9-16

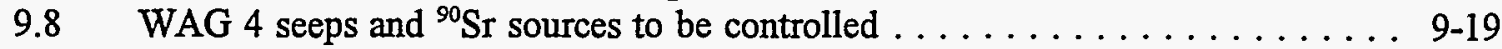

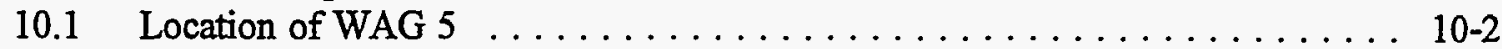

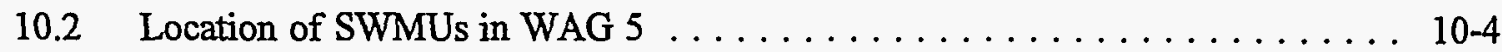

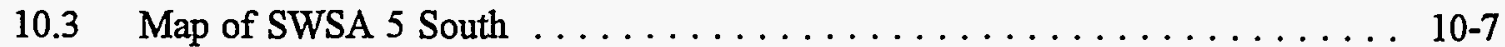

10.4 Map of SWSA 5 North . . . . . . . . . . . . . . . . 10 .

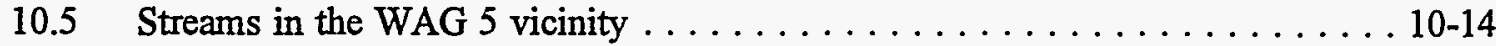

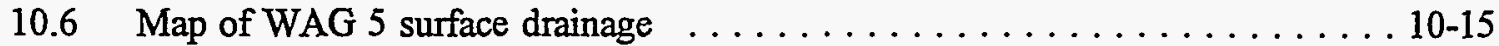

10.7 Diagram of groundwater and radionuclide contaminant

movement from a hypothetical trench to the surface environment . . . . . . . 10-16

10.8 WAG 5 site conceptual model . . . . . . . . . . . . . . . . . . . . 10-22

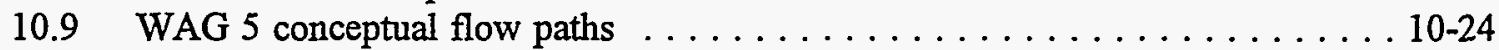

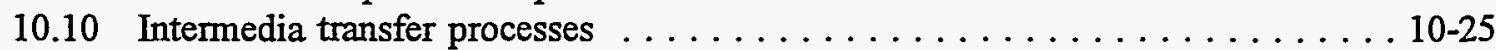

10.11 Sampling locations in Melton Branch and location of Seep Areas C and D . . . 10-31

10.12 Location of tanks T-1, T-2, T-3, T-4, and T-9 at OHF in WAG $5 \ldots \ldots$ 10-34

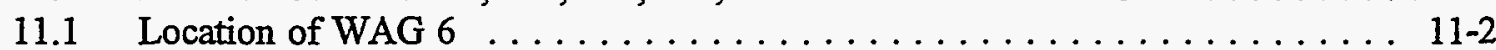

11.2 Location of WAG 6 Solid Waste Management Units . . . . . . . . . . . . . 11-3

11.3 WAG 6 solvent auger hole and biological trench areas . . . . . . . . . . 11-4

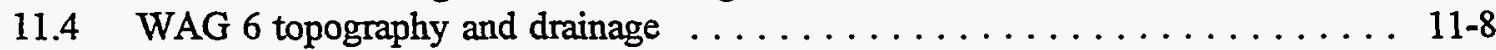

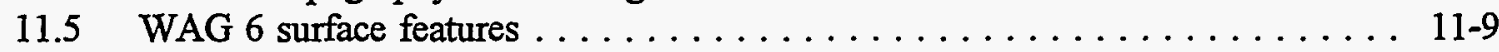

11.6 White Oak Creek basin . . . . . . . . . . . . . . . . . . . . 11-12

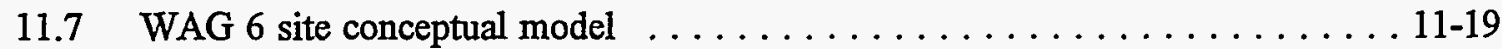

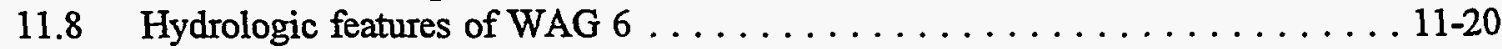

11.9 Conceptual drawing of a tumulus structure showing its major

components and primary water pathways under expected conditions $(P, R, I)$

and under the condition of cap leakage $(\mathrm{L}) \ldots \ldots \ldots \ldots \ldots \ldots \ldots \ldots \ldots \ldots 11-25$

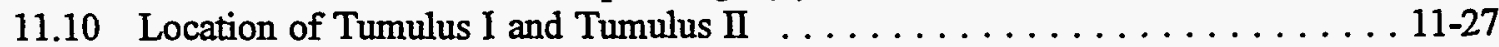

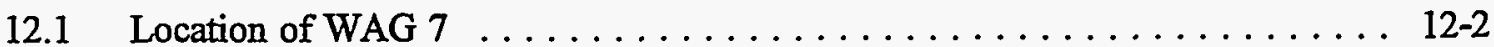

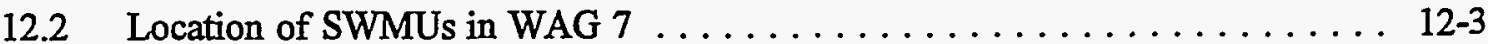

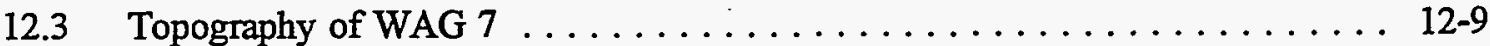

12.4 Map showing the White Oak Creek watershed boundaries . . . . . . . . 12-12

12.5 Schematic illustration of the ISV process applied

to an ORN seepage trench . . . . . . . . . . . . . . . . . 12-17

12.6 Disposition of materials during in situ vitrification processing $\ldots \ldots \ldots \ldots$ 12-18

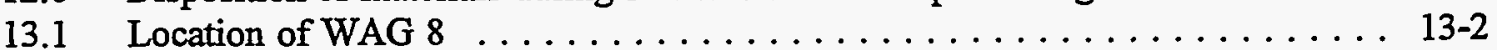

13.2 Location of WAG 8 Solid Waste Management Units . . . . . . . . . . . 13-3

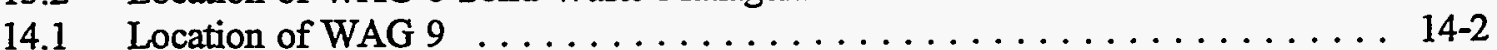

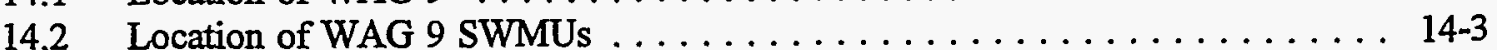

15.1 Location of the four SWMUs included in WAG $10 \ldots \ldots \ldots \ldots \ldots \ldots$. . . . . . . . .

15.2 Schematic representation of hydrofracture injection process . . . . . . . . 15-4

15.3 Generalized geologic map showing the hydrofracture facilities . . . . . . . . 15-8

15.4 Generalized geologic cross section of Melton Valley . . . . . . . . . . . 15-9 
15.5 Stratigraphic column for geologic formations on the base

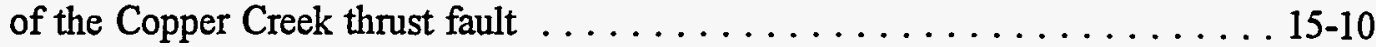

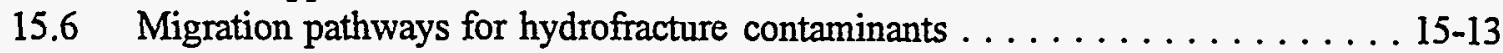

15.7 ORNL remedial investigation/feasibility study strategy for WAG $10 \ldots \ldots \ldots 15-15$

16.1 Location of WAG 11, the White Wing Scrap Yard ............. 16-2

16.2 Location of the Solid Waste Management Unit in WAG $11 \ldots \ldots \ldots \ldots$. . . . . . .

17.1 Location of WAG 12, the Closed Contractors' Landfill ............. 17-2

17.2 Location of Closed Contractors' Landfill . . . . . . . . . . . . . . . 17-3

18.1 Location of WAG 13, the Environmental Research Areas . . . . . . . . . . 18-2

18.2 Location of Solid Waste Management Units in WAG $13 \ldots \ldots \ldots \ldots \ldots$ 18-3

19.1 Location of WAG 14, the Tower Shielding Facility . . . . . . . . . 19-2

19.2 Location of WAG 14 Solid Waste Management Units . . . . . . . . . . 19-3

20.1 Location of WAG 15, ORNL Facilities at the Y-12 Plant . . . . . . . 20.2

20.2 Location of WAG 15 Solid Waste Management Units ........... 20-3

21.1 Location of WAG 16, Health Physics Research Reactor Area ........ 21-2

21.2 Location of WAG 16 Solid Waste Management Units . . . . . . . . . 21-3

22.1 Location of WAG 17, ORNL Services Area $\ldots \ldots \ldots \ldots \ldots \ldots \ldots \ldots .22-2$

22.2 Location of WAG 17 Solid Waste Management Units ............ 22-3

23.1 Location of WAG 18, Consolidated Fuel Reprocessing Area . . . . . . . 23-2

23.2 Location of WAG 18 Solid Waste Management Units . . . . . . . . . 23-3

24.1 Location of WAG 19, Hazardous Waste Treatment and Storage Facilities . . . 24-2

24.2 Location of WAG 19 Solid Waste Management Units . . . . . . . . . . 24-3

25.1 Location of WAG 20, Oak Ridge Land Farm $\ldots \ldots \ldots \ldots \ldots \ldots \ldots . \ldots \ldots$ 25-2

25.2 Location of WAG 20 Solid Waste Management Unit ........... 25-3 



\section{TABLES}

2.1 Correlation between chapters of this document and CERCLA documents . . . 2-2

2.2 Correlation between chapters of this document and selected non-CERCLA documents . . . . . . . . . . . . .

5.1 Temperature averages and extremes for Oak Ridge, Tennessee in ${ }^{\circ} \mathrm{C}\left({ }^{\circ} \mathrm{F}\right) \ldots$. . 5-6

5.2 Precipitation averages for ORNL based on the period 1963-92, both water equivalent and snowfall . . . . . . . . . . . . . . . 5-7

5.3 Maximum multiyear precipitation for a 24 -hour period $\ldots \ldots \ldots \ldots \ldots \ldots$. . . .

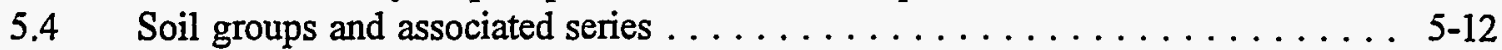

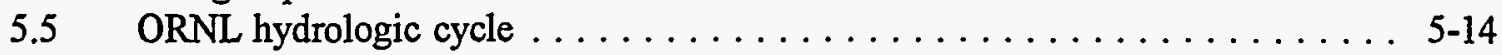

5.6 Approximate relationship among depth, flow interval, and water type

5.7 Habitats and status of rare animal species known to exist on the

Oak Ridge Reservation . . . . . . . . . . . . . . . . . . 5-23

6.1 Principal source release mechanism/contaminated media chains for WAG $1 \ldots$ 6-27

6.2 Estimated cost of GAAT treatability study . . . . . . . . . . . . . 6-39

6.3 Projected schedule for treatability study and CERCLA activities . . . . . . . 6-40

6.4 Summary of comparative analysis of alternatives for CERCLA criteria, WAG 1 Surface Impoundments project . . . . . . . . . . . . . 6-51

7.1 Contaminants known or suspected to have been released from each WAG . . . 7-14

7.2 1989 ORNL NPDES Permit TN 0002941 (discharge point X15-White Oak Dam) . . . . . . . . . . . . . . . . . 7-15

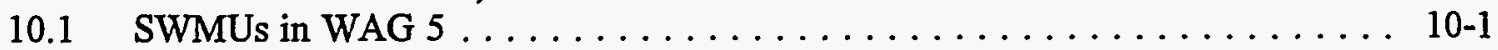

10.2 Inventory of radionuclides in OHF Impoundment sediment $\ldots \ldots \ldots \ldots$ 10-16

10.3 Concentrations and estimated inventory of radionuclides in sediment contained in the Process Waste Sludge Basin . . . . . . . . . . . . 10-17

10.4 Comparison of contaminant flux from WAG 5 and total

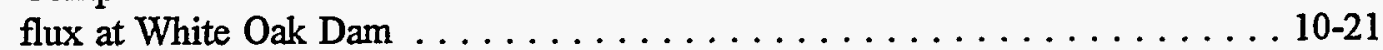

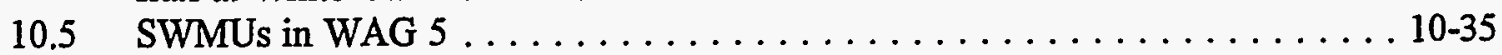

11.1 Objectives for WAG 6 Environmental Monitoring Program . . . . . . . . 11-24

13.1 Solid Waste Management Units located in WAG $8 \ldots \ldots \ldots \ldots \ldots \ldots \ldots$ 13-1

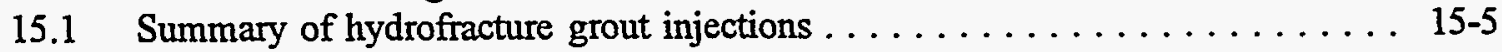

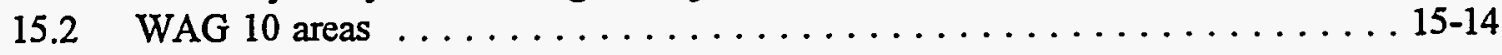




\section{ABBREVIATIONS}

AEC

ARAR

BNAE

CA

CERCLA

CFR

$\mathrm{CH}$

D\&D

DOE

DOE-ORO

DQO

EDT

$\mathrm{EE} / \mathrm{CA}$

EMP

Energy Systems

EPA

ER

ERMA

EWB

FFA

FS

GAAT

HSWA

ICM

ILLW

ISV

LLLW

LLW

MCL

MSL

MVST

NCP

NEPA

NHF

NIPDWS

NPDES

NRDA

OHF

ORNL

ORR

PCB

PVC

PWTP

RCRA

$\mathrm{RH}$
Atomic Energy Commission

applicable or relevant and appropriate regulation/requirement

base/neutral/acid extractable

Characterization Area

Comprehensive Environmental Response, Compensation, and Liability Act

Code of Federal Regulations

contact-handled

decontamination and decommissioning

U.S. Department of Energy

U.S. Department of Energy-Oak Ridge Operations

data quality objective

Explosives Detonation Trench

engineering evaluation/cost analysis

Environmental Monitoring Program

Lockheed Martin Energy Systems, Inc.

U.S. Environmental Protection Agency

Environmental Restoration (Program)

Environmental Restoration Monitoring and Assessment (Report)

Emergency Waste Basin

Federal Facility Agreement

feasibility study

Gunite and Associated Tanks

Hazardous and Solid Waste Amendments

Interim Corrective Measure

intermediate-level liquid (radioactive) waste

in situ vitrification

liquid low-level (radioactive) waste

low-level waste

maximum contaminant level

mean sea level

Melton Valley Storage Tanks

National Oil and Hazardous Substances Pollution Contingency Plan

National Environmental Policy Act

New Hydrofracture Facility

National Interim Primary Drinking Water Standards

National Pollutant Discharge Elimination System

Natural Resource Damage Assessment

Old Hydrofracture Facility

Oak Ridge National Laboratory

Oak Ridge Reservation

polychlorinated biphenyl

polyvinyl chloride

Process Waste Treatment Plant

Resource Conservation and Recovery Act

remote-handled 
RI

$\mathrm{RI} / \mathrm{FS}$

ROD

SCS

SI

SIP

SVOC

SWMU

SWP

SWSA

TCE

TDDP

TDEC

TRE

TRU

TVA

USGS

VOC

WAG

WOC

WOCE

WOD

WOL remedial investigation

remedial investigation/feasibility study

Record of Decision

seep collection system

Surface Impoundments

Site Investigation Program

semivolatile organic compound

solid waste management unit

Surface Water Program

solid waste storage area

trichloroethene

Tumulus Disposal Demonstration Project

Tennessee Department of Environment and Conservation

total rare earths

transuranic

Tennessee Valley Authority -

U.S. Geological Survey

volatile organic compound

waste area grouping

White Oak Creek

White Oak Creek Embayment

White Oak Dam

White Oak Lake 


\section{EXECUTIVE SUMMARY}

This document serves as a source document for Comprehensive Environmental Response, Compensation, and Liability Act (CERCLA) and other types of documents developed for and pertaining to Environmental Restoration (ER) Program activities at Oak Ridge National Laboratory (ORNL). It contains descriptions of the (1) regulatory requirements for the ORR ER Program, (2) Oak Ridge Reservation (ORR) ER Program, (3) ORNL site history and characterization, and (4) history and characterization of Waste Area Groupings (WAGs) 1-20.

This document was created to save time, effort, and money for persons and organizations drafting documents for the ER Program and to improve consistency in the documents prepared for the program. By eliminating the repetitious use of selected information about the program, this document will help reduce the time and costs associated with producing program documents. By serving as a benchmark for selected information about the ER Program, this reference will help ensure that information presented in future documents is accurate and complete.

This reference may be used two ways, depending on whether it is employed in the creation of a CERCLA or non-CERCLA document.

1. If the document is related to CERCLA compliance, Chaps. 4-25 of this reference may be cited in corresponding chapters of the CERCLA document, thereby relieving the authors from having to draft those chapters themselves. Due to constraints from U.S. Department of Energy regulators, Chap. 3 of this reference may not be cited in CERCLA documents; it may, however, be used as a resource for the completion of the regulatory initiative chapter in many CERCLA documents.

2. If the document is not related to CERCLA compliance, material from this reference may be cited (the preferred method) or copied into a document, whichever is most appropriate. Chapters 5-25 (history and characterization of the ORNL site and WAGs) contain summary sections comprehensive enough to satisfy reporting requirements of most non-CERCLA documents.

Only those WAGs with active projects have been fully characterized in this document; these are WAGs $1,2,4,5,6,7$, and 10 . The remaining WAGs have been included for general information purposes, and a very brief description of them has been given. 



\section{INTRODUCTION}

This document serves as a source document for Comprehensive Environmental Response, Compensation, and Liability Act (CERCLA) and other types of documents developed for and pertaining to Environmental Restoration (ER) Program activities at Oak Ridge National Laboratory (ORNL). It contains descriptions of the (1) regulatory requirements for the ORR ER Program, (2) Oak Ridge Reservation (ORR) ER Program, (3) ORNL site history and characterization, and (4) history and characterization of Waste Area Groupings (WAGs) 1-20.

This document was created to save time, effort, and money for persons and organizations drafting documents for the ER Program and to improve consistency in the documents prepared for the program. By eliminating the repetitious use of selected information about the program, this document will help reduce the time and costs associated with producing program documents. By serving as a benchmark for selected information about the ER Program, this reference will help ensure that information presented in future documents is accurate and complete. 
$=$ 


\section{INSTRUCTIONS TO USER}

This reference can be used in two ways, depending on whether it is employed in the creation of a CERCLA or non-CERCLA document.

1. If the document is related to CERCLA compliance, this reference can be cited in selected chapters of the document, thereby savings the authors from having to draft those chapters themselves. Table 2.1 illustrates how the various chapters of this reference correspond to specific chapters of CERCLA documents. If the document being written is a remedial investigation (RI) work plan, for example, Chap. 4 and any parts of Chaps. 5-25 that apply to the work plan can be cited. It is not necessary to actually include the cited material in the work plan, this reference can simply be cited (i.e., "See Source Document for Waste Area Groupings at Oak Ridge National Laboratory, Oak Ridge, Tennessee, ORNL/ER-342, for this information").

Chapter 3, Regulatory Initiative, can also be used in the creation of CERCLA documents, but not in the same way as the other chapters of this reference. U.S. Department of Energy (DOE) regulators specify that each CERCLA document specifically state the regulatory drivers pertaining to that document. Therefore, Chap. 3 of this source document cannot be cited in CERCLA documents; the material must be copied into each document. Also note that Chap. 3 gives only general regulatory drivers; authors must provide any specific drivers for their projects [e.g., DOE orders and applicable or relevant and appropriate regulations/requirements (ARARs)].

2. If the document is not related to CERCLA compliance, material from this reference can be used in any manner; it can be cited (the preferred method) or copied directly into another document. Chapter 4 (description of the ORR ER Program) will probably need to be used in its entirety. Chapters 5-25 (history and characterization of the ORNL site and WAGs) contain summaries, which are the sections that should be copied into other documents. Sections of these chapters other than the summaries may be used, but only in rare circumstances should it be necessary to use the complete chapters in any document. Table 2.2 illustrates how the various chapters of this document correspond to specific chapters of selected non-CERCLA documents.

Only those WAGs with active projects have been fully characterized in this document; these are WAGs $1,2,4,5,6,7$, and 10 . The remaining WAGs have been included for general information purposes, and a very brief description of them has been given.

This document is structured to reflect, as much as possible, the outlines of the CERCLA documents it is most useful in completing. Chapter and section titles have been written to mirror corresponding CERCLA titles, and instruction boxes have been included at the beginning of each chapter to further explain how a particular chapter can be used in CERCLA and other types of documents.

Chapters 6-25 (history and characterization of the WAGs) are an important resource for anyone drafting documents for the ER Program. Remediation is an ongoing process, however, and conditions change with time. Therefore, anyone writing for the ER Program should check the most current resources [e.g., Environmental Restoration Monitoring and Assessment Report and ORR Federal Facility Agreement (FFA) Quarterly Report] for the latest information about WAG activities. 
Table 2.1. Correlation between chapters of this document and CERCLA documents

\begin{tabular}{|c|c|c|c|c|c|}
\hline $\begin{array}{l}\text { Source Document for Waste } \\
\text { Area Groupings at Oak } \\
\text { Ridge National Laboratory, } \\
\text { Oak Ridge, Tennessee }\end{array}$ & $\begin{array}{l}\text { Preliminary } \\
\text { Assessment/Site } \\
\text { Inspection }\end{array}$ & RI Work Plan & RI Report & $\begin{array}{l}\text { Feasibility } \\
\text { Study }\end{array}$ & Proposed Plan \\
\hline $\begin{array}{l}\text { Chap. 3, Regulatory } \\
\text { Initiative }\end{array}$ & $\begin{array}{l}\text { Sect. 1.1, Statutory } \\
\text { and Regulatory } \\
\text { Requirements }\end{array}$ & $\begin{array}{l}\text { Sect. 1.1, Regulatory } \\
\text { Initiative }\end{array}$ & $\begin{array}{l}\text { Sect. 1.1, Regulatory } \\
\text { Initiative }\end{array}$ & $\begin{array}{l}\text { Sect. 1.2.1, } \\
\text { Description }\end{array}$ & \\
\hline $\begin{array}{l}\text { Chap. 4, ORR ER Program } \\
\text { Description }\end{array}$ & & $\begin{array}{l}\text { Sect. 1.2, ORR ER } \\
\text { Program }\end{array}$ & $\begin{array}{l}\text { Sect. 1.2, ORR ER } \\
\text { Program }\end{array}$ & & \\
\hline $\begin{array}{l}\text { Chap(s). } 6 \text { through } 25 \text {, } \\
\text { Characterization, History, } \\
\text { and Current Condition of } \\
\text { WAGs }\end{array}$ & $\begin{array}{l}\text { Sect. 2.1.1, Site } \\
\text { Description }\end{array}$ & $\begin{array}{l}\text { Chap. 2, History and } \\
\text { Current Conditions and } \\
\text { Chap. 3, Characterization } \\
\text { of Environmental Setting } \\
\text { and Site Conceptual } \\
\text { Model }\end{array}$ & $\begin{array}{l}\text { Chap. 2, Characterization } \\
\text { of Environmental Setting } \\
\text { and Chap. 3, Site } \\
\text { History and Current } \\
\text { Conditions }\end{array}$ & $\begin{array}{l}\text { Sect. 1.2.1 } \\
\text { Description }\end{array}$ & $\begin{array}{l}\text { Sect. } 2.1 \text {, } \\
\text { Overview of Site } \\
\text { and Sect. } 2.2 \text {, Site } \\
\text { History and Status }\end{array}$ \\
\hline
\end{tabular}


Table 2.2. Correlation between chapters of this document and selected non-CERCLA documents

\begin{tabular}{|c|c|c|}
\hline $\begin{array}{c}\text { Source Document for Waste } \\
\text { Area Groupings at Oak Ridge } \\
\text { National Laboratory, Oak } \\
\text { Ridge, Tennessee }\end{array}$ & $\begin{array}{l}\text { Site Characterization } \\
\text { Summary Reports }\end{array}$ & $\begin{array}{c}\text { Engineering } \\
\text { Evaluation/Cost Analysis } \\
\text { Reports }\end{array}$ \\
\hline Chap. 3, Regulatory Initiative & & $\begin{array}{l}\text { Chap. 2, Regulatory } \\
\text { Initiative }\end{array}$ \\
\hline \multicolumn{3}{|l|}{$\begin{array}{l}\text { Chap. 4, ORR ER Program } \\
\text { Description }\end{array}$} \\
\hline $\begin{array}{l}\text { Chap(s). } 6 \text { through } 25 \text {, History } \\
\text { and Characterization of WAGs }\end{array}$ & $\begin{array}{l}\text { Chap. 2, Site Description } \\
\text { and Background }\end{array}$ & \\
\hline
\end{tabular}

One of the primary goals of this document is to provide a comprehensive yet concise characterization of each WAG, but because this reference contains information about all 20 WAGs, it would be redundant to repeat information in each WAG chapter that was common to all. The climate of WAG 1, for instance, is identical to that of WAG 8. To keep the length of this document as short as possible, a chapter detailing the general characteristics of ORNL (Chap. 5) was included to describe conditions common to all WAGs. In each WAG chapter readers are therefore referred to the ORNL chapter for some general site characteristics. Specific characteristics are given in the individual WAG chapters if they differ from general ORNL conditions.

Your input is appreciated

This document was created to be a "living" document and will be revised periodically to keep information on the status of active projects current. Please forward any updated information on active projects or corrections to material in this document to the authors for inclusion in future drafts. 


\section{REGULATORY INITIATIVE}

\begin{tabular}{|l||}
\hline Instructions to user \\
This chapter can be copied into the following CERCLA documents: preliminary \\
assessment/site inspections, RI work plans, RI reports, feasibility studies, and \\
proposed plans. This chapter contains a general description of those regulatory \\
drivers affecting work performed for the ER Program at ORNL; it does not include \\
all of the statutory and regulatory requirements that may be pertinent to your specific \\
CERCLA document. You must include any specific drivers (e.g., DOE orders and \\
ARARs) that pertain to your work.
\end{tabular}

\subsection{FEDERAL FACILITY AGREEMENT DESCRIPTION AND GOALS}

The ORR FFA, hereafter referred to as "the Agreement," is an interagency agreement designed to coordinate environmental remediation activities undertaken on the ORR. DOE, the U.S. Environmental Protection Agency (EPA), and the Tennessee Department of Environment and Conservation (TDEC), hereafter known as "the Parties," entered into this Agreement to comply with CERCLA and coordinate remediation activities pursuant to CERCLA, the Resource Conservation and Recovery Act (RCRA), and the National Environmental Policy Act (NEPA).

The parties have a common goal to ensure that releases of hazardous substances to the environment associated with past waste management and operational activities at the ORR are adequately investigated and that appropriate remedial action is taken to protect human health and the environment.

The following are the general purposes of the Agreement:

- establish a procedural framework and schedule for developing, implementing, and monitoring appropriate response actions at the ORR in accordance with CERCLA, RCRA, NEPA, appropriate DOE and EPA guidance and policy, and Tennessee state law;

- coordinate response actions under CERCLA with closure, postclosure care, and corrective measures under way or planned under RCRA and applicable state laws to maximize flexibility and preclude redundant activity;

- minimize the duplication of investigative and analytical work and documentation and ensure the quality of data management; and

- expedite response actions with a minimum of delay.

\subsection{CONSOLIDATION OF REGULATORY INTERACTION}

\subsubsection{Resource Conservation and Recovery Act Integration Into CERCLA}

RCRA was passed by Congress in 1976 to address management of the country's huge volume of solid waste. The law requires that EPA regulate the management of hazardous waste, which 
includes many types of substances deemed potentially harmful to human health and the environment. RCRA also regulates certain nonhazardous waste and underground storage tanks used for storage of specific materials. RCRA controls all aspects of the management of hazardous waste, from the point of generation to treatment, storage, and disposal. Hazardous waste generators, including the facilities on the ORR, must follow specific requirements for handling these wastes. RCRA requires that owners and operators of hazardous waste management facilities have operating or postclosure care permits for waste management activities.

The Agreement will establish a procedural framework and schedule for developing and implementing response actions under CERCLA at the ORR. The Parties to the Agreement recognize that current and future hazardous waste management activities may be subject to RCRA permit requirements under federal and state laws. The Parties to the Agreement recognize that on-site CERCLA response actions are not subject to federal or state permits per CERCLA 121(e)(1). However, RCRA shall be considered an ARAR per CERCLA 121(d). Hence, current and future response actions at the ORR will achieve comprehensive remediation of releases or threatened releases of hazardous substances, pollutants, and contaminants. RCRA/Hazardous and Solid Waste Amendments (HSWA) administrative requirements and permitting activities will be integrated as necessary into the CERCLA process.

The three parties to the Agreement intend to coordinate the DOE CERCLA response obligations with the corrective measures required under the HSWA permit as these units are designated inactive. Response actions under the Agreement will achieve comprehensive remediation of releases or threatened releases of hazardous substances, hazardous wastes (including hazardous constituents), pollutants, or contaminants at or from the ORR. For this reason, the Agreement supplements corrective actions under the HSWA permit with response actions under CERCLA for releases not presently addressed in the HSWA permit. The Parties to the Agreement, therefore, intend that activities covered by the Agreement will achieve compliance with CERCLA and all other environmental regulations.

The Agreement expands the RCRA facility assessments and investigations presently under way at the ORR with requirements to investigate (1) releases at or from units not included in the RCRA permit and (2) releases of hazardous or radioactive substances not regulated by DOE's RCRA HSWA permit. The Parties to the Agreement intend to coordinate and consolidate these assessments, investigations, and other response actions, as well as the administrative records developed for activities under the RCRA HSWA permit and the public participation requirements of CERCLA. The Parties to the Agreement intend to modify the RCRA HSWA permit, as appropriate, to provide that remedial actions selected under the agreement for inactive units will qualify as corrective measures to satisfy Sects. 3004(u) and (v) of RCRA. With respect to releases of hazardous constituents from facilities that are or were authorized to operate under Sect. 3005(e) of RCRA, RCRA shall also be considered an ARAR under Sect. 121 of CERCLA.

\subsubsection{National Environmental Policy Act Integration with the CERCLA Process}

NEPA is the basic national charter for protection of the environment. It establishes policy, sets goals, and provides means for carrying out the policy. The purposes of NEPA include encouraging harmony between people and the environment, promoting efforts to prevent or eliminate damage to the environment and the biosphere, and encouraging the understanding of ecological systems and natural resources important to the country. NEPA ensures that federal agencies take into account the environmental impact of their actions through a procedure and detailed statement known as an Environmental Impact Statement. DOE Order 5440.1D (National 
Environmental Policy Act Compliance Program) mandates DOE compliance with the requirements of NEPA.

DOE Order 5400.4 states that where DOE remedial actions under CERCLA trigger the procedures set forth in NEPA, it is the policy of DOE to integrate the procedural and documentational requirements of CERCLA and NEPA, wherever practical. The primary instrument for this integration will be the RI/feasibility study (RI/FS) process, which is to be supplemented as needed to meet the procedural and documentational requirements of NEPA. In addition, the public review process of CERCLA and NEPA will be combined for RI/FS-NEPA documents, where appropriate. The key element for the integration process is determining the level of NEPA documentation required for a remedial action project prior to entering the RI/FS scoping process or as soon thereafter as is possible so that appropriate RI/FS-NEPA planning is achieved early in the process. DOE Order 5440.1C provides policy guidance for planning and executing NEPA on DOE projects.

\subsubsection{National Oil and Hazardous Substances Pollution Contingency Plan Integration with CERCLA}

The purpose of the National Oil and Hazardous Substances Pollution Contingency Plan (NCP) is to provide the organizational structure and procedures for preparing for and responding to discharges of oil and releases of hazardous substances, pollutants, and contaminants into the environment. The NCP is required by Section 105 of CERCLA, as amended by the Superfund Amendments and Reauthorization Act of 1986, Pub. L. 99-499, and by Sect. 311(c)(2) of the Clean Water Act, as amended, 33 U.S.C. 1321(c)(2).

On the ORR, the NCP applies to and is in effect for: (1) discharges of oil which may affect natural resources belonging to, appertaining to, or under the exclusive management authority of the United States and (2) releases into the environment of hazardous substances and pollutants or contaminants that may present an imminent or substantial danger to the public.

The NCP provides for efficient, coordinated, and effective response to discharges of oil and releases of hazardous substances, pollutants, and contaminants in accordance with the authorities of CERCLA and the Clean Water Act. It provides for:

- the national response organization that may be activated in response actions, and it specifies responsibilities among the federal, state, and local governments and describes resources available for response;

- the establishment of requirements for federal regional and on-scene coordinator contingency plans;

- procedures for undertaking removal actions pursuant to CERCLA and section 311 of the Clean Water Act;

- procedures for involving state governments in the initiation, development, selection, and implementation of response actions;

- designation of federal trustees for natural resources for purposes of CERCLA and the Clean Water Act; 
- procedures for compiling and making available an administrative record for response actions; and

- national procedures for the use of dispersant and other chemicals in removals under the Clean Water Act and response actions under CERCLA.

\subsubsection{Natural Resource Damage Assessment Implementation During the CERCLA Process}

The Natural Resource Damage Assessment (NRDA) process is used to determine whether natural resources have been injured and to calculate compensatory monetary damages to be used to restore the natural resources. Federal and state agencies acting as trustees can use the prescribed procedures to determine compensation for injuries to natural resources that have not been nor are expected to be addressed by response actions conducted pursuant to the NCP. These "residual injuries" are what remains after a Superfund cleanup is complete. The Department of the Interior is responsible for NRDA regulations, which are found at Title 43 Code of Federal Regulations (CFR) Part 11 (43 CFR 11).

DOE Order 5400.4 states that where DOE determines that natural resources for which DOE has been granted trusteeship may have been potentially injured by a release, DOE will implement the NRDA process consistent with the requirements of the NRDA regulations found at 43 CFR 11 . Therefore, DOE serves a dual role when addressing releases occurring on the ORR. First, DOE acts in the capacity of lead agency in investigating the extent of contamination, the nature of the hazard to human health and the environment, and in managing the remedial action process. Second, DOE acts in the capacity of trustee to determine the residual injury to natural resources that may remain after remedial action is completed. Guidance has been provided by DOE Headquarters addressing this situation so that both the CERCLA process and the NRDA process can proceed simultaneously and at minimal costs to the public. DOE guidance is to develop agreements with cotrustees to coordinate trustees' activities, share information, and whenever practical, use the information developed in the CERCLA remedial action process to achieve NRDA objectives.

DOE has taken a proactive role in NRDA activities on the ORR and is working with cotrustees to develop an agreement in principal on strategies and procedures for conducting NRDA activities on the ORR. DOE is providing cotrustees information on the schedule and scope of planned CERCLA activities and the results of characterization and ecological studies so that cotrustees may have an opportunity to use the CERCLA process to obtain information required for NRDA evaluations.

\subsubsection{Incorporation of ARARs into the CERCLA Process}

CERCLA requires that remedial actions for cleanup of hazardous substances must comply with all ARARs of federal orders and state environmental laws. Incorporation of other state and federal laws (e.g., those relating to water, air, safety, transportation, etc.) into the CERCLA process is accomplished through the identification of ARARs during the remedial action process as required under the NCP (40 CFR 300).

A review of all laws that might potentially be ARARs to remedial action activities on the ORR is conducted on an annual basis. Additionally, through each phase of the remedial action process, a review of chemical-, location-, or action-specific requirements is conducted on a 
project-by-project basis. For example, a remedial action project located in a wetland or floodplain would be required to comply with laws governing the protection of that area in addition to all requirements of CERCLA; those additional requirements would be location-specific ARARs. Chemical-specific ARARs set numerical limits for acceptable levels of contaminants in environmental media; in the event that both a state and federal standard exist for an identical situation, the more stringent requirement takes precedence. Should a project require movement of contaminated materials across public roads, the Department of Transportation regulations would be action-specific ARARs to CERCLA requirements or RCRA requirements for handling those materials. Waivers for compliance with ARARs may be provided by regulatory agencies when full compliance with an ARAR would adversely impact CERCLA activities or is impracticable under the circumstances.

In addition to the requirement in the NCP to identify ARARs, the NCP specifically requires compliance with worker safety and health regulations found at 29 CFR 1910.120 integrating the Occupational Safety and Health Ac) during CERCLA activities. Because the ORR remedial action activities often involve radioactive contaminants, other worker protection laws specific to nuclear facilities and the handling of nuclear materials may apply. These laws are implemented through DOE orders and would be action-specific ARARs or to-be-considered guidance on CERCLA projects.

Potential ARARs include but are not limited to the following:

- the Clean Air Act,

- the Endangered Species Act,

- the Clean Water Act,

- the Safe Drinking Water Act,

- the Atomic Energy Act,

- the Toxic Substances Control Act,

- the Hazardous Material Transportation Act,

- the Fish and Wildlife Coordination Act,

- the National Historic Preservation Act,

- the Archaeological and Historic Preservation Act, and

- the Toxic Substances Control Act.

Although CERCLA is the main driver for the completion of ER Program CERCLA projects other potential ARARs must be considered. These include (1) requirements set forth in the current management and operations contract with DOE, (2) the FFA, (3) Lockheed Martin Energy Systems, Inc., (Energy Systems) policies and procedures, and (4) DOE orders. 



\section{OAK RIDGE RESERVATION ENVIRONMENTAL RESTORATION PROGRAM DESCRIPTION}

Instructions to user
This chapter may be referenced in RI work plans and RI reports. It may also be
copied into non-CERCLA documents that require a description of the ORR ER
Program.

\subsection{MISSION}

The ORR spans approximately 37,000 acres of federally owned land in the city of Oak Ridge, Tennessee, and is bounded on the north and east by the residential area of Oak Ridge (population 27,500) and on the south and west by the Clinch River. The area around the ORR is predominately rural, used largely for residences, small farms, and pasture land. Fishing, boating, water skiing, and swimming are favorite recreational activities in the area.

ORNL, the K-25 Site, and the Y-12 Plant have generated a variety of hazardous substances, including radioactive, nonradioactive, and mixed wastes, some of which have been released into the environment at the ORR. The environmental setting of ORR is complex hydrologically and geologically. Within this complex environmental setting, the contaminated areas are quite diverse in both the nature and extent of contamination.

The mission of the ORR ER Program is to conduct investigations and to take actions to reduce risk to human health and the environment resulting from past operations and waste disposal practices. The location of ORR influences cleanup limits and response-time requirements. The magnitude of financial, qualified man power, and special equipment resources needed for remediation, and the lack of available technology for handling and disposing of wastes and contaminated soils and groundwater, dictate a long-term effort. Some early response actions will be required to protect human health and the environment prior to the selection and implementation of final remediation actions.

\subsection{OBJECTIVE}

The ORR ER Program objective is to conduct cost-effective and technically sound remediation actions to mitigate contaminant releases, reduce risk, and comply with environmental regulations to provide rapid reductions in contaminant releases and to implement and verify final remedies for contaminated areas. Through strategic planning and utilization of the technical resources in Oak Ridge, rapid and innovative actions will be implemented that address the major contaminant releases and their sources in a prioritized and hierarchical fashion. This will be done so that all efforts support the selection and implementation of final remedies. All actions will be undertaken with the full participation of the public. 


\subsection{STRATEGY}

The remediation process for the ORR is being led by the DOE-Oak Ridge Operations (DOE-ORO) office in conjunction with EPA Region IV and TDEC. This process includes the public as an important participant in all decisions concerning the remediation of ORR. Task teams, made up of representatives of the Parties, have been empowered to address the removal actions and pre-RIs at ORR to ensure immediate attention is paid to areas in which risk to the public/workers and the environment is of greatest concern.

The remediation process has the flexibility to support the use of early response activities: removal actions, routine maintenance actions, and interim remedial actions. This allows the program to reduce the environmental risk by addressing key parts of contaminated areas and selected releases of contaminants to the environment as steps toward final remediation of ORR. Management of the integration of early response actions results into the final remediation activities requires a comprehensive and coordinated strategy.

\subsection{PROGRAM MANAGEMENT}

\subsubsection{Roles and Responsibilities}

The ORR remediation program will be conducted using a "lead agency" strategy to minimize duplication of effort and maximize oversight productivity. The lead agency is designated as the responsible agency for overseeing and coordinating the activities in accordance with the Agreement. The regulators will provide support within their oversight role to the lead agency.

The lead agency for the ORR, DOE-ORO, provides the on-site coordination to plan and implement remedial actions under the NCP. Lead agency duties include the following:

- oversee and manage ORR remedial activities pursuant to the Agreement and the site management plan,

- serve as primary contact and coordinator with the regulators for the purposes of implementing the Agreement and the site management plan, and

- ensure availability of resources required to implement the site management plan.

EPA and TDEC are participating in the Agreement as both working partners in initiating the remedial action work at Oak Ridge and in a regulatory oversight role. In this capacity, they will provide regulatory opinions and counsel to the lead agency. The regulators will assist the lead agency by attending working meetings, providing timely response to action items, and providing timely review and concurrence, where applicable, of ORR remedial documentation and/or activities. EPA, DOE, and TDEC will each designate project managers to coordinate the implementation of the Agreement and the ongoing regulatory oversight duties and shall notify each other in writing of the designation.

\subsubsection{Contractors}

The Energy Systems ER Program has been designated as integrating contractor for the DOE ER Program. The primary purpose of the integrating contractor role is to ensure that all participants in the Oak Ridge ER Program approach and conduct their tasks in a technically 
consistent and operationally similar manner to ensure a common focus for technical and administrative management. The primary contractors to $\mathrm{DOE}$ as of the date of this document are Energy Systems and Jacobs Engineering.

In fulfilling its role as integrating contractor, Energy Systems will be the focal point each year for coordinating the preparation of the activity data sheets; contributions to the 5-year planning effort; and preparation of installation-specific plans, budget, schedules, and budget packages for the prioritization process. In its integrating contractor role, the Energy Systems ER Program will conduct meetings, collect information, and assemble total packages related to these activities for use by DOE-ORO. The ER Program will ensure that technical consistency is achieved among the participants in areas such as risk assessment, NEPA compliance, and WM for ER activities, among others. The Energy Systems ER Program will have primary responsibility for reporting total ER Program cost and schedule status each month. The Energy Systems ER Program will obtain budget, cost, schedule, and progress information from the technical support contractor (Jacobs Engineering), the remedial design contractor (Ebasco), the construction manager, and DOE-ORO each month and consolidate this information in the monthly status report to be submitted to the director of the DOE-ORO ER Program. 


\section{HISTORY AND CHARACTERIZATION OF THE ORNL SITE}

Instructions to User
This chapter provides general information about the Oak Ridge National Laboratory
(ORNL) site and descriptions of active, site-wide projects. To keep this document as
short as possible, information about conditions common to all WAGs (e.g., climate and
demography) is given in this chapter rather than being repeated in each WAG chapter.
Specific characteristics are given in the individual WAG chapters if they differ from
general ORNL conditions. Section 5.4 contains a summary of this chapter.

\subsection{SITE DESCRIPTION AND HISTORY}

ORNL is located on the Oak Ridge Reservation (ORR), a 13,980 ha (34,545 acre) federally owned site in East Tennessee located approximately 20 miles west of Knoxville (Fig. 5.1). ORNL is one of three primary installations on the reservation, the other two being the Oak Ridge Y-12 Plant and the Oak Ridge K-25 Site. ORNL was constructed for an atomic weapons materials research and development project known as the Manhattan Project during World War II and began operation in 1943. Its isolation from population centers, the availability of inexpensive Tennessee Valley Authority (TVA) electric power, an abundant water supply, and the availability of labor from the surrounding rural areas were factors in locating the facility. Initially the facility had a planned life of only 1 year. This period was lengthened to 2-3 years, and as nuclear research and political climates have evolved, ORNL has been in continuous activity since.

After its wartime mission was completed, the Manhattan Project was transferred from the Manhattan Engineering District in 1947 to the Atomic Energy Commission (AEC), a civilian agency created to supervise the nation's nuclear energy program. ORNL, as part of the AEC, was assigned chemical engineering and basic science program responsibilities in reactor and isotope research and development. In 1975 the Energy Research and Development Administration succeeded AEC as operator of the reservation. With the formation of the U.S. Department of Energy (DOE) in 1977, oversight of the ORR became the responsibility of DOE-Oak Ridge Operations. In 1984, Martin Marietta Energy Systems, Inc., replaced Union Carbide Nuclear Division as the prime contractor to DOE for the management of the three installations on the ORR.

During the period 1955 to 1963 , Oak Ridge was designated by the AEC as the Southem Regional Burial Ground; as such, Oak Ridge received a wide variety of poorly characterized wastes from approximately 50 different sources. These solid wastes consisted of paper, clothing, equipment, filters, animal carcasses, and related laboratory wastes, but exact proportions of each are unknown because records of this nature were not kept (ORNL 1987).

As the goals of the government agencies changed through the years, the emphasis on research and production activities at ORNL also changed. With the expansion of technology came an increase in environmental and ecological research, and ORNL has come to play a key role in applying ecological concepts to environmental problems. ORNL is currently one of DOE's largest multiprogram energy laboratories and research facilities. The Martin Marietta Energy Systems, Inc.,Information Systems Plan, 1992-1996 (Energy Systems 1992), attributes to ORNL the following major research and development and service functions: 


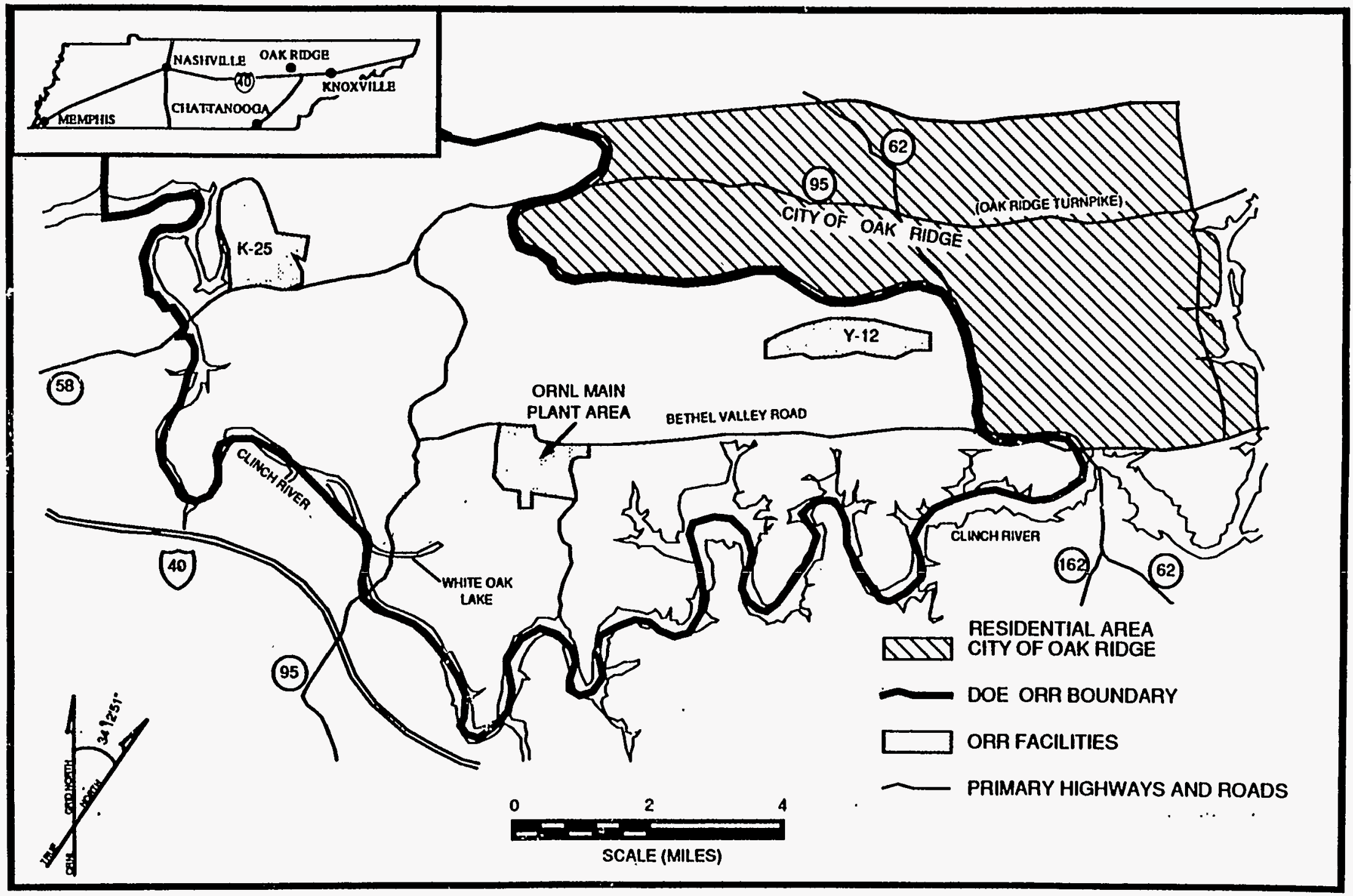

Fig. 5.1. Location of Oak Ridge National Laboratory. 
- perform energy technology research and development (including waste technologies);

- conduct basic and applied research in selected areas of the life sciences (including global environmental studies, basic science in support of waste technology development, and measurement and assessment of the impact on human health of radiological and chemical substances);

- conduct basic and applied research in selected areas of the physical sciences; and

- provide services in support of DOE's missions.

\subsection{CHARACTERIZATION}

Because of the large number of contaminated sites and the hydrologic complexity at ORNL, areas containing contiguous and similar waste sites have been organized into waste area groupings or WAGs. The WAG concept offers several advantages: it provides a more manageable approach for responding to regulatory requirements; it facilitates development of response actions that are protective of human health and the environment; and it allows the use of perimeter monitoring for both groundwater and surface water, which is important because in some WAGs hydrologic interaction has occurred among sites, making individual sites hydrologically inseparable.

Twenty WAGs have been identified at ORNL (Fig. 5.2), 14 of which are candidates for remedial action. With the exception of WAG 2 and the Groundwater Watershed, these WAGs are sources of contaminants to other areas and have been termed "contaminant source WAGs." Remedial project areas will be identified through characterization of the source WAGs.

WAG 2 and the Groundwater Watershed have been termed "integrator sources" because most contamination released from ORNL is discharged into these two, and they in turn serve as conduits for contaminants from ORNL to off-site areas.

WAG 2 is down gradient from nine of the contaminant source WAGs; therefore it receives and integrates the contaminants released from these WAGs through the surface water system. In 1994 the scope of work on WAG 2 was limited to exclude consideration of transient waterborne contaminants, and a new organization named the ORNL Surface Water Program (SWP) was formed. The objectives of SWP are to (1) quantify contaminant releases across the ORNL site; (2) help develop priorities for remedial investigations (RIs) and remedial actions; (3) identify likely mechanisms for contaminant releases from sources; and (4) assess the performance of remedial actions. SWP includes hydrologic and contaminant flux assessments activities conducted at the ORNL site-wide scale, as well as contaminant flux monitoring activities that are specific to source-scale corrective actions. SWP is described in Sect. 5.3.1.

The Groundwater Watershed encompasses the groundwater beneath ORNL and is divided into two components: the Bethel Valley Watershed and the Melton Valley Watershed. The Groundwater Watershed is identified as a discrete entity because contaminants can migrate in the subsurface from one component to another. The Groundwater Watershed is also an integrator unit because it receives the contaminants from the source WAGs that move through the groundwater system. The Groundwater Watershed is described in Sect. 5.3.2. 



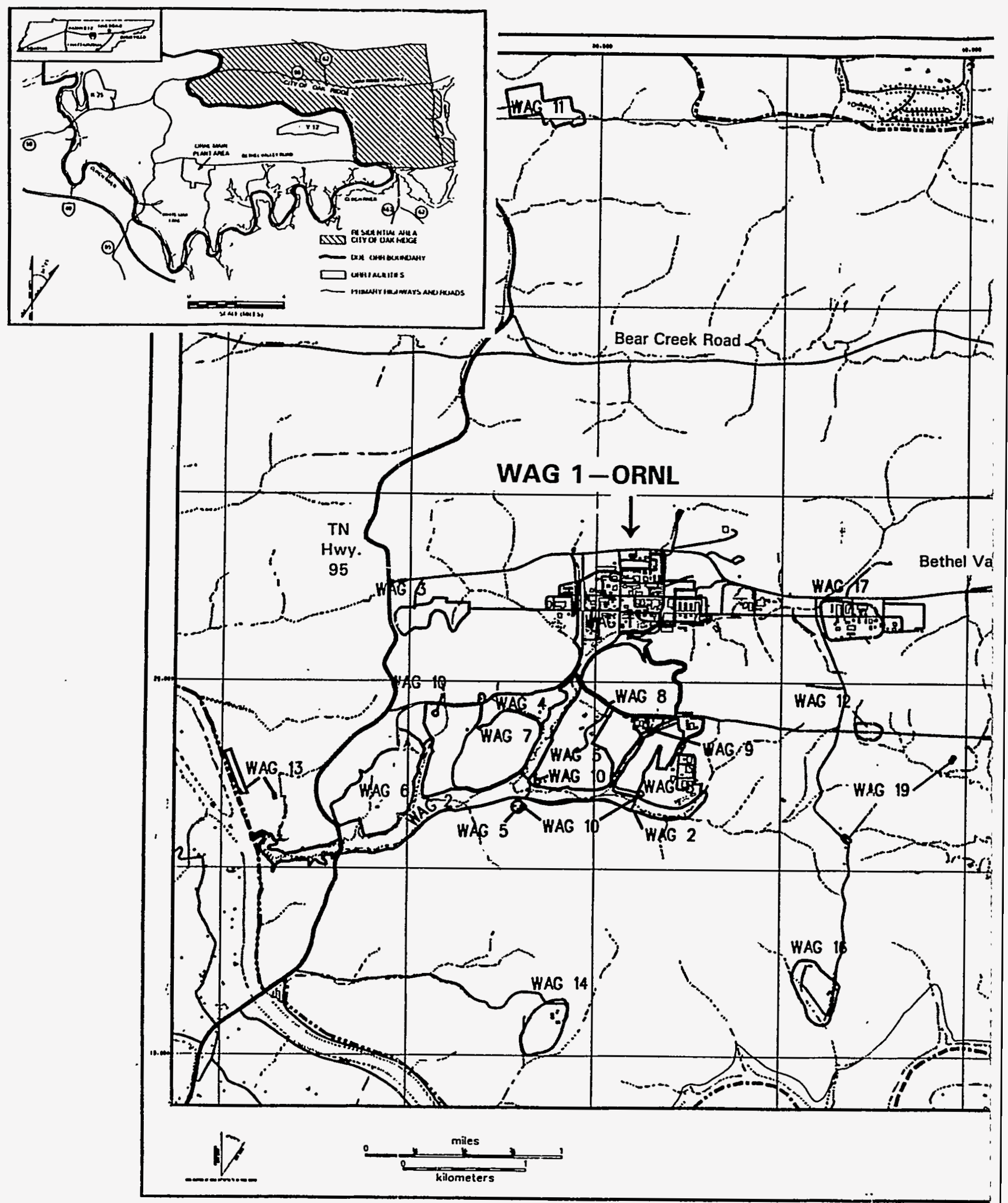

Fig. 5.2. Map of ORNL WAGs. 


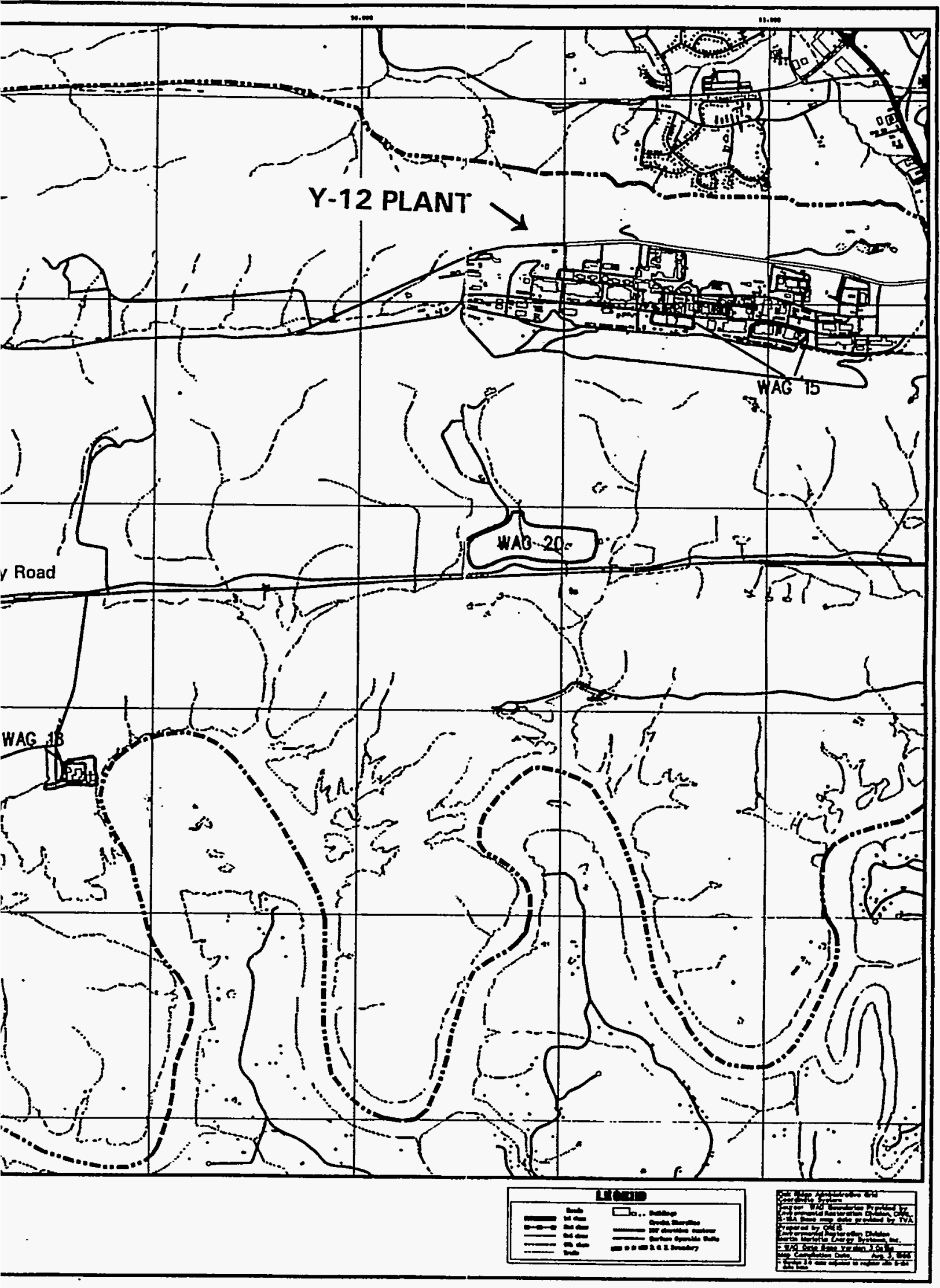




\subsubsection{Geography}

ORNL is within the physiographic region known as the Valley and Ridge province, sometimes referred to as the Valley of East Tennessee for the portion lying in Tennessee. This province is characterized by numerous elongated ridges and intervening valleys. The configuration of the area's terrain was a primary factor in the selection of Oak Ridge as the site for the top-secret Manhattan Project because it enhanced security. The Valley of East Tennessee is located between the Cumberland Plateau, which is the southern portion of the structural province known as the Appalachian Plateaus, and the Blue Ridge province, a portion of the Appalachian Mountain chain. The Great Smoky Mountains National Park, located within the Blue Ridge mountains, contains some of East Tennessee's most prominent geographical features and is $113 \mathrm{~km}$ (70 miles) to the southeast of Oak Ridge (Energy Systems 1994).

ORNL is located within the corporate limits of the city of Oak Ridge in East Tennessee, approximately 5 miles southwest of the city of Oak Ridge central business district.

\subsubsection{Climate}

ORNL's location within ridge and valley terrain and its position east of the Cumberland Plateau influences the local climate. In addition, like many other areas having continental climates, ORNL is influenced by air masses of both Arctic and tropical origin. This can result in a wide range of weather conditions. However, ORNL's mid-latitude location $\left(36^{\circ} \mathrm{N}\right)$ usually ensures some moderation of Arctic and tropical air masses before they reach the area (Birdwell 1993).

ORNL has relatively light winds compared to other parts of the United States. This is likely an effect of the presence of (1) the Cumberland Mountains and Plateau to the west and northwest, and (2) the local ridge and valley terrain. It is important to note, however, that wind speed characteristics vary significantly over short distances in the Oak Ridge area. This depends on the measuring site's location with respect to individual valley bottoms or ridges. According to a preliminary analysis of wind data from the Oak Ridge Site Survey (Eckman, Dobosy, and Pendergrass 1992), ridge-top and valley sites in the Oak Ridge area (excluding the Cumberland Plateau) apparently experience wind speeds less than $5 \mathrm{~m} / \mathrm{s}(11.2 \mathrm{mph})$ over $90 \%$ of the time. Evidence also suggests that many valley-bottom sites experience winds less than $2 \mathrm{~m} / \mathrm{s}(4.5 \mathrm{mph})$ over $70 \%$ of the time and calm winds about $25-30 \%$ of the time (Birdwell 1993). Wind data from nearby McGhee Tyson Airport in Knoxville, Tennessee, (which is more open topographically and thus likely to be windier than ORNL) suggest that highest average winds occur in March and April (3.9 m/s or $8.7 \mathrm{mph}$ at the airport).

Prevailing wind directions at ORNL are strongly oriented parallel to the direction of the local ridge and valley terrain and that of the Valley of East Tennessee itself. As a result, dominant wind directions are northeasterly (down valley) and southwesterly (up valley) (Birdwell 1993). Because the surrounding mountains cause a decrease in wind velocities, tornadoes rarely occur at ORNL or on the ORR in general.

The area has a relatively mild climate with warm to hot, humid summers and cool, wet winters. The relatively high humidity experienced year round is generally attributed to the influence of the Gulf of Mexico and the Atlantic Ocean (Birdwell 1993). According to data from the Atmospheric Turbulence and Diffusion Division of the National Oceanographic and Atmospheric Administration in Oak Ridge, the annual mean air temperature for Oak Ridge is $13.9^{\circ} \mathrm{C}\left(57.1^{\circ} \mathrm{F}\right)$. Diurnal temperature changes are relatively consistent from month to month having a range of $10-15^{\circ} \mathrm{C}$ $\left(18-27^{\circ} \mathrm{F}\right.$ ). Table 5.1 shows temperature means (maximum, minimum, average) and absolute 
temperature extremes (maximum, minimum) for Oak Ridge, Tennessee. Means are based on the 1963-92 period and extremes on the 1951-92 period (Birdwell 1993).

Table 5.1. Temperature averages and extremes for Oak Ridge, Tennessee in ${ }^{\circ} \mathrm{C}\left({ }^{\circ} \mathrm{F}\right)$

\begin{tabular}{|c|c|c|c|c|c|c|c|c|c|c|}
\hline \multirow{2}{*}{$\begin{array}{c}\begin{array}{c}\text { Season } \\
\text { and month }\end{array} \\
\text { Winter }\end{array}$} & \multicolumn{2}{|c|}{ Maximum } & \multicolumn{2}{|c|}{ Minimum } & \multicolumn{2}{|c|}{ Average } & \multicolumn{2}{|c|}{$\begin{array}{c}\text { Extreme } \\
\text { maximum }\end{array}$} & \multicolumn{2}{|c|}{$\begin{array}{l}\text { Extreme } \\
\text { minimum }\end{array}$} \\
\hline & 8.8 & $(47.8)$ & -2.3 & (27.9) & 3.2 & (37.8) & & & & \\
\hline December & 9.2 & $(48.5)$ & -1.3 & $(29.6)$ & 3.9 & $(39.0)$ & 26 & (78) & -22 & $(-7)$ \\
\hline January & 7.3 & $(45.1)$ & -3.3 & $(26.1)$ & 2.0 & (35.6) & 24 & (75) & -27 & $(-17)$ \\
\hline February & 9.8 & $(49.7)$ & -2.1 & $(28.2)$ & 3.8 & (38.9) & 26 & (79) & -17 & (1) \\
\hline Spring & 20.9 & $(69.6)$ & $7.1^{\prime}$ & $(44.8)$ & 14.0 & (57.2) & & & & \\
\hline March & 15.8 & $(60.5)$ & 2.4 & $(36.4)$ & 9.2 & $(48.5)$ & 29 & (85) & -17 & (1) \\
\hline April & 21.5 & $(70.7)$ & 7.1 & $(44.7)$ & 14.3 & (57.7) & 33 & (92) & -7 & (20) \\
\hline May & 25.3 & (77.5) & 11.8 & $(53.2)$ & 18.6 & (65.4) & 34 & (93) & 0 & (32) \\
\hline Summer & 30.0 & $(86.0)$ & 17.8 & $(64.0)$ & 23.9 & $(75.0)$ & & & & \\
\hline June & 29.2 & $(84.5)$ & 16.3 & $(61.2)$ & 22.7 & (72.9) & 38 & (101) & 4 & (39) \\
\hline July & 30.7 & (87.2) & 18.8 & $(65.8)$ & 24.7 & (76.5) & 41 & (105) & 9 & (49) \\
\hline August & 30.1 & (86.2) & 18.3 & $(64.9)$ & 24.2 & (75.5) & 39 & (103) & 10 & (50) \\
\hline Fall & 21.0 & $(69.8)$ & 8.3 & $(46.9)$ & 14.6 & (58.3) & & & & \\
\hline September & 26.9 & $(80.5)$ & 14.8 & $(58.7)$ & 20.9 & $(69.6)$ & 39 & (102) & 1 . & (33) \\
\hline October & 21.2 & $(70.2)$ & 7.4 & (45.4) & 14.3 & (57.8) & 32 & (90) & -6 & (21) \\
\hline November & 14.8 & (58.7) & 2.6 & (36.6) & 8.7 & $(47.6)$ & 28 & (83) & -12 & (10) \\
\hline Annual & & & & & 13.9 & (57.1) & 41 & (105) & -27 & $(-17)$ \\
\hline
\end{tabular}

Source: Birdwell 1993

Although ORNL receives significant precipitation during all months of the year, the precipitation is caused by a variety of air masses. The influence of these air masses varies with the season. Winter precipitation is usually associated with the passage of frontal systems, while summer precipitation primarily results from local air-mass thunderstorm development. Although adequate, precipitation does vary somewhat during the year, as shown in Table 5.2 (1963-92 base period). Annual precipitation at ORNL averages $1351 \mathrm{~mm}$ (53.2 in.). Average annual snowfall measures $25.4 \mathrm{~cm}$ (10.0 in.). Snow rarely persists for more than a few days in winter due to the natural variability of local temperatures. The wettest months are March, December, and July, respectively. The driest month is October (Birdwell 1993). 


\section{5-7}

Table 5.2. Precipitation averages for ORNL based on the period 1963-92, both water equivalent and snowfall

\begin{tabular}{lcccc}
\hline & \multicolumn{2}{c}{ Water equivalent } & \multicolumn{2}{c}{ Snowfall } \\
\cline { 2 - 5 } \multicolumn{1}{c}{ Month } & $\mathrm{cm}$ & in. & $\mathrm{cm}$ & in. \\
\hline January & 115 & 4.52 & 9.4 & 3.7 \\
February & 105 & 4.15 & 9.2 & 3.6 \\
March & 143 & 5.62 & 2.0 & 0.8 \\
April & 102 & 4.01 & 0.6 & 0.2 \\
May & 117 & 4.61 & 0.0 & 0.0 \\
June & 107 & 4.20 & 0.0 & 0.0 \\
July & 137 & 5.38 & 0.0 & 0.0 \\
August & 95 & 3.74 & 0.0 & 0.0 \\
September & 97 & 3.83 & 0.0 & 0.0 \\
October & 79 & 3.12 & 0.0 & 0.0 \\
November & 116 & 4.58 & 0.3 & 0.1 \\
December & 138 & 5.42 & 4.1 & 1.6 \\
Annual & 1351 & 53.20 & 25.6 & 10.0 \\
\hline
\end{tabular}

Source: Birdwell 1993

Table 5.3 provides a measure of precipitation extremes. The table shows the maximum 24 -hour precipitation that could be expected during a given multiyear period. This information could be useful for assessment of flood risks (Birdwell 1993).

Table 5.3. Maximum multiyear precipitation for a 24-hour period

\begin{tabular}{ccc}
\hline & \multicolumn{2}{c}{ Average } \\
\cline { 2 - 3 } Period (yr) & $\mathrm{cm}$ & in. \\
\hline 2 & 8.4 & 3.3 \\
5 & 10.7 & 4.2 \\
10 & 12.2 & 4.8 \\
25 & 14.0 & 5.5 \\
50 & 15.7 & 6.2 \\
100 & $17.0-17.8$ & $6.7-7.0$ \\
\hline
\end{tabular}

Source: Knox County Soil Conservation District with the U.S. Soil Conservation Service, 1981

\subsubsection{Demography}

Five counties in East Tennessee are directly affected by the ORR in general (and therefore ORNL): Anderson, Knox, Loudon, Morgan, and Roane. The ORR lies in Anderson and Roane counties and is adjacent to Knox and Loudon counties. Morgan County is not adjacent to the ORR, 
but its close proximity warrants its consideration. The total population of the five-county area is 499,781 . Of this number, 165,121 (33\%) reside in Knoxville and $27,310(5 \%)$ reside within the corporate limits of the city of Oak Ridge. Approximately $6 \%$ of the labor force in the five-county area is employed on the ORR. As of January 1993, 20,895 persons were employed on the ORR -4837 of these being employed at ORNL.

Five additional counties-Blount, Campbell, Cumberland, McMinn, and Monroe-are considered part of the broader planning region because they surround the five-county planning area, they are within an $80-\mathrm{km}$ ( 50 -mile) radius, and they are accessible to the ORR by an interstate highway. The ten-county area is shown in Fig. 5.3.

The proximity of population to the ORR and ORNL can affect decisions regarding potential new or expanded programmatic initiatives. Density information is essential for'emergency planning and can be a factor in decisions related to the deployment of new missions. Population density per county in the ORNL area varies considerably. Some counties are highly developed such as Knox, which encompasses Knoxville, while others are primarily rural with sparse populations, like Morgan. Population density around ORNL is shown in Fig. 5.4.

Primary land uses within the five- and ten-county areas are forestry, agriculture, residential, and recreational. The five-county area comprises 541,508 ha (1.3 million acres) of land and waterways, and the ten-county region comprises 1.26 million ha (3.1 million acres). Within the incorporated areas of Knoxville, Clinton, Norris, Lenoir city, and Lake City, the predominant land use is residential. However, residential land use comprises less than $10 \%$ of the land in Oak Ridge and is located primarily in the northeast section of the city. Oak Ridge has a population of approximately 28,000 . Other towns in close proximity to ORR include Oliver Springs ( 7 mi northwest; population 3600 ); Lenoir City (6.8 mi southeast; population 5400); Clinton (10 mi northeast, population 5300); Kingston ( 7 mi southwest, population 4400 ); and Harriman ( $18 \mathrm{mi}$ to the west, population 8300 ). The largest metropolitan area closest to ORR is Knoxville, located about $25 \mathrm{mi}$ to the east with a population of 183,000 (Energy Systems 1986).

The total incorporated area of Oak Ridge is 23,492 ha (58,048 acres). Of this total, 1,244 ha (3,073 acres) are waterways, leaving $22,248 \mathrm{ha}(54,975$ acres) as the total land area. Over $60 \%$ of the land area in Oak Ridge is designated for forestry, agriculture, industry, and research. This percentage is due primarily to the large amount of land (13,960 ha or 34,496 acres) within the incorporated city area owned by DOE. Additionally, the University of Tennessee and TVA own approximately 1890 ha (4645 acres) within the incorporated area of Oak Ridge (Energy Systems 1994).

\subsubsection{Geology and Soils}

ORNL is situated between the Cumberland Mountains to the northwest and the Great Smoky Mountains to the southeast, in the Valley and Ridge Physiographic Province of the Appalachian Mountains. The province, which is some 50 miles wide in this area, extends approximately 1300 miles from the Canadian St. Lawrence lowland into Alabama. Bounded by the Appalachian Plateaus Province to the west and the Blue Ridge Province to the east, the Valley and Ridge Province is a complex zone characterized by a succession of southwest-trending ridges and valleys. Regional strike in the Oak Ridge area is $\mathrm{N} 45^{\circ}$ to $60^{\circ} \mathrm{E}$, and dip is typically about $30^{\circ}$ southeast but can vary locally from $<20-40^{\circ}$ (Stockdale 1951). A typical northwest to southeast cross section showing the geologic structure of the ORR is shown in Fig. 5.5. 


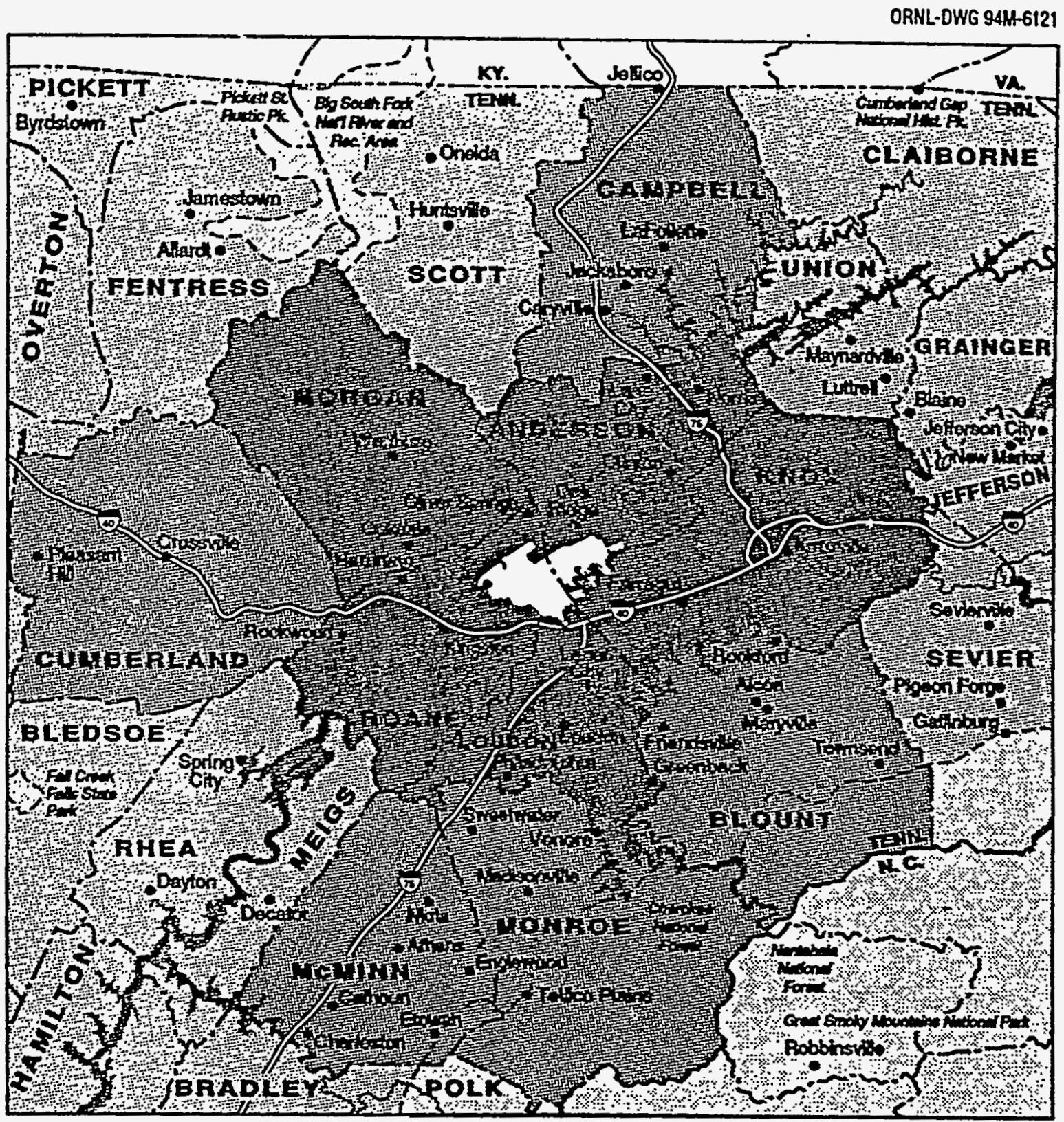

LEGEND

$\square$ Oak Ridge Reservation
Five-County Planning Area
Additional Counties in Ten-
County Planning Region
Primary State or National Park
Rivers and Lakes

- Park Boundary
- Town or City
County Line
State Line
Intersiate Highway

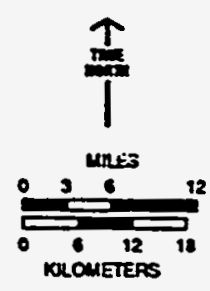

Fig. 5.3. Ten-county planning region. Source: Energy Systems 1994 
ORNL-DWG 94M-6129

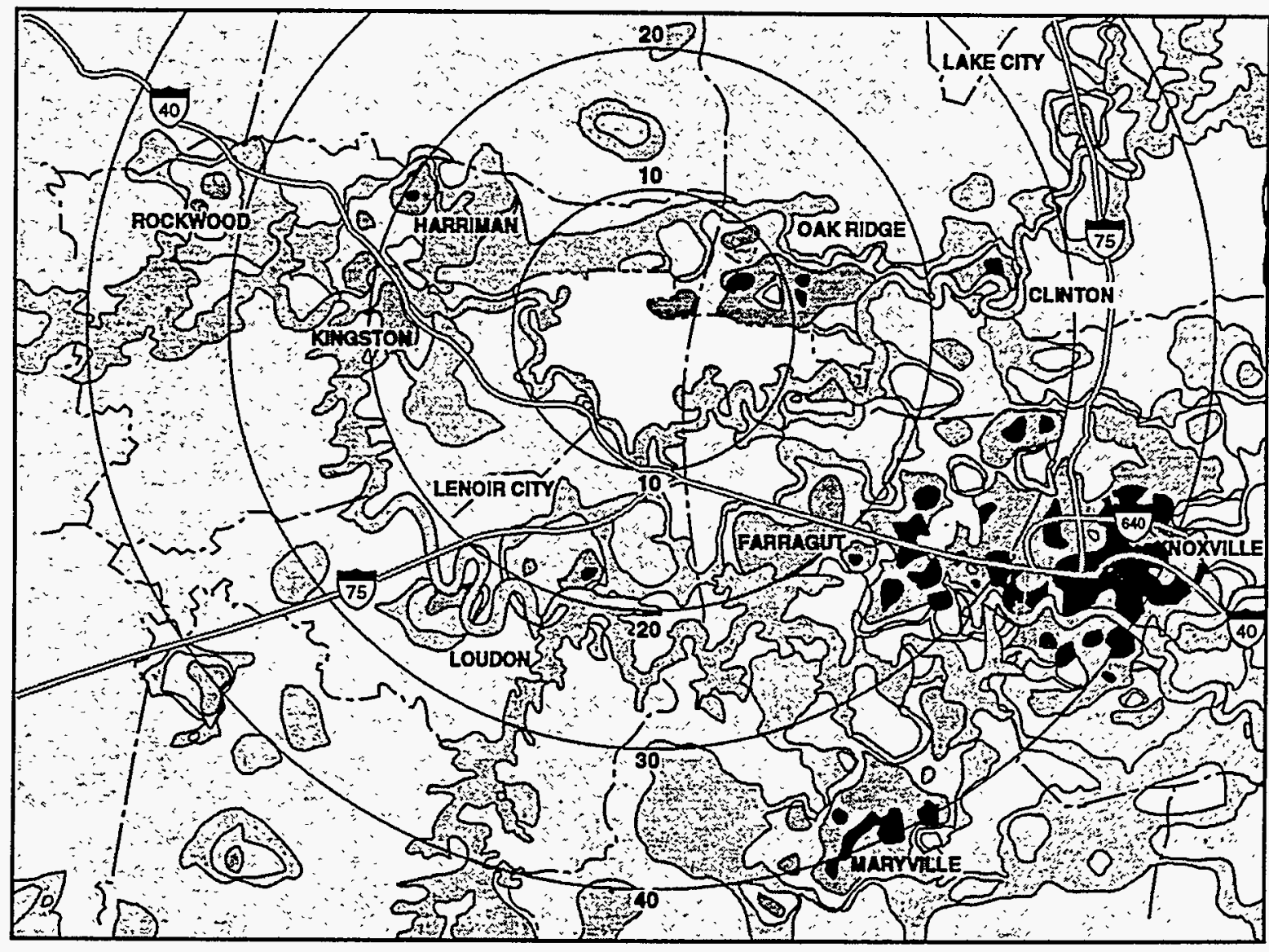

NOTE: Concentric circles rep:esent aggregate distances in kilometers.

\section{LEGEND}

$>1,000$ lnhabitants $/ \mathrm{km}^{2}$

251-1,000 Inhabitants/km²

101-250 Inhatiiants $/ \mathrm{km}^{2}$

50-100 In habitants $/ \mathrm{km}^{2}$

$<50$ Inhabitants/km² $\square$ Oak Ridge Reservation

Rivers and Lakes

(40) Interstate Highway

F-. County Line
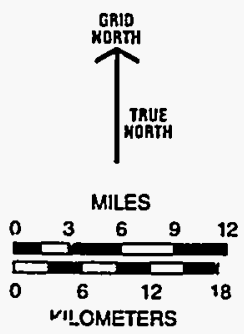

Fig. 5.4. Regional population density. Source: Energy Systems 1994

The geologic structure of the region is complex because of prehistoric faulting and deformation of the underlying material. The rock formations are sedimentary material (shales, limestone, sandstone, etc.) that have weathered and eroded at different rates depending on their composition. The ridges were formed by folding and faulting of compressed sedimentary materials due to converging tectonic plate movement during the Paleozoic era. Hard, resistant types of rock form the ridges, and the more easily eroded, less resistant bedrock forms the valleys. Over time, weathering and erosion removed the less resistant strata, leaving ridges composed of sandstone or cherty materials. Some rock is exposed, but soil cover ranges from $0.3 \mathrm{~m}$ to $10.7 \mathrm{~m}$ (1 to $35 \mathrm{ft}$ ) deep (Elder 1956). 


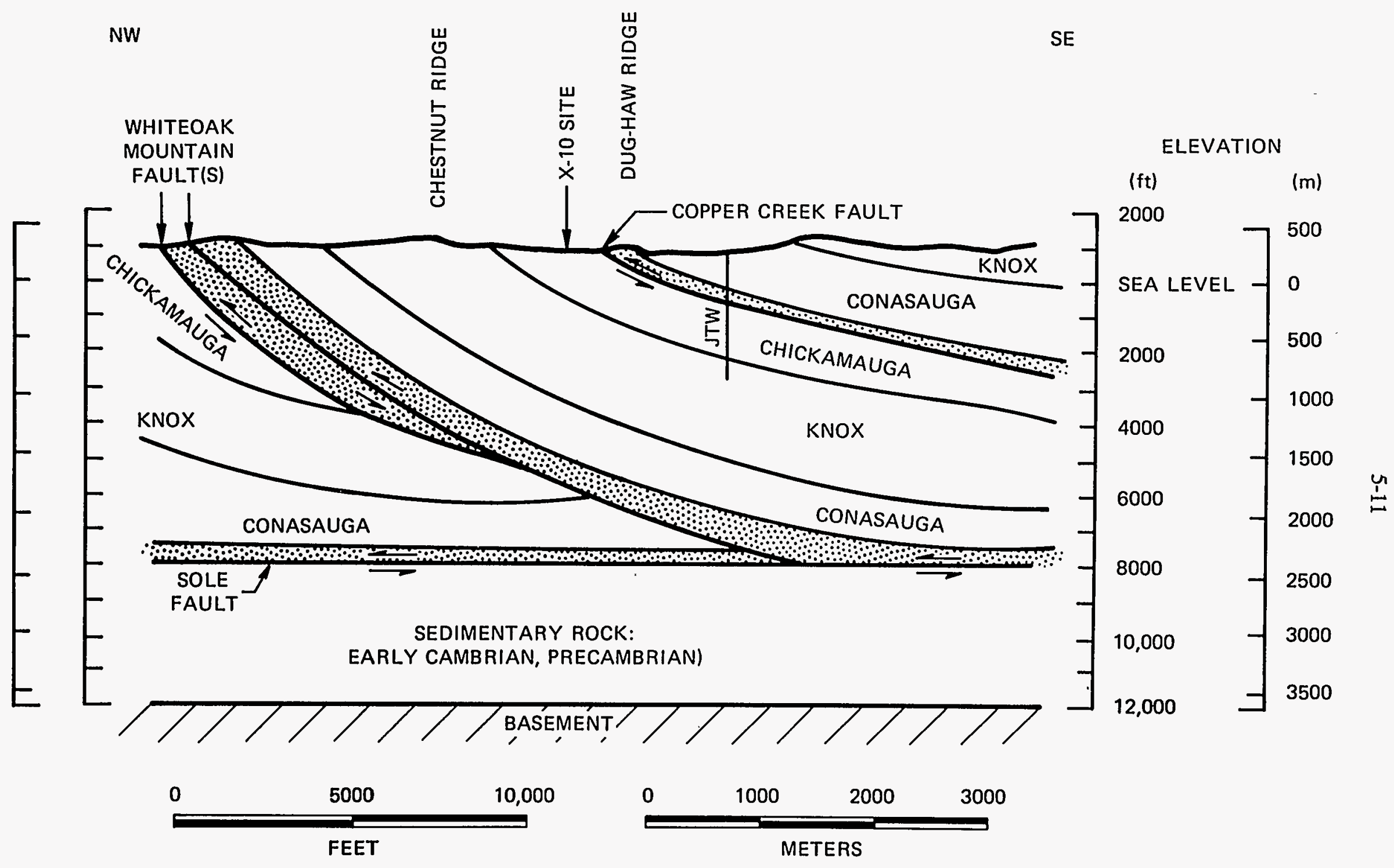

Fig. 5.5. Geologic cross section of the ORR. Source: ORNL 1987 
Principal geologic rock groups in the Valley of East Tennessee are the Rome Formation, the Conasauga Group, the Knox Group, Chickamauga Limestone, the Sequatchie Formation, the Rockwood Formation, Chattanooga Shale, the Maury Formation, and Fort Payne Chert.

There is no evidence of existing or capable faults in the Valley of East Tennessee. Several ancient fault zones within the region indicate past seismic activity, but the latest estimated movement was 280-290 million years ago. The region contains regional thrust faults, local thrust, normal and tear faults, local folding of relatively weak bedrock units, and widespread fracture development (Kornegay et al. 1992).

Native soils in the region are a mixture of eroded material from dolomite, shale, sandstone, and limestone. These soils are the residual material (residuum) from parent sedimentary rocks. In addition to the residuum, there are water-transported soils (alluvium) and washed-up rock soil deposits (colluvium). Table 5.4 identifies the predominant soil groups and associated soil series in the Valley of East Tennessee.

Table 5.4. Soil groups and associated series

\begin{tabular}{|c|c|}
\hline Soil group & Soil series \\
\hline & Residuum \\
\hline \multicolumn{2}{|l|}{ Geologic formation: } \\
\hline Rome Group & Lehew, Armuchee-Muskingum, Calvin \\
\hline Conausauga Group & Sequoia, Armuchee, Apison, Montevallo, Collegedale \\
\hline Knox Group & Fullerton, Bodine, Clarkesville, Dunmore \\
\hline Chickamauga Group & Gladeville, Talbott, Collegedale, Colbert, Upshur-Varian \\
\hline \multicolumn{2}{|r|}{ Colluvium } \\
\hline \multicolumn{2}{|l|}{ Source of colluvium: } \\
\hline Rome and Conasauga groups & Jefferson, Shouns, Leadvale, Shelocta \\
\hline Knox Group & Minvale, Tasso, Roane, Emory, Greendale, Tarklin \\
\hline \multicolumn{2}{|r|}{ Alluvium } \\
\hline \multicolumn{2}{|l|}{ Age of soil material: } \\
\hline Holocene/Modern & Hamblen, Pope-Philo, Newark, Melvin \\
\hline Pleistocene & $\begin{array}{l}\text { Allen, Dewey, Claiborne Holston, Waynesboro, Etowah, } \\
\text { Nolichucky }\end{array}$ \\
\hline
\end{tabular}

Source: Lietzke, Lee, and Tamura 1986

\subsubsection{Surface Water}

The surface hydrology in the Valley of East Tennessee is characterized by a trellis pattern in which the Tennessee River is the primary receiver of many secondary rivers and their tributaries, e.g., Powell, Clinch, Holston, French Broad, Little Tennessee, Hiwassee, Tellico, and Ocoee. The Tennessee River is formed by the juncture of the Holston and French Broad rivers at Knoxville. 
ORNL is located in the Clinch River watershed, which comprises about $11 \%$ of the Tennessee River watershed. Clinch River originates in southwestern Virginia and flows $563 \mathrm{~km}$ (350 miles) to join the Tennessee River at Kingston, Tennessee (Kornegay et al. 1992). It supplies essentially all of the water to the ORR, Oak Ridge, and other cities along its course. Because it is also the primary receiver of drainage from ORNL, discharges into the river are monitored to ensure that water passing downstream satisfies all applicable state and federal water quality standards.

The hydrologic system within the ORR (and therefore ORNL), is of major importance to the functioning of natural ecosystem processes as well as to the mobility and fate of contaminants. The hydrologic regime on the ORR, both surface water and groundwater, is controlled regionally by Clinch River, where water levels are regulated by TVA. Both surface water and groundwater drain into Clinch River through a network of small tributaries and streams in the White Oak Creek (WOC) basin (Fig. 5.6). Drainage from ORNL empties into WOC and several tributaries.

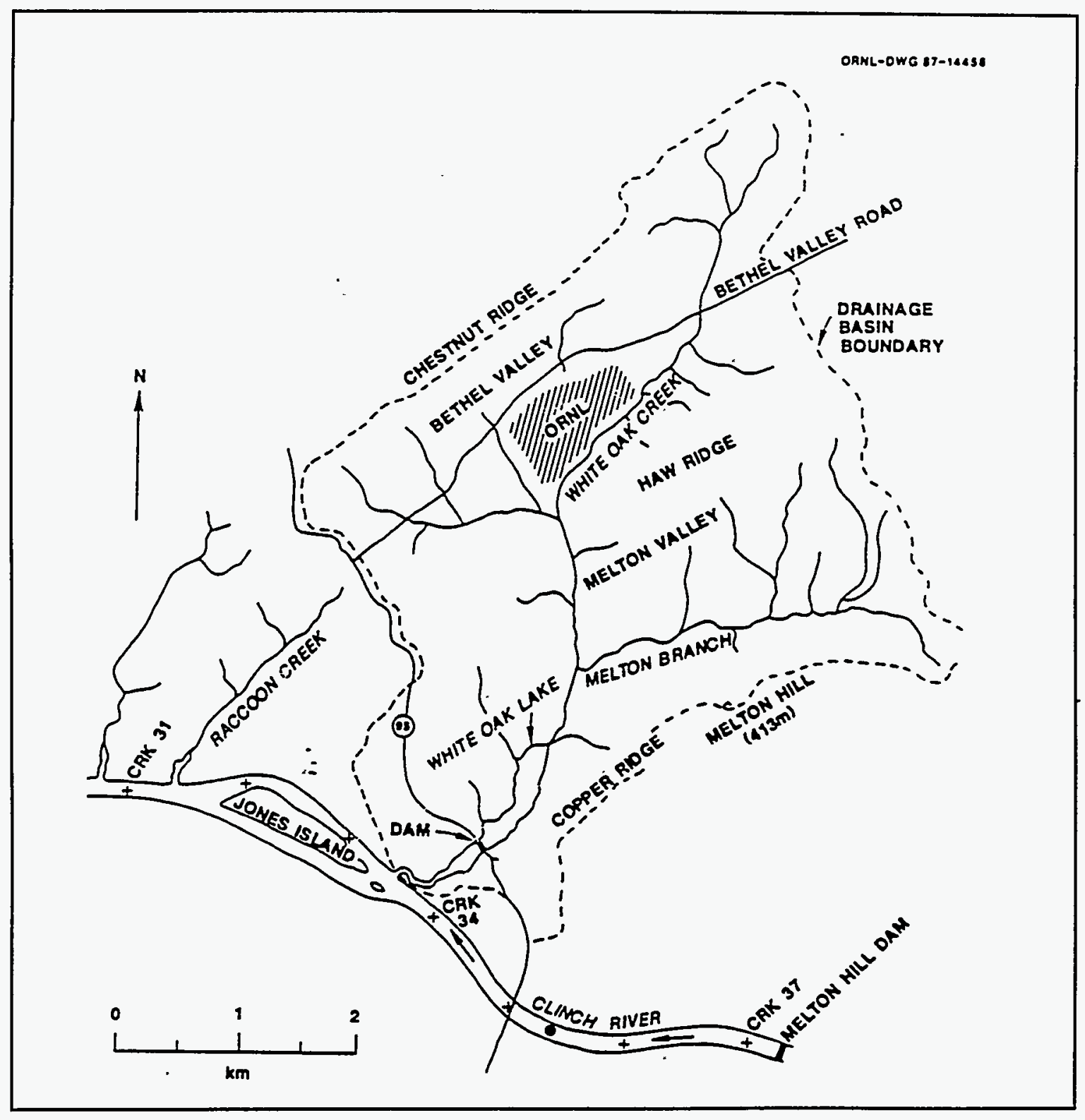

Fig. 5.6. Drainage from ORNL into White Oak Creek and its tributaries. Source: Energy Systems 1990 
Surface water is critically important at ORNL and on the ORR because it transports contaminated groundwater that seeps to the land surface. It erodes and transports contaminated sediments, and it deposits those sediments downstream, potentially causing exposures to people and biota. At the ORNL site, surface water must be viewed as a component of an integrated hydrologic system. The hydrologic cycle for ORNL consists of inputs, transports, and outputs as shown in Table 5.5 (Solomon et al. 1992).

Table 5.5. ORNL hydrologic cycle

\begin{tabular}{lll}
\multicolumn{1}{c}{ Inputs } & \multicolumn{1}{c}{ Transports } & \multicolumn{1}{c}{ Outputs } \\
\hline Precipitation & Overland flow & Evapotranspiration \\
Plant effluents & Storm flow & Surface water discharge \\
& Shallow and deep groundwater & \\
\hline
\end{tabular}

The ORNL hydrologic site conceptual model has focused largely on the flow paths and transport mechanisms of contaminants moving from buried waste sources to streams. The dynamics of contaminant concentration and flux vary within storms and throughout the year. Data collected show a clear trend of dilution during storms and also suggest a seasonal trend. This seasonal trend is actually an annual cycle between a wet season and a dry season (Clapp, Watts, and Guth 1994).

In the conceptual hydrologic model for subsurface flow (Fig. 5.7), nearly all precipitation falling on hillsiopes underlain by shale formations (where most of the buried waste is located) infiltrates into the soil. Most of the infiltrated water moves laterally to nearby tributaries via the macropores and fractures in the stormflow zone (upper 1-2 m of soil). A small portion of the infiltrated water moves vertically to the water table, where it again tends to move laterally to the nearby tributary via fractures in the saprolite (weathered rock) and bedrock. This shallow groundwater zone is termed the water table interval. A very small portion moves downward to the intermediate and deep groundwater intervals. Contaminants leached from shallow burial trenches can be transported in all of these flow paths (Clapp, Watts, and Guth 1994).

Figure 5.8 depicts the conceptual model of tributaries that drain into the main streams at ORNL. As shown, subsurface flow paths conduct water and leached contaminants from disposal sites to the receiving tributaries. Three regimes or stages of stream flow in tributaries can be defined.

1. Under baseflow conditions, stream flow is generated entirely from groundwater contributions from lateral flows draining the shallow water table interval plus minor groundwater input from the intermediate zone.

2. During moderate precipitation events, rainwater infiltrates into the surface soil layer and reaches the stream via shallow subsurface stormflow (lateral flow in he upper $2 \mathrm{~m}$ of the soil).

3. During extreme storm events, the intensity of precipitation is greater than the infiltration capacity of the surface soil, and rainwater collects on the surface and flows down slope to the stream as overland flow (Borders et al. 1994).

The three flow regimes described above define the conditions that transport contaminants into tributaries and to their eventual discharge off site. Comparison of contaminant concentration in stream flow versus discharge relationships before and after remediation provides a direct method for determining the effectiveness of remedial action. This concept is described and illustrated in the Second Annual Environmental Restoration Monitoring and Assessment Report for FY 1993 of the Oak Ridge National Laboratory, Oak Ridge, Tennessee (Clapp and Watts 1993). 
ORNL DWG 92M-14064

\section{Dip Section}

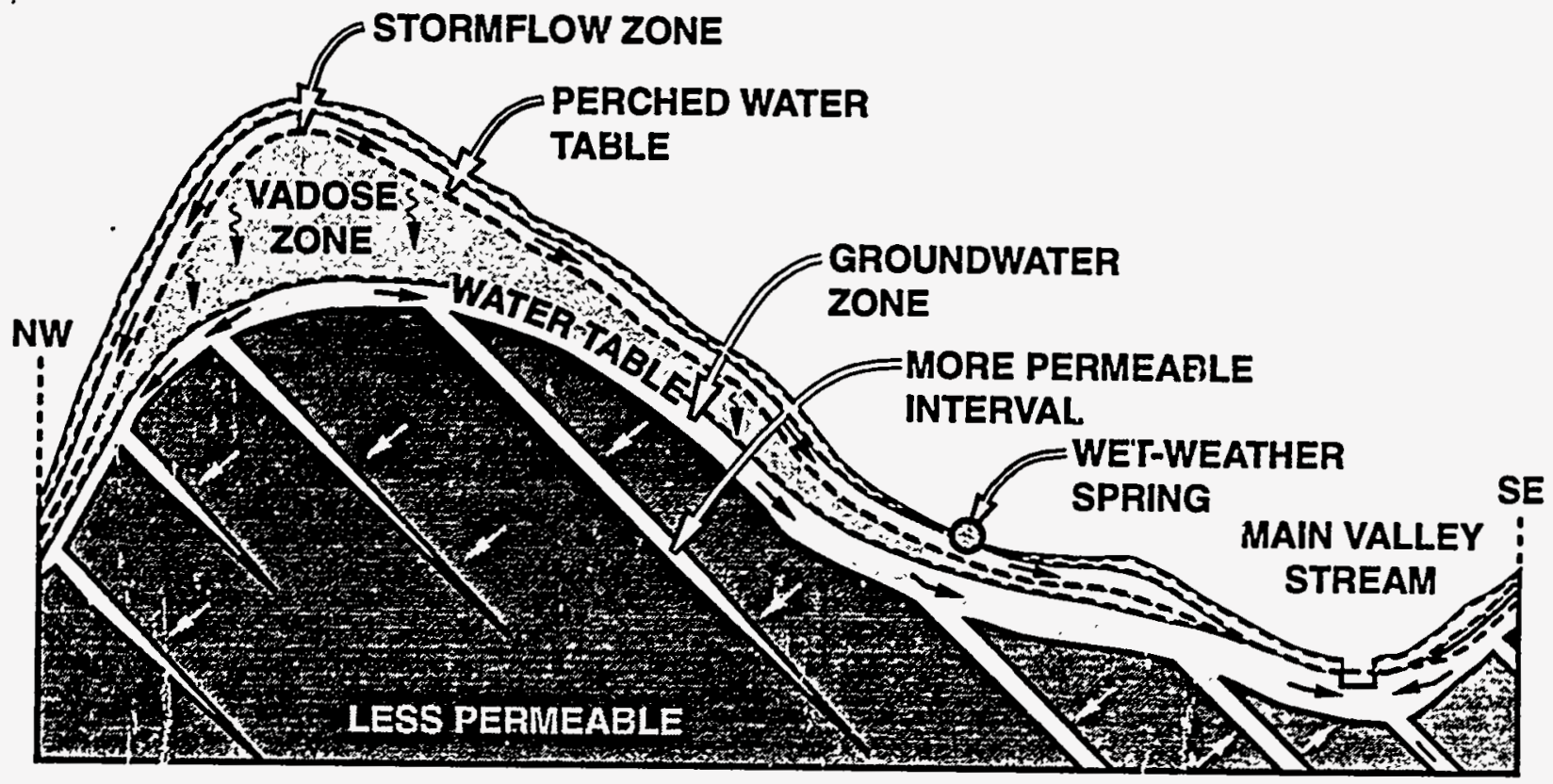

\section{Strike Section}

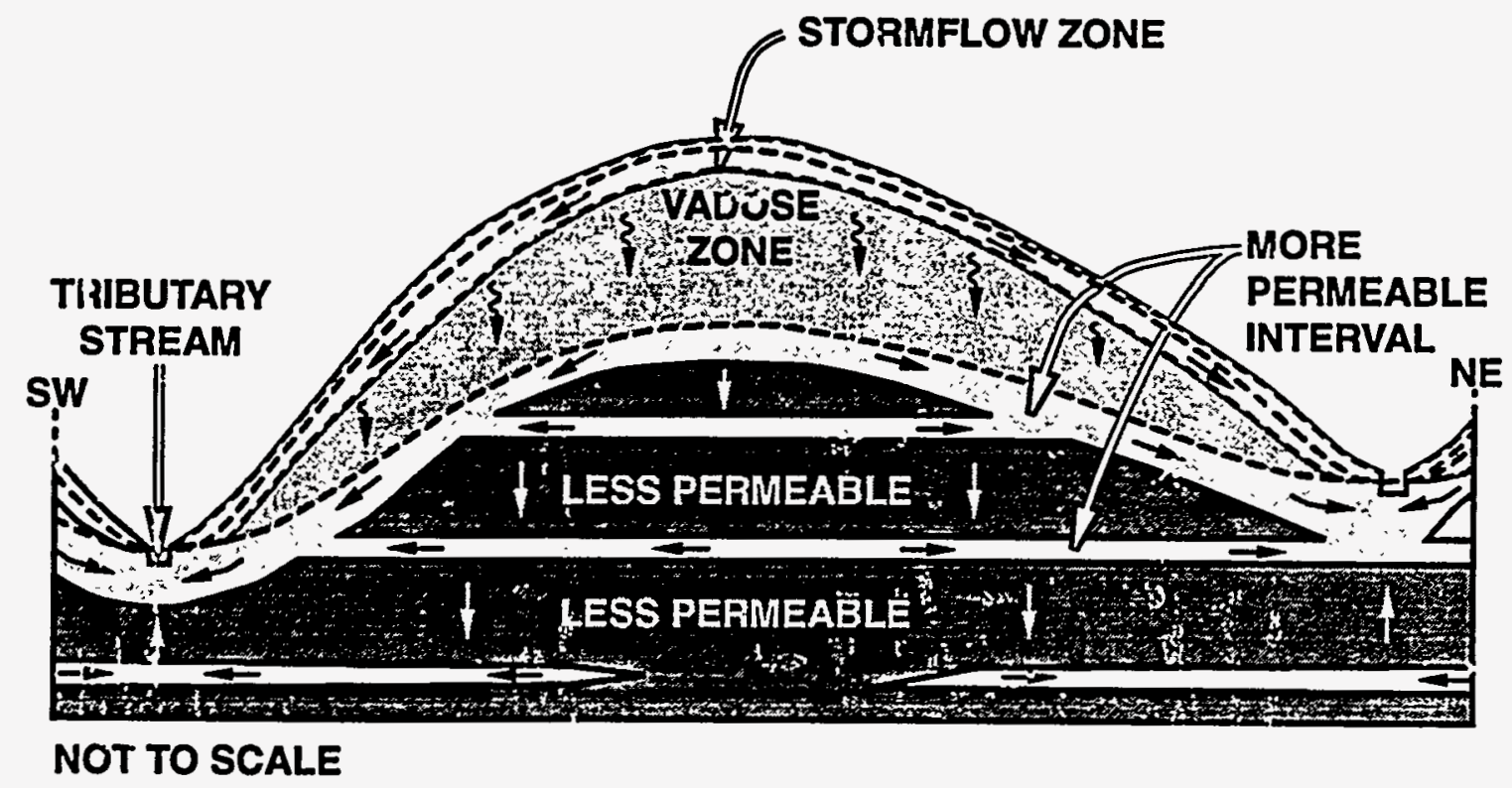

Fig. 5.7. Conceptual hydrologic model for subsurface flow in shale aquitard at ORR. Source: Clapp, Watts, and Guth 1994 


\section{Discharge and Soluble Contaminant Fluxes Draining ORNL Disposal Sites}

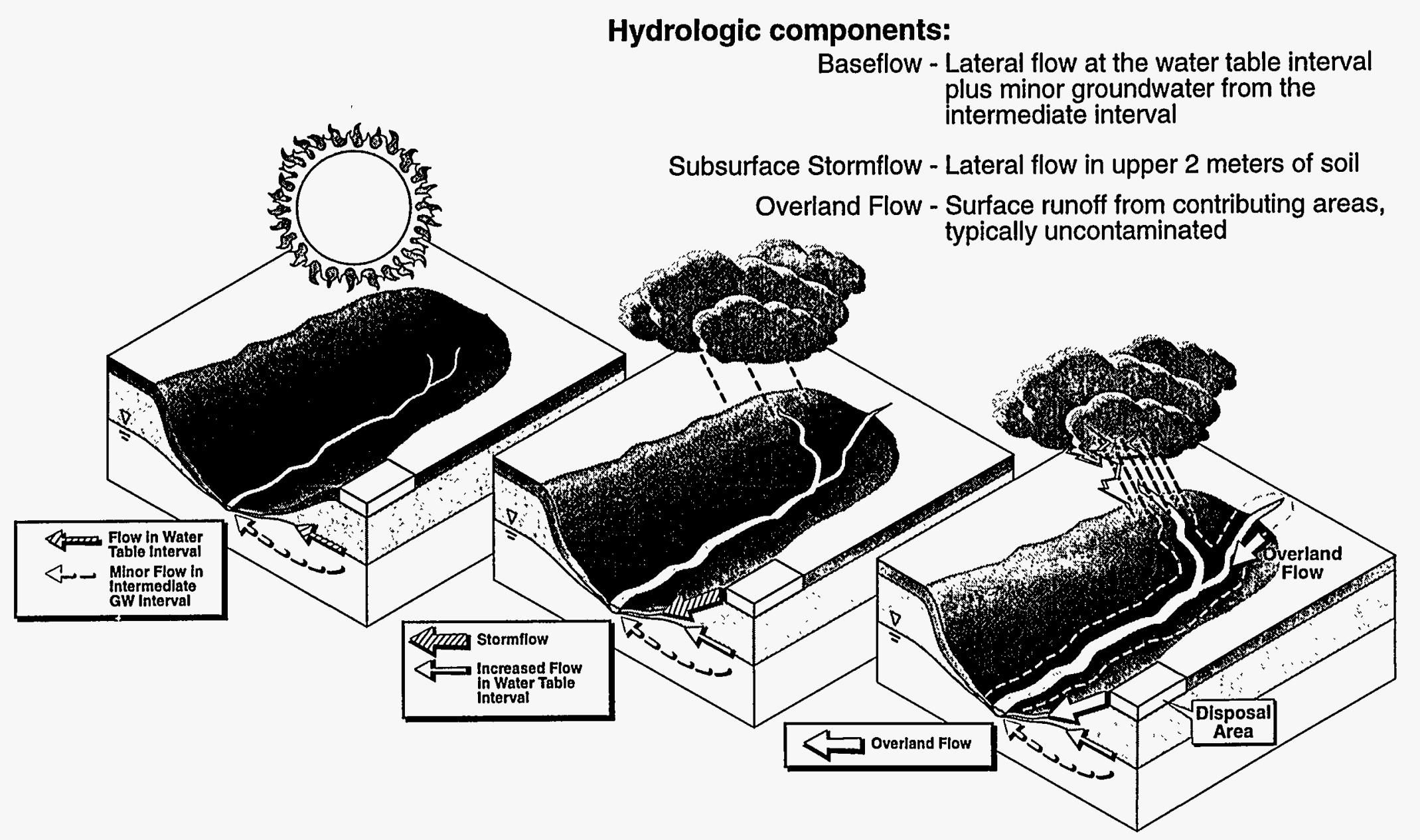

Fig. 5.8. Conceptual model for tributaries draining ORNL waste sites. Source: Clapp, Watts, and Guth 1994 


\subsubsection{Groundwater}

At ORNL, and on the ORR in general, there is a close relationship between surface water and groundwater drainage patterns. The distinction between surface water and groundwater is largely artificial because most of the surface water in the geological setting at ORNL has infiltrated into the soil, traveled through the subsurface, and emerged at springs or seeps (Solomon et al. 1992). Groundwater in the Oak Ridge area flows generally from locations at higher elevations to lower elevations, discharging into streams and Clinch River, thus sustaining baseflow to these systems. A stream will typically gain and lose flow as subsurface water seeps into the stream channel. Where streams flow over carbonate bedrock units in which solution features exist, loss of stream water to the subsurface can occur.

In general, the groundwater quality on the ORR is good, and with few exceptions, ORR groundwater discharges presently meet drinking water standards (Solomon et al. 1992). However, groundwater must be viewed as a potential pathway for exposure to hazardous wastes and as a mechanism for contaminant transport. Typically, contamination is promoted by developing or using land underlain by shallow groundwater and in karst areas by the presence of numerous direct conduits to groundwater.

Contamination is often associated with leaks in waste disposal facilities and buried pipelines or accidental spills. Once within groundwater, though, contaminant migration is buffered by the transport process and related natural chemical and physical processes in the subsurface, including diffusion and adsorption. Generally, an instantaneous release of contaminants from a primary source, such as the failure of a container, will not result in an immediate loading to steams (Solomon et al. 1992). For example, contaminants such as tritium moving from a waste area can be delayed for several to many decades in the aquitards, even along flow paths as short as a few hundred feet (Kornegay et al. 1992).

The processes that naturally retard contaminant migration and that store contaminants in the subsurface, however, are likely to be less effective in the Knox aquifer than in the aquitards. For this reason, landforms on the ORR aquitards are more suitable for waste storage than those on the Knox aquifer. Aquitards have shallow soils because of this impermeability. Additionally, while the transport processes through a porous subsurface serve to buffer contaminant migration, it also represents a secondary contaminant source that may persist for decades (Solomon et al. 1992).

The hydrologic framework or conceptual model (Solomon et al. 1992) serves as a starting point for understanding and studying the processes that control the migration of contaminants derived from leaks, spills, and leachates from buried wastes. The main ideas of the conceptual model were introduced in Sect. 5.2.5, "Surface Water."

\subsubsection{Hydrogeologic system}

In the Valley of East Tennessee, groundwater occurs in bedrock, in the regolith (loose rocky material resting on bedrock), and in a few alluvial aquifers along the largest rivers (Kornegay et al. 1992). Aquifers in the Valley of East Tennessee are carbonate aquifers, which are made from limestone and dolomite (Wilson 1982).

Groundwater presence and flow on the ORR (and therefore ORNL) is heavily influenced by the underlying geologic structure. Geologic rock units through and upon which groundwater passes affect its flow and quality. Geologic units on the ORR are assigned to two broad hydrologic groups: (1) the Knox aquifer (formed by the Knox Group and Maynardville limestone and part of the 
Cambrian-Ordovician Carbonate aquifer in East Tennessee), in which water presence and flow is dominated by solution conduits and which stores and transmits relatively large volumes of water, and (2) the ORR aquitards (formed by Rome, Conasauga, and Chickamauga rock units), in which flow is controlled by fractures and which may store fairly large volumes but transmit only limited amounts of water (Solomon et al 1992).

Both the Knox aquifer and the ORR aquitards are divided into the following vertical zones:

- the stormflow zone-a thin region near the soil surface in which transient precipitationgenerated flow accounts for an estimated $90 \%$ or more of the water moving through the subsurface and which is a major pathway for transporting contaminants from near surface sources to streams;

- the vadose zone-an unsaturated zone mostly in soil and saprolite above the water table that may be saturated locally on a transient basis;

- the groundwater zone-a continuously saturated region in which most of the remaining $10 \%$ of subsurface flow occurs and which is subdivided into the water table interval, the intermediate interval, and the deep interval; and

- the aquiclude - a zone in which water movement in negligible (Solomon et al. 1992).

Figure 5.9 shows the vertical division of the Knox aquifer and aquitards on the ORR and their typical thicknesses.

Groundwater flow is predominantly a near-surface phenomenon, influenced by topography, surface cover, and geologic structure and lithology. As such, the Knox aquifer is the primary source of sustained natural flow in perennial streams such as WOC at ORNL. Large springs on the ORR also discharge from this aquifer. Significant water movement may also occur at great depth $[>300 \mathrm{~m}$ $(100 \mathrm{ft})]$ along thrust faults and other large fissures in parent rock material. In some places the Knox aquifer can supply large quantities of water to wells. Flow volumes in the aquifer are significantly larger than in the aquitards, and flow paths are deeper. Additionally, the potential flow path length in the Knox aquifer is substantially greater than in the aquitards. The regional groundwater discharge area is thought to be Clinch River, and little flow beneath it is likely. Within the ORR, streams and tributaries are local discharge areas, and groundwater divides are usually assumed to be approximately equivalent to surface water divides, except in karst areas. (Solomon et al. 1992, Kornegay et al. 1992).

The depth to water table is generally greatest from October to December and least from January to March. The range of season fluctuations in depth to the water table and in rates of groundwater flow vary significantly across the ORR. In areas of the Knox aquifer, seasonal fluctuations in water

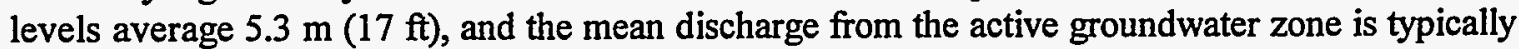
$85 \mathrm{gal} / \mathrm{min} / \mathrm{mile}^{2}$. In the Bethel Valley aquitard, seasonal fluctuations in water levels average $1.5 \mathrm{~m}$ (5 ft), and typical mean discharge is $26 \mathrm{gal} / \mathrm{min} / \mathrm{mile}^{2}$ (Kornegay et al. 1992, Solomon et al. 1992). Usually, flow divides, which occur beneath hills and ridges, are the areas of greatest seasonal fluctuation in water levels. The depth to the aquiclude is $\sim 180-240 \mathrm{~m}(594-792 \mathrm{ft})$ in Bethel Valley. The depth to the aquiclude in areas of the Knox aquifer is not known (Solomon et al. 1992).

\subsubsection{Characteristics of the groundwater zone}

The most important characteristic of the stormflow zone (the permeable upper 1-2 $\mathrm{m}$ of soil), is its capacity to conduct water down slope during and shortly after a storm. In the conceptual model 


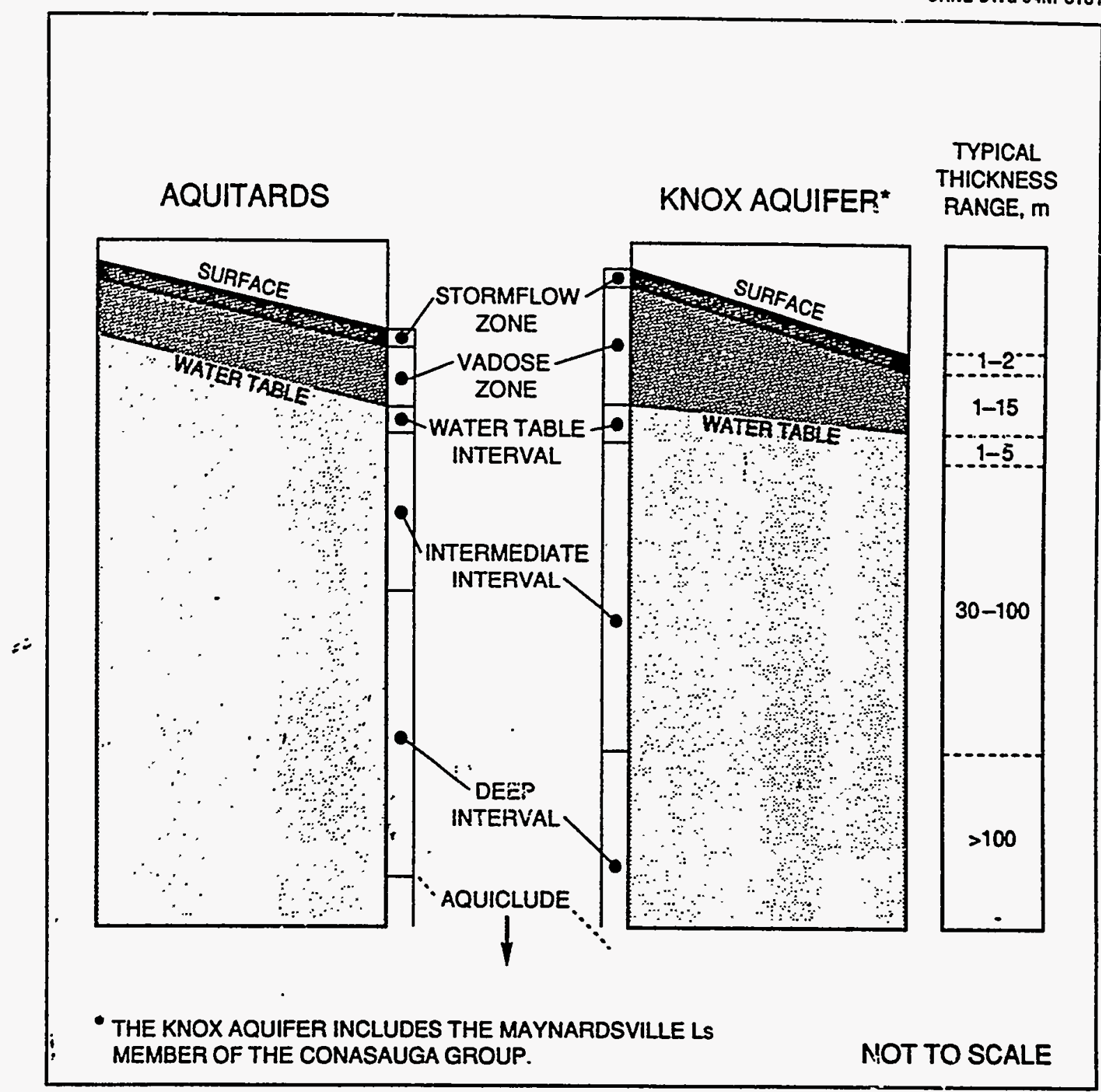

Fig. 5.9. Schematic vertical relationships of flow zones of the ORR and their estimated thicknesses. Source: Energy Systems 1994

it is estimated that $>90 \%(\sim 55 \mathrm{~cm} / \mathrm{year})$ of the water that moves out of the stormflow zone (excluding evapotranspiration) is routed to springs and seeps at the toe of the slope. Beneath the stormflow zone is the vadose zone, which receives $<10 \%$ of the flux. The vadose zone exists throughout the study area except where the water table intersects the ground surface, such as along perennial streams and springs (Clapp 1992).

At the bottom boundary of the vadose zone, the water table serves as the upper boundary to the groundwater zone, which is subdivided into intervals. The uppermost subdivision is the water table interval, estimated to be 1-3 m thick with interconnected fractures that direct water laterally to 
adjacent streams. Of the $10 \%(\sim 6 \mathrm{~cm} /$ year $)$ flux arriving at the water table interval, most is routed laterally, and less than about $2 \%$ or $1 \mathrm{~cm} /$ year moves to the next interval.

The existence of a distinct water table interval is inferred from annual well hydrographs, which show that the seasonal change in groundwater elevation is confined to a small range and that water levels never drop much below the soil/bedrock interface even during prolonged droughts. Some hydrologic data do not support the concept of the water table zone. In the vadose zone and the upper part of the groundwater zone (i.e., the water table interval and the upper part of the intermediate interval) there appears to be little or no change in hydraulic conductivity with depth (to depths of approximately $50 \mathrm{~m}$ ) within the unconsolidated material, and conductivity ranges from 0.006 to $0.3 \mathrm{~m} / \mathrm{d}$. This wide range in conductivity over most depth intervals indicates that some wells monitor zones of variable conductivities within the regolith, such as fractured zones, rather than more clay rich zones (Clapp 1992).

With the conceptual model, the base of the water table interval corresponds to the zone of transition of the soil (regolith) to the bedrock. Beneath the water table zone is the intermediate interval of the groundwater zone where groundwater movement occurs primarily in the permeable fractures that are poorly connected in three dimensions. Fracture sets and bedding planes control the flow directions. The system is shown in Fig. 5.7. Ketelle and Lee (1992) have used contaminant plume data, stratigraphic data, and structural geologic data to confirm the concept of strata bound flow of groundwater and contaminants in WAG 1 at ORNL.

With increasing depth the chemical characteristics of groundwater change from a mixed-cation $\mathrm{HCO}_{3}$ water type to a $\mathrm{NaHCO}_{3}$ type at depths ranging from 30 to $50 \mathrm{~m}$ (Table 5.6 and Fig. 5.10). Although the geochemical mechanism responsible for this change is not entirely quantified, it probable is related to water residence time. The transition from $\mathrm{CaHCO}_{3}$ to $\mathrm{NaHCO}_{3}$ serves as a useful marker and is used to distinguish the intermediate groundwater from the deep interval, a transition that is not marked by a distinct change in rock properties.

Table 5.6. Approximate relationship among depth, flow interval, and water type for the ORR aquitards

\begin{tabular}{ccc}
\hline $\begin{array}{c}\text { Depth below permanent water table } \\
\text { to bottom of flow interval }(\mathrm{m})\end{array}$ & Interval or zone & Water type \\
\hline $1-3$ & Water table & $\mathrm{Ca}-\mathrm{HCO}$ \\
$20-50$ & Intermediate & $\mathrm{Na}-\mathrm{HCO}_{3}$ \\
$150-400$ & Deep & $\mathrm{Na}-\mathrm{HCO}_{3}$ to $\mathrm{Na}-\mathrm{Cl}$ \\
\hline
\end{tabular}

Below the intermediate interval, small quantities of water are transmitted through discrete fractures in the deep interval. The fractures are fewer in number and shorter in length than in the other intervals. Wells finished in the deep interval typically yield $<0.1 \mathrm{~L} / \mathrm{min}$ and thus have no potential for water supply.

The groundwater zone terminates at the aquiclude where the water is saline. The depth to the aquiclude is about $180-240 \mathrm{~m}$ in Melton and Bethel valleys (Clapp 1992). 
ORNL-DUS $92 \cdot 9377$

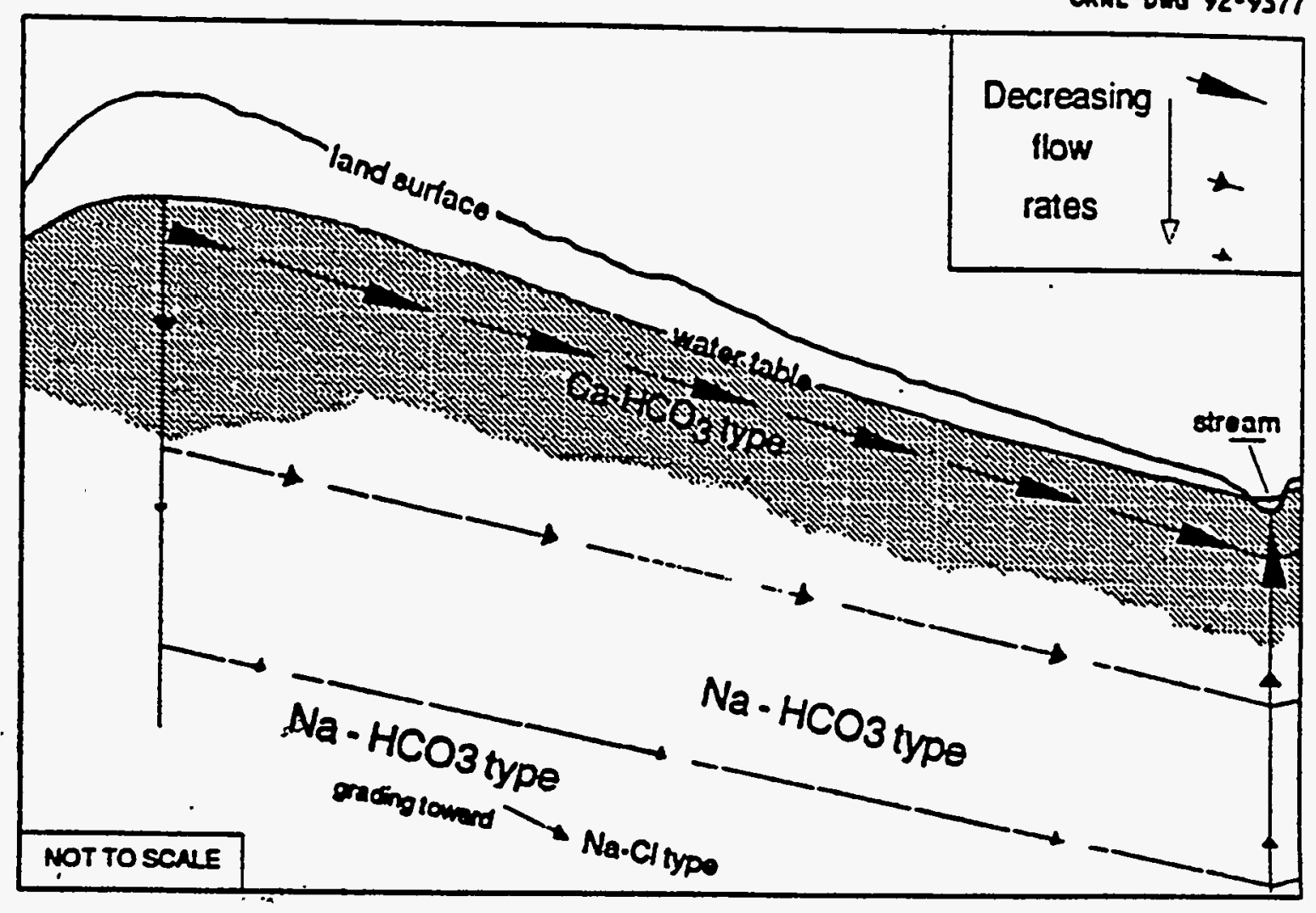

Fig. 5.10. Schematic cross section showing very generalized flow paths, related geochemical evolution, and relative flow rates. Source: Clapp 1992

\subsubsection{Importance of fractures and secondary sources}

In the conceptual model, fractures in the intermediate and deep zone are important because they can conduct small amounts of contaminants great distances over short time periods. Tritium observed in wells at depths of 60-100 m suggests that the radionuclide may have moved at velocities of about $150 \mathrm{~m} /$ year (Solomon et al. 1992, Toran et al. 1991). However, the mass of contaminants transported is small to insignificant compared with contaminant transport in other pathways. Flow in fractures also causes the accumulation of secondary sources of contamination, as described here.

Subsurface systems at the ORR consist of discrete fractures within a matrix of porous rock. When a contaminant is first introduced into fractured porous media, very large concentration gradients can occur between fractures and the surrounding porous matrix. Because of molecular diffusion, dissolved species can migrate into the porous matrix, even when no net transfer of fluid between fractures and matrix occurs. When the volume of matrix water is large relative to the volume of fracture water, this process, known as matrix diffusion, can result in substantial dilution and attenuation of migrating contaminants. However, once primary contaminant sources (i.e., waste trenches) diminish in strength, contaminants can diffuse out of the porous matrix into fracture pathways, resulting in secondary contaminant sources.

The process of matrix diffusion has far-reaching implications for environmental restoration at ORNL. The short-term effectiveness of remedial actions aimed at reducing the discharge of contaminants from subsurface to surface water systems depends critically on the mass of 
contaminants presently stored within the porous matrix (i.e., the strength of secondary sources relative to primary sources). If the contaminant mass within the matrix is small, source-level remediation such as source removal, grouting, compaction, and in situ vitrification would reduce contaminant discharge shortly after remediation. If the contaminant mass in the matrix is large, only remediations that eliminate both primary sources (e.g., trench leachate) and secondary sources (i.e., diffusion out of the matrix) will effectively reduce contaminant discharge. However, if the secondary source is located below the water table, even techniques for large-scale hydrologic isolation such as local capping and French drains may be unsuccessful because groundwater will continue to move through the secondary source area (Clapp 1992).

\subsubsection{Ecology}

The general vegetation cover on the ORR is about $80 \%$ forest. Plant communities on and near the ORR are characteristic of those found in the intermountain regions of central and southern Appalachia. The dominant forest is of the oak/hickory association and is most widely distributed on ridges and dry slopes. Other hardwoods such as yellow poplar, beech, buckeye, and white ash, are found in coves interspersed along the dissected ridge system. Coniferous forest are largely cedar, white pine, and shortleaf pine (Cunningham et al. 1993).

Seventeen plant species known to be present on the ORR are listed by the Tennessee Department of Environment and Conservation as either endangered, threatened, or of special concern. It should be noted, though, that for most of the ORR, detailed rare plant surveys have not been performed, and the rare species list for the ORR is not complete.

The various habitats found on the ORR accommodate a wide variety of wildlife species typical of East Tennessee. There are five animal habitats identified on the ORR: old fields and grasslands, hardwood/mixed hardwood forests, pine plantations, aquatic and riparian areas, and caves.

Small mammals are the primary inhabitants of the old field and grassland habitat. These include several species of shrew, the eastern harvest mouse, the hispid cotton rat, the pint mouse, and the eastern cottontail rabbit. Closely mowed or grazed areas are inhabited by groundhogs, cottontails, striped skunks, coyotes, red foxes, and deer. Large mammals, such as deer and coyote, range over wide areas and a variety of habitat types that provide forage or prey. Birds found in this habitat include bobwhites, red-tailed hawks, field sparrows, towhees, blue grosbeaks, meadowlarks, red-winged blackbirds, and eastern bluebirds. Frogs, toads, lizards, and snakes also are found in the old field areas.

Inhabitants of the hardwood/mixed hardwood habitat include small mammals, such as flying squirrels, southeastern shrews, eastern moles, white-footed mice, and eastern chipmunks. The predators in these areas are weasels and bobcats. Birds commonly found in forest areas include yellow-shafted flicker, red-bellied woodpecker, hairy woodpecker, downy woodpecker, blue jay, and Kentucky warbler.

Pine plantations are essentially barren of both small and large mammals due primarily to the dense canopy which shades out most undergrowth (Parr and Evans 1992).

Aquatic habitats on the ORR include numerous Clinch River tributary systems and several liquid waste disposal ponds. Dominant species found in Clinch River near the ORR are gizzard shad, threadfin shad, skipjack herring, carp, smallmouth buffalo, white bass, white crappie, sauger, and freshwater drum. Reptiles and amphibians found in these areas include turtles, queen snakes, water 
snakes, salamanders, and frogs. Muskrat and beaver are found close to aquatic areas. Mink and raccoon are found in aquatic habitats but range into forest and field areas.

Canada geese, great blue herons, and green-backed herons have established nesting areas near streams, lakes, and rivers on the ORR and in the surrounding area. Osprey nesting platforms have been set up to encourage that species to nest on the ORR. The American bald eagle is an occasional, transient visitor but does not nest on the ORR.

Caves are common to the area, and several species of bat are the only mammals to live deep in these caves (Parr and Evans 1992).

Kroodsma (1993) states that no threatened or endangered animal species (aquatic and terrestrial invertebrates and vertebrates) or critical habitat listed, or proposed to be listed, by the U.S. Fish and Wildlife Service is known to be present on the ORR, with the exception of the bald eagle. Also, the endangered Indian bat is a possible summer resident along East Fork Poplar Creek and must be included in environmental considerations for proposed construction projects in the area.

Several animal species listed by the state of Tennessee as threatened, endangered, or in need of management are known to occur on the ORR (Table 5.7).

Table 5.7. Habitats and status of rare animal species known to exist on the Oak Ridge Reservation

\begin{tabular}{llc}
\hline \multicolumn{1}{c}{ Species } & \multicolumn{1}{c}{ Location } & Status $^{2}$ \\
\hline $\begin{array}{l}\text { U.S. Fish and Wildlife Service } \\
\text { Bald Eagle }\end{array}$ & Melton Hill Lake and Clinch River \\
$\begin{array}{l}\text { State of Tennessee } \\
\text { Tennessee dace }\end{array}$ & $\begin{array}{l}\text { Bear Creek drainage, Ish Creek, and tributaries of East } \\
\text { Fork Poplar Creek }\end{array}$ & INM \\
Osprey & Vicinity of Melton Hill Reservoir and Clinch River & E \\
Sharp-shinned hawk & $\begin{array}{l}\text { Area between Jones Island, Grubb Island, and 500-kV } \\
\text { power line }\end{array}$ & E \\
Cooper's hawk & Entire ORR & T \\
Grasshopper sparrow & Large grassy fields & T \\
Black-crowned night heron & Clinch River & INM \\
Black vulture & Entire ORR & INM \\
Red-shouldered hawk & Forest and fields along Clinch River and relatively & INM \\
large streams; Solid Waste Storage Area 7 site & \\
\hline
\end{tabular}

${ }^{\mathrm{E}} \mathrm{E}=$ endangered; $\mathrm{T}=$ threatened; $\mathrm{INM}=$ in need of management.

Source: Kroodsma 1993 


\subsection{ACTIVE SITE-WIDE PROJECTS}

\section{Instructions to User}

Remediation is an ongoing process, and the status of active projects can change quickly. For the most up-to-date information about ORNL site-wide projects, check the Annual Environmental Restoration Monitoring and Assessment Report and the Federal Facility Agreement Quarterly Report.

\subsubsection{Surface Water Program}

In 1994 the scope of work on WAG 2 was limited to exclude consideration of transient waterborne contaminants, and a new organization named the ORNL Surface Water Program (SWP) was formed. SWP's purpose is to act as a management tool to aid decision making, accelerate cleanup actions, and enable efficient operation of Environmental Restoration (ER) Program work at ORNL. SWP was identified separately from the WAG 2 RI in the 1995 fiscal year work agreement.

The objectives of SWP are to (1) quantify contaminant releases across the ORNL site; (2) help develop priorities for RIs and remedial actions; (3) identify likely mechanisms for contaminant releases from sources; and (4) assess the performance of remedial actions. SWP includes hydrologic and contaminant flux assessments activities conducted at the ORNL site-wide scale, as well as contaminant flux monitoring activities that are specific to source-scale corrective actions. The SWP includes assessment and technical tasks consisting of field and laboratory activities, as well as the health and safety, quality assurance, records, and data management support required for the effective conduct of SWP operations.

SWP implementation is proceeding in three steps: (1) initiation of tasks essential to the maintenance of ER Program activities (under command documents and procedures produced previously through the WAG 2 \& Site Investigations Program); (2) assessment of ER Program needs and requirements, resulting in development of an SWP plan; and (3) implementation of those rescoped SWP tasks identified in the SWP plan as necessary to carry out the mission of the ER Program.

Surface water monitoring and assessment activities largely fall into four separate tasks:

- The Watershed Hydrology Task provides rainfall and discharge measurements used for data analysis, calculating contaminant fluxes, and modeling contaminant transport through the WOC system. The modeling effort, in turn, assists in evaluating the effects of alternative designs for proposed remedial actions.

- The Seep Task collects radiological and chemical data from seeps, tributaries, and main stream sites. These data provide "snapshots" of contaminant sources and movement throughout the watershed, but especially in the vicinity of WAG 2. The data depict the spatial distribution of contaminant sources.

- The Tributary Assessment Task performs intensive sampling at tributaries known to contribute significant amounts of contamination to the WOC system. The data collected under this task show the effects of storms on contaminant transport; they also help identify the mechanisms of contaminant mobilization and transport. 
- The Surface Water Chemistry Task gathers data collected by the Office of Environmental Compliance and Documentation, Environmental Surveillance and Protection Section to determine flux throughout the system. Under this task, technical staff interpret hydrologic and contaminant data to improve the conceptual model of contaminant mobilization and transport on a watershed scale.

The conceptual model for ORNL surface water is presented in Sect. 5.2.5.

\subsubsection{Groundwater Watershed}

Groundwater investigations at ORNL are performed under two major programmatic areas: the ORNL ER Program and the ORNL Compliance Monitoring Program implemented by the Office of Environmental Compliance and Documentation. Data acquisitions by these two programs is coordinated at the site level to facilitate sharing of information and to prevent duplication of effort and expenditures in groundwater monitoring activities.

The ER Program maintains a site-wide perspective on groundwater monitoring and assessment because (1) groundwater flow paths are not confined to the boundaries of the source WAGs, (2) site-wide assessment is needed to set priorities for groundwater remedial actions, and (3) information about groundwater transport mechanisms should be applied across the entire ORNL site. The broad perspective provided by the ORNL Area Groundwater Program is important to the ER Program and ORNL because it provides the basis for integrating data from varying sources and geographic areas necessary to answer key site management questions. Examples of the site management activities influenced by the Area Groundwater Program include establishing priorities for well plugging and abandonment, defining the data collection needs for area-wide groundwater level monitoring, providing site conceptual models for source WAGS, and providing technical support for Comprehensive Environmental Response, Compensation, and Liability Act activities and removal plans.

The ORNL Groundwater Watershed encompasses all of Bethel Valley, Melton Valley, and Haw Ridge between Bearden Creek, as the eastern boundary, to Clinch River, as the western boundary (Fig. 5.11). The obvious geographical boundary formed by Haw Ridge separates the Bethel Valley and Melton Valley portions of the ORNL Groundwater Watershed. The southern boundary of the Groundwater Watershed is the geologic contact between the Nolichucky shale and the Maynardville limestone of the Conasauga Group, and the northern boundary is the base of the Fleenor formation of the Chickamauga Group. The base of the Groundwater Watershed is considered to be the deepest limit of potable groundwater $(<10,000 \mathrm{mg} / \mathrm{L}$ total dissolved solids).

The ORNL Groundwater Watershed RI is a multi-year program that addresses many aspects of groundwater flow, including (1) defining the nature and extent of groundwater contamination at the site, (2) assessing potential risks to human health through groundwater discharge or use as a water supply, and (3) identifying groundwater contaminant problems that require early action to reduce risks to human health and the environment and then performing those early actions. The goals of this remediation are to:

- develop the data to define the nature and extent of groundwater contamination;

- identify and respond to critical contaminant-discharge situations through early actions;

- address the uncertainties in prediction of contaminant migration;

- monitor and document changes in contaminant concentrations and locations; 


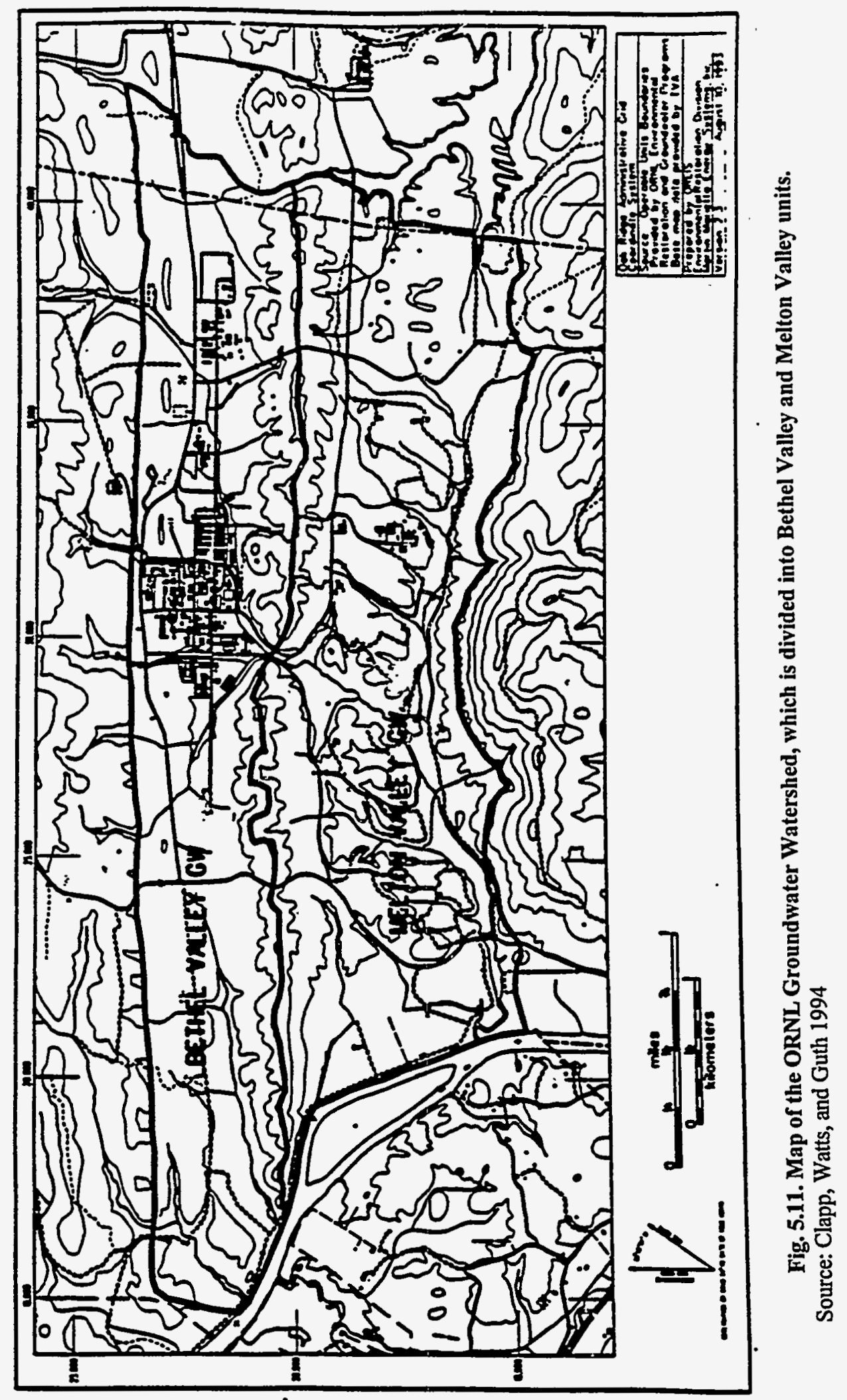


- $\quad$ support RIs and activities at the contaminant sources through interpretation of groundwater data and modeling results;

- assess potential risks to human health and the environment from long-term migration of contaminated groundwater; and

- develop feasible remedial action alternatives for control of those groundwater contaminants that may pose an unacceptable risk to human health or the environment.

The conceptual model for ONRL groundwater is presented in Sect. 5.2.6.

\subsubsection{White Oak Creek Watershed Project}

A project has been initiated to prepare an $\mathrm{RI} /$ feasibility study (FS) for the WOC watershed at ORNL. This watershed encompasses essentially all of the contaminated areas at ORNL, with the exception of WAG 11-the White Wing Scrap Yard. The project will use existing data, possibly supplemented by a small amount of new data, to prepare an RI/FS for ORNL that can be used by the decision makers and stakeholders to select a preferred alternative for the remediation of ORNL. Selection of the preferred alternative will establish the remediation goals for ORNL and identify the sequence of actions necessary to reach that goal.

\subsection{ORNL SITE SUMMARY}

ORNL is located on the ORR, a 13,980 ha (34,545 acre) federally owned site in East Tennessee located approximately 20 miles west of Knoxville, bordered on the southwest by Clinch River and the Melton Hill Lake impoundment. ORNL is one of three primary installations on the reservation, the other two being the Oak Ridge Y-12 Plant and the Oak Ridge K-25 Site. ORNL was constructed for an atomic weapons materials research and development project known as the Manhattan Project during World War II and began operation in 1943. ORNL is located within the corporate limits of the city of Oak Ridge in East Tennessee, approximately 5 miles southwest of the city of Oak Ridge central business district.

ORNL is situated between the Cumberland Mountains to the northwest and the Great Smoky Mountains to the southeast, in the Valley and Ridge Physiographic Province of the Appalachian Mountains. The province is a complex zone characterized by a succession of southwest-trending ridges and valleys. Regional strike in the Oak Ridge area is $\mathrm{N} 45^{\circ}$ to $60^{\circ} \mathrm{E}$, and dip is typically about $30^{\circ}$ southeast but can vary locally from $<20^{\circ}$ to $40^{\circ}$.The geologic structure of the region is complex because of prehistoric faulting and deformation of the underlying material. The rock formations are sedimentary material (shales, limestone, sandstone, etc.) that have weathered and eroded at different rates depending on their composition. Principal geologic rock groups in the Valley of East Tennessee are the Rome Formation, the Conasauga Group, the Knox Group, Chickamauga Limestone, the Sequatchie Formation, the Rockwood Formation, Chattanooga Shale, the Maury Formation, and Fort Payne Chert. Native soils in the region are a mixture of eroded material from dolomite, shale, sandstone, and limestone.

ORNL's location within ridge and valley terrain and its position east of the Cumberland Plateau influences the local climate. It is also influenced by air masses of both arctic and tropical origin, resulting in a wide range of weather conditions. However, ORNL's midlatitude location $\left(36^{\circ} \mathrm{N}\right)$ usually ensures some moderation of arctic and tropical air masses before they reach the area. The area has a relatively, mild climate with warm to hot, humid summers and cool, wet winters. The relatively high humidity experienced year round is generally attributed to the influence of the Gulf of Mexico 
and the Atlantic Ocean. ORNL receives significant precipitation during all months of the year. Annual precipitation at ORNL averages $1351 \mathrm{~mm}$ (53.2 in.). Average annual snowfall measures $25.4 \mathrm{~cm}$ (10 in.).

The surface hydrology in the Valley of East Tennessee is characterized by a trellis pattern in which the Tennessee River is the primary receiver of many secondary rivers and their tributaries. ORNL is located in the Clinch River watershed, which comprises about $11 \%$ of the Tennessee River watershed. Drainage from ORNL empties into WOC and several tributaries. At ORNL there is a close relationship between surface water and groundwater drainage patterns; the distinction between them is largely artificial because most of the surface water in the geological setting at ORNL has infiltrated into the soil, traveled through the subsurface, and emerged at springs or seeps. In the Valley of East Tennessee, groundwater occurs in bedrock, in the regolith, and in a few alluvial aquifers along the largest rivers. Aquifers in the Valley of East Tennessee are carbonate aquifers, which are made from limestone and dolomite.

The general vegetation cover on the ORR is about $80 \%$ forest. Plant communities are characteristic of those found in the intermountain regions of central and southern Appalachia. The dominant forest is of the oak/hickory association and is most widely distributed on ridges and dry slopes. Seventeen plant species known to be present on the ORR are listed by the Tennessee Department of Environment and Conservation as either endangered, threatened, or of special concern. The various habitats found on the ORR accommodate a wide variety of wildlife species typical of East Tennessee. Aquatic habitats on the ORR include numerous Clinch River tributary systems and several liquid waste disposal ponds.

Because of the large number of contaminated sites and the hydrologic complexity at ORNL, areas containing contiguous and similar waste sites have been organized into WAGs. Twenty WAGs have been identified at ORNL, 14 of which are candidates for remedial action. Three site-wide projects are currently active at ORNL: the SWP, the Groundwater Watershed, and the WOC Watershed Project.

\subsection{REFERENCES}

Birdwell, K., February 22, 1993. Atmospheric Turbulence and Diffusion Laboratory, Oak Ridge, Tenn., personal communication to D. Hancock, Barge, Waggoner, Sumner, and Cannon, Oak Ridge, Tenn.

Borders, D. M., et. al. 1994. Hydrologic Data Summary for the White Oak Creek Watershed at Oak Ridge National Laboratory, Oak Ridge, Tennessee (January-December 1993), ORNL/ER-269, Martin Marietta Energy Systems, Inc., Oak Ridge Natl. Lab.

Clapp, R. B. 1992. Annual Report of the Environmental Restoration Monitoring and Assessment Program at Oak Ridge National Laboratory for FY 1992, ORNL/ER-124, Martin Marietta Energy Systems, Inc., Oak Ridge, Tenn.

Clapp, R. B., and J. A. Watts 1993. Second Annual Report of the Environmental Restoration Monitoring and Assessment Program at the Oak Ridge National Laboratory, ORNL/ER-180, Martin Marietta Energy Systems, Inc., Oak Ridge Natl. Lab., Oak Ridge, Tenn. 
Clapp, R. B., J. A. Watts, and M. A. S. Guth, eds., Sept. 1994. Third Annual Environmental Restoration Monitoring and Assessment Report for FY 1994 of the Oak Ridge National Laboratory, Oak Ridge, Tennessee, DOE/OR/01-1290\&D1 (ORNL/ER-250), Martin Marietta Energy Systems, Inc., Oak Ridge Natl. Lab.

Cunningham, M., et al.1993. Resource Management Plan for the ORR, Volume 29: Rare Plants on the ORR, ORNL/NERP-7, unpublished draft, Martin Marietta Energy Systems, Inc., Oak Ridge Natl. Lab., Oak Ridge, Tenn.

Eckman, R. M., R. J. Dobosy, and W. R. Pendergrass 1992. Preliminary Analysis of Wind Data from the Oak Ridge Site Survey, Atmospheric Turbulence and Diffusion Division of the National Oceanographic and Atmospheric Administration, Oak Ridge, Tenn.

Elder, B. F. 1956. "The Geology of the Area Along the Cumberland Escarpment Between Elverton and Oliver Springs," masters thesis, University of Tennessee, Knoxville, Tenn.

Energy Systems (Martin Marietta Energy Systems, Inc.) 1986. Environmental Surveillance of the Oak Ridge Reservation and Surrounding Environs During 1985, ES/ESH-1 (ORNL-6271), Oak Ridge Natl. Lab.

Energy Systems 1990. Remedial Investigation Plan for Waste Area Grouping 2 at Oak Ridge National Laboratory, Oak Ridge, Tennessee, ES/ER-14\&D1, Martin Marietta Energy Systems, Inc., Oak Ridge, Tenn.

Energy Systems 1992. Martin Marietta Energy Systems, Inc., Information Systems Plan, 1992-1996, K/CSD/INF-92/14, Martin Marietta Energy Systems, Inc., Oak Ridge, Tenn.

Energy Systems 1994. Oak Ridge Reservation Technical Site Information, ES/EN/SFP-23, Martin Marietta Energy Systems, Inc., Oak Ridge, Tenn.

Ketelle, R. H., and R. R. Lee 1992. Migration of a Groundwater Contaminant Plume by Stratabound Flow in Waste Area Grouping 1 at Oak Ridge National Laboratory, Oak Ridge, Tennessee, ORNL/ER-126, Martin Marietta Energy Systems, Inc., Oak Ridge Natl. Lab.

Knox County Soil Conservation District, U.S. Soil Conservation Service 1981. Erosion and Sediment Control Handbook, Knoxville Metropolitan Planning Commission, Knoxville, Tenn.

Komegay, F. C., et al. 1992. Oak Ridge Reservation Environmental Report for 1991, ES/ESH-22/V1, Martin Marietta Energy Systems, Inc., Oak Ridge, Tenn.

Kroodsma, R. January 21, 1993. Martin Marietta Energy Systems, Inc., Environmental Sciences - Division, memorandum to T. Catron, Barge, Waggoner, Sumner, and Cannon, Oak Ridge, Tenn.

Lietzke, D. A., S. Y. Lee, and T. Tamura 1986. Resource Management Plan for the ORR, Volume 20: Soil Conservation Plan for the Oak Ridge Reservation, ORNL/ESH-1/V20, Martin Marietta Energy Systems, Inc., Oak Ridge Natl. Lab., Oak Ridge, Tenn.

ORNL (Oak Ridge Natl. Lab.) 1987. RCRA Facilities Assessment (RFA)-Oak Ridge National Laboratory, ORNL/RAP-12/V1, Martin Marietta Energy Systems, Inc., Oak Ridge, Tenn. 
Parr, P. D., and J. W. Evans 1992. Resource Management Plan for the ORR, Volume 27: Wildlife Management, ORNL/NERP-6, Martin Marietta Energy Systems, Inc., Oak Ridge Natl. Lab., Oak Ridge, Tenn.

Solomon, D. K., et. al. 1992. Status Report: A Hydrologic Framework for the ORR, ORNL/TM-12026, Martin Marietta Energy Systems, Inc., Oak Ridge Natl. Lab., Oak Ridge, Tenn.

Stockdale, P. B. 1951. Geologic Conditions at the Oak Ridge National Laboratory $(X-10)$ Area Relevant to the Disposal of Radioactive Waste, ORO-58, U.S. Atomic Energy Commission, Oak Ridge, Tenn.

Toran L. E., et al. 1991. "Matrix Diffusion as a Mechanism to Explain Recent Tritium and Old ${ }^{14} \mathrm{C}$ in Groundwater from Fractured Sedimentary Rock," EOS Trans. 72(17):111.

Wilson, J. 1982. Ground Water: A Non-Technical Guide, Academy of Natural Sciences, Philadelphia.

\subsection{BIBLIOGRAPHY}

Boyle, J. W., et al. 1982. Environmental Analysis of the Operation of Oak Ridge National Laboratory (X-10 Site), ORNL-5870, Martin Marietta Energy Systems, Inc., Oak Ridge Natl. Lab., Oak Ridge, Tenn.

Clapp, R. B., and J. A. Watts, eds. 1995. Fourth Annual Environmental Restoration Monitoring and Assessment Report (FY 1995), Oak Ridge National Laboratory, Oak Ridge, Tennessee, DOE/OR/01-1413\&D1, Oak Ridge Natl. Lab.

Coobs, J. H., and J. R. Gissel 1986. History of Disposal of Radioactive Wastes into the Ground at Oak Ridge National Laboratory, ORNL/TM-10269, Oak Ridge Natl. Lab.

DOE (U.S. Department of Energy) 1994. Oak Ridge Reservation Site Management Plan for the Environmental Restoration Program, DOE/OR-1001/R3, Martin Marietta Energy Systems, Inc., Oak Ridge Natl. Lab., Oak Ridge, Tenn.

Evaluation Research Corporation 1982. History of Disposal of Radioactive Wastes into the Ground at Oak Ridge National Laboratory, ORNL/CF-82/202, Martin Marietta Energy Systems, Inc., Oak Ridge Natl. Lab.

Oak Ridge Natl. Lab. 1990. ORNL Contaminated Site Summary Sheets, ORNL/M-2413, Oak Ridge Natl. Lab.

Oak Ridge Natl. Lab. 1992. Oak Ridge National Laboratory Institutional Plan, FY 1993-FY 1998, ORNL/PPA-92/3, Martin Marietta Energy Systems, Inc., Oak Ridge, Tenn.

Oak Ridge Natl. Lab. 1992. Oak Ridge National Laboratory Site Development Plan,ORNL/PPA-91/4, Martin Marietta Energy Systems, Inc., Oak Ridge, Tenn.

Oak Ridge Natl. Lab. 1993. Oak Ridge National Laboratory Site Development Plan, Martin Marietta Energy Systems, Inc., Oak Ridge, Tenn. 


\section{HISTORY AND CHARACTERIZATION OF WAG 1}

Instructions to User
This chapter provides information about WAG 1 that can be cited in certain CERCLA
documents (see Chap. 1 and Table 1 in Instructions to User). For a short description of
WAG 1 that can be copied into other types of documents, see the summary at the end
of this chapter. To keep this document as short as possible, information about
conditions common to all WAGs (e.g., climate and demography) is given in
Chap. 5-History and Characterization of the ORNL Site.

\subsection{SITE DESCRIPTION AND HISTORY}

WAG 1 is located within the main plant area of Oak Ridge National Laboratory (ORNL) on the Oak Ridge Reservation (ORR) in Roane County, Tennessee. The site is in Bethel Valley, approximately 5 miles southwest of the city of Oak Ridge central business district (Fig. 6.1). The site is bounded on the north by Bethel Valley Road, on the south by White Oak Creek (WOC), and on the west by First Creek. The eastern boundary follows Fifth Creek but extends east to include Solid Waste Storage Area (SWSA) 2 and Buildings 4501 and 4508.

A total of 167 solid waste management units (SWMUs) were initially identified within WAG 1 (ORNL 1987). Pursuant to a Resource Conservation and Recovery Act (RCRA) permit issued prior to the initiation of the WAG 1 remedial investigation, 27 SWMUs were classified as requiring no further investigation. An additional 14 SWMUs were listed for decommissioning and demolition under the DOE surplus facilities program. The remaining $126 \mathrm{SWMUs}$ include inactive underground storage tanks, waste burial grounds, surface impoundments, waste transfer lines and leak sites, active underground waste storage tanks, and mercury spill sites. Most of the SWMUs are related to current or past liquid and solid radioactive waste management operations conducted within the main plant area of ORNL. Information regarding individual SWMUs (description, location, date of operation, waste characteristics, release data, and site characterization status) can be found in Contaminated Site Summary Sheets, ORNL/M-2413 (ORNL 1990).

The ORNL main plant site initially included a nuclear reactor, a chemical separations plant, a number of large underground tanks, and a variety of support facilities. The nuclear reactor (Building 3001), referred to as the "Graphite Reactor," was air cooled and was the first nuclear reactor with production capacity. The Radiochemical Processing Pilot Plant (Building 3019), referred to as the "Hot Pilot Plant," was constructed to dissolve the irradiated fuel elements from the Graphite Reactor. The Isotopes Area, located in the east-central portion of WAG 1, was among the earliest radioisotope production area at ORNL. Facilities in this area prepared radioisotopes from the late 1940 s and early 1950 s until production activities were ceased in the early 1990s. Limited documentation is available concerning the activities performed in this area and the wastes generated in the associated facilities, and most of the information that does exist is anecdotal (SAIC 1994).

From the beginning, the management of radioactive waste required classification of the waste into categories. Despite changes over time in the names used for a category of waste and the divisions between categories, the early categories are generally recognizable and can be related to current designations. Initially, liquid wastes were divided into three main categories: metal wastes, 
6-2

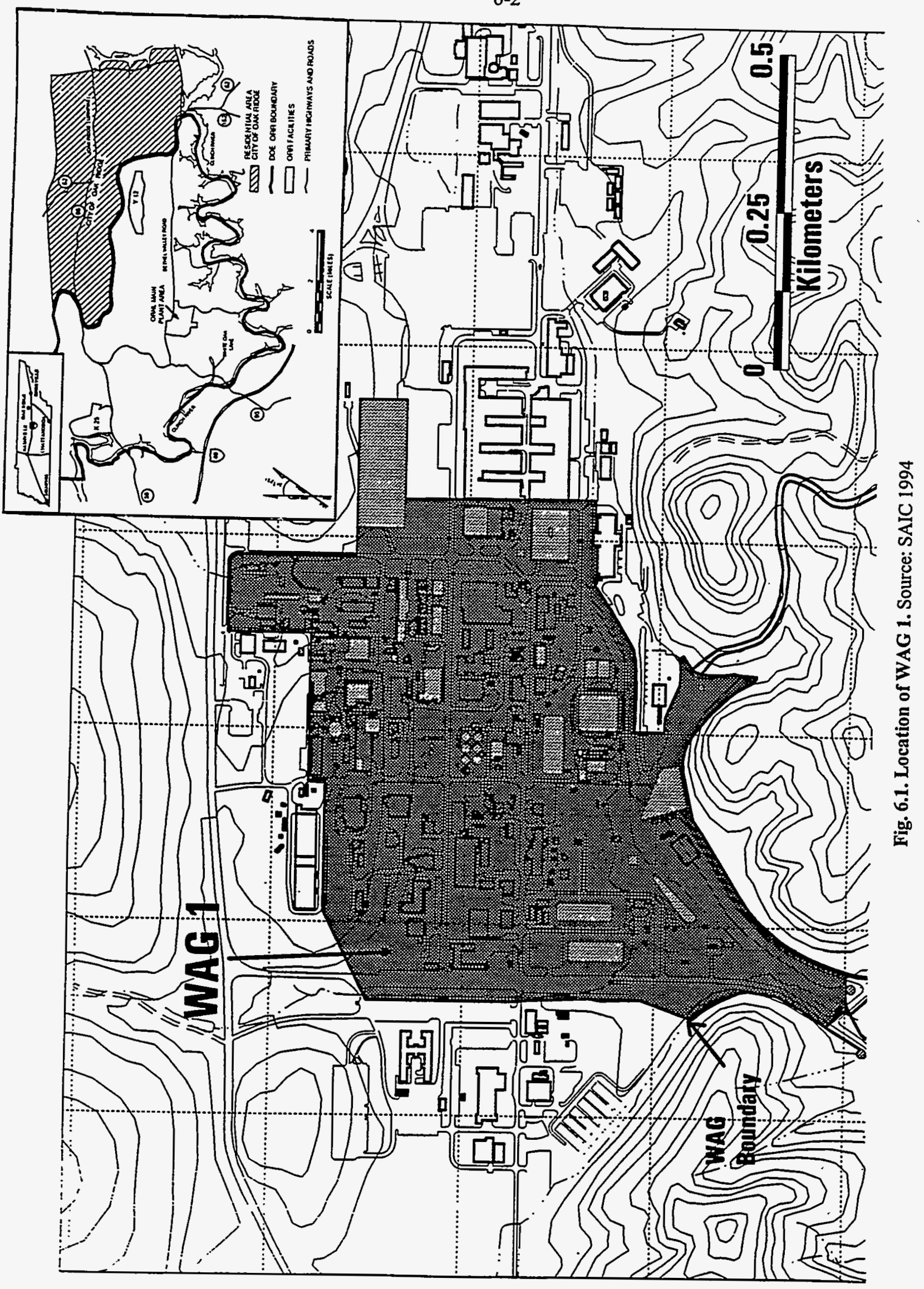


radiochemical wastes, and process wastes. Metal wastes contained primarily uranium with small quantities of plutonium or thorium. Radiochemical wastes contained primarily fission product radionuclides that have half-lives significantly shorter than the metal wastes. Radionuclides associated with this category of waste include ${ }^{137} \mathrm{Cs},{ }^{90} \mathrm{Sr},{ }^{131} \mathrm{I},{ }^{141} \mathrm{Ce},{ }^{143} \mathrm{Ce},{ }^{103} \mathrm{Ru},{ }^{140} \mathrm{Ba}$, and ${ }^{140} \mathrm{La}$. Process waste was theoretically nonradioactive or had very low activity. A fourth category of waste referred to as "warm waste" was in use during early operations. Warm waste was moderately radioactive and represented a transition between process waste and radiochemical waste.

An extensive system of underground utilities has been constructed and modified over the history of the main plant area. This system includes liquid low-level radioactive waste (LLLW) and process waste transfer lines designed to transport wastes from their generation points to treatment, storage, and disposal facilities within the main plant area or Melton Valley. Numerous underground tanks have also been installed during the operational history of the facility. The purpose of these tanks was to store wastes generated during site activities. The system includes six 643,450-L (170,000-gal) Gunite tanks in the South Tank Farm, Gunite and stainless steel tanks in the North Tank Farm, and other waste collection and storage tanks located adjacent to waste-generating facilities within WAG 1.

The Gunite tanks were originally constructed to store all of the radioactive liquid (radiochemical and metal) wastes generated by ORNL site operations. However, because of expanding requirements for aging radioactive liquid wastes, the capacity of these tanks was inadequate for permanent storage, and it became necessary to implement various waste management approaches. The first approach was to separate the different waste streams and concentrate the radioactive components in the liquids by precipitation. The large Gunite tanks in the South Tank Farm were used for the precipitation process, while the smaller Gunite tanks in the North Tank Farm were used for either storage of metal waste or collection of waste for characterization prior to transfer. The precipitation step formed a sludge at the bottom of the tanks, and the supernatant was discharged to a 5,677,500-L (1,500,000-gal) settling basin where the supernatant was diluted with large volumes of process waste before being discharged into WOC. In 1945, the precipitation of radiochemical waste was discontinued.

Starting in 1949, the radiochemical waste stream was treated by concentration using a pot-type evaporator. This operation was conducted in the Waste Evaporator Facility (Building 3506), which was constructed on the western side of the South Tank Farm. This facility operated from 1949 until 1954. In 1950, further expansion of ORNL required additional modifications to the waste management system to handle increased waste volumes and levels of radioactivity. Underground stainless steel tanks were installed near each building or area that was a source of radiochemical or metal waste. Four additional tanks were also installed within the North Tank Farm.

In 1952, some radiochemical waste was discharged directly into the ground using a series of pits and trenches located within Melton Valley. The use of the Waste Evaporator Facility was discontinued in 1954 in favor of the pits and trenches disposal practice. Gunite tanks in the South Tank Farm were used to hold radiochemical waste prior to pumping of these wastes to the pits and trenches for disposal. Disposal of waste within pits and trenches was continued until 1966, when routine disposal of the waste was initiated using a hydrofracture technique. The technique involved mixing waste with cement grout, which was then injected into subsurface shale at a depth of $\sim 305 \mathrm{~m}$ $(1000 \mathrm{ft})$.

Continuous improvements and modifications to the ORNL waste management system eventually eliminated the need for most of the older tanks. Tanks in the North Tank Farm were removed from service in the late 1950 s or early 1960 s. The liquid waste in these tanks was removed, and any sludge, as well as a small volume of residual liquid, remained in the tanks. The large Gunite tanks 
in the South Tank Farm were removed from service in the late 1970s. Accumulated sludge precipitated from solution, as well as residual solutions, remained in these tanks until they were cleaned in 1982 and 1983. Some residual liquid and sludge remain within these tanks, however (SAIC 1994).

\subsection{CHARACTERIZATION}

\subsubsection{Geography}

WAG 1 is located within the main plant area of ORNL on the ORR in Roane County, Tennessee. The site is in Bethel Valley, approximately 5 miles southwest of the city of Oak Ridge central business district (Fig. 6.1). The site is bounded on the north by Bethel Valley Road, on the south by WOC, and on the west by First Creek. The eastern boundary follows Fifth Creek but extends east to include Solid Waste Storage Area (SWSA) 2 and Buildings 4501 and 4508.

\subsubsection{Climate}

See Sect. 5.2.2 of this document for climate description.

\subsubsection{Demography}

WAG 1 lies within the boundaries of the ORNL main plant area where the majority of ORNL's approximately 4837 employees work (Site and Facilities Planning Department 1994). Within 2 miles of the boundaries of the WAG 1, all land is federally owned, and there are no residents. State Highway 95 runs through the ORR and at the closest point passes within 1 mile of the main plant area. The site is approximately 2 miles from the north bank of the Clinch River, which forms a portion of the boundary of the ORR. See Sect. 5.2.3 of this document for general demographic characteristics of ORNL.

\subsubsection{Geology and Soils}

\subsubsection{Geology}

WAG 1 lies within Bethel Valley between Chestnut Ridge and Haw Ridge and is underlain by the limestone, siltstone, and calcareous shale facies of the Ordovician Chickamauga Group (Fig. 6.2). Stockdale (1951) summarized the mappable units of the Chickamauga Group as shown in Fig. 6.3. Figure 6.4 provides a generalized geologic cross section through the main plant area showing the approximate relative positions of Stockdale's units $\mathrm{C}$ through $\mathrm{H}$ and selected WAG 1 SWMUs. Stockdale reports that the average strike of the units of the Chickamauga Group in the vicinity of WAG $1,56^{\circ} \mathrm{E}$, is slightly different from that of the regional trend of Bethel Valley, $58^{\circ} \mathrm{E}$. The dip of these units is to the southeast, commonly between $30^{\circ}$ and $40^{\circ}$.

Stockdale describes the upper limestone units of the Chickamauga Group as being tightly cemented and compact, with the exception of several small solution channels, typically around 1-in. in diameter, but up to as large as $1 \mathrm{ft}$. McMaster and Waller (1965) confirmed the categorization of Stockdale on the basis of a geologic and soil study of the WOC basin.

In 1985, five boreholes, each approximately $400 \mathrm{ft}$ deep, were completed in a northwest-southeast transect along the east side of Fifth Creek. This study provided representative cases from each of units B through $G$ of the Chickamauga Group (Boegly et al. 1987). It is reported 
that geophysical logs obtained during that study indicated that the rock is tightly cemented and competent. Fractures often appeared to be remineralized with calcite, with some exhibiting signs of motion.

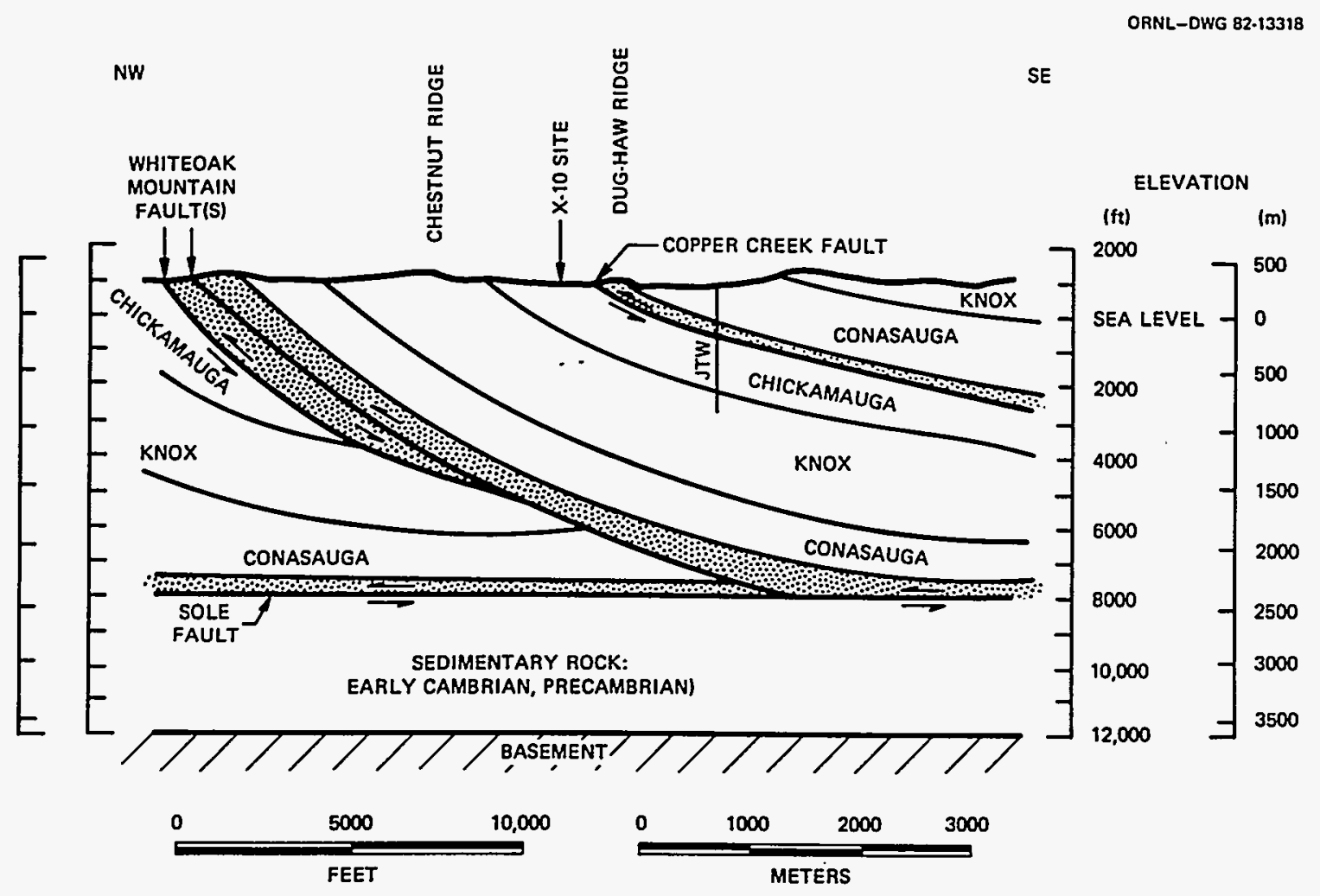

Fig. 6.2. Geologic cross-section beneath WAG 1 through ORR. Source: Bechtel 1989

\subsubsection{Soils}

Generally, soil thicknesses at the site range from 1 to $25 \mathrm{ft}$. The deepest soils are found along the low ridge that crosses the northern portion of the site, near the Graphite Reactor. The thinnest soils are found in the southern portion of the site, near the surface impoundments and WOC.

Generally, the natural soils on WAG 1 are produced by the in-place weathering of the Chickamauga bedrock. The soils typically consist of yellow, light reddish-orange, or red clay of medium stiffness containing variable quantities of chert, siltstone, and limestone fragments. The mineralogy of native soils reflects composition of the underlying bedrock (Bechtel 1989).

The soils at the site have been highly disturbed by construction activities. Reworked native soils and normative, imported fill materials have been placed in pipe trenches, under foundations and slabs, as backfill around buildings, and in other excavations throughout the site. This anthropogenic zone extends from the surface to various depths throughout the site, frequently extending to the bedrock surface, as is the case at SWMU 1.26 (South Tank Farm). The anthropogenic zone is so complex that complete characterization of all material types and their distribution is not considered to be cost effective and, for practical purposes, is infeasible. 

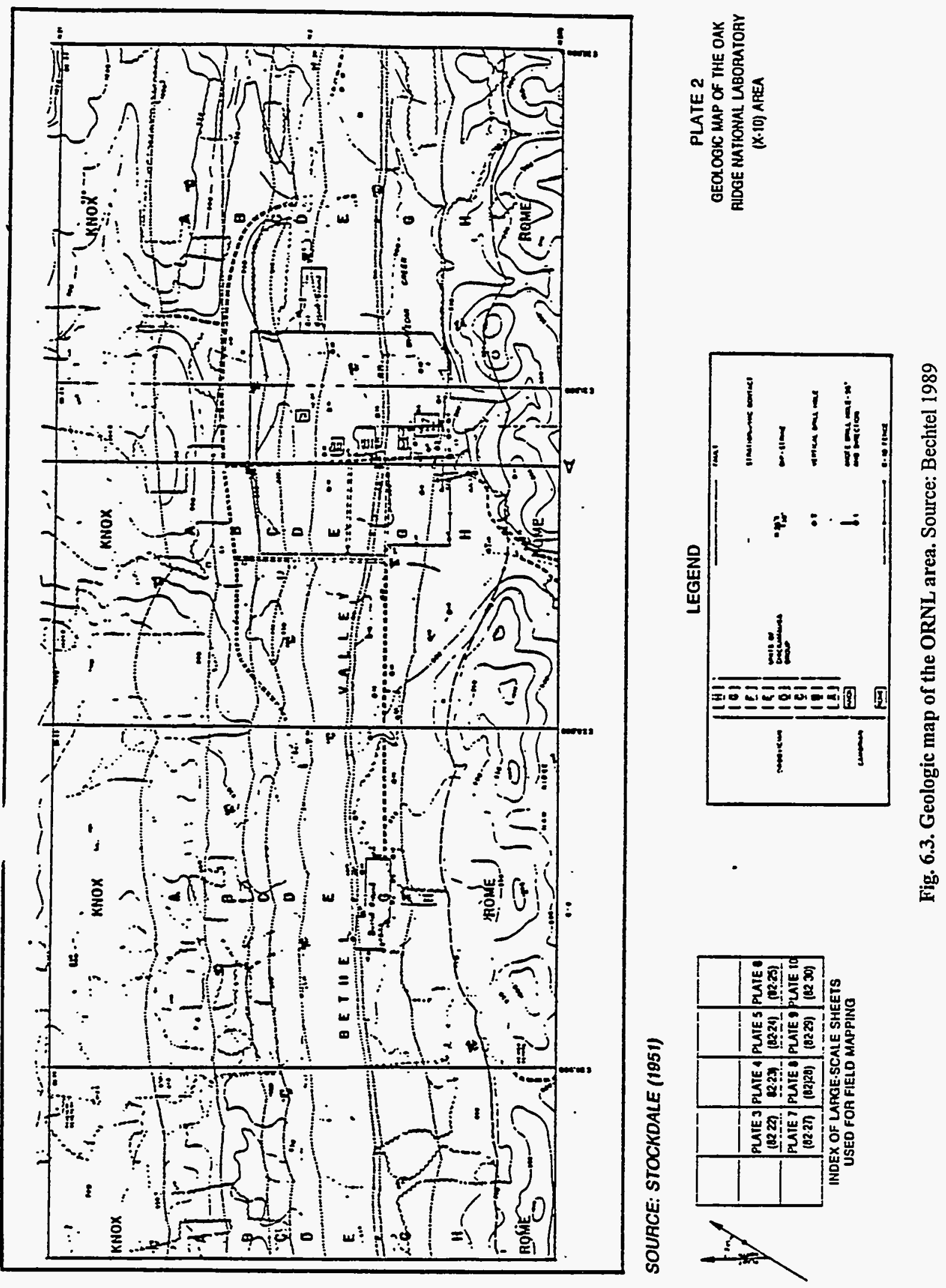


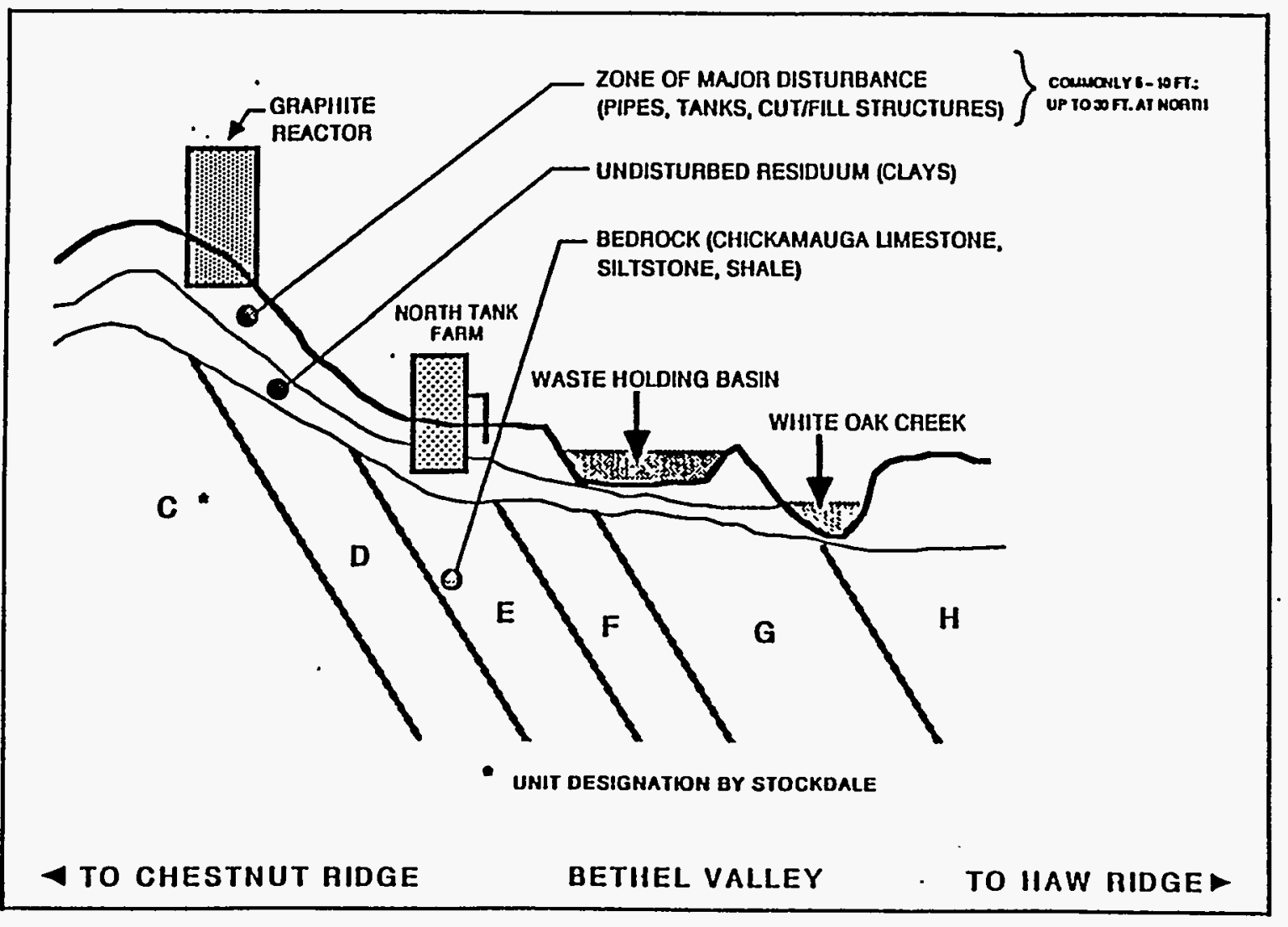

Fig. 6.4. Geologic cross-section through the main plant area. Source: Bechtel 1989

Some surface soil sampling has been conducted within the confines of WAG 1 (Fig. 6.5). Generally, sampling was conducted in specific areas, such as leak sites, spill areas, and burial grounds within the WAG boundary. In 1976 and 1977, SWSA 2 was considered as a possible location for the Energy Systems Research Laboratory, and soil core samples were collected to examine the subsurface soils for radioactive contamination (Oakes and Shank 1977). A total of 25 cores, ranging from 4 to $9 \mathrm{ft}$ deep, were collected and analyzed for alpha-, beta-, and gamma-emitting isotopes. The soil borings were collected in two phases. During the first phase, 13 samples were collected. Each sample was homogenized and a representative portion submitted for analyses. During the second phase, 12 samples were collected and separated into three samples to obtain a depth profile. Each third of the core sample was then submitted for analyses. The results from the 13 homogenized samples indicated uranium and plutonium levels slightly higher than samples collected near perimeter air monitoring stations. The samples collected for depth profile analyses indicated higher levels of radioisotopes $\left({ }^{123} \mathrm{Cs},{ }^{40} \mathrm{~K},{ }^{226} \mathrm{Ra}\right.$, and $\left.{ }^{232} \mathrm{Th}\right)$ in the shallower samples. The average core concentrations were found to be less than those from background samples.

Soils were collected by Huang et al. (1984a) as a part of preliminary characterization of 15 inactive waste tanks. In 1985, a limited soil investigation was performed in response to leaks in the LLLW waste transfer line in the 3019 and 3028 areas (Oakes 1985). Samples were collected at five general areas: (1) the leak site near Building 3074, (2) the area west of Building 3019 , (3) the series of four manholes at the southwest corner of Building 3019, (4) the southwest corner of 3001, and (5) the leak site near Building 3028. The highest levels of radioactivity were detected in samples from the leak site near Building 3028. 

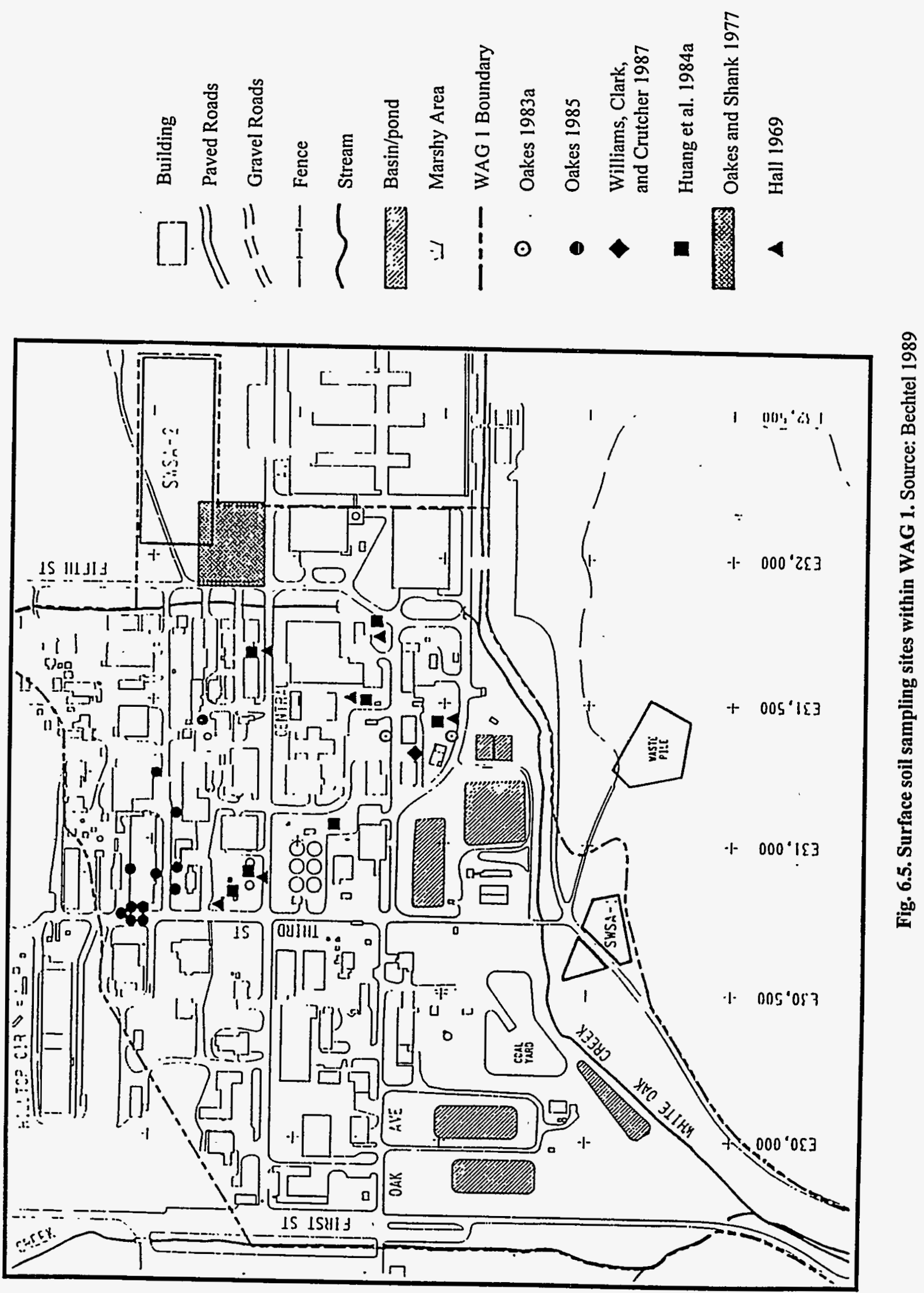
A limited soil investigation was also performed adjacent to the storage pad southwest of Building 3503 (Williams, Clark, and Crutcher 1987). Soil samples were analyzed for the RCRA hazardous waste characteristics (ignitability, corrosivity, reactivity, and extraction procedure toxicity); all results were below their respective regulatory limits. Sixty-nine samples were collected and analyzed for radionuclides, predominant of which were ${ }^{137} \mathrm{Cs},{ }^{238} \mathrm{Pu},{ }^{238} \mathrm{U},{ }^{228} \mathrm{Ra}$, ${ }^{232} \mathrm{Th}$, and ${ }^{90} \mathrm{Sr}$.

In 1983, soil sampling was performed in the areas surrounding Buildings 4501, 4505, and 4507 and along the bank of Fifth Creek (Oakes 1983a). The highest mercury levels were detected along the bank of Fifth Creek and east of Building 4505 (Oakes 1983a). Soil samples for mercury analyses were also collected south of Building 3592 and southeast of Building 3503 (Oakes 1983a). Results of both samples indicated elevated mercury levels.

\subsubsection{Surface Water}

\subsubsection{WAG 1 drainage basin}

WAG 1 lies within the Bethel Valley portion of the WOC drainage basin. The WAG boundary stops at the water gap in Haw Ridge, and for the purposes of this summary the drainage basin will be considered to end there as well. The boundaries of the basin extend to the southeast and northeast along Chestnut Ridge and Haw Ridge. The total area encompassed by the basin is about 2040 acres. WOC, its headwaters and northwest tributary, as well as First and Fifth Creeks, are included in the basin.

As shown in Fig. 6.6, White Oak, First, and Fifth creeks and the proximal end of the Northwest Tributary pass through WAG 1 . The Bethel Valley quadrangle (130-NE) shows a spring as the source for First Creek. The spring, located near the foot of Chestnut Ridge, has a potentially large recharge area. First and Fifth creeks collect runoff from the slopes of Chestnut Ridge and then course southeast through the plant area to their respective confluences with the Northwest Tributary and WOC. Both have similar gradients of about $45 \%$ at their headwaters and about 1 to $2 \%$ on their reaches within the plant (Fifth Creek is routed underground by means of concrete culverts at lower elevations in the plant area). WOC also originates on Chestnut Ridge then flows southwest along the floor of Bethel Valley through the water gap in Haw Ridge. A review of maps made before plant construction indicates that minor modifications have been made to the stream beds of all three creeks (Boegly et al. 1987). This fact is of note because the buried stream channels may influence the occurrence of groundwater.

\subsubsection{Plant contribution to stream flow}

The plant area has several major discharges to First, Fifth, and White Oak creeks. These include (1) treated sanitary waste from the sewage treatment plant, (2) cooling tower blowdown, (3) cooling water, (4) process wastewaters, (5) surface runoff from storm sewers, (6) LLLW collection and treatment system waters, and (7) demineralizer regenerant waste (Department of Environmental Management 1986).

An in-depth discussion of each discharge is beyond the scope of this document; however, a summary of the type of information available for the storm sewer system is offered here. The storm sewer system collects area runoff and water from roof drains, storm drains, and parking lot drains. Sampling of the outfalls indicates that there may also be process line leakage, building drain leakage, and seepage from previous spills entering the system, as well as leakage resulting from improper connections with other types of lines (Berry and Yook 1987). The outfalls are numbered as members of the 100,200 , or 300 series. The 100 series drains only rainwater, the 200 series drains building 


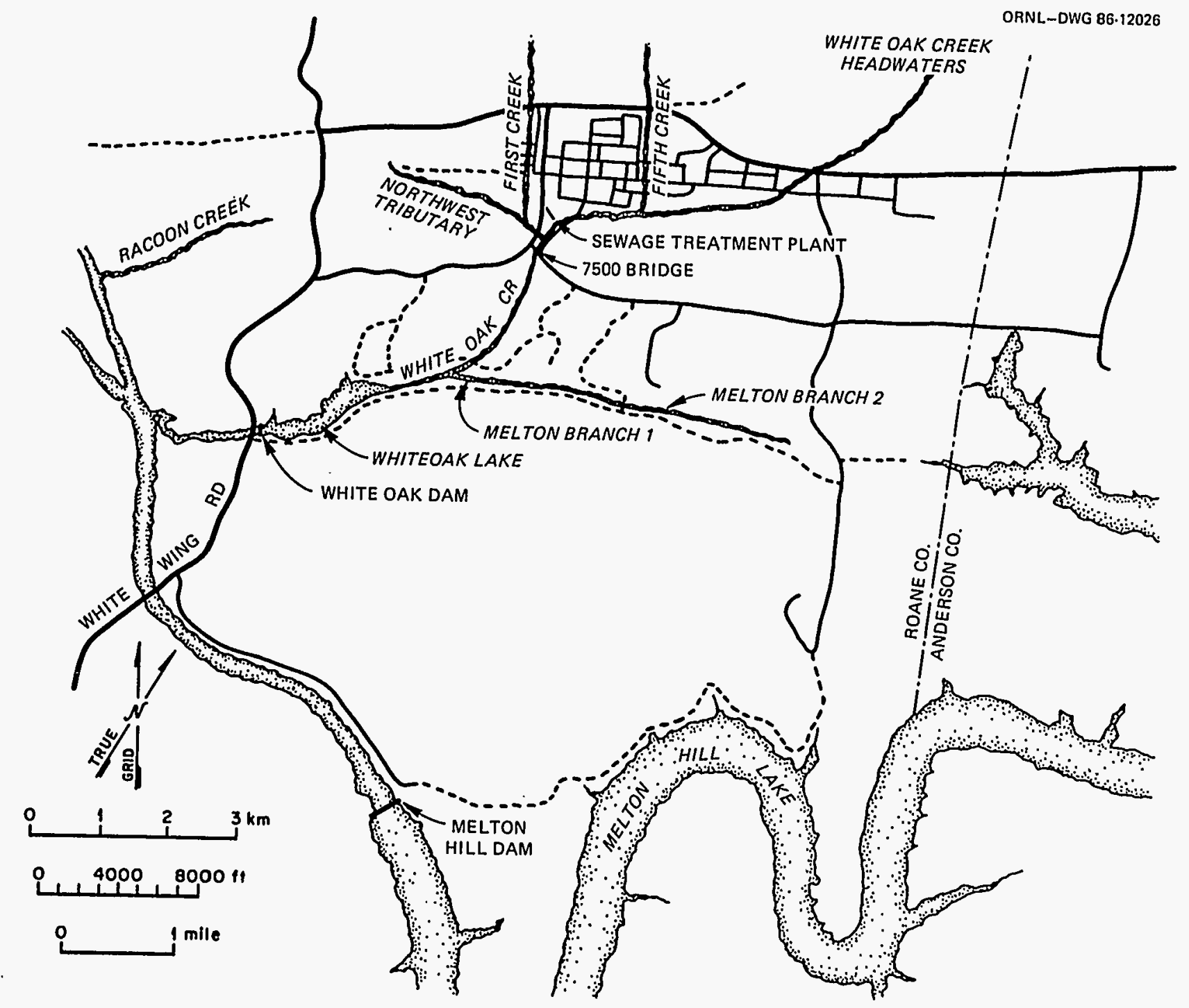

Fig. 6.6. Location map of ORNL streams. Source: Boegly et al. 1987 
and parking lots but no process effluent, and the 300 series drains buildings and areas where the presence of untreated process wastes is indicated. Flow volumes for the storm sewer system are, of course, dependent on precipitation.

\subsubsection{Surface water and sediment sampling}

Surface water samples were collected in WOC and its major tributaries at various times between 1985 to 1989. Many of these samples were collected as part of a program designed to identify, monitor, and minimize ORNL point-source discharges to the aquatic environment. The samples were analyzed primarily for radionuclides (total strontium, ${ }^{137} \mathrm{Cs},{ }^{60} \mathrm{Co}$, and tritium), mercury, and polychlorinated biphenyls (PCBs). Some studies also analyzed transuranics (TRUs). Flow regimes during sampling events were not identified in most of the published reports of these analyses. Most of the data obtained in these studies are published in the annual ORR Environmental Surveillance Program reports (Energy Systems 1985-91). Other related data are available in reports written by F. G. Taylor, Jr. (Taylor 1989; 1990a,b). Locations of previous studies and available data on WAG 1 groundwater, soil, surface water, and sediments are shown in Fig. 6.7.

Phase I characterization of surface waters for the WAG 1 site characterization summary report (Bechtel 1992) was conducted between October 1990 and March 1991; 30 surface water grab samples were collected from the major WAG 1 creeks during both low and high base flow conditions as well as during storms that occurred during low and high base conditions. Samples were analyzed for radionuclides, volatile organic compounds, base/neutral/acid-extractables (BNAEs), metals, pesticides, PCBs, cyanide, and a variety of water quality parameters. Analyses for organophosphates, herbicides, and dioxins/furans were conducted on one sample from WOC station SW-6.

An additional screening survey of First Creek was completed during September and October 1991 as part of the investigation into the nature and extent of the contamination encountered during the installation of Core Hole CH008. Because it was hypothesized that contaminated groundwater associated with that encountered in Core Hole CH008 might discharge to First Creek, samples were collected from the creek at intervals of approximately $50 \mathrm{ft}$ between Bethel Valley Road and White Oak Avenue. Samples were also collected from four outfalls (ORNL numbers 341, 342,250 , and 249) and analyzed at the Close Support Laboratory for gross alpha, gross beta, gamma spectroscopy, and tritium.

The following paragraphs summarize the findings of the site characterization report (Bechtel 1992).

\section{General Observations on Surface Water Radionuclides}

Both man-made and naturally occurring radionuclides were detected during the Phase I remedial investigation in WOC, First Creek, Fifth Creek, and Northwest Tributary. The most frequently detected were ${ }^{90} \mathrm{Sr}$ and ${ }^{137} \mathrm{Cs}$, which are man made. Radium-228 and ${ }^{234} \mathrm{U}$ were also detected above reference levels but less frequently and at lower concentrations than strontium and cesium. While ${ }^{228} \mathrm{Ra}$ and ${ }^{234} \mathrm{U}$ can be naturally occurring, it is believed that the amounts detected in samples from First Creek are man made or enriched from on-site processes.

Although strontium concentrations in surface water were highest during low base flow, the flux of strontium (expressed in $\mathrm{pCi} / \mathrm{s}$ passing through the creek at a given point) was greatest during the high base storm event. The flux of ${ }^{90} \mathrm{Sr}$ in WOC at the Haw Ridge water gap was estimated to be $9250 \mathrm{pCi} / \mathrm{s}$ during low base, $20,067 \mathrm{pCi} / \mathrm{s}$ total radioactive strontium during high base, and $85,550 \mathrm{pCi} / \mathrm{s}$ total radioactive strontium during the high base storm. 


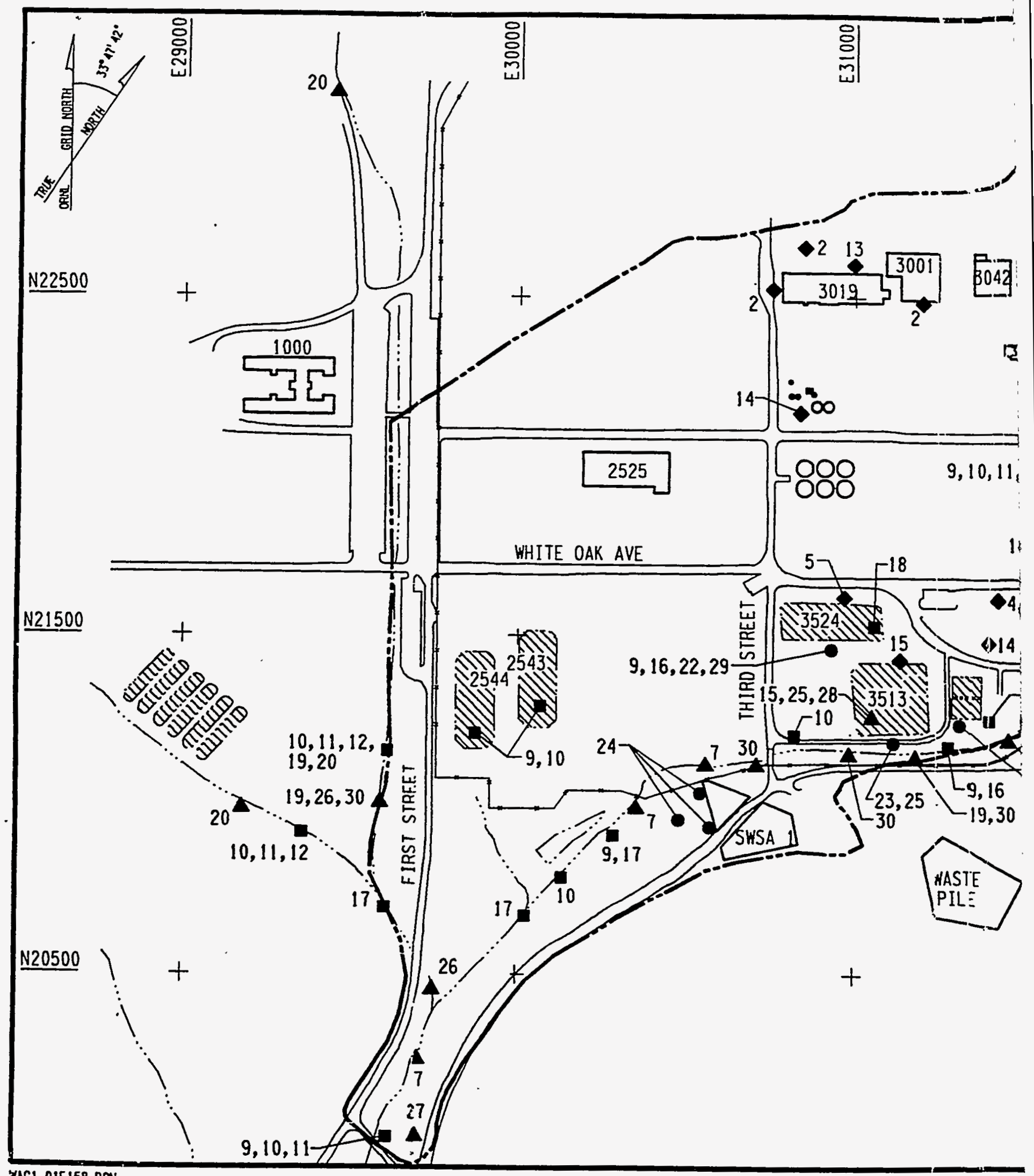
WAG! 0IF 158.DQN

Fig. 6.7. Locations of previous studies and available data of groundwater, soil, surface water, and sediments. Source: Bechtel 1992 


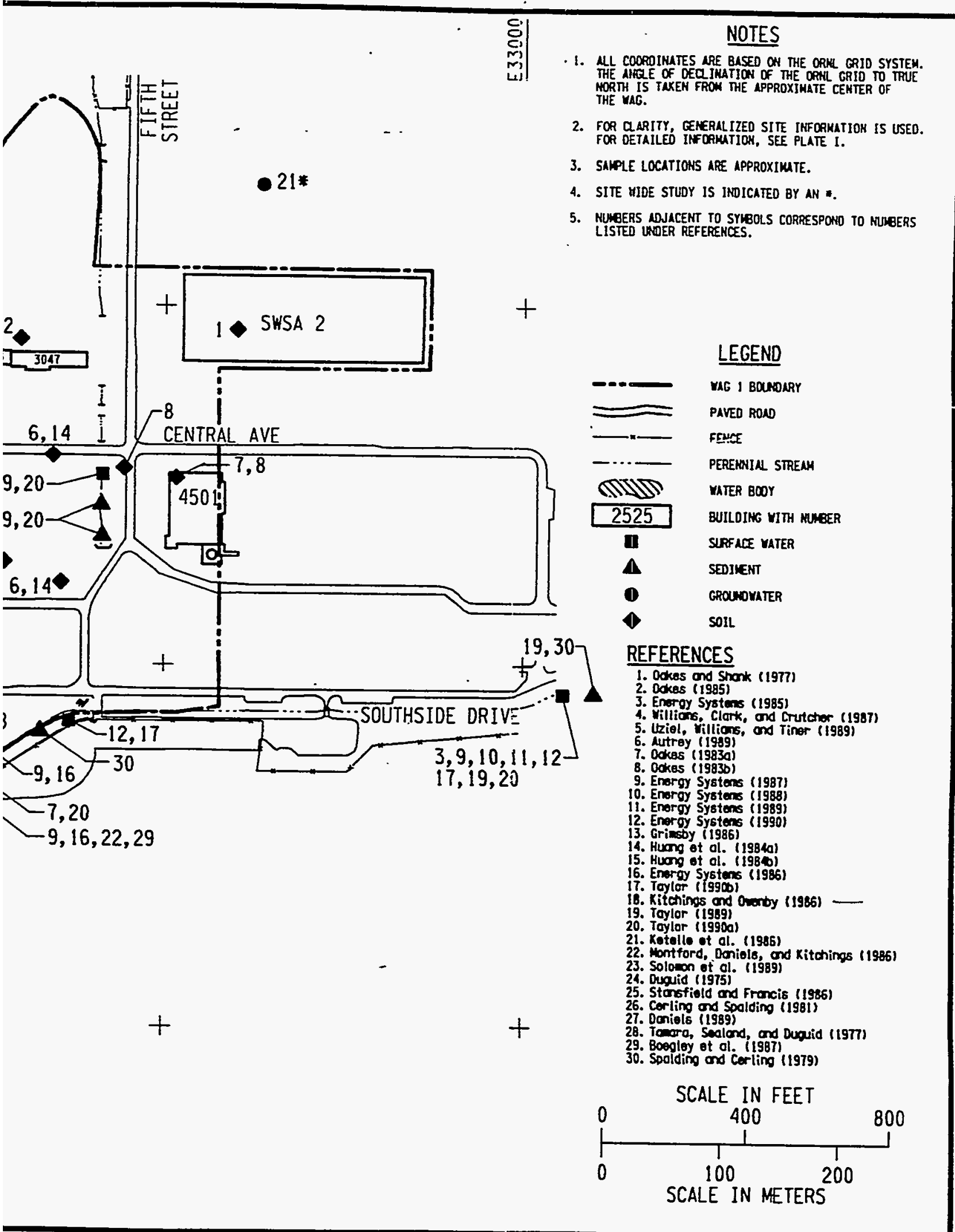

S: NOTES

MLL COORDINATES ARE BASED ON THE ORNL GRID SYSTEM. THE AHRE OF DECQIHATIOA OF THE ORTL CRID TO TRUE MORTH IS TAKEN FRON THE APPROXIMATE CEMTER OF

ISFOAMUTIOH 15 USEO. DETAILED INFORMTIOA, SEE PLATE I.

4. SITE HIDE STUDY IS INDICATED BY AN *

. NUGERS LDJACEMT tO SYHBOLS CORRESPOND TO MUMEERS LISTED UNDER REFERENCES. 
Approximately $50 \%$ of this flux is estimated to be contributed by First Creek and Northwest Tributary during low base nonstorm flow, and the nonstorm balance is estimated to be contributed by WOC. During high base conditions, however, First Creek and Northwest Tributary contribute only approximately $25 \%$ of this flux. This indicates that there is a strontium source that discharges greater quantities to WOC during high base and high base storm flow conditions than during low base conditions.

The known or potential sources of radiological contamination within these creeks include ORNL outfalls, groundwater discharge seeps, and resuspension/desorption of previously deposited contaminated sediment. Tentatively identified pathways through which contamination enters First Creek include a seep located near the geologic contact between Chickamauga Units D and E (see Fig. 6.8), approximately $350 \mathrm{ft}$ northwest of Building 2069, and two storm drain outfalls (341 and 342 ), approximately $150 \mathrm{ft}$ west of Building 2500 . Both of the outfalls and the seep are sources of beta-emitting contamination, which is probably ${ }^{90} \mathrm{Sr}$, although the samples were not analyzed for strontium.

Strontium is entering WOC between the 3513/3524 impoundments and the confluence of WOC and First Creek. Phase I samples from groundwater monitoring wells located adjacent to these impoundments (wells 874, 875, 1100, 1102, and 1104) contained elevated concentrations of ${ }^{90} \mathrm{Sr}$. A sample from well 875 contained the second highest concentration of ${ }^{90} \mathrm{Sr}$ detected in groundwater during Phase I; the filtered component contained $12,000 \mathrm{pCi} / \mathrm{L}$ and the unfiltered component contained $10,300 \mathrm{pCi} / \mathrm{L}$. There may be additional sources of strontium contamination, such as SWSA 1 and other ORNL outfalls (e.g., the radiological process waste system), although sampling data obtained during the Phase I investigation are not adequate to identify these additional sources. The surface impoundments and the radiological process waste system outfall are the most probable sources of ${ }^{90} \mathrm{Sr}$ contamination to the surface water.

In most instances, radionuclide concentrations were slightly lower in filtered than in unfiltered samples. Gross alpha activities in surface water were near background levels and below the Safe Drinking Water Act maximum contaminant level of $15 \mathrm{pCi} / \mathrm{L}$, except for two samples from First Creek. High gross alpha concentrations in First Creek may be partially attributable to ${ }^{234} \mathrm{U}$; other naturally occurring radionuclides were not present in sufficient quantities to account for the remaining alpha activity, suggesting that additional man-made radionuclides were present.

The data indicate that the presence of ${ }^{137} \mathrm{Cs}$ is limited to the portion of WOC downstream of the 3500 impoundment area. The highest concentrations of ${ }^{137} \mathrm{Cs}$ were found in samples collected during low base nonstorm conditions. Cesium-137 was not detected in filtered samples, suggesting that it is transported through adsorption to suspended sediments. Potential sources of ${ }^{137} \mathrm{Cs}$ include seepage from waste management units along WOC, discharge from outfalls, and erosion/suspension from bottom sediments and floodplain soils.

Uranium-234 and ${ }^{228} \mathrm{Ra}$ are predominantly associated with First Creek. Their presence may be related to the groundwater and storm drain discharge associated with the contamination encountered at Core Hole CH008.

Tritium was also widely detected in WAG 1 surface water; in contrast with previous investigations, however, the detected concentrations were generally below reference levels and well below the maximum contaminant level. The maximum concentration of tritium $(5780 \mathrm{pCi} / \mathrm{L})$ was detected in WOC near the Haw Ridge water gap during high base (nonstorm) flow conditions. Tritium concentrations elsewhere in WOC and other creeks were generally similar between high and low base flow. The increased tritium detected in the downstream portion of WOC during high base 


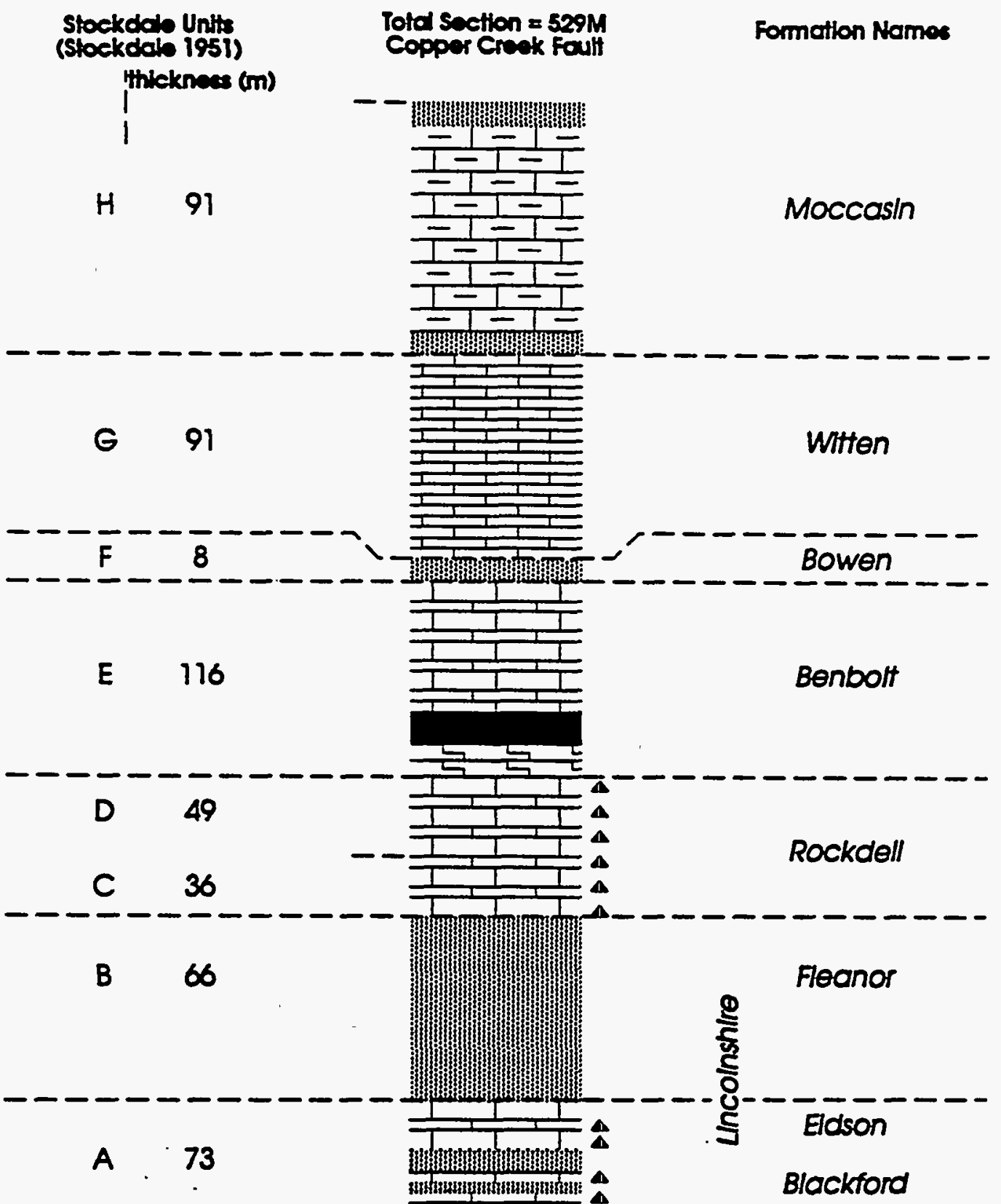

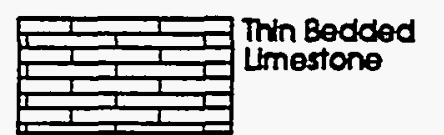
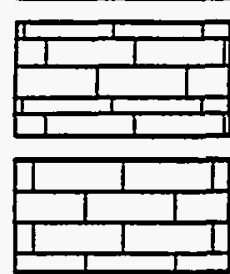

Thin - Medum - Thick Bedded Lmestone

Thick

Bedded Umestone

\section{Krox Erow}

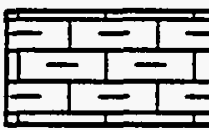

Argliaceous

Limestone

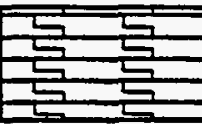

Nodular

Limestone
Chert
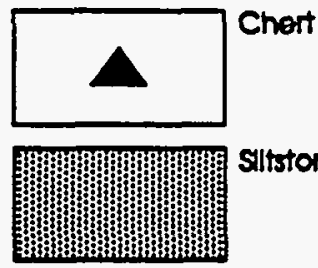

Siltstono

Fig. 6.8. Correlation of Stockdale's (1951) unit designations with formal formation names for Chickamauga Group rocks. Source: Adapted from Hatcher et al. 1992. 
flow therefore reflects increased input below WOC location SW-5 and may indicate greater discharge (or leakage) of tritium-contaminated water from the impoundments.

\section{General Observations on Surface Water Chemicals}

Of the few volatile organic compounds and BNAEs detected, only the volatile organic compounds pyridine and p-dioxane may be of concern, although they were not widely or routinely detected. Metal concentrations in all samples were well below maximum contaminant levels, although aluminum, arsenic, chromium, copper, lead, manganese, nickel, selenium, silver, vanadium, and zinc were detected above reference levels. Cadmium was detected below reference levels.

\section{Sediments}

Surface drainage and point-source discharges from WAG 1 enter WOC, Fifth Creek, or First Creek. In addition, groundwater within WAG 1 discharges to these creeks. Therefore an evaluation of point- and non-point-source releases of contamination from WAG 1 can be made by evaluating sediment from the creeks. Northwest Tributary was included in the evaluation because it converges with First Creek.

Creek channel bottom sediment samples were collected concurrently with surface water samples during the low base nonstorm flow sampling event between October 16 and October 22, 1990. Ten samples were collected: five from WOC, two from First Creek, and one from Northwest Tributary. Most samples were analyzed for radionuclides, metals, volatile organic compounds, BNAEs, cyanide, pesticides, PCBs, and sulfides. The sampling results were compared with reference location results; this comparison identifies the occurrence of sediment contamination that may be the result of releases from sources within WAG 1 and provides a focus for data discussion. Regulatory standards for sediment quality, such as maximum contaminant levels, have not been promulgated.

\section{General Observations on Sediments}

Both man-made and naturally occurring radionuclides were detected in sediment samples from WAG 1. Radionuclides associated with the natural uranium and thorium decay series were detected at concentrations within reference ranges and are not considered site contaminants.

Of the man-made radionuclides detected $\left({ }^{137} \mathrm{Cs},{ }^{60} \mathrm{Co}\right.$, and $\left.{ }^{90} \mathrm{Sr}\right),{ }^{137} \mathrm{Cs}$ was detected most frequently. All man-made radionuclides, including the TRUs ${ }^{241} \mathrm{Am},{ }^{242} \mathrm{Cm}$, and ${ }^{243 / 244} \mathrm{Cm}$, were detected at concentrations exceeding reference levels, indicating that these are site contaminants.

The maximum concentration of ${ }^{137} \mathrm{Cs}$ detected $(2489 \mathrm{pCi} / \mathrm{g})$ was lower than the maximum concentration reported in previous studies $[10,000 \mathrm{pCi} / \mathrm{g}$, reported in Cerling and Spalding (1981)], although the sampling locations were not coincident. However, the concentrations of ${ }^{137} \mathrm{Cs}$ and ${ }^{90} \mathrm{Sr}$ detected in samples from each creek, including reference locations, are generally within the same order of magnitude as the results from previous studies. One exception is First Creek, where ${ }^{90} \mathrm{Sr}$ was detected at 16 and $18 \mathrm{pCi} / \mathrm{g}$ in two samples, whereas Cerling and Spalding (1981) reported concentrations ranging from nondetect to $5.5 \mathrm{dpm} / \mathrm{g}(2.48 \mathrm{pCi} / \mathrm{g})$. While this is not clear evidence of an increase in ${ }^{90} \mathrm{Sr}$ contamination, its presence in sediment samples is consistent with the pattern of ${ }^{90} \mathrm{Sr}$ contamination found in First Creek surface water and related groundwater sampling.

A greater difference is seen in the concentrations of ${ }^{60} \mathrm{Co}$ detected in sediments collected during the Phase I investigation compared with those reported in previous studies. The maximum ${ }^{60} \mathrm{Co}$ concentration detected in samples from WOC was $12.6 \mathrm{pCi} / \mathrm{g}$, whereas in previous studies, ${ }^{60} \mathrm{Co}$ was 
detected at 250,167 , and $460 \mathrm{pCi} / \mathrm{g}$. This suggests either that the ${ }^{60} \mathrm{Co}$ loading in surface water has declined or that the contaminated sediments have been transported farther downstream or covered with less-contaminated sediment.

A number of man-made radionuclides were detected in samples collected during Phase I that were not reported in previous studies of sediment quality: ${ }^{22} \mathrm{Na},{ }^{55} \mathrm{Fe},{ }^{129} \mathrm{I}$, and ${ }^{45} \mathrm{Ca}$. These radionuclides were only detected in samples collected from WOC. Iron-55, ${ }^{129} \mathrm{~T}$, and ${ }^{45} \mathrm{Ca}$ were detected in one sample, while ${ }^{22} \mathrm{Na}$ was detected in samples collected both upstream and downstream of this location. Calcium-45 has the shortest half-life (165 days) of these radionuclides; its presence in sediments suggests that there is a new or chronic release of this radionuclide. Additional analysis of potential source areas for ${ }^{45} \mathrm{Ca}$ would aid in determining whether there is a chronic release point.

Volatile organic compounds detected were at concentrations near detection limits; however, polyaromatic hydrocarbons were detected in samples throughout WOC and in Fifth Creek. Six metals (i.e., cadmium, chromium, copper, lead, mercury, and silver) were detected above reference levels.

The concentrations of mercury detected were comparable to those reported in previous studies, although the maximum concentrations found in previous studies at locations associated with outfalls into Fifth Creek were not encountered. This difference is likely due to the selection of sampling locations and should not be viewed as an indication that the high concentrations of mercury detected in previous studies [e.g., 4874 to $7427 \mu \mathrm{g} / \mathrm{kg}$ near outfall 261 (Taylor 1990a)] have dissipated. The absence of mercury in sediment samples collected in WOC above the confluence with Fifth Creek indicates that discharge or groundwater seepage into Fifth Creek is the major pathway for mercury contamination of WOC. However, previous studies found mercury in the portion of WOC above its confluence with Fifth Creek.

Because data from previous studies on cadmium, chromium, copper, and lead were not available, it is not possible to comment on trends in metal contamination of sediments. Sediments from First Creek contained the greatest concentration of copper, and sediments from Fifth Creek contained the greatest concentration of cadmium.

With the exception of polyaromatic hydrocarbons, it appears that organic contamination is not present in the sediments at WAG 1 . Concentrations of polyaromatic hydrocarbon, which ranged from $200 \mathrm{~J}$ to $12,000 \mu \mathrm{g} / \mathrm{kg}$, may be attributable to parking lot and asphalt surface runoff (e.g., oils) or the accumulation of by-products from coal combustion.

\subsubsection{Groundwater}

\subsubsection{General characteristics of the groundwater regime}

Groundwater movement beneath WAG 1 is not well defined, although a review of published documents and conversations with ORNL investigators suggest that there are several flow regimes of concern. Reports by Stockdale (1951), Webster (1976), and Steuber and Webster (1981), and conversations with R. Ketelle (ORNL) describe plant-scale studies at ORNL or within Bethel Valley. Groundwater is observed to occur both in the unconsolidated overburden and within the bedrock; however, communication between these zones has not been fully evaluated. A summary of existing groundwater conditions, followed by study-specific findings, is reported below.

The uppermost portion of the aquifer occurs under unconfined conditions. Recharge to the system is generally through infiltration with localized recharge through surface impoundments ( 3500 area ponds). The water table appears as a subdued replica of ground surface topography. Under 
isotropic and homogeneous conditions, flow perpendicular to the groundwater contours would be predicted. However, local flow patterns at ORNL are significantly affected by activities in the anthropogenic zone, including active sump pumps, directional permeabilities, and local recharge from impoundments and leaking pipes. Additionally, vertical gradients have not been well defined and are likely influenced by directional permeabilities in bedrock. Thus, current piezometric surface data are of limited use in establishing local flow patterns (Bechtel 1989).

Flow of groundwater in bedrock may be highly influenced by directional permeabilities in bedrock, including, at least, flow through jointed and fractured bedrock, interconnected solution cavities and channels, and along bedding planes. Additionally, vertical gradients-both upward and downward within the aquifer - may be present. Components of flow that have been identified in certain portions of the site include horizontal (parallel to strike), horizontal (between units), horizontal (between groups), and vertical. A strong flow component parallel to strike, both on site and in Bethel Valley, has also been reported.

Stockdale (1951) conducted the earliest studies to characterize local groundwater flow. Stockdale's studies of the site, including coring and pressure testing bedrock, indicated that communication exists between solution cavities (1-in. to 12-in. diameter) in Unit G (Fig. 6.8) and the 3513 pond. He judged that the Copper Creek fault presented an impervious barrier to horizontal groundwater flow between the Chickamauga Group and the Rome Formation, and that Unit F of the Chickamauga Group functioned as a stratigraphic trap for groundwater, preventing its horizontal flow. Recharge to the area primarily occurs through the infiltration of meteoric waters and local recharge conditions (e.g., surface impoundments).

Webster (1976) suggested that groundwater movement should not be plotted on the basis of Stockdale's water table maps, mainly because of the anisotropic nature of the bedrock. From core logs and Stockdale's pressure tests, he concluded that solution cavity size and frequency of occurrence diminished with depth, and that circulation of groundwater in the Chickamauga Group may be restricted to the upper several hundred feet. More recent work by Stueber and Webster (1981) provided information on flow component parallel to strike within the Chickamauga Group in Bethel Valley. This is supported by observations made on site by Ketelle et al. (1986) that fluids lost during drilling were returned at the surface parallel to strike through discharge to Fifth Creek. This also indicates that flow beneath WOC and its tributaries and discharge to those same streams are possible scenarios for groundwater movement.

An additional observation made by Ketelle et al. (1986) is the presence of artesian conditions at depth in the Chickamauga, evidenced by flowing wells and elevated pore pressures at depth, thus indicating the presence of both upward and downward vertical gradients at the site. Ketelle et al. (1986) also observed a reduction in flow in two core holes during pump testing of two wells installed north of Bethel Valley Road. Further investigation of the construction of these two supply wells indicates that water is being pumped from both the Chickamauga and Knox groups in each of the wells. The source of the influence is thus not well defined. The possibility exists that there is communication across the units of the Chickamauga as well as the potential for communication between the Knox and Chickamauga groups.

Huff (1985) conducted a dry-weather dye tracer study to investigate a LLLW transfer line leak between Buildings 3019 and 3074 in WAG 1. The study showed movement of groundwater parallel to strike toward a sump located in the Oak Ridge Research Reactor building and movement around Building 3019. The study concluded that flow towards the Oak Ridge Research Reactor sump was controlled by directional permeabilities in bedrock (solution cavities, joints, and fractures) and an induced hydraulic gradient towards the Oak Ridge Research Reactor sump. Flow around 
Building 3019 was reported as a function of directional permeabilities in the anthropogenic zone along pipelines within permeable backfills.

A piezometer well network has been developed within WAG 1 to observe groundwater levels. A description of the approach used in developing these wells and subsequent interpretation of data is provided in Ketelle et al. (1986).

\subsubsection{Characterization of groundwater contamination}

\section{Overview of Contamination}

Three principal source documents were used to develop an understanding of groundwater contamination within WAG 1. These documents were the Site Characterization Summary Report for WAG 1 at ORNL (Bechtel 1992), the Phase II Remedial Investigation Work Plan for Groundwater at WAG 1 at ORNL (Energy Systems 1993), and the report concerning Migration of a Groundwater Contaminant Plume by Stratabound Flow in WAG I at ORNL (Ketelle and Lee 1992). The Site Characterization Summary Report for WAG 1 at ORNL detailed interpretations regarding the nature and extent of groundwater contamination at WAG 1 that were based on samples collected from 109 wells and piezometers during the Phase I remedial investigation/feasibility study (RI/FS). Four separate sampling events were conducted, though not all wells and piezometers were sampled during each event.

The first event involved sampling 77 wells and piezometers during low base groundwater flow conditions in September and October 1990. The second included 18 wells and piezometers sampled during a prolonged storm and high base groundwater flow conditions in February 1991. The third event involved 82 wells and piezometers sampled during normal (nonstorm) high base groundwater flow conditions in March and April 1991. The fourth sampling event was conducted in response to the addition of 33 SWMUs in 1991 to the scope of the Phase I investigation and the discovery of radioactive contaminants in well 4005 (CH008). This event entailed sampling 14 piezometers in the vicinity of the newly added SWMUs and CH008 during the period July through October 1991. In addition to the four noted sampling events, samples were also collected from 25 wells installed as part of a groundwater quality monitoring well installation program at ORNL. These wells were sampled during both low base and high base (nonstorm) groundwater flow conditions.

Several general areas of contamination were identified based on the results of the groundwater sampling conducted at WAG 1. Both radiological (Fig. 6.9) and chemical contaminants were identified in groundwater at this site. The primary radionuclides found in groundwater were strontium and tritium. Radionuclides found less frequently included ${ }^{226} \mathrm{Ra},{ }^{228} \mathrm{Ra},{ }^{99} \mathrm{Tc},{ }^{234} \mathrm{U},{ }^{238} \mathrm{U},{ }^{228} \mathrm{Th},{ }^{230} \mathrm{Th}$, ${ }^{232} \mathrm{Th},{ }^{238} \mathrm{Pu},{ }^{239} \mathrm{Pu},{ }^{240} \mathrm{Pu},{ }^{241} \mathrm{Am},{ }^{60} \mathrm{Co},{ }^{63} \mathrm{Ni},{ }^{55} \mathrm{Fe}$, and ${ }^{137} \mathrm{Cs}$. There is evidence that ${ }^{90} \mathrm{Sr}$ is migrating from WAG 1 and seeping into First Creek. There is also limited evidence that some of this plume may be underflowing First Creek and migrating westward. Other locations where groundwater contamination may be affecting surface water quality are near the surface impoundments and near SWSA 1.

The most widespread organic compounds found in groundwater at WAG 1 are trichloroethene and its degradation products 1-, 2-dichloroethene, and vinyl chloride. Benzene, toluene, xylene, and ethylbenzene were found associated with an underground petroleum storage tank previously located near the steam plant facility (Building 2519). Silver, cadmium, chromium, lead, and mercury (one sample) were detected at concentrations exceeding the maximum contaminate limits in samples from wells within and outside WAG 1. Cadmium, chromium, and lead were generally found to occur in 


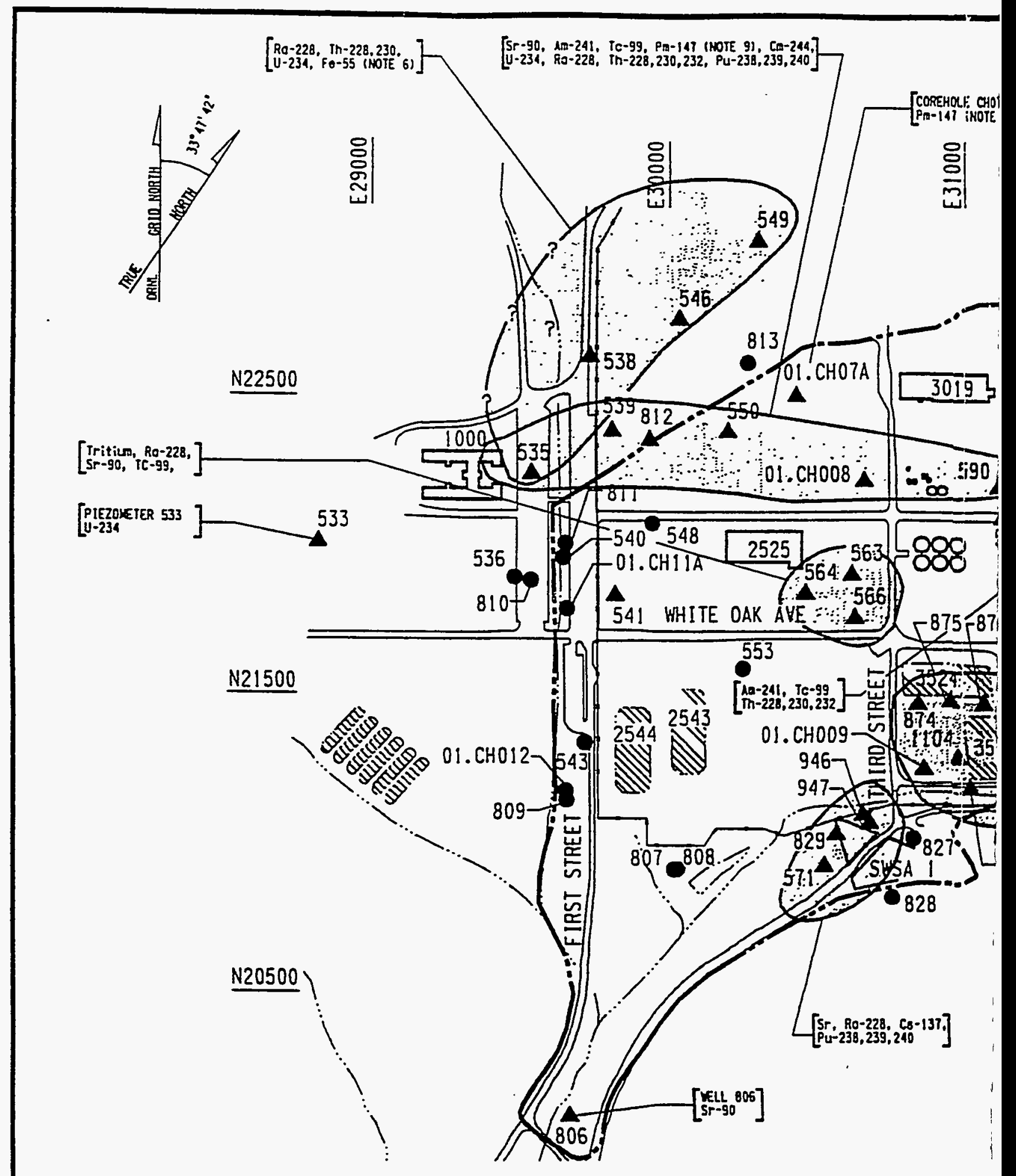


the same wells. The most widespread metal detected at elevated concentrations was cadmium, which exceeded the maximum contaminant limit at the largest number of locations throughout WAG 1.

\section{Specific Areas of Contamination}

Building 3001/3019 Area Indicator radiological data from groundwater and soil samples collected from the Building 3001/3019 area (Fig. 6.10) indicate that three areas of contamination exist: (1) the site of a past pipeline leak southwest of Building $3019,(2)$ the site of a past pipeline leak north of Building 3019, and (3) the 3019 Hot Bank. The pipeline network at 3001/3019 is believed to have a large impact on the transport of contaminated groundwater. A large, complex array of buried pipelines extends from the area to much of WAG 1 , including areas south of 3001/3019 (e.g., the Core Hole CH008 area, North Tank Farm, and the Isotopes Area); First Creek; and Fifth Creek. As a result, the pipeline system may conceivably transport contaminants from the 3001/3019 area to virtually any other part of WAG 1.

North Tank Farm Groundwater data are available only from the periphery of the tank farm and are probably not representative of groundwater data within the site or the excavations immediately around the tanks. Despite the absence of groundwater data from the North Tank Farm, its history of operation and proximity along geologic strike to Core Hole $\mathrm{CH} 008$ has made it a candidate source area for the $\mathrm{CH} 008$ plume. Alternatively, leaks from low-level waste or process waste pipelines from the Building 3019 area could be sources. Based on assumptions concerning groundwater elevation in the vicinity of the North Tank Farm, it is not considered to be a likely source area for the $\mathrm{CH} 008$ plume. However, this assumption is not confirmed, and essentially no data are available to describe the potential migration of North Tank Farm contaminants either through pipeline trenches or the groundwater flow system to the west or south.

South Tank Farm Data collected at the South Tank Farm indicate that significant amounts of contamination exist in shallow soil at the site. However, information about the nature of the tank/groundwater interactions is not known. Groundwater contamination at the South Tank Farm may have resulted from historical leaks in pipelines or from contaminants migrating along pipeline trenches. The tank farm is contained within a pit that was excavated into bedrock, and the major factor affecting groundwater is probably the tank sump system. Depending on the effectiveness of the dry well and sump system, some contaminated groundwater may be able to migrate out of the tank farm through pipeline trenches or within the groundwater flow system. Data regarding hydrogeological conditions within the tank farm are needed to evaluate these scenarios and the effectiveness of the dry well system.

Isotopes Area During the production of radioisotopes over the years, numerous spills and pipeline leaks of radioactive and nonradioactive contaminants have occurred in the Isotopes Area. Contamination that is at least partly discharging into the process waste pipeline network in the area is known to occur beneath Building 3047. Elevated levels of gross alpha, gross beta, and tritium have been detected in groundwater samples from Isotopes Area wells and sumps. Levels of these contaminants were found in a water sample collected from the Building 3033 sump; these levels included the highest tritium activity detected in WAG 1 , which were from two to four orders of magnitude higher than those detected in Isotopes Area wells.

Possible sources of the radiological contamination of groundwater within the Building 3033 sump and in the area process system could be located uphill in the 3019 or 3042 areas. Contaminants could be transported down-dip with groundwater in Unit D, discharge upward to Unit E, and move along strike to the east in a mirror image of the Core Hole CH008 plume. Alternatively, there could be a source to the west in the Building 3026 area, a localized pipeline leak, or a combination of 


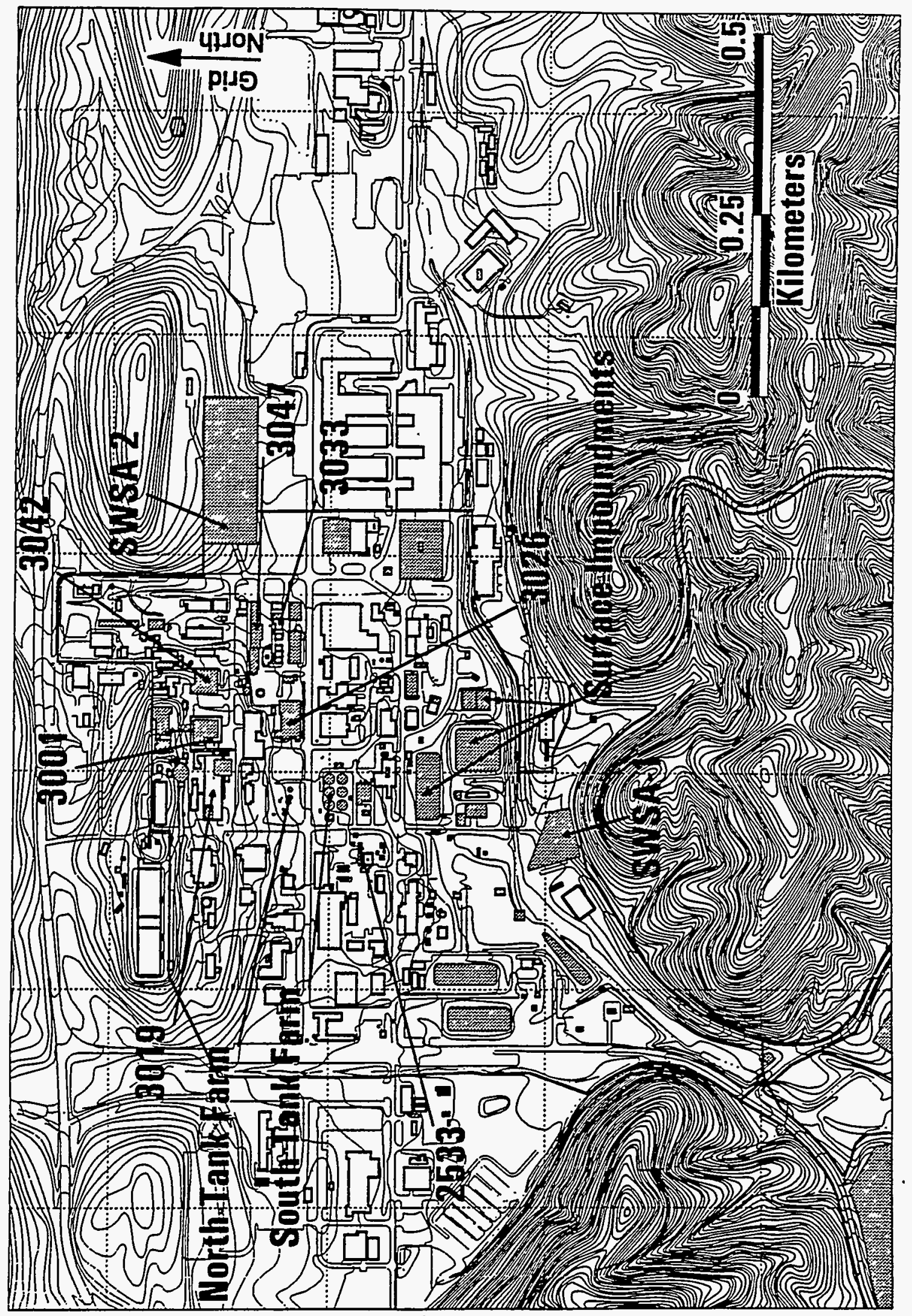

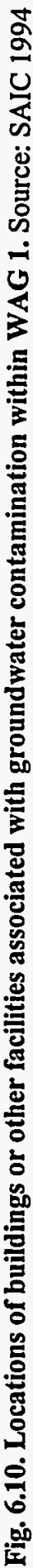


sources. This contamination could ultimately be intercepted by the process system and be treated in the Process Waste Treatment Plant (PWTP), move off WAG in permeable pipeline trench backfill, and/or underflow Fifth Creek.

Core Hole CH008 As part of the Phase I studies in WAG 1, rock core drilling was conducted to accurately describe subsurface geologic conditions and permit the performance of subsurface hydrologic tests. In June 1991, rock core drilling of Core Hole CH008 (Fig. 6.11) revealed radiologically contaminated conditions in the uppermost portions of the bedrock. The core hole was drilled to a depth of $16.3 \mathrm{~m}(53.5 \mathrm{ft})$ below ground level and was outfitted with a Westbay multilevel groundwater sampling device. Sampling results indicated that the highest levels of gross beta/gamma contamination occurred from 6.1 to $9.2 \mathrm{~m} \mathrm{(20} \mathrm{to} 30 \mathrm{ft}$ ) below the bedrock/water table interface.

The discovery of groundwater contamination at $\mathrm{CHOOO}$ prompted a detailed investigation to identify the contaminant plume. Using a working hypothesis of stratabound groundwater flow and contaminant transport, investigators analyzed existing subsurface geologic data to predict the contaminant plume discharge location in First Creek and the locations of contaminated groundwater seepage into storm drains. This hypothesis stated that differential lithologic/fracture conditions lead to the development of preferred flow and transport pathways of discrete vertical extent, which may not be coincident with the local hydraulic gradient. Results of the analysis indicated that application of the hypothesis accurately predicted the $\mathrm{CH} 008$ plume discharge in First Creek, which migrated to the discharge point parallel to geologic strike and $\sim 65^{\circ}$ oblique to the local hydraulic gradient (Fig. 6.12).

Oak Ridge Research Reactor (Building 3042) Area Groundwater samples collected from the Oak Ridge Research Reactor (Building 3042) area wells detected activities of gross alpha, gross beta, and tritium above reference levels. Higher levels of radiological contamination found in the Building 3042 area wells were observed in a water sample collected from the Building 3042 sump. Results of a dye test indicated that groundwater was flowing eastward along geologic strike to the Building 3042 sump from the area of a LLW line break that occurred between Buildings 3019 and 3074. A cavity in the limestone bedrock was observed in the excavation dug for the line break. Fluorescein dye injected into this cavity was observed in the inner (upper) Building 3042 sump within $48 \mathrm{~h}$. The hydraulic gradient calculated from the dye test is produced by pumping water, which maintains a groundwater depression in the vicinity of the sump. Therefore, radiological contamination detected in samples from the Building 3042 sump may be moving from the Buildings 3001/3019 area along cavities and solution features in Unit D. Contaminants may also be collected in the sump from leaks in nearby underground lines.

Surface Impoundments $(3524,3513,3539$, and 3540) Activities of gross alpha, gross beta, and tritium were detected above reference levels in groundwater samples collected from the Surface Impoundments area wells. In general, significant radiological contamination was found downgradient (south) of the unlined waste detention basin 3513 and equalization basin 3524 but was not found in the 3539/3540 area. The highest levels of contamination occurred in samples collected during high base storm conditions. This contamination consisted primarily of high levels of tritium, moderately high levels of gross beta (predominantly ${ }^{90} \mathrm{Sr}$ and ${ }^{228} \mathrm{Ra}$ ), and moderately low levels of gross alpha.

Seepage of contaminated water from the detention basin and equalization basin impoundments is apparently a major source of tritium, ${ }^{90} \mathrm{Sr}$, and ${ }^{228} \mathrm{Ra}$ contamination of groundwater within WAG 1 . Video inspection of a 61-cm (24-in.) storm sewer west of the equalization basin revealed numerous inleaking joints, particularly in that portion of the sewer on the northwest side of this basin. Because most of the leaks were from the equalization basin side (east) of the pipeline and a head potential 


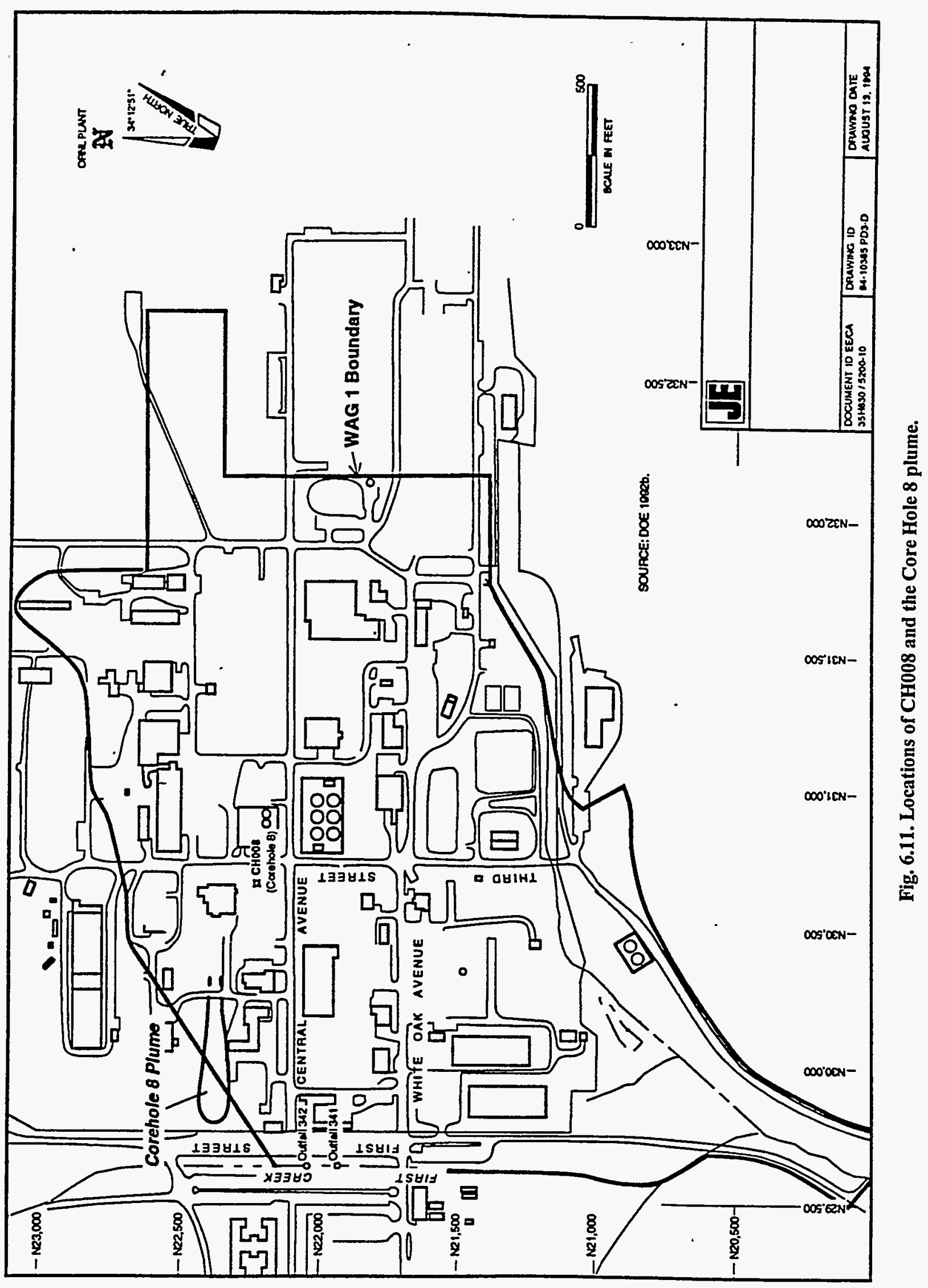




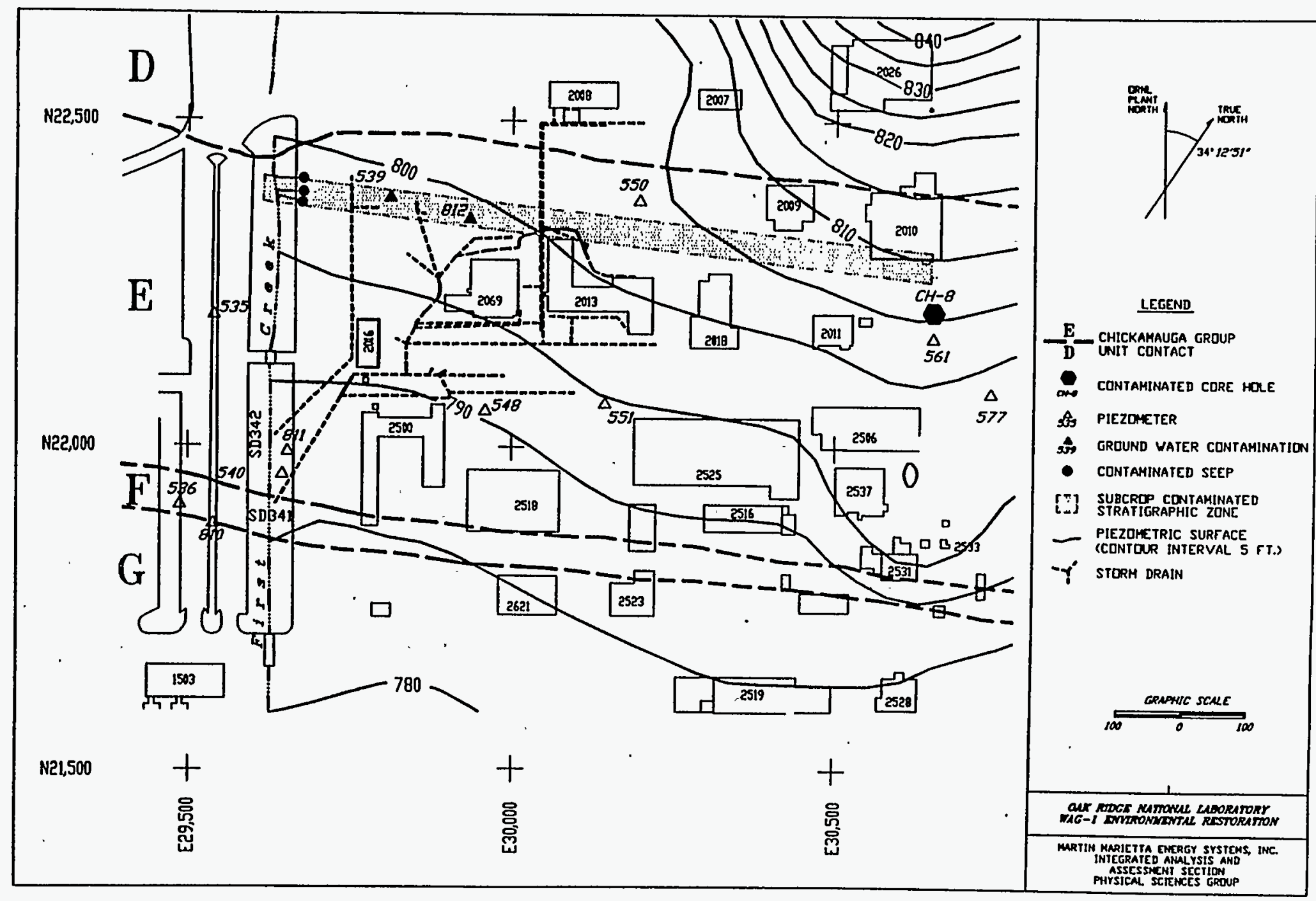

Fig. 6.12. Locations of contamination in the western portion of WAG 1 and interpreted plume configuration. Source: Ketelle and Lee 1992. 
exists from the equalization basin to the pipeline, it is reasonable to assume that the pipeline inleakage is derived at least partly from seepage from the equalization basin. Contaminants should move southward (downgradient in the overburden and down-dip in bedrock) and eventually discharge to WOC. Contaminants may also be migrating in pipeline trench backfill materials. Given the relatively short half-life and slow transport velocity in groundwater of ${ }^{228} \mathrm{Ra}$, tritium, and ${ }^{90} \mathrm{Sr}$ are the primary contaminants that could reach WOC and be transported off WAG 1 .

SWSAs 1 and 2 The relatively complete set of historical data for many wells located in SWSA 1 indicates generally stable contaminant concentrations over time and between high and low base flow groundwater conditions. Gross alpha and beta concentrations were found to be generally below reference levels, and tritium values ranged between $\sim 37$ and $92 \mathrm{~Bq} / \mathrm{L}$. The higher tritium activities in bedrock wells suggest the possibility of flow paths below the water table surface. In addition, several radionuclides $\left({ }^{239} \mathrm{Pu},{ }^{240} \mathrm{Pu}\right.$, and $\left.{ }^{228} \mathrm{Ra}\right)$ detected in a piezometer may suggest westward migration of contaminants from SWSA 1.

Groundwater samples collected from wells in SWSA 2 indicate that tritium contamination is prevalent throughout much of the area, with the highest concentrations occurring within and southwest of SWSA 2. This finding suggests that contamination may be migrating southwestward from SWSA 2. Slightly higher gross alpha and beta detected in a downgradient piezometer also suggests minor migration of these contaminants. This is corroborated by the presence of radiological contamination in Fifth Creek outfall 165, which serves a small segment of a storm sewer from Fifth Street. Because no other source for the outfall 165 contamination is apparent, it is presumed to be coming from discharging groundwater from SWSA 2. Data from an adjacent pair of bedrock wells drilled to depths of 6.1 and $24.4 \mathrm{~m} \mathrm{(20}$ and $80 \mathrm{ft}$ ) indicate that contamination decreases with depth.

Pipelines Because pipelines, particularly process waste pipelines, are known to collect significant amounts of contaminated groundwater, available flow and radiological data from process waste manholes that are monitored monthly were analyzed. Correlation between manhole contaminant flux and precipitation and/or groundwater elevation supports the concept that contaminant mobilization occurs principally during periods of elevated water table, despite apparently lower concentrations due to dilution. It also suggests that contaminants residing in groundwater, or in the vadose zone immediately above the water table, are mobilized above the bedrock weathering interface in response to elevation of the water table. Compared to contaminant concentrations in underground tank dry wells, the level of contamination in pipeline trenches is comparatively small. However, although tank dry wells tend to capture contaminated groundwater, pipeline trenches tend to distribute contamination.

With the exception of the limited data pertaining to contaminant migration in pipeline trenches within WAG 1, further resolution of migration pathways within WAG 1 is considered to be exceedingly difficult. Pipeline routes and system interconnections are only generally known, and the map atlas for the system is more than 10 years old. Rather than attempting to unravel WAG interior pathways, sampling of trench backfill near pipeline discharge locations at surface water bodies is the preferred approach for delineation. Identified excursions can then be traced back on a case-by-case basis using atlas information and/or camera examination to locate individual sources.

Unit F Because strike-parallel flow and contaminant transport in Unit F has been characterized in SWSA 3 (WAG 3), consideration is given to similar type flow in WAG 1. Three areas of contamination in or immediately outside of WAG 1 could be related to strike-parallel flow within Unit F. 
The first of these areas is located in the vicinity of piezometer 0536 and well 0810 , which are located immediately west of First Creek near the intersection of First Street and Central Avenue. Data indicate the absence of either a hydraulic or concentration gradient from piezometers or wells in WAG 1 toward piezometer 0536 or well 0810 . Very close control on the elevation of First Creek in the vicinity of Unit $F$ indicates a reverse hydraulic potential from the creek to well 0810 . These data essentially preclude WAG 1 as a source of the detected contamination. Rather, hydraulic and concentration gradients do exist from piezometer 0533 toward piezometer 0536 and well 0810 , indicating an eastward migrating plume. Because strike-parallel flow has been documented within Unit $F$ at SWSA 3, the most logical explanation for the source of contamination near WAG 1 is migration from SWSA 3. If this is the case, it suggests that Northwest Tributary is an incomplete groundwater discharge surface water body and that First Creek is the ultimate discharge location for eastward-migrating groundwater.

The second area is located in the vicinity of the Building 2533 sump. Indicator radiological data for piezometers and sumps appear to describe another contaminant plume associated with Unit $F$. The data indicate the presence of a plume originating in the vicinity of the Building $2533 \mathrm{sump}$ and migrating in a southwesterly direction. The plume exhibits highly elevated concentrations of tritium and gross beta contamination; nearly $75 \%$ of the gross beta activity in the Building 2533 sump occurs as ${ }^{137} \mathrm{Cs}$. The plume appears to terminate in Unit F, and a piezometer located south of Unit $F$ in the apparent plume migration direction does not exhibit radiological contamination. Radiological contamination slightly above background levels in a piezometer located $198 \mathrm{~m} \mathrm{(650} \mathrm{ft)} \mathrm{west} \mathrm{in} \mathrm{Unit} F$ may represent strike-parallel migration since no other apparent source for that contamination (especially ${ }^{137} \mathrm{Cs}$ ) is in the area. However, current data are insufficient to substantiate the occurrence of such migration.

The third area is located in the vicinity of Core Hole CH009. Sampling conducted in two straddle packer test intervals in this core hole [ 96 to $100 \mathrm{~m}$ and 38 to $42 \mathrm{~m}$ (314 to $327 \mathrm{ft}$ and 126 to $138 \mathrm{ft}$ )] revealed the presence of ${ }^{137} \mathrm{Cs}$ and tritium. One explanation for the contamination detected in $\mathrm{CHO} 99$ is down-dip migration within Unit F. Such migration is potentially significant because it would indicate the presence of long, deep flow paths actively involved in contaminant migration, which is contrary to the current conceptual model of the flow field. The lower $\mathrm{CH} 009$ contaminated interval is within Unit $F$, and the upper contaminated interval is within Unit G. Flow meter testing in the core hole determined that water entered the hole in the vicinity of $103 \mathrm{~m}(338 \mathrm{ft})$ and exited the hole at $41 \mathrm{~m}(135 \mathrm{ft})$. Geochemical sampling of the contaminated intervals indicated that the waters are of the sodium chloride type, which has been interpreted to represent deep and older water. Mixing between the time the hole was drilled and straddle packer testing may render results questionable for the upper interval. These data suggest that the upper interval contaminants are derived from the lower interval. However, the presence of significantly higher tritium concentrations in the upper interval is inconsistent with interpretation of upward migration of tritium within the core hole.

Localized Areas of Contamination Several localized areas of groundwater contamination have been identified within WAG 1 . Contamination detected at well 0830 and piezometers 0584,0590 , 0593, and 0601 is believed to be associated with various pipeline, sump, or tank leaks in the vicinity of these installations. Possible sources of contamination detected in piezometer 0553 include fallout from atmospheric emissions from coal combustion at the site steam plant and a release from the nearby diesel underground storage tank.

Well 4004 is located in the northwestern part of WAG 1, north of Building 2009. It was drilled to a total depth of $56.3 \mathrm{~m}(184.6 \mathrm{ft})$ and penetrated Chickamauga Unit D at $8.5 \mathrm{~m}(28 \mathrm{ft})$ and Chickamauga Unit $\mathrm{C}$ at $45.0 \mathrm{~m}(147.6 \mathrm{ft})$. Geophysical, temperature, and hydrological testing, as well 
as groundwater sampling, were performed within the Unit D interval of the borehole. The results of this testing indicated the presence of a cavity, active groundwater flow, low levels of contamination, and a low head, which imply that this interval may include a significant groundwater discharge zone in Unit D.

An area comprising the northern 2000 part of ORNL is located northwest of the WAG 1 boundary. Elevated gross alpha, gross beta, and tritium activities were detected in low base and high base groundwater samples collected from wells in this area. Radionuclides detected above reference levels were ${ }^{228} \mathrm{Th},{ }^{230} \mathrm{Th},{ }^{232} \mathrm{Th},{ }^{234} \mathrm{U},{ }^{238} \mathrm{U},{ }^{226} \mathrm{Ra},{ }^{228} \mathrm{Ra}$, and total strontium. In general, activities of these radionuclides were higher in the high base flow samples than in low base flow samples (SAIC 1994).

\subsubsection{Ecology}

The environs of WAG 1 are typical of the ecological systems of the Appalachian region. The dominant plant community is the Old Hickory Forest, with extensive stands of mixed yellow pine and hardwoods. Nonforest areas include grasslands, devegetated areas, and developed locations. Nonforest areas predominate in WAG 1 . The forests in the ORR serve as host for many forest wildlife species and therefore may serve as a refuge for wildlife. Approximately 60 species of reptiles and amphibians; more than 120 species of terrestrial birds; 32 species of waterfowl, wading birds, and shore birds; and about 40 species of mammals have been recorded on the ORR (Nix et al. 1986). The aquatic communities potentially affected by WAG 1 include the WOC watershed and Clinch River downstream from the mouth of WOC. The WOC watershed is not known to have any threatened or endangered species. Sect. 5.2.7 provides an overview of the flora and fauna commonly found on the ORR, which are believed to be representative of those found at WAG 1 .

\subsection{RELEASES AND SITE CONCEPTUAL MODEL}

For additional discussion of WAG 1 contaminants, see Sect. 6.2.4.2 for soil contaminants; see Sect. 6.2.5.3 for surface water and sediment contaminants; see Sect. 6.2.6.2 for groundwater contaminants.

\subsubsection{Site Conceptual Model}

In its most rudimentary form, the process of contamination of an environmental medium involves a source of contamination and a release mechanism whereby contamination is transferred from the source to the environmental medium. Once in the environmental medium, the contaminant can reside in it, be transported with it, or be transferred to another medium. For WAG 1, the principal potential source release mechanism/contaminated media chains are presented in Table 6.1.

Table 6.1. Principal source release mechanism/contaminated media chains for WAG 1

\begin{tabular}{lll}
\hline Source/operable unit & Release mechanism & Contaminated medium \\
\hline Tanks and pipes & Leaks & Soils, groundwater \\
Tanks & Structural failure & Soils, direct radiation \\
Impoundments & Seepage & Soils, groundwater \\
Contaminated soils, & Infiltrating precipitation & Soils in deeper vadose \\
SWSA waste pile & & zone, groundwater
\end{tabular}


Table 6.1 cont.

\begin{tabular}{lll}
\hline Source/operable unit & Release mechanism & Contaminated medium \\
\hline Contaminated groundwater & Direct contact, diffusion & Aquifer matrix \\
Contaminated groundwater & Discharge & Surface water \\
Surface water & Direct contact & Sediments \\
\hline
\end{tabular}

'Postulated, not actual

\subsubsection{Sources}

Although each SWMU within WAG 1 is a potential source for the spread of contamination in the various media, it is impractical to address them separately. SWMUs can be grouped together on the basis of their proximity and similarity of contaminant inventory; Table 6.1 uses such groupings of sources.

The principal sources of WAG 1 contamination, both radiological and chemical, are (1) the inactive tanks and their associated pipes and (2) the radiological impoundments and the contaminated soils around them. Approximately $95 \%$ of the total documented radioactivity of the inactive waste management units in WAG 1 is contained in the six large Gunite tanks in the South Tank Farm. The radiological impoundments are believed to be a major source of tritium contamination of groundwater, as evidenced by very high concentrations (ranging from a few hundred thousand to over $800,000 \mathrm{pCi} / \mathrm{L}$ ) in the groundwater downgradient of them. The inventory of tritium in these impoundments is not known. The impoundments are also sources of ${ }^{90} \mathrm{Sr}$ contamination of groundwater.

An National Pollutant Discharge Elimination System-permitted outfall associated with the PWTP (XO7) has been a known source of ${ }^{60} \mathrm{Co}$ and ${ }^{137} \mathrm{Cs}$ discharges into WOC. However, since April 1, 1990, when the new Nonradiological Wastewater Treatment Facility began operating, this outfall and some others have been eliminated (Energy Systems 1991). Some contaminants (e.g., pyridine and p-dioxane) may have discharged to the WOC surface water system through outfalls. These contaminants are distinguished by their presence in surface water only and have not been identified in groundwater samples.

\subsubsection{Release Mechanisms}

The primary release mechanisms responsible for contamination of soil and groundwater are leaks from underground tanks and their associated piping and seepage from impoundments. Infiltrating precipitation transfers soil contamination deeper, finally contaminating groundwater. Contaminated groundwater transfers contaminants to the solid aquifer matrix through direct contact and, for fractured bedrock, also through slow diffusion into the rock matrix pores. Surface water is contaminated through discharge of contaminated groundwater. Because of the extensive network of pipeline trenches in WAG 1 (some below the groundwater table), contaminated groundwater has leaked into the outfall systems. In the past, some outfall discharges, most notably X07, were significant contributors to surface water contamination. Release of contaminants by surface runoff is not believed to be significant. Sediments are contaminated through direct contact with contaminated surface water.

Some release mechanisms (e.g., those involving direct contact) are reversible, depending on the relative concentrations of contaminants in the media involved. For example, contaminated sediments 
can contaminate surface water through desorption. Such reverse releases are usually important after some level of cleanup of one of the media has been achieved.

Because of the deteriorating condition of some of the tanks, a potential for release of contaminants exists following structural failure (e.g., collapse of a tank roof). Contaminants could be released to the environment through suspension and transport of soil particles in air, through volatilization and transport of volatiles in air, and through direct radiation from radioactively contaminated sludges.

\subsubsection{Fate and Transport}

The medium most immediately and most commonly affected by a contaminant release from its source is soil. The leachability of contaminants from soil is a good indicator of their mobility and transferability to other media. Soil samples were selected from areas suspected of high metal and radiological contamination and subjected to leachability analysis using deionized water. Based on results of this analysis, all metals and radiological contaminants, with the obvious exception of tritium, are found to be strongly held in soils. Radioactive strontium was the only other radionuclide consistently detected in the extracts above quantitation limits. These observations are consistent with the generally widespread occurrence of tritium and strontium in groundwater samples.

The relative immobility of metals and radionuclides in soils explains why that, although their concentrations in soils may be high, they remain relatively low in groundwater and surface water. All BNAEs of concern in WAG 1 are also strongly held in soils, as indicated by their high $\mathrm{K}_{\mathrm{oc}}$ values; few BNAEs have been detected in surface water. Volatile organics, on the other hand, leach readily from soil to groundwater, and because their distribution coefficients are generally low, they are transported in groundwater relatively rapidly. When discharged into surface water, their concentrations decrease rapidly because of loss from volatilization.

\subsubsection{Groundwater}

Subsurface transport of particle-reactive contaminants occurs at a velocity that depends both on the average linear groundwater velocity and contaminant-specific distribution coefficient. The velocity of contaminant transport is given by

$$
V_{c}=\frac{V_{g}}{\left(1+\frac{\rho_{b} K_{d}}{\theta}\right)}=\frac{V_{g}}{R}
$$

where $\quad V_{c}=$ velocity of contaminant transport, $\mathrm{LT}^{-1}$

$\mathrm{V}_{\mathrm{g}}=$ average linear groundwater velocity, $\mathrm{LT}^{-1}$

$\rho_{b}=$ bulk density of the solid matrix, $\mathrm{ML}^{-3}$

$\mathrm{K}_{\mathrm{d}}=$ distribution coefficient, $\mathrm{L}^{3} \mathrm{M}^{-1}$

$\theta=$ moisture content, dimensionless, and

$\mathrm{R}=$ retardation factor, dimensionless.

This equation assumes Darcian (porous-media) flow; actual flow velocities of WAG 1 are likely to be greater in localized areas because of the presence of solution channels and highly developed fracture systems. The contaminant-specific retardation factor, $R$, must be estimated to ascertain the 
rate of contaminant migration. As an example, the retardation factor is estimated for trichloroethene (TCE), an organic observed to be present in WAG 1 groundwater. The distribution coefficient of an organic can be expressed as $K_{d}=f_{o c} K_{o c}$, where $f_{o c}=$ mass fraction of organic carbon content and $K_{o c}$ has been previously defined. Assuming an $f_{o c}$ of 0.0005 , and $K_{o c}$ of $126 \mathrm{~cm}^{3} / \mathrm{g}$, a value of $0.063 \mathrm{~cm}^{3} / \mathrm{g}$ for $\mathrm{K}_{\mathrm{d}}$ is determined. Assuming $\rho_{\mathrm{b}}=1.8 \mathrm{~cm}^{3} / \mathrm{g}$ and $\theta=0.4$, a retardation factor of 1.28 is calculated. This value is close to. 1 , indicating that TCE and other volatiles with comparable $K_{o c}$ levels move relatively unretarded in groundwater in a low organic carbon environment such as that expected at WAG 1. Similar calculations for metals and radionuclides would show that most metals and radionuclides are significantly retarded because of their particle-reactive nature.

\section{Radiological}

Radiological contaminants found in groundwater migrate at velocities that depend upon the groundwater velocity and the contaminant-specific retardation factor. While migrating, they undergo radioactive decay at a radionuclide-specific decay rate and form daughter products that may be more or less mobile than the parent. Because of the complex hydrogeology of the WAG 1 site, contaminant migration velocities can only be approximated. Since tritium moves unretarded in groundwater, its transport is discussed first.

The principal sources of tritium contamination of WAG 1 groundwater are the radiological impoundments. A typical groundwater velocity of $0.2 \mathrm{ft} /$ day can be assumed for the impoundment area, and the distances from the impoundments to WOC, the discharge boundary, are approximately $100-300 \mathrm{ft}$. The groundwater residence time of tritium originating from the impoundments would, therefore, range from 1 to 4 years. Because the half-life of tritium is 12.3 years, no significant decay of tritium for this case is expected. Consequently, the large differences in tritium concentrations in surface and groundwater around the impoundment areas can be attributed to dilution alone.

Impoundments are also sources of ${ }^{90} \mathrm{Sr}$ and ${ }^{232} \mathrm{Th}$. The latter is virtually immobile, having a very high $\mathrm{K}_{\mathrm{d}}$. However, a daughter, ${ }^{228} \mathrm{Ra}$, is relatively mobile and is detected in significant concentrations in wells downgradient of the impoundments. Using the estimated groundwater transport velocities for radium of $5.7 \times 10^{-3} \mathrm{ft} /$ day to $0.15 \mathrm{ft} /$ day, it would take between 2 and 48 years for ${ }^{228} \mathrm{Ra}$ to travel $100 \mathrm{ft}$ from the 3513 and 3540 impoundments to WOC. Time estimates to travel $300 \mathrm{ft}$ from the 3524 impoundment to WOC range from 6 to 144 years. If local groundwater velocities $(0.2 \mathrm{f} /$ day $)$ are used instead of area-wide averages, the transport travel times for radium range from 12 to 330 years to migrate $100 \mathrm{ft}$ and 36 to 995 years to migrate $300 \mathrm{ft}$. Thus, ${ }^{228} \mathrm{Ra}$ may have migrated from the southernmost impoundments to WOC, but it is much less likely that ${ }^{228} \mathrm{Ra}$ traveling in groundwater from the northernmost impoundments could have reached WOC. Also, ${ }^{228} \mathrm{Ra}$ would undergo significant decay before reaching WOC. (The half-life of ${ }^{228} \mathrm{Ra}$ is only 5.76 years.) Strontium-90, which has a migration velocity about three times that of ${ }^{228} \mathrm{Ra}$, would take between 34 and 50 years to travel from the farthest impoundment (3524) to WOC and would also undergo some decay. (The half-life of ${ }^{90} \mathrm{Sr}$ is 28.8 years.) Concentrations of ${ }^{90} \mathrm{Sr}$ and ${ }^{228} \mathrm{Ra}$ in surface waters would reflect the effects of both radioactive decay in groundwater and dilution in groundwater and surface water.

Potential sources of radiological contaminants associated with North Tank Farm and South Tank Farm and their associated piping are approximately in the center of the WAG. The contaminant migration pathway (for any contamination not captured by the tank farm sump system) would be predominantly along strike toward First Creek, a distance of approximately $1200 \mathrm{ft}$. A higher groundwater velocity can be assumed for this area because groundwater flow is predominantly in bedrock at steeper hydraulic gradients. Assuming a groundwater velocity of $5 \mathrm{ft} /$ day for this area, the groundwater residence time of tritium would be less than a year, too short for any significant decay. 
Regardless of the location of a tritium source within WAG 1, the groundwater residence time appears to be too short for any significant decay to occur.

Rates of potential migration of ${ }^{90} \mathrm{Sr}$ from the North Tank Farm and South Tank Farm area may vary from 0.15 to $1 \mathrm{ft} /$ day. Assuming a rate of migration of $0.5 \mathrm{ft} /$ day, it would take about 7 years for ${ }^{90} \mathrm{Sr}$ to reach First Creek. No significant decay is expected. Radium-228, however, might take three times longer and would decay to about one-twelfth its source value.

The migration pathway of radiological contaminants potentially originating in the graphite reactor area is decidedly toward Fifth Creek. Because of the relatively short distance to the discharge boundary, no significant decay in groundwater of tritium or ${ }^{90} \mathrm{Sr}$, the major contaminant, is expected. Americium-241, identified in groundwater samples collected near the Building 3042 area, flows toward Fifth Creek. $K_{d}$ values were not measured for americium, but the literature values for distribution coefficients range from 1 to $22,000 \mathrm{~cm}^{3} / \mathrm{g}$. Given this high degree of variability, it is possible that americium could reach Fifth Creek within a few years, but the migration velocity cannot be estimated without site-specific $\mathrm{K}_{\mathrm{d}}$ values; therefore, its migration velocity cannot be estimated. However, it is likely that some or most of the contamination is captured by the 3042 building sump, which has been shown to interact with groundwater.

Plutonium-238, ${ }^{239} \mathrm{Pu}$, and ${ }^{240} \mathrm{Pu}$ have been detected in some wells. Plutonium has a high $\mathrm{K}_{\mathrm{d}}$ and is relatively immobile. However, because of the long half-lives of ${ }^{239} \mathrm{Pu}$ and ${ }^{240} \mathrm{Pu}$, they would persist in groundwater for a long time.

Technetium- 99 has been detected at high concentrations in well 590 near the isotope production facility, Building 3026. It has also been detected in $\mathrm{CH} 008$ and several wells at smaller concentrations. The distribution coefficient of technetium is almost zero. For this reason and because it has a long half-life, it is expected to reach First Creek, the expected discharge boundary, undecayed. However, no ${ }^{99} \mathrm{Tc}$ has been detected in any surface water samples.

The presence in surface water of certain radionuclides that have very high distribution coefficients (for example, ${ }^{234} \mathrm{U}$ and ${ }^{232} \mathrm{Th}$ ) cannot be explained in terms of Darcian groundwater velocities and distribution coefficient-dependent retardation factors. Their presence may indicate that their mobility is affected by variations in the speciation and solubility of the elements and that these variations are not well represented by the $K_{d}$ values used for the computations. It is also possible that groundwater in this area is migrating faster than can be explained using porous-media estimation methods or that contaminants have entered the surface water system through inleakage of groundwater to the storm water system, through colloidal transport, or both.

\section{Organics}

Well 598 has the highest concentration of any organic compound detected in WAG 1 groundwater. The maximum concentration of the volatile TCE at this well was $210 \mathrm{mg} / \mathrm{L}$. TCE appears to have completely biotransformed into other products within about $600 \mathrm{ft}$ downgradient from this well; no TCE was detected in wells further downgradient, although its degradation products, vinyl chloride and 1-, 2-dichloroethylene, were detected. These transformed products in some wells could have been derived from perchlorethane, which was detected in wells $554,564,873$, and 886.

Except for $3 \mu \mathrm{g} / \mathrm{L}$ of TCE found in one sample from Fifth Creek, none of these organics were detected in surface water, where they are rapidly lost by volatilization. 
Well 553 shows significant concentrations of benzene-toluene-ethlbenzene-xylene organics. A diesel fuel storage tank at this location, which has recently been removed, is the likely source of this contamination. Because the contamination is limited in extent, the release is probably recent. Benzene-toluene-ethlbenzene-xylene can readily biodegrade in shallow groundwater in the presence of oxygen.

\section{Metals}

Metal contamination in groundwater has not been analyzed for fate and transport. In general, metal contamination is found in plumes also associated with radiological contamination. The most prevalent metals detected in groundwater are lead, chromium, and cadmium. Although several SWMUs with mercury spills have been identified, no significant mercury contamination has been detected in groundwater.

\subsubsection{Surface water and sediments}

All contaminated groundwater within WAG 1 is believed to discharge into the WOC drainage system. Surface water is thus the final off-site transport medium. Contaminants are carried either in dissolved phase or bound to suspended particles; the latter mode, however, is believed to be less important, except during large floods when contaminated floodplain sediments can constitute a significant portion of the total stream contaminant load.

In First and Fifth creeks, maximum radiological concentrations are typically observed during low base flow. During high groundwater and during storm events, the effect of dilution dominates the effect from any fresh releases and results in overall dilution of contaminants. In WOC downstream of the $3513,3524,3539$, and 3540 impoundments, this trend is not observed. The maximum radiological contamination, primarily tritium, appears to coincide with high groundwater. This difference in the pattern of contamination in WOC might be the result of influences from the surface impoundments. A plausible explanation is that high groundwater flushes out tritium from the impoundments and into pipeline trenches and the shallow groundwater system, and these in turn discharge the tritium into WOC.

In general, radiological contamination in the surface water system is consistent with the groundwater contamination. The maximum volatile organic compounds contamination observed in surface water, consisting primarily of pyridine and p-dioxane, occurred at sampling location SW-6. This event is believed to be transitory, caused perhaps by episodic discharge from building drains. A sample taken a few months earlier just upstream of SW- 6 showed none of these volatiles. In general, unless there is a continuous source, organic contaminants would be lost from surface waters within a few days to a few months because of volatilization or other degradation processes.

The occurrence of metals and highly sorbent radionuclides in the surface water system is primarily associated with sediments. For example, ${ }^{137} \mathrm{Cs}$ was only detected in unfiltered samples collected as part of the WAG 1 remedial investigation. Cesium-137 was also detected in sediment samples from WOC at concentrations as high as $2480 \mathrm{pCi} / \mathrm{g}$. These observations are consistent with the high $\mathrm{K}_{\mathrm{d}}$ values (330-1429 $\mathrm{cm}^{3} / \mathrm{g}$ ) measured for cesium in WAG 1 soils and illustrate the strong affinity of ${ }^{137} \mathrm{Cs}$ to soil particles. Other contaminants with similar characteristics include thorium, uranium, plutonium, cobalt (to a lesser degree), and mercury.

Because improved waste management practices have reduced contamination in point-source discharges, desorption of contaminants from sediments is expected. For example, bed sediment contamination with ${ }^{137} \mathrm{Cs}$ downstream of the impoundments was caused, in part, by outfall X07 
discharges. Following removal of this outfall in April 1990, some desorption of ${ }^{137} \mathrm{Cs}$ from sediments into surface water is expected. However, sediment transport is the chief migration mechanism for these contaminants in surface water.

Floodplain sediments and soils around known mercury spill sites show elevated concentrations of mercury, commonly as much as tens of thousands of micrograms per kilogram. Vaporization of mercury at these levels could be significant, depending on the acidity and humic content of the soil. Mediation by microbial processes could also be important for mercury vaporization (Nriagu 1979). Because leaching of mercury is negligible in almost all circumstances, no significant migration of mercury in solution is occurring through the water pathway.

\subsection{ACTIVE PROJECTS}

Instructions to User
Remediation is an ongoing process, and the status of active projects can change
quickly. For the most up-to-date information about WAG 1 active projects, check the
Annual Environmental Restoration Monitoring and Assessment Report and the Federal
Facility Agreement Quarterly Report.

\subsubsection{Gunite and Associated Tanks}

\subsubsection{Description of the Gunite and Associated Tanks and their components}

The Gunite and Associated Tanks (GAAT) include eight tanks in the North Tank Farm, six tanks in the South Tank Farm, Tanks W-11 and TH-4 (Fig. 6.13). The North Tank Farm and South Tank Farm are in the approximate center of ORNL (on both sides of Central Avenue). The North Tank Farm is a $150-\mathrm{ft}$ by $180-\mathrm{ft}(45.7-\mathrm{m}$ by $54.9-\mathrm{m})$ lot near the intersection of Third Street and Central Avenue. The South Tank Farm is across Central Avenue, south of the North Tank Farm. Tank W-11 is southeast of the South Tank Farm. Tank TH-4 is adjacent to the southeast corner of the Instrumentation and Controls Building (Building 3500), approximately $440 \mathrm{ft}$ (135 in) east of the South Tank Farm.

The North Tank Farm contains eight underground tanks included in GAAT. Four tanks (W-1 through W-4) are constructed of Gunite, and four tanks (W-1 A, W-13, W-14, and W-15) are stainless steel. Tanks W-1 and W-2 have an approximate capacity of 4,800 gal $(18,170 \mathrm{~L})$ each and are on the west side of the tank farm. Tanks W-3 and W-4, with capacities of 42,500 gal (160,860 L) each, are in the southeastern part of the farm. Each tank has an array of inlet and outlet lines that lead to valve boxes where waste transfers are controlled. Each tank also has an associated dry well that drains the immediate area around a tank, which is intended to control potential leaks. Waste Tanks W-13, W-14, and W-15 have approximately 2,000-gal (7,570-L) capacity each. Located in the center of the tank farm and including an array of piping and valve boxes, Tanks W-13, W-14, and W-15 are set inside a concrete cell that extends to the surface. Drainage from the cell is diverted to a single dry well. Tank W-1A, a 4,000-gal (15,140-L), stainless-steel tank in the northwest corner of the tank farm, rests on a concrete pad but is not encased in cast concrete. This tank has an associated dry well and an array of pipes and valve boxes. 


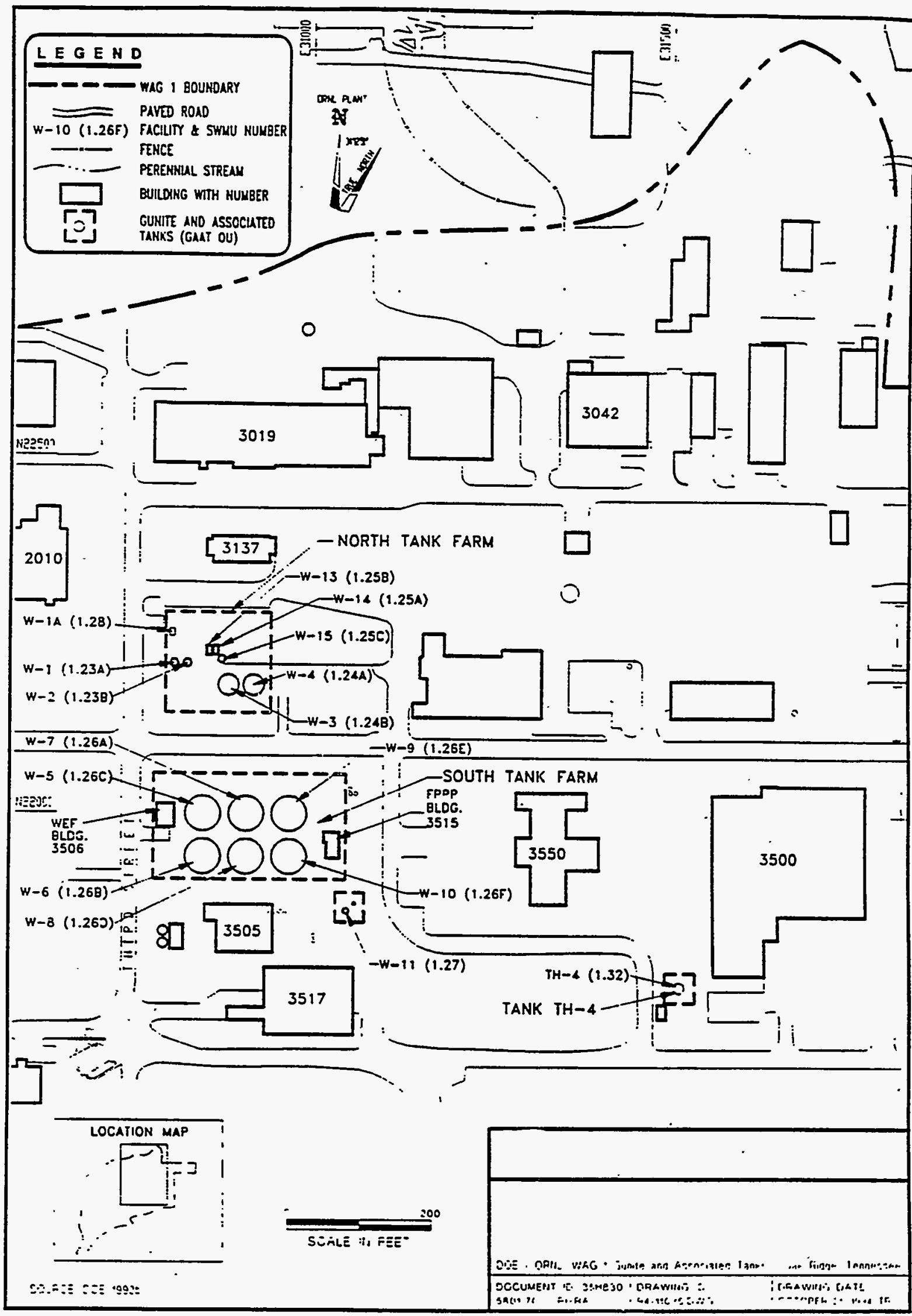

Fig. 6.13. Facilities in GAAT. Source: Jacobs 1994c 
The South Tank Farm contains six Gunite tanks (W-5 through W-10) included in GAAT. Tanks W-5 through W-10 are 170,000-gal (643,450-L) tanks arranged in two rows of three with a $60-\mathrm{ft}$ (18.3-m), center-to-center distance. The domed waste storage tanks are $50 \mathrm{ft}$ (15.2 in) in diameter, $18 \mathrm{ft}(5.5 \mathrm{in})$ high at the center, and $15 \mathrm{ft}$ (4.6 in) at the walls. Each tank has an associated dry well and an array of pipes and valve boxes.

Two tanks, W-11 and TH-4, are outside the perimeter of the tank farms. Tank W-11 is a 1,500-gal (6,434-L) underground Gunite tank located south of Tank W-10. TH-4 is a 14,000-gal $(53,000-\mathrm{L})$ underground Gunite tank located southwest of Building 3500 . Each tank has an array of pipes, valve boxes, and associated drainage dry wells. The surface of the North Tank Farm and South Tank Farm and the area around Tanks W-11 and TH-4 are covered with grass lawns. Each area is roped off and posted as a restricted access area.

\subsubsection{Site-specific conditions and problems}

The Gunite tanks contain about $90 \%$ of the documented radionuclides in inactive waste management units in WAG 1. The GAAT facilities are near the center of ORNL, which continues to operate as a multifunctional research and development facility. Remediation of the GAAT facilities will be conducted concurrently with operational and maintenance activities, resulting in technically and logistically complicated remediation.

Given the age and uncertain physical condition of some of the tanks and the infiltration of water into several of them, tank contents could discharge into the environment. Structural failure of the tanks could result in the discharge of liquids to the surface and subsurface, including storm drains, surface water, buildings, soils, and groundwater. Contaminated solid materials could be exposed to the atmosphere if a dome collapses. The removal of the existing barrier (soil cover and tank domes) could allow direct radiation exposure outside the tanks. The probability of catastrophic structural failure or slumping of the tank domes and/or walls continues to be evaluated.

Leaks could also occur from tanks that contain liquids, resulting in a discharge to the subsurface. Such a release would induce an increased hydraulic gradient emanating from the tank farms and would result in the discharge of contaminated water to the surrounding subsurface. Due to the presence of numerous utilities and subsurface foundations, elevated groundwater levels at the tank farms might result in the drainage of contaminated groundwater through utility backfill to discharge locations. Existing pumps in the dry wells drain system (Pump Station 1) collect groundwater and send it to an on-site treatment system.

Both radiological and chemical contamination is presently noted in the soils and groundwater in the area of GAAT; however, the exact source of the contamination is unknown. Even if the tanks do not presently leak, a release of hazardous material could result from liquid waste penetrating cracks in the tank walls. Because of the potential for release of hazardous materials into the environment and because the tanks are presently inactive, the Federal Facility Agreement and the placement of ORNL on the National Priorities List require that a remedial investigation (RD) and feasibility study (FS) be performed as part of site remedial activities. These studies are performed to confirm and quantify the nature and extent of contamination from thèse sources and identify potential responses.

The information and analysis provided in this RI/baseline risk assessment are needed by DOE to aid in developing and selecting remedial alternatives for GAAT. The final decision will be published as part of the Record of Decision (ROD), which is a legal and technical document 
specifying the remedial action to be used, the technical basis for the decision, and the responsiveness summary that addresses comments from public review.

\subsubsection{Project schedule}

The Comprehensive Environmental Response, Compensation, and Liability Act (CERCLA) process involves preparation and regulatory agency approval of the RI/FS report, the proposed plan, and the ROD. While preparing the RI/FS report for GAAT, DOE recognized that additional information would be necessary to verify that the remedial alternatives could meet the CERCLA threshold criteria, to properly evaluate the balancing criteria, and to compare the remedial action alternatives. Given these needs, DOE, the U.S. Environmental Protection Agency (EPA), and the Tennessee Department of Environment and Conservation agreed that a treatability study could identify more cost-effective remediation approaches with less uncertainty and clearer strategies. The Federal Facility Agreement parties also agreed that DOE should submit the RI/baseline risk assessment for regulatory review and approval and delay the FS to allow the completion of the treatability study. [The RI report was submitted to the regulators in June 1994 (Jacobs 1994c)]. Based on this agreement, DOE has initiated a treatability study that will conclude with a report in 1998. Following input from the treatability study, two FSs will be submitted for review and approval, one in 1996 and one in 1997. The associated proposed plans and RODs are scheduled for approval in the years 1997 and 1998, respectively.

\subsubsection{GAAT treatability study}

The purpose of the treatability study is to develop information to support the CERCLA decision process. The primary objectives of the treatability study are to determine (1) the relationship between tank contents and risk/applicable or relevant and appropriate requirements (ARARs), (2) the ability of selected technologies to remove waste from the tanks, and (3) the cost of implementing the technologies in GAAT (Jacobs 1995a).

The treatability study has been implemented in six phases to allow for revision of the study as new information is received or as conditions change. Phase I was completed in September 1994 and documented in January 1995 with the treatability study work plan (Jacobs 1995b). Most tasks of Phase II were completed in the first half of 1995 and documented in the baseline report and treatability study work plan (Jacobs 1995a). The phases of the treatability study are listed below, followed by a brief description of the results of tasks completed in Phases I and II (not all Phase II tasks are complete at this time).

- Phase I: This phase included three major tasks: (1) reviewing of existing GAAT conditions and developing initial planning base assumptions; (2) gathering and evaluating information, including characterizing tank content; and (3) evaluating technologies.

- Phase II: Studies initiated during Phase I were continued. In addition, a baseline cost and schedule estimate was developed.

- Phase III: Detailed engineering for equipment, facility modifications, cold-test facility, and required documentation will be completed. A final cost estimate will be prepared and equipment procurement will begin.

- Phase IV: Equipment procurement will be completed; cold- and hot-test facilities will be built.

- Phase V: Cold tests will be conducted.

- Phase VI: Hot testing of the waste removal technologies will be completed. 


\section{Results of treatability study Phases I and II}

Review of existing GAAT conditions and development of initial planning base assumptions-The first task of Phases I and II documented the existing conditions at GAAT and developed assumptions used as a planning base for the treatability study. Several assumptions were made to provide initial direction for the treatability study. The assumptions are listed here, with modifications based on Phase $\Pi$ results.

- The initial focus of the treatability study is waste removal. Later guidance from DOE and the regulators will include treatment.

- Information will be provided through studies and cold (simulated waste) and hot (actual waste) testing.

- Removal capabilities must be provided for supernate, soft sludge, hard sludge, and possibly 2.54 to $5.08 \mathrm{~cm}$ ( 1 to 2 in.) of Gunite.

- Tanks W-5 (non-TRU waste) and W-8 (TRU waste) could be used as consolidation tanks for liquids and sludges generated during the study if additional storage capacity is required.

- Removal technologies can be designed and operated without impacting tank structural integrity.

- Storage and disposal facilities for solid contaminated materials are limited or nonexistent.

- Safety requirements can be satisfied with local, double containment of surface pressurized equipment (or single containment for buried equipment if leak checked).

- Single-containment equipment/tank riser interface is required for nonpressurized situations. Containment structures over tanks are not required. Weather shelters are provided, as warranted.

- Residue removal operations will be directed toward transfer between Tanks W-3 and W-4 with the option to move waste to treatment system demonstrations or to consolidation in the South Tank Farm as part of a removal action or remedial action.

- The treatability study is to provide CERCLA evaluation criteria information for the stakeholders on alternatives for the preliminary FS.

Work performed during Phase II verified the following assumptions identified during Phase I:

- DOE support contractors will perform engineering, construction, and operation of equipment for the treatability study.

- Existing piping cannot be used for waste transfer but may be used to remove supernate from the tanks.

- Criticality is not a concern, and special processing or design considerations are not required.

- Existing sluicing and transfer equipment cannot be used to support field activities.

- Structural evaluation confirms that the tanks are in stable condition, and activities of the treatability study will not impact their structural stability.

Gathering and evaluating information-The second task of Phases I and II defined data needs, gathered and evaluated information, and started selected studies that will be completed during Phase II or Phase III. 
Supplemental sampling has been initiated to confirm the current conditions of the waste, assess criticality concerns, determine the acceptability of sending waste to the Melton Valley Storage Tanks (MVST) or other storage/disposal locations, and provide an initial understanding of the physical character of the waste to support removal equipment selection and engineering. In addition, there is an effort to map the sludge surfaces to more accurately define the volume and location of the waste within the tanks. These characterization activities will be completed during Phase III of the treatability study.

The following conclusions were drawn from the sampling:

- Criticality is not a concern for the treatability study. However, some tanks in the South Tank Farm may require additional evaluation before remediation.

- Analytical results were similar to the results from earlier sampling.

- The tanks contain $1,635,000 \mathrm{~L}$ ( 346,000 gal) of supernate containing 4,000 Ci and $163,000 \mathrm{~L}$ $(49,000 \mathrm{gal})$ of sludge containing $14,000 \mathrm{Ci}$.

- Results of the sampling indicate that Tanks W-3, W-4, W-5, W-7, and TH-4 do not exceed the TRU limit of $100 \mathrm{nCi} / \mathrm{g}$ on a wet weight basis, but the remaining tanks do.

- A consistent and distinct layer of hard sludge was not identified during sampling. Instead, it was determined that, in general, the sludge density gradually increases with depth.

- Sludge in the South Tank Farm is contained in a flat, mud-like layer in the center of the tanks with "clumps" of waste located along the wall/floor interface.

Complete results of the sampling can be found in the Oak Ridge Environmental Information System database and the report generated to document the results (Energy Systems 1996).

A subtask to develop a site-specific pathway transport model for GAAT was initiated during Phase I, with completion scheduled for Phase III. The pathway transport model is intended to be a tool stakeholders can use in determining the extent of sludge removal from the tanks required to attain an acceptable impact on WOC. To date, the model has been used to evaluate the impact associated with removal of no waste, partial removal of waste, and partial removal of waste with stabilization of the remaining waste for Tank W-10. In addition, modeling to evaluate the impact associated with the waste contained in Tanks W-7, W-8, and W-9 has been completed.

Studies for evaluating treatment alternatives were initiated during Phases I and II of the treatability study. These studies were initially focused on (1) waste removal with subsequent treatment and disposal and (2) in situ waste solidification with tank stabilization.

Several waste treatment alternatives have been identified for possible inclusion in the treatability study. These include solidification of the sludge using a vitrification process, mixing and solidifying the sludge with a grout, or drying the sludge to create a packable, stable waste form. After treatment of the sludge, the waste would be transferred to a DOE or commercial, licensed waste disposal facility. Based on this review of available treatment and disposal options, the following recommendations were made in the study:

- An evaluation should be performed before transfer to the MVST to ensure that the addition of the GAAT sludge will not jeopardize treatment of the MVST supernate and subsequent shipment to the Nevada Test Site.

- Tank W-10 wastes should be segregated until PCB issues associated with the tank are resolved. 
- Low-activity and high-activity supernates should be segregated because of different treatment requirements.

- Tank TH-4 sludges should be segregated because they could be immobilized and transferred to off-site disposal.

- Only minor quantities of supernate can be treated in the PWTP without significant pretreatment. Transfer of all the supernates to the liquid low-level waste (LLLW) system is acceptable without pretreatment if waivers are obtained for some of the supernates. Pretreatment processes for the removal of cesium may be needed.

- The GAAT supernates may be used as the sluicing media for sludge removal to minimize the addition of process water to the LLLW system.

Three options for treatment of the TRU sludges were identified. The first is to mix the waste with grout and leave it in the tanks. The second is to transfer the waste to the MVST and treat it in the TRU waste processing facility, which is currently in the initial development phase. The third option is to build an independent system for processing the waste.

Evaluation of removal technologies-The third task of Phases I and II involved evaluation of a variety of waste retrieval technologies, which were presented in Appendix A of the treatability study work plan issued January 1995. A report on the evaluation of various technologies was presented in the Technology Study of Gunite Tank Sludge Mobilization at Oak Ridge National Laboratory, Oak Ridge, Tennessee (Energy Systems 1994). Removal of the waste material by confined sluicing from a remotely operated, vehicle-based system and/or a remotely operated, manipulator arm-based system was determined to have a potential for successful application to the treatability study. These methods are attractive because they minimize water management and facility modifications. Although conventional waste dislodging and conveyance options using unconfined sluicing and/or hydraulic pumping were determined to be the most readily available removal technology, larger quantities of water are required, which will place additional requirements on down line waste management operations (e.g., storage space of MVST). For both the vehicle-based and the manipulator arm-based confined sluicing systems, comprehensive cold testing is anticipated before hot testing.

Development of a baseline cost and schedule estimate-The fourth task of Phase II is described in detail in the GAAT baseline report and treatability study work plan (Jacobs 1995a). Table 6.2 shows the estimated cost to conduct the treatability study, broken down in work breakdown structure format. These costs include engineering, procurement, construction, and operation. The total cost includes project management and documentation. Table 6.3 shows the schedule for the treatability study.

Table 6.2. Estimated cost of GAAT treatability study

\begin{tabular}{llr}
\hline \multicolumn{1}{c}{ WBS $^{1}$} & \multicolumn{1}{c}{ Activity } & $\begin{array}{c}\text { Current } \\
\text { Estimated Cost }\end{array}$ \\
\hline 12.0 & Project management & 843 \\
12.02 & Treatability study plans and reports & 3386 \\
12.03 & Facility modifications & 4738 \\
12.04 .01 & Facility management planning & 2304 \\
12.04 .02 & Unconfined sluicing & 601 \\
12.04 .03 & Confined sluicing & 3350 \\
12.04 .04 & Modified light-duty utility arm & 4033
\end{tabular}


Table 6.2 cont.

\begin{tabular}{|c|c|c|}
\hline WBS $^{1}$ & Activity & $\begin{array}{c}\text { Current Total } \\
\text { Estimated Cost }\end{array}$ \\
\hline 12.04 .05 & Vehicle-based system & 156 \\
\hline 12.04 .06 & Treatment & 748 \\
\hline 12.04.07 & Stabilization & 452 \\
\hline 12.04 .08 & Final treatability study reports & 187 \\
\hline 12.04 .11 & Sampling and characterization end effectors & 200 \\
\hline 12.04 .09 & Sludge transfer & 262 \\
\hline & Subtotal & 21,260 \\
\hline & Contingency & 0 \\
\hline & Total cost & $\$ 21,260$ \\
\hline
\end{tabular}

'WBS $=$ work breakdown structure

Source: Van Hoesen 1996

${ }^{2}$ Thousands of dollars; includes escalation and overhead

Table 6.3. Projected schedule for treatability study and CERCLA activities

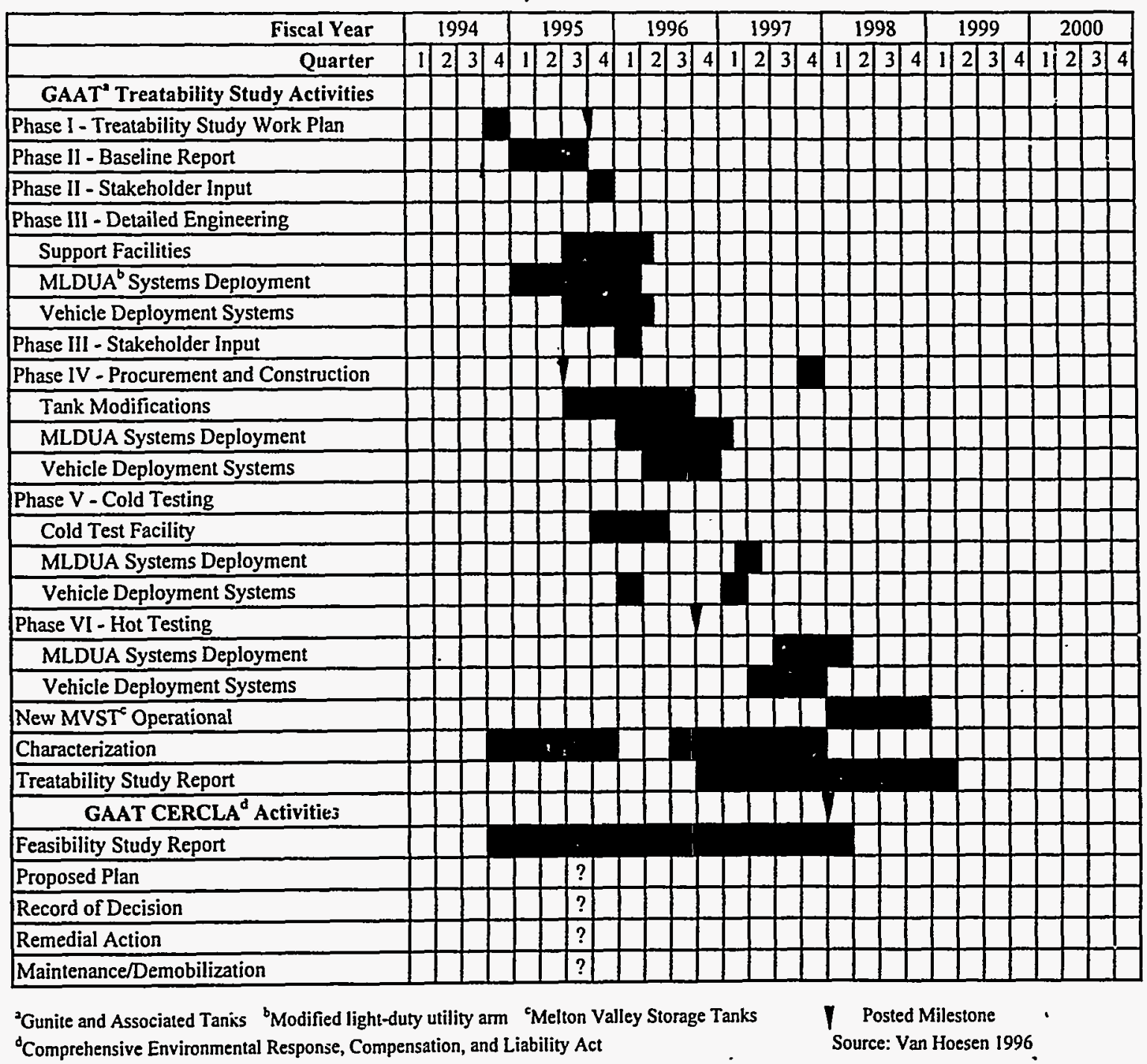




\subsubsection{Core Hole 8}

In 1991, gross beta contamination, consisting mostly of ${ }^{90} \mathrm{Sr}$, was detected at a depth of about $50 \mathrm{ft}$ below ground surface during the drilling of Core Hole 8 (Fig. 6.11) at WAG 1. That same year, First Creek was sampled and found to be receiving ${ }^{90} \mathrm{Sr}$ contamination from seeps at approximately the same geologic stratum that had the highest levels of contamination in Core Hole 8. Subsequent sampling in nearby storm sewer catch basins, also near the same geologic stratum, determined that ${ }^{90} \mathrm{Sr}$-contaminated groundwater was seeping into the bottoms of the porous catch basins. These findings lead to the development of the Core Hole 8 hypothesis, which described a geologic strike-parallel (parallel to the ORNL E-W coordinate grid) ${ }^{90} \mathrm{Sr}$ contaminant plane migrating from the vicinity of Core Hole 8 toward First Creek (LMES 1995).

Plume seepage entering the storm sewer catch basins ultimately discharges to First Creek via outfalls 341 and 342 . The 1991 First Creek sampling results strongly suggested that nearly all of the ${ }^{90} \mathrm{Sr}$ entering the creek was derived from outfalls 341 and 342. Estimates from historic National Pollutant Discharge Elimination System monitoring data indicated that First Creek contributed approximately $10 \%$ of the ${ }^{90} \mathrm{Sr}$ measured at White Oak Dam.

The removal action design (Fig. 6.14) was to passively intercept groundwater seepage into three storm sewer catch basins that lead to outfalls 341 and 342 . French drains were used to passively capture and transfer the intercepted water to the ORNL PWTP pipeline system located in the North Tank Farm. One catch basin, leading to outfall 342, is located immediately northwest of Building 2016, and two catch basins, leading to outfall 341, are located immediately north of Building 2013. Intercepted water was to gravity drain to a lift station, located northeast of Building 2016, for pumping to the PWTP pipeline system.

The scope of the Core Hole 8 plume removal action was to reduce discharges of ${ }^{90} \mathrm{Sr}$ to First Creek via the ORNL storm sewer system and subsequently reduce the amount of ${ }^{90} \mathrm{Sr}$ going off site over White Oak Dam. The chosen alternative recommended in the Engineering Evaluation/Cost Analysis for the Waste Area Grouping 1 Core Hole 8 Removal Action at the Oak Ridge National Laboratory Oak Ridge, Tennessee, (Jacobs 1994a) was to passively intercept ${ }^{90} \mathrm{Sr}$-contaminated groundwater at three locations in the western part of ORNL, where it was known to be entering the storm sewer system, and to transfer the intercepted water to the ORNL PWTP.

The detailed removal action objectives as described in the removal action work plan for Core Hole 8 (Foster Wheeler 1994) are as follows:

- Follow CERCLA guidance to implement a non-time-critical removal action that intercepts

${ }^{90} \mathrm{Sr}$-contaminated groundwater before it enters First Creek.

- Collect and treat contaminated water where pathway(s) are known and where contaminated water can be easily interpreted.

- Maintain and operate a collection and treatment system until it is no longer considered necessary or cost effective.

- Monitor the flux of ${ }^{90} \mathrm{Sr}$ into First Creek and from First Creek to WOC to measure the effectiveness of the removal action in reducing flux and to use those data in determinations about further action.

To achieve these objectives, modifications to the original system design were required by field conditions encountered in the course of construction. During construction it was discovered that a 


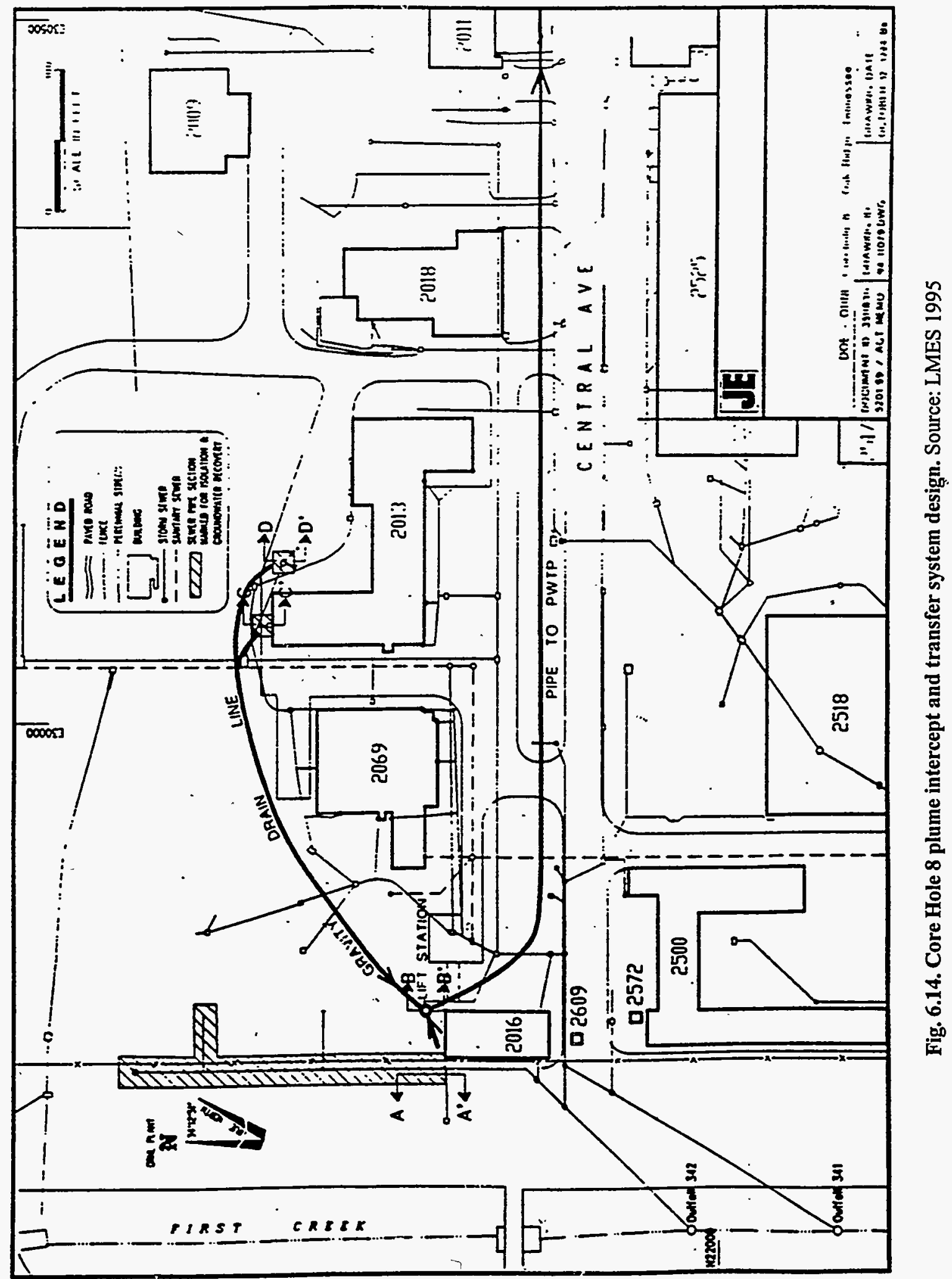


portion of the contaminated groundwater bypassed the storm sewer catch basin located northwest of Building 2016 and continued migrating along a co-located steam system pipeline. The steam pipeline and the migrating contamination continued west, and the contaminants entered a steam system valve pit located adjacent to First Creek. To halt that continued migration along the steam pipeline, the interceptor French drain excavation was extended an additional $2 \mathrm{ft}$ down, and a pump to transfer the water to the lift station was installed.

Similarly, the excavation from Building 2013 to the lift station encountered a former building foundation that necessitated constructing the pipeline above the building foundation. This modification raised the pipeline above the design elevation and again required a pump to be installed in the French drain located at the storm sewer catch basin located immediately north of Building 2013 (LMES 1995).

A $50 \%$ reduction of ${ }^{90} \mathrm{Sr}$ releases into First Creek was predicted for the modified system, which became operational on March 31, 1995. System performance monitoring, however, showed an $86 \%$ reduction of ${ }^{90} \mathrm{Sr}$ into First Creek, making further action unnecessary. The system will operate for the next several years, and monitoring of ${ }^{90} \mathrm{Sr}$ levels in First Creek will continue.

\subsubsection{WAG 1 Groundwater Characterization Area}

The WAG 1 Groundwater Characterization Area (CA) was established in 1992 to provide longterm groundwater monitoring and act as an integrator supporting remediation activities at other projects (e.g. impoundments, Gunite tanks) in WAG 1. Because ORNL continues to be an active industrial complex and remediation at all the other areas in WAG 1 will likely affect groundwater, remediation of the groundwater is not scheduled to begin until the year 2011; postremediation monitoring will continue until 2019. Monitoring and remediation costs are currently estimated to exceed $\$ 37$ million (Lee 1995).

Monitoring of groundwater began in January 1995, with analytical results suggesting that contaminant concentrations are increasing, particularly in the western portion of the WAG. Source investigations are slated to begin in FY 1996. Activities associated with the WAG 1 Groundwater CA include a long-term monitoring plan and an investigation of the source of the Core Hole 8 plume.

\subsubsection{WAG 1 Groundwater CA project objectives}

The ongoing monitoring program is targeting specific locations where past analyses have determined that contamination may exist or is known to exist, as well as locations thought to be in evolving contaminant migration pathways. The objectives of the project are to (1) establish a baseline environmental database for use in comparison with cleanup objectives, (2) identify contaminant sources and their migration pathways, (3) identify and prioritize candidate locations for early actions, and (4) support remedial activities at other WAG 1 projects. All these objectives support the program objective of reducing human health and environmental risk.

The major decision affecting the WAG 1 Groundwater CA project is future land use, which will affect groundwater cleanup objectives and selection of a remediation alternative. Another major programmatic decision is whether the program should commit relatively fewer resources at problem areas at peripheral locations (e.g. surface water) or whether relatively larger resources should be committed to identify and remediate the source of the peripheral problem. 


\subsubsection{Problem identification and possible solutions}

In 1990 and 1991, Phase I RI activities determined that extensive areas of WAG 1 groundwater were contaminated, predominantly with radioisotopes. Analyses of the data obtained from the Phase I $\mathrm{RI}$ effort determined that the contaminated groundwater, which is considered to discharge to the nearest surface water body, did not result in the significant contamination of surface water. It was thus concluded that much of the contaminated groundwater was being inadvertently intercepted by the extensive underground pipeline system, building sumps, and underground tank dry wells in WAG 1 and sent to treatment at the PWTP (Lee 1995).

Because of the long and varied history of many of the facilities in WAG 1 and the number of historical leaks and spills throughout ORNL, identifying likely contaminant source areas is difficult. Adding to the difficulty is the fact that minimal documentation exists for many of these leak and spill incidents. The groundwater flow field is altered to an undetermined extent by underground pipelines, building sumps, underground tank dry wells, and by stratabound flow. The presence of these preferred flow pathways and local groundwater collection areas complicates accurate analysis of the flow field and the identification of potential contaminant migration pathways and contaminant source areas. The very limited time for which data are available (1 year) compared to the length of time when contamination could have been occurring ( 50 years) prohibits analyses of temporal changes in groundwater quality over any meaningful time period.

Solutions to remediating WAG 1 groundwater are principally dependent on administrative decisions about future land use and remediation goals. Until such decisions are made, a wide spectrum of solutions must be considered. Currently, WAG 1 groundwater is unsuitable as a drinking water resource, and WAG 1 is an industrial facility under federal control. For purposes of considering possible solutions to WAG 1 groundwater contamination, it is assumed that these current conditions will continue for the next $30-100$ years.

Several technologies are currently available for groundwater remediation in WAG 1. The application of these various technologies will depend on the status of ORNL at the time of remediation and projected utilization options in the future. Because radioisotopes are most prevalent contaminants, pump-and-treat, in situ vitrification, and cryofracture remediation options are currently considered to be among the most feasible (Lee 1995).

Following are possible solutions for remediation of WAG 1 groundwater.

Solution 1: Complete remediation to drinking water quality standards-A cost/benefit analysis will probably not support this alternative for three reasons. First, because there are so many areas of contamination, it is not feasible to remediate them all. Second, WAG 1 is assumed to continue as an operating facility with its extensive underground pipelines and utilities, and remediation options such as in situ vitrification and cryofracture are not considered feasible. The only viable remediation technology in the foreseeable future is pump and treat, and a vast amount of water would require treatment. Third, remediating a nondrinking water resource to drinking water quality standards is considered to be a questionable resource expenditure, at best.

Solution 2: Removal actions for the most contaminated areas and monitoring of the remainder-This alternative requires sufficient data to quantitatively prioritize areas, presumably on the basis of risk. It also assumes that we know where all the areas are; we don't. Since groundwater is not a drinking water resource, a potential assumption to justify the alternative would be that the level and an estimated volume of contaminated groundwater would migrate to surface water at some rate with some credit taken for radioactive decay. As removal actions for high priority 
areas begin, previously monitored areas would make the prioritization. Remediation of prioritized areas would end when the risk from each of the remaining areas is below some threshold risk. Monitoring would continue to assure that risk remains below threshold.

Solution 3: Same as Solution 2 but removal actions only for known areas-Known areas are unlikely to be near the heart of sources. The volume of water to be treated and the duration of treatment may ultimately cost more than the cost of finding sources and focusing the remediation effort.

Solution 4: Monitor groundwater and outfalls and remediate as necessary-If leaking pipelines and their porous backfill can be reasonably assumed to be preferred contaminant migration pathways to surface water, a potential solution is to monitor pipeline outfalls and their backfill for contaminants. If conditions at any location(s) show no increase over time, then radioactive decay can accomplish a lot of remediation, and no immediate remediation may be necessary. However, if locations show an increase beyond some threshold level over time, then identifying the source of the problem becomes incredibly complex and costly. If monitoring at those locations is performed in conjunction with groundwater monitoring, then the likelihood that a problem source can be identified increases.

Solution 5: Do nothing until excursions at surface water monitoring stations exceed threshold-This solution has the same problems as Solution 4. Finding the source of the problem would be very complex and costly.

Solution 6: Treat only surface water-There is too much water to treat for this to be a viable option; furthermore, most of the surface water is uncontaminated.

\subsubsection{Conceptual model}

In the WAG 1 groundwater flow conceptual, WAG 1 is the groundwater discharge area for the Knox Group aquifer underlying the adjacent Chestnut Ridge recharge area. Local recharge occurs on the WAG 1 hilltop area underlain by Units C and D where the water table is generally beneath bedrock. Perched water develops seasonally but apparently infiltrates rapidly to the water table. Groundwater elevation is generally above bedrock in Units $E$ and G. Presumably because of its comparatively greater clastic content that adjacent units, Unit $F$ bedrock is perennially above the water table which may partially explain apparent strike-parallel flow near Unit F (Lee et al. 1994).

The groundwater system is thus envisioned to contain local recharge on the hilltop area which discharges through the overlying geologic units to surface water. Seasonal water table rise is a system-wide, piston-like response to precipitation. Throughout much of WAG 1, significant amounts of discharging groundwater are intercepted by the extensive underground process waste pipeline and liquid waste tank storage network, which is then sent to PWTP for treatment.

The greatest flux of contaminants through groundwater to this network occurs during periods of elevated water table in response to precipitation. It is partly because of this network that contaminated WAG 1 groundwater is generally not detected in adjacent surface water bodies. The extent of surface water contamination would be anticipated to be much greater in the absence of this network (Lee et al. 1994).

The occurrence of stratabound groundwater flow at WAG 1 has been described by Ketelle and Lee (1992). Observations of stratabound flow were made in Melton Valley (Webster 1976) and in WAG 3 (Stueber et al. 1981). Stratabound flow has also been suggested to occur in Chestnut Ridge 
(Lee and Ketelle 1987), in a groundwater dye tracer test in Bear Creek Valley (Lee et al. 1989), and by the configuration of the S-3 Pond plume at the Y-12 plant (Geraghty and Miller 1990).

A simplified block diagram (Fig. 6.15) illustrates the basic components of the process as it is currently envisioned. The bulk of groundwater movement is envisioned to be essentially confined within discrete geologic strata. The direction of movement is determined by the hydraulic gradient within the stratum from a point of observation to the nearest surface water drainage. Comparatively minor stratum outleakage occurs with the local or site-wide hydraulic head profile. Vertical outleakage continues until another stratum is encountered through which stratabound flow can occur. Groundwater flow and contaminant migration are thus envisioned to occur in a trellis-like pattern. The scale at which the trellis movement is not resolved but simply resembles gradient-driven flow is not known but likely varies by bedrock unit.

The underground process waste pipeline system and underground tank sumps and dry wells remove an amount of groundwater equal to approximately one-half of all expected runoff from an area the size of WAG 1, although this is only an estimate. The fractions of this water derived from bedrock groundwater, shallow subsurface flow, and leaking water supply lines are not known.

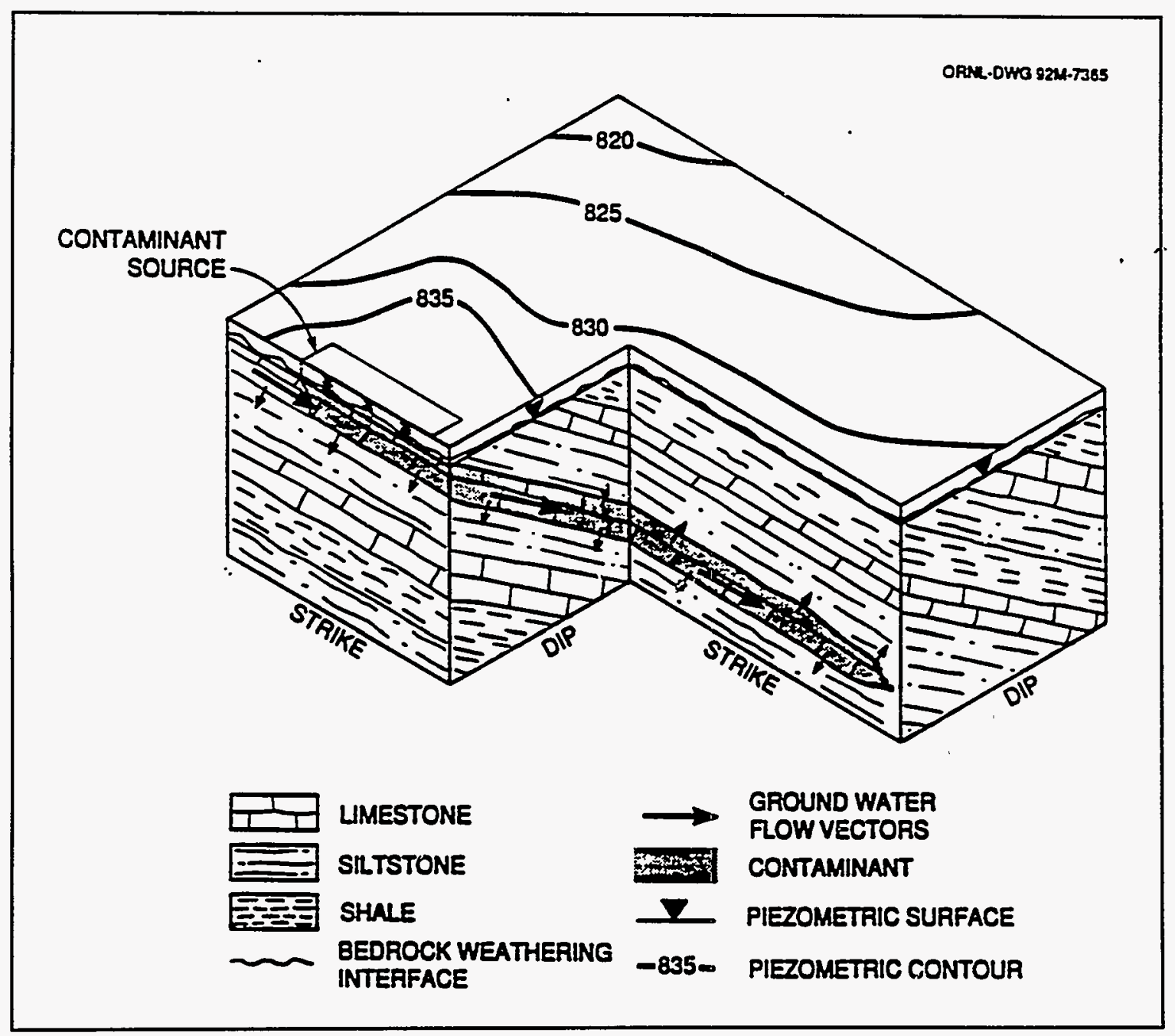

Fig. 6.15. Stratabound groundwater flow at WAG 1. Source: Lee et al. 1992 
However, estimates of expected recharge to the bedrock system from infiltration are considered to be only a few inches per year. Thus, the extensive pump and treat system that operates in WAG 1 significantly alters natural flow conditions (Lee et al. 1994).

\subsubsection{Surface Impoundments}

The Surface Impoundments (SI) project (Fig. 6.16) consists of four impoundments: Impoundment 3513 (Waste Holding Basin), Impoundment 3524 (Equalization Basin), and Impoundments 3539 and 3540 (Process Waste Ponds). The impoundments are considered a single project, principally because the four impoundments are in the same locale, share similar process histories, contain similar contaminants, and are candidates for the same remediation technology. The SI project only addresses remediation of water and sediment within the impoundments to control future releases to groundwater, surface water, and the air. [Contaminated groundwater and soils may be encountered during remediation of SI, but they will be incidental to remediation of SI and not a remediation goal. Contaminated groundwater and soils not addressed as part of the chosen remedial alternative will be addressed as part of the WAG 1 Groundwater CA and WAG 1 Watershed Soils, respectively (Jacobs 1995c)].

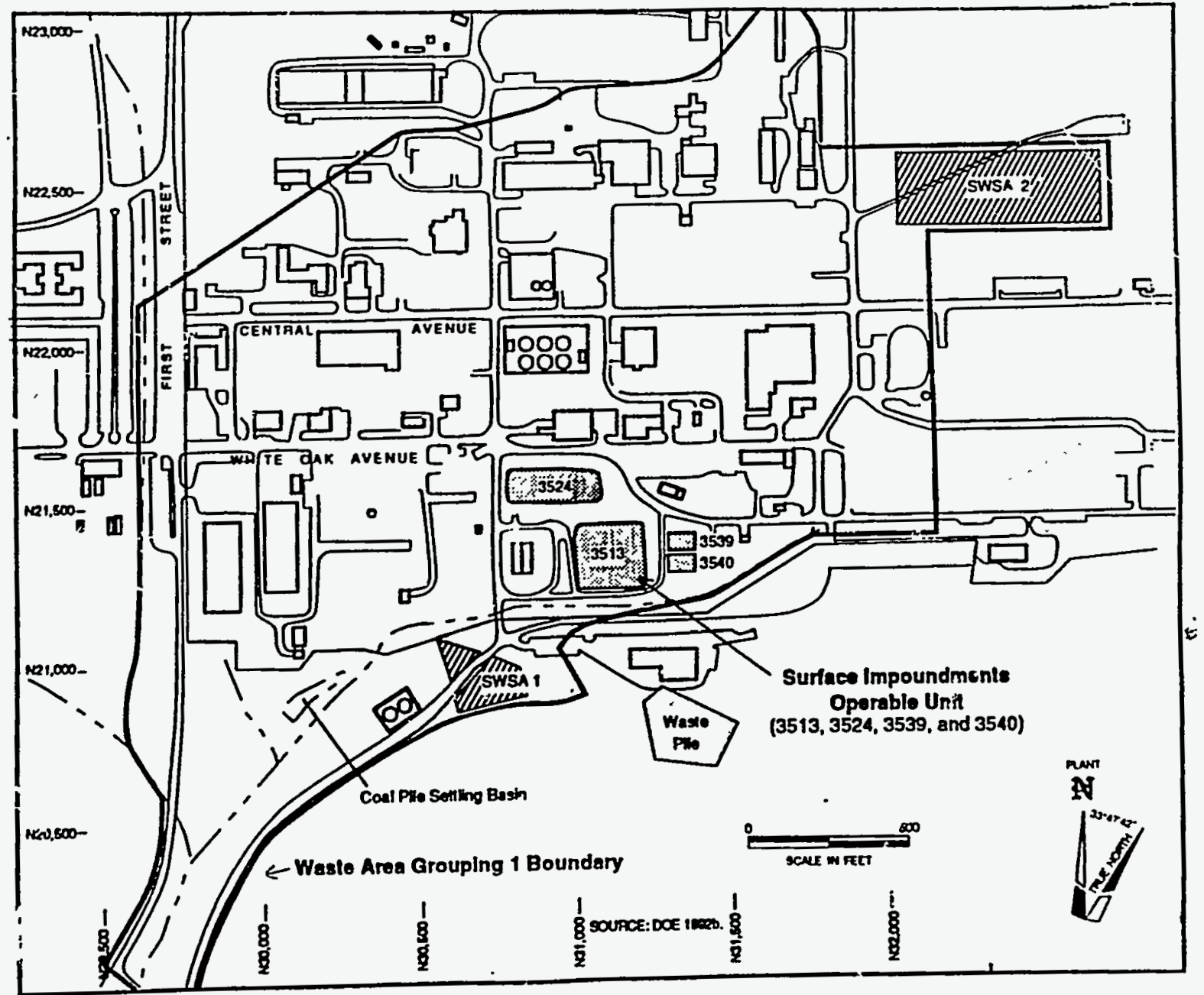

Fig. 6.16. Surface Impoundments project. Source: Jacobs 1995c 
Impoundment 3524 was constructed in 1943 as a backup for storage of wastewater from ORNL underground storage tanks. Following this, Impoundment 3513 was constructed. Later these two natural clay impoundments were used as holding basins as part of the process waste treatment system. The other two smaller impoundments (3539 and 3540) that make up the surface impoundments were constructed in 1964 with a 15.2-cm (6-in.) clay liner to hold process wastewater from the Building 4500 complex (Bechtel 1992). These impoundments contain approximately $3,500 \mathrm{~m}^{3}\left(4,640 \mathrm{yd}^{3}\right)$ of sediment. These sediments are primarily contaminated with radionuclides with some RCRA constituents (e.g., mercury and lead) and Toxic Substances Control Act constituents (polychlorinated biphenyls).

Although the impoundments were removed from routine service, Impoundments 3524, 3539, and 3540 are used occasionally to collect process wastewater when the holding capacity of the current storage tanks for the PWTP is exceeded. An additional surge tank has been designed to store process wastewater during wet weather and is scheduled to be in service by April 1996. With the additional surge tank in service, the impoundments will be removed from the waste management emergency service inventory and will be available for remediation (Jacobs 1995c).

The drivers for remediation of SI include (1) possible future human health risk; (2) the continuing release of contamination from unlined Impoundments 3513 and 3524 to the surrounding environment; and (3) potential failure of the berm/embankments for Impoundments 3513 and 3524, which were never intended to last 50 years. Remediation of SI is being addressed under CERCLA, as specified in the Federal Facility Agreement. Because the sediments in the two unlined impoundments interact with groundwater, ${ }^{90} \mathrm{Sr}$ contaminants in these sediments can be transported into WOC and Clinch River; therefore, these impoundments were selected for remediation through the ORR prioritization process.

The first step in the RJ/FS process is to collect data. Historical data and data from the WAG 1 Phase I RI are available, so limited sample collection to support the RI/FS was performed concurrently with preparation of the RI/FS.

The second, concurrent process is preparation of the baseline risk assessment for the project. Current risk was evaluated for the project as an industrial site under institutional control. Lockheed Marietta Energy Systems, Inc., monitors and maintains the protective water covers on the impoundments and expeditiously handles any compromise in the berms surrounding them. ORNL workers are protected by administrative controls; therefore, under current conditions there is no unacceptable risk to on-site employees.

Current off-site risk from water ingestion downstream from ORNL was evaluated assuming that institutional controls prevent access to the impoundments and that the only current off-site pathway is migration of contaminants from the sediments through groundwater into WOC and then to Clinch River, which is the first point where off-site receptors can be exposed to contaminants from the surface impoundments. Current off-site risk from this scenario (off-site receptor drinking Clinch River water) is well below EPA's target risk range of $1 \times 10^{-4}$ to $1 \times 10^{-6}$ (Jacobs $1995 \mathrm{c}$ ).

Future risks were evaluated for several scenarios. This area will probably be an industrial site for at least the next 30-100 years. Hypothetical, unrestricted residential scenarios were also evaluated for comparison purposes only. For the unrestricted scenario, the estimated risks suggest that corrective action is necessary to protect on-site and off-site employees and residents. The majority of the risk occurs when the protective water cover is removed by drought or berm failure, exposing sediments in the impoundments. When radionuclides such as ${ }^{137} \mathrm{Cs}$ and ${ }^{239} \mathrm{Pu}$ in the soil and sediment are exposed, future on-site risk to employees and residents is always unacceptable. In addition, when 
contamination is modeled to simulate off-site migration after a berm failure, the risk at White Oak Dam and Clinch River is unacceptable.

Current on-site and off-site risks associated with the surface impoundments are at acceptable levels; there are, however, additional considerations for the remediation of these surface impoundments. These include:

- contaminated sediments remain in contact with groundwater, and this contamination migrates into WOC;

- future risks are unacceptable in all scenarios if DOE no longer retains institutional control; and

- future risk, both on site and off site, is also unacceptable if the 50-year-old berms that retain the contents of the impoundments continue to lose their structural integrity, allowing contamination from the impoundments to increasingly migrate into WOC. As the berms age, increasing maintenance will be required to maintain their integrity. Currently during wet weather conditions, contaminated seepage appears at the base of the embankment of Impoundment 3513. Continued maintenance is focused on mitigating this seepage.

Remediation decisions for SI will focus on risk management and the benefits obtained from implementation of each alternative and the cost of achieving that benefit. Taking action at the surface impoundments at this time has several benefits, including:

- risk reduction (both on site and off site),

- controlling the migration of contamination so that future remediation is not made more difficult because contamination is more widespread,

- isolating/relocating the contamination to facilitate monitoring and maintenance, and

- preventing berm failure.

The decision process will evaluate cost versus benefit of each alternative. Decisions can then be made by considering what is the best alternative for the next 30-100 years that does not preclude further action in the future.

Remediation decisions for SI must also consider the condition and likely remediation decisions for the surrounding areas: WAG 1, ORNL, and ORR. If final remediation decisions for the surrounding areas are likely to primarily use closure-in-place strategies, then early decisions for "greenfielding" of small areas may not, in hindsight, have been the most cost-effective. Conversely, if "greenfielding" is the final remedy, final costs could be somewhat higher if early areas were remediated in place. Waste management issues must also be addressed in the decision process. These issues include decisions on the final disposition of wastes, whether on site or off site.

The following remedial action objectives must be addressed by the alternatives evaluated:

- prevent direct exposure, direct contact, inhalation, and ingestion by humans and animals with the contaminated sediments;

- prevent groundwater contact with contaminated sediments;

- prevent potential future failure of the impoundments' berms and embankments; and

- prevent the bioaccumulation of contaminants in ecological receptors. 
Alternatives developed to achieve these goals range from no action to complete removal of contaminated sediments and off-site disposal. As required by CERCLA, these alternatives were selected to represent the range of potential actions at the site and are not intended to limit the decision.

The alternatives evaluated include

- no action;

- multilayer cap and institutional control;

- consolidation cell with simple dewatering;

- consolidation cell with ex situ treatment;

- consolidation cell off-SI/on-ORNL; and

- removal, treatment, and off-site disposal.

Important considerations regarding alternative evaluation for the surface impoundments include:

- Actions to be implemented at this site should be cost effective and protective of human health and the environment for the foreseeable future (30-100 years) so that the maximum amount of funds can be directed toward the most pressing environmental problems at ORR.

- The impoundments' remediation must be viewed in the context of the environmental concerns in the main plant areas as a whole so that actions taken at this individual site are consistent with actions likely for the entire area. If complete removal and off-site disposal is not accomplished, actions taken should not preclude further action in the future.

Following is a brief description of the alternatives and issues to be considered in their evaluation. Table 6.4 summarizes the comparative analysis of the alternatives in meeting the CERCLA evaluation criteria.

Alternative 1: No action-This alternative provides a baseline for comparison with other alternatives as required by the National Contingency Plan. In the no action alternative, it is assumed that existing institutional and operation controls, including actively maintaining the water cover on the impoundments and repairing future seeps, are maintained for 100 years. During the period of institutional controls, this alternative protects human health. Releases of contamination to groundwater and to WOC would continue, causing a degradation of the environment in WOC and White Oak Lake.

Alternative 2: Multilayer cap and institutional controls-Alternative 2 includes installing a cap over all the ponds and long-term monitoring and maintenance. This alternative would protect human health during institutional control. However, groundwater contamination due to leaching of contaminants from sediments would continue. The cap would prevent airborne contamination for its several-hundred-year life.

Alternative 3: Consolidation cell with simple dewatering-Alternative 3 includes relocation of sediment and solid contaminants from Impoundment 3524 into Impoundment 3513, followed by retrofitting Impoundment 3524 with a consolidation cell liner and leachate collection system. The contaminated sediment from the surface impoundments would then be placed in this consolidation cell and maintained with a temporary cover to promote dewatering of these sediments through the 
6-51

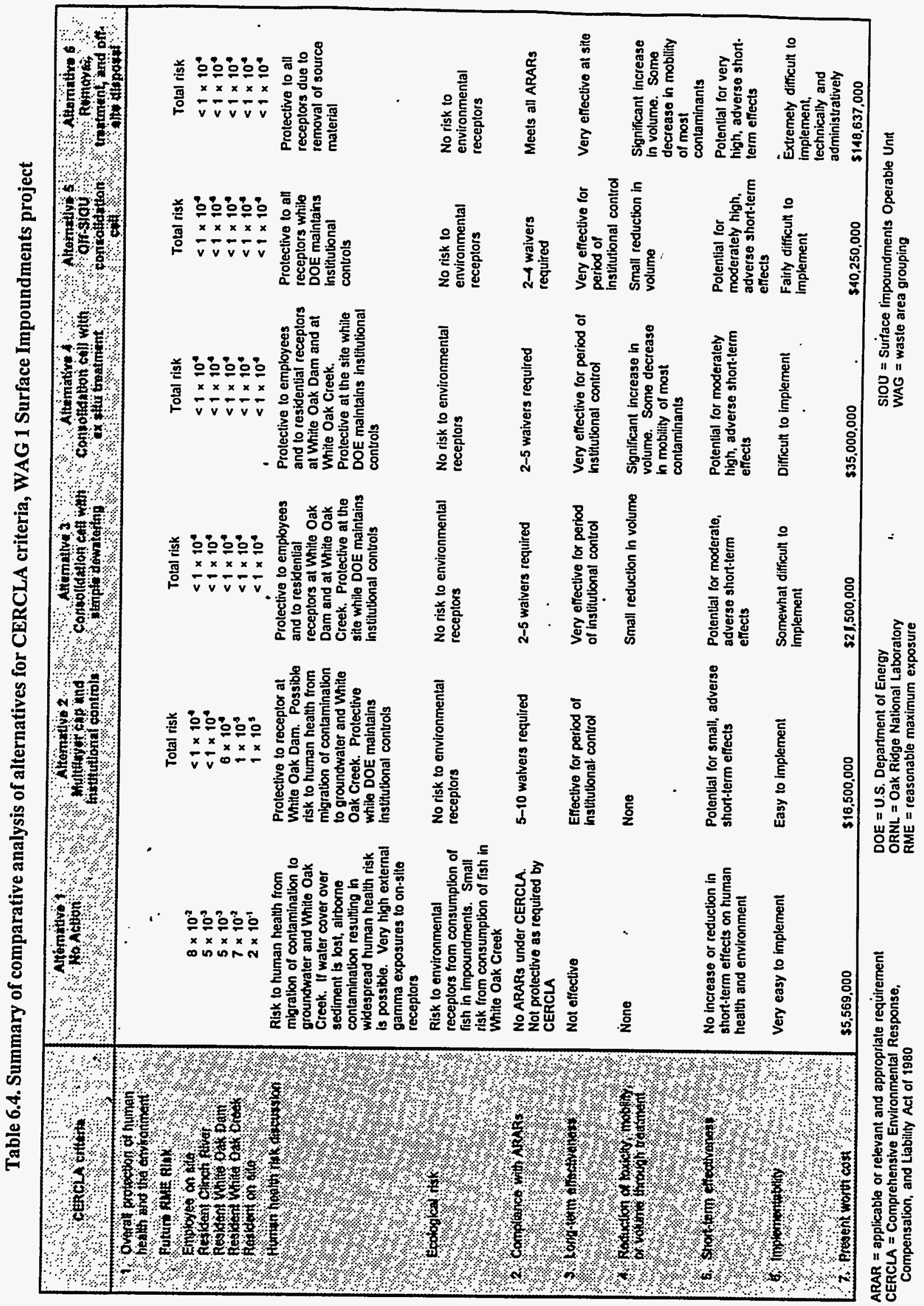


leachate collection system. Once dewatering is complete, the full cap would be placed over the consolidation cell. This alternative would protect human health and the environment during the period of institutional control. The cap and liner would prevent airborne and groundwater contamination for their life of greater than 100 years.

Alternative 4: Consolidation cell with ex situ treatment-Alternative 4 includes the same activities as Alternative 3 with the addition of constructing a new treatment facility to stabilize the waste (i.e., stabilization, solidification, and containerization of waste) before placing it in the consolidation cell. Thus, no dewatering within the disposal cell would be required. This alternative protects human health and the environment during the period of institutional control. The cap and liner would prevent airborne and groundwater contamination for their life of greater than 100 years.

Alternative 5: Off-SI consolidation cell-Alternative 5 includes the same activities as Alternative 3 except that the sediment would be transported to a consolidation cell constructed off SI at a preferred location at ORR. This alternative would protect human health and the environment at the surface impoundments site during institutional control. The cap and liner would prevent airborne and groundwater contamination for their life of greater than 100 years. Potential benefits of this alternative include (1) the opportunity to select a more hydrogeologically suitable site than the surface impoundments, (2) location of the consolidation cell away from the most active areas of ORNL, and (3) the ability to incorporate wastes from other impoundments within ORNL into the same consolidation cell.

Alternative 6: Removal, treatment, and off-site disposal-Alternative 6 includes building a new treatment facility to stabilize the waste before shipment to the Nevada Test Site for disposal. Because surrounding soils and groundwater are contaminated from other sources, long-term monitoring and other actions at the site would be subject to requirements of the WAG 1 Watershed Soils and the WAG 1 Groundwater CA.

\section{Summary of the Preferred Alternative}

The preferred alternative for cleaning up SI, as identified in the Proposed Plan for Surface Impoundments Operable Unit (DOE 1996) is Alternative 3-consolidation cell with appropriate liners, caps, and leachate collection system for simple dewatering. Based on current information, this alternative appears to provide the best balance of the nine CERCLA criteria developed by EPA. Alternative 3 protects future employees and on-site residents from direct radiation and prevents airborne migration of sediments from the impoundments. Contamination of potential drinking and irrigation water would be significantly reduced by the cap and liner. Risks to future residents on site, at WOC, White Oak Dam, and Clinch River are all within the acceptable EPA target range.

The leachate collection system will be maintained and operated indefinitely to monitor the overall integrity of the consolidation cell. Site surveillance and maintenance would be required as long as the contaminated media under the cap remains. Institutional controls, such as continued site ownership by the government and placing a notice in the site deed, would prevent on-site residential and farming land uses that could result in direct exposure to contaminated sediments.

In summary, Alternative 3 would substantially reduce site risks through waste consolidation; surface water controls; engineering controls (i.e., the cap, liner, and leachate collection system); and institutional controls. Institutional controls would allow safe management of sediment remaining in the consolidation cell. 
Based on information available at this time, DOE believes that Alternative 3 would protect human health and the environment, comply with applicable or relevant and appropriate regulation/requirements (although EPA and the Tennessee Department of Environment and Conservation agreed that appropriate waivers will be required), and be cost effective.

\subsection{WAG 1 SUMMARY}

WAG 1 is located within the main plant area of Oak Ridge National Laboratory on the ORR in Roane County, Tennessee. The site is in Bethel Valley, approximately 5 miles southwest of the city of Oak Ridge central business district. The site is bounded on the north by Bethel Valley Road, on the south by WOC, and on the west by First Creek. The eastern boundary follows Fifth Creek but extends east to include SWSA 2 and Buildings 4501 and 4508.

A total of 167 solid waste management units (SWMUs) were initially identified within WAG 1. Pursuant to a RCRA permit issued prior to the initiation of the WAG 1 remedial investigation, 27 SWMUs were classified as requiring no further investigation. An additional 14 SWMUs were listed for decommissioning and demolition under the DOE surplus facilities program. The remaining 126 SWMUs include inactive underground storage tanks, waste burial grounds, surface impoundments, waste transfer lines and leak sites, active underground waste storage tanks, and mercury spill sites.

WAG 1 lies within Bethel Valley between Chestnut Ridge and Haw Ridge and is underlain by the limestone, siltstone, and calcareous shale facies of the Ordovician Chickamauga Group, the upper limestone units of which are tightly cemented and compact, with the exception of several small solution channels. The mineralogy of native soils reflects composition of the underlying bedrock. Soil thicknesses at the site range from 1 to $25 \mathrm{ft}$ and typically consist of yellow, light reddish-orange, or red clay of medium stiffness containing variable quantities of chert, siltstone, and limestone fragments.

WAG 1 lies within the Bethel Valley portion of the WOC drainage basin. The WAG boundary stops at the water gap in Haw Ridge; the boundaries of the basin extend to the southeast and northeast along Chestnut Ridge and Haw Ridge. The plant area has several major discharges to First, Fifth, and White Oak creeks, including (1) treated sanitary waste from the sewage treatment plant, (2) cooling tower blowdown, (3) cooling water, (4) process wastewaters, (5) surface runoff from storm sewers, (6) LLLW collection and treatment system waters, and (7) demineralizer regenerant waste. Groundwater is observed to occur both in the unconsolidated overburden and within the bedrock. The uppermost portion of the aquifer occurs under unconfined conditions. Recharge to the system is generally through infiltration with localized recharge through surface impoundments. The water table appears as a subdued replica of ground surface topography.

Both man-made and naturally occurring radionuclides have been detected in WOC, First Creek, Fifth Creek, and Northwest Tributary. The most frequently detected were ${ }^{90} \mathrm{Sr}$ and ${ }^{137} \mathrm{Cs}$, which are man made. Radium-228 and ${ }^{234} \mathrm{U}$ were also detected above reference levels but less frequently and at lower concentrations than strontium and cesium. While ${ }^{228} \mathrm{Ra}$ and ${ }^{234} \mathrm{U}$ can be naturally occurring, it is believed that the amounts detected in samples from First Creek are man made or enriched from on-site processes. Tritium was also widely detected in WAG 1 surface water. Of the few volatile organic compounds and base/neutral/acid-extractables detected, only the volatile organic compounds pyridine and p-dioxane may be of concern. Metal concentrations in all samples were well below maximum contaminant levels. 
Several general areas of contamination (both radiological and chemical) were identified based on the results of the groundwater sampling conducted at WAG 1 . The primary radionuclides found in groundwater were strontium and tritium. The most widespread organic compounds found in groundwater at WAG 1 are trichloroethene and its degradation products 1-, 2-dichloroethene, and vinyl chloride.

The environs of WAG 1 are typical of the ecological systems of the Appalachian region. The dominant plant community is the Old Hickory Forest, with extensive stands of mixed yellow pine and hardwoods. Nonforest areas include grasslands, devegetated areas, and developed locations. Nonforest areas predominate in WAG 1 . The aquatic communities potentially affected by WAG 1 include the WOC watershed and Clinch River downstream from the mouth of WOC. The WOC watershed is not known to have any threatened or endangered species.

Active projects in WAG 1 are the Gunite and Associated Tanks, Core Hole 8, WAG 1 Groundwater $\mathrm{CA}$, and the Surface Impoundments project.

\subsection{REFERENCES}

Autrey, J. W. 1989. Personal communication to A.K. Brill, Bechtel National, Inc., on inactive tank sample analysis and soil survey data at tank sites (April).

Bechtel (Bechtel National, Inc.) 1989. Remedial Investigation Plan for ORNL Waste Area Grouping 1, ORNL/RAP/Sub-87/99053/4\&R1, Oak Ridge Natl. Lab.

Bechtel 1992. Site Characterization Summary Report for Waste Area Grouping 1 at Oak Ridge National Laboratory, Oak Ridge, Tennessee, DOE/OR-1043/V1\&D1, DOE/OR-1043/V2\&D1, Oak Ridge Natl. Lab.

Berry, J. B., and H. R. Yook 1987. Environmental Restoration and Facilities Upgrade, Water Pollution Control Strategy, ORNL/TM-10343, Oak Ridge Natl. Lab.

Boegly, W. J., Jr., et al. 1987. Environmental Data Package for the Main Plant Area (WAG 1), ORNL/RAP-13, Oak Ridge Natl. Lab.

Cerling, T. E. and B. P. Spalding 1981. Areal Distribution of Co-60, Cs-137, and Sr-90 in Streambed Gravels of White Oak Creek Watershed, ORNL/TM-7318, Oak Ridge Natl. Lab.

Coobs, J. H., and J. H. Myrick 1986. The ORNL Surplus Facilities Management Program, Maintenance and Surveillance Plan for Fiscal Year 1984, ORNL/TM-10268, Oak Ridge Natl. Lab.

Daniels, K. L. 1989. Oak Ridge National Laboratory, personal communication to J. T. Kitchings, Bechtel National, Inc., team on sediments from the 7500 Bridge Area (June).

Department of Environmental Management 1986. Environmental Surveillance Data Report for the Second Quarter of 1986, ORNL/M-173, Oak Ridge Natl. Lab.

DOE (U.S. Department of Energy) 1996. Proposed Plan for Surface Impoundments Operable Unit, Waste Area Grouping 1, Oak Ride National Laboratory, Oak Ridge, Tennessee, DOE/OR/02-1427\&D1, Lockheed Martin Energy Systems, Inc., Oak Ridge, Tennessee. 
Duguid, J. 0. 1975. Status Report of Radioactivity Movement from Burial Grounds in Melton and Bethel Valleys, ORNL-5017, Oak Ridge Natl. Lab.

Energy Systems 1985. Environmental Monitoring Report United States Department of Energy Oak Ridge Facilities Calendar Year 1984, ORNL-6209, Martin Marietta Energy Systems, Inc., Oak Ridge, Tenn.

Energy Systems 1986. Environmental Surveillance of the Oak Ridge Reservation and Surrounding Environs During 1985, ORNL-6271, Martin Marietta Energy Systems, Inc., Oak Ridge, Tenn.

Energy Systems 1987. Environmental Surveillance of the U.S. Department of Energy Oak Ridge Reservation and Surrounding Environs During 1986, ES/ESH-1/V1\&V2, Martin Marietta Energy Systems, Inc., Oak Ridge, Tenn.

Energy Systems 1988. Environmental Surveillance of the U.S. Department of Energy Oak Ridge Reservation and Surrounding Environs During 1987, ORNL-6209, Martin Marietta Energy Systems, Inc., Oak Ridge, Tenn.

Energy Systems 1989. Oak Ridge Reservation Environmental Report for 1988, ES/ESH-8/V1 \&V2, Martin Marietta Energy Systems, Inc., Oak Ridge, Tenn.

Energy Systems 1990. Oak Ridge Reservation Environmental Report for 1989, ES/ESH-13/V1\&V2, Martin Marietta Energy Systems, Inc., Oak Ridge, Tenn.

Energy Systems 1991. Oak Ridge Reservation Environmental Report for 1990, Volume 1, ES/ESH-18/V1, Martin Marietta Energy Systems, Inc., Oak Ridge, Tenn.

Energy Systems 1993. Phase II Remedial Investigation Work Plan for Groundwater at Waste Area Grouping 1 at Oak Ridge National Laboratory, Oak Ridge, Tennessee, DOE/OR/01-1194\&D0, Oak Ridge Natl. Lab.

Energy Systems 1994. Technology Study of Gunite Tank Sludge Mobilization at Oak Ridge National Laboratory, Oak Ridge, Tennessee, ORNL/ER-286, Oak Ridge Natl. Lab.

Energy Systems 1996. Results of 1995 Characterization of Gunite and Associated Tanks at Oak Ridge National Laboratory, Oak Ridge, Tennessee, ORNL/ER/Sub/87-99053/79, Oak Ridge Natl. Lab.

Foster Wheeler 1994. Removal Action Work Plan for Core Hole 8 in Waste Area Grouping 1 at Oak Ridge National Laboratory, Oak Ridge, Tennessee, ORNL/ER-283, Oak Ridge Natl. Lab.

Geraghty and Miller, Inc. 1990. Development of Contaminant Transport Models for Four Constituents at the S-3 Site, Y-12 Facility, Y/Sub/89-00206C/3, Oak Ridge, Tenn.

Grimsby, H. J. 1986. Inventory of ORNL Remedial Action Sites: 12 Other Contaminated Sites, ORNL/RAP/LTR-86/54, Oak Ridge Natl. Lab.

Hall, D. 1989. Personal communication, "Volumes and Treatment Costs for Contaminated Groundwater-FY 1989." 
Hatcher, R. D., et al. 1992. Status Report on the Geology of the Oak Ridge Reservation, ORNL/TM-12074, Oak Ridge Natl. Lab.

Huff, D. D. 1985. Summary of Dry-Weather Dye Tracing Activities, ORNL/RAP/LTR-85/6. Oak Ridge Natl. Lab.

Huang, S. F., et al. 1984a. Preliminary Radiological Characterization of Fifteen Waste Tanks at Oak Ridge National Laboratory, ORNL/CF-84/203, Oak Ridge Natl. Lab.

Huang, S. F., et al. 1984b. Preliminary Radiological Characterization of Waste Holding Basin 3513, ORNL/CF-84/204, Oak Ridge Natl. Lab.

Jacobs 1994a. Engineering Evaluation/Cost Analysis for the Waste Area Grouping 1 Core Hole 8 Removal Action at the Oak Ridge National Laboratory Oak Ridge, Tennessee, DOE/OR/02-1303\&D2, Oak Ridge Natl. Lab.

Jacobs 1994b. Action Memorandum for the Waste Area Grouping 1 Core Hole 8 Removal Action at Oak Ridge National Laboratory, Oak Ridge, Tennessee, DOE/OR/02-1317\&D2, Oak Ridge Natl. Lab.

Jacobs 1994c. Remedial Investigation/Baseline Risk Assessment for the Gunite and Associated Tanks Operable Unit at Waste Area Grouping 1 at Oak Ridge National Laboratory, Oak Ridge, Tennessee, DOE/OR/02-1275\&D2, Oak Ridge Natl. Lab.

Jacobs 1995a. Gunite and Associated Tanks Operable Unit Baseline Report and Treatability Study Work Plan, Oak Ridge National Laboratory, Oak Ridge, Tennessee, DOE/OR/02-1325\&D1, Oak Ridge Natl. Lab.

Jacobs 1995b. Oak Ridge National Laboratory Waste Area Grouping 1 Gunite and Associated Tanks Operable Unit Treatability Study Work Plan, Oak Ridge, Tennessee, DOE/OR/02-1300\&D2, Oak Ridge Natl. Lab.

Jacobs 1995c. Remedial Investigation/Feasibility Study for Surface Impoundments Operable Unit, Waste Area Grouping 1, Oak Ridge National Laboratory, Oak Ridge, Tennessee, DOE/OR/02-1346\&D1, Oak Ridge Natl. Lab.

Ketelle, R. H., and R. R. Lee 1992. Migration of a Groundwater Contaminant Plume by Stratabound Flow in Waste Area Grouping 1 at Oak Ridge National Laboratory, Oak Ridge, Tennessee, ORNL/ER-126, Oak Ridge Natl. Lab.

Ketelle, R. H., et al. 1986. 1986 Groundwater System Characterization, ORNL/RAP/LTR-86/75, Oak Ridge Natl. Lab.

Kitchings, J. T., and R. K. Owenby 1986. Applicability of RCRA Part B Permitting Requirements to ORNL's Surface Impoundments 3524, 3539, 3540, 7905, 7906, 7907, and 7908, ORNL/RAP/LTR-86/43, Oak Ridge Natl. Lab.

Lee, R. R. 1995. Personal communication to P. L. Osborne, Lockheed Martin Energy Systems, May. 
Lee, R. R., and R. H. Ketelle 1987. Stratigraphic Influence on Deep Groundwater Flow in the Know Group Copper Ridge Dolomite on the West Chestnut Ridge Site, ORNL/TM-10479, Oak Ridge Natl. Lab.

Lee, R. R., et al.1989. Calibration of a Contaminant Transport Computer Model: Progress Toward Model Validation, ORNL/TM-11294, Oak Ridge Natl. Lab.

Lee, R. R., et al. 1994. Site Characterization Plan for Groundwater in Waste Area Grouping 1 at Oak Ridge National Laboratory, Oak Ridge, Tennessee, ORNL/ER-248, Oak Ridge Natl. Lab.

LMES (Lockheed Martin Energy Systems) 1995. Remedial Action Report for the Core Hole 8 Removal Action at Oak Ridge National Laboratory, Oak Ridge, Tennessee, DOE/OR/01-1380\&D1, Oak Ridge Natl. Lab.

McMaster, W. M., and H. D. Waller 1965. Geology and Soils of White Oak Creek Basin, Tennessee, ORNL/TM-108, Oak Ridge Natl. Lab.

Montford, M. A., K. L. Daniels, and J. T. Kitchings 1986. Groundwater Sampling Around RCRA Impoundments, ORNL/RAP/LTR-86/76, Oak Ridge Natl. Lab.

Nix, C. E., et al. 1986. CERCLA Phase 1 Report; Identification and Preliminary Assessment of Inactive Hazardous Waste Disposal Sites and Other Contaminated Areas at ORNL, ORNL/TM-9989, Oak Ridge Natl. Lab.

Nriagu, J. O., ed. 1979. The Biogeochemistry of Mercury in the Environment, Elsevier/North-Holland Biomedical Press.

Oakes, T. W. 1983a. "Intralaboratory Memorandum to J. F. Wing on Mercury in Soil and Sediment at ORNL," June 9.

Oakes, T. W. 1983b. "Intralaboratory Memorandum to J. F. Wing on Mercury Concentrations in Soil Samples Collected Around Buildings 4501, 4505, and 4507 and from the Bank of Fifth Creek," July 5, Oak Ridge Natl. Lab.

Oakes, T. W. 1985. "Intralaboratory Memorandum to B. J. Davis on 3019 and 3028 Area Soil Sampling Results," May 3.

Oakes, T. W., and K. E. Shank 1977. Subsurface Investigation of the Energy Systems Research Laboratory Site at ORNL, ORNL/TM-5695, Oak Ridge Natl. Lab.

ORNL (Oak Ridge Natl. Lab.) 1987. RCRA Facilities Assessment (RFA)—Oak Ridge National Laboratory, ORNL/RAP-12/N1, Oak Ridge Natl. Lab.

ORNL 1990. ORNL Contaminated Site Summary Sheets, ORNL/M-2413, Oak Ridge Natl. Lab.

SAIC (Science Applications International Corp.) 1994. Remedial Investigation Work Plan for the Groundwater Operable Unit at Oak Ridge National Laboratory, Oak Ridge, Tennessee, DOE/OR/01-1252\&D1 (ORNL/ER-221\&D1), Oak Ridge Natl. Lab.

Site and Facilities Planning Department June 1994. Oak Ridge Reservation Technical Site Information, ES/EN/SFP-23, Martin Marietta Energy Systems, Inc., Oak Ridge, Tenn. 
Solomon, D. K., et al. 1989. Groundwater Monitoring in 1988 at Three Oak Ridge National Laboratory Inactive Waste Impoundments, ORNL/TM-11022, Oak Ridge Natl. Lab.

Spalding, B. P., and T. E. Cerling 1979. Association of Radionuclides with Streambed Sediments in White Oak Creek Watershed, ORNL/TM-6875, Oak Ridge Natl. Lab.

Stansfield, R. G., and C. W. Francis 1986. Characteristics of the 3513 Impoundment, ORNL/TM-9936, Oak Ridge Natl. Lab.

Stockdale, P. B. 1951. Geologic Conditions at the Oak Ridge National Laboratory (X-10) Area Relevant to the Disposal of Radioactive Waste, ORO-58, U.S. Atomic Energy Commission, Oak Ridge, Tenn.

Stueber, A. M., and D. A. Webster 1981. An Investigation of Radionuclide Release from Solid Waste Disposal Area 3, Oak Ridge National Laboratory, ORNL/TM-7323, Oak Ridge Natl. Lab.

Stueber, A. M., et al. 1981. An Investigation of Radionuclide Release from Solid Waste Disposal Area 3, Oak Ridge National Laboratory, ORNL/TM-7323, Oak Ridge Natl. Lab.

Tamara, T., 0. M. Sealand, and J. 0. Duguid 1977. Preliminary Inventory of Pu-239,-240, Sr-90, and Cs-137 in Waste Pond No. 2 (3513), ORNL/TM-5802, Oak Ridge Natl. Lab.

Taylor, F. G. Jr. 1989. Mercury Assessment for Water and Sediment in Oak Ridge National Laboratory Streams, ORNL/M-713, Oak Ridge Natl. Lab.

Taylor, F. G. Jr. 1990a. Mercury Monitoring of Water and Sediment in Oak Ridge National Laboratory Streams During 1989, ORNL/M-1030, Oak Ridge Natl. Lab.

Taylor, F. G. Jr. 1990b. Polychlorinated Biphenyls in the Aquatic Environment of Oak Ridge National Laboratory Report of 1989, ORNL/M-1041, Oak Ridge Natl. Lab.

Uziel, M. S., et al. 1989. Surface Radiological Investigations at the Equalization Basin(3542) Site, ORNL/RAP-54, Oak Ridge Natl. Lab.

Van Hoesen, S. D. 1996. Personal communication to P. L. Osborne, February 28.

Webster, D. A. 1976. A Review of Hydrologic and Geologic Conditions Related to the Radioactive Solid-Waste Burial Grounds at Oak Ridge National Laboratory, Oak Ridge, Tennessee, Open-File Report 76-727, U.S. Geological Survey, Washington, D.C.

Williams, J. K., C. Clark, Jr., and J. W. Crutcher 1987. Radiological and RCRA Hazardous Waste Scoping Survey of the Storage Pad Southwest of Building 3503, ORNL/RAP-4, Oak Ridge Natl. Lab.

\subsection{BIBLIOGRAPHY}

Bechtel National, Inc., and CH2M Hill 1992. Preliminary Risk Assessment Report for Waste Area Grouping 1 at Oak Ridge National Laboratory, Oak Ridge, Tennessee, DOE/OR-1044\&D1 (ORNL/ER-132\&D1, ORNL/ER/Sub/87-99053/60, Oak Ridge Natl. Lab. 
Bechtel National, Inc., et al. 1992. Operable Unit Strategy Document for Waste Area Grouping 1 at Oak Ridge National Laboratory, Oak Ridge, Tennessee, DOE/OR-1045\&D1 (ORNL/ER-133\&D1, ORNL/ER/Sub/87-99053/61), Oak Ridge Natl. Lab.

Clapp, R. B., and J. A. Watts, eds. 1995. Fourth Annual Environmental Restoration Monitoring and Assessment Report (FY 1995), Oak Ridge National Laboratory, Oak Ridge, Tennessee, DOE/OR/01-1413\&D1, Oak Ridge Natl. Lab.

Coobs, J. H., and J. R. Gissel 1986. History of Disposal of Radioactive Wastes into the Ground at Oak Ridge National Laboratory, ORNL/TM-10269, Oak Ridge Natl. Lab.

Ebasco 1992. Baseline Report for Waste Area Grouping I at Oak Ridge National Laboratory, Oak Ridge, Tennessee, Volume 1: Text, ORNL/ER-94/V1, Oak Ridge Natl. Lab.

Morrison, S. J. and T. E. Cerling 1987. Survey of Metal, Radionuclide and Organic Contamination at 20 Waste Area Groups (WAGs), ORNL Facilities, Oak Ridge, Tennessee, ORNL/RAP/Sub-87/27463/1, Oak Ridge Natl. Lab. 


\section{HISTORY AND CHARACTERIZATION OF WAG 2}

Instructions to User
This chapter provides information about WAG 2 that can be cited in certain CERCLA
documents (see Chap. 1 and Table 1 in Instructions to User). For a short description of
WAG 2 that can be copied into other types of documents, see the summary at the end
of this chapter. To keep this document as short as possible, information about
conditions common to all WAGs (e.g., climate and demography) is given in
Chap. 5-History and Characterization of the ORNL Site.

\subsection{SITE DESCRIPTION AND HISTORY}

WAG 2 (Fig. 7.1) consists of the White Oak Creek (WOC) drainage downstream of ORNL discharge points and includes the associated floodplain and subsurface environment. The WOC system, consisting of WOC, its tributaries, White Oak Lake (WOL), and the White Oak Creek Embayment (WOCE) on Clinch River, is the primary surface drainage for ORNL. The drainage system has been exposed to a diversity of contaminants as a result of operations and waste disposal activities at ORNL from the mid-1940s to the present time. Water, sediment, soil, and biota in WAG 2 are contaminated and continue to receive contaminants from upgradient WAGs.

The ORNL Resource Conservation and Recovery Act (RCRA) facilities assessment (ORNL 1987) identified two solid waste management units (SWMUs) located within WAG 2: (1) WOL, the WOCE of Clinch River, and the associated floodplains and subsurface environment and (2) WOC and its tributaries downstream of the ORNL main plant area/Melton Branch.

SWMU 2.1-WOL and WOCE WOL and WOCE are located south of the ORNL main complex. As Fig. 7.2 shows, WOL and WOC extend above and below White Oak Dam (WOD), which was built about 0.6 mile $(1.0 \mathrm{~km})$ upstream from where WOC empties into Clinch River at WOCE (located near Clinch River Mile 20.8). ORNL grid coordinates of the WOD are N 15,330 and E 23,360. Estimated volume in 1979 was $4,589,000 \mathrm{ft}^{3}\left(130,000 \mathrm{~m}^{3}\right)$. The site is a surface impoundment for radioactive and other hazardous wastes that drain from ORNL via the WOC watershed. It serves as a final settling basin for waste released from ORNL operations and waste storage areas.

The main radioactive contaminants in WOL and WOCE are ${ }^{90} \mathrm{Sr},{ }^{137} \mathrm{Cs}$, thorium, uranium, and transuranic waste. No accurate estimates exist for the inventory of hazardous chemicals in the lake; however, preliminary scoping surveys have shown contamination by cadmium and chromium in stream gravels. The average 1985 concentrations of radionuclides in the water discharged at WOD were ${ }^{60} \mathrm{Co}, 63 \times 10$ (E-9) $\mu \mathrm{Ci} / \mathrm{mL} ;{ }^{137} \mathrm{Cs}, 42 \times 10$ (E-9) $\mu \mathrm{Ci} / \mathrm{mL} ;{ }^{90} \mathrm{Sr}, 300 \times 10(\mathrm{E}-9) \mu \mathrm{Ci} / \mathrm{mL}$; and ${ }^{3} \mathrm{H}$, $350 \times 10(\mathrm{E}-6) \mu \mathrm{Ci} / \mathrm{mL}$. The lake bed contains an estimated sediment volume of $1.3 \times 10(\mathrm{E}+5) \mathrm{m}^{3}$ of sediment, with estimated activities of ${ }^{137} \mathrm{Cs}, 591 \mathrm{Ci} ;{ }^{60} \mathrm{Co}, 33 \mathrm{Ci}$; and ${ }^{90} \mathrm{Sr}, 20 \mathrm{Ci}$ (Ebasco 1992).

SWMU 2.2-WOC and Tributaries WOC and its tributaries are located in Melton and Bethel valleys and provide drainage for $\mathrm{ORNL}$. WOC flows into Clinch River about 1.5 miles $(2.4 \mathrm{~km})$ north of the junction of Interstate 40 and State Highway 95. This system drains an area of 3830 acres $(1550 \mathrm{ha})$. Treated sewage and process wastes are released to the creek after treatment. After 


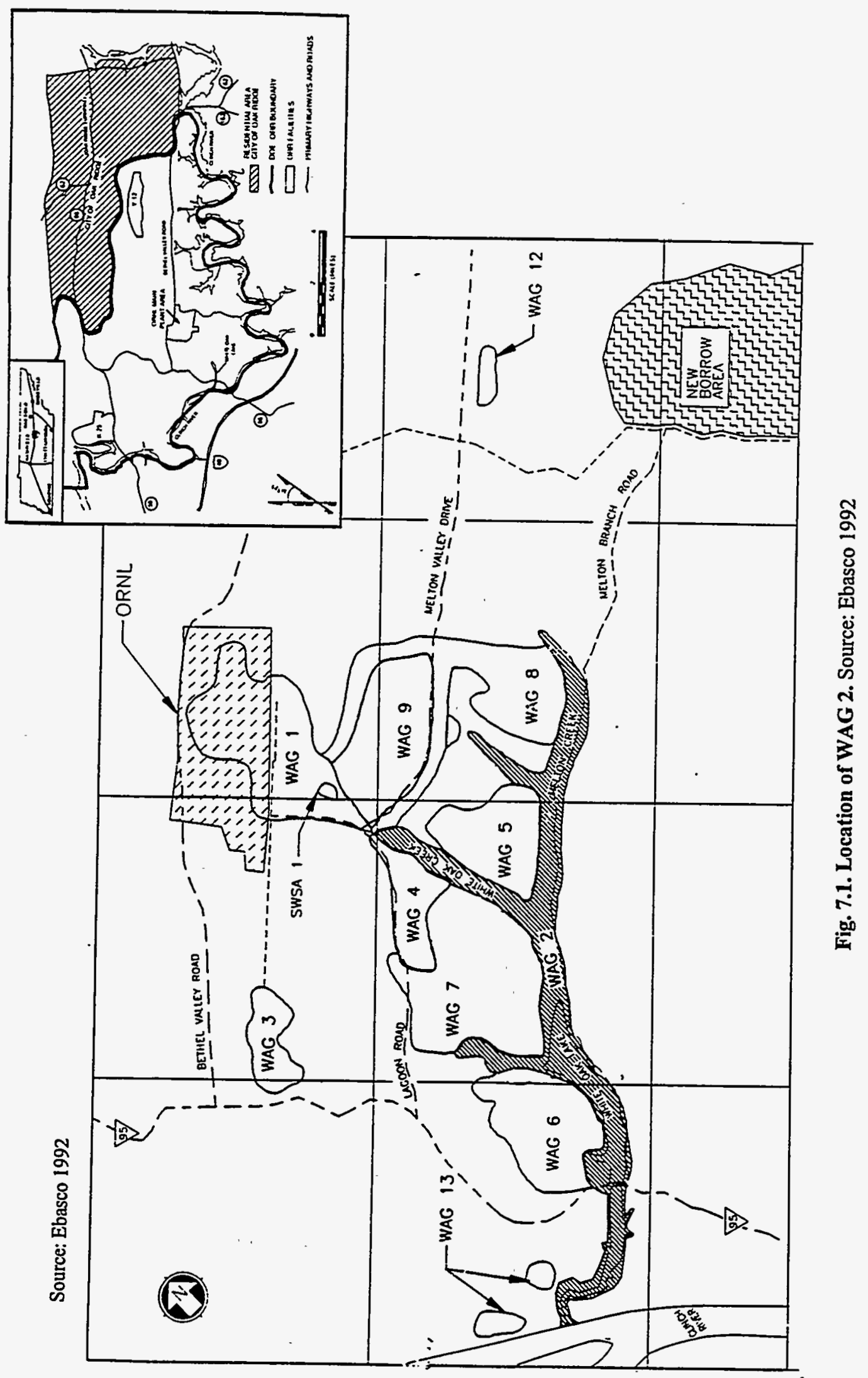




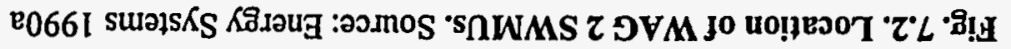

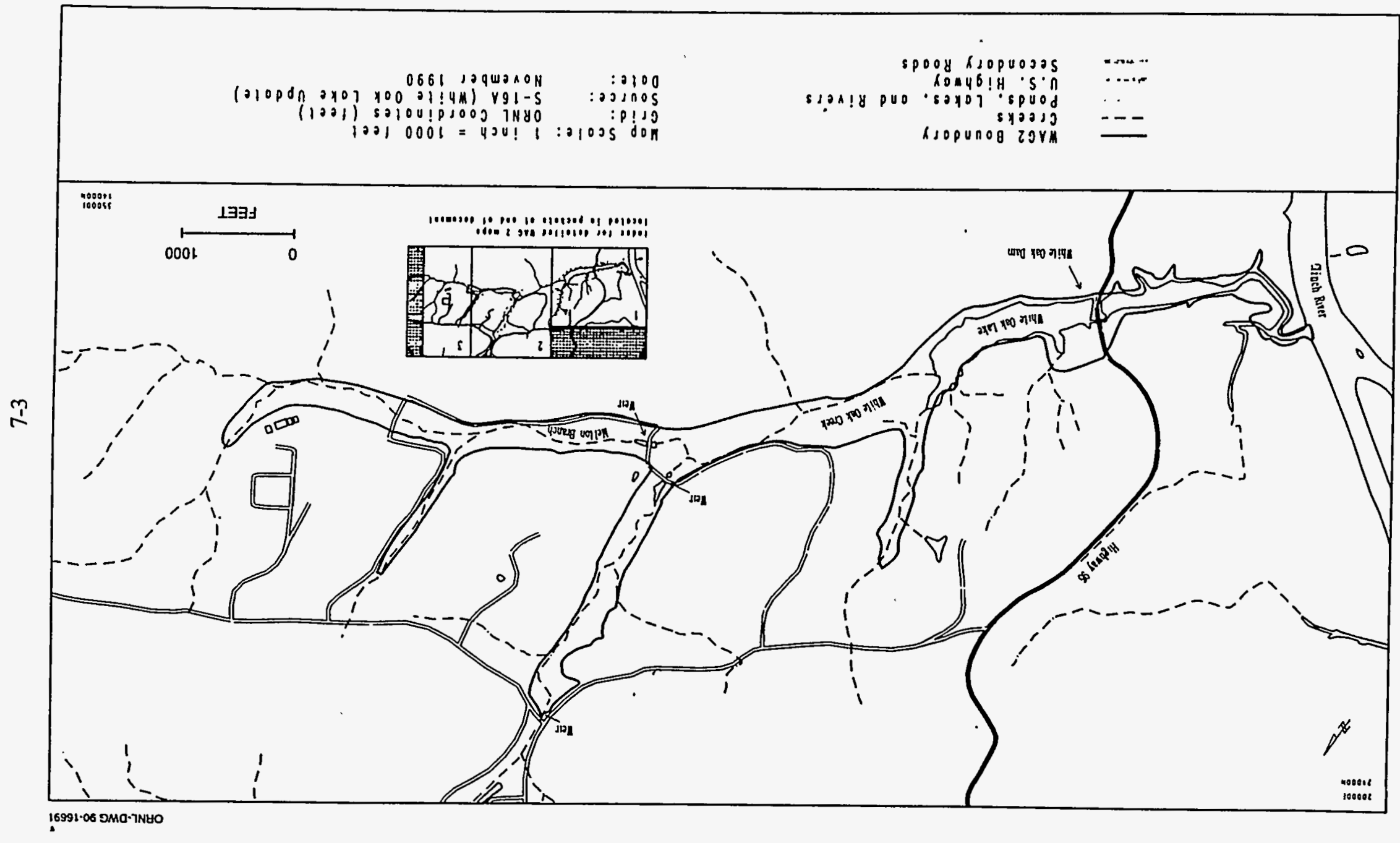


treatment in the Process Waste Treatment Plant, low-level liquid radioactive waste is also discharged to the creek. The creek and its tributaries have been used for waste disposal purposes since ORNL was opened. Main contaminants are ${ }^{90} \mathrm{Sr},{ }^{60} \mathrm{Co},{ }^{137} \mathrm{Cs},{ }^{3} \mathrm{H}$, and metals (mercury, zinc, and chromium). Hazardous chemicals, including polychlorinated biphenyls (PCBs), may also be present in the stream sediments. The estimated inventory is ${ }^{90} \mathrm{Sr}(>5 \mathrm{Ci}),{ }^{137} \mathrm{Cs}(>100 \mathrm{Ci}),{ }^{239} \mathrm{Pu}(0.5 \mathrm{Ci})$ (Ebasco 1992).

With the exception of WAG 2 (and the Groundwater Watershed), all ORNL WAGs are sources of contaminants to other areas and have been termed "contaminant source WAGs." WAG 2 and the Groundwater Watershed have been termed "integrator sources" because most contamination released from ORNL is discharged into these two, and they in turn serve as conduits for contaminants from ORNL to off-site areas. WAG 2 is downgradient from nine of the contaminant source WAGs; therefore it receives and integrates the contaminants released from these WAGs through the surface water system. Corrective measures in WAG 2 taken in the short-term could be negated by future contaminant input from upgradient WAGs; therefore, implementation of corrective measures in WAG 2 will follow the completion of remediation of upgradient WAGs.

\subsection{CHARACTERIZATION}

\subsubsection{Geography}

WAG 2 is located on the Oak Ridge Reservation (ORR) in Roane County, Tennessee, approximately 5 miles southwest of the city of Oak Ridge central business district and immediately south of the ORNL main plant area (Fig. 7.1). WOC, its tributaries, and WOL represent the major drainage system for ORNL and the surrounding facilities. The drainage area of WOC and its tributaries is approximately $6.4 \mathrm{sq}$ mile (16.8 sq km) (Ebasco 1992). WOC originates from springs and surface runoff northeast of the ORNL main plant area (WAG 1), flows to the east and south of WAG 1, and exits Bethel Valley through an opening in Haw Ridge (Fig. 7.3). Farther downstream, a small reservoir (WOL) is formed by WOD. Discharge from WOD enters an embayment 0.6 mile $(1.0 \mathrm{~km})$ prior to its confluence with Clinch River at mile 20.8. Just upstream of WOL, Melton Branch enters WOC from the east. Melton Branch collects the drainage from many of the reactor facilities in Melton Valley.

WAG 2 is a floodplain and therefore has little topographic variation. The slope of WOL and the embayment is negligible for most purposes. WOC above the weir has an average slope of less than $1 \%$, and above the weir at Melton Branch the slope is about 1.5\%. The average slope in West Seep Tributary is about $1.9 \%$ (Ebasco 1992).

The typical valley-ridge pattern of relief is evident across the watershed. Compared to a nominal level for WOL of $455 \mathrm{ft}$, the maximum elevation of Copper Ridge to the south is $1400 \mathrm{ft}$. A series of knolls or hills underlain by the Maryville formation exist in the middle of the watershed, and the maximum elevation of the formation in the pits and trenches area (approximately E27,000; N18,000) is $866 \mathrm{ft}$. This set of hills tends to increase in elevation toward the headwaters of Melton Branch. Haw Ridge, underlain by the Rome formation, has a maximum elevation of $1100 \mathrm{ft}$, and Chestnut Ridge to the north has a maximum elevation of $1200 \mathrm{ft}$.

\subsubsection{Climate}

See Sect. 5.2.2 of this document for climate description. 


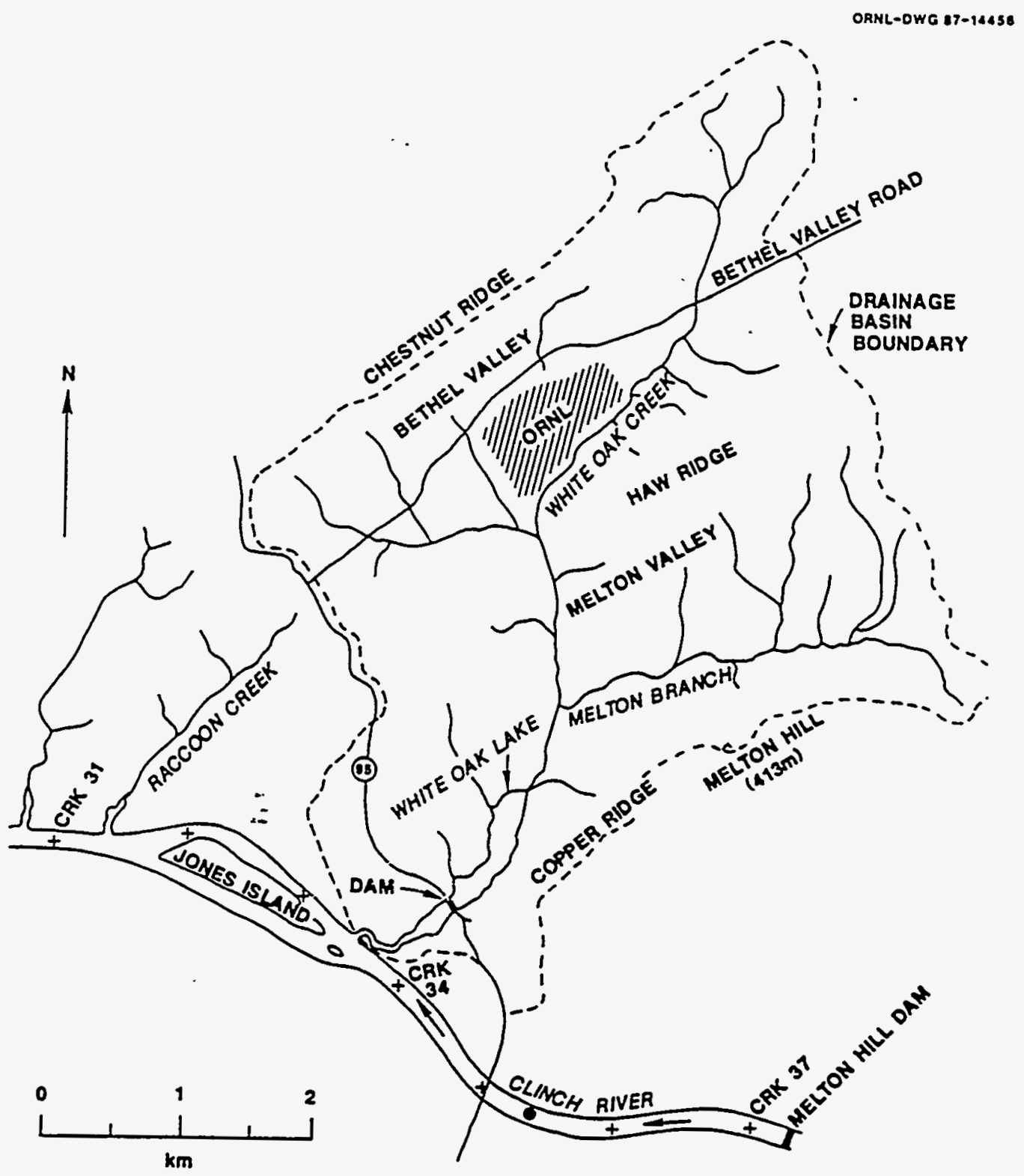

Fig. 7.3. Map showing the WOC watershed boundaries. Source: Energy Systems 1990a

\subsubsection{Demography}

At the closest point, WAG 2 is less than $1000 \mathrm{ft}$ from the ORNL main plant area, where the majority of ORNL's approximately 4837 employees work (Site and Facilities Planning Department 1994). Within 1 mile of the boundary of WAG 2 , all land is federally owned, and there are no residents. The two-lane State Highway 95 runs through the ORR and passes along the western side of WOD. WAG 2 extends to the north bank of Clinch River, which forms a portion of the boundary of the ORR. Clinch River, also known as Watts Bar Lake at this location, is open to recreational uses, such as boating, fishing, and duck and goose hunting, as permitted by the state of Tennessee.

See Sect. 5.2.3 of this document for general demographic characteristics of ORNL. 


\subsubsection{Geology and Soils}

\subsubsection{General geology}

The ORR, which includes WOC and WOL (WAG 2), is located in the Valley and Ridge physiographic province, part of the Appalachian fold and thrust belt. The area is characterized by a succession of northeast-trending ridges and valleys, which formed as a result of differential erosion of the clastic and carbonate lithologies that make up the individual thrust sheets.

WAG 2 is located in Melton Valley, which is bounded to the north and south by Haw Ridge and Copper Ridge, respectively. Maximum relief of the ridges is approximately $200 \mathrm{ft}$. These ridges and valley are part of the Copper Creek thrust sheet, which exposes Lower Cambrian to Ordovician rock units in the immediate area. The stratigraphy of the area, from oldest to youngest (and exposed from grid-north to grid-south), includes the Lower Cambrian Rome Formation (exposed on Haw Ridge), the Cambrian Conasauga Group (exposed in Melton Valley), and the Knox Group (exposed on Copper Ridge). The Conasauga Group is further divided into six formations of alternating shale and carbonate-rich lithologies. From oldest to youngest these are: the Pumpkin Valley Shale, the Rutledge Limestone, the Rogersville Shale, the Maryville Limestone, the Nolichucky Shale, and the Maynardville Limestone. Because geologic strike is approximately grid east, the north-northeast-trending streams in the WAG cut across the stratigraphy. Specifically, the northern section of WOC lies in the Pumpkin Valley Shale, Rutledge Limestone, and the Rogersville Shale. The southern section of WOC and the other streams in the WAG lie in the Maryville Limestone and the Nolichucky Shale. A geologic cross-section is presented in Fig. 7.4.

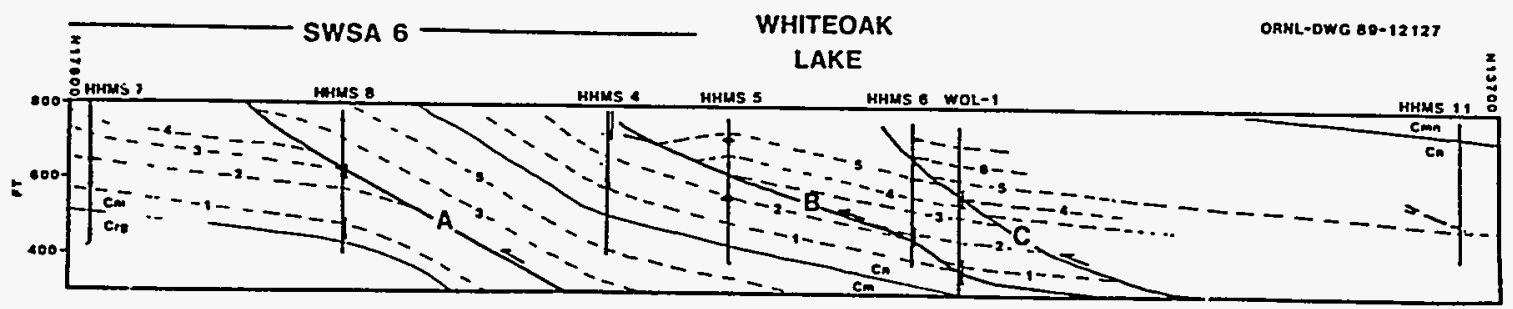

Fig. 7.4. Strike-perpendicular geologic cross-section through SWSA 6 and WOL. $\mathrm{Crg}=$ Rogersville Shale, $\mathrm{Cm}=$ Maryville Limestone, $\mathrm{Cn}=$ Nolichucky Shale. Numbered horizons represent informal stratigraphic divisions within a formation. A, B, and C are thrust faults. Source: Energy Systems 1990a.

Geologic factors that influence contaminant transport in WAG 2 include those that define the flow paths of the shallow groundwater system (geologic structure, detailed weathering characteristics of various lithologies) as well as characteristics that influence retardation of contaminants (stratigraphy/petrology). For example, the location of the seeps are geologically controlled, and these seeps are potential connectors between the shallow groundwater and surface water systems. No specific studies have been directed toward collecting this type of geologic information for WAG 2 . However, geologic investigations have been conducted in Melton Valley.

\subsubsection{Structure}

WAG 2 is located on the Copper Creek thrust sheet, which is floored by the Copper Creek thrust fault. The Copper Creek is a regional thrust fault of the Valley and Ridge, which shows at least several kilometers of displacement. The fault formed during the Permian-Pennsylvanian Alleghanian Orogeny and has not been historically active. In the vicinity of WAG 2, the fault trends parallel to 
regional strike (N55E) and dips shallowly $\left(15-5^{\circ}\right)$ to the southeast. Bedding planes dip values measured in outcrop are similar to the dip of the fault (Dreier, Solomon, and Beaudoin 1987), but locally may steepen to vertical as a result of local small-scale folding or faulting.

Melton Valley is characterized by numerous cross-strike streams with a consistent northward trend, the largest of these being WOC. Such a consistent orientation suggests that the location of these creek beds is controlled by a geological structural feature, either a minor tear fault or a prominent fracture trend. If these structures are faults, they show minor displacement but should have an associated fracture zone. The fracture zone may be more (or less) permeable to fluids than the surrounding rocks, depending on local lithologic characteristics, fault history, and depth of investigation. Because WOC shows a prominent topographic expression and there is offset of minor ridges on opposing sides of the creek, a fault-the WOC Tear Fault-has been proposed to underlie the north-trending portions of WOC (Energy Systems 1990a).

Because of the large-scale faulting, all geologic units in ORR are highly fractured. Detailed investigations of saprolite in the Conasauga Group show that three fracture sets occur consistently. One set is parallel to bedding; the other two sets are perpendicular to bedding and are either strike parallel or strike perpendicular. The bedding-parallel fractures are interpreted to be predominantly release joints. The other sets may also have formed by a release mechanism.

Fracture density varies considerably with depth. The greatest densities are measured in the shallow saprolite, averaging $60 \mathrm{ft}$. Fracture densities decrease with an increase in depth and are much lower in competent rock; however, specific fracture densities have not been quantified below the saprolite horizon.

Because WAG 2 is a floodplain, there is very little topographic variation. The slope of WOL and the embayment is negligible for most purposes. WOC above the weir has an average slope of less than $1 \%$, and above the weir at MB the slope is about $1.5 \%$. The average slope in West Seep Tributary is about $1.9 \%$.

\subsubsection{Soils}

There is no modern survey or map of the soils for the entire WOC basin or for WAG 2 in particular. The soils of Roane County, which include all of WOC basin except for a small area at the northeast edge of the basin, were mapped in the 1930s, and the results were published in 1942 (Swann et al.). The soils from this survey have been classified according to hydrologic group for purposes of watershed hydrologic modeling (Tschantz and Rghebi 1989) (Fig.7.5).

According to the county survey, above the WOC-Melton Branch confluence and for a short section below the West Seep Tributary outfall to WOC, WAG 2 is mapped asgravelly, fine, sandy, Pope loam. The lower part of WAG 2, including the areas now covered by WOL and lake sediments, is mapped as fine, sandy, Pope loam. Because of refined methods of soil mapping and the many changes in the basin, the Roane County soil map is outdated.

There are other pertinent descriptions of the soils found on ORR. Lietzke, Lee, and Lambert (1988) describe the soils in the Bear Creek area near State Highway 95, which, because of repetition of geological lithology, is similar to Melton Valley. Much of the deposited soils in Melton Valley will be very similar to four soil units that are lumped as Maryville and Nolichucky alluvium. The Maryville Limestone within the Conasauga Group forms the discontinuous knolls and hills to the north side of WOL and Melton Branch, and the Nolichucky Shale is a more eroded lithological unit 
at the toe slope of the Maryville formation. Other generalized descriptions of soils and soil-forming processes applicable to the WOC basin and WAG 2 are reported by Lee and Ketelle (1987).

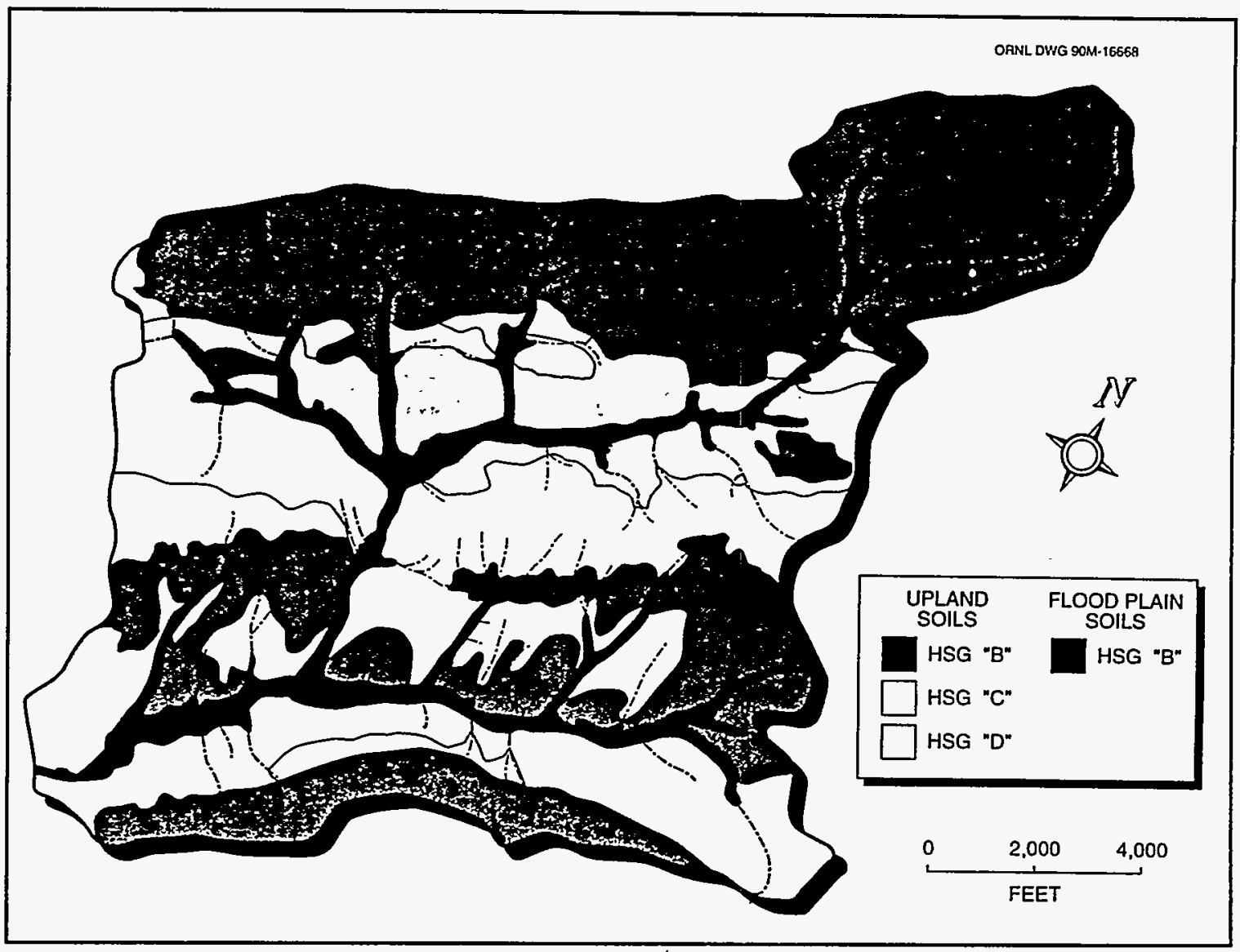

Fig. 7.5. WOC watershed soils classified according to hydrologic groups (HSGs). The HSG " $B$ " soils class has been separated into upland and floodplain soils. Source: Energy Systems 1990a.

\subsubsection{Surface Water}

\subsubsection{WOC watershed}

The stream network on the WOC watershed consists of small, perennial, and intermittent, first- to third-order streams (Fig. 7.3). Typically, these streams are less than $1 \mathrm{~m}$ in depth and consist of alternating series of riffles and pools (Loar 1981; Loar, Solomon, and Cada 1981). Springs that occur along the base of Chestnut Ridge and in its valleys are the chief sources of base flow of upper WOC. Upper WOC is underlain by a more productive water-bearing formation than upper Melton Branch, which has typically low base-flow discharge. Upper Melton Branch experiences periods of no flow at times during the summer and fall. In addition, some first-order tributaries to WOC in Melton Valley also experience periods of no flow at times.

Numerous seeps have been identified in the WOC watershed. At least 19 seeps lie along the perimeter of Solid Waste Storage Area 5 (SWSA 5), and several of these are inside the WAG 2 boundary. These seeps drain to WOC, Melton Branch, and the unnamed tributary to Melton Branch bordering SWSA 5 to the east. Five seeps lie on the southern boundary of SWSA 4 and drain to WOC. At least ten seeps are scattered throughout WAG 7, several of which are close to the WAG 2 
boundary. The WAG 7 seeps drain to WOC, the East Seep Tributary and an unnamed tributary to WOC between the mouth of Melton Branch and the East Seep Tributary. Four seeps lie in WAG 6 and drain to the two western tributaries to WOL in this area.

The seeps mentioned above have been identified and located by various studies and individual discoveries over a period of years. In the WOC watershed, SWSA 5 is probably the area most extensively investigated for location of seeps. In addition, seeps have been observed in other areas as well. Wet weather seeps are known to exist on the southern boundary of WAG 7 and have been observed on the hill slopes above Melton Branch to the south. Many areas in the vicinity of WAG 2 are suspected to contain numerous seeps, but these have not been identified by specific studies. The distribution of seep locations gives an indication of the highly localized and heterogeneous nature of subsurface discharges to streams in WAG 2.

In addition to natural run-off and groundwater discharge, WOC and its tributaries receive the treated and untreated process wastewater, treated sanitary sewage effluent, and reactor cooling water from the ORNL facilities. This water is imported from outside the watershed, and it represents a significant fraction of the annual stream flow, over $50 \%$ of in-stream flow at the WOC and Melton Branch National Pollution Discharge Elimination System (NPDES) monitoring stations during some summer dry periods.

The waters of WOC are impounded by WOD, which serves as a holding pond for ORNL waste effluents. The drainage areas upstream from the confluence with Clinch River and from WOD are approximately $16.8 \mathrm{~km}^{2}\left(6.5 \mathrm{mi}^{2}\right)$ and $16.0 \mathrm{~km}^{2}\left(6.15 \mathrm{mi}^{2}\right)$, respectively (Energy Systems 1985). Elevations in the watershed range from $226 \mathrm{~m}(741 \mathrm{ft})$ at the mouth of WOC to $413 \mathrm{~m}(1355 \mathrm{ft})$ at the top of Melton Hill, the highest point on ORR.

WOD is a low-head structure with a normal lake elevation of $745 \mathrm{ft}$. The reservoir is only $1.2 \mathrm{~m}$ (4 ft) above normal summer pool elevation in Clinch River, which is $226 \mathrm{~m} \mathrm{(741} \mathrm{ft)} \mathrm{above} \mathrm{mean} \mathrm{sea}$ level. A recent survey of WOL by Cox et al. (1991) indicates that the volume of WOL at normal pool level is approximately $43,780 \mathrm{~m}^{3}\left(1,546,330 \mathrm{ft}^{3}\right)$. Flow from WOL discharges through a weir and concrete box culvert to the embayment below WOD. In 1983, modifications were made to the flow system at the dam to increase the flood discharge capacity to $2000 \mathrm{ft}^{3} / \mathrm{s}$. Tschantz (1987) estimated the 100-year flood peak inflow to be approximately $2453 \mathrm{ft}^{3} / \mathrm{s}$ with a peak outflow of $1574 \mathrm{ft}^{3} / \mathrm{s}$ at the dam.

WOL is a small, shallow impoundment that functions as a settling basin for waste effluents discharged to the lake via WOC, Melton Branch, and other smaller streams. WOL extends approximately $0.7 \mathrm{~km}$ upstream from the WOD and has a surface area of about 17 acres ( $7 \mathrm{ha}$ ). The accumulation of sediments over the years has altered the environment of WOL. The lake bottom consists primarily of silt, clay, and organic matter. The average annual rate of sediment accumulation prior to 1953 was estimated to be $2832 \mathrm{~m}^{3}\left(100,000 \mathrm{ft}^{3}\right)$, or about $2 \mathrm{~cm} /$ year.

Because the lake is small and shallow, the water retention time is very short. Based on the average annual inflow, the retention time has been estimated to be approximately $2 \mathrm{~d}$ under normal conditions when the gate elevation is $226 \mathrm{~m}(745 \mathrm{ft})$.

\subsubsection{WOCE}

Reservoir embayments are the hydrologic links between the streams draining ORR and the Clinch River system. Along the southern boundary of ORR, WOCE flows directly from ORR into Clinch River downstream from Melton Hill Dam. Water levels and flow in WOCE are largely 
controlled by the operation of Melton Hill Dam (tailwater) and Watts Bar Dam (headwater). Melton Hill Dam is located $3.7 \mathrm{~km}$ (2.3 mi) upstream on Clinch River; Watts Bar Dam, which forms Watts Bar Reservoir, is about $94 \mathrm{~km}(58.8 \mathrm{mi})$ downstream on the Tennessee River. In addition to constituting an area of potential high contamination as a result of influx of materials from the ORNL, WOCE has been reported to be an important habitat and productive nursery area for the Clinch River/Watts Bar Reservoir fish community (Loar 1981; Loar, Solomon, and Cada 1981).

\subsubsection{Clinch River}

As described above, water-borne contaminants from ORNL enter Clinch River primarily via WOC at a point located downstream from the Melton Hill Dam and are transported further downstream into Watts Bar Reservoir. The transport, distribution, and fate of those contaminants are influenced by (1) their chemical characteristics and solubilities and (2) water and sediment dynamics in the river/reservoir system.

The flow regime of Clinch River is controlled primarily by flood control and hydropower operations at Melton Hill Dam. Peaking power is generated at Melton Hill Dam, so water flow in the lower Clinch River is pulsed. Periods of zero discharge are followed by 4-6 h of discharge, up to about $500 \mathrm{~m}^{3} / \mathrm{s}(20,000 \mathrm{cfs})$. Discharge rates also vary seasonally as a result of flood-control operations. Pulsation of flow in the lower Clinch River affects the tributaries on the reservation. During periods of power generation, backflow may occur into WOC and other embayments (Loar 1981; Loar, Solomon, and Cada 1981). Periods of no flow from Melton Hill Dam have lasted as long as $29 \mathrm{~d}$, but the average number of days of no flow per year is 13 .

\subsubsection{Surface water monitoring}

Flow has been monitored in the WOC watershed by the U.S. Geological Survey (USGS) since 1950. Early discharge data collected by the USGS at WOD, WOC (above the confluence with Melton Branch), and Melton Branch (above the confluence with WOC) indicate average annual discharges of $13.5,9.62$, and $2.50 \mathrm{ft}^{3} / \mathrm{s}$ respectively. Surface water quality monitoring in the WOC watershed of the current ORNL operations and environmental monitoring network flow has been performed by USGS and several divisions of ORNL for over 40 years, in part for radioactivity and chemical constituents at WOD and at a number of sites in WOC and its tributaries. Thirty surface-water monitoring stations have been identified on the WOC watershed and WAG 2 vicinity. Several of these stations are no longer operating, and some have been operated intermittently over a period of years.

Sediments within the WOC flow system have sorbed chemical and radioactive contaminants. Consequently, these contaminants have accumulated in the WOC floodplain and WOL sediments. Oakes et al. (1982) estimated that approximately $1.4 \times 105 \mathrm{~m}^{3}\left(5 \times 106 \mathrm{ft}^{3}\right)$ of contaminated sediments have collected in the lake bed since 1943.

\subsubsection{Groundwater}

Hydrogeologic studies of ORR (Moore 1988, 1989; Webster and Bradley 1987) have shown that subsurface materials in vegetated areas, like WAG 2, consist of a surficial stormflow zone, a vadose zone, and a groundwater zone. The stormflow zone approximately corresponds with the root zone of vegetation and is much more permeable than the underlying vadose zone. Many precipitation events produce a transient, perched water table in the stormflow zone, and water is then transmitted down slope to nearby streams (Fig. 7.6). The permanent water table occurs near the regolith and bedrock contact at a depth of $<3 \mathrm{~m}$ in most of the WAG 2 area. Recharge to the water table occurs 
at the higher elevations in WAG 2 by slow downward seepage of water after precipitation events. All groundwater is discharged to nearby streams along lateral and upward flow paths (Webster and Bradley 1987). The stormflow and groundwater zones are connected near the streams and may also be connected on steep hillsides above WAG 2. Most groundwater thus follows flow paths that extend into and through the stormflow zone to reach the streams.

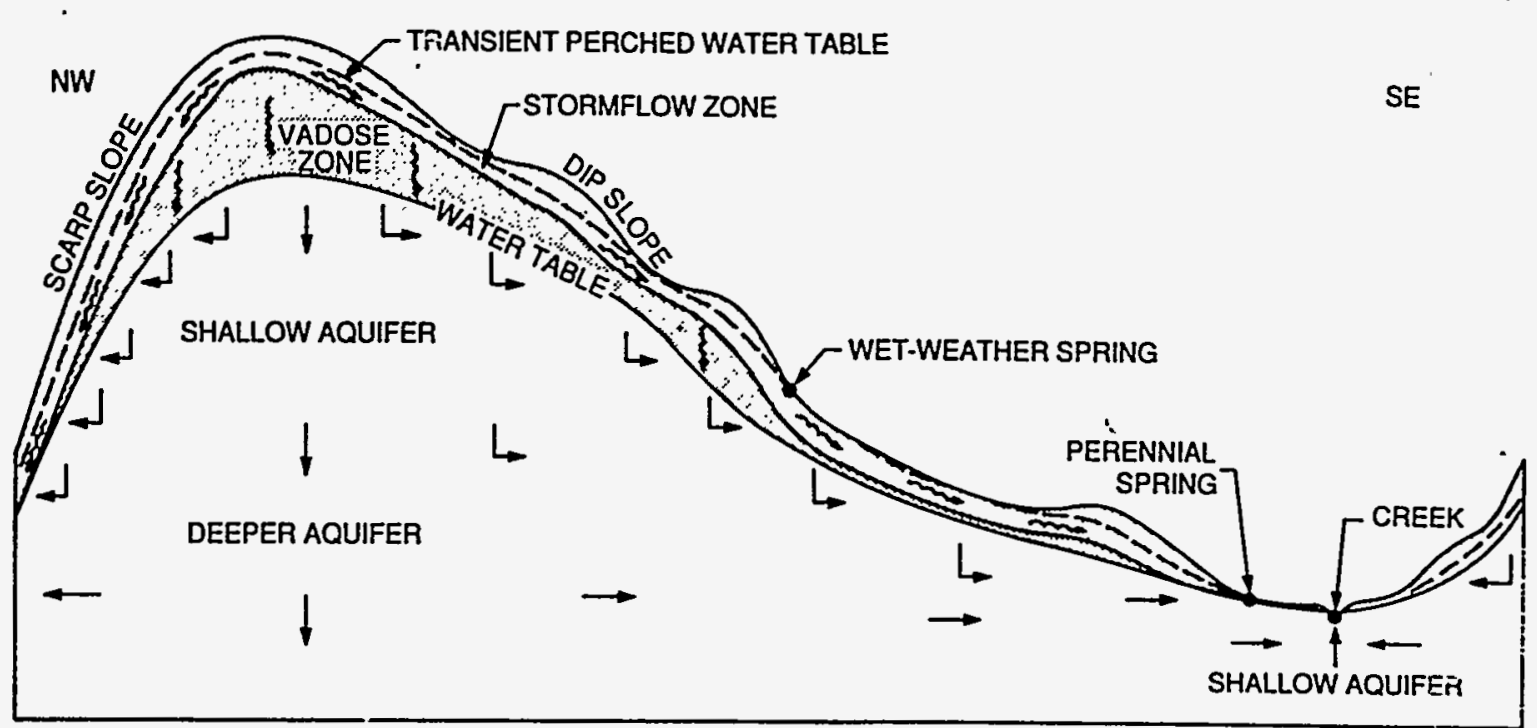

NOT TO SCALE Systems 1990a

Fig. 7.6. Section showing subsurface zones and direction of groundwater flow. Source: Energy

Stormflow monitoring tubes were installed from land surface to a depth of $79 \mathrm{~cm}$ at 17 locations in the headwaters of Melton Branch, upstream from WAG 2. All monitoring tubes had some water inflows during precipitation events, indicating a perched water table, but tubes on steep slopes and in gullies generally had water inflows during small events, whereas larger or more intense events were required to produce inflows to tubes near a drainage divide and on smooth and shallow slopes. During periods of intense precipitation, overland runoff was observed near some monitoring tubes in gullies and swales, but overland run-off apparently occurs only after the stormflow zone fills to overflowing. The overflow creates source areas and wet weather springs; the resulting runoff and erosion apparently explain the gullies. The recession rates of water levels in the stormflow monitoring tubes and in observation wells can be used to calculate stream flow components after precipitation events. Calculations based on a chemical mass balance for stream flow and on groundwater flow rates show that stormflow constitutes $80-90 \%$ of all subsurface water flow to the streams.

Water storage is intergranular in the stormflow zone, but macropores and mesopores $(>0.2 \mathrm{~mm}$ diam) formed by root channels, worm tubes, and other processes are the dominant openings for lateral flows and drainage. Lateral flow paths for water generally follow the slope of land surface in this zone, and the average hydraulic gradient in the WOC basin is about 0.075 (Moore 1989). In WAG 2 , which has many flatter areas, the average cross-valley hydraulic gradient is 0.016 , and the average down-valley hydraulic gradient is about 0.007 . The hydraulic conductivity of the stormflow zone in areas near WAG 2 has been measured by infiltration tests under saturated conditions. Virtually all of the precipitation is absorbed by vegetated soils, and overland run-off occurs mainly on saturated soils. 
Water in the stormflow zone is a slightly acidic, calcium bicarbonate type and has smaller concentrations of magnesium, sodium, and (probably) sulfate. Data for about 200 water samples show that the concentrations of the chemical constituents are lognormally distributed. All water samples from the stormflow monitoring tubes were cloudy to muddy, and nearly all of the suspended sediment was colloidal in size. The discharge of colloidal material from the stormflow zone may explain turbid stream flows after small precipitation events, and some pollutants could be sorbed by these colloids in contaminated areas and thereby transported to the streams.

In WAG 2, the vadose zone is $0-2 \mathrm{~m}$ thick and consists of fractured clayey regolith and weathered bedrock. The vadose zone is unsaturated except in the capillary fringe and except within wetting fronts during periods of vertical percolation from the stormflow zone to the water table. The groundwater zone consists of relatively permeable fracture intervals in a relatively impermeable matrix. The average thickness (vertical dimension) of the permeable intervals is about $60 \mathrm{~cm}$ and that the range is about $30-150 \mathrm{~cm}$. The vertical spacing between permeable intervals increases from about $7 \mathrm{~m}$ near the water table to $>35 \mathrm{~m}$ below a depth of $60 \mathrm{~m}$. The average effective porosity of the groundwater zone, as determined from tracer tests and pumping tests, is about 0.001 (Moore 1989), and storativity is about $5 \times 10^{-4}$. The average hydraulic gradient in the WOC basin is about 0.050 (Moore 1989); in WAG 2, the average hydraulic gradient in the groundwater zone is the same as in the stormflow zone.

Flow paths in the groundwater zone are determined by fracture orientations. Bedding planes constitute one set of fractures; the other two common fracture sets in Melton Valley (Dreier, Solomon, and Beaudoin 1987) are steeply dipping and trend approximately parallel to geologic strike (along-valley parallel) and parallel to dip (cross-valley parallel). Hydrogeologic studies in the WOC basin, as summarized by Webster (1976), agree that fracture permeability is larger in the along-valley direction than in the cross-valley direction and that, if other factors are equal, more groundwater is discharged to cross-cutting, tributary streams than to a stream along the valley axis (Webster and Bradley 1987). A conceptual model (Fig. 7.7) shows that if the orientations of permeable intervals are mainly controlled by bedding planes, along-valley flows of groundwater occur within permeable intervals, whereas cross-valley flows move through both permeable and matrix intervals. This model is hypothetical but explains the observed anisotropy in the groundwater zone. In WAG 2, the main channel of WOC through Haw Ridge and the tributary streams in Melton Valley would thus be expected to have larger inflows of groundwater per unit channel length than would Melton Branch and the channel of WOC below its junction with Melton Branch.

Progressively less groundwater follows deeper flow paths because of longer path lengths and because more matrix intervals occur along the flow paths. The base of active groundwater circulation is irregular to gradational and is not determined by stratigraphy. However, several other criteria can be used for an estimate of this depth. First, shallow groundwater is a slightly alkaline, calcium bicarbonate water type. However, wells deeper than $30-40 \mathrm{~m}$ commonly produce a sodium bicarbonate water with a $\mathrm{pH}$ in the range of 8.3-11.5, and wells deeper than about $150 \mathrm{~m}$ have a slightly acidic, sodium chloride water type with a dissolved solids content as large as $300,000 \mathrm{mg} / \mathrm{L}$. Secondly, the transmissivities of permeable fracture intervals generally decrease with depth. The geometric mean of transmissivity for wells deeper than $30 \mathrm{~m}$ is only 0.1 times as large as for shallower wells. The occurrence of cavities in limestone units of the Conasauga Group also decreases with depth; only $16 \%$ of the solution cavities are deeper than $16 \mathrm{~m}$, and only one cavity is as deep as $71 \mathrm{~m}$. Finally, only one of eight wells, which are 60-90 m deep, has tritium in the water, and this well is atop Haw Ridge. 
NW

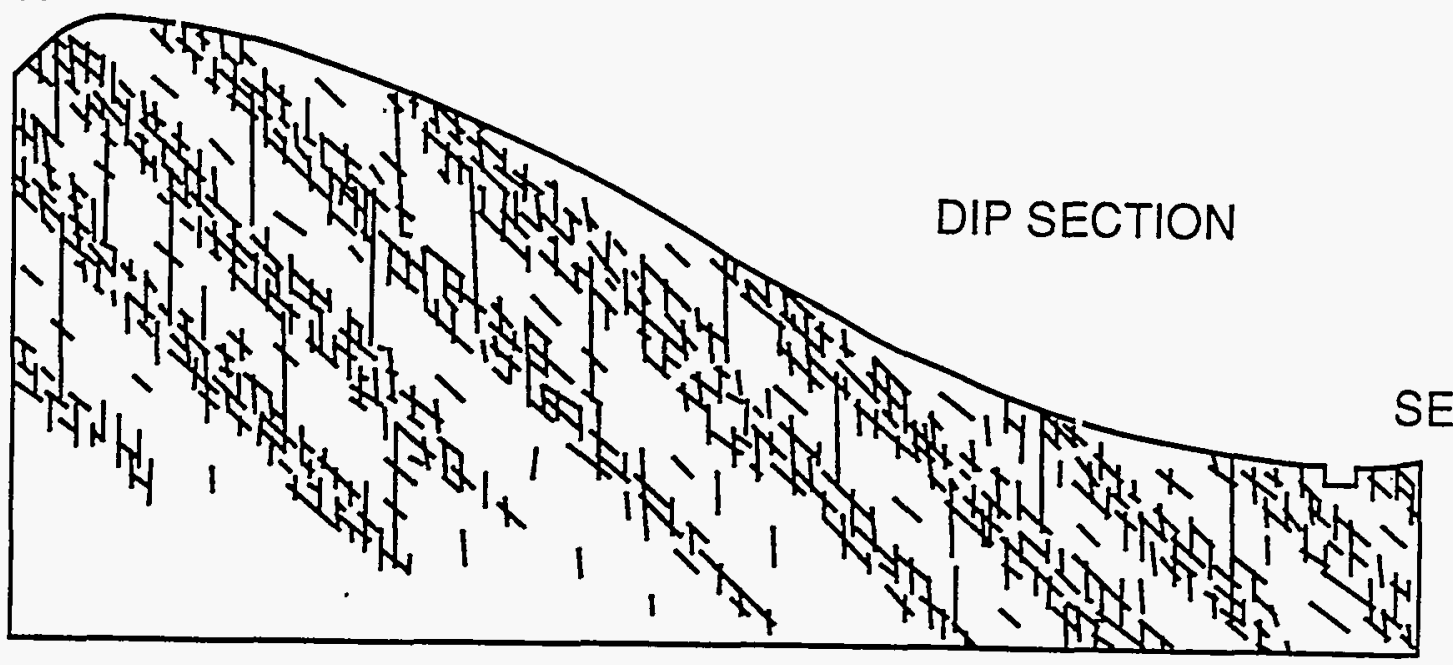

SW

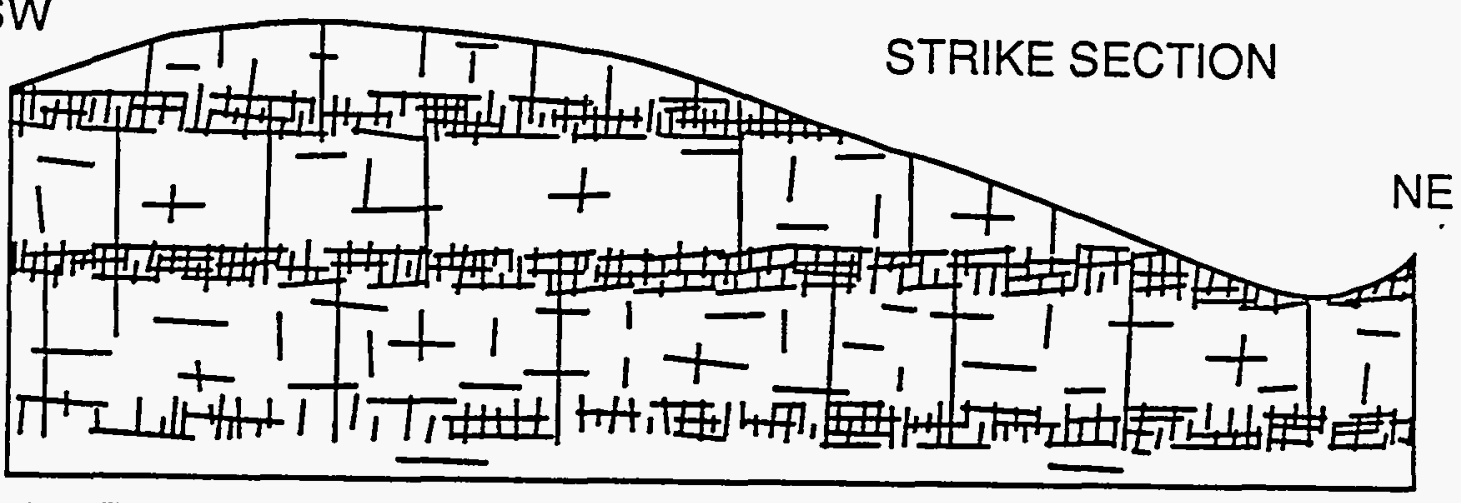

NOT TO SCALE

Fig. 7.7. A conceptual model showing differences in the trends and densities of open fractures to explain anisotrophy in the groundwater zone of Melton Valley. A third fracture in each section is represented by the plane of this paper. Source: Energy Systems 1990a

The composition of groundwater is determined by the chemical content of recharge water; the availability of soluble minerals along fracture flow paths; matrix diffusion, sorption, and ion exchange along flow paths; and mixings with water from other flow paths. These factors result in nearly unique chemical characteristics at each location and depth in the groundwater zone, and there commonly are large differences in the concentration of dissolved constituents in nearby wells.

\subsubsection{Ecology}

Sect. 5.2.7 of this document provides an overview of the flora and fauna commonly found on the ORR, which are believed to be representative of those found within WAG 2. 


\subsection{RELEASES AND SITE CONCEPTUAL MODEL}

\subsubsection{Contaminant Releases to the WOC System}

With the possible exception of WOCE below WOD, contamination in the WOC/WOL system is a result of releases from active and inactive sites in 11 WAGs located within the WOC watershed: WAGs 1, 3 through 10,13 and 17. The level of information available on known releases from each WAG to WOC/WOL is highly variable from WAG to WAG, but in no case are there sufficient data to fully characterize either the historical or continuing releases. Although available information does not support full characterization of releases from each WAG, the waste inventory and known release data can be used to identify key radioisotopes and (to a lesser extent) elements that may potentially be released from a WAG (Table 7.1). Data on organic contamination is limited to a very few sites. A review of existing information on contaminants in the WOC system and their sources can be found in the WAG 2 remedial investigation (RI) plan (Energy Systems 1990a).

Table 7.1. Contaminants known or suspected to have been released from each WAG

\begin{tabular}{ll}
\hline WAG & \multicolumn{1}{c}{ Contaminants } \\
\hline 1 & ${ }^{60} \mathrm{Co},{ }^{90} \mathrm{Sr},{ }^{137} \mathrm{Cs},{ }^{15 x} \mathrm{Eu},{ }^{232} \mathrm{Th},{ }^{23 \times} \mathrm{U},{ }^{23 \times} \mathrm{Pu},{ }^{241} \mathrm{Am},{ }^{244} \mathrm{Cm}$, other radionuclides, $\mathrm{Cd}, \mathrm{Cr}, \mathrm{Cu}, \mathrm{Hg}$, \\
3 & $\mathrm{Mo}, \mathrm{Ni}, \mathrm{Pb}, \mathrm{Zn}, \mathrm{TRE}, \mathrm{PCBs}$, chlordane \\
4 & ${ }^{3} \mathrm{H},{ }^{90} \mathrm{Sr},{ }^{137} \mathrm{Cs}, \mathrm{TRE}$ \\
5 & ${ }^{3} \mathrm{H},{ }^{60} \mathrm{Co},{ }^{90} \mathrm{Sr},{ }^{106} \mathrm{Ru},{ }^{137} \mathrm{Cs},{ }^{23 \times} \mathrm{Pu}$, other radionuclides, TRE \\
6 & ${ }^{3} \mathrm{H},{ }^{60} \mathrm{Co},{ }^{90} \mathrm{Sr},{ }^{137} \mathrm{Cs},{ }^{233} \mathrm{U},{ }^{23 \times} \mathrm{Pu},{ }^{241} \mathrm{Am},{ }^{244} \mathrm{Cm}$, other radionuclides, $\mathrm{Cr}, \mathrm{Hg}, \mathrm{Ni}, \mathrm{Pb}, \mathrm{Zn}, \mathrm{PCBs}$ \\
7 & ${ }^{3} \mathrm{H},{ }^{14} \mathrm{C},{ }^{60} \mathrm{Co},{ }^{90} \mathrm{Sr},{ }^{137} \mathrm{Cs},{ }^{15 x} \mathrm{Eu},{ }^{23 \mathrm{x}} \mathrm{U}, \mathrm{Cr}, \mathrm{Cu}, \mathrm{Hg}, \mathrm{Mo}, \mathrm{Ni}, \mathrm{Pb}, \mathrm{Zn}, \mathrm{VOCs}$, nitrates \\
8 & ${ }^{3} \mathrm{H},{ }^{60} \mathrm{Co},{ }^{90} \mathrm{Sr},{ }^{99} \mathrm{Tc},{ }^{106} \mathrm{Ru},{ }^{137} \mathrm{Cs},{ }^{233} \mathrm{U}, \mathrm{Cr}, \mathrm{Ni}, \mathrm{Zn}$, nitrates \\
9 & ${ }^{60} \mathrm{Co},{ }^{90} \mathrm{Sr},{ }^{137} \mathrm{Cs}, \mathrm{Cr}, \mathrm{Cu}, \mathrm{Zn}$ \\
10 & ${ }^{60} \mathrm{Co},{ }^{90} \mathrm{Sr},{ }^{137} \mathrm{Cs}, \mathrm{Cr}, \mathrm{Zn}$ \\
13 & ${ }^{90} \mathrm{Sr},{ }^{137} \mathrm{Cs},{ }^{244} \mathrm{Cm}$, transuranic isotopes \\
17 & ${ }^{137} \mathrm{Cs}, \mathrm{Cd}, \mathrm{Cr}, \mathrm{Cu}, \mathrm{Zn}$, fuel-derived hydrocarbons and solvents \\
\hline
\end{tabular}

'total rare earths

2polychlorinated biphenyls

Source: Energy Systems 1990a

${ }^{3}$ volatile organic compounds

\subsubsection{Contaminant Releases from the WOC System}

The potential pathways for off-site release of contaminants from WAG 2 include surface water leaving WOCE, groundwater, and pathways associated with plant and animal life. Information on the release of contaminants in surface water is readily available for recent years. The available information for known releases in groundwater or by plant and animal life is limited, although recent investigations have provided an improved understanding of the extent of contamination in these systems. The remainder of this section deals exclusively with existing information on releases through surface water discharged from the WOD. 


\subsubsection{Direct measurements of releases}

The specific contaminants and water quality parameters included in the routine surface water monitoring program at WOD are described in the WAG 2 RI plan (Energy Systems 1990a).

The 1989 summary data for this station (NPDES station X15) are listed in Table 7.2. The 1989 maximum concentrations for arsenic exceeded the Tennessee draft water quality criterion for protection of domestic water supply, and occasionally the biochemical oxygen demand exceeded the Tennessee draft criterion for protection of fish and aquatic life. Because WOC flow is diluted approximately $\mathbf{3 0 0}$ times upon entering Clinch River, the potential for water quality impairment is considered negligible (Energy Systems 1990b). The 1988 summary data for this station are given in Energy Systems 1990b. Similar data from prior years are published annually in the series Oak Ridge Reservation Environmental Report.

Table 7.2. 1989 ORNL NPDES Permit TN 0002941 (discharge point X15-White Oak Dam)

\begin{tabular}{|c|c|c|c|c|c|}
\hline \multirow[b]{2}{*}{ Parameter } & \multirow{2}{*}{$\begin{array}{c}\text { Number of } \\
\text { samples }\end{array}$} & \multicolumn{3}{|c|}{ Concentration (mg/L) } & \multirow{2}{*}{$\begin{array}{c}\text { Standard } \\
\text { error }\end{array}$} \\
\hline & & Maximum & Minimum & Average & \\
\hline Aluminum (total) & 12 & 2.8 & $<0.050$ & $<0.86$ & 0.22 \\
\hline Ammonia (as N) & 12 & 0.16 & 0.011 & 0.046 & 0.012 \\
\hline Arsenic (total) & 12 & 0.090 & $<0.050$ & $<0.055$ & 0.0034 \\
\hline Biochemical oxygen demand & 12 & $>34$ & $<5.0$ & $<7.4$ & 2.4 \\
\hline Cadmium (total) & 12 & $<0.0020$ & $<0.0020$ & $<0.0020$ & 0 \\
\hline Chlorine (total) residual & 52 & $<0.010$ & $<0.010$ & $<0.010$ & 0 \\
\hline Chloroform & 11 & $<0.025$ & $0.0010^{\mathrm{a}}$ & $0.0041^{\mathrm{z}}$ & 0.0021 \\
\hline Chromium (total) & 12 & 0.028 & $<0.0030$ & $<0.016$ & 0.0025 \\
\hline Conductivity (mS/cm) & 12 & 1.7 & 0.23 & 0.87 & 0.14 \\
\hline Copper (total) & 12 & 0.13 & 0.0050 & 0.0019 & 0.010 \\
\hline Dissolved solids (total) & 12 & 240 & 140 & 200 & 9.4 \\
\hline Flow (Mgd) & 249 & 150 & 4.2 & 14 & 1.0 \\
\hline Fluoride (total) & 12 & 1.0 & $<1.0$ & $<1.0$ & 0 \\
\hline Iron (total) & 12 & 2.3 & 0.20 & 0.67 & 0.16 \\
\hline Lead (total) & 12 & 0.0040 & $<0.0040$ & $<0.0040$ & 0 \\
\hline Manganese (total) & 12 & 0.10 & $<0.0020$ & $<0.060$ & 0.0081 \\
\hline Mercury (total) & 12 & 0.00011 & $<0.000050$ & $<0.000063$ & \\
\hline Nickel (total) & 12 & $<0.020$ & $<0.0050$ & $<0.010$ & 0.0017 \\
\hline Nitrate & 12 & $<5.0$ & $<5.0$ & $<5.0$ & 0 \\
\hline Oil and grease & 52 & $>200$ & $<2.0$ & $<10$ & 4.3 \\
\hline Organic carbon (total) & 12 & 6.4 & 1.7 & 2.9 & 0.37 \\
\hline Oxygen (dissolved) & 52 & 14 & 4.0 & 8.5 & 0.29 \\
\hline PCBs (total) & 11 & $<0.00050$ & $<0.00050$ & $<0.00050$ & 0 \\
\hline pH (standard units) & 12 & 8.9 & 6.7 & $b$ & $b$ \\
\hline
\end{tabular}


Table 7.2 cont.

\begin{tabular}{|c|c|c|c|c|c|}
\hline \multirow[b]{2}{*}{ Parameter } & \multirow[b]{2}{*}{$\begin{array}{c}\text { Number of } \\
\text { samples }\end{array}$} & \multicolumn{3}{|c|}{ Concentration (mg/L) } & \multirow[b]{2}{*}{$\begin{array}{c}\text { Standard } \\
\text { error }\end{array}$} \\
\hline & & Maximum & Minimum & Average & \\
\hline Phosphorus (total) & 12 & 0.50 & 0.10 & 0.23 & 0.031 \\
\hline Silver (total) & 12 & $<0.0050$ & $<0.0050$ & $<0.0050$ & 0 \\
\hline Sulfate (as $\mathrm{SO}_{4}$ ) & 12 & 48 & 12 & 34 & 2.9 \\
\hline Total suspended solids & 12 & 37 & $<5.0$ & $<13$ & 3.2 \\
\hline Temperature $\left({ }^{\circ} \mathrm{C}\right)$ & 64 & 28 & 3.9 & 17 & 0.80 \\
\hline Trichloroethene & 11 & $<0.025$ & $0.00070^{\mathrm{a}}$ & $0.0064^{\mathrm{a}}$ & 0.0019 \\
\hline Turbidity (NTU') & 12 & 240 & 10 & 74 & 23 \\
\hline \multirow[t]{2}{*}{ Zinc (total) } & 12 & 0.040 & $<0.0080$ & $<0.024$ & 0.00036 \\
\hline & \multicolumn{5}{|c|}{ Concentration $(\mathrm{pCi} / \mathrm{L})$} \\
\hline${ }^{241} \mathrm{Am}$ & 18 & 1.6 & -0.23 & 0.40 & 0.097 \\
\hline${ }^{244} \mathrm{Cm}$ & 10 & 1.7 & -1.6 & 0.48 & 0.27 \\
\hline${ }^{60} \mathrm{Co}$ & 52 & 27 & -14 & 8.3 & 0.87 \\
\hline${ }^{137} \mathrm{Cs}$ & 52 & 320 & -11 & 69 & 9.3 \\
\hline Gross alpha & 30 & 33 & -38 & 9.5 & 2.3 \\
\hline Gross beta & 40 & 930 & 210 & 450 & 23 \\
\hline${ }^{238} \mathrm{Pu}$ & 18 & 0.51 & -0.068 & 0.077 & 0.029 \\
\hline${ }^{239} \mathrm{Pu}$ & 18 & 0.76 & -0.30 & 0.11 & 0.058 \\
\hline Total Sr & 26 & 380 & 100 & 180 & 18 \\
\hline Tritium & 26 & 430.000 & 76.000 & 260.000 & 22.000 \\
\hline
\end{tabular}

Below detection limit but estimated

Not applicable

Source: Energy Systems 1990a

nephelometric turbidity unit

A summary of annual discharge of radionuclides from WOD to Clinch River between 1944 and 1984 is given in the WAG 2 RI plan (Energy Systems 1990a). These data indicate that, in general, the release of radioactive contamination from WAG 2 by surface water has decreased dramatically from the peak levels in the mid-1960s.

\subsubsection{Indirect evidence of releases}

In addition to the direct measurements of releases from the monitoring station at WOD, indirect evidence of contaminant releases is available from surface water quality and biological monitoring in Clinch River. Observed changes in water quality or biological indicators in Clinch River upstream and downstream of the WOCE, along with historic records of waste disposal at ORNL, can be used to infer a historic contaminant release from WOC that was not measured directly. Studies that have used this approach include Loar et al. 1987; Loar 1988, 1989, and 1990; Sherwood and Loar 1987; Energy Systems 1990c). Ongoing and additional investigations will improve the ability to infer contaminant releases from off-site environmental monitoring and information on contaminants released to the WOC system. 


\subsubsection{Contaminant transport from WOC}

Based on the existing information for contaminant releases from WOC, a tentative description can be established for the transport mechanisms involved.

In general, WOC acts as a conduit for certain contaminants transported by stream flow from discharge points within the WOL watershed into Clinch River in a relatively short period of time. Other contaminants are deposited in WOC or WOL and may reside in the watershed for extended periods of time. Measurements of sediment and water discharge at WOD have indicated that the concentration of suspended sediment in the water leaving WOD can increase sharply during rainfall runoff events. Many of the contaminants in WOC are sorbed in sediments and the increase in suspended sediment discharge from WOL during floods is a major pathway for contaminants leaving the system. The available information on sediment dynamics in WOC is limited, however. An accurate prediction of the amount of contaminant transport associated with a given flood event is not possible with the existing data base.

\subsubsection{Conceptual Model}

Essentially all components (biotic and abiotic) of the WOC system have been exposed to heavy metals, hazardous organic chemicals, radionuclides, or some combination of these. The WOC system is unlike the prototypic SWMU; therefore, RI tasks (characterizing the nature and extent of contamination and the potential human health and environmental risks and identifying and evaluating potential corrective measures and/or needs or interim corrective actions) are complicated. The contaminants that have accumulated in the WOC system have resulted from releases from other areas and redistribution within the WAG 2 area. Continued input of contaminants from unregulated sources further complicates evaluation. Fate and transport of contaminants in the WOC system are influenced by the physical, chemical, and biological processes that interact in natural systems. The WOC system has been a significant source of contaminants to off-site areas. However, whether the WOC system acts as a source, a sink, or simply a conduit for contaminants depends on the contaminant in question and the temporal scale of interest. Both biotic and abiotic media in WAG 2 have been contaminated. Soils and sediments have clearly accumulated contaminants and act as a temporary sink for the bulk of the contaminants in the system. Particle-reactive contaminants (e.g., PCBs, ${ }^{137} \mathrm{Cs}$, ${ }^{60} \mathrm{Co}$, lead, and chromium) that have accumulated in soils and in sediment depositional areas can be resuspended and transported downstream (off-site) during high-discharge events or as a result of changes in hydrology due to construction activities. For less particle-reactive contaminants (e.g., ${ }^{90} \mathrm{Sr},{ }^{3} \mathrm{H}$, and VOCs) the WOC system may serve largely as a conduit, with biota and physical characteristics influencing transport time (Energy Systems 1990a).

The conceptual model for WAG 2 (Fig. 7.8a) is a flow chart of the potential contaminant sources, transport and exposure pathways, and potential human and environmental receptors for contaminants. More detailed versions of the conceptual model (Figs. $7.8 \mathrm{~b}$ and $7.8 \mathrm{c}$ ) include hydrological phenomena, such as floodplain erosion, sediment scouring and transport, and subsurface flow and groundwater discharge, plus biological and chemical phenomena, such as sorption-desorption, biotic uptake, particle ingestion, direct exposure, and inhalation. The conceptual models are important because they identify or acknowledge the pools and pathways of contaminant movement for site characterization and risk analysis; that is, they summarize our current knowledge of contaminant dynamics (sources, pathways, pools, and receptors) (Energy Systems 1990a). 


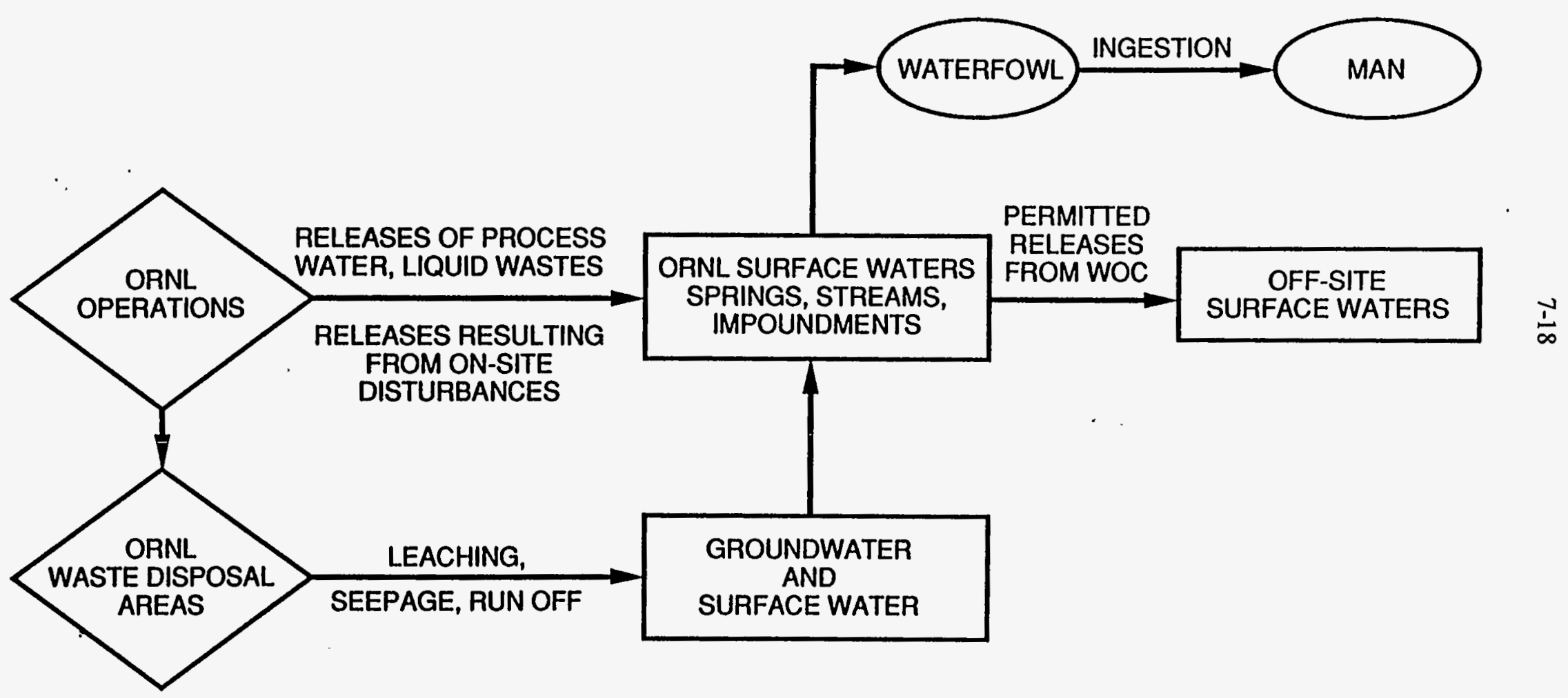

Fig. 7.8a. WAG 2 site conceptual model. This flowchart represents the contaminant sources, potential transport and exposure pathways, and potential human and nonhuman receptors for contaminants released from ORNL WAGs. Source: Energy Systems 1990a 


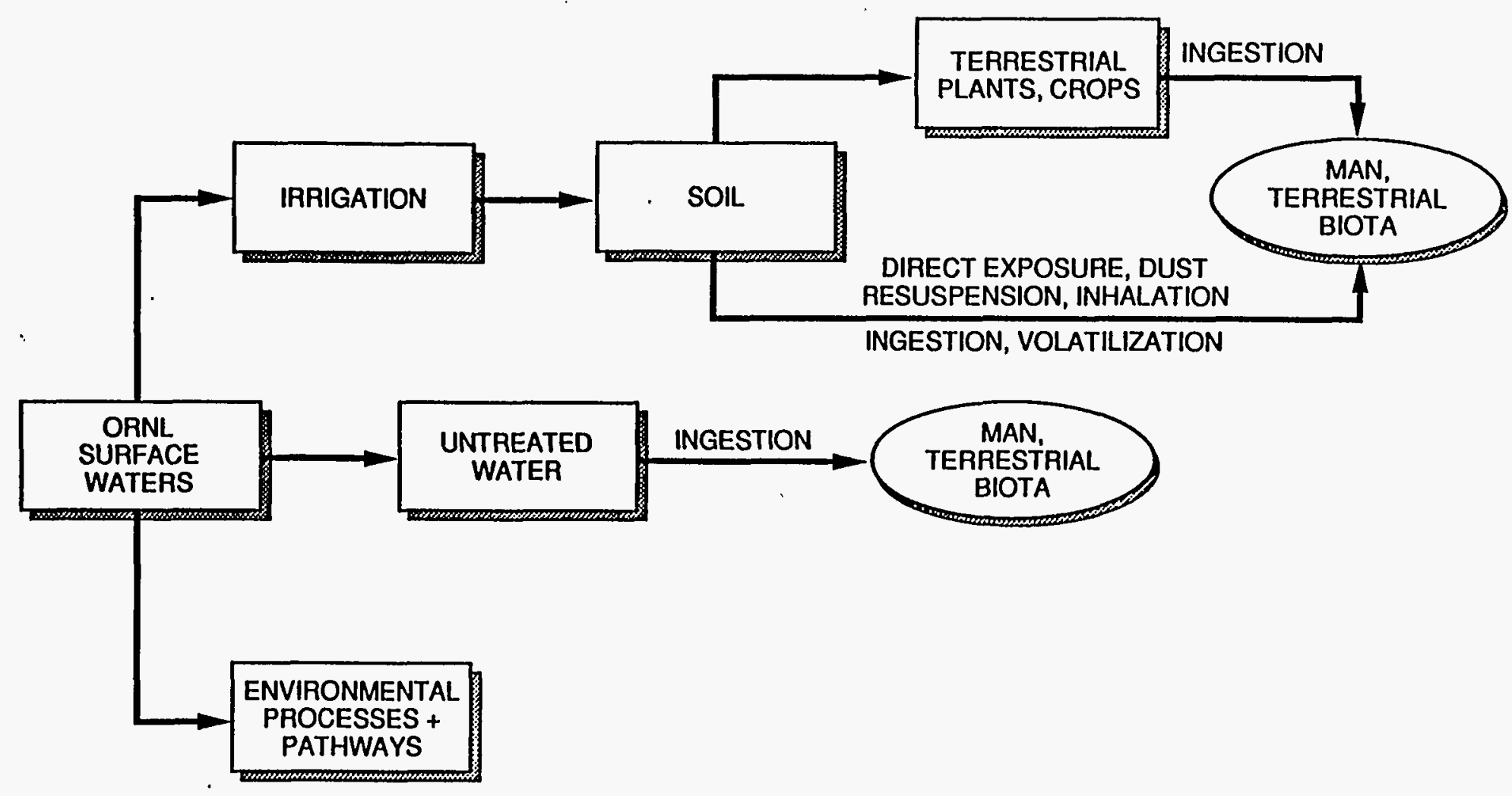

Fig. 7.8b. WAG 2 site conceptual model continued. Source: Energy Systems 1990a 


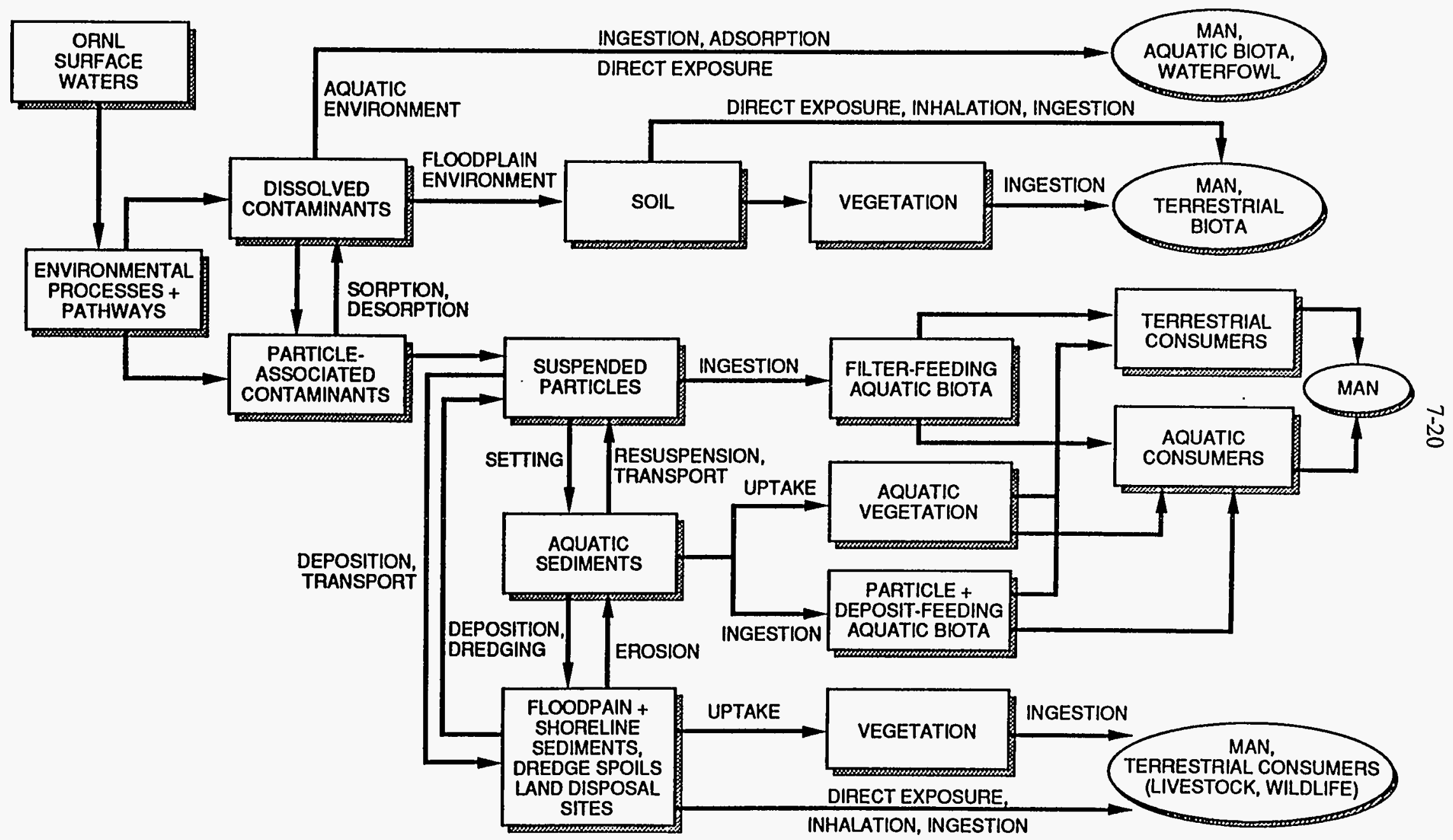

Fig. 7.8c. WAG 2 site conceptual model continued. Source: Energy Systems 1990a 


\subsection{ACTIVE PROJECTS: REMEDIAL INVESTIGATION}

\section{Instructions to User}

Remediation is an ongoing process, and the status of active projects can change quickly. For the most up-to-date information about the WAG 2 RI, check the Annual Environmental Restoration Monitoring and Assessment Report and the Federal Facility Agreement Quarterly Report.

\subsubsection{Strategy and Approach of the WAG 2 RI Project}

Because the WAG 2 system serves as a conduit for surface drainage of contaminants from the upstream WAGs and because it is known to contain contaminants that represented potential near-term hazards to human health and the environment, initiation of an RI was given a high priority for action. The WAG 2 RI was initiated at ORNL by the Environmental Restoration Program (ER) in 1990. Because the Federal Facility Agreement (FFA) had not been signed, the WAG 2 RI was initiated in compliance with Section 3004(u) of the Hazardous and Solid Waste Amendments of RCRA (Boston 1995).

Because WAG 2 was not a prototypic WAG, the RI strategy differed from that of other WAGs. As specified in the Remedial Investigation Plan for Waste Area Grouping 2 (Energy Systems 1990a) the RI was to consist of short-term and long-term components. Initial efforts were preliminary surveys to determine "hot spots" that may need interim corrective actions, identify areas where additional characterization data were needed, and identify data gaps for risk assessment. Long-term efforts were to consist of implementation of a multimedia environmental monitoring and characterization program to (1) define and monitor the input of contaminants from adjacent WAGs; (2) characterize the hydrology of the WOC system and support a mass-balance approach to determining sources, sinks, and transport of contaminants in WAG 2; and (3) establish the basis for determining long-term trends in contaminant levels.

The two-phased RI approach was modified in the Field Sampling and Analysis Plan for the Remedial Investigation of Waste Area Grouping 2 (Energy Systems 1992) to a three-phased approach to interface more effectively with the long-term ER strategy. The three phases are: (1) an initial scoping survey to determine the need for interim corrective measures, (2) multimedia monitoring during completion of remediation of upstream WAGs, and (3) formal completion of the RI following remediation of upstream WAGs.

The RI plan provided guidance for quality assurance, health and safety, and waste management activities. To comply with DOE and ER programmatic requirements that followed preparation of the initial plan and to reflect changes in the RI project structure and methods of accomplishing the project goals, additional support documents were prepared between FY 1992 and FY 1994. These included:

- Quality Assurance Plan for the Remedial Investigation of Waste Area Grouping 2 at Oak Ridge National Laboratory, Oak Ridge, Tennessee, ORNL/ER-134, (ORNL 1992a);

- Health and Safety Plan for the Remedial Investigation and Site Investigation of Waste Area Grouping 2 at Oak Ridge National Laboratory, Oak Ridge, Tennessee, ORNL/ER-169, (ORNL 1993a); and 
- Waste Management Plan for the Remedial Investigation of Waste Area Grouping 2 at Oak Ridge National Laboratory, Oak Ridge, Tennessee, ORNL/ER-235, ORNL 1994a.

\subsubsection{Consolidation of the WAG 2 RI with the Site Investigations Program}

In early FY 1992 ER directed the consolidation of the WAG 2 RI with the ORNL Site Investigations Program (SIP). SIP consisted of a series of ORNL site-wide directed investigations, and included (1) watershed hydrology; (2) groundwater contaminants, pathways, and fluxes; (3) shallow subsurface contaminant pathways and secondary source characterization; and (4) biological population contaminant accumulation and effects. The purpose of the consolidation was to bring the two activities under a common managerial structure to more effectively achieve their complementary objectives. The resultant organization was termed the WAG 2 \& SIP.

\subsubsection{Initial Studies Conducted by the WAG 2 RI}

In preparation for WAG 2 RI field activities, historical data were used to conduct a screening level risk analysis (Screening of Contaminants in Waste Area Grouping 2, ORNL/ER-62/R1, ORNL 1992b). This analysis used both conservative and nonconservative assumptions to identify the following contaminants as high priority for remedial action: ${ }^{137} \mathrm{Cs}$ and ${ }^{90} \mathrm{Sr}$, due to external exposure risk in at one or more reaches of WOC; PCBs, due to the fish ingestion pathway; and arsenic, due to the water ingestion pathway. Ecotoxicological risk screening by several methodologies did not give conclusive results.

Initial Phase I studies conducted under the WAG 2 RI were summarized in the Phase I Remedial Investigation Report of Waste Area Grouping 2 (Miller 1995). This report summarized initial field activities completed between March 1992 and October 1992, including soil and surface water characterization data, biota contaminant accumulation data, and results of a gamma walkover survey of WAG 2. Data identified seeps contributing the highest proportion of risk at WOD and identified the Intermediate Holding Pond area of WOC as the highest gamma-emitting site within WAG 2.

Additional Phase I activities-including seeps and tributary monitoring during both base flow and storms, measurement of contaminant movement of suspended sediment during storms, and floodplain sediment sampling-were conducted from November 1992 through the present.

\subsubsection{WAG 2 Phase I Data Quality Objectives Workshop}

The project Data Quality Objective (DQO) Workshop was held in Oak Ridge on June 20-21, 1994, to review project objectives with DOE and the regulators and to determine the best strategy and approach for completing the WAG 2 RI. The key issue addressed in Phase I was to evaluate the need for early corrective actions in WAG 2. DOE and the regulators concluded at that meeting that the primary decisions to be determined from Phase I of the WAG 2 RI are the following:

- Will a 100-year flood cause human health risk at Clinch River to exceed $1 \times 10^{-4}$ ?

- At what point in time will sediment deposition in WOL increase to such a degree that human health risks downstream at Clinch River exceed $1 \times 10^{-6}$ due to dissolved and sediment-bound contaminants?

- Are aquatic communities in WOC sufficiently impacted by contaminants so that the need for immediate action should be evaluated? 
- Does contaminant accumulation by aquatic biota in WOC result in sufficient ecological risk to terrestrial biota so that the need for immediate action should be evaluated?

- Does contaminant accumulation by terrestrial biota in the WOC floodplain result in sufficient ecological risk so that the need for immediate action should be evaluated?

- Is immediate action warranted if ecological risk is high but the particular species do not widely roam and remain on the reservation?

These decision statements and information needed to address the decision statements were transmitted to the U.S. Environmental Protection Agency and the Tennessee Department of Environment and Conservation in a letter from W. N. Lingle (1994). Tasks developed to provide the data required to answer these questions were detailed in the FY 1995 Remedial Investigation Work Plan for Waste Area Grouping 2 (Watkins and Herbes 1994) and implemented with the start of FY 1995.

Based on additional guidance received from the regulators at the subsequent FFA project managers' meeting in August 1994, a letter was transmitted to DOE dated October 28, 1994, requesting concurrence with three changes. One change proposed was to "discontinue the WAG 2 $\mathrm{RI}$ at the end of FY 1995, issue an RI report, and initiate a surface water monitoring program." Important elements from the Phase II RI previously identified in the July 13, 1994, Lingle letter that do need to be implemented and continued would be incorporated as individual tasks in the surface water monitoring program. This action is consistent with the strategy that the RI is to be resumed as necessary following remediation of upgradient WAGs in the WOC watershed. Present plans, as reflected in the WAG 2 baseline, define a final Phase I RI report to be submitted to the regulators (D1 deliverable date: September 30, 1996).

\subsubsection{Initiation of the ORNL Surface Water Program}

In June 1994, as a result of direction from the regulators at the WAG 2 DQO meeting that the scope of the WAG 2 RI be limited to exclude consideration of transient waterborne contaminants, ER initiated the formation of a new organization named the ORNL Surface Water Program (SWP). The reason for this action was to allow RI work to be completed and reported as quickly and efficiently as possible yet allow continuation of important activities to provide ER with information needed to make informed decisions regarding work priorities and effective allocation of resources. The SWP is intended to be a management tool to ensure well-based decisions, accelerate cleanup actions, and enable efficient ER operation. The SWP was identified separately from the WAG 2 RI in the FY 1995 Fiscal Year Work Agreement in July 1994.

A baseline change proposal (94-3302-001-103) that formalized the SWP as a separate task within ADS 3302, parallel to the WAG 2 RI, was approved in September 1994. As defined in the baseline change proposal, the SWP will: (1) quantify contaminant releases across the ORNL site, (2) help develop priorities for RIs and remedial actions, (3) identify likely mechanisms for contaminant releases from sources, and (4) assess the performance of remedial actions. The SWP includes hydrologic and contaminant flux assessment activities conducted at the ORNL site-wide scale, as well as contaminant flux monitoring activities that are specific to source-scale corrective actions (e.g., WAG 5 Seeps C and D interception projects). The SWP includes assessment and technical tasks, consisting of field and laboratory activities, as well as the health and safety, quality assurance, records, and data management support required for the effective conduct of SWP operations. 
Implementation of the SWP is proceeding in three steps: (1) initiation in October 1994, under command documents and procedures produced previously through the WAG 2 \& SIP, of tasks essential to the maintenance of ER activities; (2) initiation of assessment of ER needs and requirements, resulting in development of an SWP plan (ORNL 1995); (3) implementation in October 1995 of those rescoped SWP tasks identified in the SWP plan as necessary to carry out the ER mission. To ensure that SWP tasks will be scoped appropriately to address specific ER needs, the SWP plan will be based on completion of an internal SWP-level DQO process.

\subsubsection{Annual Environmental Restoration Monitoring and Assessment Report}

The annual Environmental Restoration Monitoring and Assessment (ERMA) report was first generated in FY 1992 as an activity with the SI component of the WAG 2 \& SI project. Generation of the ERMA report as an annual FFA deliverable, due at the end of each fiscal year, has been continued through the SWP. The goals of the document are to: (1) provide a summary assessment of environmental data collected in support of ER activities by the WAG 2 RI, the SWP, other ER projects, the ORNL Office of Environmental Compliance and Documentation, and other ORNL site organizations; (2) assess the associated risk to human health and to the environment to assist the establishing of priorities within ER; and (3) inform the public, regulators, and DOE managers about current environmental conditions and associated risks.

Three ERMA volumes have been issued to date. The first ERMA (Annual Report of the Environmental Restoration Monitoring and Assessment Program at the Oak Ridge National Laboratory for FY 1992, ORNL/ER-124, ORNL 1992c) listed the mean concentrations and contaminant fluxes at WOD and various key monitoring stations upstream. These data are used to estimate risk levels and upstream contributors to risk. This information and the subsequent annual updates are widely used in the environmental restoration community. Groundwater maps showing radiological, toxic metals, and organic contaminants provided a watershed-wide perspective on groundwater contamination. This spatial information was updated and displayed in terms of health risk in the third ERMA (Third Annual Environmental Restoration Monitoring and Assessment Report for FY 1994 of the Oak Ridge National Laboratory, DOE/OR/01-1290\&Dl, ORNL 1994b). The second ERMA (Second Annual Report of the Environmental Restoration Monitoring and Assessment Program at the Oak Ridge National Laboratory, ORNL/ER-130, ORNL 1993b) contained maps of contaminant concentrations and estimates contaminant fluxes based on intensive seep and spring sampling. The high spatial resolution of this information was used to guide corrective remedial measures at Seeps C and D draining to Melton Branch and to the tributary below WAG 4. The ERMA reports also contain summaries of soils, sediments, and biota. These reports serve to document environmental conditions on a site-wide scale and to provide an introduction to conditions at ORNL for staff, regulators, and the public.

\subsubsection{RI Summary}

The WAG 2 RI project has undergone considerable change in goals, scope, and method of accomplishment since its inception. As presently planned, the RI will be suspended following submittal of the final Phase I RI report in FY 1996; completion of the CERCLA process for WAG 2 will be deferred until completion of remedial activities of all upgradient WAGs. The SWP will continue to function, independent of the WAG $2 \mathrm{RI}$, as the surface water assessment management tool for ER. 


\subsection{WAG 2 SUMMARY}

WAG 2 consists of the WOC drainage downstream of ORNL discharge points and includes the associated floodplain and subsurface environment. The WOC system, consisting of WOC, its tributaries, WOL, and the WOCE on Clinch River, is the primary surface drainage for ORNL. The drainage system has been exposed to a diversity of contaminants as a result of operations and waste disposal activities at ORNL from the mid-1940s to the present time. Water, sediment, soil, and biota in WAG 2 are contaminated and continue to receive contaminants from upgradient WAGs.

There are two SWMUs located within WAG 2: (1) WOL, the WOCE of Clinch River, and the associated floodplains and subsurface environment and (2) WOC and its tributaries downstream of the ORNL main plant area/Melton Branch. Currently, the only active project in the WAG is the RI.

WAG 2 is located on the ORR in Roane County, Tennessee, approximately 5 miles southwest of the city of Oak Ridge central business district and immediately south of the ORNL main plant area. WAG 2 is located in Melton Valley, which is bounded to the north and south by Haw Ridge and Copper Ridge, respectively. Above the WOC-Melton Branch confluence and for a short section below the West Seep Tributary outfall to WOC, WAG 2 is mapped as gravelly, fine, sandy, Pope loam. The lower part of WAG 2, including the areas now covered by WOL and lake sediments, is mapped as fine, sandy, Pope loam.

WOC, its tributaries, and WOL represent the major drainage system for ORNL and the surrounding facilities. The stream network on the WOC watershed consists of small, perennial, and intermittent first- to third-order streams. Typically, these streams are less than $1 \mathrm{~m}$ in depth and consist of alternating series of riffles and pools. Springs that occur along the base of Chestnut Ridge and in its valleys are the chief sources of base flow of upper WOC. Numerous seeps have been identified in the WOC watershed. The permanent water table occurs near the regolith and bedrock contact at a depth of $<3 \mathrm{~m}$ in most of the WAG 2 area. Recharge to the water table occurs at the higher elevations in WAG 2 by slow downward seepage of water after precipitation events.

With the possible exception of WOCE below WOD, contamination in the WOC/WOL system is a result of releases from active and inactive sites in 11 WAGs located within the WOC watershed: WAGs 1, 3 through 10,13, and 17. The level of information available on known releases from each WAG to WOC/WOL is highly variable from WAG to WAG, but in no case are there sufficient data to fully characterize either the historical or continuing releases.

The potential pathways for off-site release of contaminants from WAG 2 include surface water leaving WOCE, groundwater, and pathways associated with plant and animal life. A summary of annual discharge of radionuclides from WOD to Clinch River between 1944 and 1984 indicate that, in general, the release of radioactive contamination from WAG 2 by surface water has decreased dramatically from the peak levels in the mid-1960s.

Essentially all components.(biotic and abiotic) of the WOC system have been exposed to heavy metals, hazardous organic chemicals, radionuclides, or some combination of these. The WOC system has been a significant source of contaminants to off-site areas. Soils and sediments have clearly accumulated contaminants and act as a temporary sink for the bulk of the contaminants in the system. Particle-reactive contaminants (e.g., $\mathrm{PCBs},{ }^{137} \mathrm{Cs},{ }^{60} \mathrm{Co}$, lead, and chromium) that have accumulated in soils and in sediment depositional areas can be resuspended and transported downstream (off-site) during high-discharge events or as a result of changes in hydrology due to construction activities. For less particle-reactive contaminants (e.g., ${ }^{90} \mathrm{Sr},{ }^{3} \mathrm{H}$, and VOCs) the WOC system may serve largely as a conduit, with biota and physical characteristics influencing transport time. 


\subsection{REFERENCES}

Boston, H. L. 1995. Historical Summary of the Waste Area Grouping 2 Remedial Investigation Project, memorandum to J. T. Sweeney, DOE, March 29.

Cox, D. K., et al. 1991. The New Definitive Map of White Oak Lake, ORNL/TM-11204, Oak Ridge Natl. Lab.

Dreier, R. B., D. K. Solomon, and C. M. Beaudoin 1987. "Fracture Characterization in the Unsaturated Zone of a Shallow Land Burial Facility," in Flow and Transport Through Fractured Rock, American Geophysical Union Monograph 42, 51-59.

Ebasco 1992. Baseline Report for Waste Area Grouping 2 at Oak Ridge National Laboratory, Oak Ridge, Tennessee, ORNL/ER-95/V1, Oak Ridge Natl. Lab.

Energy Systems (Martin Marietta Energy Systems, Inc.) 1985. Environmental Monitoring Report, United States Department of Energy Oak Ridge Facilities, Calendar Year 1984, ORNL-6209, Martin Marietta Energy Systems Environment, Safety, and Health, Oak Ridge, Tenn.

Energy Systems 1990a. Remedial Investigation Plan for Waste Area Grouping 2 at Oak Ridge National Laboratory, Oak Ridge, Tennessee, ES/ER-14\&D1, Martin Marietta Energy Systems, Inc., Oak Ridge, Tenn.

Energy Systems 1990b. Oak Ridge Reservation Environmental Report for 1989, ES/ESH-12/V1, Martin Marietta Energy Systems, Inc., Oak Ridge, Tenn.

Energy Systems 1990c. Clinch River RCRA Facility Investigation Plan, ES/ER-1\&D1, Martin Marietta Energy Systems, Inc., Oak Ridge, Tenn.

Energy Systems 1992. Field Sampling and Analysis Plan for the Remedial Investigation of Waste Area Grouping 2 at Oak Ridge National Laboratory, Oak Ridge, Tennessee, DOE/OR-1070\&D2, Oak Ridge Natl. Lab.

Lee, R. R., and R. H. Ketelle 1987. Stratigraphic Influence on Deep Groundwater Flow in the Knox Group Copper Ridge Dolomite on the West Chestnut Ridge Site, ORNL/TM-10479, Oak Ridge Natl. Lab.

Lietzke, D. A., S. Y. Lee, and R. E. Lambert 1988. Soils, Surfical Geology, and Geomorphology of the Bear Creek Valley Low-Level Waste Disposal Development and Demonstration Program Site, ORNL/TM-10573, Oak Ridge Natl. Lab.

Lingle, W.N. 1994. ORNL Waste Area Grouping 2 Remedial Investigation-Data Quality Objectives Scoping Meeting Summary-June 20-21, 1994, letter to V. Weeks (U.S. Environmental Protection Agency, Region IV) and D. McCoy (Tennessee Department of Environment and Conservation), July $13,1994$.

Loar, J. M., ed. 1981. Ecological Studies of the Biotic Communities in the Vicinity of the Oak Ridge Gaseous Diffusion Plant, ORNL/TM-6714, Oak Ridge Natl. Lab.

Loar, J. M. 1988. Second Annual Report on the ORNL Biological Monitoring and Abatement Program, ORNL/TM-10814, Oak Ridge Natl. Lab. 
Loar, J. M. 1989. Third Annual Report on the ORNL Biological Monitoring and Abatement Program, ORNL/TM-003736, Oak Ridge Natl. Lab.

Loar, J. M. 1990. Fourth Annual Report on the ORNL Biological Monitoring and Abatement Program, ORNL/TM-7698, Oak Ridge Natl. Lab.

Loar, J. M., J. A. Solomon, and G. F. Cada 1981. Technical Background Information for the ORNL Environmental and Safety Report, Vol. 2, A Description of the Aquatic Ecology of White Oak Creek Watershed and the Clinch River Below Melton Hill Dam, ORNL/TM-7509/V2, Oak Ridge Natl. Lab.

Loar, J. M., et al. 1987. First Annual Report on the ORNL Biological Monitoring and Abatement Program, ORNL/TM-10399, Oak Ridge Natl. Lab.

Miller, D. E., ed. 1995. Phase I Remedial Investigation Report of Waste Area Grouping 2 at Oak Ridge National Laboratory, Oak Ridge, Tennessee, DOE/OR/01-1179\&D2, Oak Ridge Natl. Lab.

Moore, G. K. 1988. Concepts of Groundwater Occurrence and Flow Near Oak Ridge National Laboratory, Tennessee, ORNL/TM-10969, Oak Ridge Natl. Lab.

Moore, G. K. 1989. Groundwater Parameters and Flow Systems Near Oak Ridge National Laboratory, Tennessee, ORNL/TM-11368, Oak Ridge Natl. Lab.

Oakes, T. W., et al. 1982. Technical Background Information for the ORNL Environmental and Safety Report, Vol 4: White Oak Lake and Dam, ORNL-5681, Oak Ridge Natl. Lab.

ORNL (Oak Ridge Natl. Lab.) 1987. RCRA Facilities Assessment (RFA)—Oak Ridge National Laboratory, ORNL/RAP-12/V1, Oak Ridge Natl. Lab.

ORNL 1992a. Quality Assurance Plan for the Remedial Investigation of Waste Area Grouping 2 at Oak Ridge National Laboratory, Oak Ridge, Tennessee, ORNL/ER-134, Oak Ridge Natl. Lab.

ORNL 1992b. Screening of Contaminants in Waste Area Grouping 2, ORNL/ER-62/R1, Oak Ridge Natl. Lab.

ORNL 1992c. Annual Report of the Environmental Restoration Monitoring and Assessment Program at the Oak Ridge National Laboratory for FY 1992, ORNL/ER-124, Oak Ridge Natl. Lab.

ORNL 1993a. Health and Safety Plan for the Remedial Investigation and Site Investigation of Waste Area Grouping 2 at Oak Ridge National Laboratory, Oak Ridge, Tennessee, ORNL/ER-169, Oak Ridge Natl. Lab.

ORNL 1993b. Second Annual Report of the Environmental Restoration Monitoring and Assessment Program at the Oak Ridge National Laboratory, ORNL/ER-130, Oak Ridge Natl. Lab.

ORNL 1994a. Waste Management Plan for the Remedial Investigation of Waste Area Grouping 2 at Oak Ridge National Laboratory, Oak Ridge, Tennessee, ORNL/ER-235, Oak Ridge Natl. Lab. 
ORNL 1994b. Third Annual Environmental Restoration Monitoring and Assessment Report for FY 1994 of the Oak Ridge National Laboratory, DOE/OR/01-1290\&D2, Oak Ridge Natl. Lab.

ORNL 1995. Draft Surface Water Monitoring Plan for the Environmental Restoration Program, FY 1996, ORNL/ER-323, Oak Ridge Natl. Lab.

Site and Facilities Planning Department June 1994. Oak Ridge Reservation Technical Site Information, ES/EN/SFP-23, Martin Marietta Energy Systems, Inc., Oak Ridge, Tenn.

Sherwood, C. B., and J. M. Loar 1987. Environmental Data for the White Oak Creek/White Oak Lake Watershed, ORNL/TM-10062, Oak Ridge Natl. Lab.

Swann, M. E. et al. 1942. Soil Survey, Roane County, Tennessee, U.S. Department of Agriculture, Bureau of Industry in cooperation with the Tennessee Agricultural Experiment Station and the Tennessee Valley Authority, Washington, D.C.

Tschantz, B. A. 1987. White Oak Creek Hydrologic and Spillway Adequacy Analysis, ORNL/SUB/87-32-CT213V-1, Civil Engineering Department, University of Tennessee, Knoxville, Tenn.

Tschantz, B. A., and W. A. Rghebi 1989. Hydrologic and Hydraulic Sensitivity Analysis for Supporting White Oak Dam Emergency Plan, Civil Engineering Department, University of Tennessee, Knoxville, Tenn.

Watkins, D. R., and S. E. Herbes 1994. FY 1995 Remedial Investigation Work Plan for Waste Area Grouping 2 at Oak Ridge National Laboratory, Oak Ridge, Tennessee, DOE/OR/01-1292\&D2, Oak Ridge Natl. Lab.

Webster, D. A. 1976. A Review of Hydrologic and Geologic Conditions Related to Radioactive SolidWaste Burial Grounds at Oak Ridge National Laboratory, Tennessee, U.S. Geological Survey Open-File Report 76-727, Nashville, Tenn.

Webster, D. A., and M. W. Bradley 1987. Hydrology of the Melton Valley Radioactive Waste Burial Grounds at Oak Ridge National Laboratory, Tennessee, U.S. Geological Survey Open File Report 87-686, Nashville, Tenn.

\subsection{BIBLIOGRAPHY}

Clapp, R. B., and J. A. Watts, eds. 1995. Fourth Annual Environmental Restoration Monitoring and Assessment Report (FY 1995), Oak Ridge National Laboratory, Oak Ridge, Tennessee, DOE/OR/01-1413\&D1, Oak Ridge Natl. Lab.

Coobs, J. H., and J. R. Gissel 1986. History of Disposal of Radioactive Wastes into the Ground at Oak Ridge National Laboratory, ORNL/TM-10269, Oak Ridge Natl. Lab.

Morrison, S. J. and T. E. Cerling 1987. Survey of Metal, Radionuclide and Organic Contamination at 20 Waste Area Groups (WAGs), ORNL Facilities, Oak Ridge, Tennessee, ORNL/RAP/Sub-87/27463/1, Oak Ridge Natl. Lab. 
Oak Ridge Natl. Lab. 1990. ORNL Contaminated Site Summary Sheets, ORNL/M-2413, Oak Ridge Natl. Lab.

SAIC (Science Applications International Corp.) 1994. Remedial Investigation Work Plan for the Groundwater Operable Unit at Oak Ridge National Laboratory, Oak Ridge, Tennessee, DOE/OR/01-1252\&D1 (ORNL/ER-221\&D1), Martin Marietta Energy Systems, Inc., Oak Ridge Natl. Lab. 


\section{$+$}




\section{DESCRIPTION OF WAG 3}

Instructions to user
At this time there are no active projects at WAG 3. Full characterization of this WAG
is therefore unwarranted, and a description of it [derived from the Resource
Conservation and Recovery Act facilities assessment (ORNL 1987)] has been included
in this document for general information purposes only.

\subsection{SITE DESCRIPTION}

WAG 3 is located in Bethel Valley about 0.6 mile $(1 \mathrm{~km})$ west of the west entrance of the main plant area (Fig. 8.1). WAG 3 (Solid Waste Disposal Area 3) is composed of three individual Solid Waste Management Units (SWMUs): 3.1 Solid Waste Storage Area (SWSA) 3, 3.2 [Closed Scrap Metal Area (1562)], and 3.3, [the currently operating Contractors' Landfill (1554)]. See Fig. 8.2.

SWSA 3 and the Closed Scrap Metal Area are inactive landfills known to contain radioactive solid wastes and surplus materials generated at ORNL from 1946 to 1979. Although burial of solid waste ceased at this site in 1951, use of the area as an aboveground scrap metal storage area continued until 1979. Sometime during the period 1946 to 1949, radioactive solid wastes removed from SWSA 2 were buried in this site. In 1979, most of the scrap metal stored aboveground at SWSA 3 was either transferred to other storage areas, buried in SWSA 6, or buried on-site in a triangular-shaped disposal area approximately 0.4 acres $(0.17 \mathrm{ha})$ immediately south of SWSA 3 .

The Contractors' Landfill was opened in 1975 and is used to dispose of various uncontaminated construction materials and fly ash from the ORNL steam plant. No contaminated waste or asbestos is to be buried at the site. The maximum fill depth is reported to be $20 \mathrm{ft}(6 \mathrm{~m})$, and the area of the landfill is about 6 acres (2.4 ha).

\subsection{KNOWN RELEASES}

Records of the composition of radioactive solid waste buried in SWSA 3 are nonexistent; records for SWSAs 3, 4, and part of 5 burials were destroyed in a fire in 1961. Sketches and drawings of the site indicate that alpha and beta-gamma wastes were segregated and buried in separate areas or trenches. Some of the alpha wastes may have been contained in drums placed in concrete-lined trenches; however, later in the operation, alpha-containing waste drums may have been placed in unlined trenches. Hazardous chemical wastes were probably also buried in SWSA 3 because there are no records of disposal elsewhere. Although the information is sketchy, the larger scrap metal equipment (tanks, drums, etc.) stored on the surface at this site was also probably contaminated. Because only a portion of this material is now buried in the Closed Scrap Metal Area (SWMU 3.2), it is not possible to estimate the amount of contamination that exists in this SWMU.

Because ORNL disposal procedures require that only non-RCRA, nonradioactive solid wastes are to be buried in the Contractors' Landfill, this SWMU should not represent a source of radioactivity release; however, some hazardous chemicals may have inadvertently been buried at this site prior to enactment of the Resource Conservation and Recovery Act. 


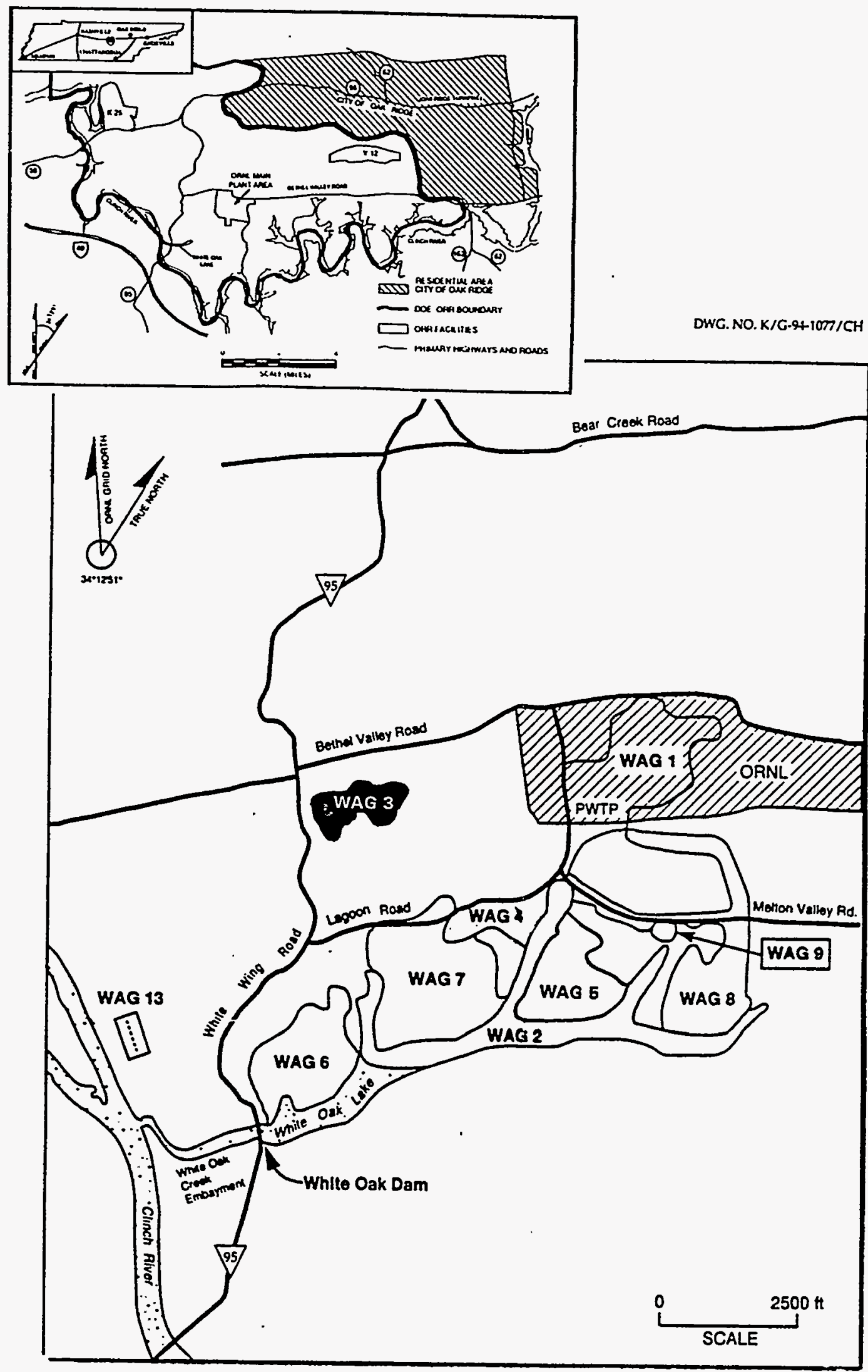

Fig. 8.1. Location of WAG 3. 
8-3

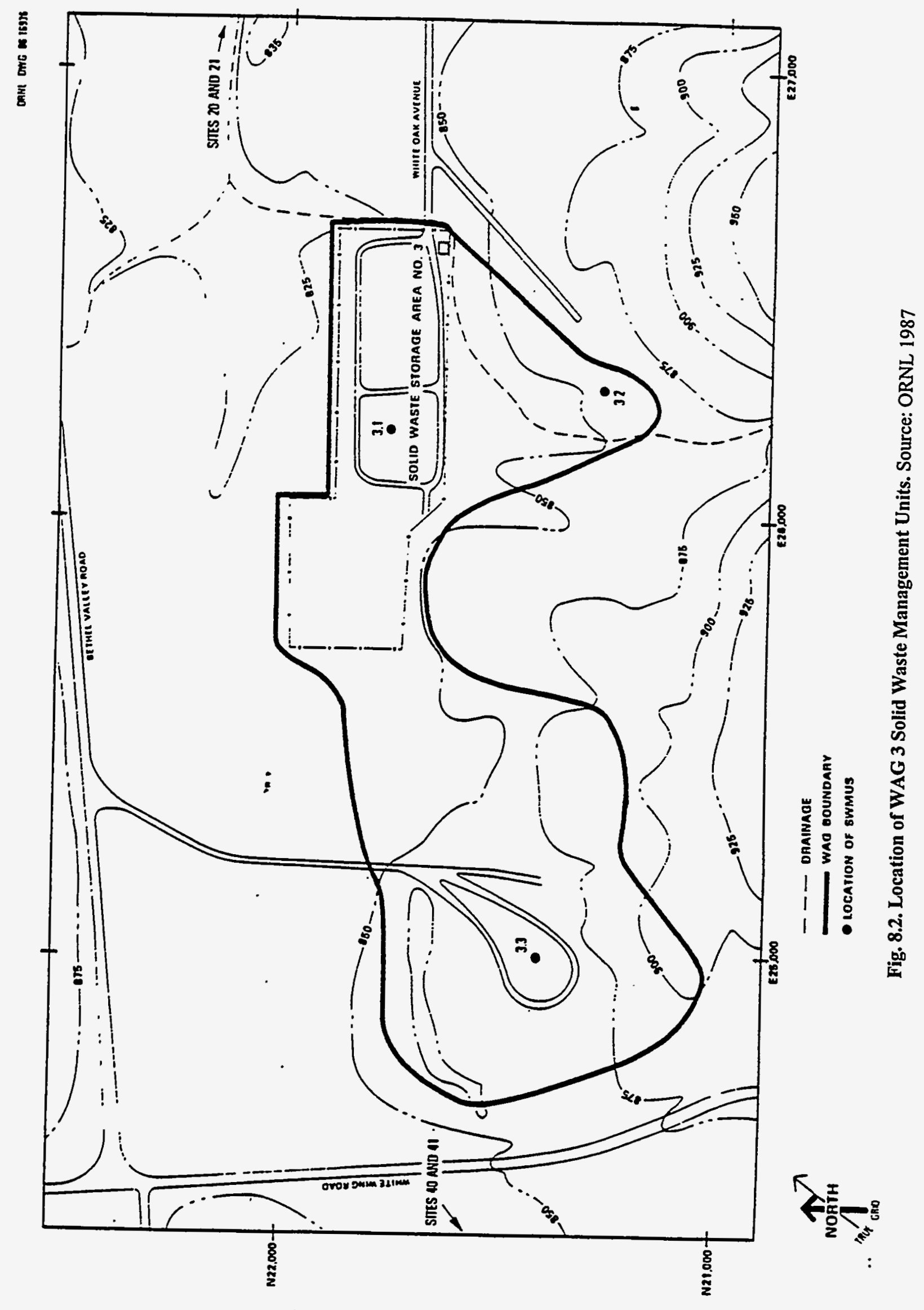


Health Physics surveys of the area indicate that a radioactive tank is buried near the SWSA 3 boundary. One area showed gross radioactivity or ${ }^{137} \mathrm{Cs}$ levels significantly above background. It is suspected that this contamination came from runoff from SWSA 3. Surveys indicate that contamination of the scrap metal is very low, if present at all (ORNL 1990).

\subsection{REGULATORY STATUS}

Based on available information, a remedial investigation plan will be required for WAG 3. Based on a description of the materials buried and the administrative controls exercised, SWMU 3.3 may have a negligible role in causing the releases observed from WAG 3; survey data did not identify releases from the Contractors' Landfill.

\subsection{REFERENCES}

ORNL (Oak Ridge Natl. Lab.) 1987. RCRA Facilities Assessment (RFA)_Oak Ridge National Laboratory, ORNL/RAP-12/N1, Oak Ridge Natl. Lab.

ORNL 1990. ORNL Contaminated Site Summary Sheets, ORNL/M-2413, Oak Ridge Natl. Lab.

\subsection{BIBLIOGRAPHY}

Coobs, J. H., and J. R. Gissel 1986. History of Disposal of Radioactive Wastes into the Ground at Oak Ridge National Laboratory, ORNL/TM-10269, Oak Ridge Natl. Lab.

Morrison, S. J. and T. E. Cerling 1987. Survey of Metal, Radionuclide and Organic Contamination at 20 Waste Area Groups (WAGs), ORNL Facilities, Oak Ridge, Tennessee, ORNL/RAP/Sub-87/27463/1, Oak Ridge Natl. Lab.

ORNL 1992. Baseline Report for Waste Area Grouping 3 at Oak Ridge National Laboratory, Oak Ridge, Tennessee, ORNL/ER-96, Oak Ridge Natl. Lab.

SAIC (Science Applications International Corp.) 1994. Remedial Investigation Work Plan for the Groundwater Operable Unit at Oak Ridge National Laboratory, Oak Ridge, Tennessee, DOE/OR/01-1252\&D1 (ORNL/ER-221\&D1), Martin Marietta Energy Systems, Inc., Oak Ridge Natl. Lab.

Shoun, R. R. 1987. Environmental Data Package for ORNL Waste Area Grouping 3 (WAG 3), Solid Waste Storage Area 3 (SWSA 3), ORNL/RAP-21, Oak Ridge Natl. Lab. 


\title{
9. HISTORY AND CHARACTERIZATION OF WAG 4
}

\begin{abstract}
Instructions to User
This chapter provides information about WAG 4 that can be cited in certain CERCLA documents (see Chap. 1 and Table 1 in Instructions to User). For a short description of WAG 4 that can be copied into other types of documents, see the summary at the end of this chapter. To keep this document as short as possible, information about conditions common to all WAGs (e.g., climate and demography) is given in Chap. 5-History and Characterization of the ORNL Site.
\end{abstract}

\subsection{SITE DESCRIPTION AND HISTORY}

WAG 4 (also known as Solid Waste Disposal Area 4) consists of three Solid Waste Management Units (SWMUs):

- SWMU 4.1 - intermediate-level liquid radioactive waste (ILLW) transfer pipelines,

- SWMU 4.2-Pilot Pits 1 and 2, and

- $\quad$ SWMU 4.3-Solid Waste Storage Area (SWSA) 4.

The location of WAG 4 is shown in Fig. 9.1, and the locations of the SWMUs in WAG 4 are shown in Fig. 9.2. Of the three SWMUs, which are described below, SWSA 4 represents the most significant potential for release of radioactive and hazardous contaminants.

\subsubsection{SWMU 4.1-ILLW Pipelines}

The ILLW transfer pipelines were an essential part of the liquid radioactive waste disposal system at ORNL from 1952 to 1975 because they were used to transport ILLW from the waste processing facilities in Bethel Valley to final disposal sites in Melton Valley. (ILLW pipeline refers to the older waste transfer pipelines, which were installed prior to the reclassification of ILLW as low-level radioactive waste; ILLW was defined at ORNL as liquid waste with a specific activity of about $0.3 \mathrm{mCi} / \mathrm{L}$.) Use of the ILLW transfer pipelines was discontinued in 1975 when a new, double-contained line was installed to service the expanded hydrofracture program.

Two ILLW transfer pipelines and one process waste line run along Lagoon Road adjacent to WAG 4 (Fig. 9.3). Both ILLW transfer pipelines are inactive; however, the process waste pipeline is still active. All three pipelines parallel Lagoon Road, leave WAG 4, turn south, and parallel the Chemical Waste Access Road. Although the process waste pipeline is listed as active, waste has never been pumped through it (Bechtel 1988).

The two ILLW transfer pipelines were modified as necessary to transfer wastes from the ORNL main plant area and/or the Transuranium Research Facility to the waste pits and trenches. The transfer pipelines were installed at a minimum depth of $3 \mathrm{ft}$ below the ground surface in weathered Conasauga shale. While the pipelines were in use, approximately $6.1 \times 10^{6} \mathrm{ft}^{3}\left(170,000 \mathrm{~m}^{3}\right)$ of liquid waste containing over $1.5 \mathrm{M} \mathrm{Ci}\left(5.5 \times 10^{16} \mathrm{~Bq}\right)$ of mixed fission products were transferred through the lines (Walls et al. 1983). Wastes handled in the transfer system were routinely generated 


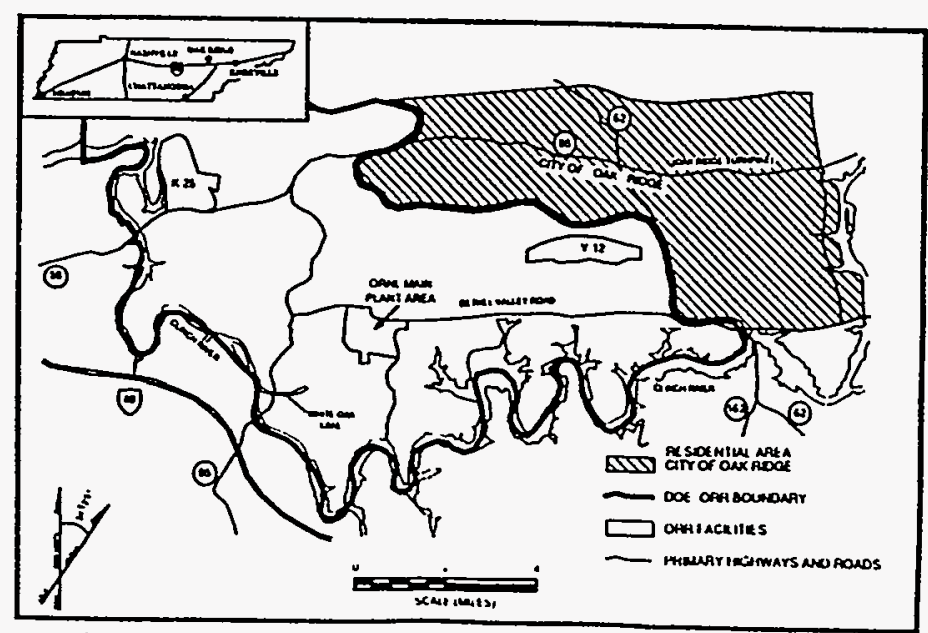

DWG. NO. K/C.9+107/CH

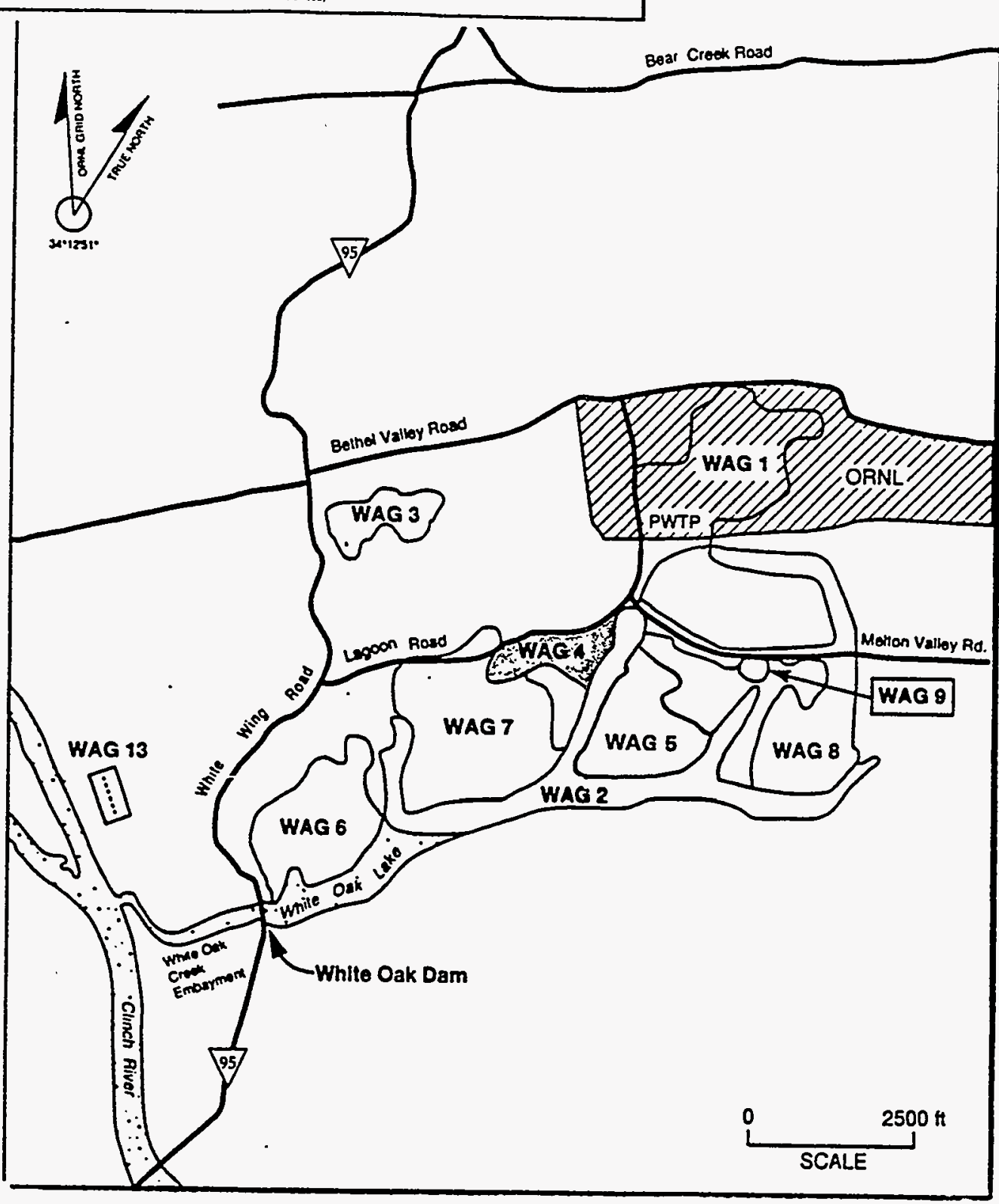

Fig. 9.1. Location of WAG 4. 


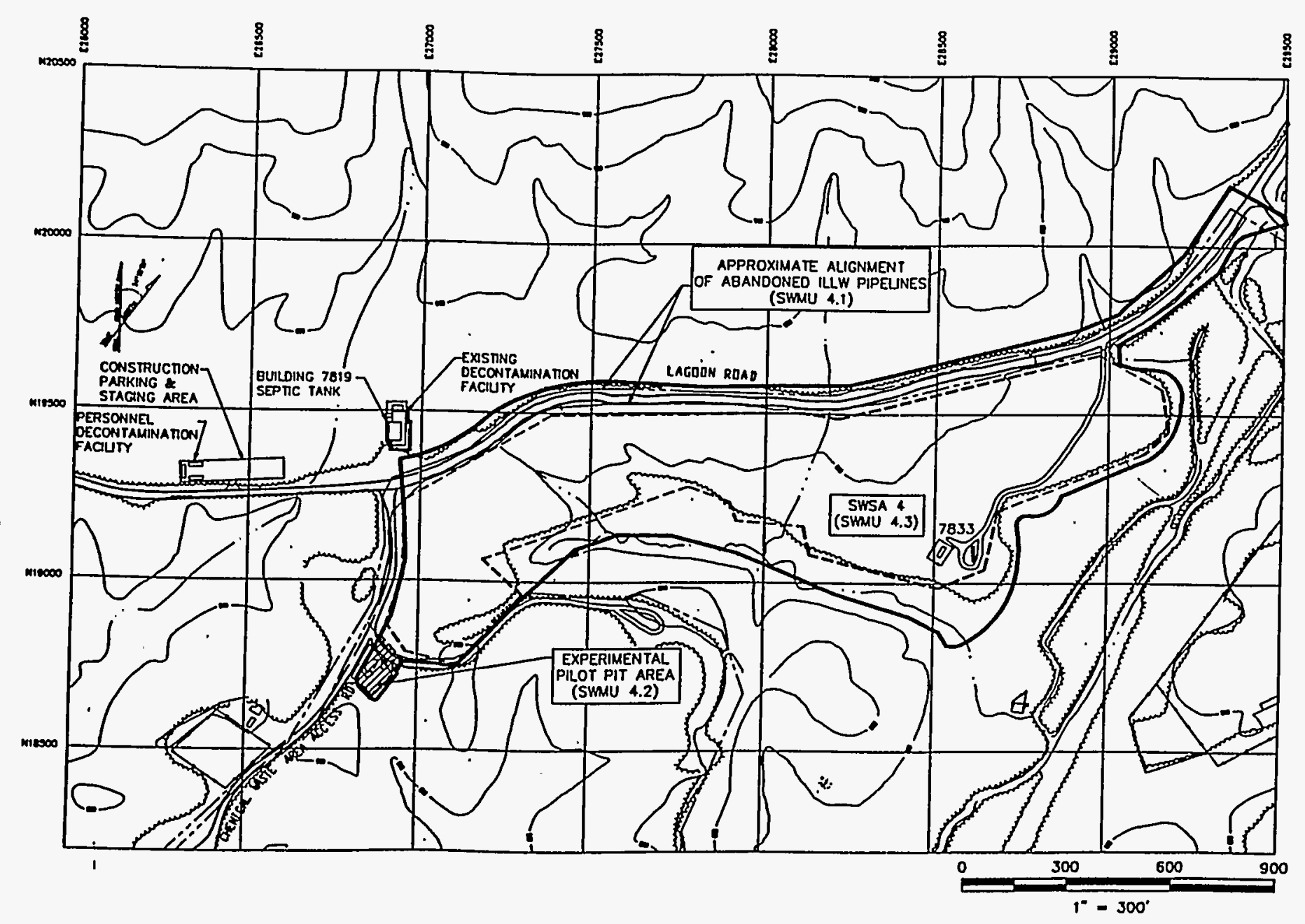

LEGEIND

- WAG 4 BOUNDARY

- FENCE

---- SWSA4

$\stackrel{\varphi}{\omega}$

- - ILW PIPELINE

7819 BUILDING 7819

PAVED ROADS

$=====$ GRAVEL ROADS

-... STREAM

Fig. 9.2. Location of SWMUs within WAG 4. Source: Ebasco 1992 


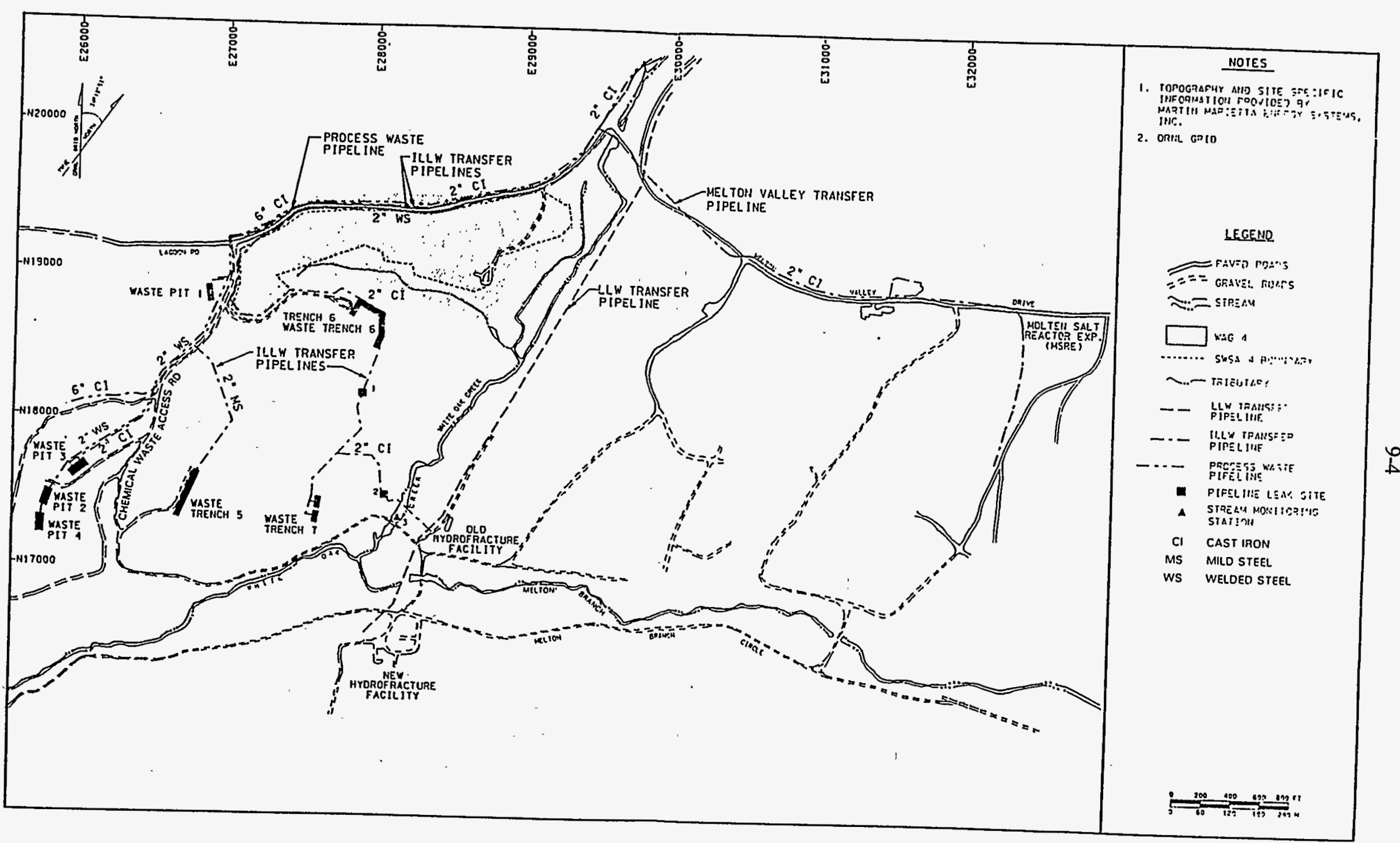

Fig. 9.3. Details of the ILLW transfer pipelines route. Source: Bechtel 1988 
laboratory low-level liquid radioactive waste (LLLW). Major radionuclides were ${ }^{90} \mathrm{Sr},{ }^{137} \mathrm{Cs},{ }^{106} \mathrm{Ru}$, ${ }^{60} \mathrm{Co}$, and various rare earths. Some plutonium, uranium, and transuranic isotopes were also present in the waste streams from certain sources.

The first transfer pipeline, which is located on the south side of Lagoon Road, is a 2-in.-diameter welded steel pipe put into operation in June 1954 to transfer waste from the ORNL main plant area to Waste Pits 2 and 3. By 1960, a 2-in.-diameter mild steel extension had been added to transfer waste to Waste Trench 5 . The welded steel and mild steel pipelines are encased in concrete where they cross under the newer ILLW transfer pipeline. When the second transfer line went into service in 1960, the welded steel line was capped at Waste Pit 2.

In July 1961, the second $\mathbb{L L W}$ transfer pipeline, a 2-in.-diameter cast iron pipe, was installed from the ORNL main plant area to Waste Pit 3 . This cast iron pipeline followed the same path as the welded steel pipeline, except it was installed on the north side of Lagoon Road. By 1963, the cast iron pipeline had been extended from Waste Trench 6 to Waste Trench 7. It serviced the waste pits and trenches until 1966. In 1966, the method of disposal of liquid waste into pits and trenches was discontinued, and a 2-in.-diameter cast iron pipeline was extended to the Old Hydrofracture Facility.

The process waste pipeline located within WAG 4 is a 6-in.-diameter cast iron pipeline. It lies adjacent to the 2 -in.-diameter cast iron ILLW pipeline. This third pipeline was installed in July 1961 at the same time and place as the cast iron pipeline, and it had the capability to transfer liquid process waste from the ORNL main plant area and the 7900 Area to the Emergency Waste Basin located north of SWSA 6.

Under the DOE Surplus Facilities Management Program, the ILLW line was decommissioned over a 2-year period beginning in 1981. Decommissioning consisted of removing short sections of pipe that had the potential to leak into White Oak Creek (WOC), flushing the remaining sections of pipeline with water, purging with air to remove excess water before capping the ends, and constructing an engineered bentonite clay cover and asphalt cap over the two known leak sites south of SWSA 4 (Walls et al. 1983).

Radiation measurements at $3 \mathrm{ft}$ above the ground and at ground surface were systematically made along the entire transfer line with Geiger-Muller counters equipped with beta shields. The measurements were made directly above the pipeline and $5 \mathrm{ft}(1.5 \mathrm{~m})$ to the right and left of the line. More than 700 readings were made beginning at the hydrofracture site; although three definite areas defining leaks were identified, those areas adjacent to SWSA 4 typically yielded activity rates of only about $0.04 \mathrm{mR} / \mathrm{h}$, thus indicating no leaks detectable at ground level (ORNL 1990). The permeable backfill around the pipes, however, could provide a conduit for the transport contaminants from upgradient sources.

\subsubsection{SWMU 4.2-Pilot Pits 1 and 2}

The Pilot Pit Area (BIdg. 7811) is located at the extreme southwest corner of WAG 4. (See Fig. 9.2). It was constructed in late 1955 for use in pilot-scale radioactive waste disposal studies on the sintering (fixation) of high-level fuel reprocessing waste into a stable solid (Morgan et al. 1956a, Morgan et al. 1956b, Boegly 1957). The experimental area consists of an asphalt pad surrounded by a 6-ft (1.8-m) chain link fence adjacent to and south of SWSA 4. Two experiments (Pilot Pit 1 and Pilot Pit 2) were conducted during 1956 and 1957, only one of which involved radioactivity [approximately $100 \mathrm{mCi}\left(3.7 \times 10^{9} \mathrm{~Bq}\right)$ of mixed fission products] (Morgan et al. 1958). The ceramic product produced in Pilot Pit 2 contained the tracer level of radioactivity and was removed from the site following its formation. The equipment from Pilot Pit 2 was removed, and the site was being 
converted for a high-level experiment when the sintering program was terminated by the Atomic Energy Commission (now DOE).

Currently, three large concrete cylinders imbedded vertically in the ground (containing some unused experimental equipment) are all that remains at the site (Boegly and Struxness 1959). The only visible features are a control building now used to store various field and laboratory equipment and four large concrete cylinders that were used in a municipal solid waste leaching experiment. Since the site was constructed, the asphalt pad has been used for temporary storage of drill rigs, drums of coal and coal waste products (gasifier ash), and other large items used in field environmental research.

\subsubsection{SWMU 4.3-SWSA 4}

SWSA 4 (Fig. 9.4) occupies the majority of the WAG 4 surface area [approximately 23 acres (9.3-ha)] and was used for the disposal of various solid radioactively contaminated wastes generated by defense- and research-related activities. SWSA 4 site was opened for routine solid waste burials in February 1951, following closing of SWSA 3. Unlike the three earlier SWSAs, SWSA 4 was located south of ORNL in Melton Valley, with buriais occurring in the Conasauga Shale. The area of this site was approximately twice that of the previous three sites [11 acres (4.6 ha)] in use from 1943 to 1951 (National Research Council 1985).

Wastes were placed in trenches, shallow auger holes ( $15 \mathrm{ft}$ deep), and in piles on the ground surface (to be covered at a later date). About 50 auger holes are located just outside the SWSA 4 fence on the south side of Lagoon Road. In addition, some special high-level waste was buried in individual stainless steel containers. The tops of some of these containers were observed during field reconnaissance by Bechtel National Inc. (1988). They occur in a two-row array embedded in concrete. Elevated levels of radioactivity were detected with field monitoring equipment at the ground surface of these containers.

Trench sizes range from 50 to $400 \mathrm{ft}$ in length, 8 to $30 \mathrm{ft}$ in width, and 8 to $15 \mathrm{ft}$ in depth. The typical method of disposal was to excavate the trench, dump waste into it, and then cover the trench with the excavated soil. For trenches known to contain alpha-contaminated waste, approximately 18 in. of concrete (overiaid by shaley fill soil) was reportedly poured over the filled trench to serve as markers and intruder barriers. The trenches reported to be capped with concrete are located in the southwest and east-southeast sections of SWSA 4 (Fig. 9.4) and comprise approximately one-fourth to one-third of the total disposal site.

Early records of the amount of waste disposed in SWSA 4 were destroyed by a fire; however, the volume of waste buried during 1957 and 1958 was approximately $2.6 \times 10^{5}$ and $3.4 \times 10^{5} \mathrm{ft}^{3}$ $\left(7,219\right.$ and $\left.9,514 \mathrm{~m}^{3}\right)$, respectively. It is estimated by the ORNL Operations Division that the total waste volume emplaced in SWSA 4 was approximately $2.0 \times 10^{6} \mathrm{ft}^{3}\left(5.7 \times 104 \mathrm{~m}^{3}\right)$, containing about $1.1 \times 10^{5} \mathrm{Ci}\left(4.1 \times 10^{15} \mathrm{~Bq}\right)$ of radioactivity (ORNL 1987). The site was closed to routine burial operations in July 1959 (Lomenick and Cowser 1961); however, it remained open as a disposal area for uncontaminated fill until July 1973.

During the period 1955 to 1963, Oak Ridge was designated by the Atomic Energy Commission as the Southern Regional Burial Ground; as such, Oak Ridge received a wide variety of poorly characterized wastes from approximately 50 different sources. These solid wastes consisted of paper, clothing, equipment, filters, animal carcaisses, and related laboratory wastes, but exact proportions of each are unknown because records of this nature were not kept. The waste from outside sources accounted for approximately $50 \%$ of the total volume buried in SWSA 4 (ORNL 1987). 


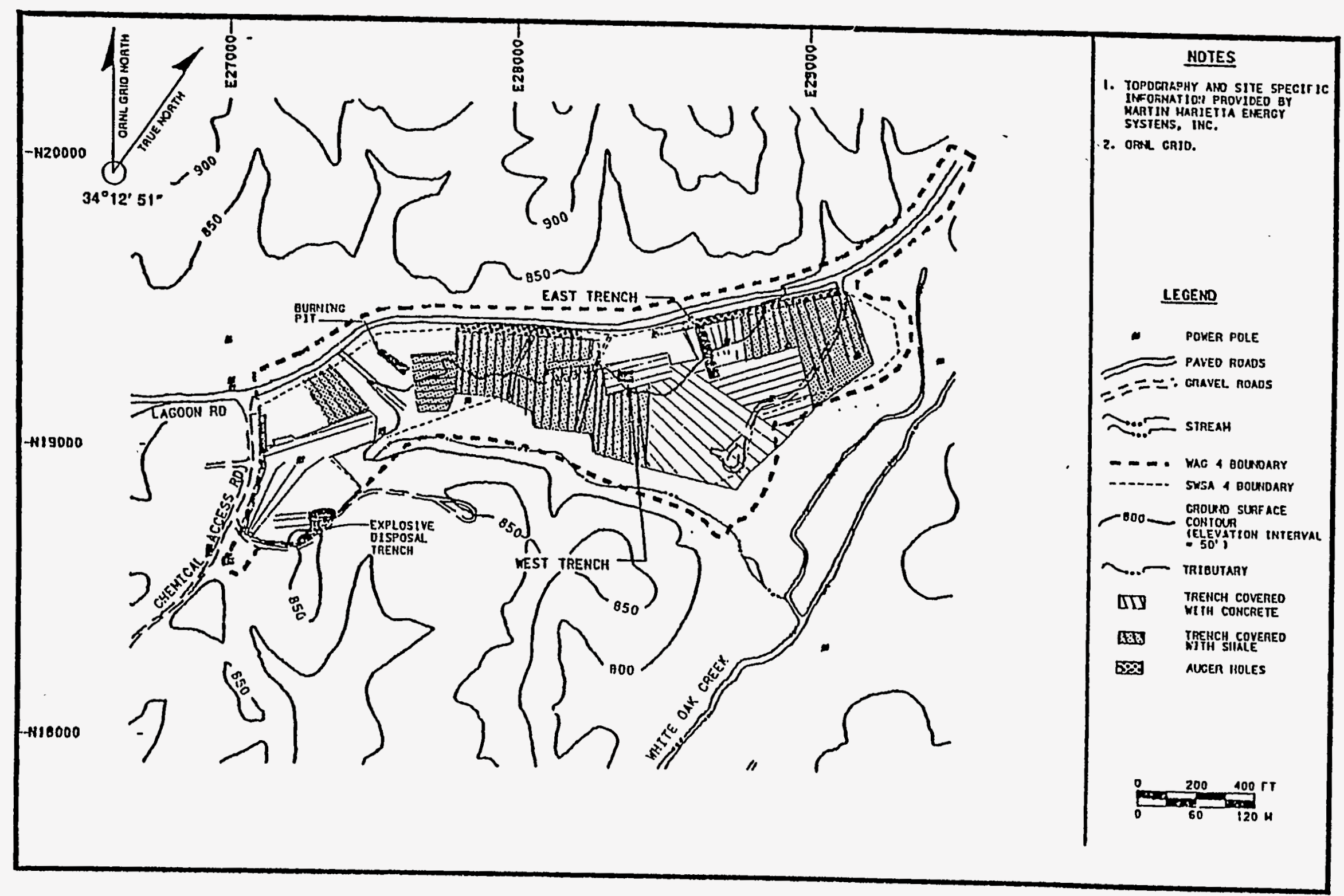

$\stackrel{\circ}{ }$

Fig. 9.4. SWSA 4 site map. Source: Bechtel 1988 
Much of the waste in SWSA 4 is located in or very near the water table. Principal radionuclides present in groundwater in and near SWSA 4 are ${ }^{3} \mathrm{H}$ and ${ }^{90} \mathrm{Sr}$, with occasional readings of boron, ${ }^{125} \mathrm{Sb}$, and ${ }^{137} \mathrm{Cs}$. SWSA 4 contributes about 35 to $50 \%$ of the ${ }^{9} \mathrm{Sr}$ discharged yearly from the WOC basin at White Oak Dam. A surface runoff collector and diversion system was constructed in 1975; a second system was built in 1983 . These diversion systems show early indications of reducing ${ }^{90} \mathrm{Sr}$ releases to WOC. Stream gravel surveys have shown that SWSA 4 is a significant source of ${ }^{90} \mathrm{Sr}$ and ${ }^{137} \mathrm{Cs}$.

SWSA 4 was surveyed to determine the level and extent of surface radiological contamination (ORNL 1990). Inside the fenced area, surface gamma exposure rates above background levels were identified at 95 areas and 58 smaller, isolated spots for a total of $\sim 2000 \mathrm{~m}^{2}$. Most of the elevated gamma exposure rates ranged from 12 to $240 \mathrm{uR} / \mathrm{h}$. Levels ranging from 241 to $420 \mathrm{uR} / \mathrm{h}$ were measured at six surface areas, and levels of greater than $1700 \mathrm{uR} / \mathrm{h}$ were identified at nine areas. Highest surface gamma radiation levels were found along the southernmost perimeter of SWSA 4 in the "bathtub seeps" area, where ground-level gamma exposure rates reached $15 \mathrm{mR} / \mathrm{h}$. A second contaminated area, encompassing $126 \mathrm{~m}^{2}$ and located in grid blocks $\mathrm{N} \mathrm{19,200/E} \mathrm{27,700} \mathrm{and}$ $\mathrm{N} 19,300 / \mathrm{E} 27,700$, had surface gamma exposure rates up to $14 \mathrm{mR} / \mathrm{h}$.

\subsection{CHARACTERIZATION}

\subsubsection{Geography}

WAG 4 is located on the Oak Ridge Reservation in Roane County, Tennessee, approximately 5 miles southwest of the city of Oak Ridge central business district and 1 mile south of the ORNL main plant area (Fig. 9.1). WAG 4 is bounded to the south and west by WAG 7 and to the east by White Oak Lake. Lagoon Road parallels the northern limit of the site, which lies on the foot slope of Haw Ridge.

WAG 4 is located in Melton Valley within the Valley and Ridge physiographic province. WAG 4 lies between Chestnut Ridge [1100 ft Mean Sea Level (MSL)], to the northwest, and Copper Ridge (1400 ft MSL), to the southeast. Bethel Valley ( $775 \mathrm{ft} \mathrm{MSL})$ is separated from Melton Valley ( $740 \mathrm{ft} \mathrm{MSL}$ ) to the southeast by Haw Ridge (1000 ft MSL).

The prefill topography of WAG 4 indicates that the current WAG 4 once comprised a portion of the southeastern toe of Haw Ridge (Baughn 1987). This southeastern toe converged with a line of knobby hills at what is now known as SWSA 4 Tributary. The southeastern toe sloped to the southeast with a typical slope of 4 to $10 \%$; the knobby hills sloped to the northeast with a typical slope of $25 \%$. The SWSA 4 Tributary drained to the northeast with a typical slope of $2 \%$. Maximum relief in WAG 4 was $40 \mathrm{ft}$, with elevations ranging from $810 \mathrm{ft}$ Mean Sea Level (MSL) in the north-central area of the site to $770 \mathrm{ft}$ MSL near the WOC floodplain in the eastern end. Three prominent drainages dissect the site carrying runoff south from Haw Ridge to SWSA 4 Tributary and WOC.

\subsubsection{Climate}

See Sect. 5.2.2 of this document for climate description. 


\subsubsection{Demography}

At the closest point, WAG 4 is approximately 1 mile from the ORNL main plant area (Fig. 9.1), where the majority of ORNL's approximately 4837 employees work (Site and Facilities Planning Department 1994). Within 2 miles of the boundary of WAG 4, all land is federally owned, and there are no residents. The two-lane State Highway 95 runs through the Oak Ridge Reservation and passes along the western side of WAG 4 within 0.5 mile of its boundary at the closest point. WAG 4 is approximately 2 miles from the north bank of the Clinch River, which forms a portion of the boundary of the Oak Ridge Reservation. The Clinch River, also known as Watts Bar Lake at this location, is open to recreational uses, such as boating, fishing, and duck and goose hunting, as permitted by the state of Tennessee.

See Sect. 5.2.3 of this document for general demographic characteristics of ORNL.

\subsubsection{Geology and Soils}

WAG 4 is in Melton Valley within the Copper Creek thrust block and is underlain by strata of the middle to late Cambrian Conasauga Group. The Conasauga Group is approximately $1877 \mathrm{ft}$ thick and lithologically heterogeneous. It is structurally complex, consisting of alternating beds of siltstones, silty limestones, calcareous shales, and mudstones. At least two types of faults are identified: the Copper Creek Thrust Fault, which is exposed at the surface on the north side of Haw Ridge, and several tear fault systems oriented perpendicular to the thrust fault motion and the strike of the valley. Other structural features of the Conasauga Group include localized folding, bedding plane and vertical fractures, and joint sets. Solution features have also been observed (Ebasco 1992).

Strata that underlie the ridges in the WAG 4 area are the resistant sandstones and dolomites; the less resistant limestones and shales occur in the valleys. Both Chestnut Ridge and Copper Ridge are formed by the Knox Group, a light-to-dark gray, dolomitic limestone with prominent zones of chert. Haw Ridge is formed by the Rome Formation, which consists of evenly bedded, fine-grained sandstone and shale. Melton Valley is underlain by the Conasauga Group. Six formations comprise the Conasauga Group (in ascending order): the Pumpkin Valley Shale, the Rutledge Limestone, the Rogersville Shale, the Maryville Limestone, the Nolichucky Shale, and the Maynardville Limestone. The Conasauga Group is made up predominantly of shale with alternating and predominant intervals of siltstone, silty limestone, and mudstone.

Silty to clayey red-yellow and red-brown podzols, common throughout the southeastern United States, occur in the ORNL area. Generally, the soils are moist, low in organic matter, strongly leached and acidic, with a pH of 4.5 to 5.7. Soils derived from the Conasauga Group typically contain illite and vermiculite as principal clay minerals. Those from the Chickamauga Group contain a mixture of kaolinite, illite, and montmorillonite clays. Piezometer well drill logs indicate that WAG 4 soils are predominantly medium brown to gray-green, silty clay containing gravel-sized rock and weathered shale fragments. The soil is composed of low- to high-plasticity clay and silt. This residual soil forms stable slopes with inclinations of 3:1 or less. Soil depths in WAG 4 range from 10 to $26 \mathrm{ft}$. Preliminary seismic data indicate that the soil depths may range up to $50 \mathrm{ft}$ in some areas (Ebasco 1992).

The presence of clay minerals in soils associated with WAG 4 enhances the ability of the soils to retard the migration of radioactive and hazardous constituents by (1) mechanical filtering, (2) adsorption of electrochemically charged ionic constituents on the surface of the clay particles,

(3) absorption of ionic species within the mineralogical lattice structure, and (4) ion exchange with 
particles already adsorbed on the surface of the clay particle. Soil core samples taken across WAG 4 indicate that contamination is migrating through the soil column.

Chemical weathering strongly affects soil formation in both the Chickamauga and Conasauga groups. The depth of weathering in the Chickamauga Group is typically less than $10 \mathrm{ft}$. Bedding and structures within the rock are not retained much above the fresh rock surface because chemical weathering in the limestone is so complete. In the Conasauga Group, the depth of weathering reportedly ranges up to $40 \mathrm{ft}$ and is closely tied to topography, with thinner zones in low-lying areas and thicker zones on the ridges.

Within WAG 4, native soils have been reworked and fill materials imported to accommodate operational and disposal activities, such as the construction of pipelines, trenches, buildings, and burial grounds. The disturbance has altered the natural structural fabric and mineralogy of soils in these areas. It has also provided a random network of conduits for the collection and conveyance of fluids, including leaked and spilled materials, throughout the site (Ebasco 1992).

\subsubsection{Surface Water}

WAG 4 is located in the Melton Valley portion of the WOC watershed (Fig. 9.5). In this portion of its watershed, downstream from the water gap at Haw Ridge, WOC flows south-southwest, coming within 98 to $492 \mathrm{ft}$ of the eastern border of WAG 4 . The stream gradient is less than $1 \%$ along this section of WOC (Bechtel 1988).

The principal natural drainage feature within WAG 4 is SWSA 4 Tributary, an intermittent stream that flows northeast to WOC. The gradient of SWSA 4 Tributary is approximately $2 \%$. Both WOC and SWSA 4 Tributary receive runoff from WAG 4 before they join and flow southwest to White Oak Lake. The SWSA 4 Tributary is generally recognized as a primary contributor of the total ${ }^{90} \mathrm{Sr}$ discharge to WOC (Stueber et al. 1981).

Water quality-related problems noted during early site operation of SWSA 4 included the shallow depth of groundwater in the low areas, radioactivity in a number of site monitoring wells, and the appearance of four distinct trench seeps that were found to contain radionuclides $\left({ }^{106} \mathrm{Ru},{ }^{60} \mathrm{Co}\right.$, ${ }^{137} \mathrm{Cs},{ }^{90} \mathrm{Sr},{ }^{95} \mathrm{Zr},{ }^{95} \mathrm{Nb},{ }^{239} \mathrm{Pu},{ }^{240} \mathrm{Pu},{ }^{210} \mathrm{~Pb}$, and the rare earths). The recognition of these problems spawned a number of field investigations of the SWSA 4 hydrology (Tamura et al. 1980; Stueber et al. 1981; Huff, Farrow, and Jones 1982; Melroy and Huff 1985), all of which indicated the importance of runoff from the 35-acre area north of Lagoon Road as a contributing factor to the SWSA 4 water quality problems.

In an attempt to lessen the impact of runoff originating north of Lagoon Road, two surface water diversion projects were undertaken in SWSA 4 in an attempt to isolate the burial trenches from the upslope discharge area, which could reduce the amount of water entering the trenches and potentially decrease the amount of contaminants mobilized. These two projects are discussed in the following paragraphs.

The first surface water diversion project was constructed at the site in 1975 and included a surface runoff collection and diversion system. To collect the surface runoff, a shallow asphalt-lined ditch was constructed along the north side of Lagoon Road above SWSA 4. The surface runoff was then diverted across SWSA 4 by means of three shallow asphalt-lined conductor ditches and one unlined natural drainage at the northeast edge of the SWSA. The asphalt-lined channels did not extend to SWSA 4 Tributary-they ended within the SWSA 4 disposal area. This system was 
observed to carry large amounts of water during heavy rains and small amounts of water for several days after a period of heavy rain (Duguid 1976).

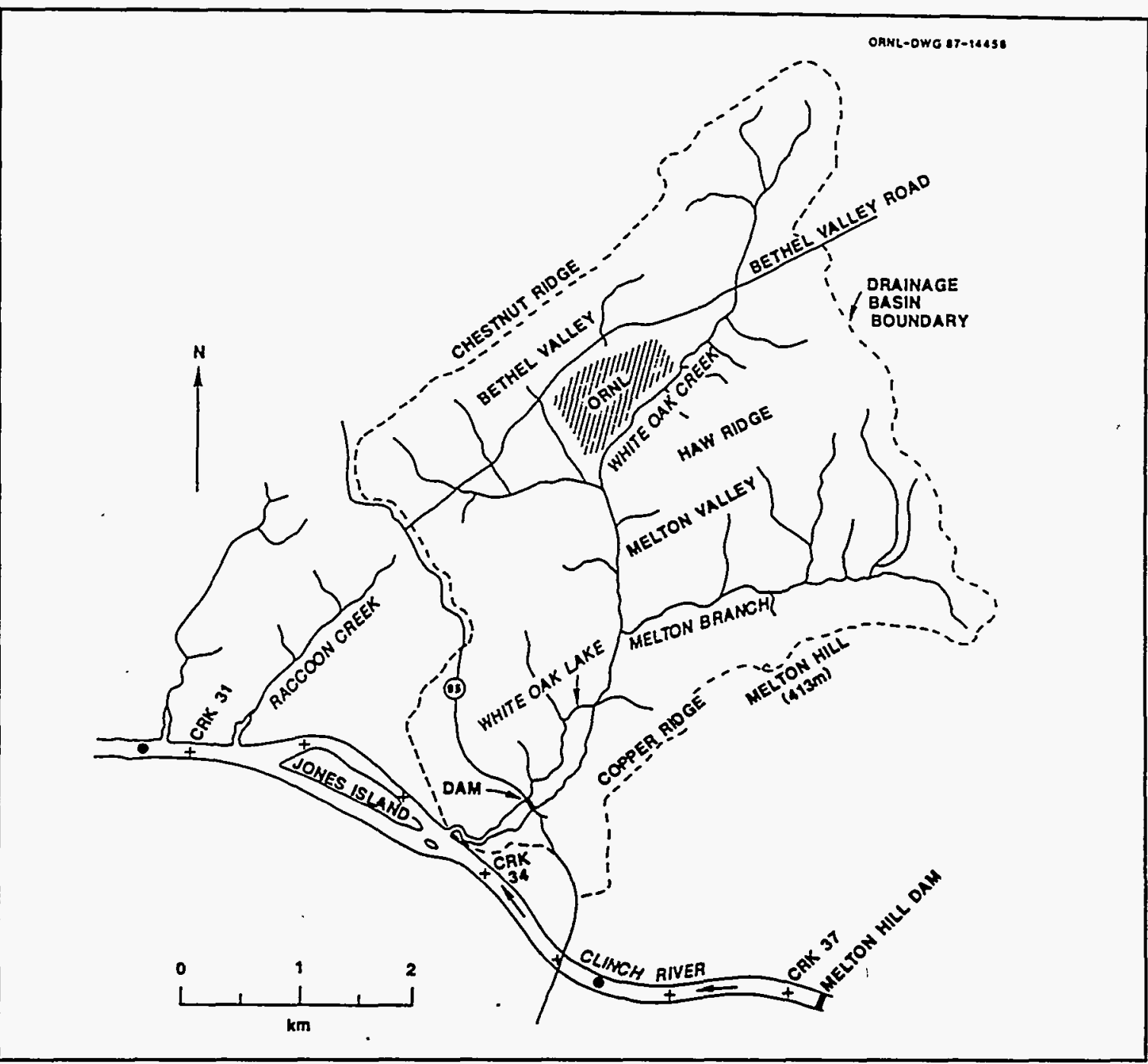

Fig. 9.5. Map showing the WOC watershed boundaries. Source: Bechtel 1988

Tamura et al. (1980) evaluated the success of the first diversion project and determined that it did not reduce the amount of ${ }^{90} \mathrm{Sr}$ released in surface water from SWSA 4. Stueber et al. (1981) concluded that SWSA 4 was the most important nonpoint ${ }^{90} \mathrm{Sr}$ source in the WOC drainage. SWSA 4 was estimated to contribute about $72 \%$ of the total ${ }^{90} \mathrm{Sr}$ discharged into WOC between Sampling Stations 2 and 3.

The second water diversion project was constructed in 1983. Its purpose was to route drainage from Haw Ridge around SWSA 4. The diversion consists of three design elements: (1) a paved interceptor channel at ground surface on the north side of Lagoon Road, (2) four catch basins that receive runoff from the interceptor channel and from the natural channels draining Haw Ridge, and (3) an underground storm drain system that diverts runoff around the disposal site to both the east and west. The existing culverts on Lagoon Road, which allowed water to pass beneath Lagoon Road 
and discharge to the asphalt ditches, were reportedly sealed so that all runoff originating north of SWSA 4 was diverted around SWSA 4.

At the completion of the drainage project, measurements of flow and water quality of SWSA 4 Tributary were continued to evaluate the project. It was concluded that the quantity of ${ }^{90} \mathrm{Sr}$ entering WOC was reduced by $46 \%$ during the initial 6 months of monitoring (Melroy and Huff 1985, Davis et al. 1985). However, net discharge of ${ }^{90} \mathrm{Sr}$ flux at White Oak Dam did not show any apparent reduction in ${ }^{90} \mathrm{Sr}$ discharge in three subsequent water years.

\subsubsection{Groundwater}

\subsubsection{General description of WAG 4 groundwater}

Groundwater occurs in the regolith and within the bedrock of the Conasauga Group, and the two flow systems are recognized as hydraulically interconnected. The groundwater table occurs near the base of the regolith at depths of less than 3 to $59 \mathrm{ft}$. Groundwater circulation occurs predominantly in the upper $100 \mathrm{ft}$ but may extend to depths of $230 \mathrm{ft}$ in the bedrock. The water table appears as a subdued replica of surface topography as expected under unconfined conditions. The hydraulic gradient ranges from 4 to $100 \mathrm{ft}$ on the southwest to 12 to $100 \mathrm{ft}$ in the draw that divides the south-central portion of SWSA 4. Local deviations in flow direction can be expected due to burial activities.

A conceptual model of flow in the Melton Valley (Webster and Bradley 1986) suggests that flow changes in direction from the water table gradient in the regolith to the hydraulic head distribution within the secondary openings in the bedrock with an intermediate zone positioned between the two. Where there is a high water table, flow through the regolith would be expected to be dominated by water table gradients that would flow radially away from topographic highs (i.e., areas of groundwater recharge). During periods of lower hydraulic head, directional permeabilities resulting from relict bedrock structure, lithology, and man-made disturbance will have a greater influence on flow patterns in the regolith.

Groundwater and surface water runoff discharge to SWSA 4 Tributary and WOC. Two closely spaced seeps are located in SWSA 4 and are known to be contaminated with ${ }^{90} \mathrm{Sr},{ }^{3} \mathrm{H}$, and ${ }^{13} \mathrm{Cs}$ (Ebasco 1992). Sampling during three storm events showed that ${ }^{90} \mathrm{Sr},{ }^{3} \mathrm{H}$, and ${ }^{137} \mathrm{Cs}$ concentrations are mostly independent of discharge at the seep; however, there was a trend to lower concentrations in the average concentrations during the winter and spring. A "washout" model for the release of contamination to soil water was proposed. The key uncertainty is the inventory and the rate of diffusion of contaminants within the soil phase. Documenting the bulk behavior of this phenomenon by monitoring seep water and groundwater during an annual cycle will provide information on the source term within the trenches.

\subsubsection{Characterization of groundwater contamination}

The groundwater monitoring system at WAG 4 includes 66 monitoring wells installed between 1959 and 1974, 13 piezometers installed in 1986 or 1987, and 15 additional monitoring wells installed between 1987 and 1990. The 66 older monitoring wells were installed as part of the preremedial action program and were constructed with perforated corrugated metal casing running the entire length of the borehole; others are of unknown construction. The 15 additional wells at WAG 4 were installed as part of a groundwater quality monitoring well installation program at ORNL. 
Two principal source documents were used to develop an understanding of groundwater contamination at WAG 4. These documents were the Preliminary Geohydrologic Site Characterization and Proposed Water Quality Well Locations for WAGs 4, 5, and 3, and SWSA 1 (ORNL 1987) and the Oak Ridge Reservation Environmental Report for 1991(Energy Systems 1992). The preliminary geohydrologic site characterization report summarized results for samples collected from seven of the preremedial action program wells in SWSA 4 and three undesignated seeps located in proximity to each other along the southern boundary of SWSA 4. All of the well and seep samples were found to be contaminated with ${ }^{90} \mathrm{Sr}$, ranging in activity from 0.89 to $1000 \mathrm{~Bq} / \mathrm{L}$ in the wells and from 42 to $800 \mathrm{~Bq} / \mathrm{L}$ in the seeps. The highest activity of ${ }^{90} \mathrm{Sr}$ was detected in Well 0191 , which is located in proximity to the seeps. Wells 0186 and 0191 also were found to be contaminated with ${ }^{137} \mathrm{Cs}$ at prepurging activities of 0.31 and $0.21 \mathrm{~Bq} / \mathrm{L}$, respectively.

The Oak Ridge Reservation Environmental Report for 1991 (Energy Systems 1992) summarized results for groundwater samples collected during March and April of 1991 from the 15 groundwater quality wells at WAG 4 . Six of these wells, located along the southeast boundary of WAG 4, were found to contain tritium contamination ranging from 2500 to $400,000 \mathrm{~Bq} / \mathrm{L}$. The four southeast boundary wells exhibiting the highest tritium activities were also found to be contaminated by nickel at concentrations ranging from 120 to $170 \mu \mathrm{g} / \mathrm{L}$. Three wells located along the north and southeast boundaries of the contained total strontium contamination ranging from 0.31 to $20 \mathrm{~Bq} / \mathrm{L}$. Finally, four wells located along the west and southeast boundaries were found to be contaminated by one or more of the following volatile organics at concentrations ranging from 7.0 to $200 \mu \mathrm{g} / \mathrm{L}: 1,2$-dichloroethane, 1, 2-dichloroethene, trichloroethane, and vinyl chloride.

Subsequent sampling of the wells in November and December of 1991 and October and November of 1992 indicated the presence of similar activities and concentrations of the noted contaminants. However, total strontium was observed to be below the maximum contaminant limit in Wells 0951 and 0953 during the later sampling events and was detected above maximum contaminant limits in Wells 0955 and 0962 . Also, nickel was observed to be below the maximum contaminant limit in Well 0957 during the later sampling events. Based on the data evaluated for WAG 4, contaminated groundwater containing ${ }^{137} \mathrm{Cs},{ }^{90} \mathrm{Sr}$, and tritium derived from the disposal trenches and/or auger holes appears to have migrated downgradient from the south and southeast boundaries of WAG 4. In addition, nickel contamination in groundwater also appears to be migrating beyond the southeast boundary of the WAG. Several source areas within WAG 4 also appear to be contributing minor amounts of volatile organic contaminants to groundwater (SAIC 1994).

\subsubsection{Ecology}

Sect. 5.2.7 of this document provides an overview of the flora and fauna commonly found on the Oak Ridge Reservation, which are believed to be representative of those found at WAG 4.

\subsection{RELEASES AND SITE CONCEPTUAL MODEL}

\subsubsection{Known Releases from WAG 4}

Even at the onset of waste burials in SWSA 4, it was evident that the buried waste was contacting water during most of the year. Lomenick and Cowser (1961) reported that burial was limited to higher elevations within SWSA 4 during the wet months, whereas the low topography areas were used in the dry summer months. Some of the water-related problems that were noted included a minimum depth to water between 2 and $3.3 \mathrm{ft}(0.6$ and $1.0 \mathrm{~m})$ in low areas, radioactivity in site monitoring wells, and the appearance of four distinct trench seeps. 
Duguid (1975) reported on the status of radionuclide movement in SWSA 4. Concentrations of ${ }^{90} \mathrm{Sr},{ }^{60} \mathrm{Co},{ }^{137} \mathrm{Cs}$, ${ }^{125} \mathrm{Sb}$, and ${ }^{3} \mathrm{H}$ were determined for a number of the existing wells and three of the four surface seeps. As a part of his study, Duguid (1975) divided SWSA 4 into eastern and western regions and reported ${ }^{90} \mathrm{Sr}$ concentrations on selected sampling dates. Duguid concluded that ${ }^{90} \mathrm{Sr}$ was the major concern in SWSA 4 and that the average concentration of ${ }^{90} \mathrm{Sr}$ on the east side of the site was lower than that observed on the west side. Furthermore, he estimated that between $4.4 \times 10^{10}$ and $1.8 \times 10^{11} \mathrm{~Bq}(1.2$ and $4.8 \mathrm{Ci})$ of ${ }^{90} \mathrm{Sr}$ per year was discharged from SWSA 4 between 1963 and 1973 . This was about one-third of the total annual release of ${ }^{90} \mathrm{Sr}$ to Clinch River (measured at White Oak Dam).

Later studies by Stueber (1981) confirmed the earlier studies by Duguid showing that SWSA 4 is a major contributor of ${ }^{90} \mathrm{Sr}$ to WOC and that a number of contaminated surface seeps appear along the southern boundary of the site, particularly during the wet months of the year. This observation is consistent with early studies by Lomenick and Cowser (1961) that the lower elevation areas of SWSA 4 could not be used for disposal trenches during wet months.

In 1984, Spalding and Munro conducted a survey of ${ }^{90} \mathrm{Sr}$ in SWSA 4 groundwater by sampling 129 locations along a $2,360-\mathrm{ft}(720-\mathrm{m})$ perimeter transect to the south and east of SWSA 4. Several peaks of ${ }^{90} \mathrm{Sr}$ occurred along the transect and were generally located in the vicinity of the seeps identified by Duguid (1975). Based on the results of the survey, Spalding and Munro (1984) concluded that groundwater in the eastern side of SWSA 4 contained much less ${ }^{90} \mathrm{Sr}$ than groundwater on the southern side and supported previous observations that future remedial actions should be directed to the southern areas of SWSA 4.

A 1995 WAG 4 radiological survey (Energy Systems 1995) showed that no new sources of ${ }^{90} \mathrm{Sr}$ have emerged in WAG 4 during the past 13 years. This suggests that the major contributors of ${ }^{90} \mathrm{Sr}$ are known. Because more than 40 years have already elapsed since disposal operations took place, new ${ }^{90} \mathrm{Sr}$ sources are unlikely to develop in the future. Evaluation of ${ }^{90} \mathrm{Sr}$ mass-transport contributions from individual seeps indicates that the Seep Collection System (SCS) 6 area is the most important contributor to WAG 4 releases, followed by the SCS 4 area (Fig. 9.6). The SCS 5 area is much less important, followed by the SCS 3 area. These results are consistent with concentration profiles along the tributary draining WAG 4 and with the ${ }^{90} \mathrm{Sr}$ concentrations in water in the trenches that appear to be the sources for the seeps. Examination of ${ }^{90} \mathrm{Sr}$ concentrations in the apparent source trenches for the SCS $6, \operatorname{SCS} 4$, and SCS 5 areas suggests that portions of four or five trenches are responsible for a very high fraction of the total ${ }^{90} \mathrm{Sr}$ released from WAG 4.

Simple calculations of radioactive decay indicate that about $60 \%$ of the ${ }^{90} \mathrm{Sr}$ originally placed in waste trenches has decayed to a stable nuclide. Further, data from 1973 (adjusted for radioactive decay) for a seep discharging in the SCS 4 area show concentrations in the same range as those measured in 1995. Thus, control of the long-term sources identified appears to be the key to controlling releases, by both surface and subsurface pathways (Energy Systems 1995).

\subsubsection{Site Conceptual Model}

The conceptual model for source release and contaminant fate at WAG 4 is summarized in Fig. 9.7, which depicts a cross section through a typical "bathtubbing" disposal trench. The term "bathtubbing trench" refers to a situation where the trench collects water along its length, the water flows to the downslope end, and in extreme cases, overflows out of the trench in a manner similar to a sloping bathtub. The exact number of bathtubbing trenches in WAG 4 is not known because records of the number and location of trenches was destroyed in a fire. The potential for a bathtubbing condition is present wherever long trenches exist that are oriented along the steepest 


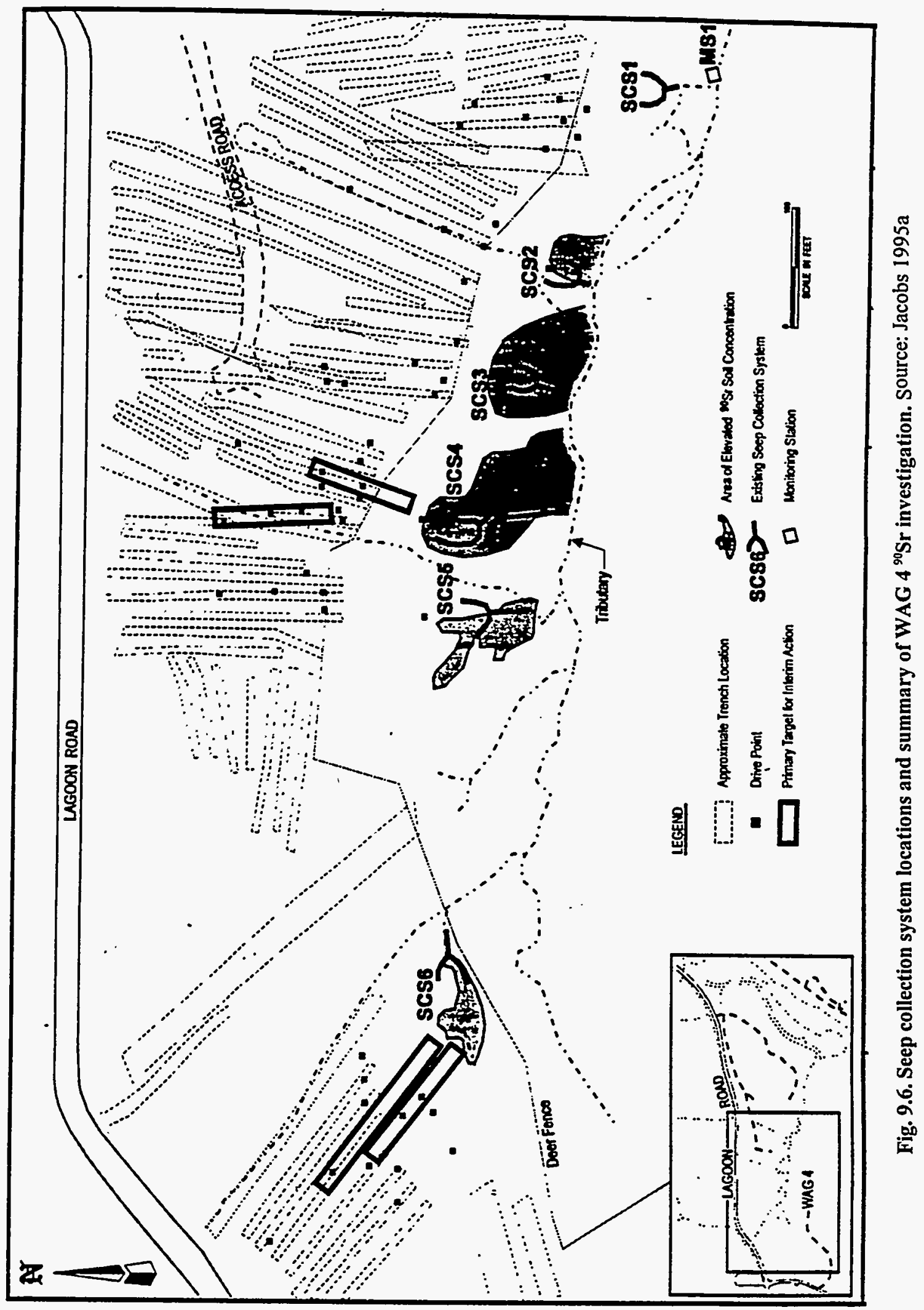




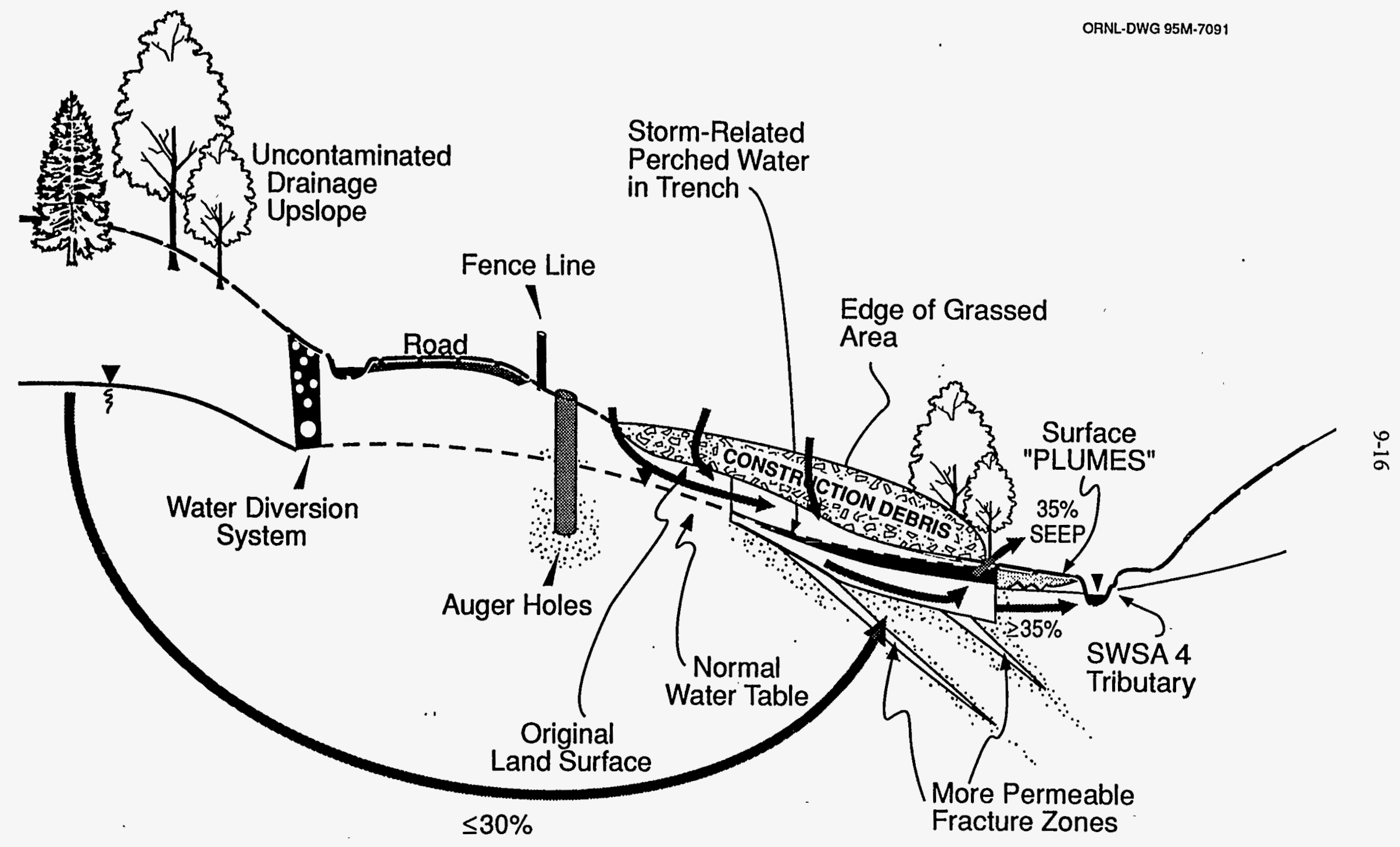

Fig. 9.7. WAG 4 bathtubbing trench conceptual model. Source: Energy Systems 1995 
downslope gradient and that terminate in topographically low areas. Three conditions must exist to create a release problem from such a trench. First, the trench must contain enough ${ }^{90} \mathrm{Sr}$ in a form that will contaminate water present in it. Second, water must be present in the trench. Third, a permeable pathway must allow water to move through the trench to be discharged either at the surface, where it can move directly into a stream, or through a subsurface pathway short enough to allow a contaminant plume to break through to a surface water discharge point.

The most important elements of the conceptual model include the proximity of the downslope ends of the trenches to the stream draining the area and the fact that the trenches extend upslope a substantial distance, allowing collection of water by lateral inflow. The large void volume and related high permeability in the trenches allow many of the trenches to act as collection drains for the lower portions of the disposal site. The presence of construction debris, placed across the site after disposal operations ended, probably enhances infiltration of rainfall. However, where the debris appears to be quite thick, especially at the downslope ends of trenches, it may be a barrier for flow and thus for contaminant release.

The relative importance of flow pathways in the conceptual model is a key to understanding and controlling processes for off-site release. Two distinct sources of water exist for the trenches: transient near-surface flows associated primarily with storm events and the stable saturated-zone groundwater-flow pathway, of which an important component originates from the full catchment area, including the area upslope from Lagoon Road. Some insights into the relative importance of pathways are available from the comparison of mass flows of ${ }^{90} \mathrm{Sr}$ at seeps and in the tributary draining the site. As storm magnitude increases, it appears that the contributions from overflowing trenches, as measured at the seep areas, also increases. For the month of March, roughly half the mass flow appears to have followed this mechanism (Energy Systems 1995). The other major pathway appears to be along a subsurface route and dominates transport in drier periods. For the fall study period in 1995 , nearly $65 \%$ of the total mass flow appears to have followed this route. At present, it is not possible to differentiate the portions of the subsurface flow that originate from direct infiltration of rainfall at the site and the portion that comes from deeper groundwater that originates in the catchment to the north of the site. Hydrograph analysis suggests that about $70 \%$ of the ${ }^{90} \mathrm{Sr}$ mass flow during the year is associated with storms, where local infiltration would be the dominant factor. Thus, a rough estimate of relative importance of pathways shown in Fig. 9.7 would be about $35 \%$ via overflowing water that emerges at seeps, up to $30 \%$ from deep groundwater, and the remainder via shallow subsurface flow (Energy Systems 1995).

\subsection{ACTIVE PROJECTS: SEEPS}

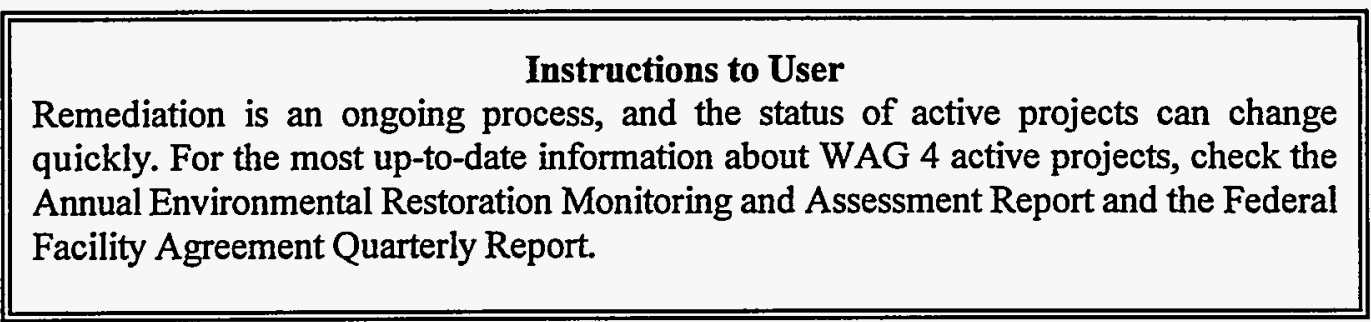

At the southern edge of SWSA 4, numerous seeps discharge into an ephemeral tributary near the downgradient end of the trenches. Six of these seeps have been associated with the release of ${ }^{90} \mathrm{Sr}$ into the tributary, which flows into WOC and downstream to White Oak Dam. The seeps were identified as the subject of a removal action within the WAG because they present levels of potential 
risk that exceed U.S. Environmental Protection Agency thresholds at the Oak Ridge Reservation boundary.

In conjunction with other sampling at WAG 4, a series of dry- and wet-weather water samples and discharge rate measurements were collected from each of the six seeps and at MS 1 in the tributary on the south edge of WAG 4 (Fig. 9.6). These data were used to calculate the ${ }^{90} \mathrm{Sr}$ flux at each location and estimate the relative contribution of ${ }^{90} \mathrm{Sr}$ from each seep at different flow conditions. The measurement results indicated that the area above MS- 1 containing the sources that supply these six seeps contributes up to $78 \%$ of the ${ }^{90} \mathrm{Sr}$ released from WAG 4 into WOC (Energy Systems 1995). The sources for two seeps (4 and 6) apparently contribute over $90 \%$ of the strontium releases measured at MS 1 (Jacobs 1995c). The sources supply roughly half of the ${ }^{90} \mathrm{Sr}$ to the tributary by subsurface pathways and the other half to the seeps.

The WAG 4 seeps removal action goal is to reduce the ${ }^{90} \mathrm{Sr}$ released from WAG 4 by $35 \%$ within the first 3 years and $75 \%$ within 10 years. As a limited action to control sources and prevent contaminant migration, this removal action is expected to significantly reduce the amount of ${ }^{90} \mathrm{Sr}$ entering WOC and reduce the risks to human health and the environment until additional and/or permanent actions to eliminate or further control the source of contamination are taken. Treating or reducing releases of ${ }^{90} \mathrm{Sr}$ from secondarily contaminated soils is not part of the removal action. Contaminated media not addressed as part of the chosen remedial alternative will be addressed as part of integrator or media-specific operable units for WAG 4. Several other radiological contaminants have been detected in and around the subject trenches; however, ${ }^{90} \mathrm{Sr}$ is the only subject of this removal action, based on concentration, mobility, and radiotoxicity.

\section{Proposed Actions}

Four alternatives, including a no action alternative, were evaluated for suitability as a removal action to reduce ${ }^{90} \mathrm{Sr}$ releases from the WAG 4 seeps (Jacobs 1995a). Because this is a removal action only, limited in scope to 20 years, all retained alternatives assumed that present institutional controls will remain in effect, including limitations on access and use. All alternatives would be most effective if existing catch basins and the drainage system on the north side of Lagoon Road are maintained and kept clear of debris. The action alternatives included (1) source control by reducing conductivity using grout (water flow); (2) enclose, collect, and treat; and (3) cap, collect, and treat. Two versions of the source control alternative were evaluated: source control by grouting and source control by cryogenics.

Three important considerations during the evaluation process included (i) the time frame implied by the removal action, (2) health and safety concerns, and (3) management of uncertainties. Short-term effectiveness and cost/benefit considerations were given extra weight in the evaluations. Health and safety concerns included the possibility of the explosion of containerized elemental sodium if exposed to water. Uncertainties were associated with the delineation of the trenches and implementability due to heterogeneity of the construction debris.

The alternative of choice at the WAG 4 seeps is identified in the engineering evaluation/cost analysis (Jacobs 1995a) as source control using grout to reduce hydraulic conductivity. This in situ remedy has neither continuing treatment nor contingency actions.

\section{Proposed Action Description}

The source control by grouting alternative includes in situ control of the ${ }^{90} \mathrm{Sr}$ sources in trench sections associated with Seeps 4 and 6 [identified as elevated contamination (Fig. 9.8)]. These trench 


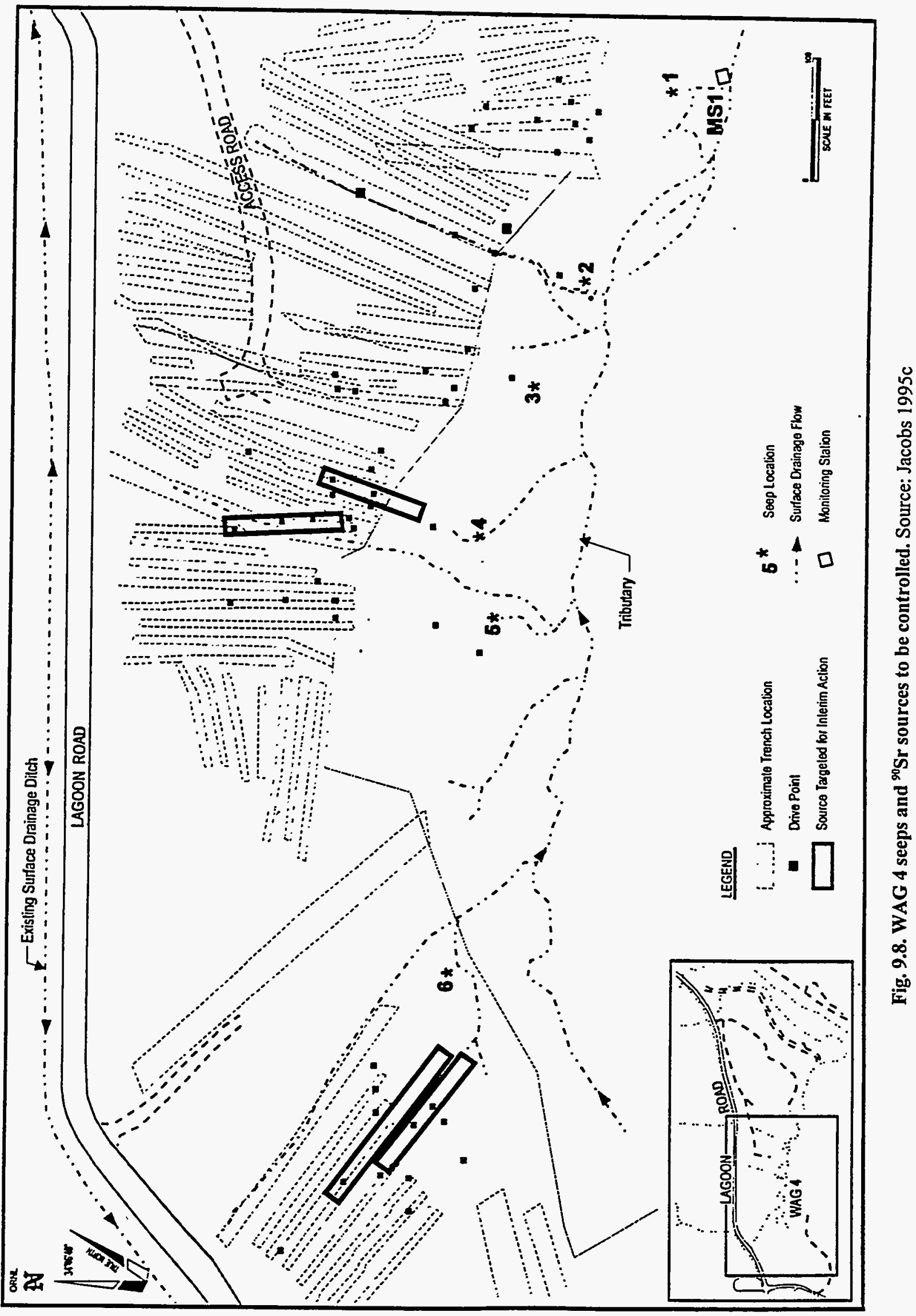


sections will be stabilized by injecting grout to form monoliths. The trench surface would be graded for construction activities. The grout formulation will provide physical stability and fill voids, reducing permeability and hydraulic conductivity. Thus, groundwater flow to the source will be reduced and/or impeded, and ${ }^{90} \mathrm{Sr}$ stabilization in the source areas will be enhanced.

In situ grouting will be accomplished using a selection of grout agents and additives. The exact formulations will be determined in grout compatability studies. Prior to grouting, the surface above the area where the grout is injected will be graded and capped with gravel and filter fabric to produce a clean work platform. The gravel should improve erosion control and help retard surface water infiltration, if necessary.

This alternative was selected for several reasons:

- The conventional construction equipment needed for grouting can be modified for semiremote installation of sleeve pipes for grout injection.

- Grouting is less intrusive than the piping array used for cryogenics or the installation of walls and is still expected to be effective in source control.

- If grouting breaches the integrity of waste containers in the trenches, the waste can be stabilized by the grout. Using cryogenics could result in loss of container integrity when the action is stopped and the area thaws; the contaminants could then migrate out of the trenches.

- Grouting is relatively inexpensive.

- This alternative will disturb a smaller area (two locations, less than 1 acre each) than the cap/collect/treat alternative and would thus result in fewer adverse environmental effects with virtually none to the floodplain or wetlands.

- This alternative will not require installation of a discharge pipe for the collection and treatment system as needed for the enclose/collect/treat and cap/collect/treat alternatives, which could require work within the tributary floodplain and potentially impact the nearby wetland.

\section{Monitoring Plan}

Monitoring will verify the overall effectiveness of the action and provide a basis for any final action decisions. Spatial and temporal profiles of ${ }^{90} \mathrm{Sr}$ flux will be developed from measurements taken over the first 5 years following construction activities. These will be made at several surface water monitoring locations by collecting samples for ${ }^{90} \mathrm{Sr}$ analysis and taking stage measurements to determine surface water discharge rates. Monitoring locations will include (1) MS 1, (2) Seeps 4 and 6, and (3) two locations in the tributary (downgradient of Seep 6 and downgradient of Seep 4) to permit contaminant mass balance calculations. The need for continued monitoring will be evaluated at the Comprehensive Environmental Response, Compensation, and Liability Act 5-year review.

\section{Contribution to Remedial Performance}

Sampling results indicate that WAG 4 contributes an average of $0.7 \mathrm{Ci}$ to the annual ${ }^{90} \mathrm{Sr}$ release detected at White Oak Dam, which is a significant source of the off-site risk from ORNL. The current removal action is expected to steadily decrease ${ }^{90} \mathrm{Sr}$ releases over an estimated 10 -year period, with a final reduction of about $75 \%$ of the average $0.6 \mathrm{Ci}$ total from WAG 4 . With this reduction of ${ }^{90} \mathrm{Sr}$ flux from WAG 4, DOE can address the next highest priority area at ORNL. 
This removal action at the WAG 4 seeps will be monitored for performance. It is expected to function satisfactorily with little or no maintenance needed for 20 years or more, the time frame anticipated for final action to be considered. Remaining secondary sources of contamination (i.e., soils or sediments) will be addressed, if necessary, in integrator operable units and/or as part of the final actions (Jacobs 1995c).

\subsection{WAG 4 SUMMARY}

WAG 4 is located on the Oak Ridge Reservation in Roane County, Tennessee, approximately 5 miles southwest of the city of Oak Ridge central business district and 1 mile south of the ORNL main plant area. WAG 4 is bounded to the south and west by WAG 7 and to the east by White Oak Lake. Lagoon Road parallels the northern limit of the site. WAG 4 is located in Melton Valley between Chestnut Ridge and Copper Ridge. State Highway 95 passes within 0.5 mile of the western side of WAG 4.

WAG 4 consists of three SWMUs: SWMU 4.1- ILLW transfer pipelines, SWMU 4.2-Pilot Pits 1 and 2, and SWMU 4.3-SWSA 4. Of the three SWMUs, SWSA 4 represents the most significant potential for release of radioactive and hazardous contaminants.

The two ILLW transfer pipelines in WAG 4 were used to transport ILLW from the waste processing facilities in Bethel Valley to final disposal sites in Melton Valley. The ILLW line was decommissioned over a 2-year period beginning in 1981 .

The Pilot Pit Area (Bldg. 7811) is located at the extreme southwest corner of WAG 4. It was constructed in late 1955 for use in pilot-scale radioactive waste disposal studies on the sintering of high-level fuel reprocessing waste into a stable solid. Two experiments were conducted during 1956 and 1957, only one of which involved radioactivity.

SWSA 4 (opened in 1951) occupies the majority of the WAG 4 surface area [ 23 acres (9.3-ha)] and was used for the disposal of various solid radioactively contaminated wastes generated by defense- and research-related activities. During the period 1955 to 1963, Oak Ridge was designated by the Atomic Energy Commission as the Southern Regional Burial Ground; as such, Oak Ridge received a wide variety of poorly characterized wastes from approximately 50 different sources, and this waste accounted for approximately $50 \%$ of the total volume buried in SWSA 4. Early records of the amount of waste disposed in SWSA 4 were destroyed by a fire; however, it is estimated that the total waste volume emplaced in SWSA 4 was $\sim 2.0 \times 10^{6} \mathrm{ft}^{3}\left(5.7 \times 104 \mathrm{~m}^{3}\right)$, containing about $1.1 \times 10^{5} \mathrm{Ci}\left(4.1 \times 10^{15} \mathrm{~Bq}\right)$ of radioactivity. The site was closed to routine burial operations in July 1959; however, it remained open as a disposal area for uncontaminated fill until July 1973.

WAG 4 lies within the Copper Creek thrust block and is underlain by strata of the middle to late Cambrian Conasauga Group. Strata that underlie the ridges in the WAG 4 area are the resistant sandstones and dolomites. Silty to clayey red-yellow and red-brown podzols occur in the area. Soil depths from 10 to $26 \mathrm{ft}$ and may range up to $50 \mathrm{ft}$ in some areas. Within WAG 4, native soils have been reworked and fill materials imported to accommodate operational and disposal activities.

WAG 4 is located in the Melton Valley portion of the WOC watershed. The principal natural drainage feature within WAG 4 is SWSA 4 Tributary, an intermittent stream that flows northeast to WOC. Both WOC and SWSA 4 Tributary receive runoff from WAG 4 before they join and flow 
southwest to White Oak Lake. SWSA 4 Tributary is generally recognized as a primary contributor of the total ${ }^{90} \mathrm{Sr}$ discharge to WOC.

Two surface water diversion projects were undertaken in SWSA 4 to isolate the burial trenches from the upslope discharge area. The first project was constructed in 1975 and included a surface runoff collection and diversion system; it did not reduce ${ }^{90} \mathrm{Sr}$ released in surface water from SWSA 4. The second project was constructed in 1983 to route drainage from Haw Ridge around SWSA 4; net discharge of ${ }^{90} \mathrm{Sr}$ flux at White Oak Dam did not show any apparent reduction in ${ }^{90} \mathrm{Sr}$ discharge in three subsequent water years.

Six of the seeps associated with release of ${ }^{90} \mathrm{Sr}$ into SWSA 4 Tributary have been identified as the subject of a removal action within the WAG because they present levels of potential risk that exceed U.S. Environmental Protection Agency thresholds at the Oak Ridge Reservation boundary. The WAG 4 seeps removal action goal is to reduce the ${ }^{90} \mathrm{Sr}$ released from WAG 4 by $35 \%$ within the first 3 years and $75 \%$ within 10 years through source control using grout to reduce conductivity.

\subsection{REFERENCES}

Baughn, D. C. 1987. Preliminary Geohydrologic Site Characterization and Proposed Water Quality Well Locations for WAG 4, WAG 5, WAG 3, and SWSA 1, ORNL/RAP/Sub-86/72139/1, MCI Consulting Engineers, Knoxville, Tenn.

Bechtel (Bechtel National, Inc.) 1988. Remedial Investigation Plan for ORNL Waste Area Grouping 4, ORNL/RAP/Sub-87/99053/11, Oak Ridge Natl. Lab.

Boegly, W. J., Jr. 1957. The Sintering of Reactor Wastes-Problems Associated with the Formation of Ceramic Clinkers, TID-7550, U.S. Atomic Energy Commission, Washington, D.C.

Boegly, W. J., Jr., and E. G. Struxness 1959. "An Experimental Facility for High-Level Waste Fixation Studies," in Industrial Radioactive Waste Disposal: Hearings Before the Special Subcommittee on Radiation of the Joint Committee on Atomic Energy, Vol. 3, U.S. Government Printing Office, Washington, D.C., 1951-65.

Davis, E. C., et al. 1985. Water Diversion at Low-Level Waste Disposal Sites, ASCE J. Environ. Eng. Div. 11(5): 714-29.

Duguid, J. O. 1975. Status Report on Radioactivity from Burial Grounds in Melton and Bethel Valleys, ORNL-5017, Union Carbide Corp. Nuclear Div., Oak Ridge Natl. Lab.

Duguid, J. O. 1976. Annual Progress Report of Burial Ground Studies at Oak Ridge National Laboratory: Period Ending September 30, 1975, ORNL-5141, Oak Ridge Natl. Lab.

Ebasco (Ebasco Services, Inc.) 1992. Baseline Report for Waste Area Grouping 4 at Oak Ridge National Laboratory, Oak Ridge, Tennessee, Volume 1: Text, ORNL/ER-97/V1, Oak Ridge Natl. Lab.

Energy Systems (Martin Marietta Energy Systems, Inc.) 1992. Oak Ridge Reservation Environmental Report for 1991, ES/ESH-22/V1 and ES/ESH-22/V2, Martin Marietta Energy Systems, Inc., Oak Ridge, Tenn. 
Energy Systems 1995. Site Investigation Report for Waste Area Grouping 4 at Oak Ridge National Laboratory, Volume 1: Text, ORNL/ER-329/V1, Martin Marietta Energy Systems, Inc., Oak Ridge, Tenn.

Huff, D. D., N. D. Farrow, and J. R. Jones 1982. "Hydrologic Factors and ${ }^{90} \mathrm{Sr}$ Transport: A Case Study," Environmental Geology, 4, 53-63.

Jacobs (Jacobs ER Team) 1995a. Interim Action Proposed Plan for Waste Area Grouping 4 Seeps, Oak Ridge National Laboratory, Oak Ridge, Tennessee, DOE/OR/02-1490\&D1, Oak Ridge Natl. Lab.

Jacobs (Jacobs ER Team) 1995b. Engineering Evaluation/Cost Analysis for Waste Area Grouping 4 Seeps, Oak Ridge National Laboratory, Oak Ridge, Tennessee, DOE/OR/02-1490\&D2, Oak Ridge Natl. Lab.

Jacobs (Jacobs ER Team) 1995c. Action Memorandum for the Waste Area Grouping 4 Seeps, Oak Ridge National Laboratory, Oak Ridge, Tennessee, DOE/OR/02-1440\&D1, Oak Ridge Natl. Lab.

Lomenick, T. F., and K. E. Cowser 1961. Status Report on Evaluation of Solid Waste Disposal at ORNL: II, ORNL-3182, Oak Ridge Natl. Lab.

Melroy, L. A., and D. D. Huff 1985. Evaluation of a Flow Diversion System for Reducing ${ }^{90}$ Sr Migration from SWSA 4 to White Oak Creek, ORNL/TM-9374, Oak Ridge Natl. Lab.

Morgan, K. Z., et al. 1956a. Health Physics Division Semi-Annual Progress Report for Period Ending January 31, 1956, ORNL-2049, Oak Ridge Natl. Lab.

Morgan, K. Z., et al. 1956b. Health Physics Division Semi-Annual Progress Report for Period Ending July 31, 1956, ORNL-2151, Oak Ridge Natl. Lab.

Morgan, K. Z., et al. 1958. Health Physics Division Annual Progress Report for Period Ending July 31, 1958, ORNL-2590, Oak Ridge Natl. Lab.

National Research Council 1985. The Management of Radioactive Waste at the Oak Ridge National Laboratory: a Technical Review, DOE/DP/48010-T1, National Research Council, Washington, D.C.

ORNL (Oak Ridge Natl. Lab.) 1987. RCRA Facilities Assessment (RFA)—Oak Ridge National Laboratory, ORNL/RAP-12/V1, Oak Ridge Natl. Lab.

ORNL 1990. ORNL Contaminated Site Summary Sheets, ORNL/M-2413, Oak Ridge Natl. Lab.

SAIC (Science Applications International Corp.) 1994. Remedial Investigation Work Plan for the Groundwater Operable Unit at Oak Ridge National Laboratory, Oak Ridge, Tennessee, DOE/OR/01-1252\&D1 (ORNL/ER-221\&D1), Martin Marietta Energy Systems, Inc., Oak Ridge Natl. Lab.

Site and Facilities Planning Department June 1994. Oak Ridge Reservation Technical Site Information, ES/EN/SFP-23, Martin Marietta Energy Systems, Inc., Oak Ridge, Tenn. 
Spalding, B. P., and I. L. Munro 1984. Determination of the Areal Distribution of ${ }^{90} \mathrm{Sr}$ in Groundwater Via Single-Use Boreholes, ORNL/TM-8991, Oak Ridge Natl. Lab.

Stueber, A. M., et al. 1981. An Evaluation of Some ${ }^{90} \mathrm{Sr}$ Sources in the White Oak Creek Drainage Basin, ORNL/TM-7290, Oak Ridge Natl. Lab.

Tamura, T., et al. 1980. Progress Report of Disposal Area Studies at Oak Ridge National Laboratory: Period of October 1, 1975, to September 30, 1977, ORNL-5514, Oak Ridge Natl. Lab.

Walls, A. A., et al. 1983. The Intermediate-Level Waste Transfer Line Decommissioning Project, ORNL/TM-8477, Oak Ridge Natl. Lab.

Webster, D. A., and M. W. Bradley 1986. Hydrology of the Melton Valley Radioactive Waste Burial Grounds at Oak Ridge National Laboratory, Tennessee (Draft), Open-File Report 86-XXX, U.S. Geologic Survey, Oak Ridge, Tenn.

\subsection{BIBLIOGRAPHY}

CDM Federal Programs Corp. 1994. Waste Area Grouping 4 Site Investigation Sampling and Analysis Plan, Oak Ridge National Laboratory, Oak Ridge, Tennessee, DOE/OR-01-1337\&D1, Lockheed Martin Energy Systems, Inc., Oak Ridge, Tenn.

Clapp, R. B., and J. A. Watts, eds. 1995. Fourth Annual Environmental Restoration Monitoring and Assessment Report (FY 1995), Oak Ridge National Laboratory, Oak Ridge, Tennessee, DOE/OR/01-1413\&D1, Oak Ridge Natl. Lab.

Coobs, J. H., and J. R. Gissel 1986. History of Disposal of Radioactive Wastes into the Ground at Oak Ridge National Laboratory, ORNL/TM-10269, Oak Ridge Natl. Lab.

Davis, E. C., and R. R. Shoun 1986. Environmental Data Package for ORNL Solid Waste Storage Area Four, the Adjacent Intermediate Level Liquid Waste Transfer Line, and the Liquid Waste Pilot Pit Area, ORNL/TM-10155, Oak Ridge Natl. Lab.

Francis, C. W., et al. 1993. In Situ Grouting of Low-Level Burial Trenches with a Cement-Based Grout at Oak Ridge National Laboratory, ORNL/TM-11838, Environmental Sciences Div. Pub. 3872, Oak Ridge Natl. Lab.

Martin Marietta Energy Systems, Inc. 1994. Preliminary Assessment Report for Waste Area Grouping 4 at Oak Ridge National Laboratory, Oak Ridge, Tennessee, ORNL/ER-171, Martin Marietta Energy Systems, Inc., Oak Ridge, Tenn.

Melroy, L. A., D. D. Huff, and N. D. Farrow 1986. Characterization of the Near-Surface Radionuclide Contamination Associated with the Bathtub Effect at Solid Waste Storage Area 4, Oak Ridge National Laboratory, Tennessee, ORNL/TM-10043, Oak Ridge Natl. Lab.

Morrison, S. J. and T. E. Cerling 1987. Survey of Metal, Radionuclide and Organic Contamination at 20 Waste Area Groups (WAGs), ORNL Facilities, Oak Ridge, Tennessee, ORNL/RAP/Sub-87/27463/1, Oak Ridge Natl. Lab.

Oak Ridge Natl. Lab. 1994. Preliminary Assessment Report for Waste Area Grouping 4 at Oak Ridge National Laboratory, Oak Ridge, Tennessee, ORNL/ER-271, Oak Ridge Natl. Lab. 


\section{HISTORY AND CHARACTERIZATION OF WAG 5}

Instructions to User
This chapter provides information about WAG 5 that can be cited in certain CERCLA
documents (see Chap. 1 and Table 1 in Instructions to User). For a short description of
WAG 5 that can be copied into other types of documents, see the summary at the end
of this chapter. To keep this document as short as possible, information about
conditions common to all WAGs (e.g., climate and demography) is given in
Chap. 5-History and Characterization of the ORNL Site.

\subsection{SITE DESCRIPTION AND HISTORY}

WAG 5 is located directly south of the ORNL main plant area (Fig. 10.1). The WAG contains 16 Solid Waste Management Units (SWMUs) (Table 10.1); several of these are tanks used to store low-level radioactive waste (LLW) prior to disposal by the hydrofracture process. WAG 5 also includes the surface facilities constructed in support of both the old and new hydrofracture facilities. The largest land areas in WAG 5 are devoted to Solid Waste Storage Area (SWSA) 5 and the Transuranium (TRU) Waste Storage Area. The remaining SWMUs are support facilities for ORNL's hydrofracture operations, two LLW leak/spill sites, three septic tanks, and an impoundment in SWSA 5 used to dewater sludge from the original Process Waste Treatment Plant (PWTP).

Table 10.1. SWMUs in WAG 5

\begin{tabular}{llll}
\hline SWMU & Site name & SWMU & Site name \\
\hline 5.1 & LLW Lines and Leak Sites & 5.9 & $\begin{array}{l}\text { Radioactively Contaminated Waste } \\
\text { Oil Storage Tank 7860A }\end{array}$ \\
5.2 & $\begin{array}{l}\text { Old Hydrofracture Facility (OHF) } \\
\text { Impoundment }\end{array}$ & 5.10 & $\begin{array}{l}\text { SWSA 5 North -TRU Waste } \\
\text { Storage Area }\end{array}$ \\
5.3 & OHF Site Surface Facilities & 5.11 & $\begin{array}{l}\text { Septic Tank 7831 } \\
5.4\end{array}$ \\
$\begin{array}{l}\text { New Hydrofracture Facility (NHF) } \\
\text { Site Surface Facilities }\end{array}$ & 5.12 & Septic Tank 7860 \\
5.5 & Inactive OHF Waste Storage Tanks & 5.13 & Septic Tank 7853 \\
5.6 & Process Waste Sludge Basin & 5.14 & Old Landfill (at NE edge of SWSA 5) \\
5.7 & SWSA 5 South & 5.15 & $\begin{array}{l}\text { Active Liquid Low-Level (radioactive) } \\
\text { Waste (LLLW) Slotting Tank T-13 }\end{array}$ \\
5.8 & $\begin{array}{l}\text { Active LLW Waste Concentrate } \\
\text { Storage Tanks }\end{array}$ & 5.16 & Inactive LLLW Tank T-14 \\
\hline
\end{tabular}

Included in the WAG 5 boundary are the surface facilities for both the old and new hydrofracture installations. It should also be noted that because Melton Branch (part of WAG 2) flows between the old and new hydrofracture facilities, it was necessary to provide a separate WAG boundary for the NHF, even though NHF is considered part of WAG 5 . This was done because a separate WAG was not justified for NHF, and the site's location was next to WAG 5 (ORNL 1987). 
$10-2$

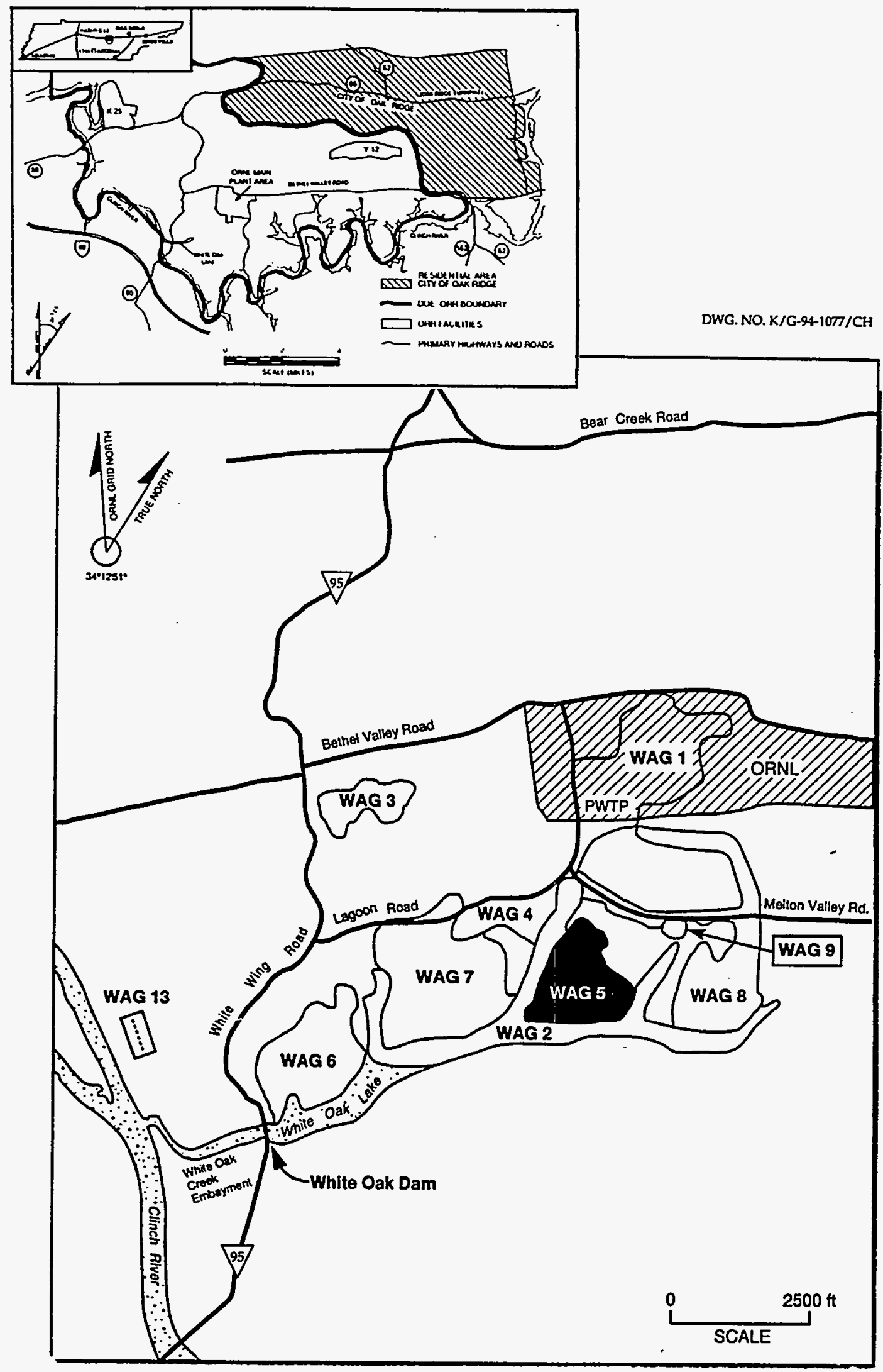

Fig. 10.1. Location of WAG 5. Source: Enserch 1994 
In general, the Old Hydrofracture Facility (OHF) and NHF surface facilities consist of buildings containing pumping equipment, control rooms, mixing equipment, and solids storage and handling equipment. Although listed as separate SWMUs, the OHF Impoundment (SWMU 5.2) and the Radioactively Contaminated Oil Storage Tank at the NHF (SWMU 5.9) are really a part of the hydrofracture surface facilities. The WAG 5 SWMUs are shown in Fig. 10.2 and briefly discussed in the paragraphs below. Additional information about the SWMUs can be found in the Contaminated Site Summary Sheets (ORNL 1990).

\subsubsection{LLW Lines and Leak Sites (SWMU 5.1)}

There are two OHF leak sites: OHF Observation Well Leak Site (SWMU 5.1a) and OHF Grout Release (SWMU 5.1b). There are also some intermediate-level liquid waste (ILLW) and LLW transfer pipelines (SWMU 5.1c,d) located on the west side of WAG 5 that are potential leak sites.

OHF Observation Well Leak (SWMU 5.1a)-This leak resulted from water flowing from an observation well (S-100) drilled as part of the fracturing experiments at the OHF. The leak occurred in 1968 and is located in the southern part of the OHF site at ORNL coordinates N17,050 and E28,620.

OHF Grout Release (SWMU 5.1b)-This leak is the result of a contaminated grout release from $\mathrm{OHF}$. The leak is located near Building 7852 at ORNL coordinates N17,200 and E28,550.

ILLW/LLW Transfer Pipelines (SWMU 5.1c,d)-The ILLW Transfer Pipeline refers to the older waste transfer pipeline, which was installed prior to the reclassification of ILLW as LLW. The ILLW was defined at ORNL as liquid waste with a specific activity of about $0.3 \mathrm{mCi} / \mathrm{L}$ (PEER and MCI 1987). The ILLW transfer pipeline is a 2-in. diameter cast iron pipe completed in 1965 and used to transfer liquid radioactive waste from ORNL storage tanks to the OHF Waste Storage Tanks (Duguid and Sealand 1975). Previously, the ILLW transfer pipeline was used to transfer waste from the tanks to the seepage pits and trenches. There are no reported transfer pipeline leaks within the WAG 5 boundary.

\subsubsection{OHF Impoundment (SWMU 5.2)}

The OHF Impoundment is located northwest of the waste pits. The impoundment was used as an emergency storage basin for grout during the hydrofracture operation. It was constructed in 1963 with bottom dimensions of $20 \times 100 \mathrm{ft}$ and side slopes at 1 vertical to 1.5 horizontal. The depth of the impoundment is slightly greater than $5 \mathrm{ft}$ at the low (west) side and has a capacity of 100,000 gal. The sides are lined with limestone riprap varying in diameter. Inflow was at the south end of the impoundment via a buried 18-in. line from the injection well cell. An 8-in. line from a waste pit, which was part of the injection operation, is also shown on drawings as entering the impoundment

at the same location. Construction drawings specified that the impoundment bottom be sprayed with liquid asphalt to control erosion and that a plastic liner be placed prior to experimental injections. However, no evidence of either of these treatments was observed during sediment sampling in 1986 by Stansfield and Francis.

The impoundment has an emergency spillway provided by a concrete standpipe located at the north end. The standpipe is connected with a drain pipe that goes through the bottom of the pond and extends $50 \mathrm{ft}$ to the west toward the White Oak Creek (WOC) floodplain.

In 1965 and 1977, pump system malfunctions caused unknown quantities of radioactive grout to be diverted to the impoundment. Before the impoundment was contaminated by radioactive waste, 


$$
\text { - }
$$




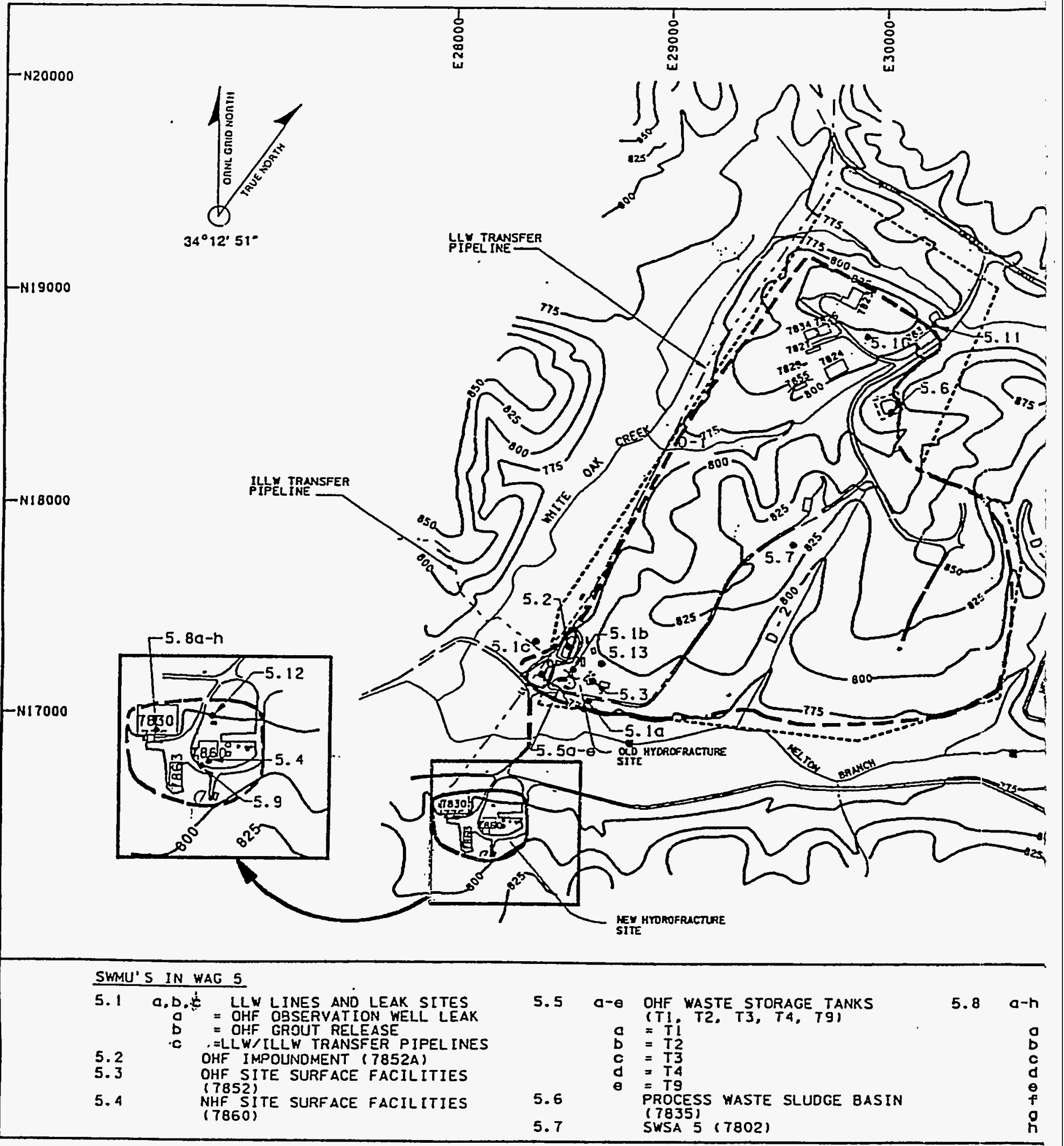

Source: Bechtel 1988

Fig. 10.2. Location of SWMUs in WAG 5. 


\section{NOTES}

1. TOPOGRAPHIC AND SITE SPECIFIC INFORMATION PROVIDED BY ENERGY SYSTEMS IORNL DWG NO C-20923-EA-001-E).

2. ORNL GRID.

\section{LEGEND}

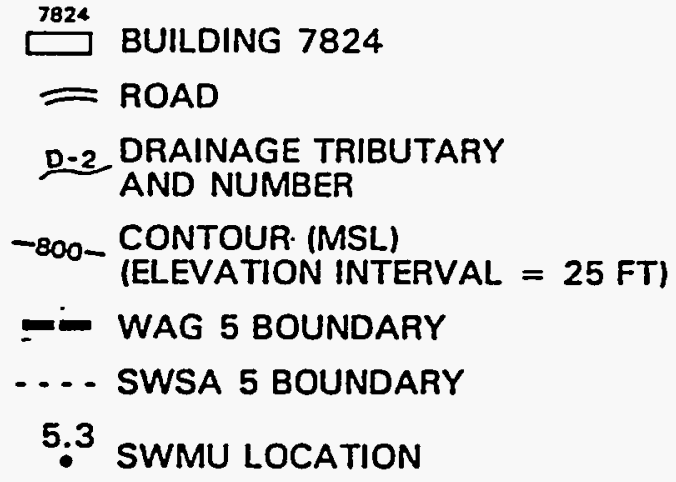


water was siphoned to the WOC floodplain. Following radioactive contamination of the impoundment, the water was pumped to the LLW treatment system for processing. Currently, no pumping activities are being implemented at the OHF Impoundment.

The 1986 study by Stansfield and Francis indicated radiological and chemical contaminants present within the sediment and liquid samples taken from the impoundment. Probings made during this study indicate that the thickness of the sediment in the impoundment averages approximately $11 \mathrm{in.}$ This amounts to approximately $1950 \mathrm{ft}^{3}$ of sediment.

\subsubsection{OHF Site Surface Facilities (SWMU 5.3)}

The OHF is located in the southwest part of SWSA 5, approximately $390 \mathrm{ft}$ to the northeast of the confluence of WOC and Melton Branch. Construction of the OHF began in the spring of 1963 . Between 1964 and 1979, the OHF was used for the permanent disposal of liquid radioactive waste in low-permeability shale formations at well bore depths between 780 and $950 \mathrm{ft}$. The grout mixture was composed of cement, special clays, and radioactive liquid or sludge waste. The mixing and blending of solids occurred in bins surrounding the injection well prior to mixing with the waste in the mixing cell.

The OHF site surface facilities (SWMU 5.3) include Buildings 7852 and 7853, T-4 waste pit, pump house, and all the above-ground tanks and bins. Waste containment facilities such as the OHF Waste Storage Tanks (Tanks T-1, T-2, T-3, T-4 and T-9) (SWMU 5.5a-e), the OHF Impoundment (SWMU 5.2), and the Septic Tank at Building 7853 (SWMU 5.13) are discussed in Sections 10.1.5, 10.1.2, and 10.1.13, respectively.

\subsubsection{NHF Site Surface Facilities (SWMU 5.4)}

The NHF Site is located southwest of the OHF on the south side of Melton Branch. The NHF Site is enclosed by a fence and has a surface area of approximately $240,000 \mathrm{ft}^{2}$.

After the closure of the OHF in 1979, the NHF was constructed and used to inject radioactive waste from June 1982 through January 1984. Prior to injection, concentrated LLW/TRU waste sludges sluiced from the South Tank Farm Gunite tanks (Tanks W-5 through W-10) in WAG 1 were pumped to, and stored in, the LLW Concentrate Storage Tanks (W-24 through W-31). The NHF was designed to inject about 140,000 gal of grout per injection, although actual grout and waste injections averaged about 220,000 gal for each of the 13 injections. The facility operated in a batch mode, in which solids were blended in blending tanks and then stored in bulk storage tanks prior to being mixed with waste and subsequent injection (Bechtel 1988).

The NHF site surface facilities consist of the injection well, a network of observation and monitoring wells associated with hydrofracturing, a storage tank for the slotting waste wash-up solutions, an emergency waste storage tank, storage bins for the dry solids mix, a solids-liquid mixer, a mixing tub, and an injection pump and associated high pressure piping.

\subsubsection{Inactive OHF Waste Storage Tanks (SWMU 5.5a-e)}

The OHF Waste Storage Tanks consist of Tanks T-1, T-2, T-3, T-4, and T-9. The tanks were used during OHF operations to store liquid waste until it was ready to be blended with grout for hydrofracture injection. The OHF operations were discontinued in 1980, and all the tanks are considered to be inactive. No tank leaks have been reported; however, water samples taken from the dry wells have shown slightly elevated levels of beta activity (maximum of $1.2 \mathrm{~Bq} / \mathrm{mL}$ ). Also, the 
soil core taken adjacent to Tank T-4 showed some elevated levels of gamma activity at depths of approximate $5 \mathrm{~m}$. Therefore, it is possible that one or more of these five carbon steel tanks, which are susceptible to rust (although cathodically protected), may have developed leaks over the years. Because of possible risk to human health and the environment, a project is currently underway to remove the contents of these tanks; see Sect. 10.4 .3 for a description of the project.

\subsubsection{Process Waste Sludge Basin (SWMU 5.6)}

The Process Waste Sludge Basin is located in the northern part of SWSA 5 South, next to the surface drainage divide $\mathrm{D}-1$. The basin was used for the storage and decantation of sludge produced by the ORNL PWTP from 1976 to 1981 . The outside dimensions of the basin are $85 \times 85 \mathrm{ft}$, with a depth of $7.8 \mathrm{ft}$. Prior to use, a polyvinyl chloride liner was placed on the compacted clay bottom of the basin. The sludge remained in the basin while the supernatant was pumped backed to the PWTP. Presently, the basin perimeter is fenced, with the surface exposed to the elements. The basin contains standing water, with approximately $4 \mathrm{ft}$ of sludge and sediment on the bottom. Sludge constituents have been identified as ferrous sulfate and ferric hydroxide, with some fission products present. As much as $50 \mathrm{Ci}$ may be contained in the 4-ft layer of sediment (Bechtel 1988).

\subsubsection{SWSA 5 South (SWMU 5.7)}

SWSA 5 (Fig. 10.3) was opened in 1959 as SWSA 4 neared fill capacity. The SWSA 5 site is located in Melton Valley on a hillside east of WOC between SWSA 4 and Melton Branch. SWSA 5 is composed of two distinct geographical areas that provide different solid waste storage functions. SWSA 5 South (SWMU 5.7) has been used for routine disposal of LLW and nonretrievable TRU waste. SWSA 5 North (SWMU 5.10) has been used almost exclusively for retrievable storage of all TRU waste generated after 1970 (Oakes and Shank 1979).

SWSA 5 South slopes moderately to the south, with drainage generally from northeast to southwest. Two surface water systems border the SWSA 5 South burial grounds: WOC on the west and Melton Branch on the south.

During the operation of SWSA 5 South, waste accepted for disposal included poorly characterized solid LLW wastes generated by the ORNL main plant facilities from 1959 to 1973 and wastes from approximately 50 different agencies from 1955 to 1963 , when ORNL was designated as the Southern Regional Burial Ground by the Atomic Energy Commission (now DOE). Existing records indicate $3 \times 10^{6} \mathrm{ft}^{3}$ of waste containing approximately $200,000 \mathrm{Ci}$ of radioactivity have been buried in SWSA 5 South. The buried waste was primarily solid LLW, but prior to the designation of the northern portion as the TRU Waste Storage Area in 1970, an unknown quantity of TRU wastes was also buried in SWSA 5 South (Bechtel 1988).

\subsubsection{Active LLW Concentrate Storage Tanks (SWMU 5.8)}

The Active LLW Concentrate Storage Tanks consist of Tanks W-24 through W-31. Construction of the tanks was initiated in 1976 (Shoun 1987) at the NHF facility, inside Building 7830. The tanks were commissioned in 1980. These tanks are used to store the concentrated LLW from the Evaporator Facility (Building 2531) via Tanks W-23, C-1, and C-2. Transfer from the evaporator tanks in Bethel Valley to the Active LLW Concentrate Storage Tanks in Melton Valley is through a double-contained stainless steel pipeline [LLW transfer pipeline (SWMU 5.1c)]. This pipeline is buried in a specially prepared bed of clay and is cathodically protected. During active operations of NHF, the LLW concentrate stored in these tanks was disposed by the hydrofracture process. Since ORNL has discontinued use of the hydrofracture process, concentrated waste is 


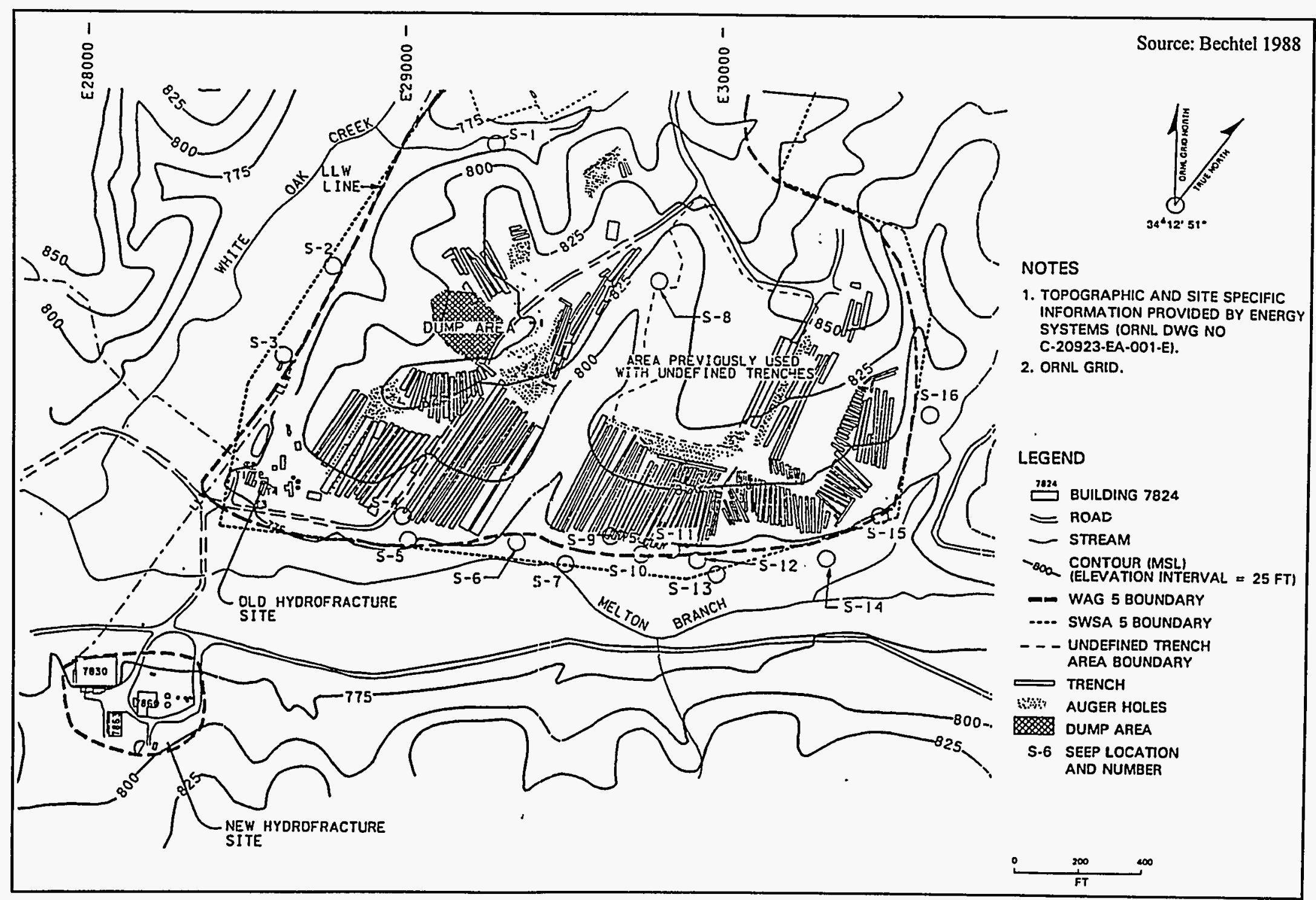

운

Fig. 10.3. Map of SWSA 5 South. 
currently being stored in these tanks until it can be disposed by a solidification process (ORNL 1987). The tanks will also be used to receive liquids from the vault sumps from the discontinued hydrofracture process (ORNL 1987).

Tanks W-24 through Tank W-31 (SWMU 5.8a-h) are horizontal, stainless steel tanks with an outside diameter of $12 \mathrm{ft}$, a length of $60 \mathrm{ft}$, and a capacity of 50,000 gal. The tanks were installed in a common stainless steel-lined concrete vault (double containment). In the vault, a concrete dividing wall separates Tanks W-24 through W-27 from Tanks W-28 through W-31. On each side of the dividing wall, there is a dry well for leak detection. The tanks are positioned $15 \mathrm{ft}$ center-to-center within the vault and are ventilated to the atmosphere through a high-efficiency particulate air filter. Each tank is still active and connected to a double-contained transfer pipeline from Bethel Valley. The tanks are currently active, and no leaks or spills have been reported. The radioactive contaminants in the tank contents were found to mainly consist of ${ }^{137} \mathrm{Cs},{ }^{90} \mathrm{Sr},{ }^{60} \mathrm{Co}$, and TRU.

\subsubsection{Radioactively Contaminated Waste Oil Storage Tank 7860A (SWMU 5.9)}

Tank $7860 \mathrm{~A}$ was installed in 1981 at the NHF and was active until 1985, being used to store small quantities of waste oil contaminated with radionuclides as a result of use in the pumps and other equipment associated with the NHF facility. The tank is $20 \mathrm{ft}$ east of the southeast corner of the Building 7863 and $60 \mathrm{ft}$ south of the southwest corner of the Building 7860.

Tank 7860A is a horizontal, stamped-pressure vessel constructed of mild steel, with no interior liner. The tank has an outside diameter of $6.5 \mathrm{ft}$, a length of $15 \mathrm{ft}$, and a capacity of approximately 4,500 gal (PEER and MCI 1987). The tank rests on a concrete pad and has three penetrations in the manhole cover. These penetrations were added to facilitate connections for venting, filling, and pumping. No underground piping or other ancillary equipment exists for the tank, and the tank is covered by approximately 18 in. of soil.

Tank $7860 \mathrm{~A}$ was previously used as the receiver tank for the compressed air system that served Building 7600. The operating procedures called for neutralizing all incoming waste to prevent corrosive attack on the Gunite walls (Horton 1984). The tank received waste from vacuum pumps, pressure pumps, cooling systems, and other hydraulic systems that produced contaminated lubricants (Burwinkle 1987). The tank was taken out of service in 1985 when hydrofracture operations were curtailed. Tank 7860A is currently controlled by the Operations Division and is believed to be structurally sound, with no leaks (Burwinkle 1987).

\subsubsection{SWSA 5 North-TRU Waste Storage Area (SWMU 5.10)}

Since October 1970, when segregation of waste began, TRU waste has been stored in SWSA 5 North (Fig. 10.4), either in stainless steel drums, mild steel boxes, concrete casks, or stainless steel-lined wells. TRU waste is further categorized by individual DOE field offices as contact-handled $(\mathrm{CH})$, remote-handled $(\mathrm{RH})$, or buried waste. CH-TRU waste exhibits a dose rate of less than $200 \mathrm{mrem} / \mathrm{h}$ at the surface of the package. RH-TRU waste exhibits a dose rate greater than $200 \mathrm{mrem} / \mathrm{h}$ at the surface of the package (Bates 1987).

The CH-TRU wastes were packaged in stainless steel drums or boxes and held temporarily in a staging facility, Building 7823. Drums were placed in partially underground storage facilities, Buildings 7826 and 7834; the CH-TRU waste boxes remain in Building 7823 (Bechtel 1988).

The RH-TRU wastes, which require shielding before disposal, were placed in concrete casks. Until 1980, these casks were buried in the trench area. Currently, the casks are stored in 


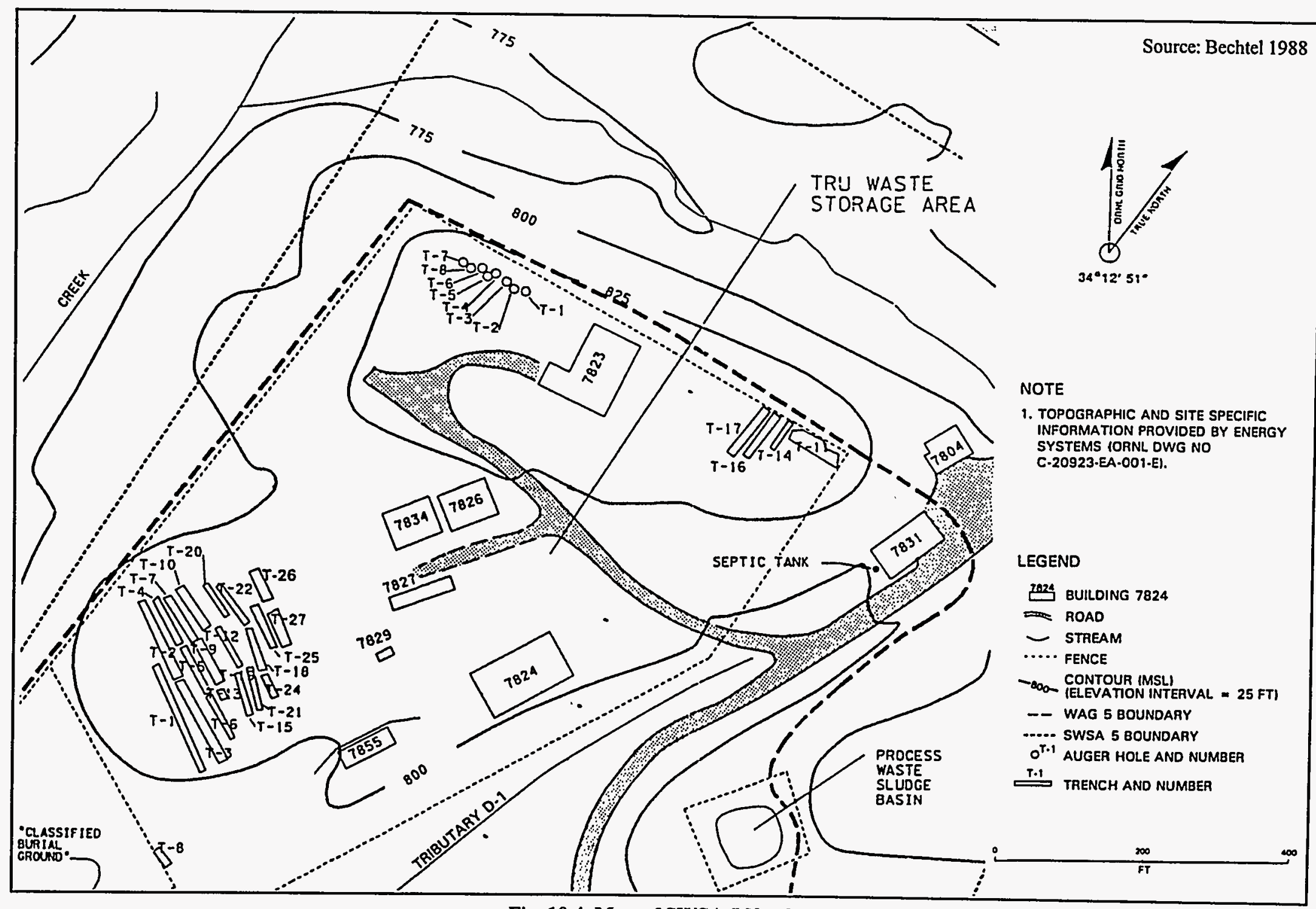

Fig. 10.4. Map of SWSA 5 North. 
Building 7855. The high-activity, beta-gamma background RH-TRU wastes were placed in capsules and then retrievably stored below ground in stainless steel-lined wells in Buildings 7827 and 7829 .

In addition to the storage facilities, SWSA 5 North contains the following:

- Building 7824, which is used for storing miscellaneous equipment and houses the Waste Examination Assay Facility;

- The Solid Waste Compactor Facility (Building 7831), located outside the interior fence near the WAG 5 main entrance gate;

- Building 7804, which is used for equipment storage and maintenance, located near the WAG 5 main gate entrance; and

- a classified burial ground surrounded by a secondary security fence, located in the southwest corner of the TRU Waste Storage Area.

\subsubsection{Septic Tank 7831 (SWMU 5.11)}

Septic Tank 7831 is located on the southwest side of Building 7831 in SWSA 5 North. The septic tank is a concrete structure with a capacity of $500 \mathrm{gal}$, used to collect and dispose of raw domestic sewage from Building 7831. The installation date of the septic tank is not known, and it is still in service. Only domestic sewage from Building 7831 has been collected and stored in the tank. No leaks or releases have been reported, and no hazardous or radioactive wastes have been added to the system. Septic tank contents are periodically pumped into a tanker truck and disposed in the ORNL Sewage Treatment Plant; therefore, there is no drain field associated with the septic tank.

\subsubsection{NHF Septic Tank 7860 (SWMU 5.12)}

NHF Septic Tank 7860 is located in the southwest corner of WAG 5, just east of Building 7860 at the NHF site. The septic tank is a concrete structure with a capacity of 500 gal, used to collect and dispose of raw domestic sewage from Building 7860. The septic tank was installed in 1978 and is currently in service. Only domestic sewage from Building 7860 has been collected and stored in the tank. No leaks or releases reported, and no hazardous or radioactive wastes have been added to the system. Septic tank contents are periodically pumped into a tanker truck and disposed in the ORNL Sewage Treatment Plant; therefore, there is no drain field associated with the septic tank.

\subsubsection{OHF Septic Tank 7853 (SWMU 5.13)}

OHF Septic Tank 7853 is located in the vicinity of Building 7853 at the OHF site. The septic tank is a concrete structure with a capacity of 750 gal, used to collect and dispose of raw domestic sewage from Building 7853. The septic tank was installed in 1968 and is currently not in service. Only domestic sewage from Building 7853 has been collected and stored in the tank. No leaks or releases reported, and no hazardous or radioactive wastes have been added to the system. Septic tank contents are periodically pumped into a tanker truck and disposed in the ORNL Sewage Treatment Plant; therefore, there is no drain field associated with the septic tank.

\subsubsection{Old Landfill (at NE Edge of SWSA 5) (SWMU 5.14)}

The landfill, which was used as a dump site for noncontaminated rubbish from ORNL operations, is located at the northeast edge of SWSA 5 at ORNL grid coordinates $N$ 18,170, 
E 30,150. The dates of operation, dimensions, and capacity are unknown. Wastes disposed of in the Old Landfill include general rubbish, debris, metal containers, and other noncontaminated items.

\subsubsection{Active LLLW Slotting Tank T-13 (SWMU 5.15)}

Tank T-13 is a $304 \mathrm{~L}$ stainless steel tank with a 4000 gal capacity, located at the NHF at ORNL grid coordinates N 16,500, E 28,180. The tank collects inleakage into hot cells at NHF; the contents are piped into the evaporator of the LLLW system. The tanks was in operation from 1982 to 1985 and is currently on standby status. No analysis of wastes contained in the tank are available, but no hazardous waste constituents or radionuclides should be present (ORNL 1990).

\subsubsection{Inactive LLLW Tank T-14 (SWMU 5.16)}

Tank T-14 is an unlined concrete tank with a 48,500 gal capacity, located at the NHF at ORNL grid coordinates $\mathrm{N} 16,500, \mathrm{E} 28,180$. The tank, which was designed to collect drainage from the well cell, was in service from 1982 to 1985 and is currently on standby status. Wastes handled in the collection system were routinely generated LLLW, including ${ }^{90} \mathrm{Sr},{ }^{137} \mathrm{Cs},{ }^{60} \mathrm{Co}$, and various rare earths. Some plutonium, uranium and TRU isotopes were also present in the waste streams.

\subsection{CHARACTERIZATION}

\subsubsection{Geography}

WAG 5 is located on the ORR in Roane County, Tennessee, approximately 5 miles southwest of the city of Oak Ridge central business district and 1 mile south of the ORNL main plant area (Fig. 10.1). WAG 5 is bounded to the south and west by WAG 2 and to the east by WAG 9. Melton Valley Drive parallels the northern limit of the site, which lies on the foot slope of Haw Ridge.

WAG 5 is located in Melton Valley within the Valley and Ridge physiographic province. WAG 5 lies between Chestnut Ridge [1100 $\mathrm{ft}$ Mean Sea Level (MSL)], to the northwest, and Copper Ridge (1400 $\mathrm{ft} \mathrm{MSL}$ ), to the southeast. Bethel Valley ( $775 \mathrm{ft} \mathrm{MSL}$ ) is separated from Melton Valley ( $740 \mathrm{ft} \mathrm{MSL}$ ) to the southeast by Haw Ridge (1000 ft MSL).

\subsubsection{Climate}

See Sect. 5.2.2 of this document for climate description.

\subsubsection{Demography}

At the closest point, WAG 5 is approximately 1 mile from the ORNL main plant area (Fig. 10.1), where the majority of ORNL's approximately 4837 employees work (Site and Facilities Planning Department 1994). Within 1 mile of the boundary of WAG 5, all land is federally owned, and there are no residents. The two-lane State Highway 95 runs through the ORR and passes along the western side of WAG 5 within 1 mile of its boundary at the closest point. WAG 5 is approximately 1 mile from the north bank of the Clinch River, which forms a portion of the boundary of the ORR. The Clinch River, also known as Watts Bar Lake at this location, is open to recreational uses, such as boating, fishing, and duck and goose hunting, as permitted by the State of Tennessee.

See Sect. 5.2.3 of this document for general demographic characteristics of ORNL. 


\subsubsection{Geology and Soils}

WAG 5 is in Melton Valley within the Copper Creek thrust block and is underlain by strata of the middle to late Cambrian Conasauga Group. The Conasauga Group is approximately $1877 \mathrm{ft}$ thick and lithologically heterogeneous. It is structurally complex, consisting of alternating beds of siltstones, silty limestones, calcareous shales, and mudstones. At least two types of faults are identified: the Copper Creek Thrust Fault, which is exposed at the surface on the north side of Haw Ridge, and several tear fault systems oriented perpendicular to the thrust fault motion and the strike of the valley. Other structural features of the Conasauga Group include localized folding, bedding plane and vertical fractures, and joint sets. Solution features have also been observed.

Strata that underlie the ridges in the WAG 5 area are the resistant sandstones and dolomites; the less resistant limestones and shales occur in the valleys. Both Chestnut Ridge and Copper Ridge are formed by the Knox Group, a light-to-dark gray, dolomitic limestone with prominent zones of chert. Haw Ridge is formed by the Rome Formation, which consists of evenly bedded, fine-grained sandstone and shale. Melton Valley is underlain by the Conasauga Group. Six formations comprise the Conasauga Group (in ascending order): the Pumpkin Valley Shale, the Rutledge Limestone, the Rogersville Shale, the Maryville Limestone, the Nolichucky Shale, and the Maynardville Limestone. The Conasauga Group is made up predominantly of shale with alternating and predominant intervals of siltstone, silty limestone, and mudstone.

Silty to clayey red-yellow and red-brown podzols, common throughout the southeastern United States, occur in the ORNL area. Generally, the soils are moist, low in organic matter, strongly leached and acidic, with a pH of 4.5 to 5.7. Soils derived from the Conasauga Group typically contain illite and vermiculite as principal clay minerals. Those from the Chickamauga Group contain a mixture of kaolinite, illite, and montmorillonite clays. Piezometer well drill logs indicate that WAG 5 soils are predominantly medium brown to gray-green, silty clay containing gravel-sized rock and weathered shale fragments. The soil is composed of low- to high-plasticity clay and silt. This residual soil forms stable slopes with inclinations of 3:1 or less. Soil depths in WAG 4 range from 10 to $26 \mathrm{ft}$. Preliminary seismic data indicate that the soil depths may range up to $50 \mathrm{ft}$ in some areas.

The presence of clay minerals in soils associated with WAG 5 enhances the ability of the soils to retard the migration of radioactive and hazardous constituents by (1) mechanical filtering, (2) adsorption of electrochemically charged ionic constituents on the surface of the clay particles, (3) absorption of ionic species within the mineralogical lattice structure, and (4) ion exchange with particles already adsorbed on the surface of the clay particle. Soil core samples taken across WAG 5 indicate that contamination is migrating through the soil column.

Chemical weathering strongly affects soil formation in both the Chickamauga and Conasauga groups. The depth of weathering in the Chickamauga Group is typically less than $10 \mathrm{ft}$. Bedding and structures within the rock are not retained much above the fresh rock surface because chemical weathering in the limestone is so complete. In the Conasauga Group, the depth of weathering reportedly ranges up to $40 \mathrm{ft}$ and is closely tied to topography, with thinner zones in low-lying areas and thicker zones on the ridges.

\subsubsection{Surface Water}

WAG 5 lies in the Melton Valley portion of the WOC watershed. There are four streams in its immediate vicinity: WOC to the west, Melton Branch to the south, and two unnamed creeks to the east and north (Fig. 10.5). All four streams lie close to, but outside, the WAG 5 boundary. Both Melton Branch and WOC lie between 100 to $300 \mathrm{ft}$ of the WAG 5 boundary. There are no perennial 
streams within WAG 5; the two principal natural drainages are intermittent. One (D-1) flows southwestward to WOC and drains mainly the TRU Waste Storage Area, whereas the other (D-2) flows approximately southward and drains portions of SWSA 5 South (Fig. 10.6). A substantial portion of surface runoff does not flow in well-defined channels but flows as sheet flow. Some of the runoff from the SWSA 5 South area is intercepted by perimeter concrete channels. A third drainage (D-3) lies just outside the WAG 5 boundary to the east. This drainage is fed in part by runoff from the SWSA 5 South burial area.

Discharge of all surface runoff from WAG 5 is either to the WOC or to Melton Branch. Surface water drainage in SWSA 5 South is, however, predominantly southeast to Melton Branch. Therefore, most of the radionuclide transport from SWSA 5 is monitored at Station 4 (Fig. 10.5) on Melton Branch (Myrick 1984). There is no record of flooding of any portion of WAG 5 by WOC or Melton Branch.

There are two important man-made surface water features within WAG 5: the OHF Impoundment at the southeast corner of WAG 5 and the Process Waste Sludge Basin north of SWSA 5. In addition, 16 groundwater seeps have been identified around the perimeter of SWSA 5 South (Fig. 10.3).

A diagram showing general routes of water and contaminant movement from the hypothetical trench to the surface environment is shown in Fig. 10.7. Contamination characterization studies have been performed in the past for OHF impoundment sediments and water, Process Waste Sludge Basin sediments, surface water from the drainage that divides WAG 5 into north and south areas, and seeps from SWSA 5.

\subsubsection{OHF Impoundment contamination characterization}

Two studies have been conducted to characterize the contaminants present in the OHF Impoundment sediments. The first one is an undocumented study by Huang which is referenced in the second study by Stansfield and Francis (1986). Results obtained in the latter study are summarized here; discrepancies between the results of the two studies are also noted. A third recently published study (Francis and Sealand 1987) generally corroborates the findings of Stansfield and Francis.

Sediment samples were taken from the north, center, and south sections of the impoundment. Two sets of samples were obtained; the first in November 1984 and the second in February 1985. The purpose of the sampling was to determine whether the sediment waste in the bottom of the OHF Impoundment would be classified as a hazardous waste under the Comprehensive Environmental Restoration, Compensation, and Liability Act (CERCLA) or Resource Conservation and Recovery Act (RCRA) regulations. The $\mathrm{pH}$ of the sediment slurry was found to be 5.2; thus, the waste does not have the characteristic of corrosivity as defined by the U.S. Environmental Protection Agency (EPA).

Where detection limits were low enough, the concentrations of RCRA-regulated constituents measured in the extraction procedure toxicity extracts were well below RCRA maximum allowable concentrations. The mean concentration of selenium of $1.205 \mathrm{mg} / \mathrm{L}$ is higher than the allowable limit $(1.0 \mathrm{mg} / \mathrm{L})$; however, the mean value is suspect because of the high analytical detection level for selenium. 
OAML-DWO $11-21024 n$

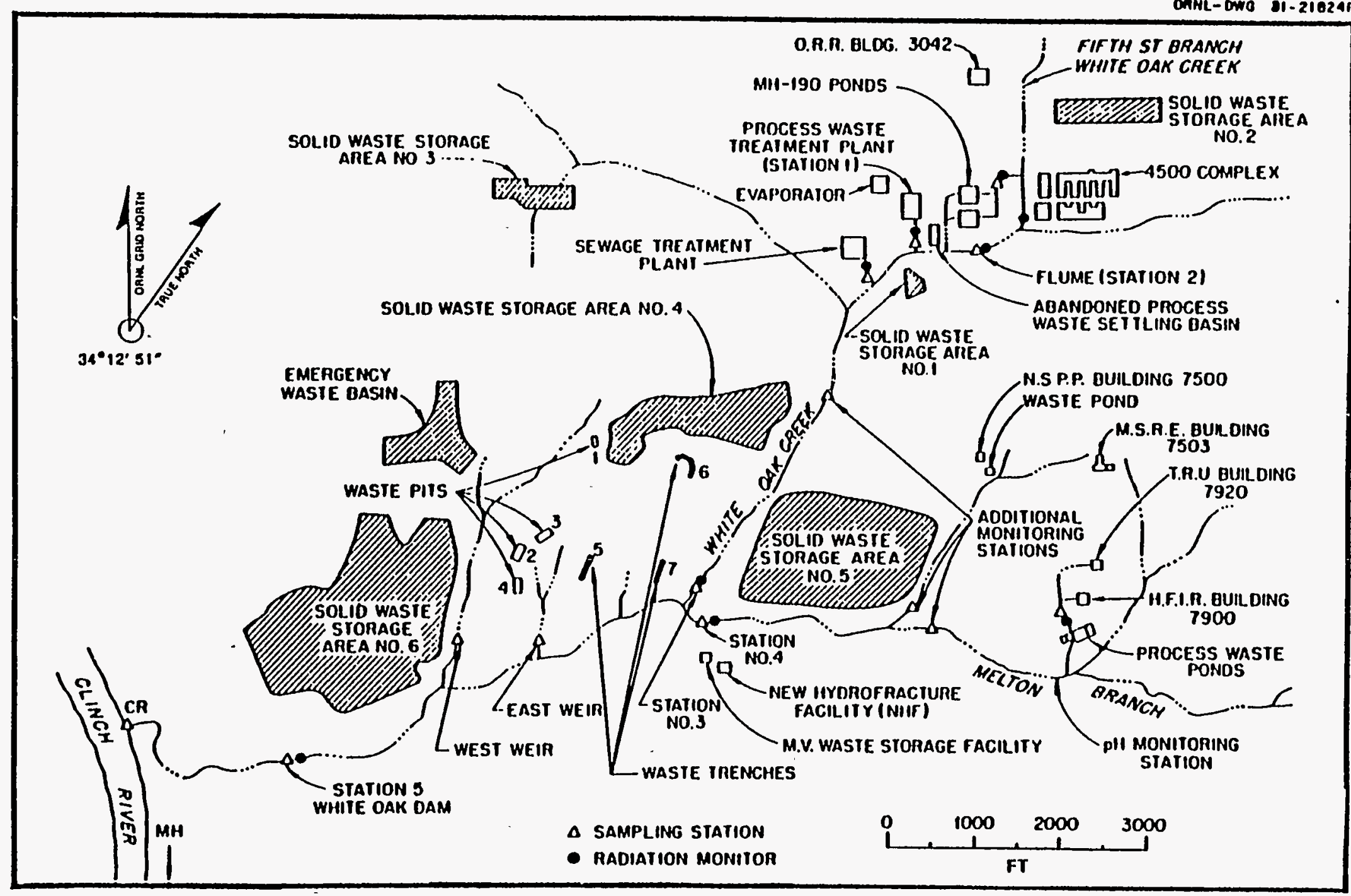




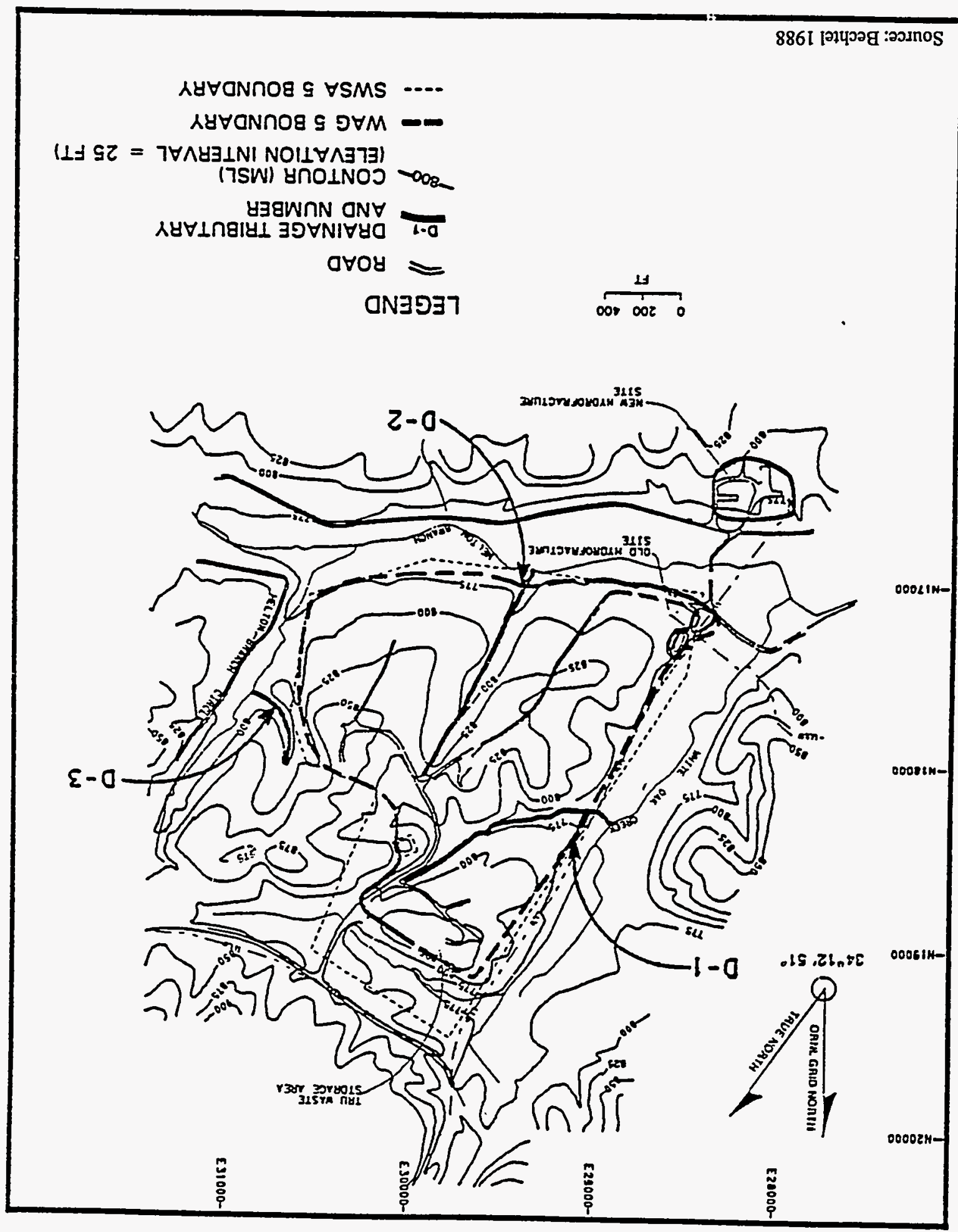




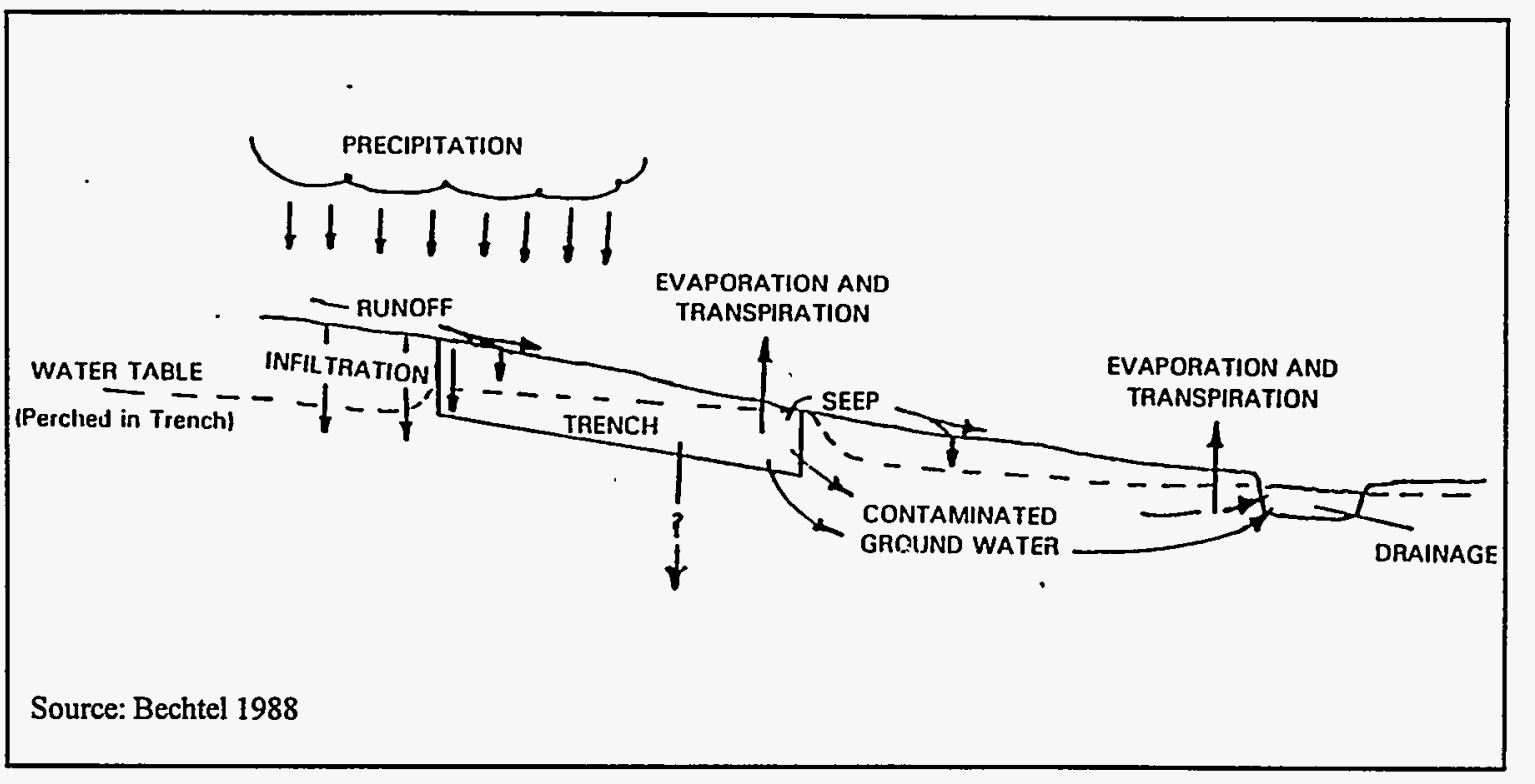

Fig. 10.7. Diagram of groundwater and radionuclide contaminant movement from a hypothetical trench to the surface environment.

Total elemental analyses of the sediments were also performed. Stansfield and Francis (1986) compared these data with proposed hazardous substance guidelines, and indications were that the sediments exceed maximum soil limits for copper, nickel, chromium, lead, polychlorinated biphenyls, and possibly silver and cadmium. The mean chromium concentration of $341.9 \mathrm{mg} / \mathrm{kg}$ in the sediments was over 50 times the guidelines maximum for soil $(5 \mathrm{mg} / \mathrm{kg})$. The measured chromium concentrations were considerably higher than those reported by Huang et al. (1984), which were only 17 to $27 \mathrm{mg} / \mathrm{kg}$ on a wet-weight basis. After converting the concentration found in the Stansfield and Francis (1986) study to a wet-weight basis, the chromium concentration in the sediment is approximately four times that determined by Huang et al. (1984).

The major radionuclides measured in the sediments were ${ }^{137} \mathrm{Cs}$ and ${ }^{90} \mathrm{Sr}$. Their concentrations (approximately $1.25 \times 10^{5}$ and $3.9 \times 10^{4} \mathrm{~Bq} / \mathrm{g}$, respectively) were similar to those determined by Huang. The inventory of radionuclides in the OHF sediment presented in Table 10.2 indicates an activity of approximately $2 \mathrm{GBq}$ of gross alpha and slightly under $2000 \mathrm{GBq}$ of gross beta (which is largely a result of the ${ }^{90} \mathrm{Sr}$ and ${ }^{90} \mathrm{Y}$ decay). The radionuclide measured in greatest quantity was ${ }^{137} \mathrm{Cs}$ (approximately $2400 \mathrm{GBq}$ ), followed by ${ }^{90} \mathrm{Sr}$ (approximately $750 \mathrm{GBq}$ ).

Table 10.2. Inventory of radionuclides in OHF Impoundment sediment

\begin{tabular}{cccc}
\hline Constituent & Total inventory $\left(\operatorname{mean}^{1}\right)$ & Constituent & Total inventory (mean) \\
\hline alpha & 1.95 & ${ }^{154} \mathrm{Eu}$ & 0.43 \\
beta & 1774.28 & ${ }^{234} \mathrm{U}$ & 0.64 \\
${ }^{134} \mathrm{Cs}$ & 0.38 & ${ }^{238} \mathrm{U}$ & 11.72 \\
${ }^{137} \mathrm{Cs}$ & 2391.86 & ${ }^{142} \mathrm{Am}$ & 0.38 \\
${ }^{90} \mathrm{Sr}$ & 741.93 & ${ }^{60} \mathrm{Co}$ & 11.64 \\
\hline
\end{tabular}

'Measured in gigabecquerels

Source: Stansfield and Francis (1986) 
At the same time sediments were collected from the impoundment, surface water samples were obtained (Stansfield and Francis 1986). Chemical analysis of the OHF Impoundment water indicated that arsenic, barium, cadmium, chromium, mercury, lead, fluorine, and nitrates, pesticides, and herbicides were below the maximum allowable National Interim Primary Drinking Water Standards (NIPDWS). The measured concentration of selenium $(0.016 \mathrm{mg} / \mathrm{L})$, slightly over the NIPDWS level $(0.01 \mathrm{mg} / \mathrm{L})$, and the detection limit of silver $(0.07 \mathrm{mg} / \mathrm{L})$ determined in the May sampling were the only indicators that chemical constituents in the impoundment water exceeded the allowable NIPDWS levels. Detectable concentrations of PCBs were observed in the impoundment water $(0.0001 \mathrm{mg} / \mathrm{L})$.

The bulk of the radioactivity was associated with the concentrations of ${ }^{137} \mathrm{Cs}$ and ${ }^{90} \mathrm{Sr}$, $(3900$ and $4400 \mathrm{~Bq} / \mathrm{L}$, respectively). Average values reported in the OHF Impoundment water by Huang et al. (1984) were 29,000 and $7100 \mathrm{~Bq} / \mathrm{L}$, respectively for ${ }^{137} \mathrm{Cs}$ and ${ }^{90} \mathrm{Sr}$.

\subsubsection{Process Waste Sludge Basin contamination characterization}

A study by Francis and Sealand (1987) has characterized the Process Waste Sludge Basin sediment. Concentrations of radionuclides are shown in Table 10.3. The dominant radionuclide in sediment of this impoundment is ${ }^{90} \mathrm{Sr}$ (and ${ }^{90} \mathrm{Y}$ ). Total inventory is estimated to be between 20 and $30 \mathrm{Ci}$.

Table 10.3. Concentrations and estimated inventory of radionuclides in sediment contained in the Process Waste Sludge Basin

\begin{tabular}{cccc}
\hline Radionuclide & $\begin{array}{c}\text { Concentration } \\
(\mathrm{Bq} / \mathrm{g})\end{array}$ & $\mathrm{GBq}$ & Inventory $^{2}$ \\
\hline Gross alpha & $98 \pm 5$ & 9.3 & $\mathrm{Ci}$ \\
Gross beta & $13,000 \pm 1000$ & 1200 & 0.25 \\
${ }^{134} \mathrm{Cs}$ & $0.85 \pm 0.47$ & 0.08 & 33 \\
${ }^{137} \mathrm{Cs}$ & $1600 \pm 100$ & 150 & $<0.01$ \\
${ }^{152} \mathrm{Eu}$ & $13 \pm 2$ & 1.2 & 4.1 \\
${ }^{154} \mathrm{Eu}$ & $9.2 \pm 1.3$ & 0.87 & 0.03 \\
${ }^{57} \mathrm{Co}$ & $7.9 \pm 0.6$ & 0.75 & 0.02 \\
${ }^{60} \mathrm{Co}$ & $330 \pm 10$ & 31 & 0.02 \\
${ }^{90} \mathrm{Sr}$ & $5700 \pm 100$ & 540 & 0.85 \\
Estimated total inventory & 724 & 15 \\
\hline
\end{tabular}

${ }^{1}$ Oven dry weight basis on composite of six samples taken from the 7835 Impoundment, error term represents counting error of two standard deviation.

${ }^{2}$ Estimated inventory based on $9.6 \times 10^{5} \mathrm{~L}$ of sediment with a mean depth of $152 \mathrm{~cm}$, bulk density of $1.1 \mathrm{~g} / \mathrm{cm}^{3}$, and $91 \%$ water.

Source: Francis and Sealand (1987) 


\subsubsection{Intermittent stream water and seeps contamination characterization}

In 1964, radiochemical analyses were performed on water samples from the drainage that divides the site into two sections (SWSA 5 South area and SWSA 5 North area) (Shoun 1987). The principal contaminants found were ${ }^{90} \mathrm{Sr},{ }^{106} \mathrm{Ru}$, tritium, and trivalent rare earths.

The two primary streams in SWSA 5, D-1 and D-2 (Fig. 10.6), have not previously been characterized for either their water or ${ }^{90} \mathrm{Sr}$ fluxes. A preliminary characterization of these tributaries was performed by intermittent grab sampling and flow measurements made during 1980 and 1981 . The large middle tributary, D-2, averaged $72 \mathrm{~Bq} / \mathrm{L}$ of ${ }^{90} \mathrm{Sr}$ for 45 sampling dates and was reasonably constant over this period. Under low-flow conditions, this tributary exhibited a median flow of $1.3 \mathrm{gal} / \mathrm{min}$. Assuming this base flow rate, ${ }^{90} \mathrm{Sr}$ concentration over the period of a year would result in a calculated discharge of $215 \mathrm{MBq}$ from this tributary; the total annual discharge of ${ }^{90} \mathrm{Sr}$ from SWSA 5, as measured by monitoring at the Melton Branch gauging station, was $7620 \mathrm{MBq}$ in 1981 . This indicates that the contribution of this tributary to the total ${ }^{90} \mathrm{Sr}$ discharge may be small. However, if the transport of ${ }^{90} \mathrm{Sr}$ from SWSA 5 via D-2 operates similarly to the SWSA 4 tributary (Huff, Farrow, and Jones 1982), then storm events, rather than base flow, may have a much more important contribution to the total annual flux.

Duguid (1975) identified 16 groundwater seeps around SWSA 5. The highest concentration of ${ }^{\text {Do }} \mathrm{Sr}(517.0 \mathrm{kBq} / \mathrm{L})$ was found at Seep 4 by Duguid but was not apparent in the study of Spalding and Munro (1984) since the seep was dry. Since Duguid's study, some corrective actions were taken which initially contributed to a decrease in the amount of ${ }^{90} \mathrm{Sr}$ and tritium migrating from SWSA 5. However, the annual migration of these radionuclides has apparently recovered to earlier rates.

\subsubsection{Groundwater}

\subsubsection{General description of WAG 4 groundwater}

Groundwater occurs in the regolith and within the bedrock of the Conasauga Group, and the two flow systems are recognized as hydraulically interconnected. The groundwater table occurs near the base of the regolith at depths of less than 3 to $59 \mathrm{ft}$. Groundwater circulation occurs predominantly in the upper $100 \mathrm{ft}$ but may extend to depths of $230 \mathrm{ft}$ in the bedrock. The water table appears as a subdued replica of surface topography as expected under unconfined conditions.

A conceptual model of flow in the Melton Valley (Webster and Bradley 1986) suggests that flow changes in direction from the water table gradient in the regolith to the hydraulic head distribution within the secondary openings in the bedrock with an intermediate zone positioned between the two. Where there is a high water table, flow through the regolith would be expected to be dominated by water table gradients that would flow radially away from topographic highs (i.e., areas of groundwater recharge). During periods of lower hydraulic head, directional permeabilities resulting from relict bedrock structure, - lithology, and man-made disturbance will have a greater influence on flow patterns in the regolith.

Four primary areas of recharge to the groundwater system are identified by Webster and Bradley (1986) as the topographic highs in WAG 5. Recharge to the bedrock aquifer is reported as local through the regolith aquifer except in the topographically low areas near the drainages. In these low-lying areas, artesian conditions have been observed between some water-bearing zones in the bedrock. The OHF Impoundment and the Process Waste Sludge Basin may also act as areas of local recharge. Surface drainage channels within and around WAG 5 (Melton Branch, WOC, and unnamed drainages that divide or border SWSA 5) are recognized as points of groundwater discharge; 
however, the interrelationship between groundwater (particularly groundwater in the bedrock) and surface water is not fully understood. Groundwater seeps from the banks of these drainages are common.

\subsubsection{Characterization of groundwater contamination}

The groundwater monitoring system at WAG 5 includes 93 monitoring wells installed between 1958 and 1977,7 piezometers installed in 1986 or 1987, and 22 additional monitoring wells installed in 1987. The 93 older monitoring wells were installed prior to initiation of the Remedial Action Program, and many were constructed with perforated corrugated metal casing running the entire length of the borehole. However, 29 of these wells installed between 1976 and 1977 were constructed of plastic casing with discrete screened intervals. The piezometers were constructed of 5-cm (2-in.) polyvinyl chloride casing and screens. The 22 additional wells at WAG 5 were installed as part of a groundwater quality monitoring well installation program at ORNL. These wells were constructed of $5-\mathrm{cm}$ or $10-\mathrm{cm}(2-\mathrm{in}$. or 4-in.) stainless steel casing and screens. The remainder of the well construction was the same as described for the piezometers. In addition to the monitoring system elements noted above, four monitoring wells constructed of fiberglass casing and screens are also located around the perimeter of the OHF Pond (SAIC 1994).

Two principal source documents were used to develop an understanding of groundwater contamination at WAG 5. These documents were the Preliminary Geohydrologic Site Characterization and Proposed Water Quality Well Locations for WAG 4,WAG 5,WAG 3, and SWSA 1 (Energy Systems 1987), and the Oak Ridge Reservation Environmental Report for 1991 (Energy Systems 1992). The preliminary geohydrologic site characterization report summarized results from three previous studies regarding groundwater contamination at WAG 5 . The first study reported results for groundwater samples collected from the four monitoring wells located around the perimeter of the OHF Pond. Analyses indicated that all four wells contained ${ }^{90} \mathrm{Sr}$, ${ }^{137} \mathrm{Cs}$, and tritium contamination and that the concentration of tritium in the single upgradient well (MW-1) was higher than in the three downgradient wells. This occurrence suggests that the source of tritium is upgradient of the pond and that the pond may act as a recharge zone, thereby diluting the concentration of tritium downgradient.

The second study reported results from six monitoring wells and one undesignated seep located around the southern boundaries of WAG 5. Analyses indicated that all six wells were contaminated with ${ }^{90} \mathrm{Sr}$, ranging from 8.2 to $520 \mathrm{~Bq} / \mathrm{L}$ and with ${ }^{137} \mathrm{Cs}$, ranging from 0.13 to $5.8 \mathrm{~Bq} / \mathrm{L}$. The undesignated seep was found to be contaminated with ${ }^{90} \mathrm{Sr}$ at an activity of $13,000 \mathrm{~Bq} / \mathrm{L}$. Two of the wells were also found to be contaminated with the following metals: 1767 (cadmium and lead) and 0454 (barium, lead, and selenium). The third study reported results for groundwater samples collected along the southern perimeter of SWSA 5 from temporary boreholes. Results of this study indicated seven distinct areas of ${ }^{90} \mathrm{Sr}$ contamination; however, the locations of these areas were not presented in the preliminary geohydrologic site characterization report.

The Oak Ridge Reservation Environmental Report for 1991 (Energy Systems 1992) summarized results for groundwater samples collected during June and July of 1991 from the 22 groundwater quality wells at WAG 5. A majority of these wells located around the southeast, south, and southwest boundaries of the WAG were found to be contaminated with total strontium ranging from 0.34 to $19 \mathrm{~Bq} / \mathrm{L}$ and tritium ranging from 770 to $9,500,000 \mathrm{~Bq} / \mathrm{L}$. Four of the wells located along the perimeter of WAG 5 were found to be contaminated by one or more of the following volatile organics at concentrations ranging from 10 to $4700 \mu \mathrm{g} / \mathrm{L}$ : trichloroethene, benzene, and vinyl chloride. Subsequent sampling of the wells in September and October 1992 and April 1993 indicated the presence of similar activities and concentrations of the noted contaminants. However, total 
strontium was observed to be below the maximum contaminant limit in Well 0972 during the later sampling events and was detected above the maximum contaminant limit in Well 0977. Also, tritium and thallium were detected above maximum contaminant limit in Wells 0968 and 0974, respectively, during the later sampling events.

Based on the data evaluated for WAG 5, contaminated groundwater containing ${ }^{137} \mathrm{Cs},{ }^{90} \mathrm{Sr}$, and tritium (probably derived from wastes in SWSA 5) appears to have migrated beyond the southern boundaries of WAG 5 . In addition, metal and volatile organic contaminants in groundwater also appear to be migrating beyond the southern WAG boundaries. However, these contaminants do not appear to be as widespread within the local groundwater system as are the radioactive contaminants.

\subsubsection{Ecology}

Sect. 5.2.7 of this document provides an overview of the flora and fauna commonly found on the ORR, which are believed to be representative of those found at WAG 5.

\subsection{RELEASES AND SITE CONCEPTUAL MODEL}

\subsubsection{Releases}

Contamination of environmental media at WAG 5 is mostly related to hydrologic processes: water is the key release and transport medium, responsible for mobilizing the radionuclide and chemical contaminants in the wastes, moving them through the subsurface or across the land surface to the perennial streams border the site, and finally transporting them away from the site. Along the way, some of the contamination in the water is being transferred to other media - to surface soils along drainage paths and in seep areas, onto subsurface soils (and saprolite) in the vadose zone and water table interval and to the sediment in the streams (Bechtel 1995).

The distribution of contamination is thus a function of these hydrologic processes, and the presence or absence of contamination in a given area can be explained in strictly hydrologic terms (e.g., the area is hydraulically downgradient of the source as described by groundwater flowpaths, or is downstream of a contaminated seep discharge point). Any attempts to explain the distribution of contamination at WAG 5 must be based on a clear understanding of hydrologic processes at the site. For example, the trenches in SWSA 5 South exert considerable influence on the movement of water in the subsurface and thus the release and migration of contaminants. The hydrologic role of the trenches-in addition to their status as a contaminant source-is a fundamental part of the hydrologic model of the site.

Contamination in WAG 5 can therefore be summarized almost entirely in the context of site hydrology: the trenches inundated by groundwater are the most active sources and greatest contributors of contamination; groundwater is the principal release mechanism and contaminant migration pathway and as a result is the most widely spread contaminated medium at the site; the discharge of this groundwater and the resulting contamination of surface water creates on-site exposure points and leads to the off-site (and for some of the contamination, off-ORR) transport of WAG 5 contaminants (Bechtel 1995). Contaminant- and media-specific highlights from the evaluation of WAG 5 contamination include the following.

- Most of the contaminant source material consists of low-level radioactive solid wastes in unlined trenches and auger holes of SWSA 5 South. Disposal of these wastes has resulted in a significant ongoing release of contamination to soils, groundwater, and surface water. 
- From an on-site risk perspective, the most significant contaminants detected are ${ }^{90} \mathrm{Sr},{ }^{3} \mathrm{H},{ }^{137} \mathrm{Cs}$, ${ }^{60} \mathrm{Co},{ }^{243} \mathrm{Cm},{ }^{244} \mathrm{Cm},{ }^{238} \mathrm{Pu},{ }^{239} \mathrm{Pu},{ }^{226} \mathrm{I}$, and ${ }^{228} \mathrm{Ra}$. Contaminants most responsible for off-site risk are ${ }^{90} \mathrm{Sr},{ }^{3} \mathrm{H}$, and to a lesser extent, ${ }^{137} \mathrm{Cs}$.

- Significant levels of groundwater contamination were detected in SWSA 5 South; the principal contaminants are ${ }^{3} \mathrm{H}$ and ${ }^{90} \mathrm{Sr}$. High concentrations of ${ }^{3} \mathrm{H}$ are ubiquitous in SWSA 5 South; high concentrations of ${ }^{90} \mathrm{Sr}$ are less widespread, typically occurring along migration pathways between source trenches and contaminated seep discharge areas.

- Cesium-137 has a strong affinity for adsorption onto clay soil particles and was shown to be much less mobile than ${ }^{90} \mathrm{Sr}$ in the surface and subsurface waters of WAG 5.

- Results from the inundated trench water sampling in SWSA 5 South show levels of contamination at the microcurie and millicurie level.

- Contaminated seep discharges along the southern perimeter of SWSA 5 South are significant components of the overall flux of ${ }^{3} \mathrm{H}$ and ${ }^{90} \mathrm{Sr}$ measured at White Oak Dam.

- Soil contamination at WAG 5 is mostly due to ${ }^{137} \mathrm{Cs},{ }^{90} \mathrm{Sr}$, and ${ }^{60} \mathrm{Co}$ and is limited to areas contaminated by seep discharges, overflowing (bathtubbing) trenches, or surface debris.

- Transuranic radionuclides are currently being released from WAG 5 at negligible levels, but they are migrating through the subsurface and being discharged at seeps along the site perimeter and interior drainages (Bechtel 1995).

Off-site fluxes of contamination from WAG 5 to Melton Branch and WOC were calculated and compared to the total flux measured at White Oak Dam (Table 10.4). Tritium and ${ }^{90} \mathrm{Sr}$ are the primary WAG 5 contributions to the contaminant flux measured at the dam. The primary sources of ${ }^{3} \mathrm{H}$ and ${ }^{90} \mathrm{Sr}$ were identified as inundated trenches in SWSA 5 South (Bechtel 1995).

Table 10.4. Comparison of contaminant flux from WAG 5 and total flux at White Oak Dam

\begin{tabular}{ccc}
\hline Analyte & Flux from WAG 5 (mCi/yr) & $\begin{array}{c}\text { Contribution from WAG 5 to } \\
\text { White Oak Dam }\end{array}$ \\
\hline Gross alpha & 29.8 & 15 \\
${ }^{3} \mathrm{H}$ & $2,450,000$ & 81 \\
${ }^{60} \mathrm{Co}$ & 8.75 & 4.5 \\
${ }^{90} \mathrm{Sr}$ & 1390 & 49 \\
${ }^{137} \mathrm{Cs}$ & 50.1 & 2.5 \\
\hline
\end{tabular}

\subsubsection{Site Conceptual Model}

The site conceptual model is the framework within which environmental pathways of potential concern for WAG 5 are identified and illustrated. It also serves as the framework for conceptualizing general response actions. Figure 10.8 is a conceptual model of WAG 5 which illustrates the environmental pathways by which humans and environmental receptors can be exposed to contaminants released from the source areas within WAG 5. The conceptual model includes a set of hypotheses about the environmental pathways selected based on the existing data and information generated by the ORNL research activities to date, site tours, and interviews with ORNL personnel 


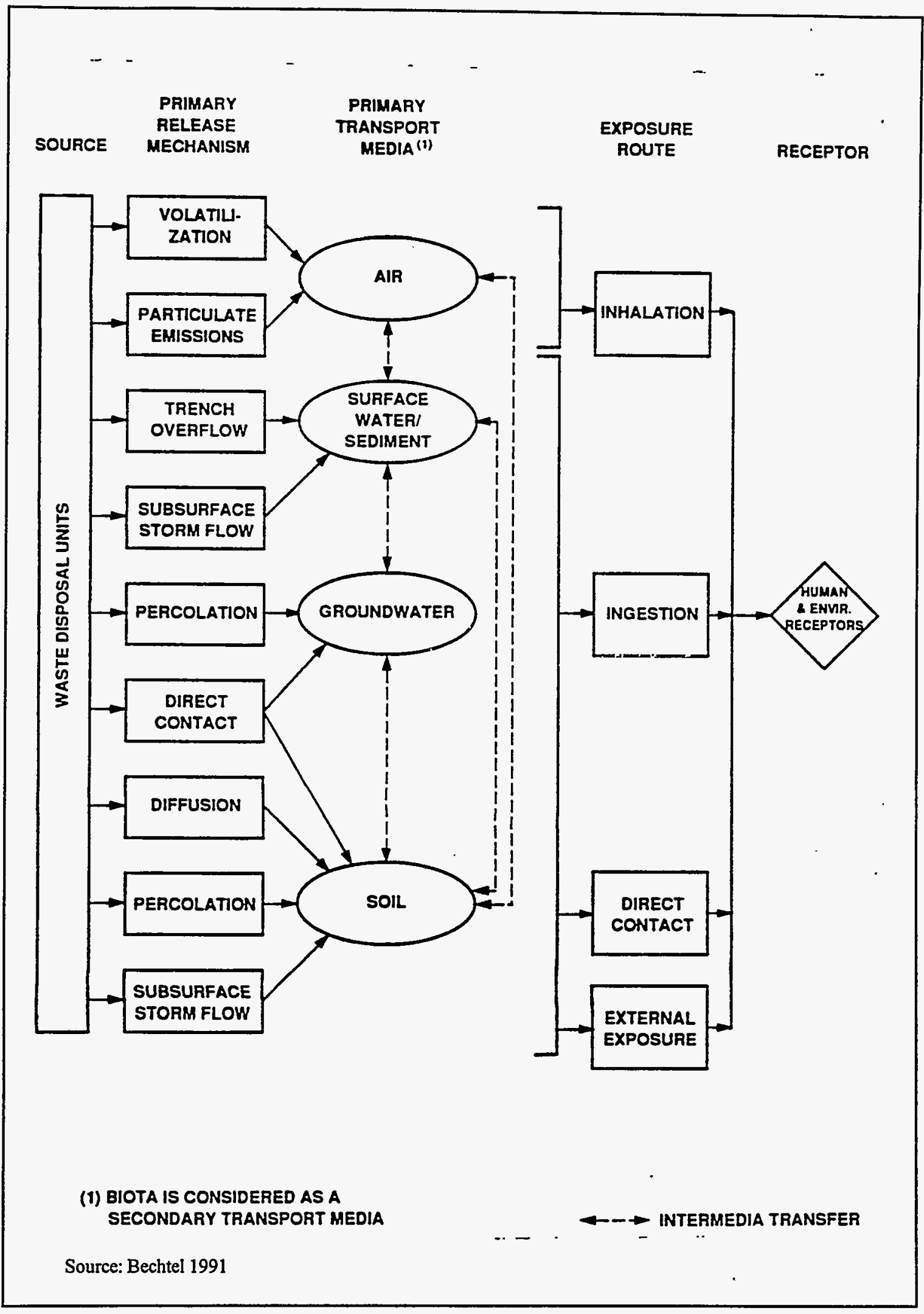

Fig. 10.8. WAG 5 site conceptual model. 
(Bechtel 1991). These hypotheses form the content of the elements of the conceptual model shown in Fig. 10.8, including the source areas of the contaminants, primary release mechanisms, primary transport media, intramedia transformations, intermedia transfers, and exposure routes and receptors. The following paragraphs discuss the basic elements of the conceptual model.

The source areas refer to actual and potential areas where contaminants are located. These are grouped as the pipelines and leak sites, impoundments, subsurface disposal areas (trenches and auger holes), and tanks. Except for impoundments, these areas constitute shallow land buried source areas. In Fig. 10.9, these source areas are illustrated schematically within the general hydrologic setting of WAG 5. The radionuclide and chemical inventories are known only for some of the disposal units and even then incompletely.

A contaminant release mechanism is defined as any process that results in migration of the contaminant from a source area into the immediate environment. Contaminants may be released via the mechanisms identified in Fig. 10.8 into the primary transport media: groundwater, surface water/sediments, soil, biota, and air. To date, however, quantification of release rates has not been possible at ORNL (Bechtel 1991).

Contaminants in source areas and environmental media are subject to transformation processes. For radionuclides, the process is radioactive decay; for organic chemicals it involves photochemical, biological, and chemical transformation processes. Once in the environment, contaminants can be transferred among media (Fig. 10.10), and transported out of WAG 5. Humans are exposed to contaminant concentrations via exposure routes, including inhalation of air, ingestion, direct contact, and external exposure in other media.

The pathways involving each primary transport medium are discussed in the following subsections.

\subsubsection{Groundwater pathway}

Groundwater is known to be contaminated in WAG 5, as supported by previous analytical data presented in the WAG 5 remedial investigation (RD) plan (Bechtel 1988). Also, migration of contaminants from WAG 5 has occurred, extending from source areas toward site streams, which are WOC (Wickliff, Morrissey, and Ashwood 1991) and Melton Branch (Solomon et. al. 1991).

The contaminant release mechanisms to groundwater are identified as percolation and direct contact (i.e., inflows/outflows) of groundwater with the waste. Contaminants can come into contact with groundwater in saturated or partially saturated trenches. In disposal units located above the normal water table, leachate is generated when infiltrating water mixes with the waste material and then percolates to the groundwater.

Intermedia transfer of contaminants occurs between groundwater, soil, and surface water. Some contaminants in groundwater move at velocities much lower than the characteristic flow velocity of groundwater because they are retarded by interaction with the solid matrix of the aquifer (sorption). When the groundwater intersects the streams, groundwater contaminants are discharged to surface waters. Under certain conditions, seepage from the stream beds and impoundments can also transfer contaminants to the groundwater.

Contaminants are transported in groundwater by advection and dispersion. The hydrogeology of WAG 5 is complex, and contaminant transport occurs through secondary porosity features such 


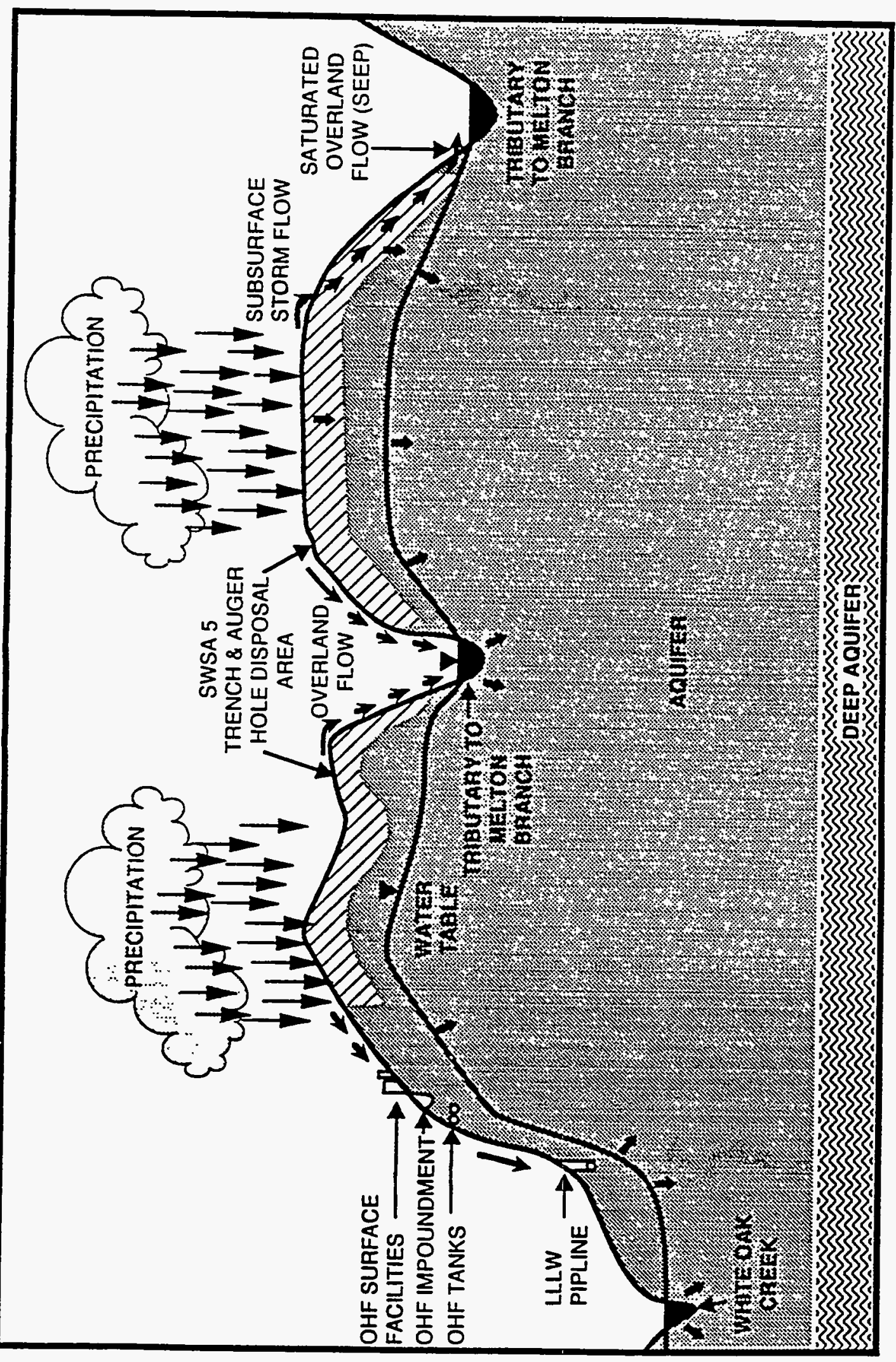



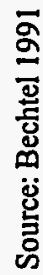




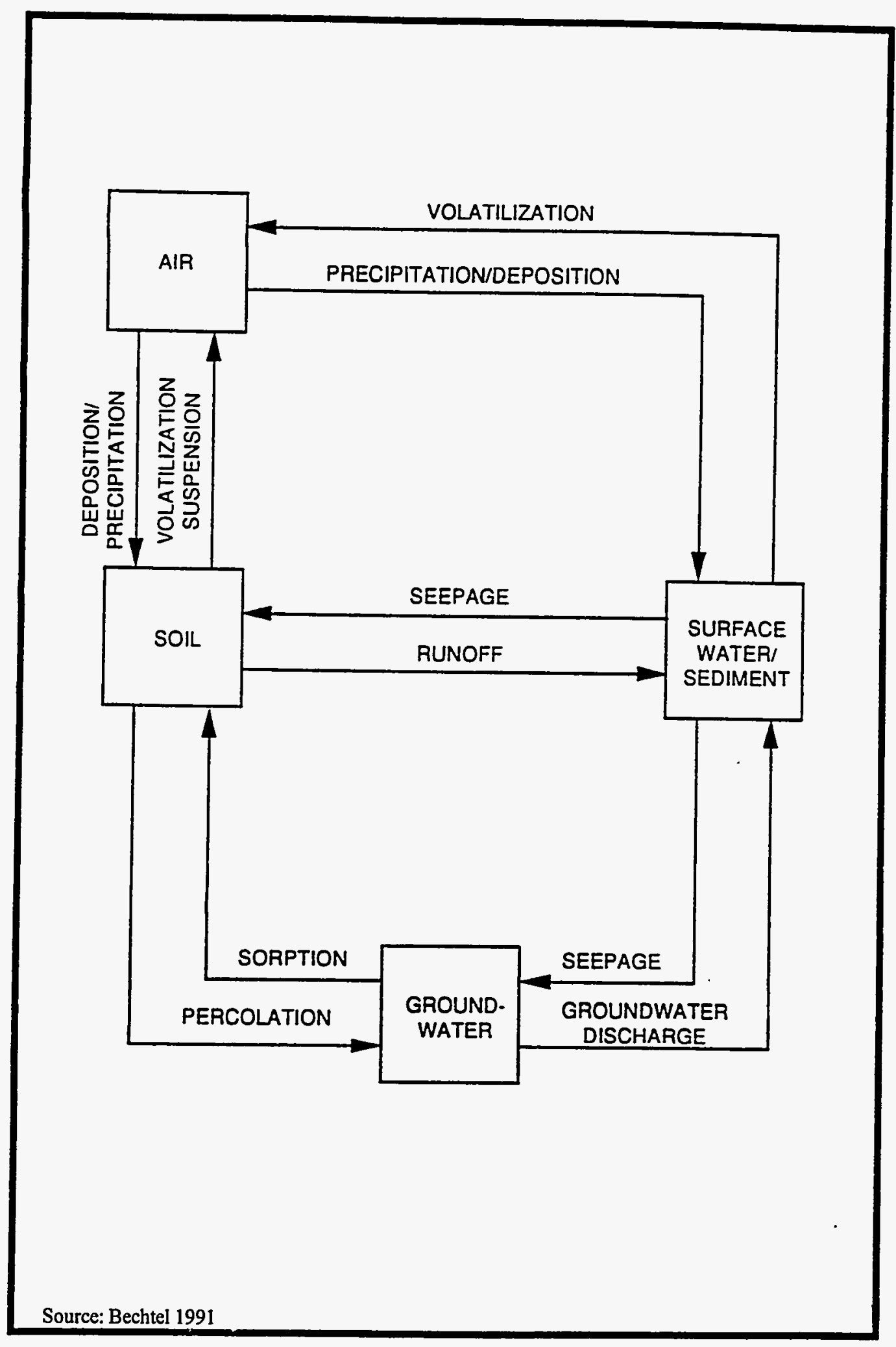

Fig. 10.10. Intermedia transfer processes. 
as fractures. As indicated by Solomon et al. (1991), contaminant transport is through discrete paths. Flow and transport characteristics of the media are not presently fully characterized.

Extensive refinement of the groundwater pathway conceptual model may not, however, be appropriate because of the considerable uncertainty associated with contaminant release rates and hydrogeologic parameters. Because source areas comprise heterogeneous units with heterogeneous waste forms, packaging, and containers, contaminant release rates may vary unpredictably as random disintegration of waste containment occurs. The hydrogeology exhibits characteristics of both porous media and fractured rock. These latter characteristics cannot be completely characterized by field measurements on a local scale because the horizontal range, vertical extent, orientation, and hydraulic conductivity of fractures will vary at specific locations across the site. Therefore, fractured-media transport cannot be modeled numerically (Bechtel 1991).

\subsubsection{Surface water and sediment pathway}

Contaminants are suspected to be present in Drainages D-2 and D-3 in WAG 5 and transported off site into WOC and Melton Branch. Surface water bodies with known contamination are Drainage D-1, the OHF Impoundment, and the Process Waste Sludge Basin. These impoundments also contain contaminated sediments. Sediments in Drainage D-1 are known to be contaminated; sediments of Drainages D-2 and D-3 are also suspected to be contaminated.

The potential mechanisms identified for the release of these contaminants from the source areas are the SWSA 5 burial trench overflow subsurface storm flow and overflow of the impoundments. Trench overflow occurs when a trench is saturated and spills leachate at the surface. These leachate spills manifest themselves as surface seeps. Trench overflow mixes with overland flow and is carried into streams. Contaminant release into surface water may also occur via subsurface storm flow. Leachate in bathtubbing trenches or in trenches within the groundwater table could mix with these subsurface storm flows, move laterally with the flows, and be discharged into the streams.

From surface waters, intermedia transfers can occur to air via volatilization, to groundwater via seepage from stream beds, and to soil via seepage. Stream widths in WAG 5 are relatively small, and streams carry water intermittently; therefore, volatilization of contaminants is minimal. In the upper reaches of the streams, seepage into soil and groundwater occurs. Contaminants in stream water can also be transferred to sediments in suspension and/or on the stream bed.

Contaminants can also be transferred into surface waters from air via precipitation/deposition; from soil via runoff, including overland flow, saturated overland flow, and subsurface storm flow; and from groundwater via groundwater discharge (baseflow).

Surface water transport of contaminants out of WAG 5 appears to be relatively rapid, since streams exiting the site are quite short. Contaminant flux (contaminant concentration times flow) out of WAG 5 via storm flow could, therefore, be a major component of the total contaminant flux exiting WAG 5, since most of the flux from groundwater is discharged into site streams.

Further refinement of the surface water pathway is not appropriate because contaminant release rates into surface waters for the different release mechanisms discussed cannot be measured. The stream flows in WAG 5 consist of overland flows, saturated overland flows, subsurface storm flows, and base flows. Further, no models exist that address subsurface storm flow. Subsurface storm flow may exist only in certain areas of WAG 5 . The other individual flow components and contaminant concentrations associated with these components need not be estimated because it is the total surface 
water contaminant flux out of WAG 5 that is of primary interest and it can be monitored at stream outlets.

\subsubsection{Soil Pathway}

Surface and subsurface soil contamination in WAG 5 have been known or suspected to occur. However, soil contamination is limited to specific areas, and these areas do not appear to represent significant secondary source areas. Known contamination that is supported by analytical data is around leak/spill sites, areas adjacent to the OHF Impoundment, and OHF site surface facilities. Contamination of soils is suspected (based on site visits and information from ORNL staff) in areas adjacent to:

- ILLW/LLLW transfer pipelines,

- OHF waste storage tanks,

- Process Waste Sludge Basin, and

- $\quad$ SWSA 5 South site (Bechtel 1991).

Since most of the source areas in WAG 5 contain disposal units located in the vadose zone, contaminants are released into soil by direct contact, diffusion, percolating water, and subsurface storm flows. Vertical and lateral movement of the advancing soil moisture front, especially from the unlined trenches, spread the dissolved contaminants in the vadose zone soil.

From soil, contaminants are transferred to air via volatilization and particulate suspension, to groundwater via percolation, and to surface water via runoff and groundwater discharge. Also, contaminants are transferred to soil via precipitation/deposition from air, via sorption from groundwater, and via seepage from surface water.

No specific transport mechanism is considered for soil, because soil acts as a storage medium in which transport occurs mostly via water.

\subsubsection{Air Pathway}

Based on modeling experience for WAG 6, which is approximately $1.6 \mathrm{~km}(1 \mathrm{mi})$ west of WAG 5 and has similar buried waste, air is considered to be a minor pathway for WAG 5 receptors. Volatilization and particulate emissions (due to upwind erosion of source area soils) are the two mechanisms for contaminant releases to air. No database presently exists to quantify these release rates. Volatilization rates would be contaminant specific and vary according to waste characteristics, the characteristics of the waste units, natural and engineered barriers, and climatic and meteorologic conditions. In the southern part of WAG 5, opportunity exists for volatilization of tritium from the seeps along Melton Branch. Volatilization also would occur readily from the impoundments.

As in WAG 6, particulate emissions due to source area soil erosion in WAG 5 would likely be minimal because of high annual rainfall, low wind speeds, extensive grass cover, and rapid regrowth of vegetation in temporarily disturbed areas.

Contaminants released into the air could be transferred to both surface waters and surface soil by deposition (dry settling) and precipitation, thereby creating diffuse secondary sources which lead to further contamination of other media. For example, from the soil surface, infiltrating rainwater could carry the contaminants into the vadose zone and from there into groundwater. Air-soil and air-water transfers are functions of solubility, adsorption, particle size, and precipitation. Transport 
of contaminants in air occur by advection and dispersion in the predominant wind directions of southwest and northeast.

\subsubsection{Baseline Risk Assessment}

Baseline risks for current residential and industrial scenarios were assessed for nine designated areas on site. Calculations were also performed for residential scenarios downstream at the Melton Branch and WOC weirs (opposite the southwest corner of WAG 5) and for drinking water risks farther downstream at White Oak Dam and Clinch River. The site conceptual model was used to integrate these risk results with site hydrology and contaminant dynamics.

Under current conditions, residential or industrial use of the site would result in an increased risk of developing cancer that exceeds $1 \times 10^{-4}$ in all nine areas (Bechtel 1995). In most of the areas, direct external radiation exposure to contaminated soils was primarily responsible for the calculated risks; ingestion of groundwater and produce represented a secondary, but important, exposure pathway for the residential scenario. Groundwater inundation of sources and bathtubbing in trenches are primarily responsible for the release of contaminants.

Hypothetical off-site residents at the weirs would also be subject to an increased cancer risk. The risk associated with the Melton Branch location is primarily attributable to ingestion of drinking water (from the creek) contaminated with ${ }^{3} \mathrm{H}$ and ${ }^{90} \mathrm{Sr}$ released from trenches in the southern portion of the site. Risk at the WOC location is also due primarily to contaminated surface water ingestion; however, the ${ }^{90} \mathrm{Sr}$ and ${ }^{137} \mathrm{Cs}$ driving the risks originate from other ORNL sources upstream of WAG 5.

Drinking water risks calculated for White Oak Dam are lower, due to dilution, but still exceed the threshold of $1 \times 10^{-4}$ (Bechtel 1995). Strontium-90, ${ }^{3} \mathrm{H}$, and ${ }^{137} \mathrm{Cs}$ flux from the inundated trenches in the southern portion of WAG 5 are responsible for approximately $50 \%$ of this risk. Based on dilution factors, the calculated drinking water risk for Clinch River downstream of the mouth of WOC is approximately $2 \times 10^{-6}$ due to ${ }^{90} \mathrm{Sr}$ and ${ }^{3} \mathrm{H}$. WAG 5 contributions are again responsible for about half of this risk (i.e., $1 \times 10^{-6}$ ).

Current and future ecological risks to terrestrial and aquatic endpoints were evaluated for six habitat-based areas on site, and the contaminant contributions from these areas to off-site terrestrial and aquatic receptors were assessed. Ranked on four categories ranging from "no impact" to "likely impact," none of the areas received a ranking exceeding "possible impact" for current or future cases on site or for contributions to off-site receptors. Possible impacts were due primarily to concentrations of metals in soil (Bechtel 1995).

\subsection{ACTIVE PROJECTS}

\section{Instructions to User}

Remediation is an ongoing process, and the status of active projects can change quickly. For the most up-to-date information about WAG 5 active projects, check the Annual Environmental Restoration Monitoring and Assessment Report and the Federal Facility Agreement Quarterly Report. 


\subsubsection{Remedial Investigation}

An RI was performed to support environmental restoration activities for WAG 5 (Bechtel 1995). The WAG 5 RI made use of the observational approach, which concentrates on collecting only information needed to assess site risks and support future cleanup work. This information was interpreted and is presented using the framework of the site conceptual model, which relates contaminant sources and release mechanisms to migration pathways and exposure points keyed to current and future environmental risks for both human and ecological receptors. The site conceptual model forms the basis of the WAG 5 remedial action strategy and remedial action objectives. The $\mathrm{RI}$ provided the data necessary to verify this model and allows recommendations to be made to accomplish those objectives.

Future remediation work at WAG 5 will be constrained by a number of factors-technical feasibility, resource (funding) availability, and the overall risk management strategy for the ORR. A remedial action strategy for WAG 5 must recognize these constraints and at the same time ensure that significant problems are addressed in a timely fashion. Dividing the site into smaller "remedial project areas" allowing for phased cleanup actions is an approach that has been used elsewhere at ORNL and is particularly well suited for WAG 5; this approach also is consistent with the operable unit concept described in Section XII of the Federal Facility Agreement (DOE 1992).

The environmental problems and concerns associated with each project area were identified to support identification of response actions necessary to achieve a given remediation target, determination of the benefits that would result from implementing various actions, and prioritization of potential actions. The discussion of problems and concerns for the WAG 5 remedial project areas is based on the following considerations:

- $\quad$ source term-inventory, waste volumes, contaminant types and distribution, source dimensions;

- releases and impacts-types of release mechanisms, extent of current releases, potential for future releases, flux (type and magnitude), affected area; and

- relative significance-based on source term, type, extent and magnitude of releases, resulting - impacts (exposures and risks) on and off site.

Remediation targets, essentially land use and/or restoration goals, were developed to cover a full spectrum of potential remediation scenarios for WAG 5 (Bechtel 1995). Evaluating a range of alternatives is consistent with EPA guidance on the conduct of CERCLA feasibility studies and provides a stronger foundation to support risk management decisions and ensure that realistic restoration goals are identified. The list of targets includes the following:

- Monitoring: Continued monitoring and maintenance would be performed to detect changes in site exposures, releases, or other conditions so that appropriate future actions would be taken if needed.

- Stabilization: Action would be taken as needed to prevent an increase in contaminant flux of fission products and transuranics and minimize impacts to surveillance and monitoring activates.

- Recreational use: Expanded actions would be taken to make the site (or at least most of the site) safe for recreational use and as wildlife habitat.

- Water quality: Relatively aggressive remediation steps would be taken so that discharges from the site attained applicable or relevant and appropriate requirements, such as Tennessee water quality standards in Melton Branch and WOC. 
- Remove wastes: Relocate high-activity and long half-life wastes to a more secure industrial facility, and in the process, potentially render the site suitable for limited industrial use.

The remediation targets were used to develop a remediation strategy matrix intended to function as the primary tool for guiding the pre-feasibility study strategy for WAG 5 . The matrix presents general response actions, cost, and a feasibility rating (index) based on the objectives associated with each remediation target. The matrix shows that both cost and technology limitations increase with the increasing scope and complexity of the remediation targets. Actions necessary to attain the objectives for the monitoring and stabilization targets could be readily implemented with a relatively high degree of confidence that the overall goals would be achieved. The feasibility index is lower for the expanded actions associated with the recreational use scenarios, primarily due to uncertainty regarding the ability to identify and effectively mitigate all on-site exposures potentially impacting recreational users of the site.

The absence of a clear path for near-term resolution of the most significant site problems at the site does not preclude the identification of near-term actions that can effectively mitigate some of the more manageable problems at the site. A principal consideration in the identification of these near-term actions is whether it makes sense to remediate portions of WAG 5 when other problem at the site are not addressed (at least in the near term). The benefit from any actions toward cleanup of WAG 5 must therefore be weighed against the impact of not remediating the entire site-for example, it may not make sense to remediate a relatively small area adjacent to or surrounded by a much larger and more highly contaminated area. Additionally, it may not be prudent to undertake certain types of actions when the site conceptual model has shown that the area will be recontaminated in the future. An effective way to conduct this evaluation is to establish the benefits associated with the various response actions identified in the remedial strategy matrix.

Evaluation of cost, feasibility, and potential benefits indicates that the most appropriate near-term goals for WAG 5 should be based on the stabilization or recreational use targets (Bechtel 1995). Near-term actions would thus be limited to smaller and more manageable tasks, such as pond closure or hot spot capping. In the longer term, more aggressive (and costly) remedial actions can be considered if new technologies become available or conditions change such that more aggressive actions are both warranted and technically feasible. All near-term actions would constitute definite progress toward a final remediation of the site and could be designed and implemented to be consistent with future actions and land uses.

Further refinement of the WAG 5 remedial action strategy will be accomplished through a series of DOE-led workshops with the Tennessee Department of Environment and Conservation and EPA to better define the issues affecting remediation decisions and integrate the WAG 5 remedial projects into the Federal Facility Agreement prioritization system.

A much higher level of uncertainty is associated with the ability of the actions identified to attain the objectives of the water quality and waste removal targets. For the water quality target, complexities in the hydrogeologic system at the site, the absence of source control actions, and the potentially insurmountable difficulties in treating all of the discharges render the primary components of the action-isolation of SWSA 5 South and interception of discharges along Melton Branch-as technically impracticable (Bechtel 1995). A similar conclusion applies to the waste removal target, due to the health and safety concerns associated with excavating the buried wastes and problems in trying to dispose of the excavated materials. Future technology developments or changes in the site dynamics may offer opportunities to implement final actions involving source control and/or isolation technologies; consequently, a comprehensive solution should be the long-term goal for the buried LLW. 


\subsubsection{Seeps C and D Removal Action}

The objective of the WAG 5 Seeps Removal Action was to reduce the release of ${ }^{90} \mathrm{Sr}$ into Melton Branch from WAG 5 and consequently reduce the amount of ${ }^{90} \mathrm{Sr}$ going off site over White Oak Dam. WAG 5 Seeps C and D combined were known to be the primary contributors to the release of ${ }^{90} \mathrm{Sr}$ over White Oak Dam. When inundated by groundwater, the SWSA 5 trenches were the most active sources in WAG 5 and were the greatest contributors to off-site migration of ${ }^{3} \mathrm{H}$ and ${ }^{90} \mathrm{Sr}$ at White Oak Dam, contributing $81 \%$ and $49 \%$ of the total flux, respectively. Seep C is believed to have contributed approximately $25 \%$ of the ${ }^{90} \mathrm{Sr}$ found at White Oak Dam and Seep D approximately $10 \%$ (Clapp and Watts 1995).

The chosen removal action alternative recommended in the Engineering Evaluation/Cost Analysis Document (Radian 1994) had two elements that were common to both seep sites: (1) an interception device to collect and divert the contaminated groundwater before it reached Melton Branch and (2) an in situ treatment system that would remove at least $90 \%$ of the ${ }^{90} \mathrm{Sr}$ from the diverted groundwater. The location of the seep treatment units is shown in Fig. 10.11, and a summary of the construction follows.

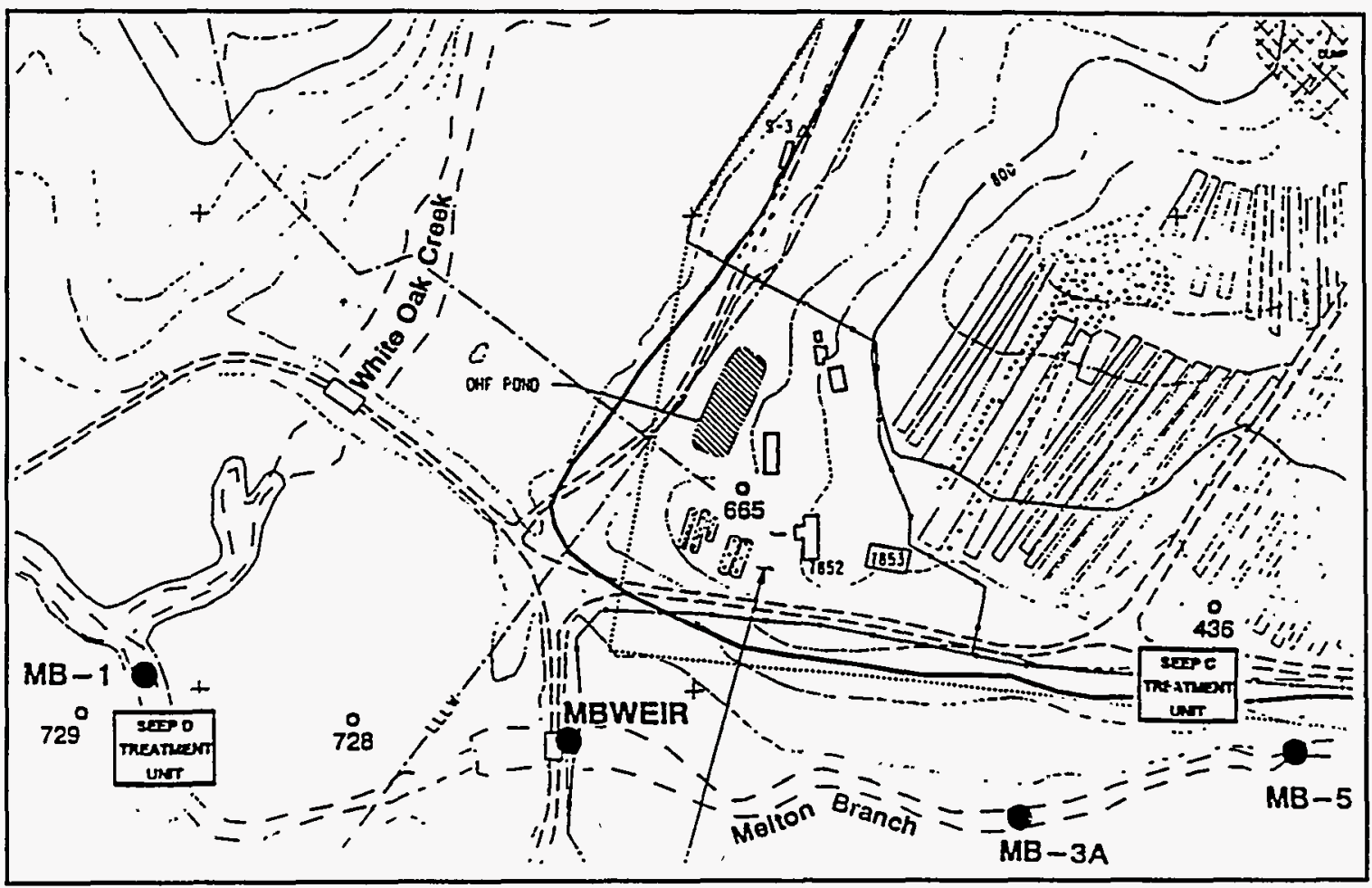

Fig. 10.11. Sampling locations in Melton Branch and location of Seep Areas C and D. Source: ORNL 1995

\section{Seep Area C}

A French drain was constructed up gradient of the treatment unit, directly on top of bedrock at a depth of $6-8 \mathrm{ft}$. The drain consists of river rock wrapped in a geotextile membrane. Dimensions are $65 \mathrm{ft} \times 4 \mathrm{ft} \times 2 \mathrm{ft}$. A 20-ft length of 6-in., perforated, polyvinyl chloride pipe was placed along the midsection of the bottom of the drain. An attached section of solid high-density polyethylene pipe connects the French drain to the treatment unit. 
The treatment unit was constructed down gradient of the French drain composed of a 8- $\mathrm{ft} \times 12-\mathrm{ft}$ $\times 12$-ft concrete vault with a removable lid. Eight removable, 55-gal drums filled with zeolite were used. The drum arrangement consists of four primary drums in parallel, each connected to a polishing drum in series. An outlet pipe discharges the effluent into the original seep channel up gradient of the 100-year floodplain. The discharge, therefore, leaves the system as surface runoff rather than subsurface flow through a sump.

\section{Seep Area D}

A French drain was not built for Seep Area D because testing performed after the initial excavation revealed the seep to be localized in two areas on the east side of the Melton Branch channel. Two discreet seeps were seen flowing out of the bedrock, one from the floor and one from the south wall. Five recovery tests were performed along with extensive sampling and analysis of the seeps. The tests indicated quite conclusively that the two seeps accounted for all of the ${ }^{90} \mathrm{Sr}$ flux previously measured at Seep D, thus eliminating the need for additional excavation. Placement of the collection structure on the east side of the channel reduced the concerns about having the structure completely across the stream bed and made it more structurally sound.

Instead of a French drain, a concrete collection box with inner dimensions of $6 \mathrm{ft} \times 10 \mathrm{ft}$ was built in the bed of Melton Branch. The collection box is essentially an upside down box $3 \mathrm{ft}$ high resting inside of an excavation $4 \mathrm{ft}$ deep. Seep water enters the box from the bedrock beneath it and causes the box to fill. The collection box is in essence a sump and collects a reservoir that can be pumped to the treatment system. A pipe rack was built above Melton Branch to pump the collected seep water to the treatment unit. Two 140-gal zeolite columns were installed above ground on the west side of Melton Branch and above the 100-year floodplain. Process water exits the zeolite columns through an underground pipe that discharges onto riprap on the bank of Melton Branch.

\section{Performance Monitoring}

Two automatic composite samplers were installed at each seep to collect flow proportional samples from both the influent and effluent. Sampling ports were provided to allow the collection of grab samples from the effluent of each of the eight drums at Seep C and from the effluent of each of the zeolite columns at Seep D (Environmental Consulting Engineers 1995). Monitoring began on November 14, 1994, and has been performed according to the plans stated in the postconstruction report (Environmental Consulting Engineers 1995). Figure 10.11 shows the upstream/downstream sampling locations in Melton Branch. Flow proportional composite samples have been collected only at the influent and effluent to each treatment unit. All other samples are strictly grab samples.

As of June 1995, the treatment units were removing more than $99 \%$ of the ${ }^{90} \mathrm{Sr}$ from the water collected and are credited with an average $33 \%$ reduction in ${ }^{90} \mathrm{Sr}$ at White Oak Dam during March-May 1995. The Seep C treatment system captured $81 \mathrm{mCi}$ of ${ }^{90} \mathrm{Sr}$ during the months of April and May, resulting in an average $21 \%$ reduction at White Oak Dam. Similarly, the Seep D treatment system captured $55.6 \mathrm{mCi}$ of ${ }^{90} \mathrm{Sr}$ during April and May, resulting in a $14 \%$ reduction at the dam (Clapp and Watts 1995). Further monitoring will be continued to demonstrate that the removal actions have been effective and that the overall performance is improving.

\subsubsection{OHF Inactive Tanks Contents Removal Project}

OHF, located in WAG 5, was used from 1964 to 1979 for permanent disposal of liquid radioactive waste in shale formations at depths between 780 and $950 \mathrm{ft}$. More than 2 million gal of LLLW and grout mixture containing several hundred thousand curies of beta-gamma 
radionuclides-primarily ${ }^{137} \mathrm{Cs}$, ${ }^{90} \mathrm{Sr}$, and ${ }^{60} \mathrm{Co}$, with lesser amounts of ${ }^{233} \mathrm{U},{ }^{244} \mathrm{Cm}$, and ${ }^{241} \mathrm{Am}$-were injected. Five carbon-steel, underground storage tanks ranging in volume from 13,000 to 25,000 gal [Tanks T- 1, T-2, T-3, T-4, and T-9 (Fig. 10.12)] were used for storage of LLLW before mixing with grout for injection. During OHF operations, radioactive sludges accumulated in the tanks as particles settled out of the liquid in the tanks. After hydrofracture operations at OHF ceased in 1980, sludges remained in the tanks, and presently the tanks contain approximately 42,000 gal of LLW consisting of residual sludges, some aqueous-based waste materials, and supernatant water. Additional information about the OHF tanks is provided in Sect. 10.1.5; a brief description of OHF facilities is provided in Sect. 10.1.3. For more detailed information about the OHF tanks, the OHF facilities and historical operations, and the hydrofracture process, see the Site Characterization Summary Report for the Old Hydrofracture Facility (AIMS 1995).

Based on the age of the tanks and the severity of service, the structural integrity of the tanks became a concern, and in 1995 a CERCLA non-time-critical removal action was initiated to remove the sludges from the five LLLW tanks in the OHF area. The primary human health risks, which provide the justification for performance of this work, were the presence of approximately $30,000 \mathrm{Ci}$ of radioactive material in the tanks; the fact that the single-wall tanks are constructed of carbon-steel and buried without active corrosion protection (the tanks were buried in the early 1960s, and the cathodic protection system was found to be inoperative in the early 1990s); and the existence of an expedient pathway to public receptors via the under-tank drain system (ORNL 1996). A substantial future off-site risk is posed to human health and the environment by the contents of these tanks. Removing and disposing of the contents from the inactive OHF LLLW tanks will reduce the consequence of a potential release from the tanks and therefore reduce this future off-site risk potential.

The purpose of the OHF Inactive Tanks Contents Removal Project is to remove and dispose of the contents from the five inactive OHF tanks. The project goal is to sluice, to the extent practicable, the current inventory (both liquid and sludge) in the inactive OHF tanks and transfer the inventory to the active LLLW system. Transfer will be accomplished by using existing sluicing technologies and equipment coupled with construction of a new pipeline/valve box as needed to complete the transfer. Elements of the project include sampling and analysis, preparation of a characterization report, evaluation of the tanks, development of an engineering evaluation/cost analysis (EE/CA), preparation of an action memorandum, design and construction of a support facility (valve box) to permit access to the active LLLW system, removal of the tanks' contents, and transferral of the tanks' contents to the active LLLW system (ORNL 1996).

The project consists primarily of the following major work packages.

- Establish clear and concise data quality objectives for all sampling and analyses information needed to satisfy the active LLLW system waste acceptance criteria and engineering design considerations.

- Sample and analyze the contents of the OHF tanks.

- Prepare an EE/CA and an action memorandum.

- Perform preliminary engineering, prepare installation drawings and specifications, and construct piping and ancillary equipment and systems to transfer the OHF tanks' contents to the active LLLW system.

- Conduct the CERCLA removal action. 


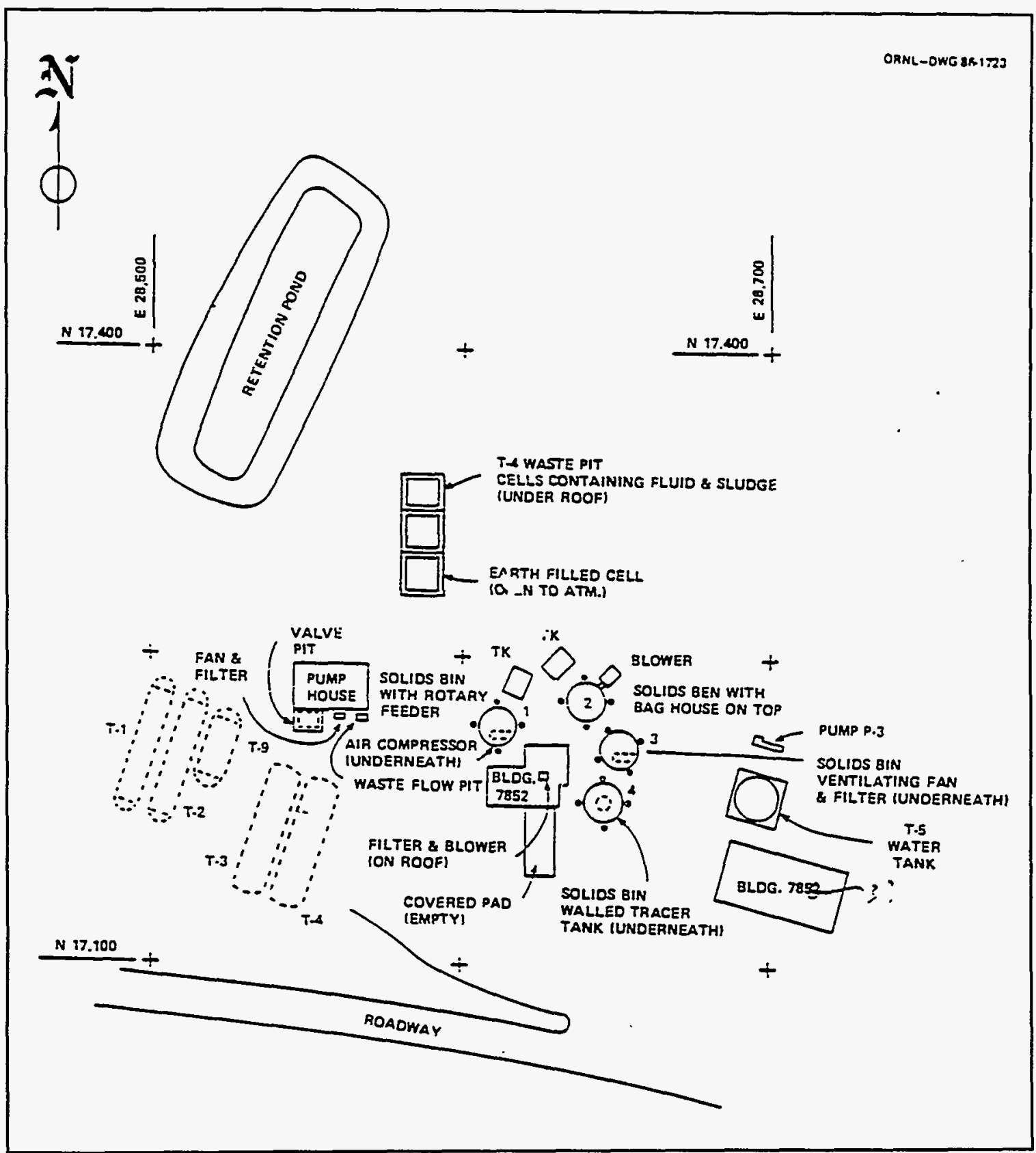

Fig. 10.12. Location of tanks T-1, T-2, T-3, T-4, and T-9 at OHF in WAG 5. Source: AIMS 1995

The primary schedule objectives for the project are to submit the final removal action memorandum for DOE approval in the fall of 1996, start removal action field activities in the summer of 1997 , and complete tank contents removal activities and site restoration activities by the fall of 1998 (ORNL 1996).

\subsection{WAG 5 SUMMARY}

WAG 5 is located on the ORR in Roane County, Tennessee, approximately 5 miles southwest of the city of Oak Ridge central business district and 1 mile south of the ORNL main plant area. 
WAG 5 is bounded to the south and west by WAG 2 and to the east by WAG 9. Melton Valley Drive parallels the northern limit of the site. The WAG contains 16 SWMUs (Table 10.5) and includes the surface facilities constructed in support of both the old and new hydrofracture facilities. The largest land areas in WAG 5 are devoted to SWSA 5 and the TRU Waste Storage Area. The remaining SWMUs are support facilities for ORNL's hydrofracture operations, two LLW leak/spill sites, three septic tanks, and an impoundment in SWSA 5 used to dewater sludge from the original PWTP.

Table 10.5. SWMUs in WAG 5

\begin{tabular}{llll}
\hline SWMU & Site name & SWMU & Site name \\
\hline 5.1 & LLW Lines and Leak Sites & 5.9 & $\begin{array}{l}\text { Radioactively Contaminated Waste } \\
\text { Oil Storage Tank 7860A }\end{array}$ \\
5.2 & OHF Impoundment & 5.10 & $\begin{array}{l}\text { SWSA 5 North-TRU Waste } \\
\text { Storage Area }\end{array}$ \\
5.3 & OHF Site Surface Facilities & 5.11 & Septic Tank 7831 \\
5.4 & NHF Site Surface Facilities & 5.12 & Septic Tank 7860 \\
5.5 & Inactive OHF Waste Storage Tanks & 5.13 & Septic Tank 7853 \\
5.6 & Process Waste Sludge Basin & 5.14 & Old Landfill (at NE edge of SWSA 5) \\
5.7 & SWSA 5 South & 5.15 & Active LLLW Slotting Tank T-13 \\
5.8 & Active LLW Waste Concentrate & 5.16 & Inactive LLLW Tank T-14 \\
& Storage Tanks & & \\
\hline
\end{tabular}

SWSA 5 was opened in 1959 and is composed of two distinct geographical areas that provide different solid waste storage functions. SWSA 5 South has been used for routine disposal of LLW and nonretrievable TRU waste. SWSA 5 North has been used almost exclusively for retrievable storage of all TRU waste generated after 1970. During the operation of SWSA 5 South, waste accepted for disposal included poorly characterized solid LLW wastes generated by the ORNL main plant facilities from 1959 to 1973 and wastes from approximately 50 different agencies from 1955 to 1963, when ORNL was designated as the Southern Regional Burial Ground by the Atomic Energy Commission (now DOE). Existing records indicate $3 \times 10^{6} \mathrm{ft}^{3}$ of waste containing approximately $200,000 \mathrm{Ci}$ of radioactivity have been buried in SWSA 5 South. The buried waste was primarily solid LLW, but prior to the designation of the northern portion as the TRU Waste Storage Area in 1970, an unknown quantity of TRU wastes was also buried in SWSA 5 South. Since October 1970, TRU waste has been stored in SWSA 5 North, either in stainless steel drums, mild steel boxes, concrete casks, or stainless steel-lined wells.

WAG 5 is in Melton Valley within the Copper Creek thrust block and is underlain by strata of the middle to late Cambrian Conasauga Group. Strata that underlie the ridges in the WAG 5 area are the resistant sandstones and dolomites; the less resistant limestones and shales occur in the valleys. Piezometer well drill logs indicate that WAG 5 soils are predominantly medium brown to gray-green, silty clay containing gravel-sized rock and weathered shale fragments. The soil is composed of low- to high-plasticity clay and silt.

WAG 5 lies in the Melton Valley portion of the WOC watershed. There are four streams in its immediate vicinity: WOC to the west, Melton Branch to the south, and two unnamed creeks to the east and north. All four streams lie close to, but outside, the WAG 5 boundary. Both Melton Branch and WOC lie between 100 to $300 \mathrm{ft}$ of the WAG 5 boundary. There are no perennial streams within WAG 5; the two principal natural drainages are intermittent. Discharge of all surface runoff from 
WAG 5 is either to the WOC or to Melton Branch. There are two important man-made surface water features within WAG 5: the OHF Impoundment at the southeast corner of WAG 5 and the Process Waste Sludge Basin north of SWSA 5. In addition, 16 groundwater seeps have been identified around the perimeter of SWSA 5 South.

Groundwater occurs in the regolith and within the bedrock of the Conasauga Group, and the two flow systems are recognized as hydraulically interconnected. The groundwater table occurs near the base of the regolith at depths of less than 3 to $59 \mathrm{ft}$. Groundwater circulation occurs predominantly in the upper $100 \mathrm{ft}$ but may extend to depths of $230 \mathrm{ft}$ in the bedrock. The water table appears as a subdued replica of surface topography as expected under unconfined conditions.

Contamination in WAG 5 can therefore be summarized almost entirely in the context of site hydrology: the trenches inundated by groundwater are the most active sources and greatest contributors of contamination; groundwater is the principal release mechanism and contaminant migration pathway and as a result is the most widely spread contaminated medium at the site; the discharge of this groundwater and the resulting contamination of surface water creates on-site exposure points and leads to the off-site transport of WAG 5 contaminants.

Most of the contaminant source material consists of low-level radioactive solid wastes in unlined trenches and auger holes of SWSA 5 South. From an on-site risk perspective, the most significant contaminants detected are ${ }^{90} \mathrm{Sr},{ }^{3} \mathrm{H},{ }^{137} \mathrm{Cs},{ }^{60} \mathrm{Co},{ }^{243} \mathrm{Cm},{ }^{244} \mathrm{Cm},{ }^{238} \mathrm{Pu},{ }^{239} \mathrm{Pu},{ }^{226} \mathrm{I}$, and ${ }^{228} \mathrm{Ra}$. Contaminants most responsible for off-site risk are ${ }^{90} \mathrm{Sr},{ }^{3} \mathrm{H}$, and to a lesser extent, ${ }^{137} \mathrm{Cs}$. Contaminated seep discharges along the southern perimeter of SWSA 5 South are significant components of the overall flux of ${ }^{3} \mathrm{H}$ and ${ }^{90} \mathrm{Sr}$ measured at White Oak Dam. Soil contamination at WAG 5 is mostly due to ${ }^{137} \mathrm{Cs},{ }^{90} \mathrm{Sr}$, and ${ }^{60} \mathrm{Co}$ and is limited to areas contaminated by seep discharges, overflowing (bathtubbing) trenches, or surface debris. Transuranic radionuclides are currently being released from WAG 5 at negligible levels, but they are migrating through the subsurface and being discharged at seeps along the site perimeter and interior drainages.

There are three active projects at WAG 5: the RI, the Groundwater Seeps Project, and the OHF Inactive Tanks Contẹnts Removal Project.

\subsection{REFERENCES}

AIMS (Advanced Integrated Management Services, Inc.) 1995. Site Characterization Summary Report for the Old Hydrofracture Facility (draft), Lockheed Martin Energy Systems, Inc., Oak Ridge, Tenn.

Bates, L. D. 1987. Presentation on "TRU Waste System Description," Briefing for Tennessee Department of Health and Environment on June 9, 1987, Oak Ridge Natl. Lab.

Bechtel (Bechtel National, Inc.) 1988. Remedial Investigation Plan for ORNL Waste Area Grouping 5, ORNL/RAP/Sub-87/99053/8\&V1, Oak Ridge Natl. Lab.

Bechtel 1991. Supplement to the Remedial Investigation Plan for ORNL Waste Area Grouping 5, ORNL/RAP/Sub-87/99053/8\&V2 (Supplement), Oak Ridge Natl. Lab.

Bechtel 1995. Remedial Investigation Report on Waste Area Grouping 5 at Oak Ridge National Laboratory, Oak Ridge, Tennessee; Volume 1: Technical Summary, DOE/OR/01-1326\&D1/V1 (ORNL/ER-284\&D1/V1) (ORNL/ER/Sub/87-99053/76/V1), Oak Ridge Natl. Lab. 
Burwinkle, T. W. 1987. The ORNL Surplus Facilities Management Program Maintenance and Surveillance Plan-FY 1988-1997, ORNL/RAP-16, Oak Ridge Natl. Lab.

Clapp, R. B., and J. A. Watts, eds. 1995. Fourth Annual Environmental Restoration Monitoring and Assessment Report (FY 1995), Oak Ridge National Laboratory, Oak Ridge, Tennessee, DOE/OR/01-1413\&D1, Oak Ridge Natl. Lab.

DOE (U.S. Department of Energy) 1992. Federal Facility Agreement for the Oak Ridge Reservation, DOE/OR-1014, U.S. Environmental Protection Agency, Region IV, Atlanta, GA.; U.S. Department of Energy, Oak Ridge Operations, Oak Ridge, Tenn.; and Tennessee Department of Environment and Conservation, Nashville, Tenn. January 1.

Duguid, J. O. 1975. Status Report on Radioactive Movement from Burial Grounds in Melton and Bethel Valleys, ORNL-5017, Oak Ridge Natl. Lab.

Duguid, J. O., and O. M. Sealand 1975. Reconnaissance Survey of the Intermediate-Level Liquid Waste Transfer Line Between $X-10$ and the Hydrofracture Site, ORNL/TM-4743, Oak Ridge Natl. Lab.

Energy Systems (Martin Marietta Energy Systems, Inc.) 1987. Preliminary Geohydrologic Site Characterization and Proposed Water Quality Well Locations for WAG 4,WAG 5,WAG 3, and SWSA 1, ORNL/RAP/Sub-86/72139/1, Martin Marietta Energy Systems, Inc., Oak Ridge, Tenn.

Energy Systems 1992. Oak Ridge Reservation Environmental Report for 1991, ES/ESH-22/V1 and ES/ESH-22/V2, Martin Marietta Energy Systems, Inc., Oak Ridge, Tenn.

Energy Systems 1993. Engineering Evaluation/Cost Analysis for the Seep Removal Action at Waste Area Grouping 5 at the Oak Ridge National Laboratory, Oak Ridge, Tennessee, DOE/OR/02-1217\&D1, Martin Marietta Energy Systems, Inc., Oak Ridge, Tenn.

Energy Systems 1994. Action Memorandum for the Waste Area Grouping 5 Seep c at the Oak Ridge National Laboratory, Oak Ridge, Tennessee, DOE/OR/02-1235\&D2, Martin Marietta Energy Systems, Inc., Oak Ridge, Tenn.

Enserch (Enserch Environmental Corporation) 1994. Oak Ridge National Laboratory Waste Area Grouping 5 Groundwater Seeps Project, Oak Ridge Natl. Lab.

Environmental Consulting Engineers, Inc., 1995. Postconstruction Report for Waste Area Grouping 5 Seeps Removal Action at Oak Ridge National Laboratory, Oak Ridge, Tennessee, DOE/OR/01-1334\&D1, Lockheed Martin Energy Systems, Inc., Oak Ridge, Tenn.

Francis, C. W., and O. M. Sealand 1987. Concentrations of Radionuclides in ORNL Waste Pond Sediments and Their Leaching Characteristics, ORNL/RAP/LTR-87/70, Oak Ridge Natl. Lab.

Horton, J. R. 1984. Preliminary Decommissioning Study Reports, Volume 3: Low-Level Liquid Waste (LLW) Collection and Storage Tanks, X-OE-231, Vol. 3, Oak Ridge Natl. Lab.

Huang, S. F., et al. 1984. Preliminary Radiological Characterization of the Old Hydrofracture Facility at Oak Ridge National Laboratory, ORNL/CF-84/202, Oak Ridge Natl. Lab. 
Huff, D. D., N. D. Farrow, and J. R. Jones 1982. "Hydrologic Factors and ${ }^{90} \mathrm{Sr}$ Transport: A Case Study," Environmental Geology, 4, 53-63.

Myrick, T. E. 1984. The ORNL Surplus Facilities Management Program Long Range Plan, ORNL/TM-8957, Oak Ridge Natl. Lab.

Oakes, T. W., and K. E. Shank 1979. Radioactive Waste Disposal Areas and Associated Environmental Surveillance Data at Oak Ridge National Laboratory, ORNL/TM-6893, Oak Ridge Natl. Lab.

ORNL (Oak Ridge Natl. Lab.) 1987. RCRA Facilities Assessment (RFA)—Oak Ridge National Laboratory, ORNL/RAP-12/V1, Oak Ridge Natl. Lab.

ORNL 1990. ORNL Contaminated Site Summary Sheets, ORNL/M-2413, Oak Ridge Natl. Lab.

ORNL 1995. Performance Assessment for the Waste Area Grouping 5 Seeps C\&D Removal Action, ORNL/M-4210, Oak Ridge Natl. Lab.

ORNL 1996. Project Management Plan for Old Hydrofracture Facility Tanks Contents Removal at Oak Ridge National Laboratory, Oak Ridge, Tennessee (draft), Oak Ridge Natl. Lab.

PEER and MCI (PEER Consultants and MCI Consulting Engineers, Inc.) 1987. Draft Inactive Waste Storage Tanks Remedial Action Plan, ORNL/RAP-32, Oak Ridge Natl. Lab.

Radian Corporation 1994. Engineering Evaluation/Cost Analysis for the Seep Removal Action at Waste Area Grouping 5 at the Oak Ridge National Laboratory, Oak Ridge, Tennessee, DOE/OR/02-1217\&D2, Martin Marietta Energy Systems, Inc., Oak Ridge, Tenn.

SAIC (Science Applications International Corp.) 1994. Remedial Investigation Work Plan for the Groundwater Operable Unit at Oak Ridge National Laboratory, Oak Ridge, Tennessee, DOE/OR/01-1252\&D1 (ORNL/ER-221\&D1), Martin Marietta Energy Systems, Inc., Oak Ridge Natl. Lab.

Shoun, R. R. 1987. Environmental Data Package for ORNL Waste Area Grouping 5 (WAG 5), Solid Waste Storage Area 5 (SWSA 5), ORNL/RAP-19, Oak Ridge Natl. Lab.

Site and Facilities Planning Department June 1994. Oak Ridge Reservation Technical Site Information, ES/EN/SFP-23, Martin Marietta Energy Systems, Inc., Oak Ridge, Tenn.

Soloman, D. K., et al. 1991. Transport of Contaminants During Storms in the White Oak Creek and Melton Branch Watersheds, ORNL/TM-11360, Oak Ridge Natl. Lab.

Spalding, B. P., and I. L. Munro 1984. Determination of the Areal Distribution of ${ }^{90} \mathrm{Sr}$ in Groundwater Via Single-Use Boreholes, ORNL/TM-9990, Oak Ridge Natl. Lab.

Stansfield, R. G., and C. W. Francis 1986. Characterization of the Old Hydrofracture Facility (OHF) Impoundment, ORNL/TM-9990, Oak Ridge Natl. Lab.

Webster, D. A., and M. W. Bradley 1986. Hydrology of the Melton Valley Radioactive-Waste Burial Grounds at Oak Ridge National Laboratory, Tennessee (Draft), Open-File Report 86-XXX, U.S. Geologic Survey, Oak Ridge, Tenn. 
Wickliff, D. S., C. M. Morrissey, and T. L. Ashwood 1991. Active Sites Environmental Monitoring Program: Mid-FY 1990 Summary Report, ORNL/TM-1179, Oak Ridge Natl. Lab.

\subsection{BIBLIOGRAPHY}

Coobs, J. H., and J. R. Gissel 1986. History of Disposal of Radioactive Wastes into the Ground at Oak Ridge National Laboratory, ORNL/TM-10269, Oak Ridge Natl. Lab.

Ebasco Services, Inc. 1992. Baseline Report for Waste Area Grouping 5 at Oak Ridge National laboratory, Oak Ridge, Tennessee, ORNL/ER-92/V1, Oak Ridge Natl. Lab.

Environmental Consulting Engineers 1995. Postconstruction Report for Waste Area Grouping 5 Seeps Removal Action at Oak Ridge National Laboratory, Oak Ridge, TN, DOE/OR/01-1334\&D1, Oak Ridge Nat1. Lab.

Morrison, S. J. and T. E. Cerling 1987. Survey of Metal, Radionuclide and Organic Contamination at 20 Waste Area Groups (WAGs), ORNL Facilities, Oak Ridge, Tennessee, ORNL/RAP/Sub-87/27463/1, Oak Ridge Natl. Lab.

Oak Ridge Natl. Lab. 1994. Action Memorandum for the Waste Area Grouping 5 Seep D at Oak Ridge National Laboratory, Oak Ridge, TN, DOE/OR/02-1283\&D1, Oak Ridge Natl. Lab. 



\title{
11. HISTORY AND CHARACTERIZATION OF WAG 6
}

\begin{abstract}
Instructions to User
This chapter provides information about WAG 6 that can be cited in certain CERCLA documents (see Chap. 1 and Table 1 in Instructions to User). For a short description of WAG 6 that can be copied into other types of documents, see the summary at the end of this chapter. To keep this document as short as possible, information about conditions common to all WAGs (e.g., climate and demography) is given in Chap. 5-History and Characterization of the ORNL Site.
\end{abstract}

\subsection{SITE DESCRIPTION AND HISTORY}

WAG 6 (Fig. 11.1) comprises three solid waste management units (SWMUs):

- SWMU 6.1-Solid Waste Storage Area (SWSA) 6

- SWMU 6.2-the Explosives Detonation Trench (EDT)

- SWMU 6.3-the Emergency Waste Basin (EWB)

The locations of the WAG 6 SWMUs are shown in Fig. 11.2. SWSA 6, the largest of the contaminated WAG 6 sites and the principal source of environmental contamination at WAG 6, covers 68 acres, approximately 19 of which have been used for waste disposal. SWSA 6 also includes two testing areas: the Engineered Test Facility and the Hill Cut Test Facility. The following sections present a summary of the site histories of the three SWMUs in WAG 6. The site histories present information on construction, operation, and maintenance activities; additional information can be found in the ORNL Contaminated Site Summary Sheets (ORNL 1990).

\subsubsection{SWSA 6}

SWSA 6 (Fig. 11.2) was opened for limited disposal operations in 1969 and began full-scale operations in 1973. SWSA 6 received wastes (radioactive and chemical) from every operational activity conducted at ORNL. The wastes included solvents, scintillation liquids, laboratory glassware and equipment, protective clothing, worn-out or obsolete mechanical equipment, construction materials, asbestos, filter media and resins, animal remains, and contaminated earth. Currently, only low-level liquid (radioactive) waste (LLLW) is disposed of in SWSA 6. No chemical wastes have been disposed there since April 1986. Prior to 1986, packaging of these wastes was highly variable, ranging from plastic bags to stainless-steel drums to no containerization at all (International Technology 1986).

Trenches are classified based on the form of disposed waste: high activity (unlined), low activity (unlined), biological, asbestos, baled, fissile, high-activity concrete lined, or low-activity concrete lined. A map indicating the locations of the various trench types is shown in Fig. 11.3. The demolition landfill, which is still active, is used for disposal of shredded radiological contaminated (suspect) waste. 
11-2

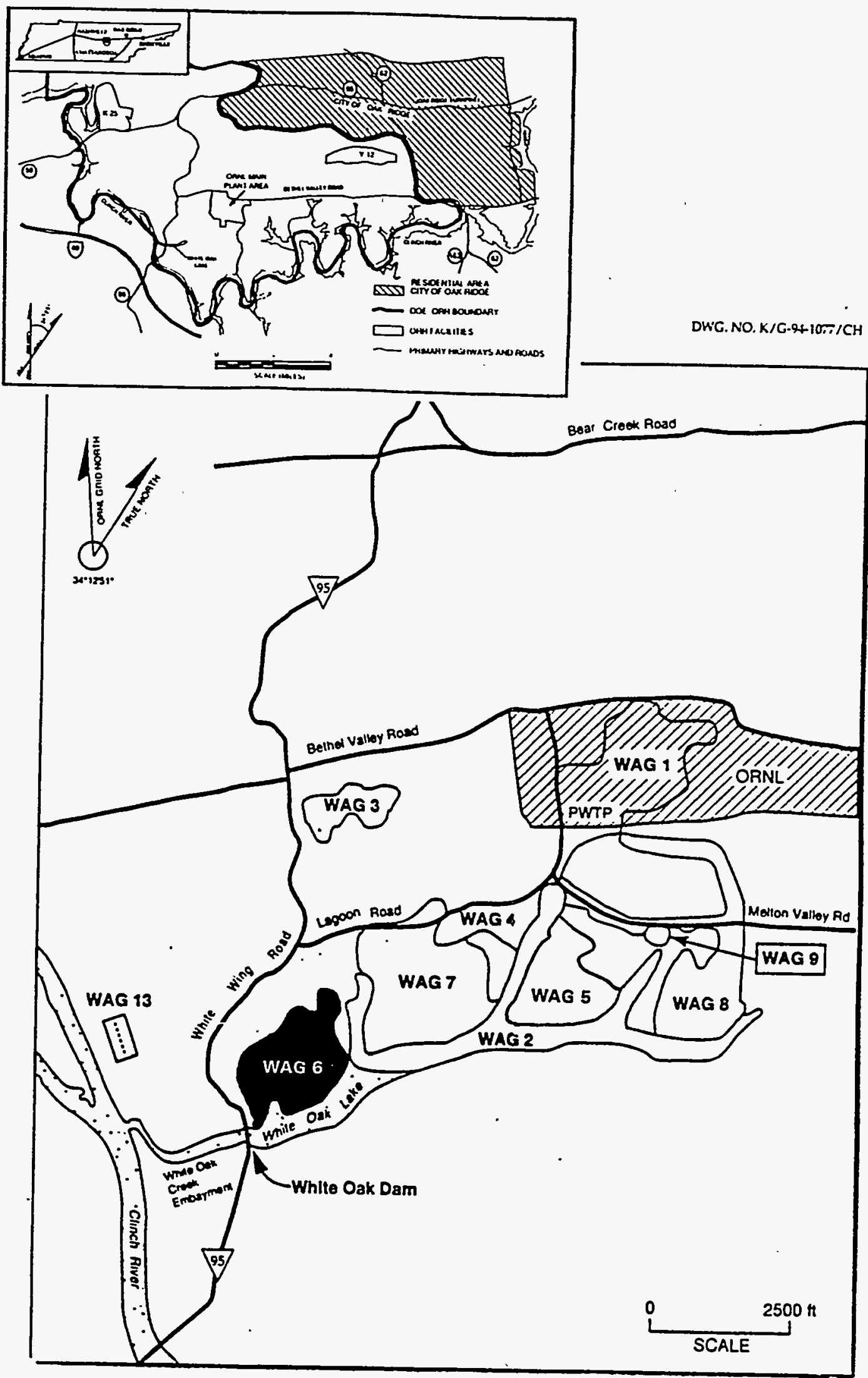

Fig. 11.1 Location of WAG 6. 


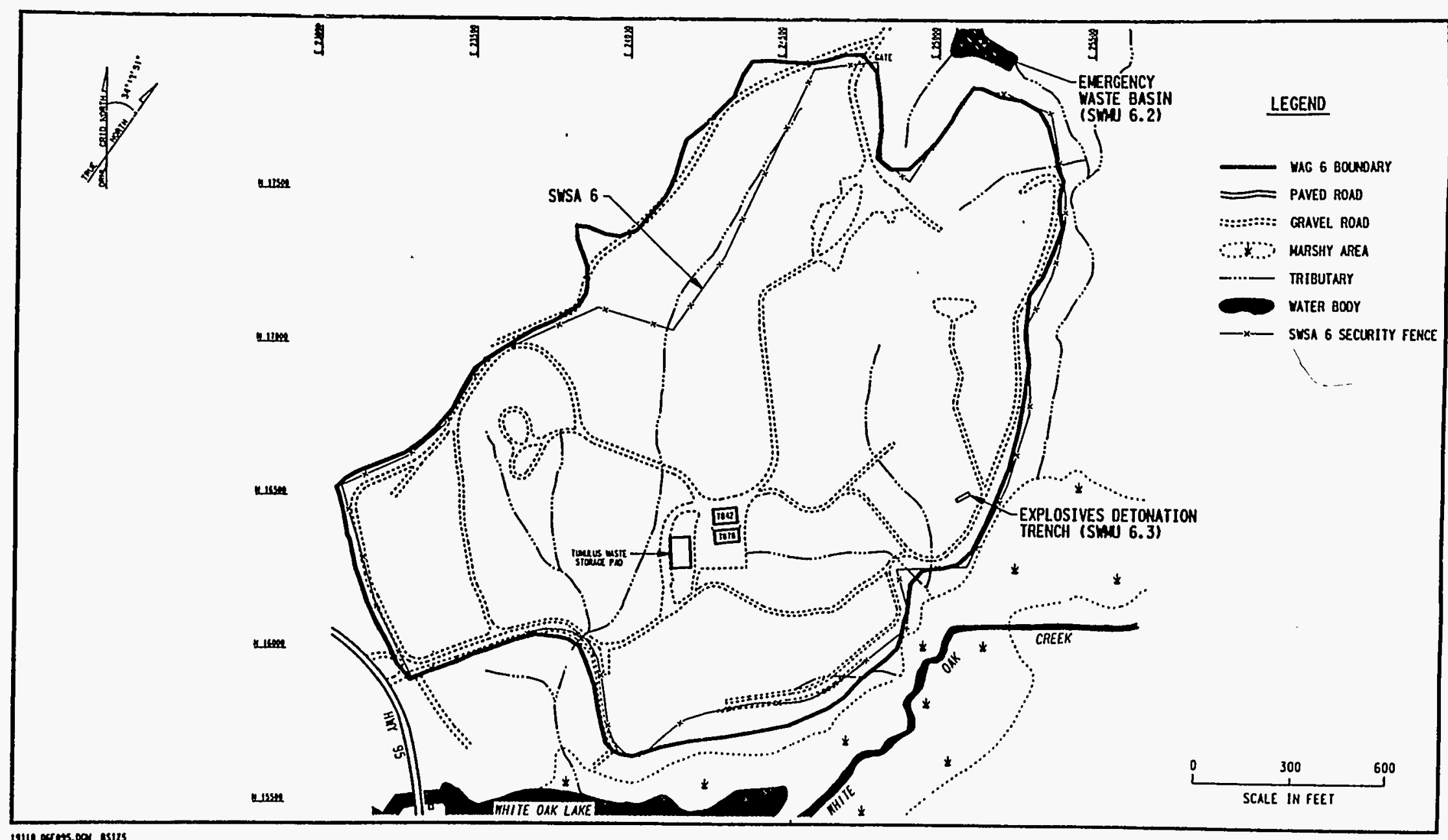

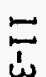

Fig. 11.2. Location of WAG 6 Solid Waste Management Units. Source: Bechtel 1990 


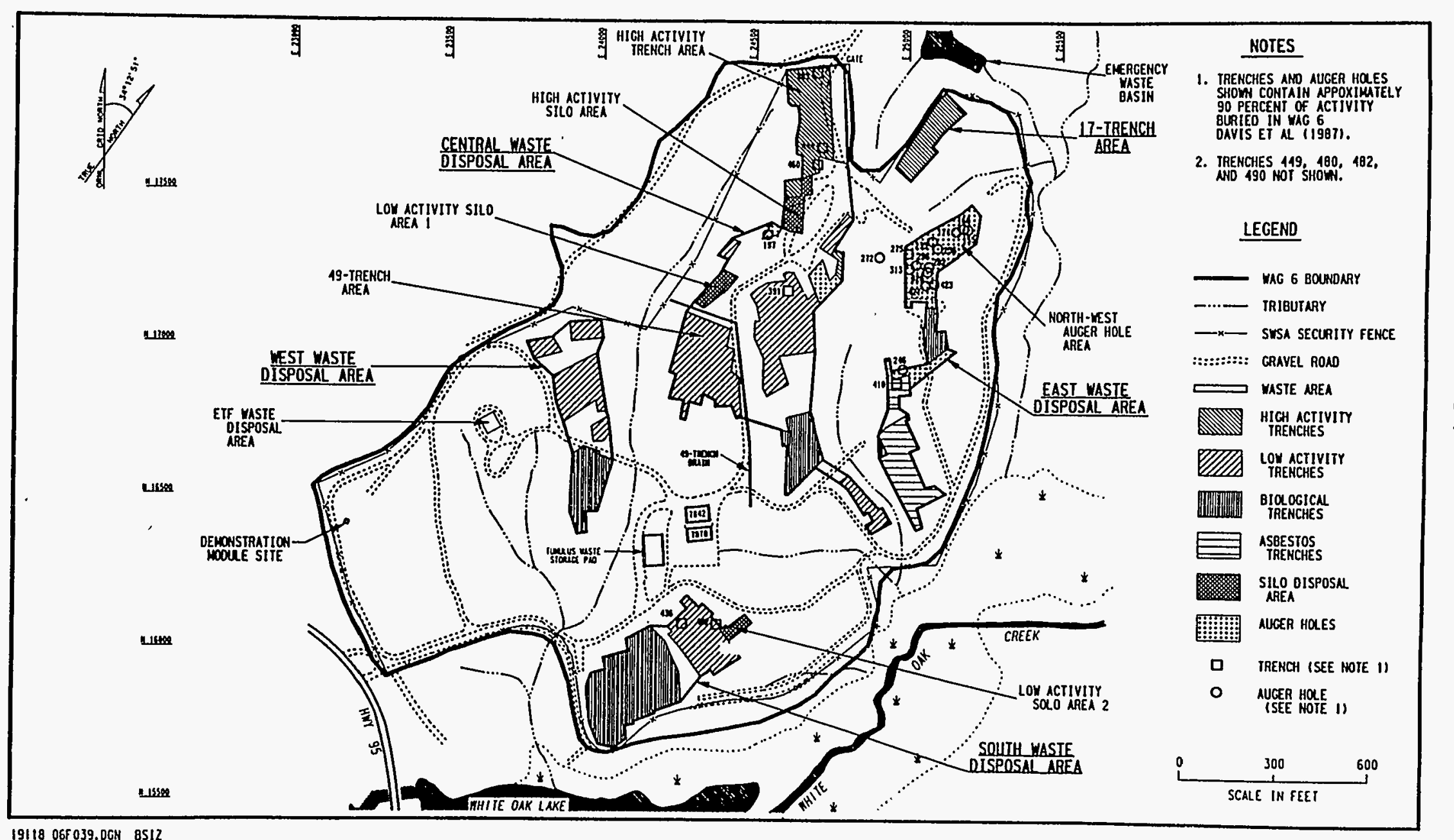

$\bar{b}$

Fig. 11.3. WAG 6 solvent auger hole and biological trench areas. Source: Bechtel 1990 
The high-activity (unlined) trenches are concentrated in two areas at the northern edge of the site where the height above the water table is greatest. These trenches occupy approximately 2 acres, or $3 \%$ of the total area of SWSA 6 . High-activity trenches were used for disposal of waste with a reading on the surface of the container equal to or exceeding $200 \mathrm{mR} / \mathrm{h}$. After being placed in the trench, wastes were covered with sufficient soil to lower the surface radiation reading to $100 \mathrm{mR} / \mathrm{h}$ or less.

Low-activity (unlined) trenches occupy the most area in SWSA 6 and are second in number only to biological trenches. The low-activity trenches were used to dispose wastes with radiation readings on the surface on the container of less than $200 \mathrm{mR} / \mathrm{h}$. These wastes included metal, wood, construction debris, concrete, paper, plastics, clothing, and lead shielding (International Technology 1986). Before June 1985, wastes were simply dumped into trenches; after that time, most waste was packaged in plywood boxes or 55-gal steel drums and stacked in the trenches.

Asbestos trenches, which occupy only 0.7 acre, or $1 \%$ of the total area of SWSA 6 , received both radioactively contaminated and uncontaminated asbestos. These trenches were used infrequently, and the waste was covered with soil the same day (ORNL 1986).

Compacted bale trenches comprise about 0.15 acre, or $2 \%$ of the total area (ORNL 1986). These trenches received compacted wastes (e.g., gloves, shoe covers, and blotter paper), which were not alpha radioactively contaminated and had a contact radiation reading of $200 \mathrm{mR} / \mathrm{h}$ or less. Wastes were compacted about twice a month into $10 \mathrm{ft}^{3}$ bales weighing approximately $650 \mathrm{lb}$.

The biological trenches comprise the largest group of trenches in SWSA 6, occupying approximately 3.2 acres, or $5 \%$ of the total area (ORNL 1986). The trenches are distributed throughout four areas of the site, primarily in the central and southern portions of SWSA 6 . The biological trenches received materials from biomedical laboratories, including carcasses of experimental animals, bedding, excreta, gloves, and shoe covers. The waste is reported to be primarily low-activity, low-level, nonalpha contaminated, less than $200 \mathrm{mR} / \mathrm{h}$, with most waste being approximately $5 \mathrm{mR} / \mathrm{h}$. The biological trenches also contain the largest volume of scintillation fluids (primarily xylene and toulene) in SWSA 6. Records indicate that between 1972 and 1976, over 12,500 gal of scintillation fluids may have been disposed of in 35 biological trenches (ORNL 1986).

Auger holes have been classified as high-activity, solvent, or fissile (Davis and Solomon 1987). The auger holes, which comprise approximately 1.2 acres, or $1.7 \%$ of the total SWSA 6 area, are located in higher elevation areas (Fig. 11.3). The holes are generally 1 to $4 \mathrm{ft}$ in diameter, $20 \mathrm{ft}$ in depth, and spaced approximately $3 \mathrm{ft}$ apart. Three or four disposals were routinely made in each auger hole. Wastes were disposed of in various sized containers up to 55 -gal drums. If the radiation reading was greater than $100 \mathrm{mR} / \mathrm{h}$ after waste disposal, soil was backfilled until the radiation level was reduced to $100 \mathrm{mR} / \mathrm{h}$ or less. Fissile auger holes received wastes containing ${ }^{235} \mathrm{U}$, possibly mixed with other radionuclides, such as ${ }^{137} \mathrm{Cs}$, ${ }^{238} \mathrm{U}$, and ${ }^{90} \mathrm{Sr}$.

Unlined auger holes were used to dispose of high-activity waste with radiation readings at the surface of the unshielded container equal to or exceeding $200 \mathrm{mR} / \mathrm{h}$. Waste disposed in high-activity auger holes included other LLLW not classified as fissile, such as cobalt and tritium. If a high-activity waste could physically fit into an auger hole, it was placed there. 
Before 1980, solvent auger holes were used to dispose of a variety of chemical wastes, some of which were radioactively contaminated. Exact volumes disposed of are not known, but wastes included oils, cleaning solutions, alcohols, paint thinners, kerosene, jet fuel, acids, and sodium (Bechtel 1990).

The demolition landfill, used for disposal of low hazard (suspect) waste, is also located within SWSA 6. This waste has no measurable surficial radiological contamination but has been judged by the generator to be radioactively contaminated above ORNL "Health Physics Material Transfer Clearance Tag" limits (free of radiation or other contamination hazards) or to be such that some areas cannot be surveyed (such as the insides of pipes). This landfill occupies approximately 5 acres and is located in the northeastern portion of SWSA 6 . Waste is shredded to reduce its volume, and when it is placed in the landfill it is covered with soil.

Approximately 100 Greater Confinement Disposal Silos exist at SWSA 6. These silos consist of cylindrical concrete silos with top and bottom caps, placed below grade in a vertical orientation. Dimensions include 6-in. thick concrete walls and an 8-in.-thick steel-reinforced concrete top and bottom. The majority of the silos are also equipped with a 3-in.-diameter polyvinyl chloride monitoring well on the inner wall of the silo for detection and sampling of waste leachate in the silos (Baldwin et al. 1989).

The silos were constructed using three different techniques. The initial 12 silos were constructed using precast concrete drainage pipe. Four of the pipes were placed adjacent to one another in a trench. The trench around the pipes was then backfilled, and a steel-reinforced concrete bottom was poured into each silo. The joint between the concrete silo walls and floor was sealed with tar. The second construction method, which was used to construct 24 silos, consisted of using 2 diameters $(8 \mathrm{ft}$ and $9 \mathrm{ft}$ ) of comugated metal pipe as forms for pouring the concrete side walls. The two pipes were aligned vertically, positioned concentrically, and attached with welding struts. The bottoms were formed by pouring a steel-reinforced concrete floor and sealing the joint between the inner corrugated metal pipe and the concrete floor with tar. The third technique also involved using metal piping as forms for pouring the concrete side walls. However, the inner of the two pipes was raised approximately $1 \mathrm{ft}$ above the outer pipe before being welded in place. The floor and walls were then poured as one continuous element.

SWSA 6 also includes two testing areas: the Engineered Test Facility and the Hill Cut Test Facility. The Engineered Test Facility was established as a field-scale demonstration site for investigating improved shallow land burial technology. The Hill Cut Test Facility was created as a demonstration project to evaluate using hill slope cuts for disposing of radioactive waste.

\subsubsection{Explosives Detonation Trench}

The EDT, which is now backfilled and covered by an Interim Corrective Measure (ICM) cap, was used to detonate explosives and shock-sensitive chemicals, such as acids and oxidizers (e.g., picric acid, phosphorus, and ammonium nitrate). The trench is located in the northern portion of SWSA 6 (Fig. 11.2) and is approximately $15 \mathrm{ft}$ long by $5 \mathrm{ft}$ wide by $4 \mathrm{ft}$ deep. Wastes were placed in the bottom of the trench and detonated with small plastic charges; debris from the explosions generally remained in the trench. A closure plan for the EDT has been filed in accordance with 40 CFR Sect. 270.14(b) (13-18), Sects. 264.110-115, and Sect. 264.178, and TN 1200-1-11-.07(5) (a) (13-16) (ORNL 1985). 


\subsubsection{Emergency Waste Basin}

The EWB (Fig. 11.2) was constructed in 1961-1962 to serve as an emergency holding basin for LLLW or process wastes. It was to be used when ORNL was unable to release to White Oak Creek (WOC). The basin, which encompasses approximately 2 acres and has a potential storage volume of 15 million gal, has reportedly never been used (Bechtel 1990). The EWB is technically outside the ORNL boundary for WAG 6, which, along the northem edge of the WAG, is marked by the SWSA 6 fence. The EWB, however, receives some runoff from the northern portion of WAG 6 and for that reason is considered a WAG 6 SWMU (Bechtel 1991).

\subsection{CHARACTERIZATION}

\subsubsection{Geography}

WAG 6 is located on the Oak Ridge Reservation (ORR) in Roane County, Tennessee, approximately 5 miles southwest of the city of Oak Ridge central business district (Fig. 11.1). WAG 6 is part of ORNL and is located approximately 2 miles southwest of the ORNL main plant area. WAG 6 is bordered on the south by White Oak Lake (WOL) near White Oak Dam and on the west by State Highway 95 . WOL and WOC are part of WAG 2, which extends into the ORNL main plant area.

WAG 6 is located at the southwestem end Melton Valley, a northeast-southwest trending valley roughly 1.2 miles wide that lies between Haw Ridge on the north and Copper Ridge on the south. The site's topography is gently to moderately sloping, draining to WOL on the south and an unnamed tributary of WOC on the east (Fig. 11.4). Crest elevations along Haw Ridge and Copper Ridge reach $1000 \mathrm{ft}$ and $1356 \mathrm{ft}$, respectively. A line of lower hills with crest elevations of approximately $850 \mathrm{ft}$ occurs near the center of Melton Valley, and WAG 6 is situated on the southeast flank of one of these hills. Ground surface elevations within WAG 6 range from $745 \mathrm{ft}$ mean sea level to greater than $850 \mathrm{ft}$ mean sea level at the crest of the series of knobs along the northwest boundary (Bechtel 1991).

As Fig. 11.4 shows, the WAG 6 topography is dissected by four principal surface water drainages-FA, FB, DA, and DB. With the exception of stream DA, which trends grid east-west, streams in WAG 6 are oriented roughly grid north-south. The resulting undulating topography and relief plays an important role in the hydrogeologic framework of WAG 6.

The surface features present at WAG 6 are shown in Fig. 11.5. The main surface features of WAG 6 include: three SWMUs, a series of interconnected unpaved roads, two permanent buildings, power and telephone lines, a tumulus pad with stacked concrete vaults, two weather stations, and numerous wells. Except for the EWB, located just north of SWSA 6, the entire area is enclosed by an 8-ft-high chain link fence topped with barbed wire. Various equipment, including bull dozers, backhoes, graders, forklifts, and trucks are commonly on site. Concrete vaults used to store and bury waste are also on site but are moved frequently. Six large areas in SWSA 6 were capped with a high-density polyethylene geomembrane to reduce the infiltration of precipitation as part of the ICM project. These areas are roped off. Other than where roads and buildings exist, WAG 6 is covered by either stands of trees or fields of grass and weeds. The grassy areas are mowed during the growing season. Numerous natural and man-made drainages transect the site. Some of these drainages are rip rap lined. Culverts have been installed where drainages cross the roads (Bechtel 1990). 


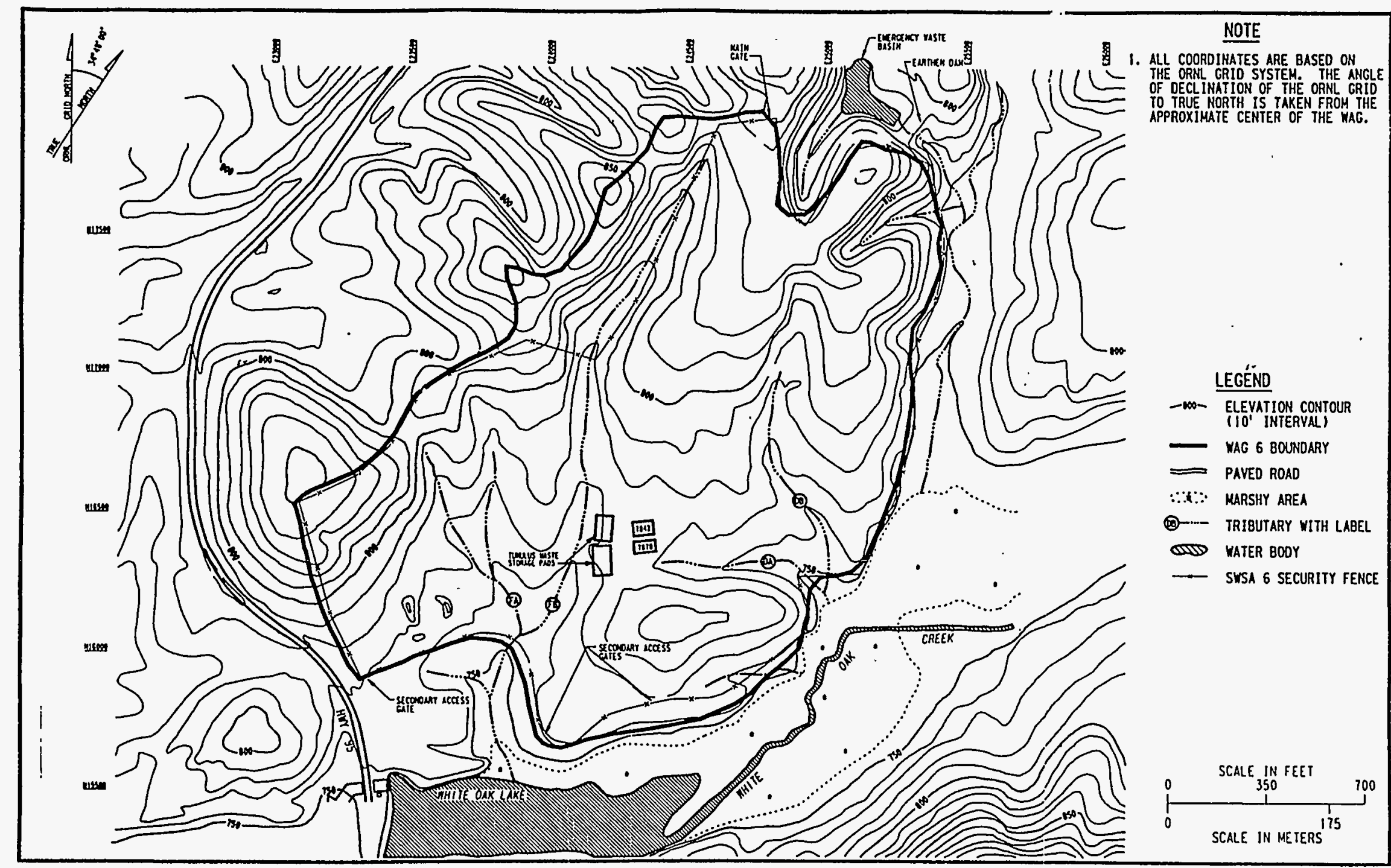

Fig. 11.4. WAG 6 topography and drainage. Source: Bechtel 1991 


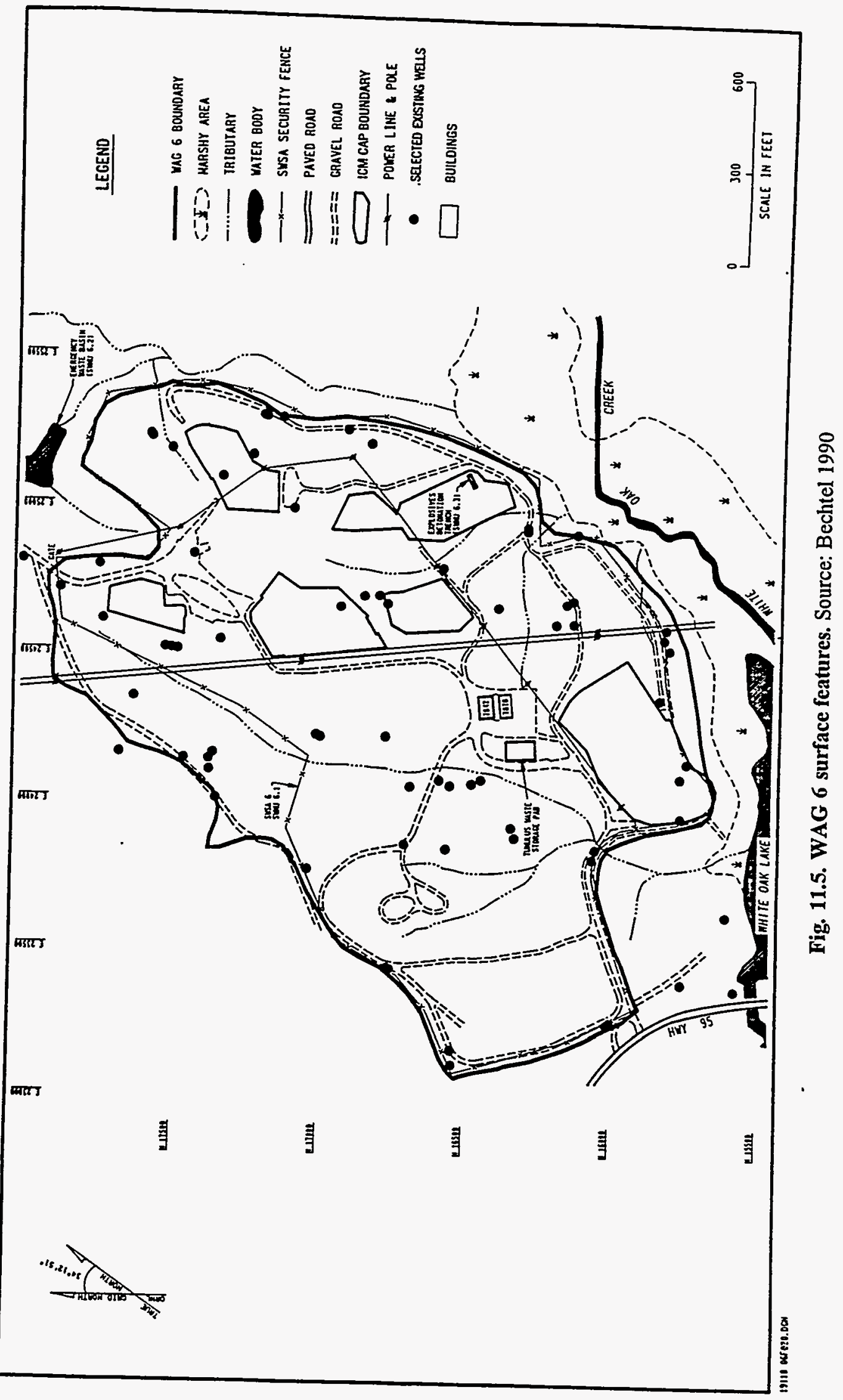




\subsubsection{Climate}

See Sect. 5.2.2 of this document for climate description.

\subsubsection{Demography}

Because SWSA 6 is an active facility, ORNL workers are on site daily during the work week and frequently on the weekends. Activities performed by these workers include construction of disposal units, waste transportation and disposal, technology demonstrations, and site maintenance and monitoring. All workers are required to have undergone site safety training in accordance with ORNL Environmental Safety and Health procedures.

At the closest point, WAG 6 is approximately 1 mile from the ORNL main plant area, where the majority of ORNL's approximately 4837 employees work (Energy Systems 1994). Within 0.5 mile of the boundary of WAG 6, all land is federally owned, and there are no residents. The two-lane State Highway 95 runs through the ORR and passes along the western side of WAG 6 within $100 \mathrm{ft}$ of its boundary at the closest point. WAG 6 is approximately 0.42 mile from the north bank of the Clinch River, which forms a portion of the boundary of the ORR. Clinch River, also known as Watts Bar Lake at this location, is open to recreational uses, such as boating, fishing, and duck and goose hunting, as permitted by the state of Tennessee.

See Sect. 5.2.3 of this document for general demographic characteristics of ORNL.

\subsubsection{Geology and Soils}

The geology of the WAG 6 site has a controlling influence on the occurrence of groundwater and contaminant transport, and it impacts the selection and design of remedial action alternatives. This section summarizes the key geologic findings from $R C R A$ Facility Investigation Report for Waste Area Grouping 6 at Oak Ridge National Laboratory, Oak Ridge, Tennessee, Vol. 1, ES/ER-22/V1\&D1 (Bechtel 1991). Sect. 5.2.4 of this document provides a general discussion of ORNL geology and soils.

Overall, the geology of the WAG 6 site is complex, being a product of original depositional patterns in the bedrock, severe and variable structural deformation, weathering, and human activities. Consequently, there is considerable uncertainty in determining hydrogeologic processes on a local scale, such as assessing specific flow paths from a particular trench source to a well or surface water.

Maryville Limestone and Nolichucky Shale bedrock underlie the northem and southern parts of the site, respectively. These formations were deposited in an environment whereby rapid lateral and vertical variations in lithology are common. Consequently, correlations of individual beds within these formations from well to well are uncertain. Although bedrock generally strikes grid east-west and dips towards grid south (i.e., true northeast strike and southeast dip), due to local structural complexities a wide range in bedding strike and dip has been documented at WAG 6 . Site borehole televiewer logs and rock cores show that strikes and dips change rapidly in relatively short vertical distances.

Minor folding (i.e., kink folds) and normal, reverse, and thrust faults are widespread. Two principal thrust faults have been identified trending roughly east-west across WAG 6 . Other faults and fault splays are also possible. Faults may act as either conduits or impediments to groundwater 
flow (i.e., a given fault or fault zone may in one location facilitate groundwater flow and in another serve as a barrier to flow). However, faults at WAG 6 are not active faults. Structural complexity increases from north to south across WAG 6 and is likely related to the occurrence of the two principal thrust faults.

Little or no primary porosity exists in the bedrock. However, fractures (secondary porosity) are widespread. As many as five distinct fracture sets may be encountered at a given location at WAG 6. Principal fracture orientations include strike parallel and bedding plane parallel fractures (generally trending ORNL grid east-west) and a high-angle fracture set oriented perpendicular to bedding. Most fractures are short (less than $3 \mathrm{ft}$ long) but interconnected so as to form a complicated network (i.e., stair-stepping patterns in all directions) for groundwater flow. Open fracture density decreases with depth.

Depth to bedrock varies with topography, ranging from 2.5 to $51 \mathrm{ft}$ below land surface. Along the perimeter of WAG 6 the depth to bedrock was found to be 20 to $25 \mathrm{ft}$ below grade, an average $10 \mathrm{ft}$ below grade along the eastern perimeter (ranging from 2.5 to $21 \mathrm{ft}$ ), and greater than $23 \mathrm{ft}$ along the southern boundary adjacent to WOL.

Saprolite overlies bedrock throughout the site and is formed in place from weathering of underlying bedrock. Saprolite thickness varies across the site with degree and depth of weathering, and it is generally thicker on hilltops. Relict bedrock structural fabric is preserved, and in some cases (owing to movement of fluids through the saprolite), porosity associated with the structural feature is either enhanced or occluded. Weathering has further resulted in dissolution of calcium carbonate cements such that the saprolite shows considerably more matrix (primary) porosity than underlying unweathered bedrock.

Eleven different soil types have been delineated at WAG 6, and these are typically thin and acidic. In many areas soils have been removed, reworked, or otherwise altered during site operations. This has created discontinuous zones of variable and somewhat unpredictable permeability, both laterally and vertically. Although thin and variable, WAG 6 soils have high sorptive capacities for retaining cobalt, strontium, and uranium.

\subsubsection{Surface Water}

This section presents a summary description of the surface water hydrology of WAG 6. Key findings and conclusions regarding the surface water hydrology at WAG 6 are summarized in the following paragraphs from RCRA Facility Investigation Report for Waste Area Grouping 6 at Oak Ridge National Laboratory, Oak Ridge, Tennessee, Vol. I, ES/ER-22/V1\&D1 (Bechtel 1991). Sect. 5.2.5 of this document provides a more general discussion of ORNL surface water hydrology.

Surface water at WAG 6 is significant because the majority of contaminant transport, either via storm flow or groundwater discharge, is to the surface water features within and surrounding WAG 6. Because of this, surface water is a principal pathway for contaminant transport off WAG 6 and is of concern with respect to potential health risks associated with exposure.

WAG 6 is situated on a hillside within the WOC basin, as shown in Fig. 11.6. The site is just north of WOL, which is an impounded segment of WOC. Outflow from WOL is controlled at a dam located about 0.6 mile upstream of the confluence of WOC and Clinch River. All of the WAG 6 area drains to the WOL floodplain either directly or via the several drainages located 


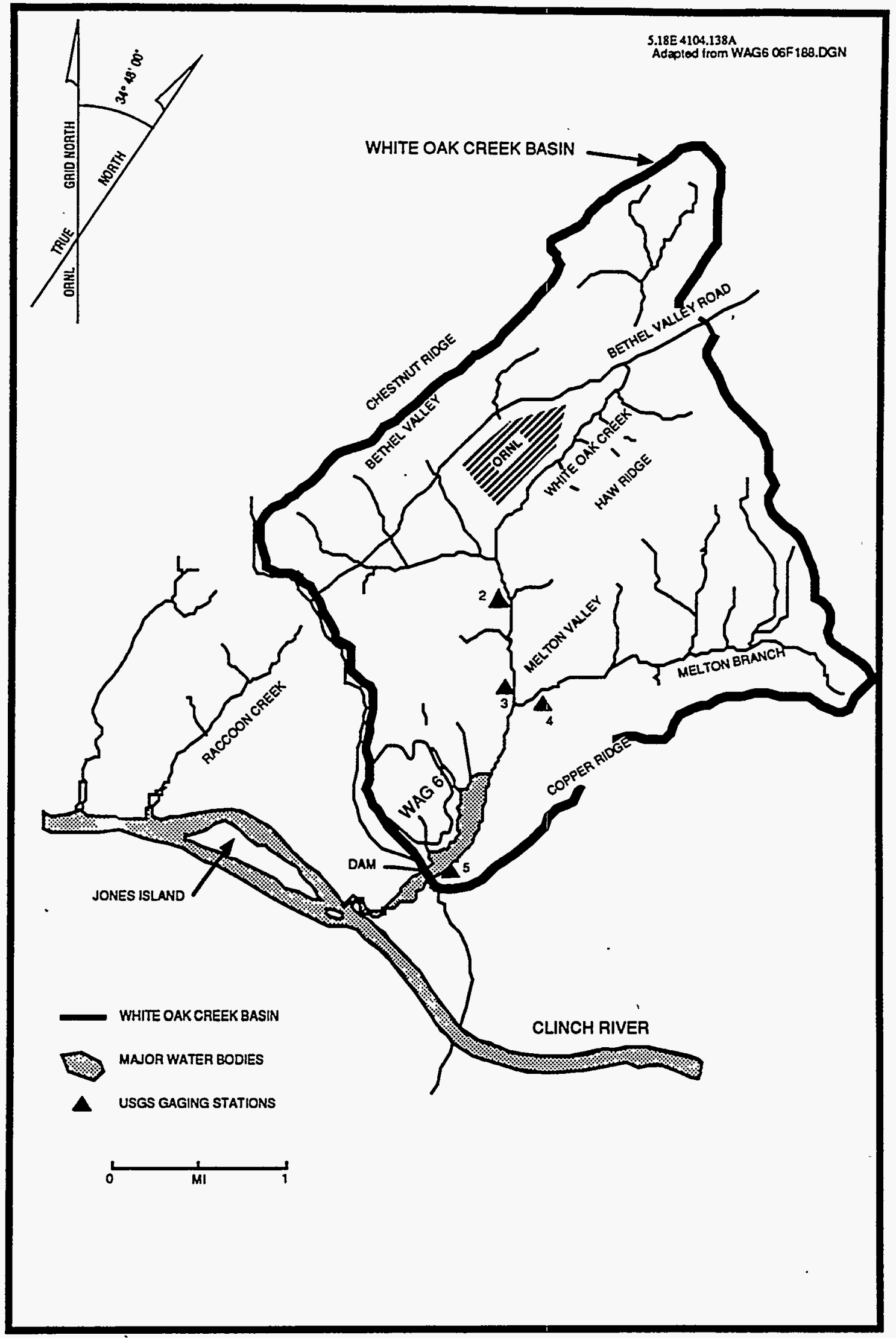

Fig. 11.6. White Oak Creek basin. Source: Bechtel 1990 
within the WAG 6 boundary and along its eastern boundary. WOC joins Clinch River at Clinch River Mile 21. The receiving waters of WAG 6 are the Emergency Waste Basin, an unnamed tributary to WOC that flows along the eastern side of WAG 6, WOL and the WOC embayment, WOC, and Clinch River. The surface waters of WAG 6 include seven streams, all originating within WAG 6.

Waste management and research activities at the site since the 1970s have impacted the surface water hydrology of WAG 6. Flow paths have been altered due to construction of service roads, culverts, the French drain, and the drainage features associated with the ICM caps over eight waste areas. This increase in impervious surfaces, plus clearing of some wooded areas, has increased overall flow rates and volumes; the increase, however, is small.

Streams in WAG 6 are intermittent, and except for some groundwater discharge, they are mostly dry during summer months. The stream density of the site is considered high, and streams are short-the longest being about $1900 \mathrm{ft}$. Therefore, potential for dissolved contaminant migration from WAG 6 via surface waters is quite high.

While steep slopes in WAG 6 promote fast response to rainfall events, high vegetative cover and variability in soil infiltration rates across the site moderate the storm response somewhat. The flow of the streams includes surface runoff (overland flow, saturated overland flow, subsurface storm flow) and base flow components. Adequate data do not exist to assess the relative percents of each of these flow components. However, the storm hydrographs at the stream outlets at the site boundary exhibit peak flow occurring within 1 hour of peak storm rainfall in most cases. Therefore, it can be stated that overland flow and saturated overland flow dominate the storm hydrograph shape and the storm volume.

The long term (1948 to 1990) annual precipitation as measured at the Oak Ridge Station is 54 in. The average annual precipitation for WAG 6 (Engineered Test Facility site) has been estimated to be $52 \mathrm{in}$. The average annual evapotranspiration is $30 \mathrm{in}$. The balance, $22 \mathrm{in}$., is the average annual discharge from WAG 6 . The average annual amount of groundwater discharge to on-site streams and into WOL cannot be accurately quantified. Estimated average annual recharge to groundwater ranges from 1.3 to 10 in. ( 3 to $20 \%$ of precipitation).

Seasonal runoff distribution is proportional to variations in precipitation, evapotranspiration, and soil moisture levels. During the wet season, precipitation is highest and evapotranspiration is minimal, but soil moisture content is quite high, such that runoff is high. Just the opposite occurs in dry periods; much of the precipitation infiltrates into the subsurface and runoff is low. In WAG 6, runoff ranges from $10 \%$ during dry periods (July through September) to $51 \%$ in wet months (January through March). Similar trends occur in wet versus dry years.

The natural water in the streams is of the calcium-bicarbonate type, is moderately hard to very hard, and has low sodium, potassium, and chloride content. The $\mathrm{pH}$ of the water is neutral to slightly acidic (between 6.6 and 7.6).

\subsubsection{Groundwater}

This section summarizes the key findings and conclusions regarding the groundwater hydrology at WAG 6 from RCRA Facility Investigation Report for Waste Area Grouping 6 at Oak Ridge National Laboratory, Oak Ridge, Tennessee, Vol. 1, ES/ER-22/V1\&D1 (Bechtel 1991). Sect. 5.2.6 of this document provides a more general discussion of ORNL groundwater hydrology. 
In the saturated zone, groundwater occurs under water table conditions in the regolith and/or shallow bedrock. No major aquitards or confining layers are present, so that groundwater is a continuum from the water table to depth in bedrock. Perched water occurs in the unsaturated zone at WAG 6 but appears to be of limited extent and significance.

Transient storm flow occurs in the unsaturated zone at WAG 6. However, the storm flow zone is highly variable and likely discontinuous due to considerable removal or reworking of surficial soils, the lack of vegetative cover, ICM capping over approximately $15 \%$ of the site, and other physical features resulting from waste disposal activities. Therefore, storm flow paths are likely discrete and short from point of infiltration to discharge along streams or seeps within WAG 6. Considerable uncertainty exists with respect to the impact of the storm flow zone on WAG 6 hydrology, and it is neither feasible nor practical to characterize storm flow in detail on a site-wide basis. However, storm flow can serve as a transport mechanism for contamination, and consequently remedial alternatives must address uncertainties associated with subsurface storm flow.

The water table configuration mimics topography, indicating groundwater flow towards WAG 6 surface water features and in an overall southerly direction towards WOL. The water table occurs below the top of unweathered bedrock over much of the northern half of WAG 6 for all or most of the year. Groundwater flow in these areas is solely through fractured bedrock. Conversely, the water table occurs in the regolith in the southern half of the site, such that shallow groundwater flow occurs both in the saturated regolith and uppermost fractured bedrock. The water table adjacent to WOL fluctuates proportionally to lake stage fluctuations. Disposal trenches greater than $15 \mathrm{ft}$ deep adjacent to WOL are inundated, and water levels in these trenches also fluctuate with lake levels. Shallower trenches are apparently unaffected.

Groundwater flow diagrams (analogous to flownets) indicate groundwater flow is local rather than regional. Groundwater follows short flow paths within WAG 6, flowing from higher elevation points of recharge to discharge along intervening surface water drainages.

Hydraulic conductivity in the regolith or bedrock varies by several orders of magnitude laterally and at any given depth but shows a marked decrease with depth. The decrease in hydraulic conductivity is related to the decreasing density of open fractures with depth. Aquifer testing results indicate the bedrock aquifer is a low-yield aquifer (less than $1 \mathrm{gal} / \mathrm{min}$ ) with limited storage capacity principally related to fractures; well yields are generally too low to encourage use as a potable water supply. Aquifer testing (pump and tracer tests) in bedrock showed considerable nonradial, anisotropic response, which illustrates the difficulty in predicting groundwater flow between two points with confidence and suggests that remedial alternatives involving groundwater extraction by pumping are likely to prove ineffective.

A preponderance of evidence exists to support the conclusion that a majority of groundwater flow at WAG 6 occurs in the upper 50 to $100 \mathrm{ft}$ of the aquifer with virtually no flow occurring below $250 \mathrm{ft}$. Groundwater flow in the regolith, where saturated, is through a combination of matrix porosity and secondary porosity features and generally is expected to follow mapped hydraulic gradient on a larger scale. However, the degree of anisotropy increases with depth in the regolith in inverse proportion to the degree of weathering. Consequently, some uncertainty remains in predicting local groundwater flow between two points.

In the unweathered bedrock, groundwater flow occurs along secondary permeability features, principally fractures. Principal groundwater flow directions in bedrock follow strike-parallel and 
bedding plane fractures except where crossing secondary fractures with different orientations and lower heads. This results in tortuous, stair-stepping flow paths in three dimensions. Flow directions and rates in the saturated regolith and upper bedrock are controlled by a combination of the hydraulic gradient and the orientation, density, and degree of interconnecting fractures. While strike-parallel flow dominates in the bedrock, it can be assumed that on a larger scale flow is in the direction of hydraulic gradient, as determined from potentiometric mapping, particularly in areas where the water table occurs above the top of competent bedrock. Nonetheless, there is considerable uncertainty in predicting flow between two given points at WAG 6 .

Groundwater flow rates (average linear velocities) in the regolith range from $0.10 \mathrm{~m} /$ day to $2.28 \mathrm{~m} /$ day, with an overall geometric mean linear velocity of $0.33 \mathrm{~m} /$ day (395 $\mathrm{ft} /$ year). Flow rates in the shallow bedrock range from 0.04 to $0.49 \mathrm{~m} /$ day, with a geometric mean linear velocity of $0.15 \mathrm{~m} /$ day ( $180 \mathrm{ft} / \mathrm{year}$ ). The difference is largely related to the order of magnitude difference in hydraulic conductivities between the two.

The Trench 49 French drain installed in 1983 has been effective in intercepting groundwater and lowering the water table below trench bottoms over portions of the Trench 49 disposal area.

Comparing pre- and post-ICM capping maps, the construction of ICM Caps 4, 5, and 6 have apparently had little effect on dewatering trenches or preventing bathtubbing and/or inundation of the trenches (largely due to the position on slopes and limited size). Conversely, Ashwood and Spalding (1991) report that ICM Caps 2 and 8 are effective due to the significant reduction of the storm flow recharge area upgradient of the trenches. None of the caps had any effect on groundwater levels.

\subsubsection{Ecology}

This section provides information pertaining specifically to the ecology of WAG 6 . Sect. 5.2.7 provides an overview of the flora and fauna commonly found on the ORR, which are believed to be representative of those found at WAG 6 .

Areas of WAG 6 that remain undisturbed are typical of habitats found throughout the ORR. However, most of the site has been altered because it is an active disposal area and an area for research and development of waste storage and disposal techniques. Much of WAG 6 has also been covered with temporary impermeable caps. Currently the site consists primarily of fields planted in fescue and relatively young wooded areas along drainages, which have moderately steep terrain. The forested areas are generally oak-hickory hardwood stands interspersed among the areas used for waste disposal.

A field survey for rare plant species was conducted in May 1990 on WAG 6. This included a walk over of all currently undisturbed areas, but no rare species were found (Cunningham 1990a). In addition, in July 1990 a wetlands survey was conducted of the stream drainages within the fenced area at SWSA 6 (Cunningham 1990b). Although a few wetland species were found, there was essentially no wetland community development.

The fauna at WAG 6 are typical of those associated with maintained and forested areas. During a cursory survey of WAG 6 in June 1990, 33 bird species and 1 mammal species were observed (Kroodsma 1990). However, most of the bird, mammal, reptile, and amphibian species listed by Kitchings and Mann (1976) could be present at some time (even if only temporarily) on WAG 6. 
No threatened or endangered bird or mammal species listed by the U.S. Fish and Wildlife Service and no critical habitats are known to be present on the ORR. Therefore, none should be present on WAG 6 . Some species listed by the state of Tennessee as threatened or endangered, such as the Cooper's hawk and the sharp-shinned hawk, may occasionally hunt for prey on the site. However, these species are not known to nest on WAG 6, nor would they be expected to do so. A lack of suitable habitat and the ongoing disturbances on SWSA 6 would be preventing factors (Kroodsma 1990).

Aquatic communities on the ORR are typical of lake and stream systems in East Tennessee. Within SWSA 6, three relatively small, intermittent streams comprise the principal aquatic communities. Distinct habitats within the streams consist of riffles, pools, and leaf packs. A habitat evaluation based upon comparisons with similarly sized streams on the ORR indicated that the east tributary did not contain sufficient quality habitat to maintain a fish population (Ryon 1990). The two branches of the west tributary had pools of sufficient depth, appropriate undercut banks, and established pool-riffle sequences to support some fish species; however, none were found during a fish survey in May 1990.

In September 1990, personnel from the ORNL Environmental Sciences Division surveyed the EWB by electrofishing and found five fish, all of which were bass (Micropterus spp.), and several frogs of undetermined species (Ryon 1990).

In May 1990, a survey was conducted of invertebrate species within the streams in SWSA 6 (Smith 1991). The three distinct habitat types (i.e., riffles, pools, and leaf packs), were sampled, and the samples were examined for species listed by the state of Tennessee or the U.S. Fish and Wildlife Service as threatened or endangered. None of the listed freshwater invertebrates are known to exist on the ORR, and none were found in the streams in SWSA 6 (Smith 1990).

\subsection{RELEASES AND SITE CONCEPTUAL MODEL}

\subsubsection{Nature and Extent of Contamination}

Data collected during the WAG 6 Resource Conservation and Recovery Act (RCRA) facility investigation (Bechtel 1991) indicate that contaminants are widespread downgradient of source areas; however, specific contaminants generally were detected infrequently and/or at low concentrations. Within the site, there are areas where particular contaminants were detected at elevated concentrations.

\subsubsection{Groundwater}

Both man-made and naturally occurring radionuclides were detected in groundwater at WAG 6 . Tritium was by far the most prevalent contaminant, and in locations adjacent to waste disposal areas, tritium concentrations frequently exceeded the $20,000 \mathrm{pCi} / \mathrm{L}$ maximum contaminant level (MCL). Other man-made radionuclides detected included ${ }^{60} \mathrm{Co},{ }^{90} \mathrm{Sr}$, and ${ }^{137} \mathrm{Cs}$; however, these were detected far less frequently and at relatively low concentrations. Cobalt-60 was detected predominantly in the northeastern comer of the site, and ${ }^{90} \mathrm{Sr}$ was primarily associated with the high-activity trench area. Transuranics were detected in groundwater infrequently and at low concentrations. 
Like tritium, volatile organic compounds (VOCs) were detected in groundwater adjacent to most waste disposal areas. The highest concentrations, frequently exceeding MCLs, were associated with the biological trench areas and the solvent auger hole areas. Few semivolatile organic compounds (SVOCs) were detected in groundwater. Of metals detected that exceeded identified criteria, lead and barium were detected most often. Metals contamination in groundwater appeared to be restricted primarily to areas immediately adjacent to waste disposal units (Bechtel 1991).

\subsubsection{Surface water}

In WAG 6 surface water, as in groundwater, tritium was the most frequently detected contaminant. Tritium was detected in all drainages, and in the majority of samples concentrations exceeded the MCL. Cobalt- 60 was detected only once in surface water, near the same area where it was detected in groundwater and in soils. Strontium-90 was detected in several drainages at concentrations exceeding the MCL. The highest ${ }^{90} \mathrm{Sr}$ concentrations were detected in drainage $\mathrm{FB}$, which appears to be receiving ${ }^{90} \mathrm{Sr}$ from the high-activity trench area.

The primary VOCs detected in surface water at levels exceeding MCLs were 1-, 2-dichloroethene, tetrachloroethane, and trichloroethene. SVOCs generally were detected at low concentrations; frequently, these SVOCs were common laboratory contaminants. Barium and cadmium concentrations exceeded reference or $\mathrm{MCL}$ values for only two surface water samples (Bechtel 1991).

\subsubsection{Sediments}

Cesium-137 was the man-made radionuclide most frequently detected in sediments. Apart from one ${ }^{60} \mathrm{Co}$ detection, concentrations of other man-made radionuclides did not exceed identified criteria. Strontium-90 was detected in sediments in drainage FB, the same drainage in which surface water appears to be receiving ${ }^{90} \mathrm{Sr}$ from the high-activity trench area.

VOCs were detected in most sediment sampling locations, but at concentrations less than the identified criteria. SVOCs were detected infrequently and were typically common laboratory contaminants. Metals concentrations in sediments did not appear to be significantly elevated when compared to reference concentrations (Bechtel 1991).

\subsubsection{Soils}

The WAG 6 radiological walkover survey and the soil sampling program indicated minimal surface soil contamination and the absence of gross soil contamination adjacent to source areas. Radiological contaminants detected in soils were limited primarily to ${ }^{90} \mathrm{Sr}$ and ${ }^{60} \mathrm{Co}$; each was detected in three soil borings. The maximum concentrations of ${ }^{90} \mathrm{Sr}$ and ${ }^{69} \mathrm{Co}$ did not exceed identified criteria.

Both VOCs and SVOCs were detected in soil samples. Compounds detected were frequently laboratory contaminants, and concentrations did not exceed criteria proposed in RCRA Subpart S. Metal contamination in soils at WAG 6 appears to be very localized. Arsenic, lead, mercury, and cobalt were detected in a few samples at concentrations significantly above background (Bechtel 1991). 


\subsubsection{Contaminant Fate and Transport}

The site conceptual model (Bechtel 1991) forms the framework within which environmental pathways of potential concem for WAG 6 were identified and illustrated. Figure 11.7 is a conceptual model of WAG 6 that illustrates the environmental pathways by which humans can be exposed to contaminants released from the source areas (shallow land burial waste disposal units) where contaminants have been placed. These units are illustrated schematically within the general hydrologic setting in Fig. 11.8.

Simplified contaminant fate and transport modeling was conducted to predict future on-WAG radionuclide concentrations in groundwater, surface water, sediments, and soils and to predict the off-WAG flux of contaminants. Contaminant fluxes were used to calculate contaminant concentrations downstream in Clinch River.

Modeling used essentially two models: an integrated surface/subsurface water contaminant fate and transport model and an air model. For each contaminant modeled, time-series predictions of concentrations were generated and employed in the baseline risk assessment. Selected conclusions of the fate and transport analysis are summarized below.

- Water was the major transport mechanism for off-WAG migration of contaminants. Most of the radionuclide flux out of WAG 6 was expected to continue to occur via surface water.

- Tritium, ${ }^{60} \mathrm{Co},{ }^{90} \mathrm{Sr}$, and ${ }^{137} \mathrm{Cs}$ were predicted to occur in most of the wells in WAG 6. Peak future groundwater concentrations were predicted to be within 2 orders of magnitude of present-day concentrations.

- The first appearances of europium and uranium in groundwater were predicted to occur in years 1998 and 2025, respectively.

- Air modeling, which was performed conservatively, indicated that the air pathway contributed negligible exposure-point concentrations of on-WAG and off-WAG contaminants.

\subsubsection{Baseline Risk Assessment}

A baseline risk assessment (Bechtel 1991) was performed to assess the potential impacts WAG 6 contaminants would have on human health and the environment if no remedial actions were taken. The baseline risk assessment included a human health evaluation and an environmental evaluation.

\subsubsection{Human health evaluation}

Two hypothetical scenarios were assumed for WAG 6: no action and institutional controls. The no action scenario assumed that the U.S. Department of Energy's (DOE's) current access restrictions for the site would become ineffective immediately. The institutional control scenario assumed that DOE would continue to use WAG 6 as an low-level waste disposal site for the next 10 years and that this operational period would be followed by a 100-year institutional control period. Under the toxicological and exposure assumptions used in the evaluation, the lower limit of the U.S. Environmental Protection Agency's (EPA's) target range $\left(1 \times 10^{-4}\right.$ to $\left.1 \times 10^{-6}\right)$ was exceeded for the following receptors: 


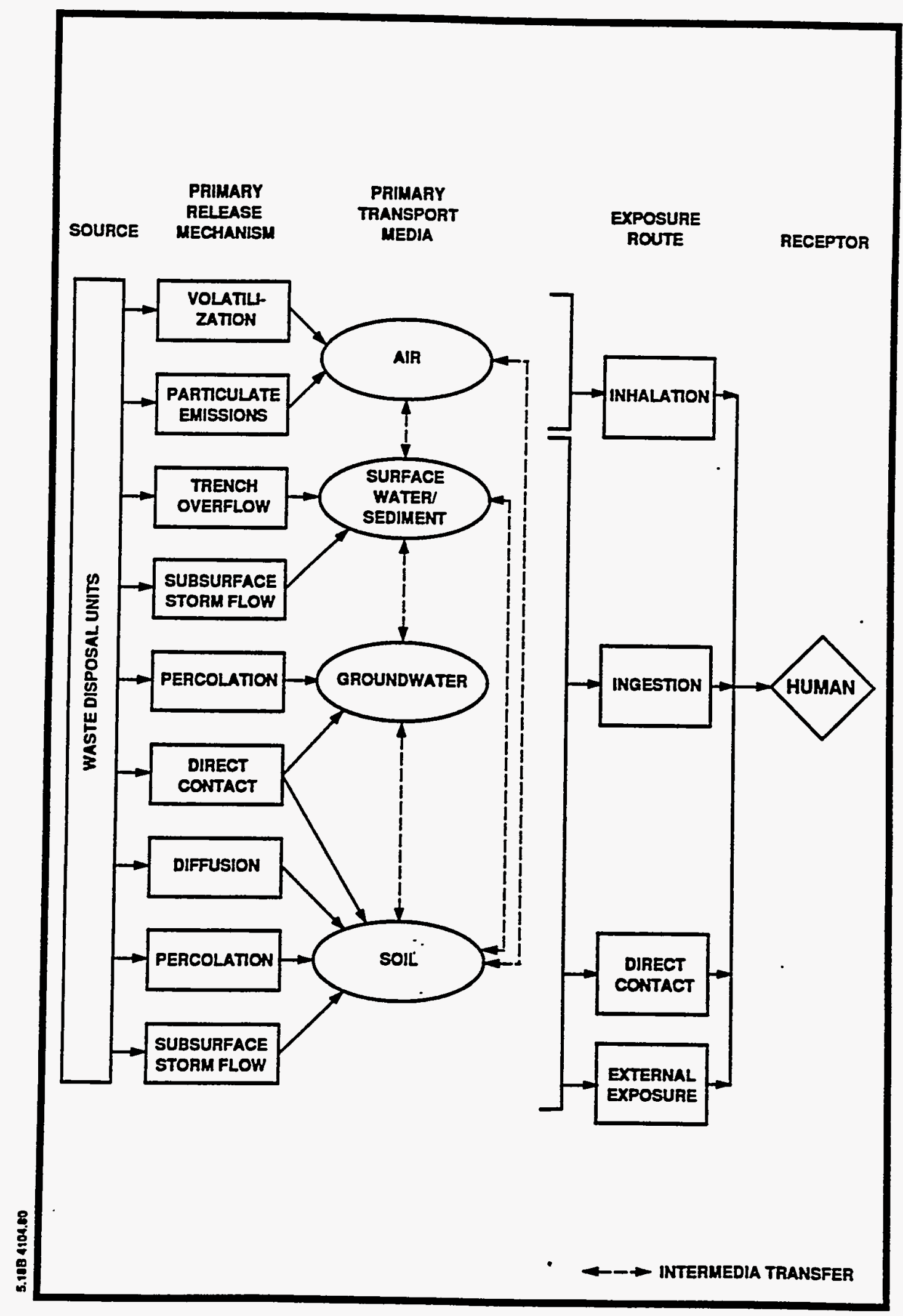

Fig. 11.7. WAG 6 site conceptual model. Source: Bechtel 1991 


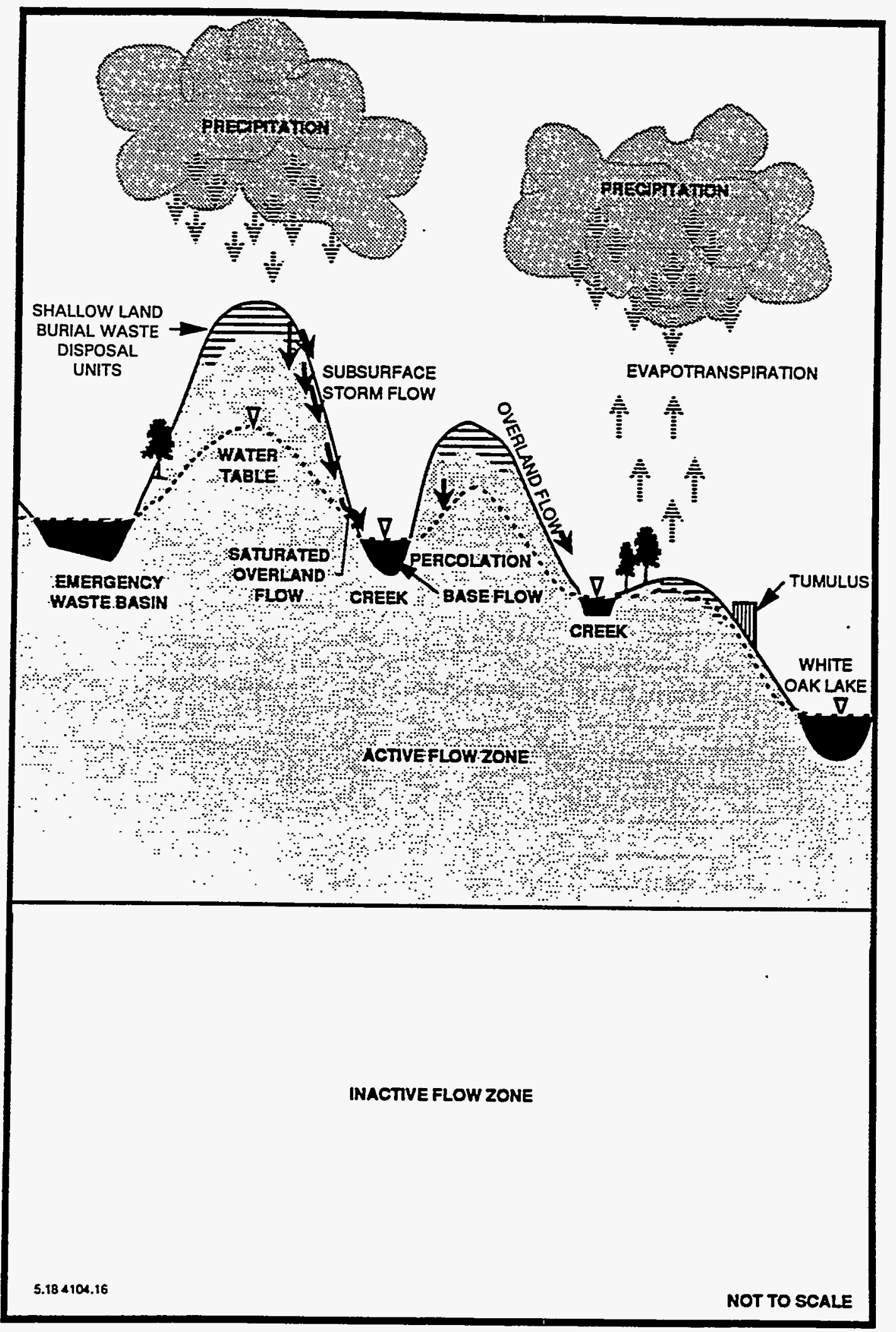

Fig. 11.8. Hydrologic features of WAG 6. Source: Bechtel 1991 
- No Action Scenario

- On-WAG homesteader (1990-2020)

- Institutional Control Scenario

- On-WAG ORNL employee (1990-2020)

- Off-WAG (Clinch River) homesteader (1990-2020)

- On-WAG homesteader (2100-2130)

Results for each scenario are briefly discussed in the following paragraphs.

Receptor risks for no action scenario:

On-WAG homesteader (evaluated for 1990-2020). The estimated radionuclide and chemical carcinogen risks for the current day on-WAG receptor evaluated for site average concentrations were 1 (unity) and $3 \times 10^{-4}$, respectively. Ninety-nine percent of the radiological risk was associated with external exposure, with the majority of the dose resulting from radioisotopes of europium. The majority of the chemical risk was due to ingestion of groundwater and inhalation of water vapor while showering. Vinyl chloride, carbon tetrachloride, and trichloroethene were the predominant contributors to this risk.

Critical effect-specific hazard indexes computed for noncarcinogens were greater than 1 for the on-WAG homesteader (adult and child).

Receptor risks for institutional control scenario:

On-WAG ORNL employee (1990-2020). The estimated radionuclide risk for the maintenance receptor was $1 \times 10^{-3}$. The radionuclide risk was attributable almost exclusively to an estimated external radiation dose of $2 \mathrm{rem}$ accumulated over 30 years, which is considerably below the 5-rem-per-day limit established in federal guidance for occupational exposure. Because the scenario assumed the worker spends 8 hours per day for 30 years working over SWSA 6 waste disposal areas, the risk estimate is conservative.

Off-WAG homesteader (1990-2020). The estimated radionuclide risk for the off-WAG homesteader was $6 \times 10^{-5}$. This risk was primarily a result of extemal radiation exposure from ${ }^{60} \mathrm{Co}$ and ${ }^{137} \mathrm{Cs}$ that has accumulated in soils as a result of crop irrigation over a period of decades. The contribution to radionuclide risk from assumed ingestion of surface water was $3 \times 10^{-6}$. Because heavy irrigation is highly unlikely given the abundant rainfall in the region, and because a homesteader is most likely to use groundwater as a drinking water source rather than untreated surface water, this scenario was conservative.

On-WAG homesteader (2100-2130). The estimated radionuclide risk for the future on-WAG receptor evaluated for site average concentrations was $3 \times 10^{-1}$. The majority of the radionuclide risk was associated with external exposure from isotopes of europium. Due to the assumption of steady state conditions for chemicals, chemical risks were the same as computed for the no action scenario on-WAG homesteader (1990-2020). 


\subsubsection{Environmental evaluation}

As an operating solid waste disposal facility, the majority of WAG 6 has been cleared of natural habitat. Regular site mowing and ongoing construction have discouraged re-establishment of natural habitats and wildlife communities. Aquatic and terrestrial surveys conducted at WAG 6 revealed no threatened and endangered species or developed wetland communities.

Potential impacts on target species were evaluated, including the tulip poplar-representing terrestrial flora; the white-tailed deer, red-tailed hawk, and raccoon-representing terrestrial fauna; bluegills and fathead minnows-representing aquatic vertebrates; and benthic macroinvertebratesrepresenting aquatic invertebrates. These species are found on the ORR and might be expected on WAG 6 under a no action scenario.

The tulip poplar would likely uptake contaminants; the prediction of specific effects is not possible for most of the contaminants because of the lack of phytotoxicity data.

Strontium-90 likely would pose a significant threat to wildlife at WAG 6 . It is readily absorbed and deposited in bone tissue where it can result in bone tumors and leukemia. Species from lower trophic levels, such as rabbits and shrews, may bioconcentrate ${ }^{90} \mathrm{Sr}$ in their bone tissue, suffer adverse effects, and subsequently cause adverse effects in red-tailed hawks and raccoons that prey upon them.

Cadmium, copper, and ${ }^{90} \mathrm{Sr}$ could potentially affect fish populations. Cadmium and copper exceeded both chronic and acute ambient water quality criteria for protection of aquatic organisms. Strontium-90 may accumulate in bone tissues.

Macroinvertebrate communities could potentially be affected by cadmium and copper. These two metals produce chronic effects at concentrations above $10 \mathrm{ppb}$. The maximum concentration of cadmium in surface water at WAG 6 was $30 \mathrm{ug} / \mathrm{L}$, and the maximum concentration of copper was $88 \mathrm{ug} / \mathrm{L}$. Both values exceed those reported to produce chronic effects in macroinvertebrates. Bioconcentration of ${ }^{90} \mathrm{Sr}$ by macroinvertebrates is expected to be low because of their short life cycle and frequent molting.

\subsubsection{Conclusions of the baseline risk assessment}

Evaluation of hypothetical on-WAG homestead receptors demonstrated that the no action scenario could result in unacceptable risks to the public. Calculations further showed that if a receptor unknowingly excavated into one of the small number of high-activity auger holes in which reactor control plates have been disposed, radiation doses could cause acute effects. If the control plates were removed, residual risks associated with the remaining inventory were still predicted to exceed EPA's target range.

The no action scenario is not a realistic scenario and was evaluated solely to define a baseline against which to compare alternatives for site closure and remediation. The location of SWSA 6 on the U.S. government-owned ORR, its proximity to an operating facility (ORNL), and the existence of site fencing and security patrols make it highly unlikely that a member of the public could occupy the site and remain undetected.

Under the institutional control scenario, estimated risks for hypothetical public receptors did not exceed the upper limit of EPA's target risk range. For the off-WAG (Clinch River) receptor, 
risks fell within the upper end of the range; however, due to the conservative assumptions associated with this scenario, this result should not be the basis for implementing actions beyond those already inherent in the scenario (e.g., access restrictions, site maintenance).

The evaluation of an on-WAG receptor for the period 2100-2130 did indicate unacceptable risks. This demonstrates that, without appropriate site closure and remediation, access restrictions should continue beyond the year 2130 to prevent the possibility of on-WAG homesteading.

\subsection{ACTIVE PROJECTS}

Instructions to User
Remediation is an ongoing process, and the status of active projects can change
quickly. For the most up-to-date information about WAG 6 active projects, check
the Annual Environmental Restoration Monitoring and Assessment Report and the
Federal Facility Agreement Quarterly Report.

\subsubsection{Environmental Monitoring Program}

The WAG 6 Environmental Monitoring Program (EMP) was established in 1994 in response to a letter of agreement signed by DOE, the Tennessee Department of Environment and Conservation, and EPA documenting a tri-party agreement on the near-term future of WAG 6 (Lingle, McCoy, and Weeks). The agreement specified that (1) no active source control measures would be implemented at the WAG in the near term under Comprehensive Environmental Response, Compensation, and Liability Act authority; (2) surveillance, maintenance, and monitoring would occur to track off-WAG releases to ensure that any significant changes in the rate of contaminant flux off the WAG are identified early enough to take appropriate action; and (3) DOE would initiate an Environmental Restoration Technology Program to develop and demonstrate new technologies for site characterization and remediation of WAG 6 and for potential use at other sites on the ORR.

The EMP is currently in the Baseline Monitoring Period-that portion of the program during which baseline release conditions at the site are to be established. These conditions will be the benchmark against which future releases at the site are measured (SAIC 1995).

The decision to defer active source control measures at WAG 6 was based primarily on data presented to the public indicating that WAG 6 contributes a relatively small percentage (less than $2 \%$ ) of the total off-site contamination released across White Oak Dam, the exit point for contamination leaving ORNL via the WOC watershed. The primary objective of the WAG 6 EMP is to track changes in releases from WAG 6 to determine if resources need to be shifted back to this WAG. This objective supports those of the Environmental Restoration Program.

The objectives of the WAG 6 EMP are to provide stakeholders with the information needed to track the status of the contribution WAG 6 makes to total risk at White Oak Dam in relation to other WAGs in the WOC watershed. Because the various WAGs at ORNL release different contaminants, it is necessary to translate contaminant releases into potential risks to compare WAG 6 to other WAGs. For this reason, estimating the risk associated with the WAG 6 releases 
is a primary goal of the monitoring effort. Table 11.1 presents other primary and secondary objectives of the program.

Table 11.1. Objectives for WAG 6 Environmental Monitoring Program

\begin{tabular}{ll}
$\begin{array}{l}\text { Primary objective } \\
\text { (PO) identifier }\end{array}$ & \multicolumn{1}{c}{ Objective description } \\
\hline PO1 & Identify changes in risk associated with WAG 6 \\
PO1-1 & Estimate risk at boundary of waste unit and relative risk at White Oak Dam \\
PO-2 & Verify primary contaminants of concern that contribute to risk \\
PO1-3 & Refine risk estimates \\
PO2 & Meet regulatory requirements \\
PO2-1 & Meet RCRA reporting requirements \\
PO2-2 & Meet NPDES reporting requirements \\
PO2-3 & Address DOE orders 5400.1, 5400.5, and 5820.2A \\
P03 & Support implementation of interim or final actions \\
PO3-1 & Identify major sources of off-WAG contaminant migration \\
PO3-2 & Develop technologies to support site characterization and remediation activities \\
\hline
\end{tabular}

As part of the data quality objective process, a decision rule was developed to address Primary Objective 1-identify changes in risk associated with WAG 6 . The decision rule states:

If the risk at the boundary of the WAG is greater than $1 \times 10^{-4}$, then access control of the site must be maintained.

If the relative risk associated with WAG 6 contamination loading to White Oak Dam increases by a factor of 10 total during the monitoring period (or a factor of 2 annually), then: (1) aspects of the EMP for the subsequent year may be altered to better understand the increase, and/or (2) source control measures may be implemented.

As budget constraints begin to play a role in the long-term monitoring of WAG 6 , an interim step will likely be added to the decision rule. An intermediate confirmation step would allow the project to use screening level data in the routine monitoring effort. If the screening data indicated a factor of 2 increase in flux, the intermediate step would require verifying the increase with definitive-level data prior to making decisions (SAIC 1995).

\subsubsection{Tumulus Disposal Demonstration Project}

The Tumulus Facility was constructed at WAG 6 as part of the Tumulus Disposal Demonstration Project (TDDP), an alternative technology for disposal of solid, low-level radioactive waste. The TDDP was initiated under the Low Level Waste Disposal Development Demonstration Program. Tumulus technology involves placement of containerized low-level radioactive waste into rectangular concrete vaults. Once filled with containerized waste, each vault's void spaces are grouted and a concrete cover (lid) is placed on the vault. The vaults are stacked on a concrete pad that rests on a gravel, sand, and geotextile drainage system. The 


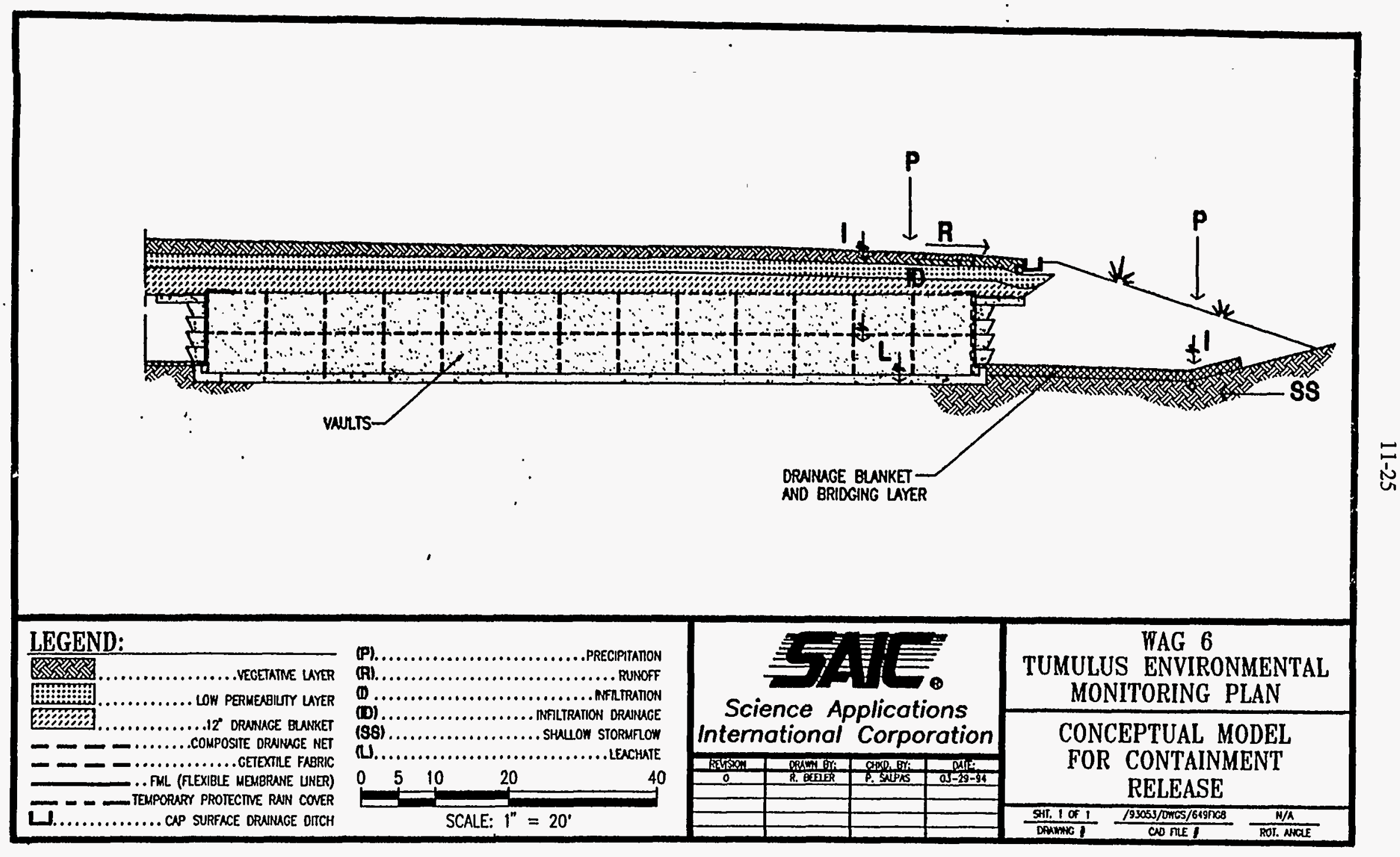

Fig. 11.9. Conceptual drawing of a tumulus structure showing its major components and primary water pathways under expected conditions (P, R, D) and under the condition of cap leakage (L). Source: SAIC 1994 
underpad drain is designed to keep groundwater levels below the pad, thereby isolating the vaults from the groundwater system (Fig. 11.9). When the concrete pad is loaded to capacity with vaults, a plastic rain cover is placed over the vaults, and then the pad and vaults are covered with an engineered multilayered cap designed to prevent precipitation from coming into contact with the vaults. The multilayered cap includes a low-permeability clay layer as well as a geomembrane layer. These drainage systems also allow monitoring of discharges from the facility. For example, at the WAG 6 Tumulus Facility, the pad and underpad drain lines empty into sumps in the Tumulus Facility monitoring shed. The sumps are equipped with pumps that automatically measure water volume when water is pumped from the sumps.

The WAG 6 Tumulus Facility consists of two structures, designated Tumulus I and Tumulus II, covered by a common cap (Fig. 11.10). Loading of waste vaults on the Tumulus I pad began in June 1987; the pad was filled to capacity by May 1990 (SAIC 1994). Following loading, Tumulus I was covered with a temporary cover to prevent precipitation from reaching the waste vaults. However, precipitation was able to reach the Tumulus I pad on occasion as a result of cover damage and removal of the temporary cover to install a more efficient one over both pads.

Loading of the Tumulus II pad began in October 1990 and the pad was fully loaded by late 1991 (SAIC 199). Tumulus II was uncovered during this time period and exposed to precipitation. Beginning in mid-January 1992 and until the spring of 1994, the vaults and pads of both Tumulus I and Tumulus II were covered by temporary, tent-like structures that completely covered the pads above and on both sides (RUBB buildings) to prevent rainwater from falling directly on the vaults. The RUBB buildings remained in place until February 1994 when dismantling began. This task was completed in March 1994. The RUBB buildings were replaced by an interim plastic raincover laid directly over the vaults so that construction of the permanent cap could begin. In July 1994, when the point in cap construction was reached that the vaults were to be covered by the multilayer cap, the interim rain cover was removed from the Tumulus I vaults but left intact on the Tumulus II vaults. Construction of the cap was completed on January 11, 1995.

The performance of the Tumulus Facility will be evaluated against its two design objectives:

1. Wastes contained within the facility will be completely isolated from surrounding hydrologic influences (e.g., precipitation and groundwater).

2. No contaminants will be released to the environment during the institutional control period of 100 to 300 years. By the end of this period, the bulk of the wastes contained within the facility should be rendered innocuous and present no significant danger to the environment and/or intruders.

In response to the anticipated completion of the Tumulus Facility, the Tumulus Environmental Monitoring Plan (SAIC 1994) was issued in July 1994. The plan includes a detailed physical description of the facility, expected contaminant release and hydrologic isolation conditions at the facility, a strategy for monitoring these conditions, and response actions if deviations from the expected conditions are observed. 


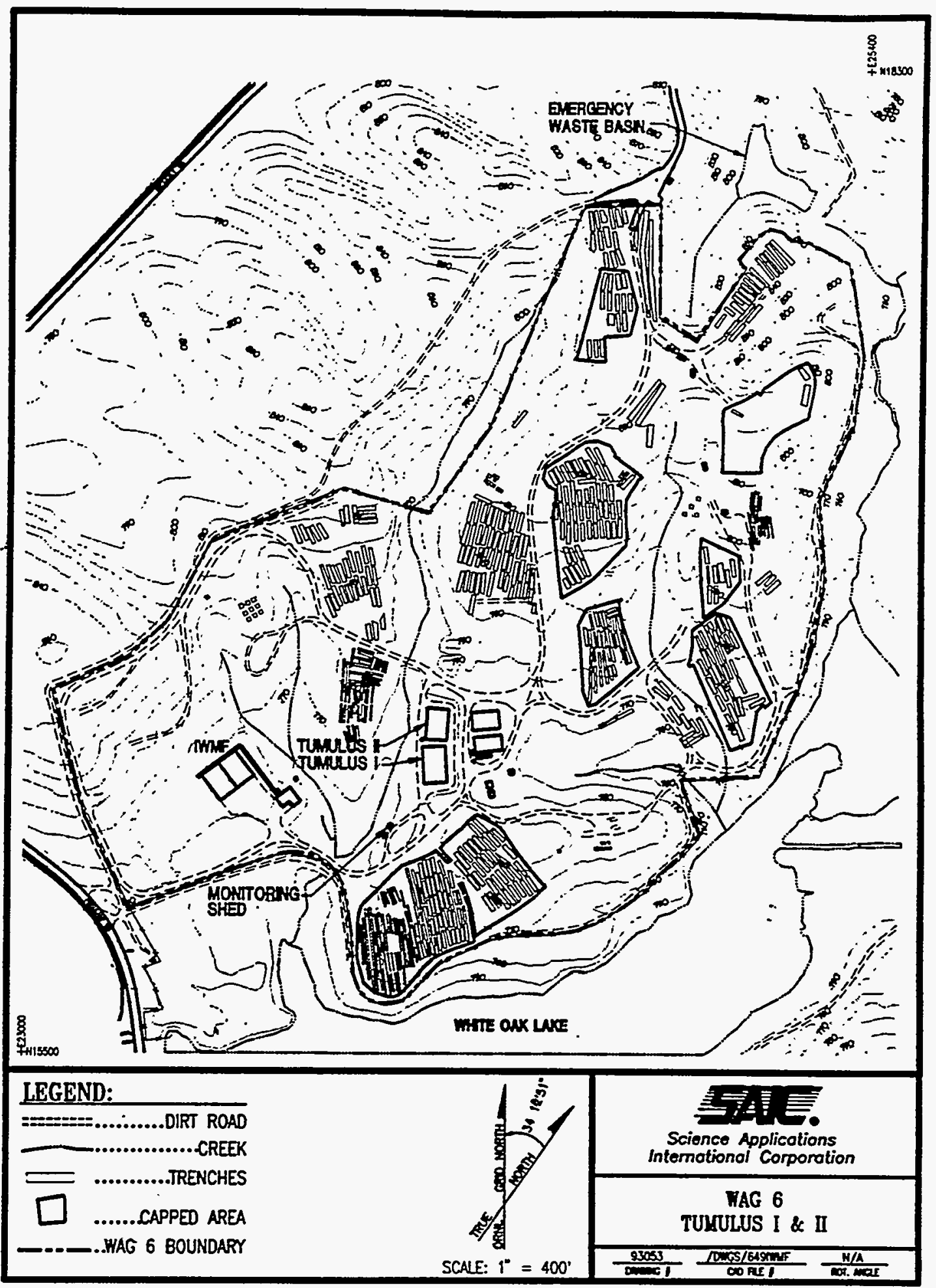

Fig. 11.10. Location of Tumulus I and Tumulus II. Source: SAIC 1994 


\subsection{WAG 6 SUMMARY}

WAG 6 is located on the Oak Ridge Reservation in Roane County, Tennessee, approximately 5 miles southwest of the city of Oak Ridge central business district. WAG 6 is part of Oak Ridge National Laboratory and lies approximately 2 miles southwest of the main plant area at the southwestern end of Melton Valley.

WAG 6 comprises three solid waste management units: Solid Waste Storage Area (SWSA) 6 , the Explosives Detonation Trench, and the Emergency Waste Basin. SWSA 6, which was opened for limited disposal operations in 1969 and began full-scale operations in 1973, is the main source of environmental contamination at WAG 6. It overs 68 acres, approximately 19 of which have been used for waste disposal. The Explosives Detonation Trench has been backfilled and covered by an Interim Corrective Measure (ICM) cap. The Emergency Waste Basin has reportedly never been used. Two Environmental Restoration Program projects are currently active at WAG 6: the Environmental Monitoring Program and the Tumulus Disposal Demonstration Project.

The geology of the WAG 6 site is complex due to original bedrock depositional patterns, severe structural deformation, weathering, and human activities. Maryville Limestone and Nolichucky Shale bedrock underlie the northern and southern parts of the site, respectively. Minor folding and normal, reverse, and thrust faults are widespread. Depth to bedrock varies with topography, ranging from $2.5 \mathrm{ft}$ to $51 \mathrm{ft}$ below land surface. Saprolite overlies bedrock throughout the site, varying in thickness across the site with degree and depth of weathering. Eleven different soil types have been noted at WAG 6 , and these are typically thin and acidic.

Surface water is a principal pathway for contaminant transport off WAG 6, and activities at the site since the 1970s have impacted the surface water hydrology of WAG 6 . Flow paths have been altered due to construction of service roads, culverts, the French drain, and the drainage features associated with the ICM caps over eight waste areas. Streams in WAG 6 are intermittent, and they are mostly dry during summer months. The site's topography is gently to moderately sloping, draining to White Oak Lake on the south and an unnamed tributary of White Oak Creek on the east.

Because no major aquitards or confining layers are present, groundwater is a continuum from the water table to depth in bedrock. Transient storm flow occurs in the unsaturated zone at WAG 6; however, the storm flow zone is highly variable and likely discontinuous due to removal or reworking of surficial soils, the lack of vegetative cover, ICM capping, and other physical features resulting from waste disposal activities. Considerable uncertainty exists with respect to the impact of the storm flow zone on WAG 6 hydrology. The water table configuration mimics topography, indicating groundwater flow towards WAG 6 surface water features and in an overall southerly direction towards White Oak Lake. Evidence exists to support the conclusion that a majority of groundwater flow at WAG 6 occurs in the upper 50 to $100 \mathrm{ft}$ of the aquifer with virtually no flow occurring below $250 \mathrm{ft}$. In the unweathered bedrock, groundwater flow occurs along secondary permeability features, principally fractures.

Areas of WAG 6 that remain undisturbed are typical of habitats found throughout the Oak Ridge Reservation although most of the site has been altered. A field survey for rare plant species was conducted in 1990 on WAG 6, but no rare species were found. No threatened or endangered bird or mammal species are thought to be present on WAG 6.

Data collected indicate that contaminants are widespread downgradient of source areas; however, specific contaminants generally were detected infrequently and/or at low concentrations. There are areas, however, where particular contaminants were detected at elevated concentrations. 
Tritium was by far the most prevalent contaminant in surface water and groundwater; others include ${ }^{60} \mathrm{Co},{ }^{90} \mathrm{Sr}$, and ${ }^{137} \mathrm{Cs}$. Volatile organic compounds (VOCs) were detected in groundwater adjacent to most waste disposal areas. Strontium-90 was detected in several drainages. The primary VOCs detected in surface water were 1, 2-dichloroethene, tetrachloroethane, and trichloroethene. Cesium-137 was the man-made radionuclide most frequently detected in sediments. VOCs were detected in most sediment sampling locations, but at concentrations less than the identified criteria. The WAG 6-radiological walkover survey and the soil sampling program indicated minimal surface soil contamination. Both VOCs and Semivolatile organic compounds were detected in soil samples.

Wag 6 has two active projects: the Environmental Monitoring Program and the Tumulus Disposal Demonstration Project.

\subsection{REFERENCES}

Ashwood, T. L., and B. P. Spalding 1991. SWSA 6 Interim Corrective Measures Environmental Monitoring: FY 1990 Results, ORNL/ER-36, Martin Marietta Energy Systems, Inc., Oak Ridge Natl. Lab.

Baldwin, J. S., et al. 1989. Oak Ridge National Laboratory Waste Management Plan for the Department of Energy, ORNL/TM-11433, Martin Marietta Energy Systems, Inc., Oak Ridge Natl. Lab.

Bechtel (Bechtel National, Inc.) 1990. ORNL WAG 6 Site Characterization Summary, Volume 1, Main Report, ORNL/ER-11/V1\&D1 (ORNL/RAP/Sub-87/99053/27\&V1), Martin Marietta Energy Systems, Inc., Oak Ridge, Tenn.

Bechtel 1991. RCRA Facility Investigation Report for Waste Area Grouping 6 at Oak Ridge National Laboratory, Oak Ridge, Tennessee, ES/ER-22/V1\&D1 (ORNL/ER/Sub-87/99053/5/V1), Martin Marietta Energy Systems, Inc., Oak Ridge, Tenn.

Cunningham, M. 1990a. "Rare Plant Survey of SWSA 6," personal communication with J. M. Loar, May 28, Oak Ridge Natl. Lab.

Cunningham, M. 1990b. "Wetland Survey of SWSA 6," personal communication with J. M. Loar, July 26, Oak Ridge Natl. Lab.

Davis, E. C., and D. K. Solomon 1987. A Summary of the ORNL SWSA 6 Waste Inventory; 1972 Through 1986, ORNL/RAP/LTR-87/6, Martin Marietta Energy Systems, Inc., Oak Ridge Natl. Lab.

Energy Systems (Martin Marietta Energy Systems, Inc.) 1994. Oak Ridge Reservation Technical Site Information, ES/EN/SFP-23, Martin Marietta Energy Systems, Inc., Oak Ridge, Tenn.

International Technology Corp. 1986. Draft Closure Plan for Solid Waste Storage Area (SWSA 6), ORNL/Sub-86-72127/1. Martin Marietta Energy Systems, Inc., Oak Ridge Natl. Lab.

Kitchings, J. T., and L. K. Mann 1976. A Description of the Terrestrial Ecology of the Oak Ridge Environmental Research Park, ORNL/TM-5073, Union Carbide Corp. Nuclear Div., Oak Ridge Natl. Lab. 
Kroodsma, $R$ 1990. Threatened and Endangered Animal Species on the WAG 6 Site, unpublished memo to J. M. Loar, Environmental Sciences Division, Oak Ridge Natl. Lab., June 1.

Lingle, W. N. (DOE), R. D. McCoy (Tennessee Department of Environment and Conservation), and V. Weeks (U.S. Environmental Protection Agency) 1994. Record of Agreement, Oak Ridge National Laboratory Waste Area Grouping 6,Oak Ridge Natl. Lab.

ORNL (Oak Ridge National Laboratory) 1985. Explosives Detonation Trench: Inspection Plan and Schedules, Martin Marietta Energy Systems, Inc., Oak Ridge Natl. Lab.

ORNL (Oak Ridge National Laboratory) 1986. Draft Remedial Investigation Plan for Solid Waste Storage Area Six, ORNL/RAP-2, Martin Marietta Energy Systems, Inc., Oak Ridge Natl. Lab.

ORNL 1990. ORNL Contaminated Site Summary Sheets, ORNL/M-2413, Oak Ridge Natl. Lab.

Ryon, M. G. 1990. Fish Survey of SWSA 6, unpublished memo to J. M. Loar, Environmental Sciences Division, Oak Ridge Natl. Lab., May 15.

SAIC (Science Applications International Corp.) 1994. Tumulus Environmental Plan for the Tumulus Demonstration Disposal Project at Oak Ridge National Laboratory, Oak Ridge, Tennessee, ORNL/ER-255, Oak Ridge Natl. Lab.

SAIC 1995. Annual Report on Activities at Waste Area Grouping 6 from February through September 1994 at Oak Ridge National Laboratory, Oak Ridge, Tennessee, DOE/OR/01-1377\&D1, Oak Ridge Natl. Lab.

Smith, J. G. 1990. "SWSA 6 Survey for Threatened and Endangered Invertebrate Species," personal communication to J. M. Loar, Environmental Sciences Division, Oak Ridge Natl. Lab.

Smith, J. G. 1991. "Results of Benthic Macroinvertebrate Surveys of Streams in SWSA 6-May 1990," personal correspondence to J. M. Loar, Environmental Sciences Division, Oak Ridge Natl. Lab.

\subsection{BIBLIOGRAPHY}

Bechtel National, Inc. 1988. Closure Plan for Solid Waste Storage Area 6, Volume 1: Closure Plan Oak Ridge National Laboratory Remedial Investigation/Feasibility Study, ORNL/RAP/Sub-87/99053/9\&V1, Oak Ridge Natl. Lab.

Bechtel National, Inc. 1988. An Evaluation of the Remedial Investigation for ORNL Waste Area Grouping 6, Oak Ridge National Laboratory Remedial Investigation/Feasibility Study, ORNL/RAP/Sub-87/30B-99053C/2106, Oak Ridge Natl. Lab.

Bechtel National, Inc. 1988. Solid Waste Storage Area 6 Hazardous Materials Survey Report for the Oak Ridge National Laboratory Remedial Investigation/Feasibility Study (Rev. 1), ORNL/RAP/Sub-87/99053/23\&R1, Oak Ridge Natl. Lab.

Bechtel National, Inc. 1994. Revised Closure Plan for Waste Area Grouping 6 at Oak Ridge National Laboratory, Oak Ridge, Tennessee, DOE/OR/01-1234\&D1, Oak Ridge Natl. Lab. 
Boegly, W. J. 1984. Site Characterization Data for Solid Waste Storage Area 6, ORNL/TM-9442, Environmental Sciences Division Publication No. 2436, Oak Ridge Natl. Lab.

Boegly, W. J., et al. 1985. Characterization Plan for Solid Waste Storage Area 6, ORNL/TM-9877, Environmental Sciences Division Publication No. 2638, Oak Ridge Natl. Lab.

Clapp, R. B., and J. A. Watts, eds. 1995. Fourth Annual Environmental Restoration Monitoring and Assessment Report (FY 1995), Oak Ridge National Laboratory, Oak Ridge, Tennessee, DOE/OR/01-1413\&D1, Oak Ridge Natl. Lab.

Coobs, J. H., and J. R. Gissel 1986. History of Disposal of Radioactive Wastes into the Ground at Oak Ridge National Laboratory, ORNL/TM-10269, Oak Ridge Natl. Lab.

Kannard, J. R. 1992. Addendum: RCRA Facility Investigation Report for Waste Area Grouping (WAG) 6 at Oak Ridge National Laboratory,

Morrison, S. J. and T. E. Cerling 1987. Survey of Metal, Radionuclide and Organic Contamination at 20 Waste Area Groups (WAGs), ORNL Facilities, Oak Ridge, Tennessee, ORNL/RAP/Sub-87/27463/1, Oak Ridge Natl. Lab.

Oak Ridge Natl. Lab. 1987. RCRA Facilities Assessment (RFA)_Oak Ridge National Laboratory, ORNL/RAP-12/VI, Oak Ridge Natl. Lab.

Oak Ridge Natl. Lab. 1995. Environmental Monitoring Plan for Waste Area Grouping 6 at Oak Ridge National Laboratory, Oak Ridge, Tennessee, DOE/OR/01-1192\&D2, Oak Ridge Natl. Lab.

Radian Corp. 1992. Feasibility Study/Environmental Assessment for Waste Area Grouping 6 at Oak Ridge National Laboratory, Oak Ridge, Tennessee, DOE/OR-994\&D1, Oak Ridge Natl. Lab.

Radian Corp. 1992. Proposed Plan for the Oak Ridge National Laboratory Waste Area Grouping 6 Interim Remedial Action, DOE/OR-995\&D3, Oak Ridge Natl. Lab.

Radian Corp. 1993. Response to Comments on the Waste Area Grouping 6 Proposed Plan, Oak Ridge National Laboratory, Oak Ridge, Tennessee, DOE/OR/02-1166\&D1/R3, Oak Ridge Natl. Lab.

SAIC (Science Applications International Corp.) 1994. Remedial Investigation Work Plan for the Groundwater Operable Unit at Oak Ridge National Laboratory, Oak Ridge, Tennessee, DOE/OR/01-1252\&D1 (ORNL/ER-221\&D1), Martin Marietta Energy Systems, Inc., Oak Ridge Natl. Lab.

Stansfield, R. G. 1992. Well Plugging and Abandonment Plan for Waste Area Grouping 6 at Oak Ridge National Laboratory, Oak Ridge, Tennessee, ORNL/ER-82, Oak Ridge Natl. Lab. 



\section{HISTORY AND CHARACTERIZATION OF WAG 7}

Instructions to User
This chapter provides information about WAG 7 that can be cited in certain CERCLA
documents (see Chap. 1 and Table 1 in Instructions to User). For a short description of
WAG 7 that can be copied into other types of documents, see the summary at the end
of this chapter. To keep this document as short as possible, information about
conditions common to all WAGs (e.g., climate and demography) is given in
Chap. 5-History and Characterization of the ORNL Site.

\subsection{SITE DESCRIPTION AND HISTORY}

WAG 7 is located on the Oak Ridge Reservation (ORR) in Roane County, Tennessee, approximately 5 miles southwest of the city of Oak Ridge central business district and 1 mile south of the ORNL main plant area (Fig. 12.1). WAG 7 lies in Melton Valley and consists of approximately 47 ha (116 acres), which are predominantly woodland. The site is irregularly shaped and bounded to the south, southwest, and southeast by White Oak Lake (WOL) and the floodplain of White Oak Creek (WOC) (Fig. 12.2). To the east the site is bordered by uplands that drain toward WOC; to the northeast it is bounded by Solid Waste Storage Area (SWSA) 4, which adjoins the site. Lagoon Road parallels the northern limit of the site, which lies on the foot slope of Haw Ridge. On its western flank the site is adjoined by WAG 2 and the head of a north-south draw that drains toward WOL.

During the period from 1951 through 1966, ORNL disposed of intermediate-level liquid waste (ILLW) by means of shallow seepage pits and trenches. The liquid wastes were generated as part of routine plant operations and were stored and treated with a caustic precipitant in Gunite tanks located in the main plant area. These wastes were initially hauled from the Gunite tanks to the pits in a tank truck but later were piped to the pits and trenches after construction of the ILLW lines in 1954. The pits were open-topped earthen impoundments; the trenches were long, narrow trackhoe excavations that were backfilled with crushed stone and covered with an earthen cap.

The liquid waste system at ORNL was formerly called the ILLW system but is now referred to as the LLW system because the waste stream has been reclassified. However, the pipe network and leak sites related to WAG 7 were active or occurred prior to the reclassification; thus, the waste stream is referred to herein as $\mathbb{L L W}$. The ILLW system components include: collection tanks in the main plant area and in Melton Valley, an evaporator in the main plant area, and a piping network used to transfer waste within the main plant area and to the disposal sites in Melton Valley. The first section of the ILLW line was constructed in June of 1954. The line was fabricated of 5-cm (2-in.) cast iron pipe and ran underground from the main plant area through the gap in Haw Ridge to its discharge point at Pit 2 in Melton Valley. The line was extended to Trench 5 in 1960, with additional extensions to Trenches 6 and 7 in 1961 and 1962, respectively. In 1966 the first hydrofracture facility became operational, and the ILLW line was extended southeastward from Trench 7 to this facility. This extension was also constructed of cast iron but was replaced with stainless steel in 1971 (SAIC 1994).

WAG 7 contains 11 Solid Waste Management units (SWMUs), which are shown in Fig. 12.2 and discussed in Sects. 12.1.1-11. 
$12-2$

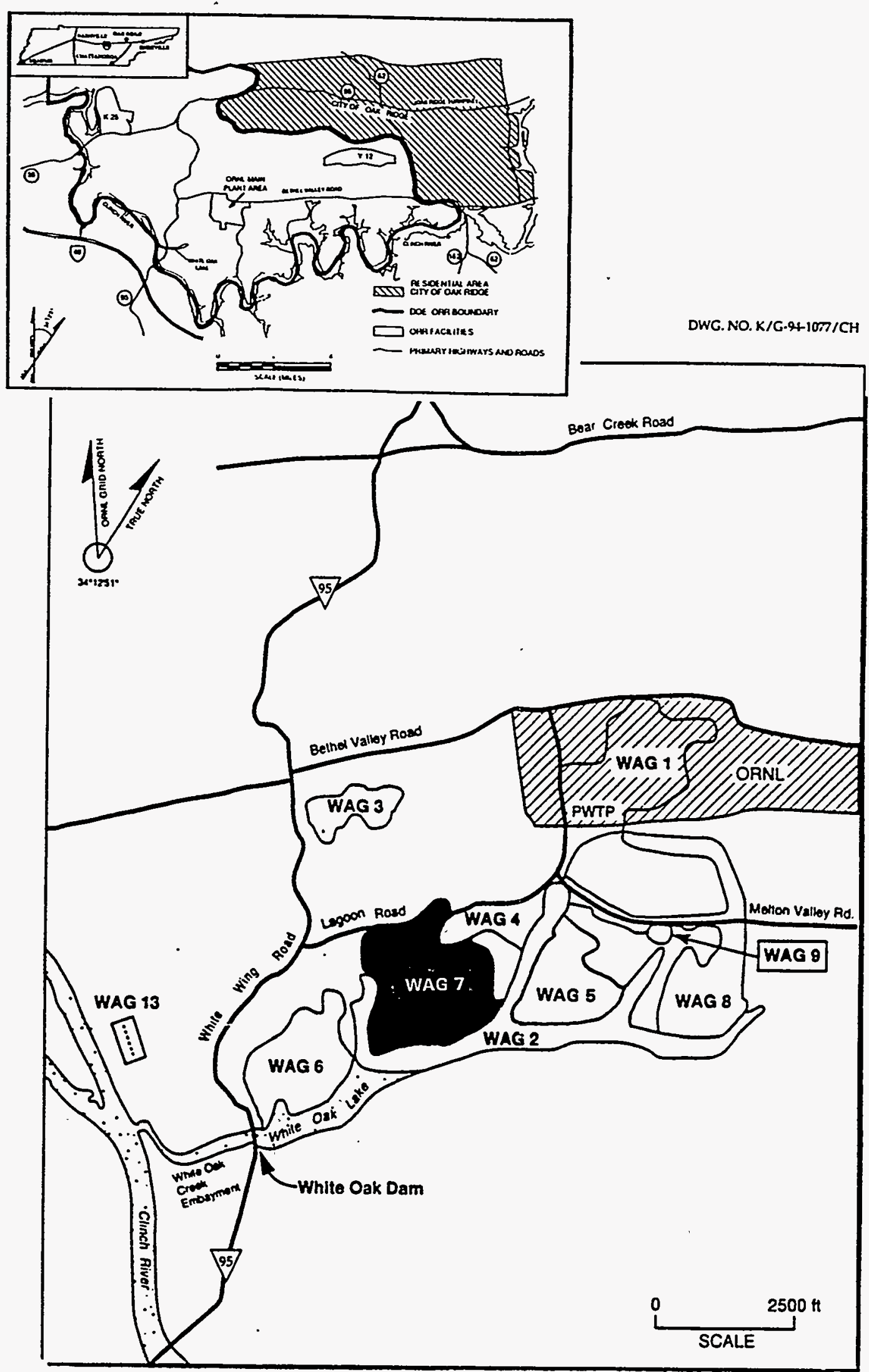

Fig. 12.1. Location of WAG 7. 


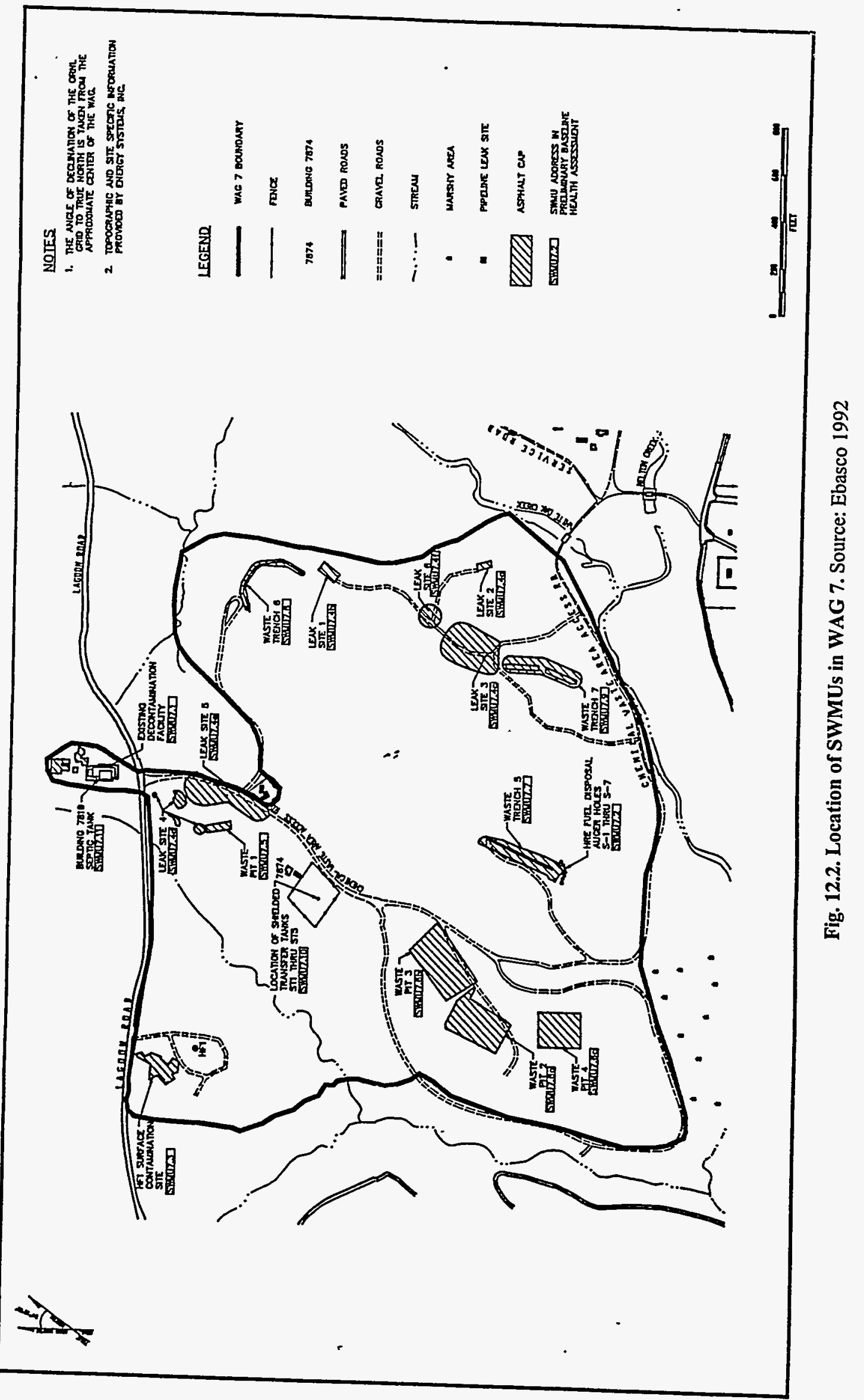




\subsubsection{SWMU 7.1-Building 7819 Decontamination Facility}

This facility is located on the north side of Lagoon Road near the western corner of SWSA 4. It was used for unshielded decontamination operations, which included acid baths, sandblasting, and other unspecified procedures. The residual contamination on the site includes portions of the

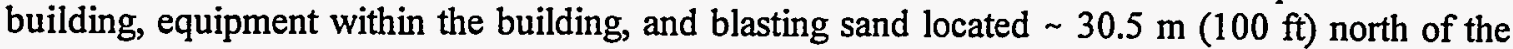
building. The blasting sand located outside the building has a maximum exposure rate of $2.0 \mathrm{mR} / \mathrm{h}$ (SAIC 1994).

\subsubsection{SWMU 7.2-Homogeneous Reactor Experiment Fuel Wells}

There are reportedly seven Homogeneous Reactor Experiment fuel wells (identified as S-1 through S-7) located just south of Trench 5, although field reconnaissance of the area in April 1987 could only confirm the location of four of these wells. The wells were used to dispose of the Homogeneous Reactor Experiment liquid fuel. The wells were actually auger holes $30.5 \mathrm{~cm}$ (12 in.) in diameter and were reported to be $5.2 \mathrm{~m}(17 \mathrm{ft})$ deep and $\sim 3 \mathrm{~m}(10 \mathrm{ft})$ apart. The liquid fuel consisted of uranium in solution with $4.0 \mathrm{M}$ sulfuric acid. Some fission products were also associated with the waste, predominantly strontium and ruthenium. Laboratory correspondence documented the disposal of $367 \mathrm{~L}$ (97 gal) of fuel solution distributed between wells S-3 through S-7 during the period from March to April of 1964 (SAIC 1994). Disposal of the solution was accomplished through a plastic transfer line, which was run to the bottom of the auger holes. Afterwards, the plastic line was lowered into the holes, and the wells were backfilled with earth.

\subsubsection{SWMU 7.3-Hydrofracture Experimental Site 1 Soil Contamination}

The Hydrofracture Experimental Site 1 is located near the northwestern corner of WAG 7, just southwest of Lagoon Road. In October of 1959, the first hydrofracture experiment was conducted to determine the orientation of hydraulically initiated fractures. The experiment was conducted in an

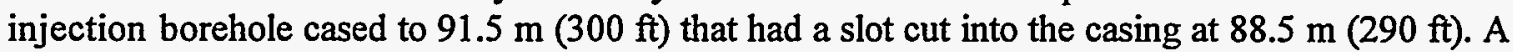
fracture was created in a subsurface shale bed and 102,195 L (27,000 gal) of water, cement, diatomaceous earth, and a fluid loss additive were pumped into the fracture. The grout mixture was tagged with $35 \mathrm{Ci}$ of ${ }^{137} \mathrm{Cs}$ and $8.7 \mathrm{Ci}$ of ${ }^{144} \mathrm{Ce}$. The grout sheet created during the experiment extends $\sim 122 \mathrm{~m}(400 \mathrm{ft})$ north-northeast from the injection well location.

After the grout was pumped into the shale, the injection well was flushed with water. Toward the end of the flushing operation, grout was observed flowing out of a 7.6-cm (3-in.) diameter core hole located $60 \mathrm{~m}$ (199 ft) north of the injection well. Pumping was stopped, but grout continued to flow for a period of several hours, followed by clear water, which continued to flow from the core hole for $\sim 2$ months. The grout and adjoining soil were excavated after the grout had cured and were disposed of in SWSA 5 (SAIC 1994).

\subsubsection{SWMU 7.4a-f-ILLW Line Leak Sites}

The transfer pipeline system was used from 1952 to 1972 to transport ILLW from the waste processing facilities in the Bethel Valley area at ORNL to final disposal sites in Melton Valley. During the history of pipeline operations, approximately 45 million gal of $\mathbb{L L W}$, containing more than 1.5 million curies of mixed fission products were transferred via this system to waste disposal pits and trenches in WAG 7 and to the Old Hydrofracture Facility. Use of these transfer pipelines was discontinued in 1972 when that year's series of hydrofracture injections was complete. There have 
been six known leaks associated with these pipelines; the details of these leaks are discussed in the following paragraphs.

SWMU 7.4a - Gauging Station Northwest of Building 7852: This leak site (Leak Site 2) is located on the cast iron pipeline extension leading to Old Hydrofracture Facility, northwest of Building 7852 and approximately $200 \mathrm{ft}$ west of WOC. The first leak occurred July 9, 1970, at a gasket joint. Liquid waste seeped out of the mechanical, neoprene joint and reached the ground surface, where it spread laterally over a small area (ORNL 1987).

SWMU 7.4b-Leak Site Southeast of Trench 6: This leak site (Leak Site 1) is located

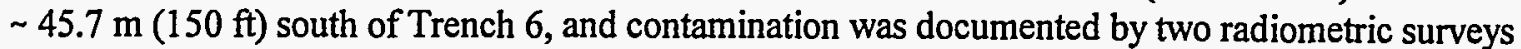
of the ILLW line. The surveys indicated that contamination has spread down slope of the site to the southwest and was present over several feet of soil. The principal contaminants identified were ${ }^{137} \mathrm{Cs}$, ${ }^{90} \mathrm{Sr},{ }^{244} \mathrm{Cm},{ }^{241} \mathrm{Am},{ }^{238} \mathrm{Pu}$, and ${ }^{239} \mathrm{Pu}$, and soil samples indicated beta-gamma activity ranging from 0.01 to $50 u \mathrm{Ci} / \mathrm{g}$ and alpha activity of about $1.0 \mathrm{uCi} / \mathrm{g}$. The leak site was cleared of vegetation, and both contaminated soil $\left[\sim 76.5 \mathrm{ml}\left(100 \mathrm{yd}^{3}\right)\right]$ and the ILLW were removed. Clean fill mixed with bentonite was placed over the spill area and graded. Finally, $15 \mathrm{~cm}(6 \mathrm{in}$.) of crushed stone was applied to the area, and it was capped with asphalt (SAIC 1994).

SWMU 7.4c-End of Trench 7 Access Road: The leak site Leak Site 3) is located $100 \mathrm{ft}$ north of Trench 7 along the polyvinyl chloride (PVC) pipeline extension that runs from Trench 6 to Trench 7. The leak occurred in April 1966 near the end of the last waste transfer to Trench 7. A section of the PVC pipeline ruptured, and approximately 3,000 gal of liquid waste was released. Energy Systems personnel have stated that none of the contamination was permitted to reach the creek (Spalding 1987). Analyses of near-surface soil collected at this leak site in July and August 1987 indicated substantial concentrations of ${ }^{90} \mathrm{Sr},{ }^{60} \mathrm{Co}$, and ${ }^{137} \mathrm{Cs}$ and high alpha-activity levels (Duguid 1976). The total area of contamination at the leak site is estimated to be 0.75 acre (Williams, Roberts, and Uziel 1988). Remediation of this site consisted of applying $1.5 \mathrm{~m}$ (5 ft) of graded clay cover (SAIC 1994).

SWMU 7.4d-Leak in Transfer Line from Building 7819 Decontamination Facility to Pit 1: This leak site (Leak Site 4) is located along the vitrified pipeline between the Decontamination Facility (Building 7819) and Pit 1. The leak site is $120 \mathrm{ft}$ south of Lagoon Road and $70 \mathrm{ft}$ west of Chemical Waste Access Road. First indications of the leak occurred in 1968 and 1969 when trees began dying in areas where runoff accumulated along the pipeline. This toxic effect is thought to be due to strong acids and/or alkalies used in the facility's decontamination procedures (Spalding 1987). Wastes transferred from the facility to Pit 1 via the vitrified pipeline probably consisted of various decontamination agents, including soaps, chelating agents, oxalates, nitric acid, alkalies, and caustics, and radioactive wastes associated with decontamination procedures (Spalding 1987).

SWMU 7.4e- LLLW Line Leak Site, Leak in Line Between Pit 3 and Trench 6: This leak site (Leak Site 5) is located at a valve at the connection between the cast iron pipeline to Pit 3 and the cast iron pipeline to Trench 6 . The leak at this valve was suspected to have existed in 1973, but no remedial actions were taken until March 1974 (Ebasco 1992). It appears that the major contributor to the observed residual soil contamination and subsequent tree uptake is the ILLW transfer pipeline leak site, located on the west side of the Chemical Waste Access Road.

SWMU 7.4f-LLLW Transfer Pipeline Leak Site, Leak at Valve Pit North of Waste Trench 7: This leak site (Leak Site 6) is located at a valve pit directly north of Trench 7. The valve pit is located on the 2 in.-diameter cast iron pipeline that extends to the Old Hydrofracture Facility. Two metal identification tags located by Williams, Roberts, and Uziel (1988) were inscribed with 
$\mathrm{V}-120$ and $\mathrm{V}-121$, indicating that the valve pit probably contains two valves. A portion of an old pipeline with an attached valve was found on the ground surface near the pit area. Radiological examination of the pipe revealed low levels of gamma activity. In addition, a radiological survey of the valve pit performed in July and August indicated primarily gamma activity on the ground surface (Williams, Roberts, and Uziel 1988).

\subsubsection{SWMU 7.5-Pit 1}

Pit 1 was constructed just west of SWSA 4 and south of Lagoon Road in July of 1951. The pit

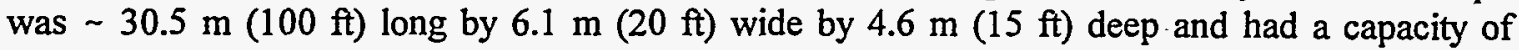
$681,300 \mathrm{~L}(180,000 \mathrm{gal})$. About $465,555 \mathrm{~L}(123,000 \mathrm{gal})$ of liquid waste were placed in the pit during its period of operation. The waste reportedly had a $\mathrm{pH}$ of about 12.5 and was principally contaminated with ${ }^{137} \mathrm{Cs}$ and ${ }^{106} \mathrm{Ru}$, although operating records indicate that $196 \mathrm{~kg}$ of uranium and $266 \mathrm{mg}$ of plutonium were also disposed of in Pit 1. In October 1951 the pit was closed to ILLW disposal after a ruthenium-contaminated seep was discovered. However, Pit 1 received additional waste in the form of drain discharge from Decontamination Building 7819, which began in 1962 and continued until at least 1964 but may have continued until as recently as 1981 . The nature and duration of discharges from the decontamination building are not clearly documented, but the total amount of activity from this source is thought to have been low. Pit 1 was filled with shale and covered with a sloping asphalt cap in 1981 (SAIC 1994).

\subsubsection{SWMU 7.6a-c-Pits 2,3 , and 4}

SWMU 7.6a-Pit 2: Pit 2 was constructed in 1952 and is located on a $427 \mathrm{~m}(1400 \mathrm{ft})$ south

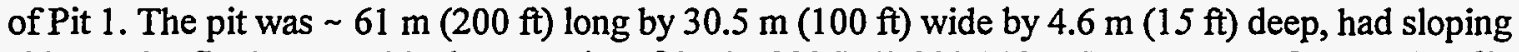
sides and a flat base, and had a capacity of 3,785,000 L (1,000,000 gal) at a stage of $3.7 \mathrm{~m} \mathrm{(12} \mathrm{ft).}$ The pit received ILLW via tank trucks until completion of the ILLW pipeline; however, tank trucks continued to transport inactive chemical wastes composed primarily of aluminum and ammonium nitrates to Pit 2 for disposal. The amount of active waste disposed of in Pit 2 is difficult to assess because overflow from Pit 2 was routed to Pits 3 and 4. Therefore, the relative distribution of ILLW among these three pits is not known, but the total quantity for all three is estimated at 79,485,000 L $(21,000,000 \mathrm{gal})$.

The principal waste constituents disposed of in the three pits were ${ }^{137} \mathrm{Cs},{ }^{106} \mathrm{Ru},{ }^{90} \mathrm{Sr}$, and the trivalent rare earths. During the years 1959 and 1961 , considerable amounts of ${ }^{106} \mathrm{Ru}$ were discharged to the pits and a seep contaminated with ${ }^{106} \mathrm{Ru}$ was discovered on the west side of Pit 2 . A trench was excavated at this location to intercept and collect the seep discharge, which was then pumped back into Pit 2. Sodium sulfide was added to Pit 2 in an effort to reduce the flux of ${ }^{106} \mathrm{Ru}$, but this was ineffective, and subsequently the levels of ruthenium discharged to the pit were decreased. Pit 2 was closed by backfilling with soil as it continued to drain over a period from 1962 to 1963. Final grading was completed in late 1963, and a sloping asphalt cap was placed over the pit in 1970 (SAIC 1994).

SWMU 7.6b-Pit 3: Pit 3 is located on the same hill as Pit 2 and is immediately northeast and up slope of Pit 2. This pit was constructed in January of 1955 and had the same dimensions and holding capacity as Pit 2 . Pit 3 became the initial discharge point for the $\mathbb{L L W}$ pipeline and was designed to overflow through a pipe into Pit 2. The principal radionuclides disposed of in Pit 3 were ${ }^{137} \mathrm{Cs},{ }^{106} \mathrm{Ru}$, and the trivalent rare earths, as well as sodium and nitrate from the treatment process in the main plant Gunite tanks. Other radionuclides disposed of in lesser amounts in Pit 3 included ${ }^{89} \mathrm{Sr}$, ${ }^{90} \mathrm{Sr},{ }^{60} \mathrm{Co}$, and ${ }^{125} \mathrm{Sb}$ (SAIC 1994). Seepage from Pit 3 was observed on its eastern side, but the flow was relatively small compared to that at Pit 2; therefore, no corrective measures were taken. Pit 3 was closed in September of 1961 in the same general manner as Pit 2. 
SWMU 7.6c-Pit 4: Pit 4 is located immediately south and down slope of Pit 3 . This pit had the same dimensions and holding capacity as Pits 2 and 3 and went into operation in April 1956 when it began to receive ILLW overflow piped in from Pit 2. Pit 4 proved to be more permeable than its predecessors, and an increase in ruthenium discharges to the pits in 1959 apparently resulted in a contaminated seep on the eastern side of the pit. An interception/collection trench measuring $3 \mathrm{~m}$ $(10 \mathrm{ft})$ deep and $53 \mathrm{~m}$ (175 ft) long was excavated along the eastern side of Pit 4 and used to pump accumulated liquid back into the pit. Copper compounds were also placed into the pit in the hope of immobilizing the ruthenium. Ultimately, discharges to the pits were discontinued, but it took some time for the seepage to abate. During this period another interception/collection trench was excavated on the west side of Pit 4, and 10 tons of sodium sulfide was added to the pits to reduce ruthenium mobility. Beginning in 1976, Pit 4 was gradually backfilled and was capped with asphalt in 1980 (SAIC 1994).

\subsubsection{SWMU 7.7-Trench 5}

Trench 5 was constructed in May of 1960 and is located on a hill $223 \mathrm{~m} \mathrm{(730} \mathrm{ft)} \mathrm{east} \mathrm{of} \mathrm{Pit} 4$. The design of this trench was markedly different from that of the WAG 7 pits in that it was intended to minimize worker exposure and reduce the amount of meteoric water collected. The design also called for the trench to be oriented perpendicular to geologic strike, which would enhance its seepage capacity because most of the seepage was believed to occur along strike via bedding planes. Trench 5

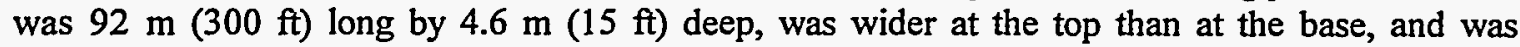
calculated to have a seepage rate of $\sim 15,140 \mathrm{~L} / \mathrm{d}(4000 \mathrm{gal} / \mathrm{d})$. Prior to operation, the trench was treated with $\sim 817 \mathrm{~kg}(1800 \mathrm{lb})$ of copper sulfate and $\sim 454 \mathrm{~kg}(1000 \mathrm{lb})$ of sodium sulfide to reduce the mobility of ruthenium. Trench 5 operated near its seepage capacity for a period of $\sim 6$ years and ultimately received $\sim 36,000,000 \mathrm{~L}(9,500,000 \mathrm{gal})$ of waste contaminated with ${ }^{89} \mathrm{Sr},{ }^{90} \mathrm{Sr},{ }^{13} \mathrm{Cs}$, ${ }^{106} \mathrm{Ru}$, and ${ }^{60} \mathrm{Co}$. Disposal of ILLW into the trench was discontinued in 1966, and it was capped with asphalt in 1970 (SAIC 1994).

\subsubsection{SWMU 7.8-Trench 6}

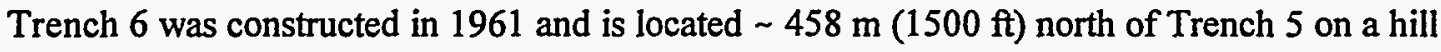
crest above a draw. Contrary to the intended design criteria for the WAG 7 trenches, Trench 6 was excavated in a U-shaped configuration, and thus portions of it were probably normal to geologic strike while other portions were perpendicular to strike. This trench was also treated with copper sulfate prior to operation to reduce ruthenium mobility. However, approximately 1 month after becoming operational, Trench 6 was removed from service because of seepage outbreaks contaminated with ${ }^{90} \mathrm{Sr}$ and ${ }^{137} \mathrm{Cs}$. Only 492,050 L (130,000 gal) of ILLW discharge contaminated with ${ }^{90} \mathrm{Sr},{ }^{137} \mathrm{Cs},{ }^{106} \mathrm{Ru}$, and ${ }^{60} \mathrm{Co}$ were disposed of in the trench. In 1981, Trench 6 was capped with asphalt (SAIC 1994).

\subsubsection{SWMU 7.9-Trench 7}

Trench 7 was completed in August of 1962 and is located $\sim 244 \mathrm{~m}(800 \mathrm{ft})$ east of Trench 5. This trench was designed with three separate segments, only two of which were built because shallow groundwater was discovered beneath the site of the proposed third segment. Trench 7 was oriented

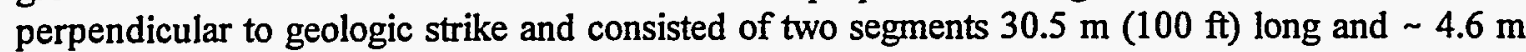
$(15 \mathrm{ft})$ deep. Prior to operation, the trench was treated with $189,250 \mathrm{~L}(50,000 \mathrm{gal})$ of $4 \%$ sodium hydroxide. This trench operated until 1966 during which time it received $\sim 36,000,000 \mathrm{~L}$ $(9,500,000 \mathrm{gal})$ of $\amalg L W$ discharge contaminated with ${ }^{90} \mathrm{Sr},{ }^{137} \mathrm{Cs},{ }^{106} \mathrm{Ru}$, and ${ }^{60} \mathrm{Co}$ (SAIC 1994). Only one documented seep containing relatively low levels of ruthenium occurred on the eastern side of the trench, and no remedial measures were taken. In 1970, Trench 7 was capped with asphalt, which 
was expanded in 1985 to enhance runoff and decrease surface water infiltration. In 1985 and 1986 a grout curtain was installed at varying depths on the northern and eastern sides of the trench; the grout curtain was not intended to completely seal off lateral groundwater movement, but rather was designed to plug preferred migration routes.

\subsubsection{SWMU 7.10a-e-Shielded Transfer Tanks}

There are five heavily shielded transfer tanks (designated ST1 through ST5) located above

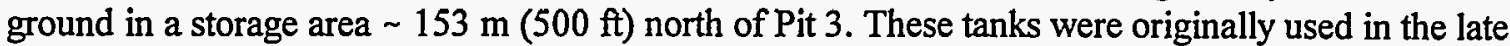
1950 s to transfer low concentrations of aqueous cesium and strontium waste from Arco, Idaho, to ORNL. During the 1960s, the tanks were used for the transfer of cesium-loaded ion exchange resins from Hanford, Washington, to ORNL. In 1967, all but one of the tanks were taken out of service. The single active tank was used at ORNL in 1970 and 1971 for the transfer of a caustic solution contaminated with high-level fission product waste. All of the tanks are now inactive but contain residual contamination, principally ${ }^{137} \mathrm{Cs}$. At present, none of the tanks is known to be leaking (SAIC 1994).

\subsubsection{SWMU 7.11-Building 7819 Septic Tank}

The septic tank is a concrete structure with a capacity of $540 \mathrm{gal}$ and is located $60 \mathrm{ft}$ west of the Building 7819 Decontamination Facility. The tank was used to collect and dispose raw domestic sewage from the facility. The septic tank system consists of a drain field comprising three lines of 4-in.-diameter vitrified clay pipe. Only domestic sewage from the Decontamination Facility has been collected and stored in the tank; no leaks or releases have been reported, and no known hazardous or radioactive wastes have been known to have been added to the system (Ebasco 1992).

\subsection{CHARACTERIZATION}

\subsubsection{Geography}

WAG 7 is located on the ORR in Roane County, Tennessee, approximately 10 miles southwest of the city of Oak Ridge and 1 mile south of the ORNL main plant area (Fig. 12.1). WAG 7 is bounded to the south, southwest, and southeast by WOL and the floodplain of WOC. To the east the site is bordered by uplands that drain toward WOC and to the northeast by SWSA 4, which adjoins the site. Lagoon Road parallels the northern limit of the site, which lies on the footslope of Haw Ridge. On its western flank the site is adjoined by WAG 2 and the head of a north-south draw that drains toward WOL.

WAG 7 is located in Melton Valley within the Valley and Ridge physiographic province. WAG 7 lies between Chestnut Ridge [1100 $\mathrm{ft}$ Mean Sea Level (MSL)], to the northwest, and Copper Ridge (1400 $\mathrm{ft} \mathrm{MSL),} \mathrm{to} \mathrm{the} \mathrm{southeast.} \mathrm{Bethel} \mathrm{Valley} \mathrm{(} 775 \mathrm{ft} \mathrm{MSL}$ ) is separated from Melton Valley (740 $\mathrm{ft} \mathrm{MSL}$ ) to the southeast by Haw Ridge (1000 ft MSL).

Analysis of the WAG 7 topography prior to use as a disposal area (Baughn 1987) indicated that the area was composed of two drainages that divided the majority of WAG 7 into three southerly trending lobes. The northwestern corner of the site is bisected by a southerly trending drainage that joins a larger drainage system just southwest of the WAG boundary. The drain ways receive drainage from numerous smaller drainages that dissect the uplands, giving the overall landform an irregular, "knobby" appearance (Fig. 12.3). 


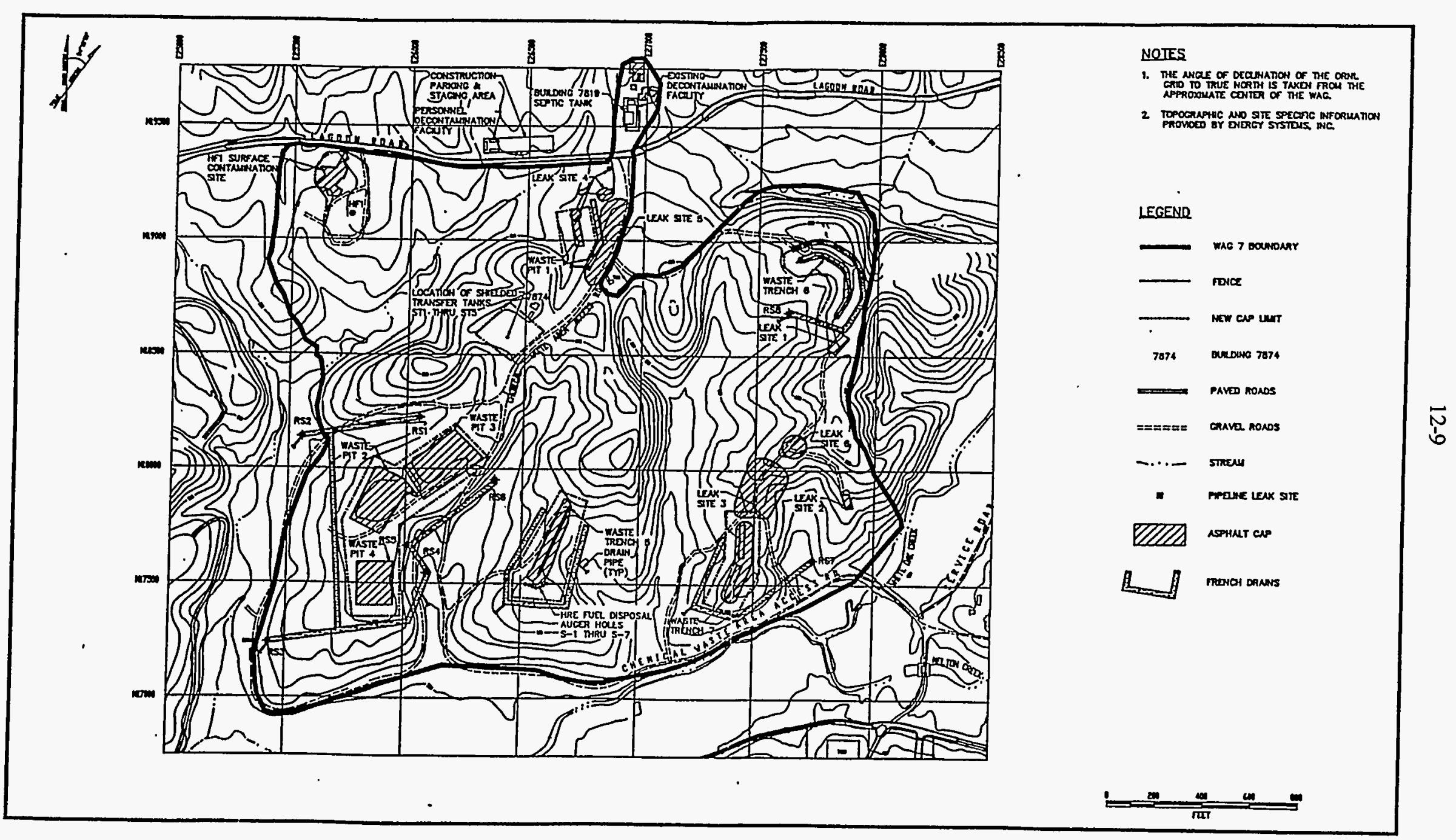

Fig. 12.3. Topography of WAG 7. Source: Ebasco 1992 
Slopes range from less than $1 \%$ western uplands in the vicinity of Pits, 2,3 , and 4 , to greater than $50 \%$ on the flanks of the draws that drain the site. Maximum relief is about $115 \mathrm{ft}$, with elevations ranging from a high of $870 \mathrm{ft}$ on the east-central border to $755 \mathrm{ft}$ near the floodplain of WOC (Baughn 1987).

\subsubsection{Climate}

See Sect. 5.2.2 of this document for climate description.

\subsubsection{Demography}

At the closest point, WAG 7 is approximately 1 mile from the ORNL main plant area (Fig. 12.1), where the majority of ORNL's approximately 4837 employees work (Site and Facilities Planning Department 1994). Within 1 mile of the boundary of WAG 7, all land is federally owned, and there are no residents. The two-lane State Highway 95 runs through the ORR and passes along the western side of WAG 7 within 0.25 mile of its boundary at the closest point. WAG 7 is approximately 1 mile from the north bank of the Clinch River, which forms a portion of the boundary of the ORR. The Clinch River, also known as Watts Bar Lake at this location, is open to recreational uses, such as boating, fishing, and duck and goose hunting, as permitted by the state of Tennessee.

See Sect. 5.2.3 of this document for general demographic characteristics of ORNL.

\subsubsection{Geology and Soils}

The bedrock that immediately underlies the Valley and Ridge province in the vicinity of the ORR is sedimentary rock of early Paleozoic age. From oldest to youngest, the strata that occur between Chestnut Ridge and Copper Ridge are the Early Cambrian Rome Formation, the Middle to Late Cambrian Conasauga Group, the Late Cambrian to Early Ordovician Knox Group, and the Middle Ordovician Chickamauga Group. The stratigraphic units in the ORR area are exposed in a series of linear northeast/southwest trending belts that are the result of motion along the Copper Creek and White Oak Mountain thrust faults (Ebasco 1992).

WAG 7 rests on weathered materials from the Conasauga Group-weak, light-brown, layered and banded rock broken into small prisms (De Laguna et al. 1968). Weathering extends to a depth of 30 to $40 \mathrm{ft}$ ( 9 to $12 \mathrm{~m}$ ) under the low ridges and to a depth of about $10 \mathrm{ft}(3 \mathrm{~m})$ under the valleys; in many places, the bottom of the weathered zone is roughly at the water table. The fresh shale below is composed of thin alternating layers of hard, dark-gray calcareous shale and light-gray shaly limestone. Much of the carbonate is leached out by the weathering; usually, the limestone layers are turned into silty clay and the shale layers into a fine, silty sand.

In general, the shale dips to the southeast at about $35^{\circ}$, but there are several types of structures that complicate this simple pattern. During excavation of Pit 3 , a reversal of dip was observed that produced a small anticline and syncline [the width of the structure being about $150 \mathrm{ft}(46 \mathrm{~m})$ ]. The dips are gentle, and there is no evidence of crumpling or faulting. In the area occupied by Pit 4 , the beds are intensely and irregularly folded and crumpled. Exposures suggest that this belt of crumpled beds is roughly $200 \mathrm{ft}(61 \mathrm{~m})$ wide and that it extends east and west along the strike for at least $1,000 \mathrm{ft}(305 \mathrm{~m})$. Some hydrological evidence exists to suggest that this belt of crumpled rock is bordered on the south by a fault, possibly a thrust fault related to the Copper Creek fault. South of Pit 4 and south of the presumed fault, there are a number of small folds. Exposures in and near Pit 2 are poor, but it appears possible that no folds or faults exist in that area (ORNL 1987). 
Silty to clayey red-yellow and red-brown podzols, common throughout the southeastern United States, occur in the ORNL area. Generally the soils are moist, low in organic matter, strongly leached and acidic, with a pH of 4.5 to 5.7. Soils derived from the Conasauga Group typically contain illite and vermiculite as principal clay minerals. Those from the Chickamauga Group contain a mixture of kaolinite, illite, and montmorillonite clays. Soils of the WAG 7 site are generally derived from the weathering of rocks of the Conasauga Group. Boring logs from the ORNL piezometer installation in WAG 7 describe the soils and subsoils as medium brown to red silty clays with shale float (Baughn 1987). The boring logs record soil thicknesses ranging from $4.5 \mathrm{ft}$ in the lower elevations near WOC to $22 \mathrm{ft}$ on the slopes below Waste Pit 6 . The drill logs also indicate that the transition from soil to bedrock is gradational in shale lithologies and more distinct in limestone lithologies. Examination of cores obtained from Hydrofracture Experimental Site I during a 1955 study indicated that the top 10 to $20 \mathrm{ft}$ of soil is composed of weak, silty, punky clay (Struxness, Morton, and Straub 1955).

The presence of clay minerals in soils associated with WAG 7 enhances the ability of the soils to retard the migration of radioactive and hazardous constituents by (1) mechanical filtering; (2) adsorption of electrochemically charged ionic constituents on the surface of the clay particles; (3) absorption of ionic species within the mineralogical lattice structure; and (4) ion exchange with particles already adsorbed on the surface of the clay particle.

Chemical weathering strongly affects soil formation in both the Chickamauga and Conasauga groups. The depth of weathering in the Chickamauga Group is typically less than $10 \mathrm{ft}$. Bedding and structures within the rock are not retained much above the fresh rock surface because chemical weathering in the limestone is so complete. In the Conasauga Group, the depth of weathering reportedly ranges from 0 to $40 \mathrm{ft}$ and is closely tied to topography, with thinner zones in low-lying areas and thicker zones on the ridges (Ebasco 1992).

Within WAG 7, native soils have been reworked and fill materials imported to accommodate operational and disposal activities, such as the construction of pipelines, trenches, building foundations, and burial grounds. The disturbance has altered the natural structural fabric and mineralogy of soils in these areas. It has also provided a random network of conduits for the collection and conveyance of fluids, including leaked and spilled materials throughout the site (Ebasco 1992).

\subsubsection{Surface Water}

ORR is bounded on the south and west by the Clinch River, and ORNL is located within the Clinch River drainage basin. Melton Hill Dam is located on the river at Clinch River Mile 23 and forms Melton Hill Reservoir. The Emory River enters the Clinch River north of the town of Kingston and in turn enters the Tennessee River just south of Kingston.

WOC is a part of the surface water system that drains the area in and around the ORR. WOC drains an area of approximately $6.5 \mathrm{mi}^{2}$ in Bethel and Melton valleys. The headwaters of WOC are located to the north of ORNL in Chestnut Ridge. After leaving Chestnut Ridge, WOC flows southwest through Bethel Valley and then cuts perpendicular to the valley through a gap in Haw Ridge and enters Melton Valley. From its confluence with Melton Branch, WOC continues to flow southwest towards WOL, and a confluence with the Clinch River (Fig. 12.4). 


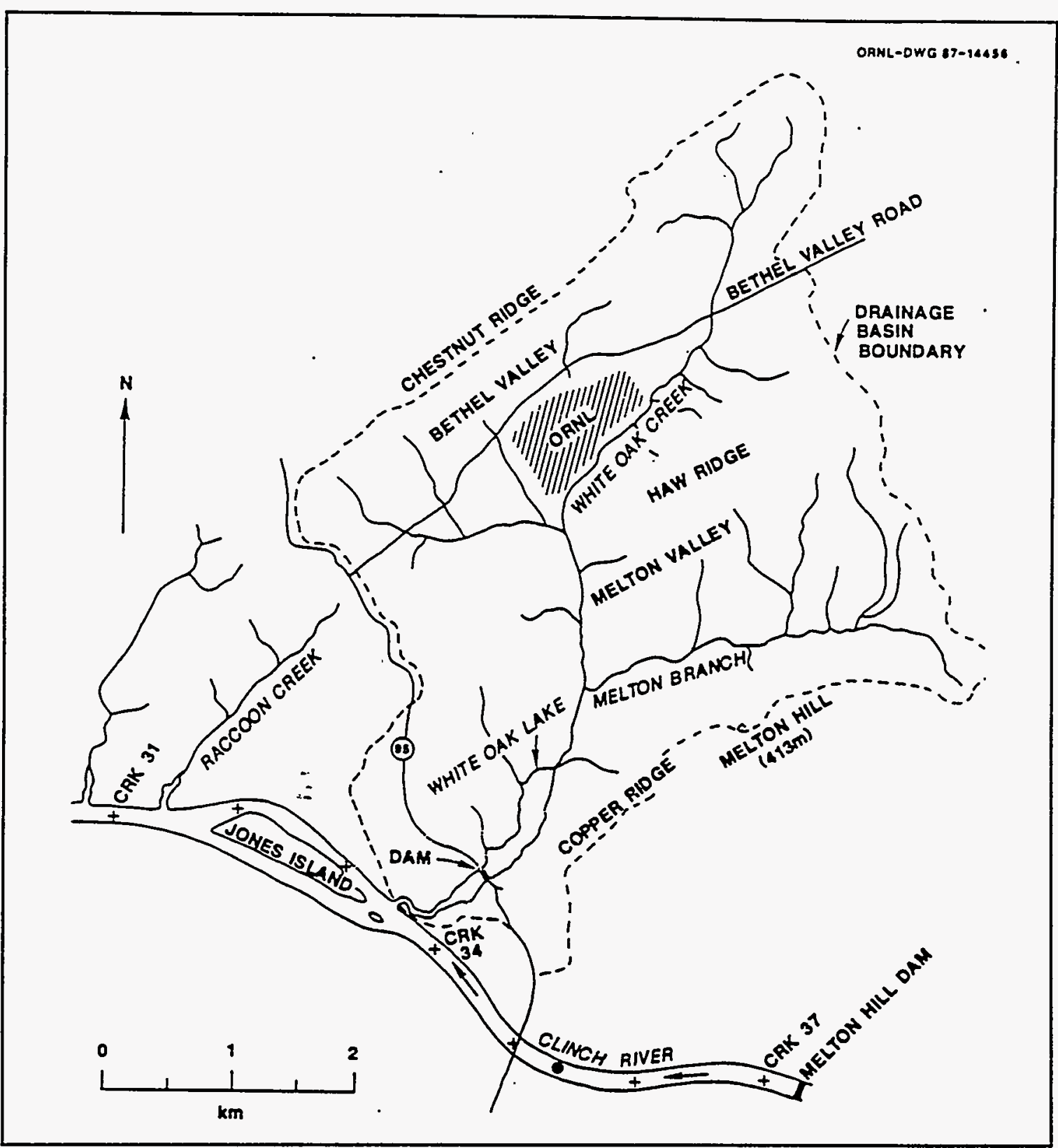

Fig. 12.4. Map showing the White Oak Creek watershed boundaries. Source: Bechtel 1988

WAG 7 lies in the Melton Valley portion of the WOC watershed. WAG 7 is characterized by closely spaced ridges and valleys through which three streams of WOC flow south toward WOL.

The western boundary of WAG 7 is skirted by a perennial stream that discharges directly into WOL. This stream has two branches: the longer, eastern branch drains areas of Haw Ridge and receives runoff diverted from north of Lagoon Road; the western branch runs along the northeastern edge of WAG 6. This stream collects discharge from seeps RSI, RS2, and RS 3 as well as runoff from the process waste transfer pipeline leak site, Hydrofracture Experimental Site 1, and portions of Pits $1,2,3$, and 4. 
A second tributary to WOC, located east of the perennial stream, flows directly into the upper reaches of WOL, which drains the area between Pits 2, 3, and 4 and Trench 5. Seeps RS4, RS5, and RS6 and the Homogeneous Reactor Experiment fuel disposal auger holes are adjacent to this stream.

A third tributary to WOC, located farther east, drains an area in which Pit 6, portions of Pits 5 and 7, Seep RS8, and some ILLW leak sites are located. This stream joins WOC between WOL and the confluence of WOC and Melton Branch.

As WOC flows along the east and southeast boundary of WAG 7 it receives runoff from two small intermittent drainages; Seep RS7 and the ILLW transfer pipeline leak sites are located along these drainages. The stream gradient along this southeast reach of WOC is less than two percent. All three tributaries all have gradients of less than five percent (Bechtel 1988).

The surface waters of this area are of the calcium-magnesium-bicarbonate type (McMaster 1967). They have a moderate hardness and typically have a total dissolved solids ranging from 100 to $250 \mathrm{mg} / \mathrm{L}$. Essentially all of the water used at ORNL is obtained from the Clinch River, and what is not consumed is discharged to the various surface streams. This discharge is often a significant fraction of the flow in some streams during low flow periods. For example, in the drier summer months, little or no flow occurs in Melton Branch above the confluence of the discharge from the High Flux Isotope Reactor/transuranic area. During this period virtually all the flow below this point is attributable to the High Flux Isotope Reactor tributary (Bechtel 1988).

\subsubsection{Groundwater}

The occurrence and movement of groundwater at ORR is affected by many factors including: (1) ground surface topography; (2) surface water features; (3) anthropogenic disturbance; (4) bedrock geology including lithology, karst features, stratigraphic strike and dip, degree and orientation of fractures; and (5) vertical hydraulic gradients within a given aquifer.

Two distinct but hydraulically interconnected flow systems have been identified in the study area: one each within the regolith and the bedrock. Both systems are described as heterogeneous and anisotropic (Stockdale 1951, Webster and Bradley 1986).

The surface of the water table generally appears as a subdued replica of the ground surface topography (Webster and Bradley 1986). The depth to the water table varies both seasonally and with the topography and is found closer to the surface in the valleys and at greater depths on the ridges. The water table generally occurs within the regolith at depths of a few feet to more than $60 \mathrm{ft}$ (Webster 1976). Under water table conditions, the direction of groundwater movement would be strongly controlled by the topography; however, directional permeabilities resulting from underlying geologic units, relict bedrock structure within the weathered bedrock zone, anthropogenic disturbance, and vertical gradients also influence the movement of groundwater through the regolith. Under seasonally high water table conditions, the topographic influence likely dominates groundwater movement; however, this may not be the case under seasonally low water table conditions (Webster and Bradley 1986).

Groundwater occurs in bedrock formations that underlie the WOC basin: the Knox Group and the Chickamauga Group are the principal water bearing units, while the Rome Formation and the Conasauga Group contain relatively minor amounts of water (Webster 1976). Within these units, circulation of groundwater may be limited to the upper $200 \mathrm{ft}$ (Webster and Bradley 1986). In the carbonate-rich lithologies, groundwater moves primarily along openings of secondary permeability, such as joints, fractures, and solution channels. In other lithologies, bedding planes also provide a 
significant pathway of flow. The rate of flow is controlled by hydraulic head differences and the size, orientation, and degree of interconnection among these permeable openings. The direction of flow is controlled by hydraulic gradients along permeable openings. Both horizontal and vertical components of flow have been identified at ORNL with directions parallel, perpendicular, and at oblique angles to bedrock strike (Bechtel 1988).

Shallow (less than $200 \mathrm{ft}$ ) groundwater quality in the Conasauga Group is typically neutral to slightly alkaline (pH 7 to 8 ) and is of the calcium-bicarbonate type (high content of calcium and bicarbonate), reflecting the carbonate-rich lithologies through which it flows (Webster 1976, Webster and Bradley 1986). The presence of calcium and magnesium in the groundwater decreases the ability of the soils to retard the migration of certain radionuclides because of competition for available ion exchange positions on the clay (Webster 1976). Most radionuclides migrate as charged or neutral ionic complexes, not as individual ions. The chemical character of the groundwater, then, will affect the chemical state of the radioactive material and its potential for migration in a specified environment.

Information regarding the occurrence of groundwater beneath WAG 7 is derived from studies that are either regional in nature (i.e., on the scale of the ORNL facility or Melton Valley), specific to other WAGs within Melton Valley, or specific to WAG 7. Of those that are specific to WAG 7, data are generally derived from wells and seeps around certain SWMUs, including Pits 2, 3, and 4, Waste Trench 5, and Waste Trench 7.

Groundwater occurs in both the regolith and within the bedrock of the Conasauga Group, although the two flow systems are recognized as hydraulically interconnected (with flow from zones of higher hydraulic head to those that are lower). The groundwater table, which varies seasonally, generally occurs near the base of the regolith at depths ranging from less than $3 \mathrm{ft}$ up to $60 \mathrm{ft}$. Webster and Bradley (1986) suggest that the lower limit of groundwater circulation probably occurs in the bedrock between 200 and $250 \mathrm{ft}$ below ground surface with most circulation occurring in the upper $100 \mathrm{ft}$.

Toran and Solomon (1987) describe the geochemistry and aquifer responsiveness to precipitation events in wells installed at various depths up to approximately $400 \mathrm{ft}$. Their study suggests that groundwater circulation in bedrock occurs up to depths of at least $200 \mathrm{ft}$ in certain areas but that the communication between zones below $200 \mathrm{ft}$ is not evident. Depth, not geologic formation, is regarded as the limiting factor (Toran and Solomon 1987).

A conceptual model of flow in Melton Valley described by Webster and Bradley (1986) suggests that the primary control on the direction of flow changes from the water table gradient in the regolith (at and just below the water table) to the hydraulic head distribution within the secondary openings in the bedrock with an intermediate zone positioned between the two. During periods of high water table conditions, flow through the regolith would be expected to be dominated by water table gradients (radially away from topographic highs). During periods of lower water table conditions, flow paths controlled by relict bedrock structure, lithology, and manmade disturbance will have a greater influence on flow patterns in the regolith. At WAG 7, several areas of known structural deformation of bedrock (i.e., folding and faulting) exist. These structural features have been identified as influencing groundwater flow paths and subsequently contaminant transport from known SWMUs (Means, Crerar, and Duguid 1976; Olsen et al. 1983). The certainty of predicting local flow patterns based on water table mapping is greatly reduced with recognition of these directional permeabilities. 


\subsubsection{Ecology}

Sect. 5.2.7 of this document provides an overview of the flora and fauna commonly found on the ORR, which are believed to be representative of those found at WAG 7.

\subsection{RELEASES AND SITE CONCEPTUAL MODEL}

Two principal source documents were used to develop an understanding of groundwater contamination within WAG 7. These documents were the Preliminary Geohydrologic Site Characterization and Proposed Water Quality Well Locations for WAGs 7, 8, and 9 (Energy Systems 1987), and the Oak Ridge Reservation Environmental Report for 1991 (Energy Systems 1992). The Preliminary Geohydrologic Site Characterization and Proposed Water Quality Well Locations for WAGs 7, 8, and 9 summarized results from two previous studies regarding groundwater contamination at WAG 7.

The first study reported results for groundwater samples collected from nine of the pre-Remedial Action Program monitoring wells located in the vicinity of Pits 2, 3, and 4, and trenches 6 and 7. Six monitoring wells located around the perimeter of Pits 2,3, and 4 were sampled. Results from this sampling indicated the presence of ${ }^{60} \mathrm{Co}$ and $\mathrm{Sr}$ contamination in all of the wells, with the exception of well 0096, which only contained ${ }^{60} \mathrm{Co}$ contamination. Activities of ${ }^{60} \mathrm{Co}$ and ${ }^{90} \mathrm{Sr}$, respectively, ranged from 0.83 to $4.4 \mathrm{~Bq} / \mathrm{L}$ and 0.34 to $1.4 \mathrm{~Bq} / \mathrm{L}$ in the northern half of the pits area and from 23 to $120 \mathrm{~Bq} / \mathrm{L}$ and 0.36 to $3.2 \mathrm{~Bq} / \mathrm{L}$ in the southern half of the area. Results from two monitoring wells sampled west of Trench 7 indicated the presence of ${ }^{60} \mathrm{Co}$ and ${ }^{90} \mathrm{Sr}$ contamination averaging $0.3 \mathrm{~Bq} / \mathrm{L}$ for both contaminants. Samples from well 1764 located in the vicinity of Trench 6 indicated the presence of ${ }^{60} \mathrm{Co},{ }^{90} \mathrm{Sr}$, and ${ }^{137} \mathrm{Cs}$ at activities of $2.7,54$, and $180 \mathrm{~Bq} / \mathrm{L}$, respectively. Tritium was not detected above detection limits at any of the sampling locations.

The second study reported results for groundwater samples collected from 12 of the pre-Remedial Action Program monitoring wells, one soil boring, and one seep located near Trench 7. All of the sampling locations were found to be contaminated by tritium and ${ }^{90} \mathrm{Sr}$, with activities ranging from 85 to $27,300 \mathrm{~Bq} / \mathrm{L}$ for tritium and from 0.3 to $2350 \mathrm{~Bq} / \mathrm{L}$ for ${ }^{90} \mathrm{Sr}$. A majority of the sampling locations were also found to be contaminated by ${ }^{60} \mathrm{Co}$ and ${ }^{233} \mathrm{U}$, with activities ranging from 14 to $2040 \mathrm{~Bq} / \mathrm{L}$ for ${ }^{60} \mathrm{Co}$ and from 0.13 to $12.9 \mathrm{~Bq} / \mathrm{L}$ for ${ }^{233} \mathrm{U}$.

The Oak Ridge Reservation Environmental Report for 1991 (Energy Systems 1992) summarized results for groundwater samples collected during April and May of 1991 from the 16 groundwater quality wells at WAG 7. Five of the perimeter wells, four located along the southwest boundary of WAG 7 and one along the southeast boundary, were found to be contaminated with tritium. Activities of tritium in the southwest perimeter wells ranged from 760 to $38,000 \mathrm{~Bq} / \mathrm{L}$; the activity within well 1084 was $4500 \mathrm{~Bq} / \mathrm{L}$. Wells 1079 and 1085 were found to contain nickel contamination above the maximum contaminant limit at concentrations of $370 u \mathrm{~g} / \mathrm{L}$ and $146 \mathrm{ug} / \mathrm{L}$, respectively. Subsequent sampling of the wells in April and May of 1992 indicated the presence of similar activities and concentrations of the noted contaminants, with the exceptions that no tritium was detected in well 1082 and no nickel was detected in well 1085.

Based on the data evaluated for WAG 7, contaminated groundwater containing ${ }^{60} \mathrm{Co},{ }^{90} \mathrm{Sr}$, and tritium derived from one or more of the disposal pits and/or trenches appears to have migrated downgradient to the southern boundaries of WAG 7. Trench 7 also appears to be a possible source of ${ }^{23} \mathrm{U}$ contamination; Trench 6 may be a possible source of ${ }^{137} \mathrm{Cs}$. The absence of tritium contamination in the pre-Remedial Action Program wells sampled around Pits 2, 3, and 4 does not 
correlate with later detection of this contaminant in the groundwater quality perimeter wells. This observation may be attributed to different well depths, resulting in the sampling of two different groundwater horizons, or it may be attributed to arrival of tritium contamination in this area of the WAG between the two sampling events. Regardless of the explanation, the detection of tritium in wells 1076 and 1078 suggests that one or both of the upgradient disposal sites (Pit 1 or Trench 6) in WAG 7, or possibly WAG 4, are sources of tritium contamination (Ebasco 1992).

\subsection{ACTIVE PROJECTS: IN SITU VITRIFICATION}

Instructions to User
Remediation is an ongoing process, and the status of active projects can change
quickly. For the most up-to-date information about WAG 7 in situ vitrification, check
the Annual Environmental Restoration Monitoring and Assessment Report and the
Federal Facility Agreement Quarterly Report.

In situ vitrification (ISV) is a promising technology that has been selected as the baseline closure technology for several pits and trenches at WAG 7. ISV, developed and patented for DOE by Battelle Pacific Northwest Laboratory, involves placing electrodes in an array above a contaminated volume of soil, applying power to the electrodes, and melting the entire mass of soil into a chemically homogeneous and durable glassy-to-microcrystalline waste form.

ISV could play an important role in environmental remediation at ORNL because of the large number of soil sites that have been significantly contaminated with mixed fission products and transuranic isotopes. From 1951 through 1966, ORNL disposed of more than a million curies via liquid waste seepage into seven shallow pits and trenches contained in WAG 7. Presently the pits and trenches are covered with asphalt and require regular maintenance. However, this inventory of radioactivity is situated within $20 \mathrm{ft}$ of the water table and in places only $100 \mathrm{ft}$ from perennial surface streams. The present and potential mobility of radionuclides, particularly ${ }^{90} \mathrm{Sr}$, into shallow groundwater and streams represents one of the most significant long-term risks posed by ORNL waste management units. The high levels of radioactivity in the ORNL seepage pits and trenches would restrict any direct contact by remediation workers or machine operators, and any exhumation approach would entail a large risk for environmental releases because of the proximity to surface water and the generally wet climate of the area. Such hazards, coupled with the lack of any credible alternative disposal site or method for exhumed waste, have focused consideration on in situ stabilization and closure techniques, particularly for high-radiation-hazard waste management units like the ORNL seepage pits and trenches (Spalding 1993).

In 1996, the ISV Project will carry out the vitrification of approximately 1500 tons of radioactively contaminated soil in Pit 1 , in collaboration with Battelle Pacific Northwest Laboratory and Geosafe Corporation, a commercial vendor of ISV technology. Pit 1 was selected for the demonstration because of its limited size $\left(30,000 \mathrm{ft}^{3}\right)$ and small inventory of mixed fission products. Pit 1 is an abandoned pit that was filled with soil in 1981. It was then covered with an asphalt cap but has continued to exhibit perched groundwater within $10 \mathrm{ft}$ of the surface. Pit 1 was used in 1951 as a prototype for disposal of liquid radioactive waste by ground seepage after which it was abandoned. The characterization study has found that the pit still contains about $38 \mathrm{Ci}$ of ${ }^{137} \mathrm{Cs}$ and about $2 \mathrm{Ci}$ of ${ }^{90} \mathrm{Sr}$ with minor amounts of $\mathrm{U}$ and $\mathrm{Pu}$ isotopes. No nonradioactive hazardous contaminants were found. Pit 1 is only a small problem in itself but it is representative of six other 
seepage pits and trenches that are 5 to 10 times larger in size and contain very significant radionuclide inventories, up to $200,000 \mathrm{Ci}$ each (Spalding 1995).

The ISV process to be conducted at Pit 1 is depicted in Fig. 12.5. During ISV, an array of vertical electrodes is inserted into the soil to a nominal depth (about two electrode diameters) above the waste site, and, since dry soil is not electrically conductive, a conductive material (typically glass frit and graphite flake) is placed in paths between the electrodes to act as a resistive heating element. The soil-melting process is initiated when an electric potential applied to the electrodes establishes a current in the path, in turn heating the path and the surrounding soil to temperatures above the melting point of soil. Once molten, the soil becomes electrically conductive. Power to the melt is controlled as the process continues and the molten soil mass grows downward and outward (typically maintaining temperatures between $1400^{\circ} \mathrm{C}$ and $2000^{\circ} \mathrm{C}$ ). The melt dissolves and/or incorporates radionuclides and nonvolatile hazardous elements, such as heavy metals, and destroys organic components by pyrolysis. Semivolatile metals are largely retained in the melt, but the small quantity of material that does escape from the melt is captured and treated (Spalding 1993). The fate and disposition of various materials during ISV processing is depicted in Fig. 12.6.

.

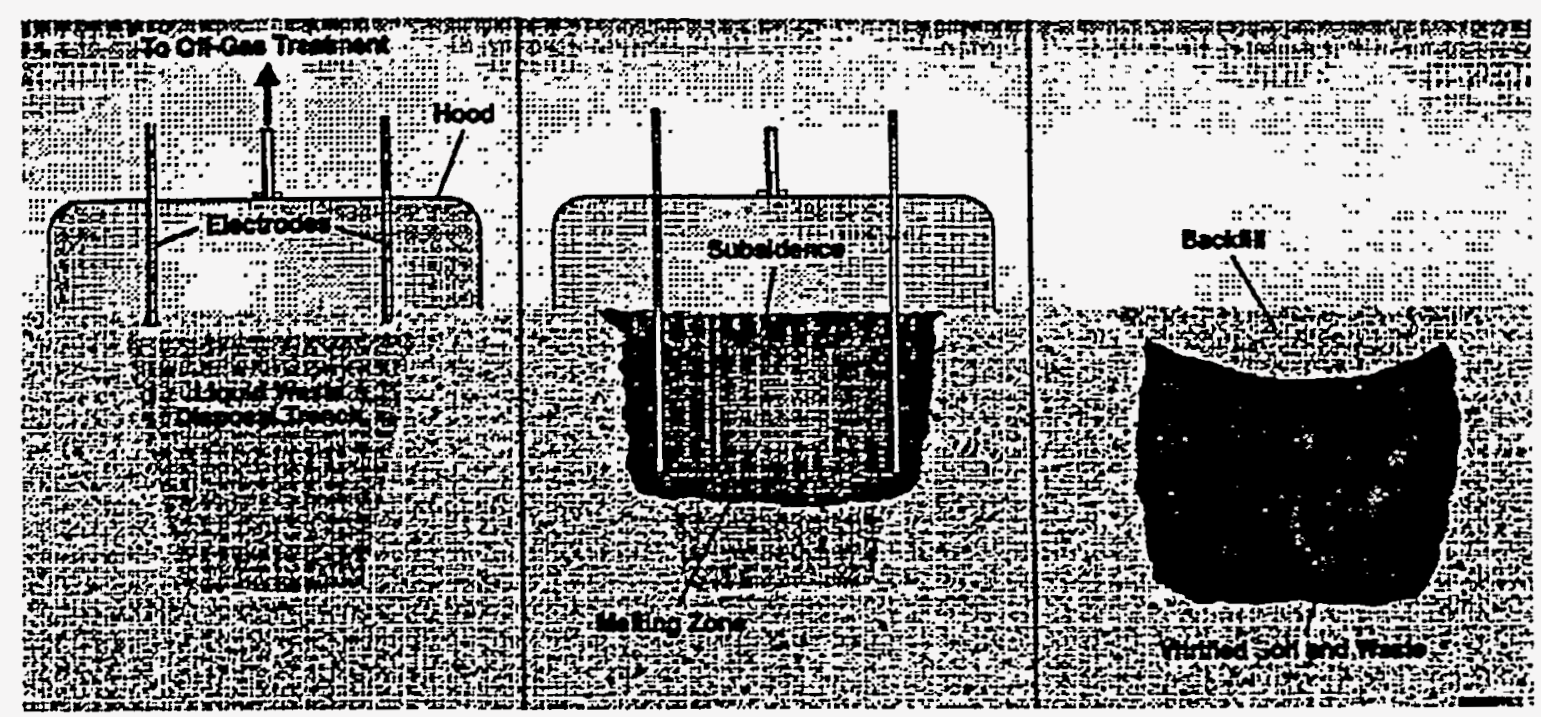

Fig. 12.5. Schematic illustration of the ISV process applied to an ORNL seepage trench. Source: Spalding 1993

A hood placed over the area being vitrified confines the gases released from the melt and directs them to an off-gas treatment system that uses a combination of wet-scrubbing and dryfiltering. Power to the melt is maintained until the desired depth is obtained and the soil and its contents are melted. Because the conductivity of the melt increases as the melt volume increases, the ISV power supply is equipped with a series of voltage taps to maintain a constant power level to the melt. Upon cooling, the molten soil solidifies into a vitrified mass resembling natural obsidian in appearance and durability, with a leach resistance approaching that of high-quality laboratory glassware (Buelt et al. 1987; Callow et al. 1991).

The ISV Project has the basic objectives to demonstrate that ISV can be (1) carried out to the geometric requirements of the ORNL seepage pits, (2) produce an excellent waste form, (3) perform safely with minimal secondary wastes, and (4) perform the required overlap of three melt settings. The ISV Project is being performed with high regulatory and public visibility to build the required support base for future use in ORNL remediations. 


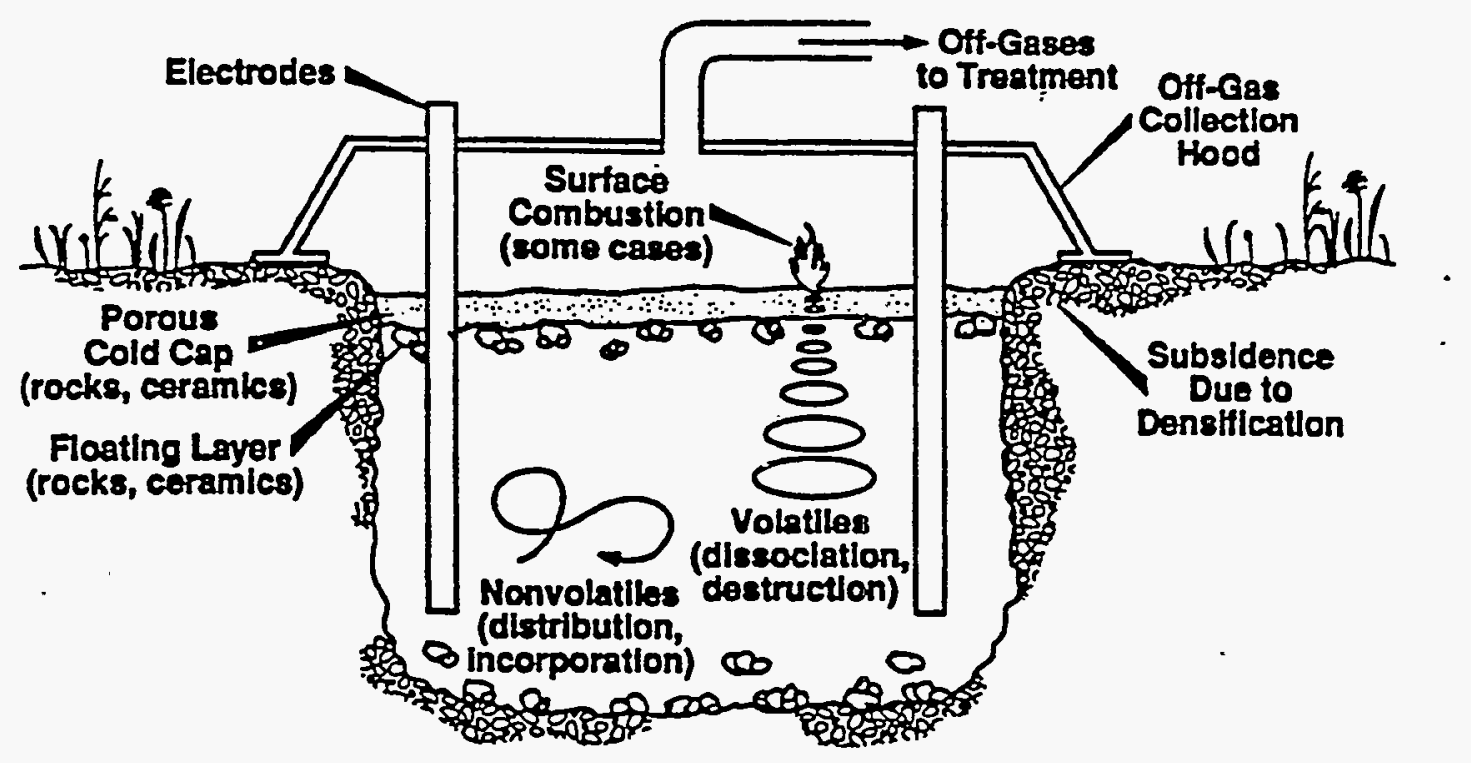

Fig. 12.6. Disposition of materials during in situ vitrification processing. Source: Spalding 1993

The ISV Project was initiated in November 1993 and is scheduled be completed in June 1996. Pit 1 site characterization was completed in FY 1994 and demonstrated in situ radioactivity logging using driven pipes as a facile method to establish ISV depth and lateral goals in a poorly known contaminant distribution. Site preparations were completed April 1, 1995, and set up of Battelle Pacific Northwest Laboratory's large-scale ISV equipment has been completed. A new off-gas collection hood has been fabricated; equipment assembly and site setup have been completed. Three large-scale overlapping melts are planned for and should complete treatment of all of the pit's source contamination (Clapp and Watts 1995).

\subsection{WAG 7 SUMMARY}

WAG 7 is located on the Oak Ridge Reservation in Roane County, Tennessee, approximately 5 miles southwest of the city of Oak Ridge central business district and 1 mile south of the ORNL main plant area. WAG 7 lies in Melton Valley and consists of approximately 47 ha (116 acres), which are predominantly woodland. The site is irregularly shaped and is bounded to the south, southwest, and southeast by White Oak Lake and the floodplain of White Oak Creek. To the east the site is bordered by uplands that drain toward WOC; to the northeast it is bounded by SWSA 4, which adjoins the site.

WAG 7 contains 11 solid waste management units (SWMUs):

\begin{tabular}{ll}
\hline \multicolumn{1}{c}{ SWMU } & \multicolumn{1}{c}{ Description } \\
\hline 7.1 & Building 7819 Decontamination Facility \\
7.2 & Homogeneous Reactor Experiment Fuel Wells \\
7.3 & Hydrofracture Experimental Site 1 Soil Contamination \\
$7.4 \mathrm{a}-\mathrm{f}$ & Intermediate-Level Liquid Waste Line Leak Sites \\
\hline
\end{tabular}




\begin{tabular}{ll}
\hline \multicolumn{1}{c}{ SWMU } & \multicolumn{1}{c}{ Description } \\
\hline 7.5 & Pit 1 \\
$7.6 a-c$ & Pits 2, 3, and 4 \\
7.7 & Trench 5. \\
7.8 & Trench 6 \\
7.9 & Trench 7 \\
$7.10 a-e$ & Shielded Transfer Tanks \\
7.11 & Building 7819 Septic Tank \\
\hline
\end{tabular}

WAG 7 is located in Melton Valley within the Valley and Ridge physiographic province and lies between Chestnut Ridge, to the northwest, and Copper Ridge, to the southeast. Bethel Valley is separated from Melton Valley to the southeast by Haw Ridge.

WAG 7 rests on weathered materials from the Conasauga Group-weak, light-brown, layered and banded rock broken into small prisms. Weathering extends to a depth of 30 to $40 \mathrm{ft}$ $(9$ to $12 \mathrm{~m}$ ) under the low ridges and to a depth of about $10 \mathrm{ft}(3 \mathrm{~m})$ under the valleys; in many places, the bottom of the weathered zone is roughly at the water table. Boring logs from the ORNL piezometer installation in WAG 7 describe the soils and subsoils as medium brown to red silty clays with shale float.

WAG 7 lies in the Melton Valley portion of the White Oak Creek watershed. WAG 7 is characterized by closely spaced ridges and valleys through which three streams of WOC flow south toward White Oak Lake. The western boundary of WAG 7 is skirted by a perennial stream that discharges directly into White Oak Lake. A second tributary to White Oak Creek, located east of the perennial stream, flows directly into the upper reaches of White Oak Lake. A third tributary to White Oak Creek, located farther east, drains an area in which Pit 6, portions of Pits 5 and 7, Seep RS8, and some intermediate-level liquid waste leak sites are located. The surface waters of this area are of the calcium-magnesium-bicarbonate type.

The surface of the water table generally appears as a subdued replica of the ground surface topography. The depth to the water table varies both seasonally and with the topography and is found closer to the surface in the valleys and at greater depths on the ridges. The water table generally occurs within the regolith at depths of a few feet to more than $60 \mathrm{ft}$. Groundwater occurs in bedrock formations that underlie the WOC basin: the Knox Group and the Chickamauga Group are the principal water bearing units. A conceptual model of flow in Melton Valley described by Webster and Bradley (1986) suggests that the primary control on the direction of flow changes from the water table gradient in the regolith (at and just below the water table) to the hydraulic head distribution within the secondary openings in the bedrock with an intermediate zone positioned between the two.

Contaminated groundwater containing ${ }^{60} \mathrm{Co},{ }^{90} \mathrm{Sr}$, and tritium derived from one or more of the disposal pits and/or trenches appears to have migrated downgradient to the southern boundaries of WAG 7. Trench 7 also appears to be a possible source of ${ }^{233} \mathrm{U}$ contamination; Trench 6 may be a possible source of ${ }^{137} \mathrm{Cs}$. The detection of tritium in wells 1076 and 1078 suggests that one or both of the upgradient disposal sites (Pit 1 or Trench 6) in WAG 7, or possibly WAG 4, are sources of tritium contamination.

In situ vitrification has been selected as the baseline closure technology for several pits and trenches at WAG 7. The in situ vitrification process involves placing electrodes in an array above a 
contaminated volume of soil, applying power to the electrodes, and melting the entire mass of soil into a chemically homogeneous and durable glassy-to-microcrystalline waste form. The project was initiated in November 1993 and will be completed in June 1996.

\subsection{REFERENCES}

Baughn, D. C. 1987. Preliminary Geohydrologic Site Characterization and Proposed Water Quality Well Locations for WAG 7,WAG 8, and WAG 9, ORNL/RAP/Sub-86/72139/2, MCI Consulting Engineers, Knoxville, Tenn.

Bechtel (Bechtel National, Inc.) 1988. Remedial Investigation Plan for ORNL Waste Area Grouping 7-Oak Ridge National Laboratory Remedial Investigation/Feasibility Study, ORNL/RAP/Sub-87/99053/16\&R1, Oak Ridge Natl. Lab.

Buelt, J. L., et al. 1987. In Situ Vitrification of Transuranic Waste: Systems Evaluation and Applications Assessment, PNL-4800, Supplement 1, Battelle Pacific Northwest Lab. Richland, Wash.

Callow, R. A., et al. 1991. In Situ Vitrification Application to Buried Waste: Final Report of Intermediate Field Tests at Idaho National Engineering Laboratory, EGG-WTD-9807, Idaho Natl. Engineering Lab., Idaho Falls, Idaho.

Clapp, R. B., and J. A. Watts, eds. 1995. Fourth Annual Environmental Restoration Monitoring and Assessment Report (FY 1995), Oak Ridge National Laboratory, Oak Ridge,' Tennessee, DOE/OR/01-1413\&D1, Oak Ridge Natl. Lab.

De Laguna, W. et al. 1968. Engineering Development of Hydraulic Fracturing as a Method for Permanent Disposal of Radioactive Wastes, ORNL/TM-4259, Oak Ridge Natl. Lab.

Duguid, J. O. 1976. Annual Progress Report of Burial Ground Studies at Oak Ridge National Laboratory: Period Ending September 30, 1975, ORNL-5141, Oak Ridge Natl. Lab.

Ebasco (Ebasco Services Inc.) 1992. Baseline Report for Waste Area Grouping 7 at Oak Ridge National Laboratory, Oak Ridge, Tennessee, ORNL/ER-99/V1, Oak Ridge Natl. Lab.

Energy Systems (Martin Marietta Energy Systems, Inc.) 1987. Preliminary Geohydrologic Site Characterization and Proposed Water Quality Well Locations for WAG 7, WAG 8,WAG 9, ORNL/RAP/Sub-86/72139/2, Oak Ridge Natl. Lab.

Energy Systems (Martin Marietta Energy Systems, Inc.) 1992. Oak Ridge Reservation Environmental Report for 1991, ES/ESH-22/V1 and ES/ESH-22/V2, Martin Marietta Energy Systems, Inc., Oak Ridge, Tenn.

Loar, J. M., J. A. Solomon, and G. F. Cada 1981. A Description of the Aquatic Ecology of White Oak Creek Watershed and the Clinch River Below Melton Hill Dam, ORNL/TM-7509/V2, Oak Ridge Natl. Lab.

McMaster, W. M. 1963. Geologic Map of the ORR, Tennessee, ORNL/TM-713, Oak Ridge Natl. Lab. 
Means, J. L., D. A Crerar, and J. O. Duguid 1976. Chemical Mechanisms of Co-60 Transport in Groundwater from Intermediate-Level Liquid Waste Trench 7: Progress Report for Period Ending June 30, 1985, ORNL/TM-5348, Oak Ridge Natl. Lab.

Olsen, C. R., et al. 1983. Chemical, Geological, and Hydrological Factors Governing Radionuclide Migration from a Formerly Used Seepage Trench: A Field Study, ORNL/TM-8839, Oak Ridge Natl. Lab.

ORNL(Oak Ridge Natl. Lab.) 1987. RCRA Facilities Assessment-Oak Ridge National Laboratory, ORNL/RAP-12/V1, Oak Ridge Natl. Lab.

SAIC (Science Applications International Corp.) 1994. Remedial Investigation Work Plan for the Groundwater Operable Unit at Oak Ridge National Laboratory, Oak Ridge, Tennessee, DOE/OR/01-1252\&D1 (ORNL/ER-221\&D1), Martin Marietta Energy Systems, Inc., Oak Ridge Natl. Lab.

Site and Facilities Planning Department June 1994. Oak Ridge Reservation Technical Site Information, ES/EN/SFP-23, Martin Marietta Energy Systems, Inc., Oak Ridge, Tenn.

Spalding, B. P. 1987. Environmental Data Package for the ORNL Seepage Pits and Trenches Waste Area Grouping, ORNL/RAP-10, Oak Ridge Natl. Lab.

Spalding, B. P. 1993. Treatability Study Work Plan for In Situ Vitrification of Seepage Pit 1 in Waste Area Grouping 7 at Oak Ridge National Laboratory, Oak Ridge, Tennessee, DOE/OR/01-1 158\&D2 (ORNL/ER-190\&D2), Oak Ridge Natl. Lab.

Spalding, B. P. June 29, 1995. Lockheed Martin Energy Systems, Oak Ridge, Tenn., personal communication to P. L. Osborne, Lockheed Martin Energy Systems, Oak Ridge, Tenn.

Stockdale, P. B. 1951. Geological Conditions at the Oak Ridge National Laboratory $(X-10)$ Area Relevant to the Disposal of Radioactive Waste,ORO-58, U.S. Department of Energy, Oak Ridge, Tenn.

Struxness, E. G., R. J. Morton, and C. P. Straub 1955. "Disposal of High Level Radioactive Liquid Wastes in Terrestrial Pits, Reactor Technology and Chemical Processing," Proceedings of the International Conference on the Peaceful Uses of Atomic Energy, 9, 684-91, Geneva, Switzerland, August 8-20, 1955.

Toran, L. E. and D. K. Solomon 1987. Hydrogeology and Geochemistry of the Hydraulic Head Monitoring Stations (Cluster Wells): Preliminary Interpretations, ORNL/RAP/LTR-87/76, Oak Ridge Natl. Lab.

Webster, D. A. 1976. A Review of Hydrologic and Geologic Conditions Related to the Radioactive Solid-Waste Burial Grounds at Oak Ridge National Laboratory, Oak Ridge, Tennessee, Open-File Report 76-727, U.S. Geological Survey, Washington, D.C.

Webster, D. A. And M. W. Bradley 1986. Hydrology of the Melton Valley Radioactive Waste Burial Grounds at Oak Ridge National Laboratory, Tennessee, Open-File Report 86-XXX (draft), U. S. Geologic Survey, Oak Ridge, Tenn. 
Williams, J. K., J. A. Roberts, and M. S. Uziel 1988. Radiological Investigation of Areas Near Trench 7 and Including LLW Line Leak Sites, ORNL/RAP/LTR-87/46, Oak Ridge Natl. Lab.

\subsection{BIBLIOGRAPHY}

Coobs, J. H., and J. R. Gissel 1986. History of Disposal of Radioactive Wastes into the Ground at Oak Ridge National Laboratory, ORNL/TM-10269, Oak Ridge Natl. Lab.

Davis, E. C. and R. G. Stansfield 1984. Design and Construction of a French Drain for Groundwater Diversion in Solid Waste Storage Area 6 at the Oak Ridge National Laboratory, ORNL/TM-9014, Oak Ridge Natl. Lab.

Davis, E. C. And R. R. Shoun 1986. Environmental Data Package for ORNL Solid Waste Storage Area Four, the Adjacent Intermediate Level Liquid Waste Transfer Line, and the Liquid Waste Pilot Pit Area, ORNL/TM-10155, Oak Ridge Natl. Lab.

Dreier, R. B. and C. M. Beaudoin 1987. Summary of Geological Data from the GPP 84 (Pits and Trenches) and GPP 85 (SWSA 6) HHMS Well clusters, ORNL/RAP/LTR-87/73, Oak Ridge Natl. Lab.

Dreir, R. B., et al. 1987. Summary of Geological Data in the Vicinity of the Hydrofracture Facilities, ORNL/RAP/LTR-87/26, Oak Ridge Natl. Lab.

Duguid, J. O. and O. M. Sealand 1975. Reconnaissance Survey of the Intermediate-Level Liquid Waste Transfer Line Between X-10 and the Hydrofracture Site,ORNL/TM-4743, Oak Ridge Natl. Lab.

Francis, C. W. and R. G. Stansfield 1986. Characterization Plan for the Old Hydrofracture Facility,ORNL/TM-9991, Oak Ridge Natl. Lab.

Morrison, S. J. and T. E. Cerling 1987. Survey of Metal, Radionuclide and Organic Contamination at 20 Waste Area Groups (WAGs), ORNL Facilities, Oak Ridge, Tennessee, ORNL/RAP/Sub-87/27463/1, Oak Ridge Natl. Lab.

Oak Ridge Natl. Lab. 1990. ORNL Contaminated Site Summary Sheets, ORNL/M-2413, Oak Ridge Natl. Lab.

Spalding, B. P. and W. J. Boegly, Jr. 1985. ORNL Radioactive Liquid Waste Disposal Pits and Trenches: History, Status, and Closure Characterization Needs, ORNL/CF-85/70, Oak Ridge Natl. Lab.

Stansfield, R. G. 1984. Proposed Mitigating Action at Low-Level Liquid Waste (LLW) Trench 7, ORNL/NFW-84/8, Oak Ridge Natl. Lab.

Uziel, M. S., et al. 1989. Surface Radiological Investigations of Pits 2, 3, 4, and Environs, ORNL/RAP/LTR-89/21, Oak Ridge Natl. Lab.

Williams, J. K., C. Clark, Jr., and J. W. Crutcher, 1987a. Radiological and RCRA Hazardous Waste Scoping Survey of the Decontamination Facility (Building 7819) Transfer Line Leak Site, ORNL/RAP-22, Oak Ridge Natl. Lab. 
Williams, J. K., C. Clark, Jr., and J. W. Crutcher 1987b. Radiological and RCRA Hazardous Waste Scoping Survey of the Decontamination Facility (Building 7819),ORNL/RAP-3, Oak Ridge Natl. Lab.

Williams, J. K., J. A. Roberts, and M. S. Uziel 1988a. Surface Radiological Investigations at the Hydrofracture Experimental Site 1, ORNL/RAP/LTR-88/16, Oak Ridge Natl. Lab.

Williams, J. K., J. A. Roberts, and M. S. Uziel 1988b. Radiological Investigation of Areas Near Trench 7 and Including LLW Line Leak Sites, ORNL/RAP/LTR-87/46, Oak Ridge Natl. Lab. 


\section{DESCRIPTION OF WAG 8}

Instructions to user

At this time there are no active projects at WAG 8. Full characterization of this WAG is therefore unwarranted, and a description of it [derived from the Resource Conservation and Recovery Act facilities assessment (ORNL 1987)] has been included in this document for general information purposes only.

\subsection{SITE DESCRIPTION}

WAG 8 (Fig. 13.1) includes the Molten Salt Reactor Experiment and the High Flux Isotope Reactor (HFIR). Wastes from these facilities are collected on site in low-level radioactive waste (LLW) tanks and pumped to WAG 1 for storage and treatment. In addition to the WAG 8 waste transfer line and its collection tanks, WAG 8 includes a number of holding ponds, waste storage facilities, and one of the experimental hydrofracture sites (Fig. 13.2). Table 13.1 lists the Solid Waste Management Units (SWMUs) in WAG 8.

Table 13.1. Solid Waste Management Units located in WAG 8

\begin{tabular}{|c|c|c|c|}
\hline SWMU & Description & SWMU & Description \\
\hline $8.1 \mathrm{a}-\mathrm{d}$ & $\begin{array}{l}\text { HFIR/Transuranic Waste Collection } \\
\text { Basins }\end{array}$ & 8.6 & $\begin{array}{l}\text { Active LLW Collection /Storage Tank } \\
\text { (HFIR) }\end{array}$ \\
\hline 8.2 & $\begin{array}{l}\text { Hydrofracture Exp. Site 2, Soil } \\
\text { Contamination }\end{array}$ & $8.7 a-b$ & $\begin{array}{l}\text { Active LLW Collection/Storage Tanks T-1, } \\
\text { T-2 }\end{array}$ \\
\hline $8.3 \mathrm{a}-\mathrm{g}$ & LLW Line and Leak Sites & 8.8 & Mixed Waste Storage Pad \\
\hline 8.4 & Hazardous Waste Storage Facility & 8.9 & Sewage Treatment Plant \\
\hline 8.5 & $\begin{array}{l}\text { Active LLW Collection/Storage Tank } \\
\text { WC-20 }\end{array}$ & 8.10 & Silver Recovery Plant \\
\hline
\end{tabular}

\subsection{KNOWN RELEASES}

Initial stream gravel studies identified WAG 8 as a major source of ${ }^{60} \mathrm{Co}$ contamination, with measurable releases of ${ }^{137} \mathrm{Cs}$ also being detected. In general, the source of this contamination appeared to be the cooling water effluent from the High Flux Isotope Reactor. Strontium-90 was not detected above background concentrations. In a 1985 survey, essentially the same findings for radionuclides were reported; in addition, there was clear evidence that WAG 8 was also a potential source of zinc and chromium releases.

\subsection{REGULATORY STATUS}

WAG 8 is reported to be the major point-source discharge of ${ }^{60} \mathrm{Co}$, and the HFIR cooling water appears to be the source of significant heavy metal contamination. As a result, it appears 


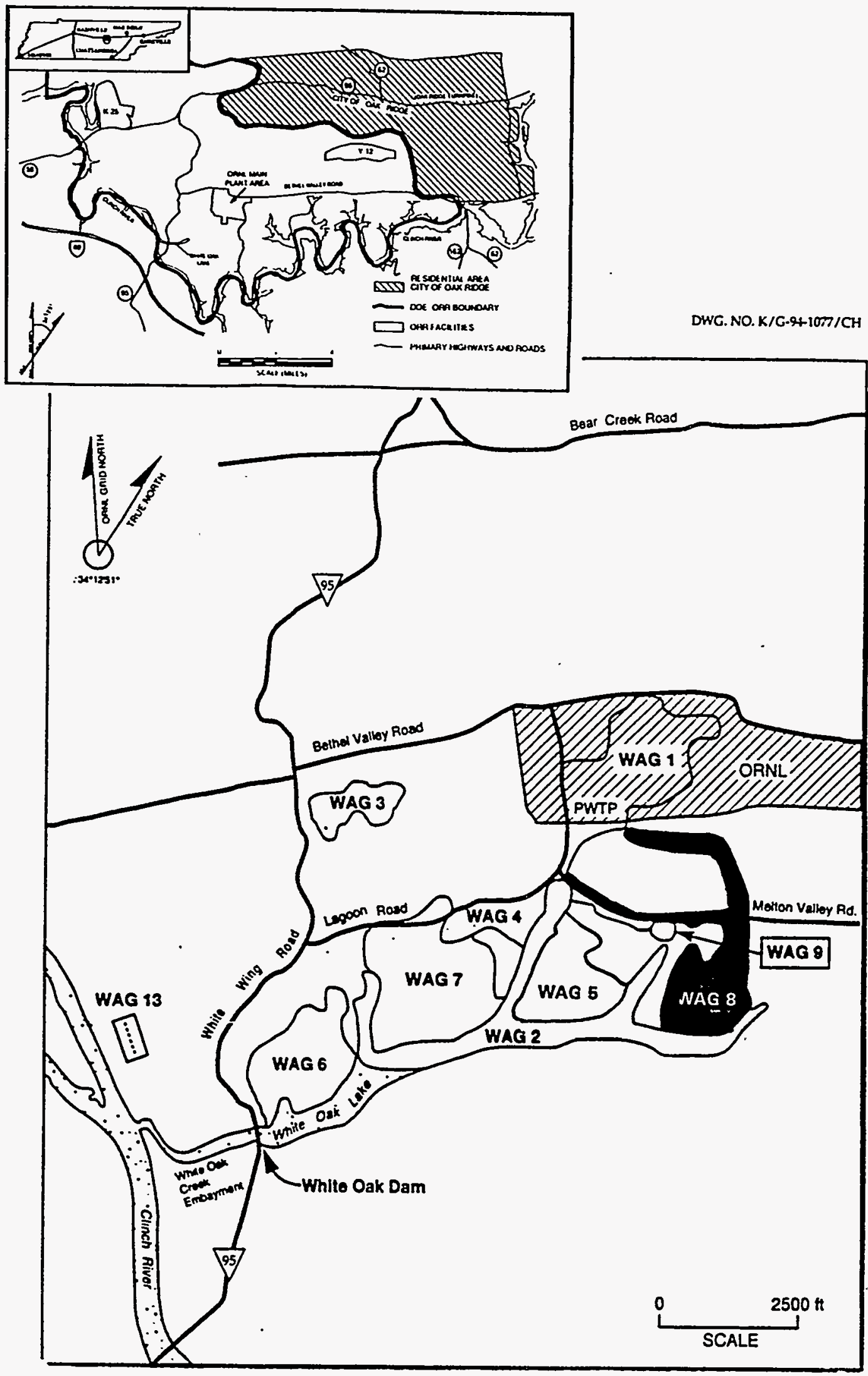

Fig. 13.1. Location of WAG 8. 
ORHLOW6 I7-203

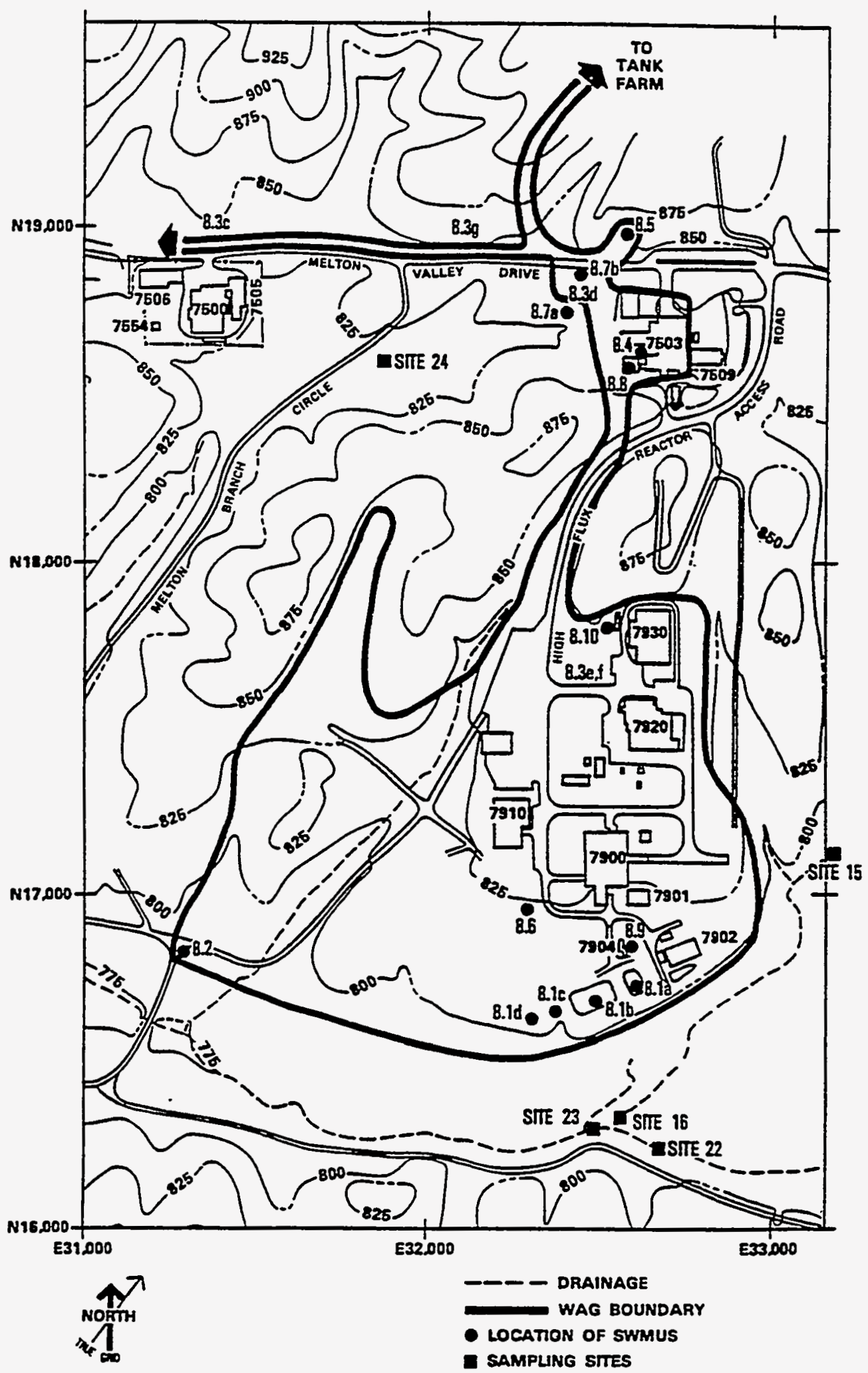

Fig. 13.2. Location of WAG 8 Solid Waste Management Units. Source: ORNL 1987 
that a remedial investigation plan will be required for WAG 8. SWMUs 8.4 (Hazardous Waste Storage Facility) and 8.8 (Mixed Waste Storage Pad) are scheduled for replacement by other storage facilities (located in WAG 19) in the near future and should be removed from consideration as potential sources of release when certified free of contaminants. SWMUs 8.5, 8.6, and 8.7 are still in service and have no reported releases. SWMU 8.9 is a sewage treatment plant (now used as a sewage holding tank) and should not represent a source of release of hazardous chemicals or radionuclides, and ORNL is currently in the process of submitting revising the National Pollutant Discharge Elimination System permit application for SWMU 8.10. Thus, in WAG 8 only SWMUs 8-la-d, 8.2, and 8.3a-g appear to require further remedial action consideration.

\subsection{REFERENCES}

ORNL (Oak Ridge Natl. Lab.) 1987. RCRA Facilities Assessment (RFA)-Oak Ridge National Laboratory, ORNL/RAP-12/V1, Oak Ridge Natl. Lab.

\subsection{BIBLIOGRAPHY}

Bechtel National, Inc. 1988. Remedial Investigation Plan for Waste Area Grouping 8; Volume 1: Sections 1-5, ORNL/RAP/Sub-87/99053/15\&V1, Oak Ridge Natl. Lab.

Boegly, W. J., and A. F. Iglar 1987. Environmental Data Package for the Melton Valley Area (WAG 8), ORNL/RAP-28, Oak Ridge Natl. Lab.

Coobs, J. H., and J. R. Gissel 1986. History of Disposal of Radioactive Wastes into the Ground at Oak Ridge National Laboratory, ORNL/TM-10269, Oak Ridge Natl. Lab.

Morrison, S. J. and T. E. Cerling 1987. Survey of Metal, Radionuclide and Organic Contamination at 20 Waste Area Groups (WAGs), ORNL Facilities, Oak Ridge, Tennessee, ORNL/RAP/Sub-87/27463/1, Oak Ridge Natl. Lab.

ORNL 1990. ORNL Contaminated Site Summary Sheets, ORNL/M-2413, Oak Ridge Natl. Lab.

SAIC (Science Applications International Corp.) 1994. Remedial Investigation Work Plan for the Groundwater Operable Unit at Oak Ridge National Laboratory, Oak Ridge, Tennessee, DOE/OR/01-1252\&D1 (ORNL/ER-221\&D1), Martin Marietta Energy Systems, Inc., Oak Ridge Natl. Lab. 


\section{DESCRIPTION OF WAG 9}

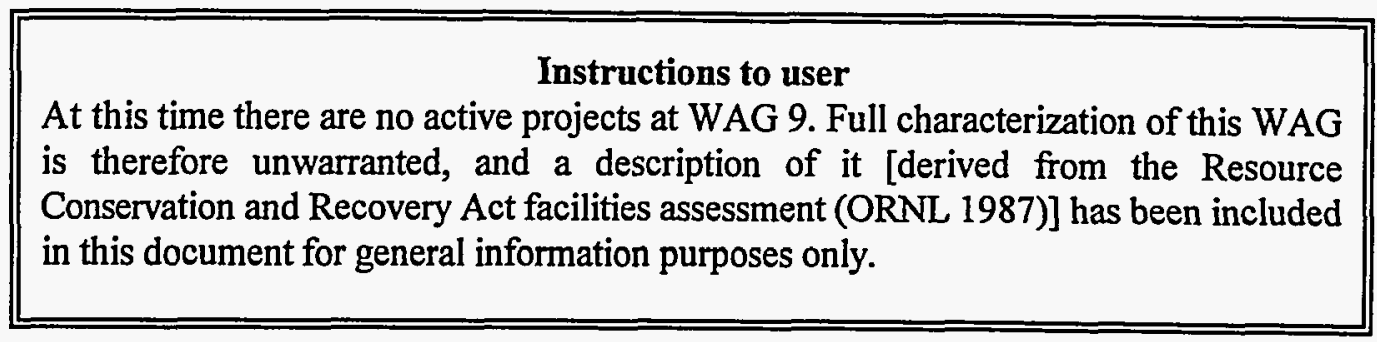

\subsection{SITE DESCRIPTION}

WAG 9 is located in Melton Valley about 0.6 mile $(1.0 \mathrm{~km})$ southeast of the ORNL main plant area (Fig. 14.1). There are three Solid Waste Management Units (SWMUs) in this WAG: the Homogeneous Reactor Experiment (HRE) Pond (SWMU 9.1); the low-level radioactive waste (LLW) Collection and Storage Tanks (SWMU 9.2); and the HRE Septic Tank (SWMU 9.3), now the Nuclear Safety Pilot Plant (NSPP).

The HRE Pond was constructed in 1955 as a waste storage impoundment for contaminated condensate from the HRE waste evaporator. Later, the pond was used for low-level shield water discarded during cell maintenance. The capacity of the pond was 316,000 gal (1.2M L). In 1970, the impoundment was filled with soil and capped with asphalt.

The LLW Collection and Storage Tanks SWMU consists of two buried stainless steel tanks, one having a capacity of $1,000 \mathrm{gal}(3,800 \mathrm{~L})$ and the other $12,000 \mathrm{gal}(46,000 \mathrm{~L})$. The 1,000-gal tank is not in service; the 12,000-gal tank was used at the NSPP for collection of LLW until 1986.

The HRE Septic Tank is a 1,400-gal (5,300-L) tank installed to handle domestic sewage from the HRE (now NSPP) facility. The tank services lavatories and should not contain any radioactive or hazardous wastes.

\subsection{KNOWN RELEASES}

Stream gravel surveys were conducted on the unnamed tributary draining WAG 9 to Melton Branch and the branch tributary leading to the Molten Salt Reactor Experiment. The surveys showed that ${ }^{90} \mathrm{Sr}$ and ${ }^{137} \mathrm{Cs}$ contamination existed and that the probable source of this contamination was the HRE area, with the HRE pond being the major contributor of ${ }^{137} \mathrm{Cs}$ and additional ${ }^{90} \mathrm{Sr}$.

\subsection{REGULATORY STATUS}

WAG 9 appears to be a source of continuing release of ${ }^{90} \mathrm{Sr}$ and ${ }^{137} \mathrm{Cs}$ from both the HRE facility and the HRE settling basin. WAG 9 also receives releases of ${ }^{90} \mathrm{Sr}$ and ${ }^{137} \mathrm{Cs}$ from the Molton Salt Reactor Experiment area in WAG 8 through a stream drainage into the WAG. There is also an indication that contamination by chromium and zinc is occurring. Although a comparison of the stream gravel data taken in 1986 and 1978 appears to indicate that the releases are diminishing, releases are still occurring. An RI plan should be formulated for WAG 9. Although this WAG 


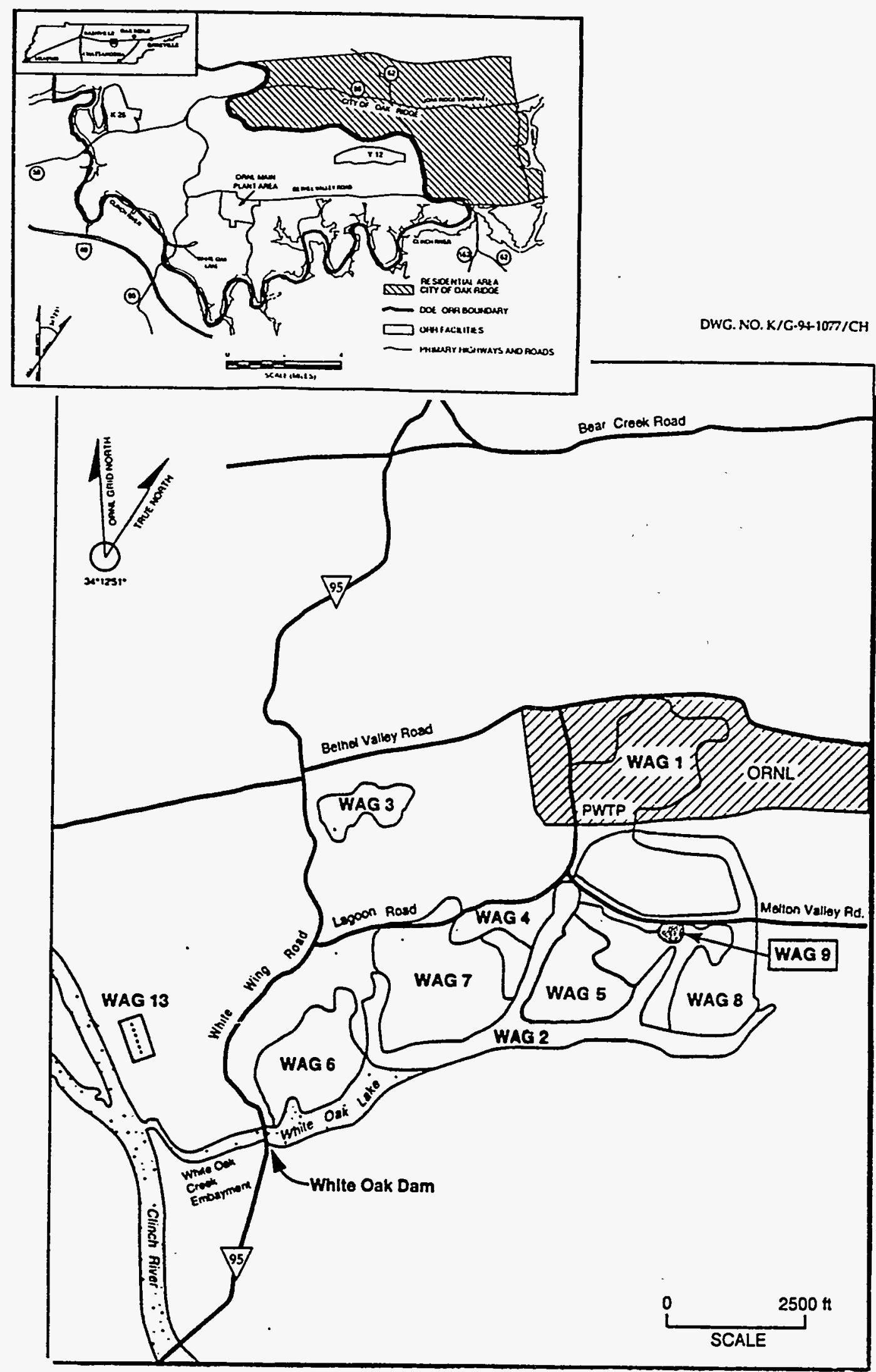

Fig. 14.1. Location of WAG 9. 


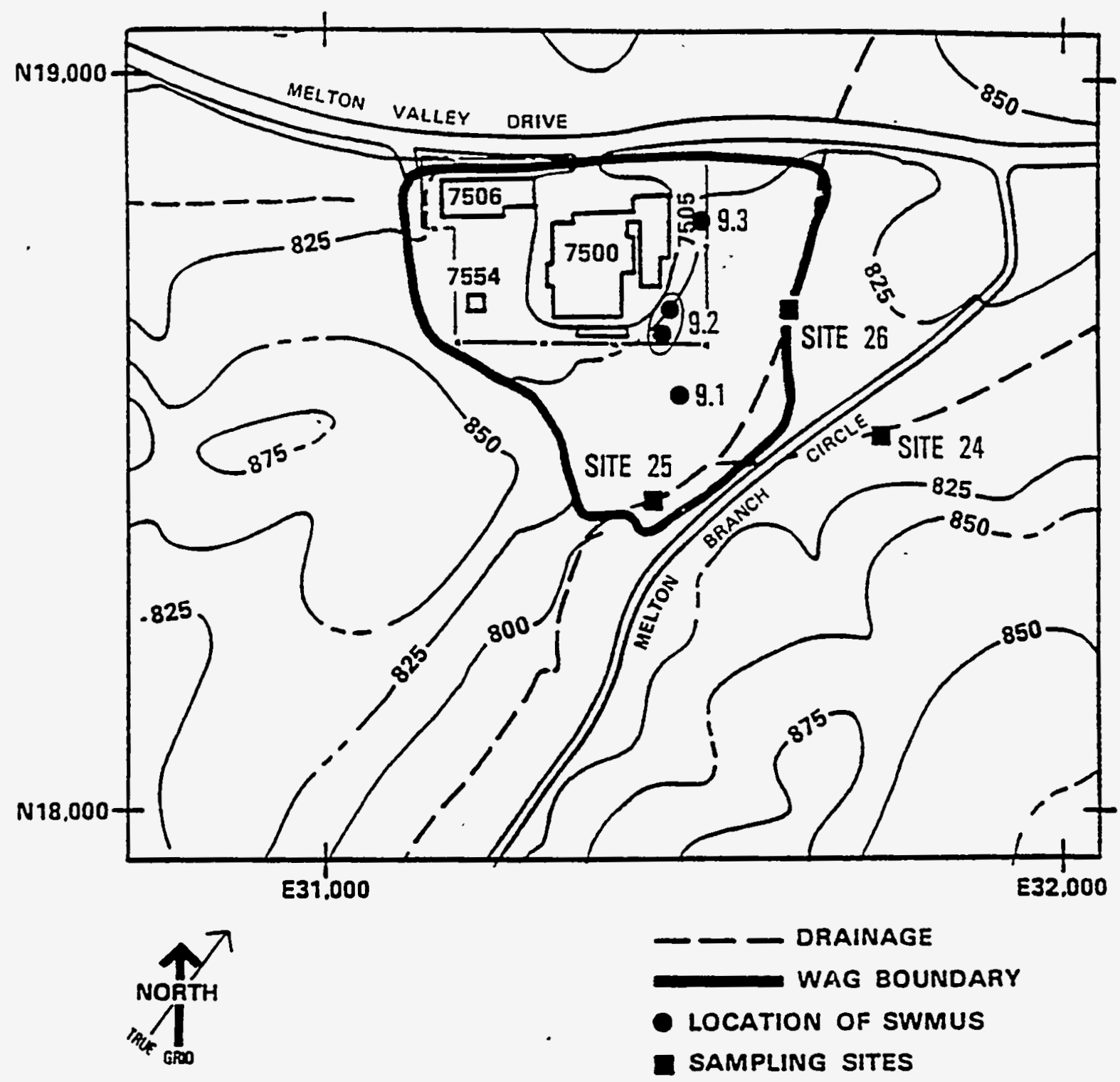

Fig. 14.2. Location of WAG 9 SWMUs. Source: ORNL 1987

includes two underground radioactive waste storage tanks, there is no record of releases from these tanks; however, there does appear to be some indication of surface contamination resulting from overfilling or spillage that occurred while LLW was being removed from the tank. The other SWMU in WAG 9 is a septic tank that services the NSPP building. This tank should not be a source of radionuclides or hazardous chemicals.

The main concern in WAG 9 is represented by the HRE settling basin. This SWMU represents a source of continuing release of ${ }^{90} \mathrm{Sr}$ to the tributary draining the WAG 9 area. 


\subsection{REFERENCES}

ORNL (Oak Ridge Natl. Lab.) 1987. RCRA Facilities Assessment (RFA)-Oak Ridge National Laboratory, ORNL/RAP-12/V1, Oak Ridge Natl. Lab.

\subsection{BIBLIOGRAPHY}

Bechtel National, Inc. 1988. Remedial Investigation Plan for ORNL Waste Area Grouping 9, ORNL/RAP/Sub-87/99053/12, Oak Ridge Natl. Lab.

Coobs, J. H., and J. R. Gissel 1986. History of Disposal of Radioactive Wastes into the Ground at Oak Ridge National Laboratory, ORNL/TM-10269, Oak Ridge Natl. Lab.

Ebasco Services, Inc. 1992. Baseline Report for Waste Area Grouping 9 at Oak Ridge National Laboratory, Oak Ridge, Tennessee, ORNL/ER-101/V1, ORNL/ER-101/V2, Oak Ridge Natl. Lab.

Morrison, S. J. and T. E. Cerling 1987. Survey of Metal, Radionuclide and Organic Contamination at 20 Waste Area Groups (WAGs), ORNL Facilities, Oak Ridge, Tennessee, ORNL/RAP/Sub-87/27463/1, Oak Ridge Natl. Lab.

ORNL 1990. ORNL Contaminated Site Summary Sheets, ORNL/M-2413, Oak Ridge Natl. Lab.

SAIC (Science Applications International Corp.) 1994. Remedial Investigation Work Plan for the Groundwater Operable Unit at Oak Ridge National Laboratory, Oak Ridge, Tennessee, DOE/OR/01-1252\&D1 (ORNL/ER-221\&D1), Martin Marietta Energy Systems, Inc., Oak Ridge Natl. Lab. 


\section{HISTORY AND CHARACTERIZATION OF WAG 10}

\section{Instructions to User}

This chapter provides information about WAG 10 that can be cited in certain CERCLA documents (see Chap. 1 and Table 1 in Instructions to User). For a short description of WAG 10 that can be copied into other types of documents, see the summary at the end of this chapter. To keep this document as short as possible, information about conditions common to all WAGs (e.g., climate and demography) is given in Chap. 5-History and Characterization of the ORNL Site.

\subsection{SITE DESCRIPTION AND HISTORY}

WAG 10 consists of the injection wells and grout sheets from four solid waste management units (SWMUs). Two of the SWMUs (SWMUs 10.1 and 10.2) were experimental sites used in the development of the hydrofracturing process at ORNL; the other two sites (SWMUs 10.3 and 10.4) were operating facilities (now inactive) that were used to dispose of ORNL's low-level waste (LLW). All four SWMUs are located in Melton Valley; however, they are not adjacent to each other. The locations of the four SWMUs included in WAG 10 are shown in Fig. 15.1.

WAG 10 comprises the hydrofracture injection wells and grout sheets only and does not include the surface facilities used for the hydrofracture injections - these facilities are part of WAG 5 and are described in Chap. 10. SWMUs 10.1 and 10.2 (the experimental sites) did not have permanent surface facilities. Surface facilities for SWMU 10.3 (the Old Hydrofracture Facility) are described in Sect. 10.1.3; surface facilities for SWMU 10.4 (the New Hydrofracture Facility) are described in Sect. 10.1.4. The four SWMUs comprising WAG 10 are described below.

SWMU 10.1-Hydrofracture Experimental Site 1: This site marked the first experimental injection of grout as a test for observing the fracture pattern created in the shale and identifying potential operating problems. The site used was south of Lagoon Road in an area called the Four Acre Site, which is within the boundary of WAG 7. ORNL grid coordinates for the injection well are $\mathrm{N} 18,920$ and $E 25,890$. The injection well was cased with 3.5 -in. (9-cm) casing to a depth of $300 \mathrm{ft}$ $(91 \mathrm{~m})$. The injection was performed on October 16,1959, at a depth of $290 \mathrm{ft}(88 \mathrm{~m})$. A total of 27,000 gal $(102,200 \mathrm{~L})$ of grout (diatomaceous earth and cement) was injected. Waste injected was water-tagged with $35 \mathrm{Ci}$ of ${ }^{137} \mathrm{Cs}$ and $8.7 \mathrm{Ci}$ of ${ }^{141} \mathrm{Ce}$. No low-level liquid (radioactive) waste (LLLW) was used. No hazardous waste constituents should have been present in the grout. During the final stages of the injection, grout was observed flowing from an open core hole about $200 \mathrm{ft}(61 \mathrm{~m})$ north of the injection well (see SWMU 7.3) (ORNL 1990).

SWMU 10.2-Hydrofracture Experimental Site 2: The site is in Melton Valley, about 0.5 mile $(800 \mathrm{~m})$ south of the 7500 (Experimental Reactor) Area. The injection well was cased with 4.5 -in. $(11-\mathrm{cm})$ casing to a depth of $1,050 \mathrm{ft}(320 \mathrm{~m})$. ORNL grid coordinates for the injection well are $\mathrm{N} 16,817$ and $\mathrm{E} 31,260$. The second hydrofracture experiment was designed to duplicate in scale an actual disposal operation. However, radioactive tracers were used instead of actual waste. Two separate injections were performed in September 1960. Grout volumes injected were 91,600 and $132,700 \mathrm{gal}(346,745$ and $502,325 \mathrm{~L})$, respectively. Injection depths were $934 \mathrm{ft}(284 \mathrm{~m})$ and $695 \mathrm{ft}$ $(212 \mathrm{~m})$. Water tagged with ${ }^{137} \mathrm{Cs}(50 \mathrm{Ci}$ for the two injections), cement, and bentonite were used in 


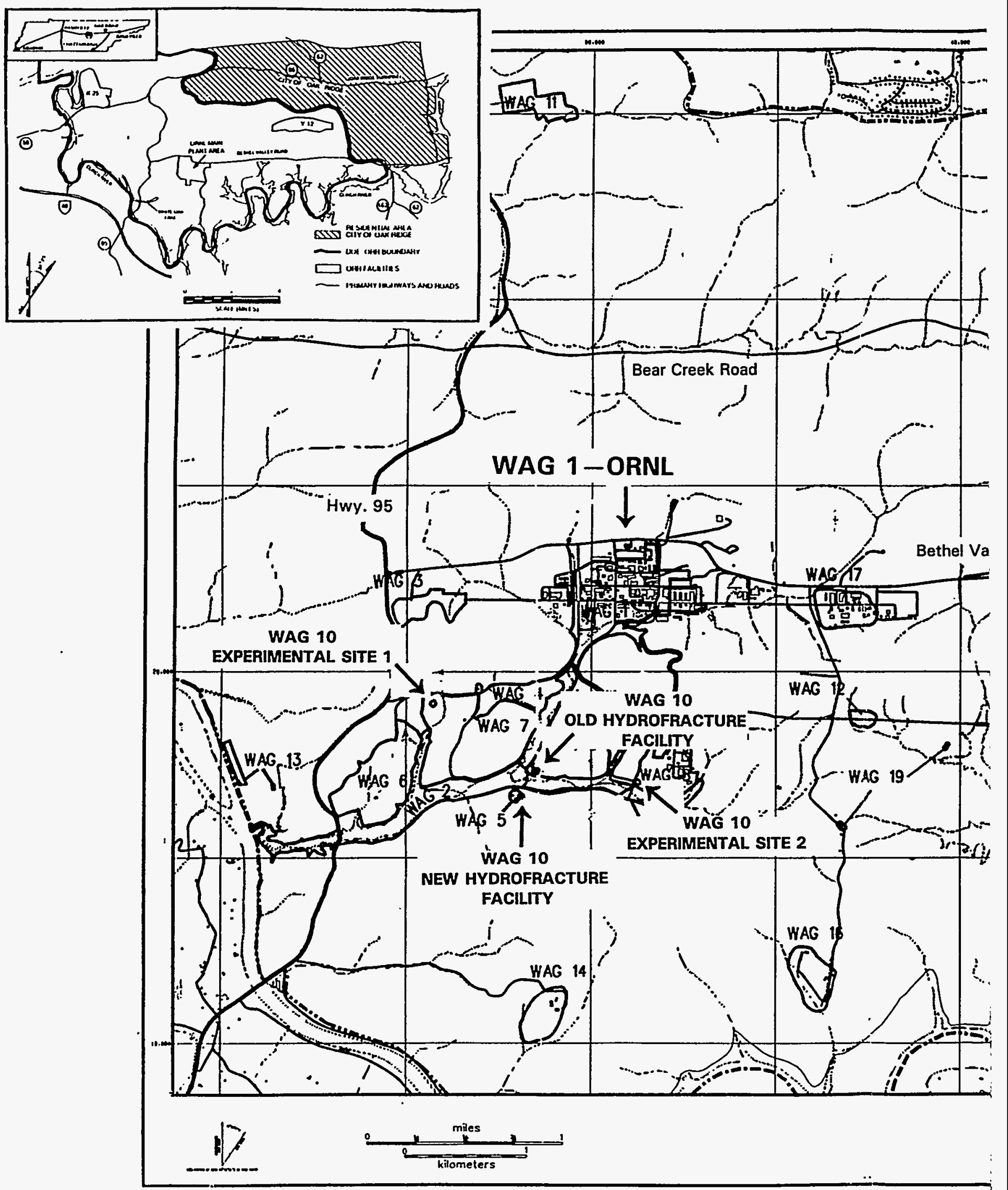

Fig. 15.1. Location of the four SWMUs included in WAG 10. 


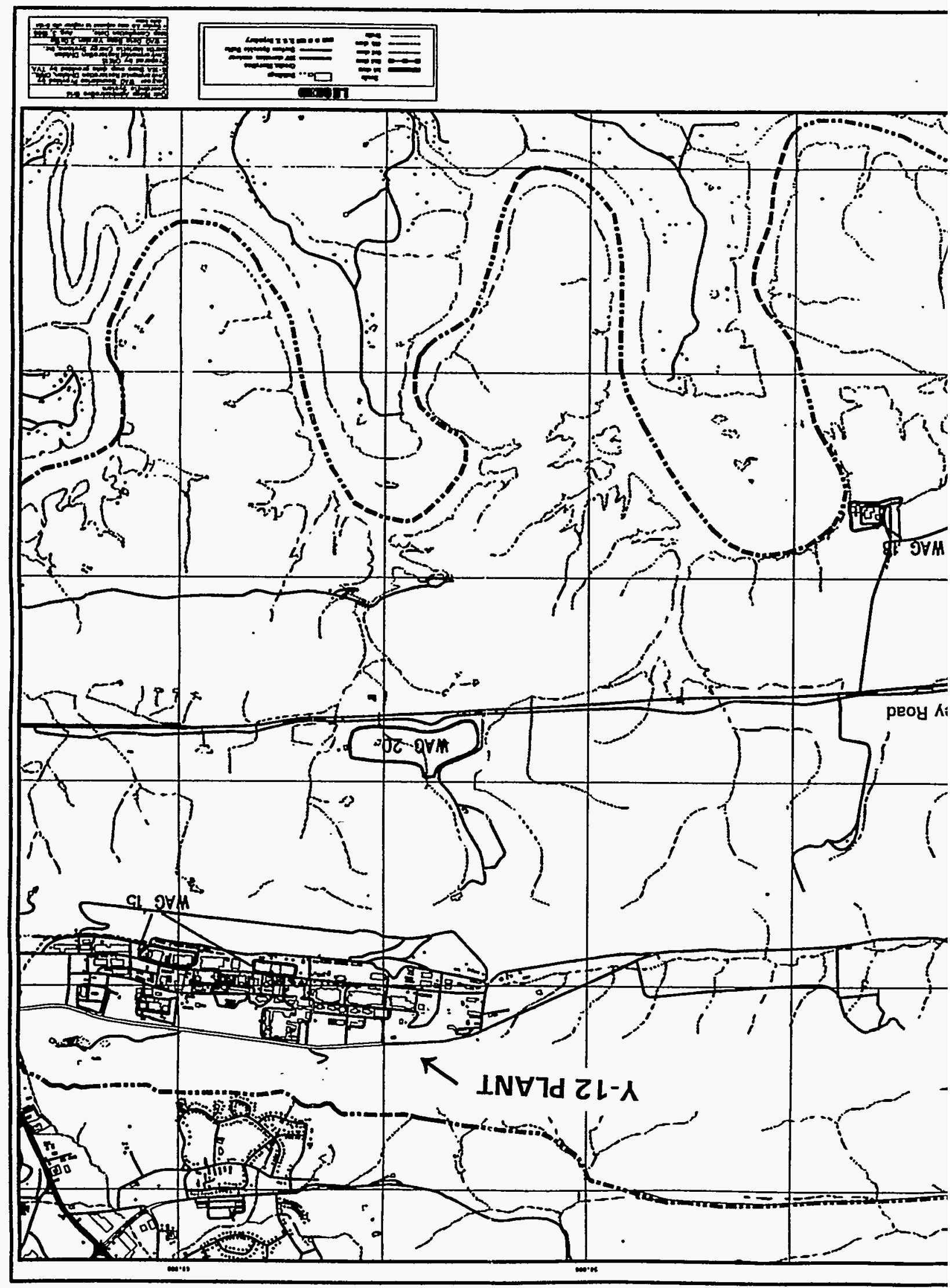


formulating the grout. No nonradioactive hazardous constituents should have been present in the grout. No releases or spills have been reported (ORNL 1990).

SWMU 10.3-Grout Sheets and Wells at the Old Hydrofracture Facility: The grout sheets and wells are located 1 mile $(1.8 \mathrm{~km})$ southwest of the main ORNL complex, west of Solid Waste Storage Area (SWSA) 5. ORNL grid coordinates are N 17,155 and E 28,617. The hydrofracture facility (which is part of WAG 5, not WAG 10) served as a pilot plant to demonstrate the feasibility of permanent disposal of liquid radioactive waste in impermeable shale formations by hydrofracture methods. The site was commissioned in 1963 and taken out of service in 1980.

Waste used in the experiments was evaporator-concentrated LLLW transferred from the Bethel Valley waste storage tanks. During the period the facility was operated, 7 experimental injections and 22 operational injections were conducted. Grout injected totaled $2.3 \times 10(\mathrm{E}+6)$ gal $[8.7 \times 10$ $(\mathrm{E}+6) \mathrm{L}]$ and contained $40,000 \mathrm{Ci}$ of ${ }^{90} \mathrm{Sr}, 609,000 \mathrm{Ci}$ of ${ }^{137} \mathrm{Cs}, 233 \mathrm{Ci}$ of ${ }^{244} \mathrm{C}, 5.8 \mathrm{Ci}$ of transuranic waste, and other unidentified radionuclides. There were no reported surface releases of grout, with the exception of an incident in which it was necessary to divert grout to the Old Hydrofracture Facility waste pit until it could be retrieved and pumped down the well (ORNL 1990).

SWMU 10.4-Grout Sheets and Wells at the New Hydrofracture Facility: The grout sheets and wells are located $900 \mathrm{ft}(300 \mathrm{~m})$ southwest of the Old Hydrofracture Facility, on the south side of Melton Branch. The injection well is located at ORNL grid coordinates N 16,502 and E 28,178. The injection well casing is 5.5 in. diameter; the well is $1,069 \mathrm{ft}(326 \mathrm{~m})$ deep. Injections occurred at depths between $990 \mathrm{ft}(300 \mathrm{~m})$ and $1,069 \mathrm{ft}$. In December 1982 the injection well failed, and it was placed back in operation in 1983. The New Hydrofracture Facility (which is part of WAG 5, not WAG 10) was constructed to replace the old facility and serve as the operational LLLW waste disposal system for ORNL. The test injection was performed in 1974; the site was commissioned in 1982 and removed from service in 1985.

Waste used in the injections was composed of concentrated LLLW and sludge removed from the Gunite tanks in the South Tank Farm. During the period of operation, 1 experimental injection (water plus tracer) and 13 operational injections were conducted. A total of $2.9 \times 10(\mathrm{E}+6) \mathrm{gal}$ $[1.1 \times 1 \mathrm{O}(\mathrm{E}+7) \mathrm{L}]$ of grout was injected. The grout contained $644,000 \mathrm{Ci}$ of ${ }^{90} \mathrm{Sr}, 83,800 \mathrm{Ci}$ of ${ }^{137} \mathrm{Cs}$, $7,500 \mathrm{Ci}$ of ${ }^{244} \mathrm{Cm}, 2,100 \mathrm{Ci}$ of transuranic waste, and 13,300 $\mathrm{Ci}$ of other nuclides. No releases were reported during operations. In 1984, three deep monitoring wells were dug, and contaminated water was found in two of the wells. Depths at which the contamination was observed are approximately the depths at which some of the New Hydrofracture Facility grout sheets occur. The New Hydrofracture Facility is now inactive, and closure of the facility is being planned (ORNL 1990).

WAG 10 is significantly different from other WAGs because the grout sheets are located at considerable depths: 300 to $1000 \mathrm{ft}$ ( 90 to $300 \mathrm{~m}$ ) below the ground surface. The grout sheet are 1-in. layers of a solidified, cement-based LLW slurry that was injected into a fracture in the underground geologic structure (Fig. 15.2). The fracture into which the slurry was pumped was initiated by pumping water under pressure into a slot cut into the injection well casing. The grout slurry was then pumped into the formation and allowed to harden. The slurry constituents were selected and formulated to produce a solid product that would retain the radionuclides in the LLW. Using this technique, it was felt that the radionuclides would be retained in the grout and would not be subject to groundwater transport (de Laguna et al. 1968). Over a 25-year period (1959-84), over 12 million liters of waste containing more than $1.4 \times 10^{6} \mathrm{Ci}$ of radioactivity was disposed of at ORNL through hydrofracture process (Bechtel 1990). Table 15.1 provides a summary of hydrofracture grout injections. 


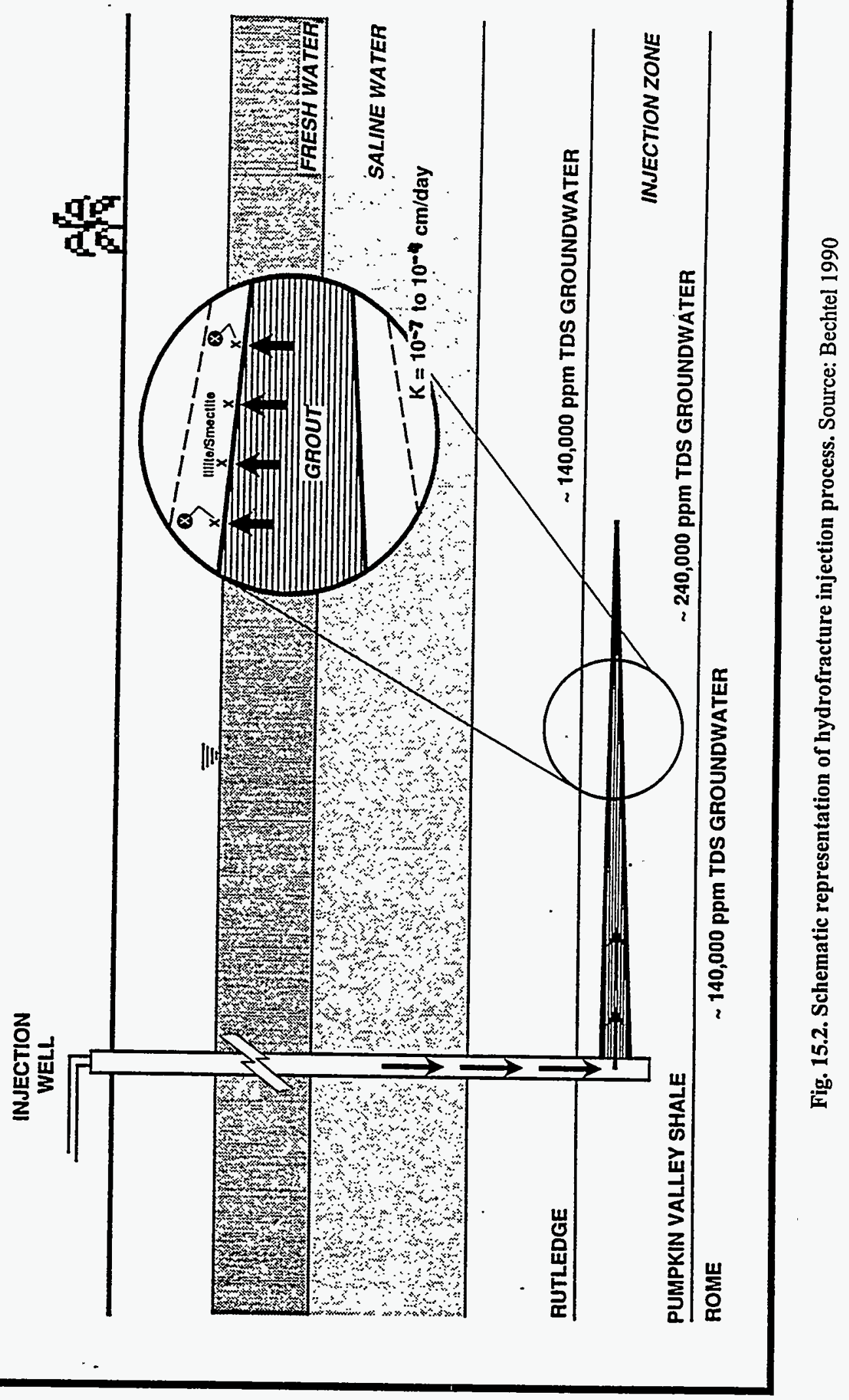


Table 15.1. Summary of hydrofracture grout injections ${ }^{*}$

\begin{tabular}{|c|c|c|c|c|c|c|c|c|c|c|}
\hline \multirow[b]{2}{*}{ Injection Type } & \multirow[b]{2}{*}{$\begin{array}{l}\text { Number of } \\
\text { Injections }\end{array}$} & \multicolumn{3}{|c|}{ Waste Plus } & \multicolumn{6}{|c|}{ Primary Waste Constituents (Curies) } \\
\hline & & $\begin{array}{c}\text { Waste } \\
\text { Volume } \\
\left(\mathrm{gal} \times 10^{3}\right) \\
\end{array}$ & $\begin{array}{c}\text { Water } \\
\text { Volume } \\
\left(\mathrm{gal} \times 10^{3}\right) \\
\end{array}$ & $\begin{array}{c}\text { Grout } \\
\text { Volume } \\
\left(\mathrm{gal} \times 10^{3}\right) \\
\end{array}$ & ${ }^{90} \mathrm{Sr}$ & ${ }^{137} \mathrm{Cs}$ & ${ }^{244} \mathrm{Cm}$ & TRU $^{c}$ & Other & Total \\
\hline \multicolumn{11}{|l|}{ SWMU 10.1} \\
\hline Experimental (1959) & 1 & $\mathrm{~N} / \mathrm{A}^{\mathrm{d}}$ & N/A & 27 & - & 35 & - & - & $8.7^{141} \mathrm{Ce}$ & 44 \\
\hline \multicolumn{11}{|l|}{ SWMU 10.2} \\
\hline Experimental (1960) & 2 & N/A & N/A & 224 & - & 50 & - & - & - & 50 \\
\hline \multicolumn{11}{|l|}{ SWMU 10.3} \\
\hline $\begin{array}{l}\text { Experimental } \\
(1963-65)\end{array}$ & 11 & N/A & 457 & 678 & 1,436 & 5,237 & $\mathrm{~N} / \mathrm{A}$ & N/A & N/A & 6,673 \\
\hline Operational (1966-79) & 18 & 969 & 1,200 & 1,650 & 38,640 & 603,881 & $233^{d}$ & $5.8^{\mathrm{c}}$ & N/A & 642,760 \\
\hline \multicolumn{11}{|l|}{ SWMU 10.4} \\
\hline Experimental (1982) & 1 & N/A & 66 & 98 & - & - & - & - & $20{ }^{198} \mathrm{Au}$ & 184 \\
\hline Operational (1982-84) & 13 & 2,240 & 2,540 & 2,873 & 644,505 & 83,765 & 7,464 & 2,125 & 13,314 & 751,173 \\
\hline Total & 46 & & & 5,550 & & & & & & $1.4 \times 10^{6}$ \\
\hline
\end{tabular}

"Values are estimates of injected volumes only. Accurate determination of phase separation and bleed-back volumes cannot be made for many of the injections.

'Other radionuclides were present in waste in much smaller quantities, were in equilibrium with listed radionuclides, or were not analyzed prior to injection.

TRU represents transuranic elements.

N $/ \mathrm{A}=$ not analyzed.

Totals here should be used with caution. Data on radionuclide content are not available for injections in this series.

Source: Modified from Myrick and Stow (1987) 
In 1984, radiological contamination was detected in groundwater samples collected from deep wells DM1 and DM2, located $300 \mathrm{~m}$ east and west of the New Hydrofracture Facility, respectively. These wells were, at that time, constructed with large open-hole intervals that typically spanned several formation contacts. Groundwater grab samples were collected from several depth intervals in each hole in September 1984 and January 1985 and were selected based upon geophysical logs. As such, and further considering the large open-hole intervals, these samples were only grossly representative of groundwater composition. Significant concentrations of radionuclides characteristic of the wastes injected at both the old and new hydrofracture facilities were detected in DMl and DM2 but were essentially absent from DM3A. Significant concentrations of ${ }^{90} \mathrm{Sr}$ (up to $140,000 \mathrm{~Bq} / \mathrm{L}$ ), ${ }^{60} \mathrm{Co}$ (up to $180 \mathrm{~Bq} / \mathrm{L}$ ), ${ }^{99} \mathrm{Tc}$ (up to $1.3 \mathrm{~Bq} / \mathrm{L}$ ), and ${ }^{137} \mathrm{Cs}$ (up to $1,100 \mathrm{~Bq} / \mathrm{L}$ ) were detected in most samples from DMl and DM2 during these two sampling rounds. Haase et al. (1987) further report that trace concentrations of ${ }^{106} \mathrm{Ru}$ were also detected in DMl and DM2, adding further support that the contamination was related to the waste-grout injection activities.

In 1986 the three existing deep wells were reconfigured to allow for monitoring smaller discreet formation intervals. In addition, a total of four new wells were installed adjacent to the three original deep monitoring wells as three well clusters designed to monitor the formations immediately above and below the injection formation. Currently, there are three wells open to the Pumpkin Valley shale, two wells open to the overlying Rutledge Limestone, and two wells open to the underlying Rome Formation. Analytical results for groundwater samples collected from the seven deep monitoring wells in January 1986 revealed significant ${ }^{90} \mathrm{Sr}$ contamination in the Pumpkin Valley wells DM1-PV and DM2-PV (35,000 to $94,000 \mathrm{~Bq} / \mathrm{L}$, respectively) and the wells in the underlying Rome Formation, $\mathrm{DM} 1-\mathrm{RM}$ and DM2-RM $\left(15,000\right.$ to $20,000 \mathrm{~Bq} / \mathrm{L}$, respectively). Low concentrations of ${ }^{90} \mathrm{Sr}$ were detected in the overlying Rutledge Limestone wells DM1-RT and DM3-RT (250 and $46 \mathrm{~Bq} / \mathrm{L}$, respectively). Detailed analytical results for the deep wells are presented in Haase, Switek, and Stow (1987). To date, groundwaters from the Rutledge, Pumpkin Valley, and Rome formations have not been analyzed for organic contamination.

It is still unclear whether the contamination observed in the Rutledge and Rome formations are representative of ambient groundwater quality or whether they reflect cross-contamination introduced from wells initially open over all three formations. Because of the low permeability of the deeper bedrock zones, well development is difficult. It is possible that the groundwater sampled in 1986 reflected incomplete well development and is not representative of ambient conditions.

Since discovery of groundwater contamination, further injections of grout were discontinued and closure of ORNL's hydrofracture facility begun.

\subsection{CHARACTERIZATION}

\subsubsection{Geography}

The four sites collectively known as WAG 10 are located on the Oak Ridge Reservation (ORR) in Roane County, Tennessee, approximately 5 miles southwest of the city of Oak Ridge central business district (Fig. 15.1). The WAG 10 sites are part of ORNL and are located approximately 0.75 to 1 mile south of the ORNL main plant area. The WAG 10 sites are located at the southwestern end Melton Valley, a northeast-southwest trending valley roughly 1.2 miles wide that lies between Haw Ridge on the north and Copper Ridge on the south. As shown in Fig. 15.1, WAG 10 Experimental Site 1 (SWMU 10.1) is located south of Lagoon Road in an area called the Four Acre Site, which is within the boundary of WAG 7. WAG 10 Experimental Site 2 (SWMU 10.2) is located at the western boundary of WAG 8, adjacent to WAG 2. The grout sheets and wells at the Old Hydrofracture 
Facility (SWMU 10.3) are located just south of WAG 2 and are designated as part of WAG 5. The grout sheets and wells at the New Hydrofracture Facility (SWMU 10.4) are located at the southwest border of WAG 5, adjacent to the northern border of WAG 2 .

\subsubsection{Climate}

See Sect. 5.2.2 of this document for climate description.

\subsubsection{Demography}

The WAG 10 sites are approximately 0.75 to 1 mile from the ORNL main plant area (Fig. 15.1) where the majority of ORNL's approximately 4837 employees work (Site and Facilities Planning Department 1994). Within 1 mile of the boundaries of the WAG 10 sites, all land is federally owned, and there are no residents. State Highway 95 runs through the ORR and at the closest point passes within 0.25 mile of Experimental Site 1. The grout sheets and wells at the New Hydrofracture Facility are approximately 1 mile from the north bank of Clinch River, which forms a portion of the boundary of the ORR. Because the grout sheets are well below the ground surface, contamination from them does not directly affect workers at the sites; workers may, however, be exposed to contamination from sampling operations at the well heads.

See Sect. 5.2.3 of this document for general demographic characteristics of ORNL.

\subsubsection{Geology}

A discussion of the ORNL site geology is found in Sect. 5.2.4 of this document, and a discussion of WAG 10 site geology is found in Haase $(1983,1985)$ and Haase, Switek, and Stow (1985). While much of the recent published geologic information on the stratigraphy and structure of Melton Valley has been directed toward the New Hydrofracture Facility, these observations can be generally applied to all four sites. In the following discussion emphasis is placed on the disposal formation-the Pumpkin Valley Shale.

Representative geologic features for the old and new hydrofracture sites are shown in Figs. 15.3 and 15.4. Figure 15.3 illustrates the generalized geology for the four site locations. The Old Hydrofracture Facility is located $240 \mathrm{~m}$ north-northeast of the New Hydrofracture Facility. Figure 15.4 is a generalized cross section showing the location of the New Hydrofracture Facility and drill holes for which there is accurate stratigraphic information.

At the hydrofracture sites, the stratigraphic sequence in the basal portion of the Copper Creek fault block consists of, from bottom to top, the Rome Formation; the Conasauga Group, which includes the disposal formation; and the Knox Group (Fig. 15.5). The Rome Formation is 90 to $150 \mathrm{~m}$ thick and consists of massive sandstones, thinly bedded siltstones, and laminated shales and mudstones. The Conasauga Group is 550 to $610 \mathrm{~m}$ thick and consists of six formations. These are, in ascending order, the Pumpkin Valley Shale (the disposal formation), the Rutledge Limestone, the Rogersville Shale, the Maryville Limestone, the Nolichucky Shale, and the Maynardville Limestone. The clastic-rich formations, including the Pumpkin Valley Shale, consist of thinly bedded siltstones and laminated shales and mudstones. The carbonate-rich formations consist of coarse to fine-grained limestones, conglomerates, and calcareous siltstones and shales. The Knox Group consists of chert-rich carbonates, principally dolostone with subordinate amounts of limestone, and locally abundant sandstones. The Knox group has been divided into five formations near the ORNL site and ranges from 610 to $670 \mathrm{~m}$ thick (Milici 1973). 
ORNL-DWG 83-13887

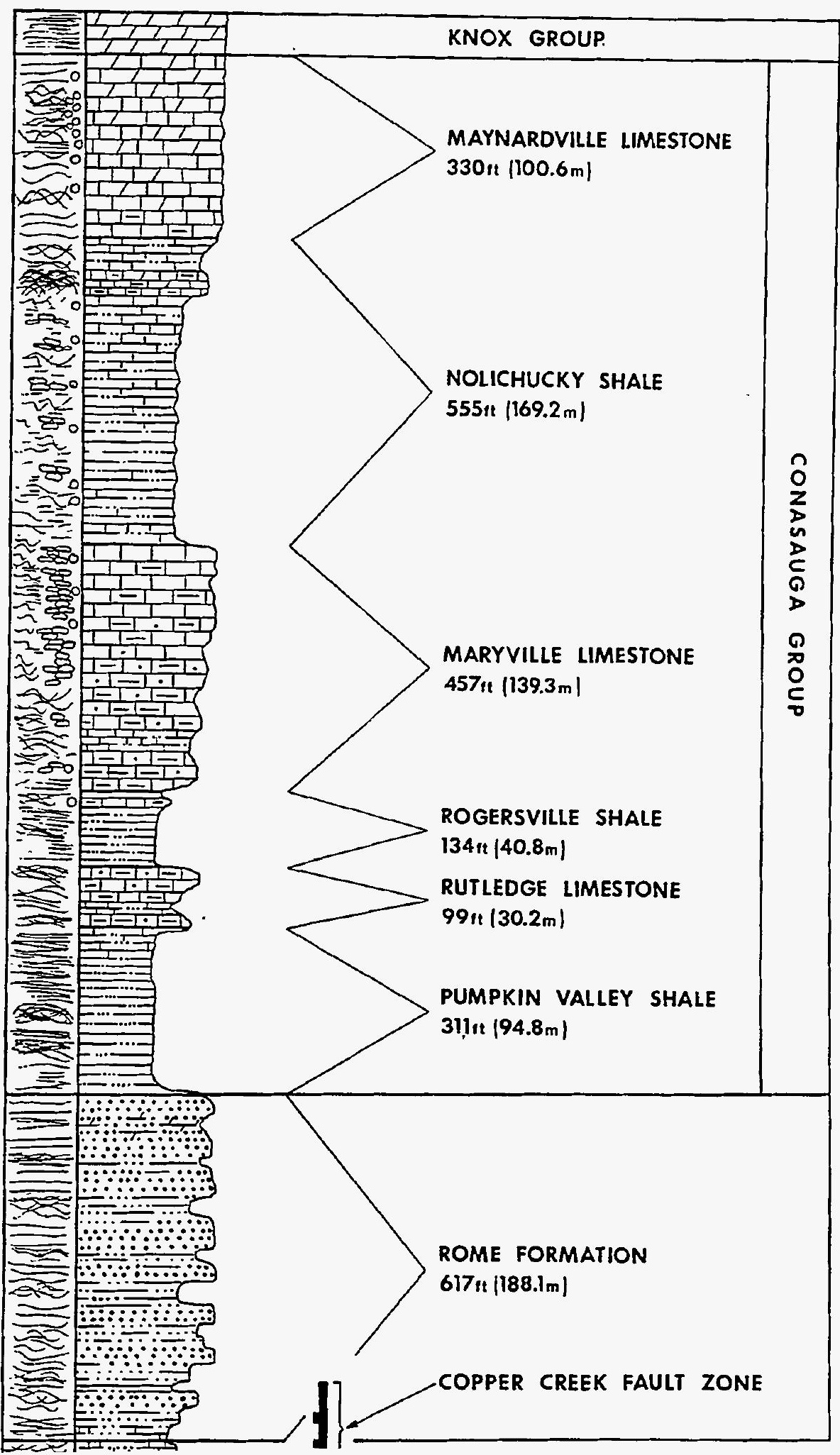


A description of soils at the four hydrofracture sites can be found in the chapters of this document characterizing the specific WAGs the sites are found in: for Experimental Site 1, see WAG 7; for Experimental Site 2, see WAG 8; for grout sheet and wells at the hydrofracture facilities, see WAG 5. A general discussion of soils found at ORNL is provided in Sect. 5.2.4.

\subsubsection{Surface Water}

A description of surface water characteristics at the four hydrofracture sites can be found in the chapters of this document characterizing the specific WAGs the sites are found in; for Experimental Site 1, see WAG 7; for Experimental Site 2, see WAG 8; for grout sheet and wells at the hydrofracture facilities, see WAG 5. A general discussion of the ORNL surface water system is provided in Sect. 5.2.5.

\subsubsection{Groundwater}

There are few data describing deep groundwaters at the hydrofracture sites. Although many wells and coreholes have been drilled throughout the last three decades, only recently have groundwater wells been constructed for hydrologic data acquisition. A general discussion of the ORNL groundwater system is provided in Sect. 5.2.6.

Permeability data for the strata at depths similar to the injection zone are sparse. De Laguna (1961) and De Laguna et al. (1968) reported laboratory measurements on the order of $10^{-5}$ millidarcy for drill core of the Pumpkin Valley Shale. Observed rates of recovery of wells recently drilled to the injection interval also indicate a low permeability. The impact of the hydrofracture injections on the hydraulic characteristics of the strata is presently unknown.

Recent sampling of deep wells in the vicinity of the old and new hydrofracture facilities indicates that the deep groundwaters $(300 \mathrm{~m})$ are extremely saline, with total dissolved solids contents as much as $240,000 \mathrm{ppm}$. The dominant constituents are sodium and chlorine (Haase, Switek, and Stow 1987; Switek, Haase, and Stow 1987).

Based on available data, it appears that the deep groundwaters (associated with the injection interval) are not part of an active flow system and are not interconnected with surface waters, such as fresh water aquifers.

\subsubsection{Ecology}

Sect. 5.2.7 of this document provides an overview of the flora and fauna commonly found on the ORR, which are believed to be representative of those found at the four hydrofracture sites.

\subsection{RELEASES AND SITE CONCEPTUAL MODEL}

The hydrogeologic setting of WAG 10 is in the Valley and Ridge Province in East Tennessee. Strata in the area strike approximately $N 55^{\circ} \mathrm{E}$ with an average southeasterly dip of less than $30^{\circ}$. The hydrofracture facilities are located in the Copper Creek Thrust Block with the area near the facilities cut by a tentatively identified near-vertical tear fault. The strata of concern in the area are rocks of the Conasauga Group and the Rome Formation. The injection zone is the Pumpkin Valley Shale, which is identified as a low permeability formation, at a depth of about $1,000 \mathrm{ft}$. The overlying Rutledge Limestone and the underlying Rome Formation may have slightly higher, but still low, permeability. Fracture and bedding plane permeability predominate (Bechtel 1990). 
Groundwater samples from the Pumpkin Valley shale yield total dissolved solids of approximately $240,000 \mathrm{ppm}$ in the uncontaminated formation at a depth of about $900 \mathrm{ft}$. Groundwater in both the Rutledge and the Rome contain approximately $140,000 \mathrm{ppm}$ total dissolved solids. A freshwater-saline-water interface is observed in Melton Valley at a depth of about $200 \mathrm{ft}$ and is generally formation independent. A schematic representation of the injection activity is shown in Fig. 15.2.

Liquid contaminants may have been injected as part of the hydrofracture process or through incomplete mixing of the grout or as phase separation water released during grout setup. Contaminated liquids could, under pressure drive, migrate along bedding planes and through fractures, if available and open, into the overlying or underlying formations. Contaminants could also move in well bores through annular or intrawell flow. High levels of salinity in the groundwaters suggest limited flow and limited mixing with fresh groundwater. The postulated tear fault could act as a conduit or a barrier to contaminate migration depending on the hydraulic properties of the fault. If groundwater flow is not a major contaminant transport mechanism, then molecular diffusion becomes the mechanism for contaminant release from the injection zone (Bechtel 1990). The migration pathways discussed above are shown in Fig. 15.6.

Two separate incidents have been reported in which water from the grout sheets has been released through wells drilled into the grout sheets. Two of the deep monitoring wells have shown concentrations of 94,000 to $400,000 \mathrm{~Bq} / \mathrm{L}$. The third deep monitoring well showed no contamination (ORNL 1987).

WAG 10 was not included in the Morrison and Cerling (1987) survey conducted in 1986. Although radionuclides have been detected in wells drilled into the grout sheets from earlier LLLW injections, there is no existing information to suggest that the radionuclides have migrated from the grout sheets to surface streams within the ORNL area. Releases by surface spills or leaks related to hydrofracture well drilling and monitoring operations have occurred in drainage areas included in the preliminary studies for other WAGs.

\subsection{ACTIVE PROJECTS: HYDROFRACTURE WELLS AND BOREHOLES PLUGGING AND ABANDONMENT}

\section{Instructions to User}

Remediation is an ongoing process, and the status of active projects can change quickly. For the most up-to-date information about the WAG 10 Hydrofracture Wells and Boreholes Plugging and Abandonment Project, check the Annual Environmental Restoration Monitoring and Assessment Report and the Federal Facility Agreement Quarterly Report.

In response to adoption of the "observational approach" by DOE for use in the remedial investigation/feasibility study process and in response to U.S. Environmental Protection Agency (EPA) comments on the WAG 10 remedial investigation implementation plan (Bechtel 1990), ORNL has developed a strategy for expediting action at WAG 10. In the near term, the strategy focuses available resources on achieving an interim record of decision addressing the numerous existing wells and boreholes associated with WAG 10 . In the intermediate term, the strategy calls for additional investigations to delineate the nature and extent of groundwater contamination; this information will 


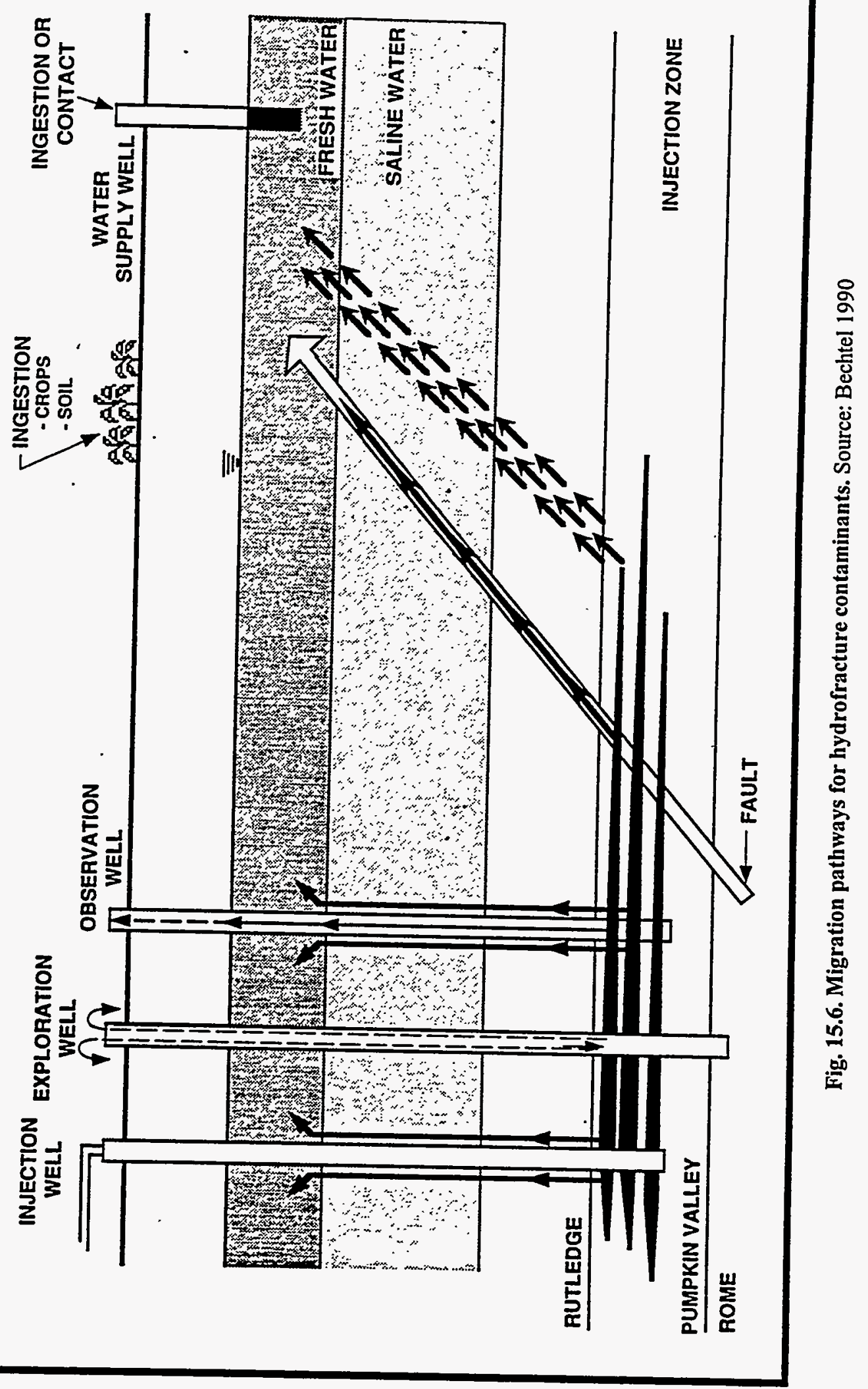


support design of a long-term monitoring network for WAG 10 and, if required, remedial design for groundwater remediation. At specified milestones, workshops involving DOE, EPA, and the Tennessee Department of Environment and Conservation (TDEC) will be conducted. The strategy acknowledges the impetus for early actions while recognizing that WAG 10 presents long-term monitoring requirements. This strategy for the WAG 10 remedial investigation/feasibility study was presented to EPA and TDEC on February 13, 1992, at a working group meeting held in Oak Ridge, Tennessee.

Integral to the strategy is the proposed division of WAG 10 into three areas, as defined in Table 15.2.

Table 15.2. WAG 10 areas $^{1}$

\begin{tabular}{ll}
\hline \multicolumn{1}{c}{ Unit } & \multicolumn{1}{c}{ Description } \\
\hline 1. Grout Sheets Characterization Area & $\begin{array}{l}\text { Solidified grout and contaminated rock layered between or } \\
\text { surrounding the grout sheets. }\end{array}$ \\
2. Groundwater/Watershed & $\begin{array}{l}\text { Contaminated groundwater, including free liquids } \\
\text { resulting from hydrofracture injections and contaminated } \\
\text { groundwater that may be migrating toward the surface. }\end{array}$ \\
$\begin{array}{ll}\text { 3. Wells and Boreholes } \\
\text { Characterization Area }\end{array}$ & $\begin{array}{l}\text { Injection wells, deep observation and monitoring wells, } \\
\text { and deep boreholes associated with WAG 10. }\end{array}$ \\
\hline $\begin{array}{l}\text { 'These areas were initially proposed in the ORNL Environmental Restoration Division Life Cycle Costing Workshop } \\
\text { conducted in October 1991. }\end{array}$
\end{tabular}

Key elements of the strategy related to each of the areas are identified below. The elements are identified in the approximate sequence in which they would occur and correspond to the activities identified in the flowchart in Fig. 15.7. The sequence of activities specified in Fig. 15.7 illustrates a general strategy only; it does not preclude the possibility of early starts on specific tasks when appropriate.

Area 3-Wells and Boreholes: The field sampling plan and the quality assurance project plan published in the March 1990 remedial investigation implementation plan (Bechtel 1990) have been revised and reissued. The revised field sampling plan specifies activities primarily designed to provide data to support an interim record of decision for area 3 . The data collected will be compiled into an area 3 site investigation report for submittal to EPA and TDEC.

An area 3 interim remedial measures study will be performed concurrently with the area 3 investigations; this interim remedial measures study will support an area 3 interim record of decision for area 3 remedial action.

Area 2-Groundwater: This area will be incorporated into the ORNL site-wide groundwater watershed.

Area 1-Grout Sheets: Any field investigation related to area 1 will be integrated with that related to area 2. After the data have been collected and analyzed, DOE will complete an interim remedial measures study to support an interim record of decision for area 1. 


\section{LEGENO}

FSP FIELD SAMPLING PLAN

IRM INTERIM. REMIEDIAL MIEASURE

IROD INTERIM RECORD OF DECISION

OU OPERABLE UNIT

RA REMEDIAL ACTION

RD REMEDIAL DESIGN

RIIP RI IMPLEMENTATION PLAN

SI SITE INVESTIGATION
IMPLEMENT REVISED FSP

FOR OU2/OU1 INVESTIGATIONS
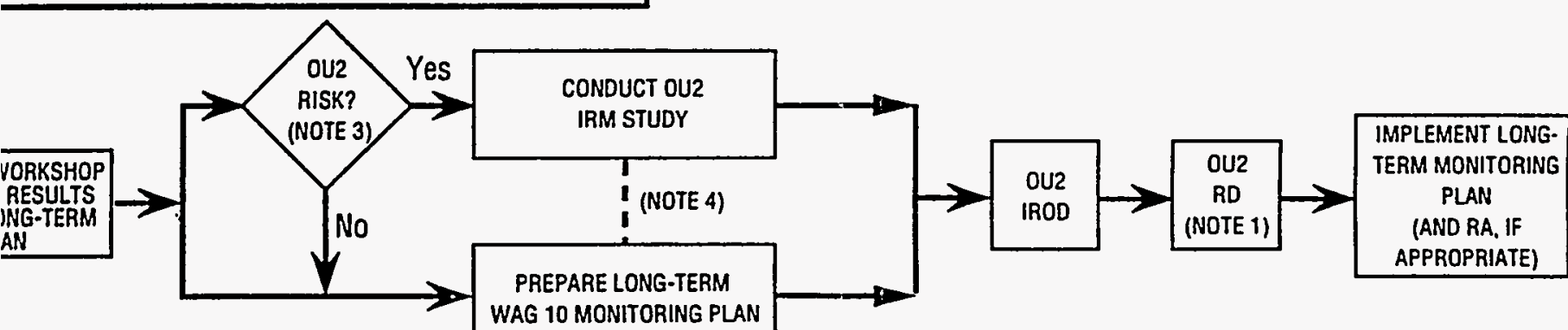

WAG 10 MONITORING PLAN

NOTES:

1. RD ACTIVITIES MAY INCLUDE FREDESIGN INVESTIGATIONS IF ADDITIONAL DATA ARE REOUIRED.

IMPLEMENT OU1

- IROD
2. THE OU2JOU1 SI REPORT WILL INCLUDE A BASELINE RISK ASSESSMENT (BLRA) IF COMPLETE PATHWAYS FOR EXPOSURE AR: IDENTIFIED.

3. I.E., DOES THE OU2 BLRA INDICATE THAT CONTAMINATED GROUNDWATER ASSOCIATED WITH WAG 10 PRESENTS A SIGNIFICANT THR:AT TO HUMAN HEALTH ANO THE ENVIRONMENT?

4. PLANNING FOR LONG-TERM MONITORING AND FOR POTENTIAL REMEDIAL ACTIONS FOR OU2 WILL BE INTEGRATED.

Fig. 15.7. ORNL remedial investigation/feasibility study strategy for WAG 10. Source: Bechtel 1990 


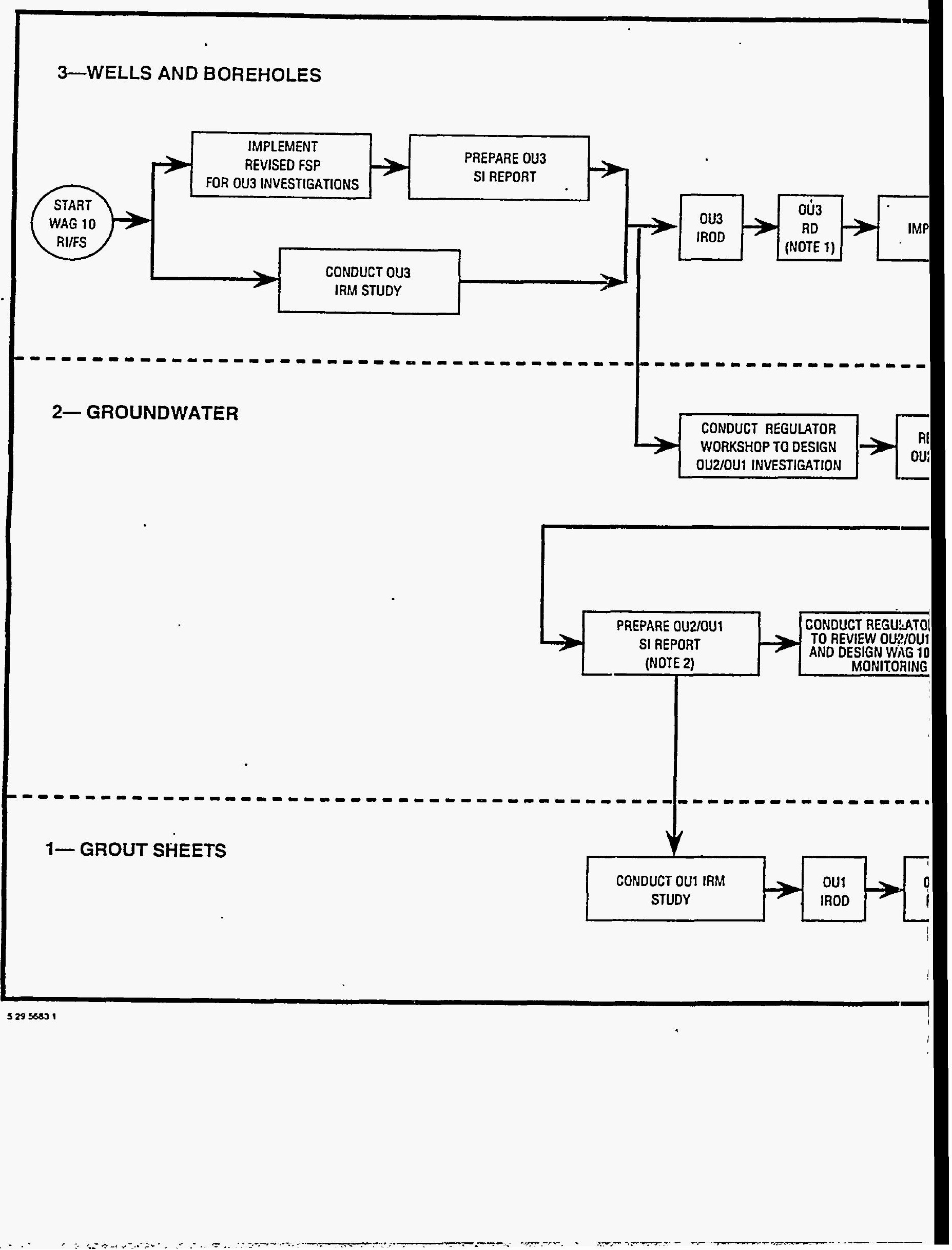




\subsection{WAG 10 SUMMARY}

WAG 10 consists of the injection wells and grout sheets from four solid waste management units (SWMUs). Two of the SWMUs (SWMUs 10.1 and 10.2) were experimental sites used in the development of the hydrofracturing process at ORNL; the other two sites (SWMUs 10.3 and 10.4) were operating facilities (now inactive) that were used to dispose of ORNL's low-level waste. All four SWMUs are located in Melton Valley; however, they are not adjacent to each other.

WAG 10 comprises the hydrofracture injection wells and grout sheets only and does not include the surface facilities used for the hydrofracture injections - these facilities are part of WAG 5. The four SWMUs are:

- SWMU 10.1-Hydrofracture Experimental Site 1: The site used for the first experimental injection of grout was south of Lagoon Road, which is within the boundary of WAG 7. ORNL grid coordinates for the injection well are $\mathrm{N} 18,920$ and E 25,890.

- SWMU 10.2-Hydrofracture Experimental Site 2: This site is in Melton Valley, about 0.5 mile $(800 \mathrm{~m}$ ) south of the 7500 (Experimental Reactor) Area. ORNL grid coordinates for the injection well are $\mathrm{N} 16,817$ and $\mathrm{E} 31,260$.

- SWMU 10.3-Grout Sheets and Wells at the Old Hydrofracture Facility: This site is located 1 mile $(1.8 \mathrm{~km})$ southwest of the main ORNL complex, west of SWSA 5. ORNL grid coordinates are $\mathrm{N} 17,155$ and $\mathrm{E} 28,617$.

- SWMU 10.4-Grout Sheets and Wells at the New Hydrofracture Facility: This site is located $900 \mathrm{ft}(300 \mathrm{~m})$ southwest of the Old Hydrofracture Facility, on the south side of Melton Branch. The injection well is located at ORNL grid coordinates N 16,502 and E 28,178.

The four sites collectively known as WAG 10 are located on the Oak Ridge Reservation in Roane County, approximately 5 miles southwest of the city of Oak Ridge central business district. The WAG 10 sites are part of ORNL and are located approximately 0.75 to 1 mile south of the ORNL main plant area. The WAG 10 sites are located at the southwestern end Melton Valley, a northeast-southwest trending valley roughly 1.2 miles wide that lies between Haw Ridge on the north and Copper Ridge on the south.

WAG 10 is significantly different from other WAGs because the grout sheets are located at considerable depths: 300 to $1000 \mathrm{ft}(90$ to $300 \mathrm{~m}$ ) below the ground surface. The grout sheet are 1-in. layers of a solidified, cement-based low-level waste slurry that was injected into a fracture in the underground geologic structure. In 1984, radiological contamination was detected in groundwater samples. Significant concentrations of ${ }^{90} \mathrm{Sr},{ }^{60} \mathrm{Co},{ }^{99} \mathrm{Tc}$, and ${ }^{137} \mathrm{Cs}$ were detected. Since discovery of groundwater contamination, further injections of grout were discontinued and closure of ORNL's hydrofracture facility begun.

The hydrofracture facilities are located in the Copper Creek fault block with the area near the facilities cut by a tentatively identified near-vertical tear fault. Strata in the area strike approximately $\mathrm{N} 55^{\circ} \mathrm{E}$ with an average southeasterly dip of less than $30^{\circ}$. At the hydrofracture sites, the stratigraphic sequence in the basal portion of the Copper Creek fault block consists of, from bottom to top, the Rome Formation; the Conasauga Group, which includes the Pumpkin Valley Shale (the disposal formation); and the Knox Group. The Pumpkin Valley Shale is $105 \mathrm{~m}$ thick and can be divided into a siltstone-rich, 45-m-thick lower member and a shale-rich, 60-m-thick upper member. 

Recent sampling of deep wells in the vicinity of the old and new hydrofracture facilities indicates that the deep groundwaters $(300 \mathrm{~m})$ are extremely saline and suggest limited flow and limited mixing with fresh groundwater. Based on available data, it appears that the deep groundwaters (associated with the injection interval) are not part of an active flow system and are not interconnected with surface waters, such as fresh water aquifers.

Liquid contaminants may have been injected as part of the hydrofracture process or through incomplete mixing of the grout or as phase separation water released during grout setup. Contaminated liquids could, under pressure drive, migrate along bedding planes and through fractures into overlying or underlying formations. Contaminants could also move in well bores through annular or intrawell flow. The postulated tear fault could act as a conduit or a barrier to contaminate migration depending on the hydraulic properties of the fault. If groundwater flow is not a major contaminant transport mechanism, then molecular diffusion becomes the mechanism for contaminant release from the injection zone.

WAG 10 has one active project: hydrofracture wells and boreholes plugging and abandonment.

\subsection{REFERENCES}

Bechtel (Bechtel National Inc.) 1990. Remedial Investigation Implementation Plan for ORNL WAG 10, Oak Ridge National Laboratory Remedial Investigation/Feasibility Study, ES/ER-4\&D1 (ORNL/RAP/Sub-87/99053/6\&R2), Oak Ridge Natl. Lab.

De Laguna, W. 1961. "First and Second Fracturing Experiments," unpublished manuscript distributed at a meeting of the Waste Disposal Committee, Division of Earth Sciences, National Academy of Sciences, Savannah River Plant, December 6, 1961.

De Laguna, W. et al. 1968. Engineering Development of Hydraulic Fracturing as a Method for Permanent Disposal of Radioactive Wastes, ORNL/TM-4259, Oak Ridge Natl. Lab.

Haase, C. S. 1983. "Geological and Petrological Considerations Relevant to the Disposal of Radioactive Wastes by Hydraulic Fracturing: An Example at the U.S. Department of Energy's Oak Ridge National Laboratory," in Proceedings of the Sixth Material Research Society Symposium on the Scientific Basis for Radioactive Waste Management, Boston.

Haase, C. S. 1985. Subsurface Geological Data for Conasauga Group on the White Oak Mountain and Copper Creek Fault Blocks, DOE Oak Ridge Reservation, ORNL/TM-9159, Oak Ridge Natl. Lab.

Haase, C. S., J. Switek, and S. H. Stow 1985. "Formation Water Chemistry of the Conasauga Group and Rome Formation Near Oak Ridge, Tennessee, Preliminary Data for Major Elements," Geologic Society of American Abstracts with Programs, 16.

Haase, C. S., J. Switek, and S. H. Stow 1987. Geochemistry of Formation Waters in the Lower Conasauga Group at the New Hydrofracture Facility: Preliminary Data from the Deep Monitoring (DM) Wells, ORNL/RAP-6, Oak Ridge Natl. Lab.

Haase, C. S., et al. 1987. Chemical and Radionuclide Data from the DM and Associated Wells at the New Hydrofracture Facility, Fall 1986, ORNL/RAP/LTR-86/95, Oak Ridge Natl. Lab. 
Milici, R. H. 1973. "The Stratigraphy of Knox County, Tennessee," in Geology of Knox County, Tennessee, Tennessee Division of Geology Bulletin 70, Nashville, Tenn.

Morrison, S. J., and T. E. Cerling, 1987. Survey of Metal, Radionuclide and Organic Contamination at 20 Waste Area Groups (WAGs), ORNL Facilities, Oak Ridge, Tennessee, ORNL/RAP/SUB-87/27463/1, Oak Ridge Natl. Lab.

Myrick, T. E., and S. H. Stow 1987. Remedial Action Plan for ORNL Hydrofracture Operations, ORNL/RAP-9, Oak Ridge Natl. Lab.

ORNL (Oak Ridge Natl. Lab.) 1987. Remedial Investigation Plan for the Surface Characterization of the ORNL Hydrofracture Sites, ORNL/RAP-7, Oak Ridge Natl. Lab.

ORNL 1990. ORNL Contaminated Site Summary Sheets, ORNL/M-2413, Oak Ridge Natl. Lab.

Ossi, E. J. 1979. "Mesoscopic Structures and Fabric Within the Thrust Sheets Between the Cumberland Escarpment and the Saltville Fault," (unpublished M.S. thesis), University of Tennessee, Knoxville, Tenn.

Site and Facilities Planning Department June 1994. Oak Ridge Reservation Technical Site Information, ES/EN/SFP-23, Martin Marietta Energy Systems, Inc., Oak Ridge, Tenn.

Sledz, J. J., and D. D. Huff 1981. Computer Model for Determining Fracture Porosity and Permeability in the Conasauga Group, ORNL/TM-7695, Oak Ridge Natl. Lab.

Switek, J., C. S. Haase, and S. H. Stow 1987. Geochemistry of Formation Waters in the Lower Conasauga Group at the New Hydrofracture Facility: Preliminary Data from the Rock Cover (RC) Wells, ORNL/RAP-5, Oak Ridge Natl. Lab.

\subsection{BIBLIOGRAPHY}

Clapp, R. B., and J. A. Watts, eds. 1995. Fourth Annual Environmental Restoration Monitoring and Assessment Report (FY 1995), Oak Ridge National Laboratory, Oak Ridge, Tennessee, DOE/OR/01-1413\&D1, Oak Ridge Natl. Lab.

Coobs, J. H., and J. R. Gissel 1986. History of Disposal of Radioactive Wastes into the Ground at Oak Ridge National Laboratory, ORNL/TM-10269, Oak Ridge Natl. Lab.

Dreier, R. B., et al. 1987. Summary of the Geological Data in the Vicinity of the Hydrofracture Facilities, ORNL/RAP/LTR-87/26, Oak Ridge Natl. Lab.

Ebasco Services, Inc. 1992. Baseline Report for Waste Area Grouping 10 at Oak Ridge National Laboratory, Oak Ridge, Tennessee, ORNL/ER-102/V1, Oak Ridge Natl. Lab.

Oak Ridge Natl. Lab. 1987. RCRA Facilities Assessment (RFA)—Oak Ridge National Laboratory, ORNL/RAP-12/V1, Oak Ridge Natl. Lab.

Oak Ridge Natl. Lab. 1995. Site Characterization Summary Report for the Phase I Investigation of WAG 10, OU3, at Oak Ridge National Laboratory, Oak Ridge, Tennessee, ORNL/ER/Sub/87$99053 \mathrm{C} / 78$, Oak Ridge Natl. Lab. 
SAIC (Science Applications International Corp.) 1994. Remedial Investigation Work Plan for the Groundwater Operable Unit at Oak Ridge National Laboratory, Oak Ridge, Tennessee, DOE/OR/01-1252\&D1 (ORNL/ER-221\&D1), Martin Marietta Energy Systems, Inc., Oak Ridge Natl. Lab.

Weeren, H. O. 1974. Shale Fracturing Injections at ORNL: 1972 Series, ORNL/TM-4457, Oak Ridge Natl. Lab.

Weeren, H. O. 1976. Shale Fracturing Injections at ORNL: 1975 Series, ORNL/TM-5545, Oak Ridge Natl. Lab.

Weeren, H. O. 1980. Shale Fracturing Injections at ORNL: 1977 Series, ORNL/TM-7421, Oak Ridge Natl. Lab.

Weeren, H. O. 1984. Hydrofracture Injections at Oak Ridge National Laboratory-1982-1984 Series, ORNL/NFW-84/43, Oak Ridge Natl. Lab. 



\section{DESCRIPTION OF WAG 11}

\section{Instructions to user}

At this time there are no active projects at WAG 11. Full characterization of this WAG is therefore unwarranted, and a description of it has been included in this document for general information purposes only.

\subsection{SITE DESCRIPTION}

The White Wing Scrap Yard (WAG 11) is a roughly 20-acre (8-ha), largely wooded area located in the McNew Hollow area on the western edge of East Fork Ridge (Fig. 16.1). It is 0.9 mile (1.5 km) east of the junction of White Wing Road and the Oak Ridge Turnpike and is roughly contained within the K-25 Site grid coordinates N 35,000-35,800 and E 27,500-29,250. There is only one SWMU in WAG 11 (Fig. 16.2).

White Wing Scrap Yard was used for the aboveground storage of contaminated material from ORNL, the K-25 Site, and the Y-12 Plant. The material consisted largely of contaminated steel tanks; trucks; earth-moving equipment; and assorted, large pieces of steel, stainless steel, and aluminum; as well as reaction vessels used in Building 3019 (ORNL 1987).

The area began receiving material in the early 1950 s. However, the precise dates of material storage are uncertain, as is the time when the area was closed to further storage. In 1966, efforts were begun to clean up the area by a combination of the disposal of contaminated materials in ORNL's SWSA 5 and the sale of uncontaminated material to an outside contractor for scrap. Cleanup continued at least into March 1970, and in October 1970 removal of about $6,000 \mathrm{yd}^{3}\left(4,585 \mathrm{~m}^{3}\right)$ of contaminated soil began. Most of the area is now enclosed by a chain link fence; however, about 3 acres (1.2 ha) is partially open and enclosed by a barbed wire fence. The area is overgrown with weeds, trees, and other types of vegetation (ORNL 1987).

\subsection{KNOWN RELEASES}

A surface radiological investigation of WAG 11 was conducted intermittently from December 1989 until July 1991 (Williams et al. 1991). The primary purpose of the survey was to determine the presence, nature, and extent of surface radiological contamination. Measurement surveys of alpha, beta, and gamma radiation revealed that contaminants were present on some of the debris in levels high enough to be of concern. Results of radiological surveys on the debris ranged from approximately $0.5 \mathrm{mrad} / \mathrm{h}$ to $21 \mathrm{mrad} / \mathrm{h}$ (Williams et al. 1991). An inventory of the WAG 11 surface debris on 30 of the 100 numbered grids was conducted in 1992, and it concluded that an estimated $3100 \mathrm{ft}^{3}$ of surface debris existed on the 30 grids (Rodriguez, Tiner, and Williams 1992). By extrapolation, an estimated $10,000 \mathrm{ft}^{3}$ of debris existed at the site.

Groundwater samples were taken from selected piezometer wells in WAG 11. Most of the values obtained from the downgradient wells were not significantly above those observed in the 



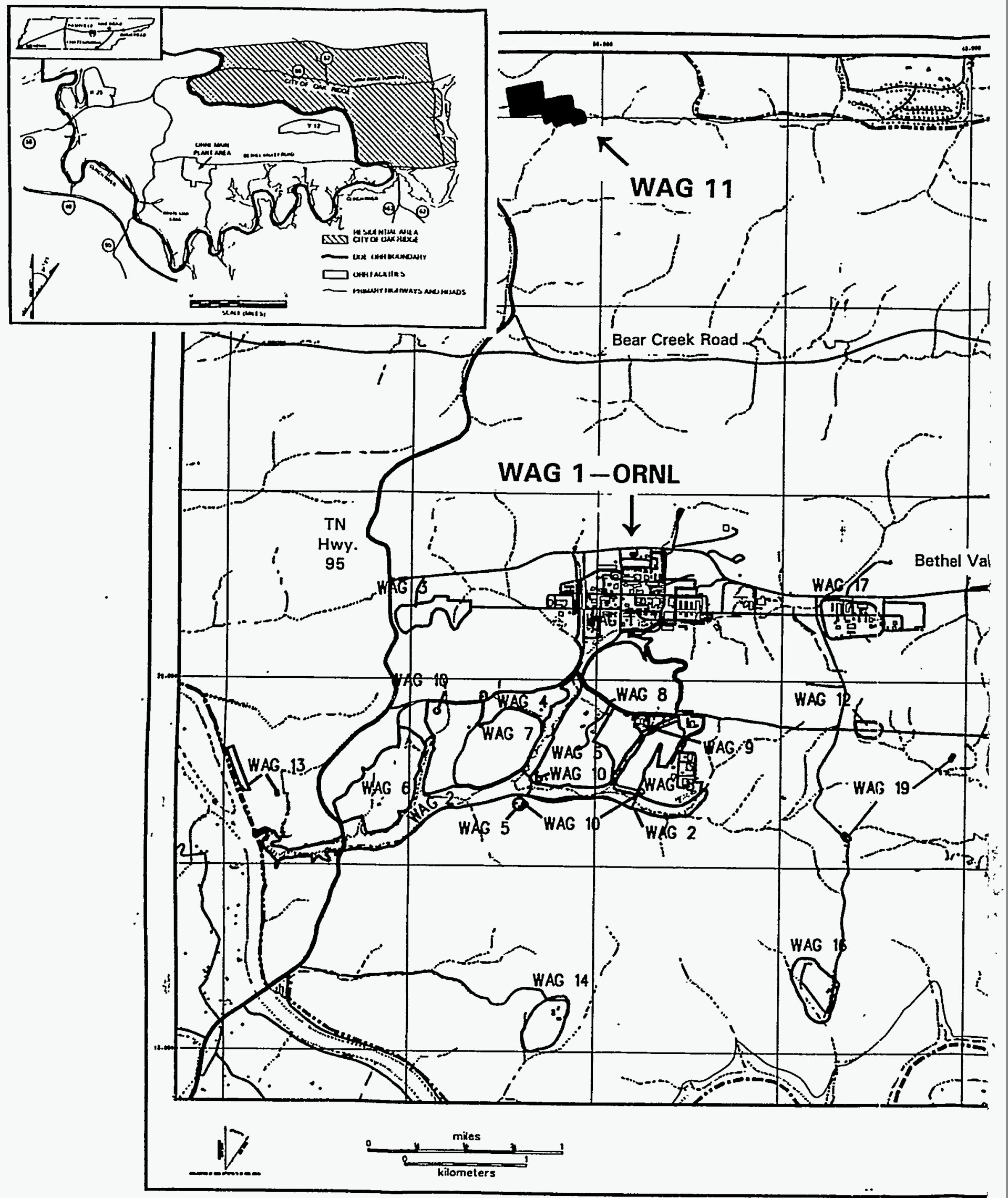

Fig. 16.1. Location of WAG 11, the White Wing Scrap Yard. 


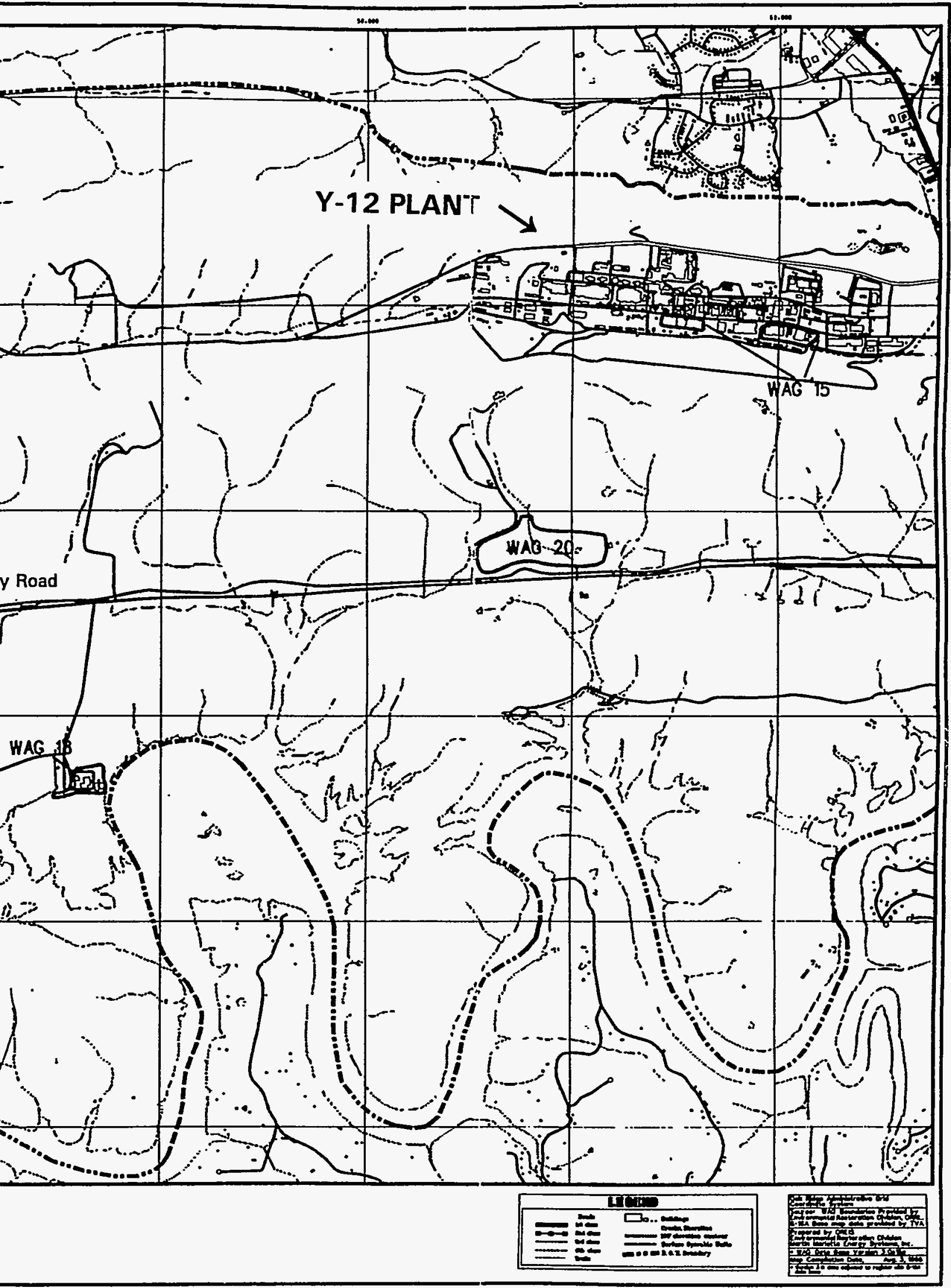


OnMI Denc eners

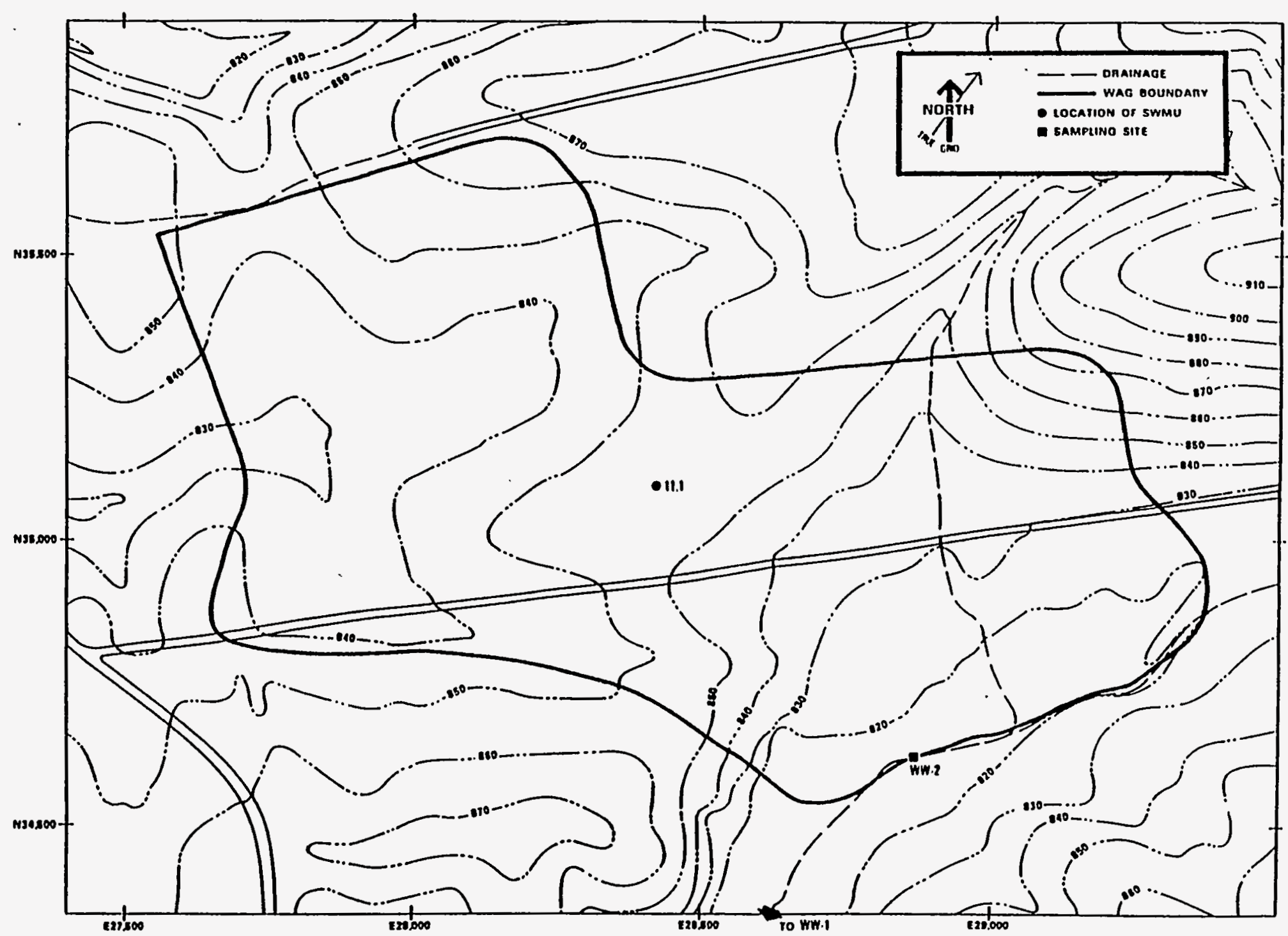

Fig. 16.2. Location of the Solid Waste Management Unit in WAG 11. Source: ORNL 1987 
upgradient well; however, the concentration of chromium in the upgradient well was above the National Interim Primary Drinking Water Standard (ORNL 1990). Analysis of groundwater samples for volatile and semivolatile organics established the presence of three volatile contaminants: methylene chloride, trichloroethylene, and acetone, at concentrations of $6 \mathrm{ppb}, 184 \mathrm{ppb}$, and $23 \mathrm{ppb}$, respectively. Only methylene chloride was detected in more than one sample. Concentrations of all the semivolatile organics were below detection limits. The concentration of trichloroethylene is significantly above the recently determined allowable limit of $5 \mathrm{ppb}$ in drinking water. Previous radiological' surveys detected surface radiation levels up to $21 \mathrm{mrad} / \mathrm{h}$; however, the source of these "hot spots" remains undetermined. Based on the results from previous scoping studies, it appears that WAG 11 is not a significant source of releases of hazardous constituents. There remain, however, uncertainties concerning the source of elevated levels of chromium, cadmium, some organic contaminants, and surface radiation "hot spots." Further investigations are needed to resolve these concerns. Two additional findings of significant in a 1989-90 survey of the area are: (1) the presence of buried 55-gal metal drums and (2) elevated concentrations of PCBs ( 10 ppm total PCBs) in three soil samples collected from a region of dead vegetation (ORNL 1990).

An aerial geophysical survey was also conducted at WAG 11. This survey indicated that several areas north of the gravel road bisecting the site had anomalous magnetic intensity signatures. A walkover survey was then conducted in April and May 1994 to obtain better resolution to define the extent of the anomalies. An evaluation of the electromagnetic and magnetic data collected in the survey indicated that most buried materials are located north of the road; some isolated areas on the south side contain buried material (CDM 1995). The material was characterized as being primarily of high conductivity and magnetic intensity, indicating that it contains steel objects. The survey was documented and referenced to the WAG 11 grid system so that the anomalies can be readily located in the future. It was recommended that these areas of high intensity be given high priority in future characterization of this site (Clapp and Watts 1995).

\subsection{REGULATORY STATUS}

An interim remedial measures study of the WAG 11 site (Radian 1992a) to evaluate the alternatives for reducing the health threat was completed. A proposed plan also was completed, which reviewed the alternatives and listed the preferred alternative for remedial action (Radian 1992b). Following receipt of and response to public comment, an interim remedial action alternative was selected and documented in the Interim Record of Decision (Radian 1992c). The Interim Record of Decision stated that the surface debris would be collected, transported, and stored in underground silos at WAG 6. The Interim Record of Decision received final approval from the Tennessee Department of Environment and Conservation, the U.S. Environmental Protection Agency, and DOE on October 6, 1992. The remedial action work plan (Energy Systems 1993) was approved in July 1993. Remedial action began on November 1, 1993, and was completed on May 27, 1994 (Dawson and Garrett 1994).

The Interim Record of Decision stated that the interim action was intended to reduce the threats to human health and to the environment posed by a variety of radiological and physical hazards located within the bounds of WAG 11. The major components of the interim remedial action were the collection of surface debris and the transportation and storage of debris into silos at WAG 6. Most all of the surface debris $\left(\sim 10,300^{3}\right)$ was collected and transported to WAG 6 from November 1993 through March 1994. Unknown specialty items (compressed gas cylinders, bottles containing unknown liquids, and drums containing unknown substances) were discovered, sampled, analyzed, and taken off site for storage during May 1994 (Dawson and Garrett 1994). 
Although materials and debris are buried on site, implementation of the Interim Record of Decision covered only the removal of contaminated surface debris, and a final Record of Decision for WAG 11 must take account of the large volumes of buried debris. Subsequent actions at WAG 11 are planned to address fully the principal threats posed by the site. Review of the site and of the selected remedy will be continuing as part of the development of the final remedy for the site. Because the interim remedial action will result in hazardous substances remaining on the site, a review will be conducted within 5 years after commencement of the remedial action as final remedial alternatives are developed (Radian 1992a).

\subsection{REFERENCES}

CDM (CDM Federal Programs Corp.) 1995. Geophysical Survey Report for White Wing Scrap Yard (Waste Area Grouping 11) at Oak Ridge National Laboratory, Oak Ridge, Tennessee, ORNL/ER-295, Oak Ridge Natl. Lab.

Clapp, R. B., and J. A. Watts, eds. 1995. Fourth Annual Environmental Restoration Monitoring and Assessment Report (FY 1995), Oak Ridge National Laboratory, Oak Ridge, Tennessee, DOE/OR/01-1413\&D1, Oak Ridge Natl. Lab.

Dawson, P. M., and D. L. Garrett 1994. Interim Remedial Action Postconstruction Report for Waste Area Grouping 11 at Oak Ridge National Laboratory, Oak Ridge, Tennessee, . DOE/OR/01-1263\&D2, Martin Marietta Energy Systems, Inc., Oak Ridge, Tenn.

Energy Systems (Martin Marietta Energy Systems, Inc.) 1993. Interim Remedial Action Work Plan for the Surface Debris at Waste Area Grouping 11 at Oak Ridge National Laboratory, Oak Ridge, Tennessee, DOE/OR/01-1121\&D3, Martin Marietta Energy Systems, Inc., Oak Ridge, Tenn.

ORNL (Oak Ridge Natl. Lab.) 1987. RCRA Facilities Assessment (RFA)-Oak Ridge National Laboratory, ORNL/RAP-12/V1, Oak Ridge Natl. Lab.

ORNL 1990. ORNL Contaminated Site Summary Sheets, ORNL/M-2413, Oak Ridge Natl. Lab.

Radian Corp. 1992a. Interim Remedial Measures Study for Oak Ridge National Laboratory Waste Area Grouping 11, DOE/OR-1015\&D2, Martin Marietta Energy Systems, Inc., Oak Ridge, Tenn.

Radian Corp. 1992b. Proposed Plan for the Oak Ridge National Laboratory Waste Area Grouping 11 Interim Remedial Action, DOE/OR-1017\&D4, Martin Marietta Energy Systems, Inc., Oak Ridge, Tenn.

Radian Corp. 1992c. Interim Record of Decision for Oak Ridge National Laboratory Waste Area Grouping 11 Surface Debris, Oak Ridge, Tennessee, DOE/OR-1055\&D4, Martin Marietta Energy Systems, Inc., Oak Ridge, Tenn.

Rodriguez, R., P. Tiner, and J. Williams 1992. Surface Debris Inventory at White Wing Scrap Yard, Oak Ridge Reservation, Oak Ridge, Tennessee, ORNL/ER-135, Oak Ridge Natl. Lab.

Williams, J. K., et al. 1991. Surface Radiological Investigations at White Wing Scrap Yard, Oak Ridge Reservation, Oak Ridge, Tennessee, ORNL/ER-52, Oak Ridge Natl. Lab. 


\subsection{BIBLIOGRAPHY}

Boegly, W. J., and G. K. Moore 1988. Environmental Sciences Division Environmental Data Package for the White Wing Scrap Yard, ORNL/RAP-45, Martin Marietta Energy Systems, Inc., Oak Ridge, Tenn.

Coobs, J. H., and J. R. Gissel 1986. History of Disposal of Radioactive Wastes into the Ground at Oak Ridge National Laboratory, ORNL/TM-10269, Oak Ridge Natl. Lab.

Lee Wan and Associates 1990. Environmental Restoration Program, Oak Ridge National Laboratory Waste Area Grouping 11 Remedial Investigation Work Plan, DOE/OR-942\&D1, Martin Marietta Energy Systems, Inc., Oak Ridge, Tenn.

Morrison, S. J. and T. E. Cerling 1987. Survey of Metal, Radionuclide and Organic Contamination at 20 Waste Area Groups (WAGs), ORNL Facilities, Oak Ridge, Tennessee, ORNL/RAP/Sub-87/27463/1, Oak Ridge Natl. Lab. 


\section{DESCRIPTION OF WAG 12}

Instructions to user
At this time there are no active projects at WAG 12. Full characterization of this WAG
is therefore unwarranted, and a description of it [derived from the Resource
Conservation and Recovery Act facilities assessment (ORNL 1987)] has been included
in this document for general information purposes only.

\subsection{SITE DESCRIPTION}

The Closed Contractors' Landfill (WAG 12) is the only Solid Waste Management Unit in WAG 12. The landfill used to bury general construction debris generated by contractors working at ORNL. WAG 12 is located about 1.4 miles ( $2.2 \mathrm{~km}$ ) ESE of WAG 1 and about $500 \mathrm{ft}$ (152 m) ENE of the intersection of Melton Valley Access Road at ORNL grid coordinates N 18,650 and E 37,500 (Figs. 17.1 and 17.2). WAG 12 is approximately $505 \mathrm{ft}(154 \mathrm{~m}$ ) long (in the east-west direction), and $259 \mathrm{ft}(79 \mathrm{~m}$ ) wide (in the north-south direction). The approximate area is about 2.9 acres (1.2 ha). The original land surface sloped from north to south so that the depth of fill probably ranges from less than $6 \mathrm{ft}(1.8 \mathrm{~m})$ on the north side to about $30 \mathrm{ft}(9 \mathrm{~m})$ on the south. Estimates of the amount of material buried ranges from $1.06 \times 10^{6}$ to $1.77 \times 10^{6} \mathrm{ft}^{3}\left(30,000\right.$ to $\left.50,000 \mathrm{~m}^{3}\right)$, depending on the depth of excavation, the existence of natural depressions, and the degree of compaction of the waste, if any.

The landfill functioned as the disposal point for ORNL contractors' construction and demolition waste from 1950 until 1975 when disposal stopped and the site was graded level and seeded with grass. No waste-specific records were kept on the landfill operation, and no administrative controls were maintained on the nature of the waste being buried. As a result, construction waste sent to the landfill probably included empty paint cans and other debris that could include small amounts of hazardous waste.

\subsection{KNOWN RELEASES}

No records indicate that WAG 12 represents a source of release of radioactive or hazardous materials. Aerial radiation surveys and walkover radiation surveys ( $3 \mathrm{ft}$ above land surface) have not detected radiation levels above background. No visible leakage or seeps have been observed or documented.

\subsection{REGULATORY STATUS}

Based on the results of surveys and existing information on the types of waste supposedly buried in the Contractors' Landfill, WAG 12 does not appear to require a remedial investigation plan; however, ORNL suggests that additional surveys for organic contaminants be conducted to verify the absence of releases. 



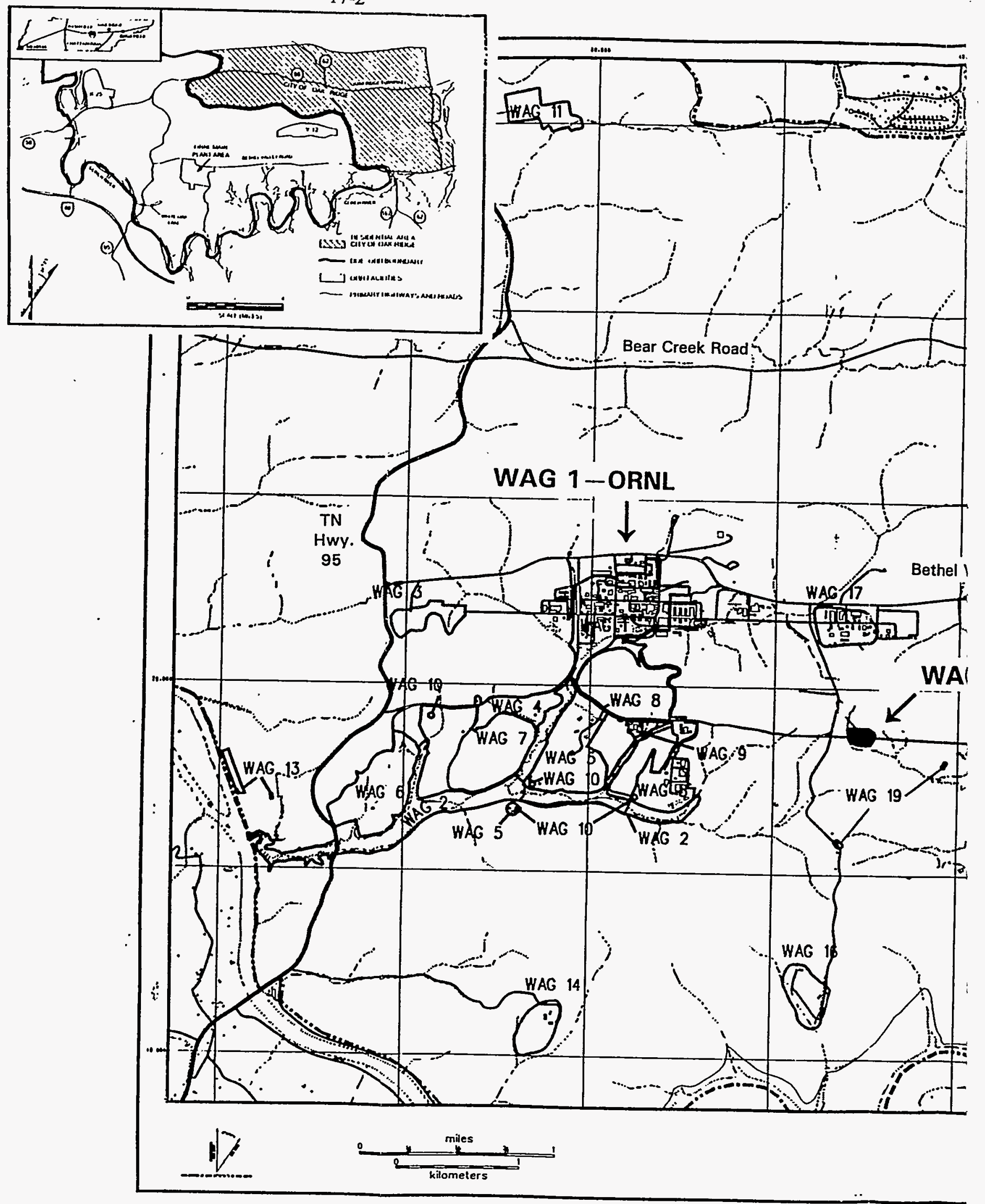

Fig. 17.1. Location of WAG 12, the Closed Contractors' Landfill. 


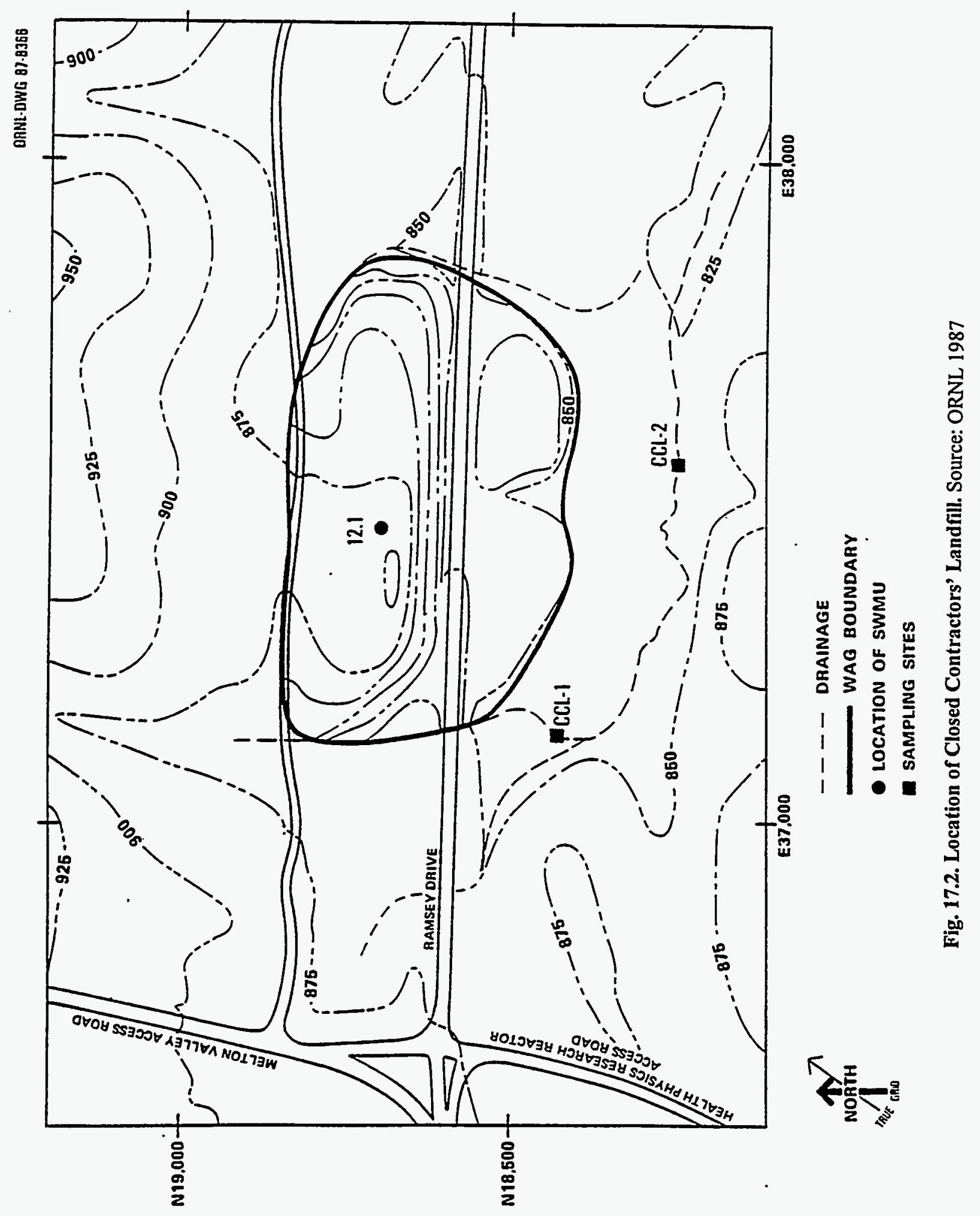




\subsection{REFERENCES}

ORNL (Oak Ridge Natl. Lab.) 1987. RCRA Facilities Assessment (RFA)-Oak Ridge National Laboratory, ORNL/RAP-12/V1, Oak Ridge Natl. Lab.

\subsection{BIBLIOGRAPHY}

Boegly, W. J. 1988. "WAG 12 Data Package," Environmental Restoration Document Management Center Bar Code ER011358, Martin Marietta Energy Systems, Inc., Oak Ridge, Tenn.

Coobs, J. H., and J. R. Gissel 1986. History of Disposal of Radioactive Wastes into the Ground at Oak Ridge National Laboratory, ORNL/TM-10269, Oak Ridge Natl. Lab.

Morrison, S. J. and T. E. Cerling 1987. Survey of Metal, Radionuclide and Organic Contamination at 20 Waste Area Groups (WAGs), ORNL Facilities, Oak Ridge, Tennessee, ORNL/RAP/Sub-87/27463/1, Oak Ridge Natl. Lab.

ORNL 1990. ORNL Contaminated Site Summary Sheets, ORNL/M-2413, Oak Ridge Natl. Lab.

SAIC (Science Applications International Corp.) 1994. Remedial Investigation Work Plan for the Groundwater Operable Unit at Oak Ridge National Laboratory, Oak Ridge, Tennessee, DOE/OR/01-1252\&D1 (ORNL/ER-221\&D1), Martin Marietta Energy Systems, Inc., Oak Ridge Natl. Lab. 


\section{DESCRIPTION OF WAG 13}

Instructions to user
At this time there are no active projects at WAG 13. Full characterization of this WAG
is therefore unwarranted, and a description of it has been included in this document for
general information purposes only.

\subsection{SITE DESCRIPTION}

WAG 13 (Fig. 18.1) includes two environmental research areas and is part of what is called the 0800 Area. The two Solid Waste Management Units (SWMUs) in WAG 13 (Fig. 18.2) are located about $1,300 \mathrm{ft}(400 \mathrm{~m})$ apart in separate parts of the WAG. This area (0800 Area) was the site of a number of simulated fallout experiments using ${ }^{137} \mathrm{Cs}$.

SWMU 13.1 consists of a 5-acre (2-ha) fenced area in a fescue grassland community $~ 330 \mathrm{ft}$ $(100 \mathrm{~m})$ north of Clinch River at mile $20.5(33 \mathrm{~km})$ and 1.3 miles southwest of the intersection of Bethel Valley Road and Tennessee State Route 95. The site included eight 33- by 33-ft (10- by 10-m) treatment plots, each of which was enclosed by metal sheeting 18 in. $(46 \mathrm{~cm})$ below the surface and 24 in. $(61 \mathrm{~cm})$ above the ground. In August 1968, four of the plots were contaminated with ${ }^{137} \mathrm{Cs}$ fused at high temperatures to silica particles ( 88 to $177 \mu \mathrm{m}$ diameter), and the remaining four plots were used as controls. Each enclosed plot received $\sim 2.2 \mathrm{Ci}\left(8.1 \times 10^{10} \mathrm{~Bq}\right)$ of ${ }^{137} \mathrm{Cs}$, or a total of $8.8 \mathrm{Ci}\left(3.3 \times 10^{11} \mathrm{~Bq}\right)$ to the site (ORNL 1987). The particle size distribution was selected to simulate particle size characteristics of nuclear weapons fallout. During the period of experimental observation, samples of vegetation clippings and soil cores were removed from the enclosures, analyzed, and disposed of elsewhere. Since the ${ }^{137} \mathrm{Cs}$ was applied in 1968 , radioactive decay $(\sim 0.6$ half-life $)$ has reduced the remaining radioactivity to less than $5.7 \mathrm{Ci}\left(2.1 \times 10^{11} \mathrm{~Bq}\right)$, assuming that no particle losses occurred due to weathering, runoff, or wind transport. The site is presently inactive. Numerous experiments with shorter half-life isotopes have been conducted in the vicinity of the cesium plots; however, the isotopes are no longer present in detectable amounts (ORNL 1987).

SWMU 13.2 was an experimental area used to study ${ }^{137} \mathrm{Cs}$ runoff, erosion, and infiltration on a silt-loam soil. This study was also related to ORNL's Civil Defense Program. The isotope in this experiment was sprayed as a liquid on soils having varying degrees of ground cover. A total of $15 \mathrm{mCi}\left(5.6 \times 10^{8} \mathrm{~Bq}\right)$ of ${ }^{137} \mathrm{Cs}$ was used to contaminate an area less than $215 \mathrm{ft}^{2}\left(20 \mathrm{~m}^{2}\right)$. Since the isotope was applied on October 20,1964 , approximately 0.72 half-life has passed, and the maximum amount of radioactivity remaining should be about $9.1 \mathrm{mCi}\left(3.4 \times 10^{8} \mathrm{~Bq}\right)$. The site is currently inactive (ORNL 1987).

\subsection{KNOWN RELEASES}

A surface radiological investigation (Yalcintas et al. 1988) was conducted at and around the ${ }^{137} \mathrm{Cs}$ plots site between June 1987 and March 1988. The results of that investigation concluded that the maximum exposure to the public would be $\sim 0.029 \mathrm{mR} / \mathrm{h}$ along the shoreline closest to the ${ }^{137} \mathrm{Cs}$ plots and up to $0.15 \mathrm{mR} / \mathrm{h}$ at the perimeter fence. Gamma-ray exposure rates measured at the 


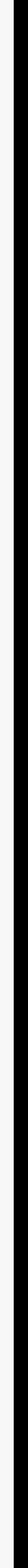




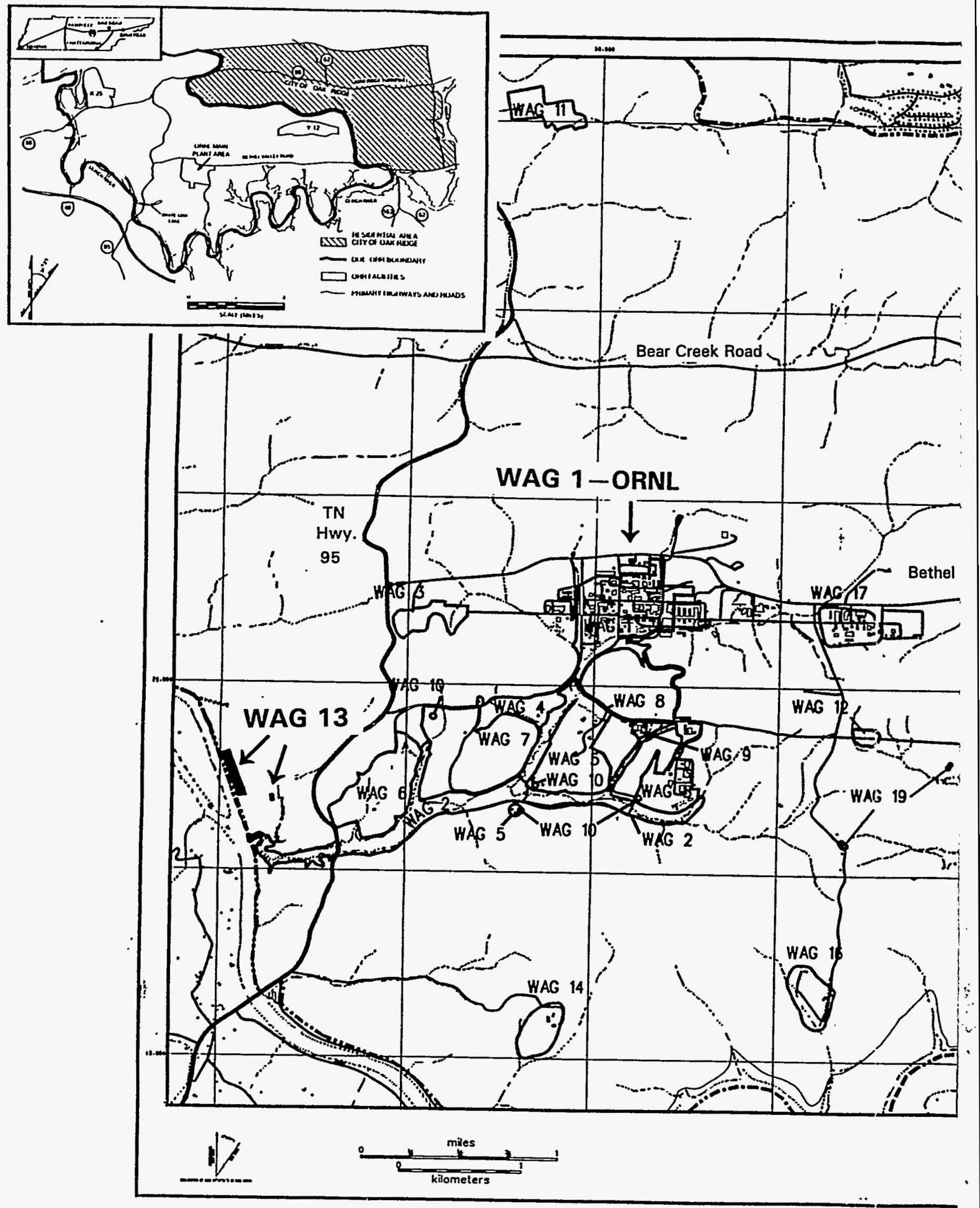

Fig. 18.1. Location of WAG 13, the Environmental Research Areas. 


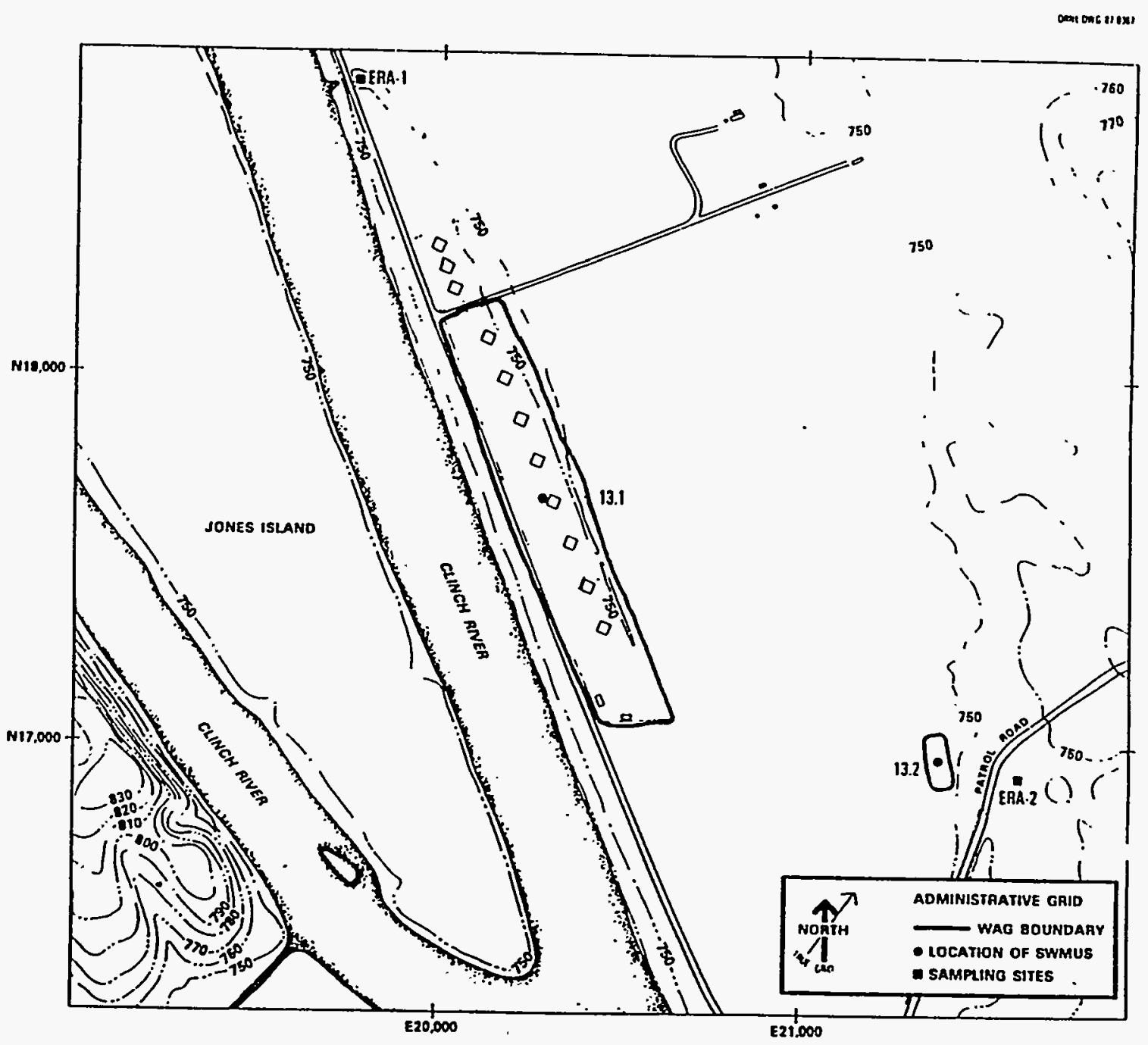

Fig. 18.2. Location of Solid Waste Management Units in WAG 13. Source: ORNL 1987

contaminated plot boundaries within the fenced area ranged from 1.3 to $35 \mathrm{mR} / \mathrm{h}$. The water table at Wag 13 is $\sim 8 \mathrm{ft}$ below the surface, so ${ }^{137} \mathrm{Cs}$ contamination could feasibly migrate through groundwater at the site.

\subsection{REGULATORY STATUS}

An interim remedial measures study for the WAG 13 cesium plots (Radian 1992a) was completed. Results of that study determined the best alternatives for reducing the health threat posed by the gamma radiation in the plots. Following receipt of and response to public comment an interim remedial action alternative was selected and documented in the Interim Record of Decision (IROD) (Radian 1992b). The IROD certified that the action selection process was conducted in accordance with the Comprehensive Environmental Response, Compensation, and Liability Act; described the technical parameters of the remedial action; and provided the public with a consolidated source of information about the site and the chosen action, including the rationale behind the selection. After publication of notices of intent, DOE documented in the IROD the selection of the alternative to 
excavate the cesium-contaminated soil and store it in underground silos at WAG 6. The IROD for WAG 13 received final approval on October 6,1992, from the Tennessee Department of Environment and Conservation, the U.S. Environmental Protection Agency, and DOE. The interim remedial action work plan (Energy Systems 1993) was approved in July 1993. Remedial action began on August 30, 1993; the IROD scope for the remedial action was completed on October 29, 1993; and the excavation of hot spots of contamination around plot perimeters was completed in May 1994 (Dawson and Garrett 1994).

No further action is currently planned for the experimental study area. The ER Program will continue to monitor the WAG 13 site, as required by the Comprehensive Environmental Response, Compensation, and Liability Act, to ensure the removal action reduced the risks posed by WAG 13 contamination to acceptable levels (Clapp and Watts 1995).

\subsection{REFERENCES}

Clapp, R. B., and J. A. Watts, eds. 1995. Fourth Annual Environmental Restoration Monitoring and Assessment Report (FY 1995), Oak Ridge National Laboratory, Oak Ridge, Tennessee, DOE/OR/01-1413\&D1, Oak Ridge Natl. Lab.

Dawson, P. M., and D. L. Garrett 1994. Interim Remedial Action Postconstruction Report for Waste Area Grouping 13 at Oak Ridge National Laboratory, Oak Ridge, Tennessee, DOE/OR/01-1218\&D2, Martin Marietta Energy Systems, Inc., Oak Ridge, Tenn.

Energy Systems (Martin Marietta Energy Systems, Inc.) 1993. Interim Remedial Action Work Plan for Cesium Plots at Waste Area Grouping 13 at Oak Ridge National Laboratory, Oak Ridge, Tennessee, DOE/OR/01-1122\&D3, Martin Marietta Energy Systems, Inc., Oak Ridge, Tenn.

ORNL (Oak Ridge Natl. Lab.) 1987. RCRA Facilities Assessment (RFA)—Oak Ridge National Laboratory, ORNL/RAP-12/V1, Oak Ridge Natl. Lab.

Radian (Radian Corp.) 1992a. Interim Remedial Measures Study for Oak Ridge National Laboratory Waste Area Grouping 13, DOE/OR/1016\&D3, Oak Ridge Natl. Lab.

Radian 1992b. Interim Record of Decision for the Oak Ridge National Laboratory Waste Area Grouping 13 Cesium Plots, Oak Ridge, Tennessee, DOE/OR/1059\&D4, Oak Ridge Natl. Lab.

Yalcintas, M. G., M. S. Uziel, J. A. Roberts, and I. Uslu 1988. Radiation Exposures from a Cesium-Contaminated Field, ORNL/RAP-36, Oak Ridge Natl. Lab.

\subsection{BIBLIOGRAPHY}

Boegly, W. J., and G. K. Moore 1988. Environmental Data Package for the Environmental Research Area (WAG 13), ORNL/RAP-48, Martin Marietta Energy Systems, Inc., Oak Ridge, Tenn.

Coobs, J. H., and J. R. Gissel 1986. History of Disposal of Radioactive Wastes into the Ground at Oak Ridge National Laboratory, ORNL/TM-10269, Oak Ridge Natl. Lab. 
Morrison, S. J. and T. E. Cerling 1987. Survey of Metal, Radionuclide and Organic Contamination at 20 Waste Area Groups (WAGs), ORNL Facilities, Oak Ridge, Tennessee, ORNL/RAP/Sub-87/27463/1, Oak Ridge Natl. Lab.

ORNL 1990. ORNL Contaminated Site Summary Sheets, ORNL/M-2413, Oak Ridge Natl. Lab.

Radian 1992. Proposed Plan for Oak Ridge National Laboratory Waste Area Grouping 13 Interim Remedial Action, DOE/OR/1022\&D3, Oak Ridge Natl. Lab.

Tiner, P. F. 1994. Surface Radiological Investigations at the 0816 Site, Waste Area Grouping 13, Oak Ridge National Laboratory, Oak Ridge, Tennessee, ORNL/ER-291, Oak Ridge Natl. Lab. 


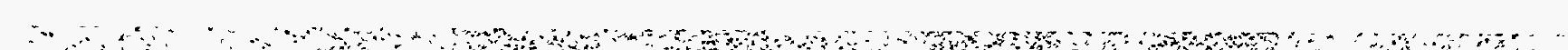




\section{DESCRIPTION OF WAG 14}

\section{Instructions to user}

At this time there are no active projects at WAG 14. Full characterization of this WAG is therefore unwarranted, and a description of it [derived from the Resource Conservation and Recovery Act facilities assessment (ORNL 1987)] has been included in this document for general information purposes only.

\subsection{SITE DESCRIPTION}

WAG 14 (the Tower Shielding Facility) is located about 2.2 miles ( 3.5 to $4 \mathrm{~km}$ ) south of the ORNL main plant area (WAG 1). The location of WAG 14 is shown in Fig. 19.1; its two associated Solid Waste Management Units (SWMUs) are shown in Fig. 19.2.

The facility was constructed in 1954 to provide an economical means for obtaining shielding performance data free from ground scatter or structure scatter for use in the development of portable reactors. This objective was accomplished by placing a small, low-power reactor in a cylindrical tank and measuring the radiation from the reactor at various angles while the reactor and tank were suspended about $200 \mathrm{ft}(60 \mathrm{~m})$ above the ground. Four large towers [about $330 \mathrm{ft}(100 \mathrm{~m}) \mathrm{high}$ ] were installed from which to suspend reactors and their associated measuring equipment. The towers have also been used for drop testing of transportable shielding containers (casks).

SWMU 14.1 (Tower Shielding Facility Scrap Yard) is an accumulation of used vessels, tanks, and drums that have collected over time as a result of work conducted at the facility. In addition to the scrap materials, there are about 30055 -gal drums of sodium used for shielding. One of these drums shows evidence of earlier leakage but appears to have sealed itself; all of the other drums appear to be adequate for containment. Also present at the site are sheets of depleted uranium.

SWMU 14.2 is a septic tank installed to provide sewage treatment services for personnel employed at the site. No evidence exists to indicate that any hazardous materials have been discharged to the tank. Sludge from the tank is pumped into a tank truck and transported to the ORNL sewage treatment facilities for treatment.

\subsection{KNOWN RELEASES}

There is no reported information of releases of hazardous materials from operation of this facility. However, some of the scrap materials currently located at the site contain induced radioactivity because of past use. Initial contaminant scoping studies indicate that there are no significant exposure hazards caused by the induced activity. At the present time, some cleanup of the site and removal of the inactive sodium tank is under way under the ORNL Surplus Contaminated Facilities Program. 


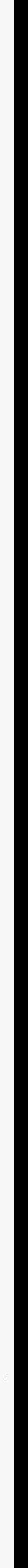




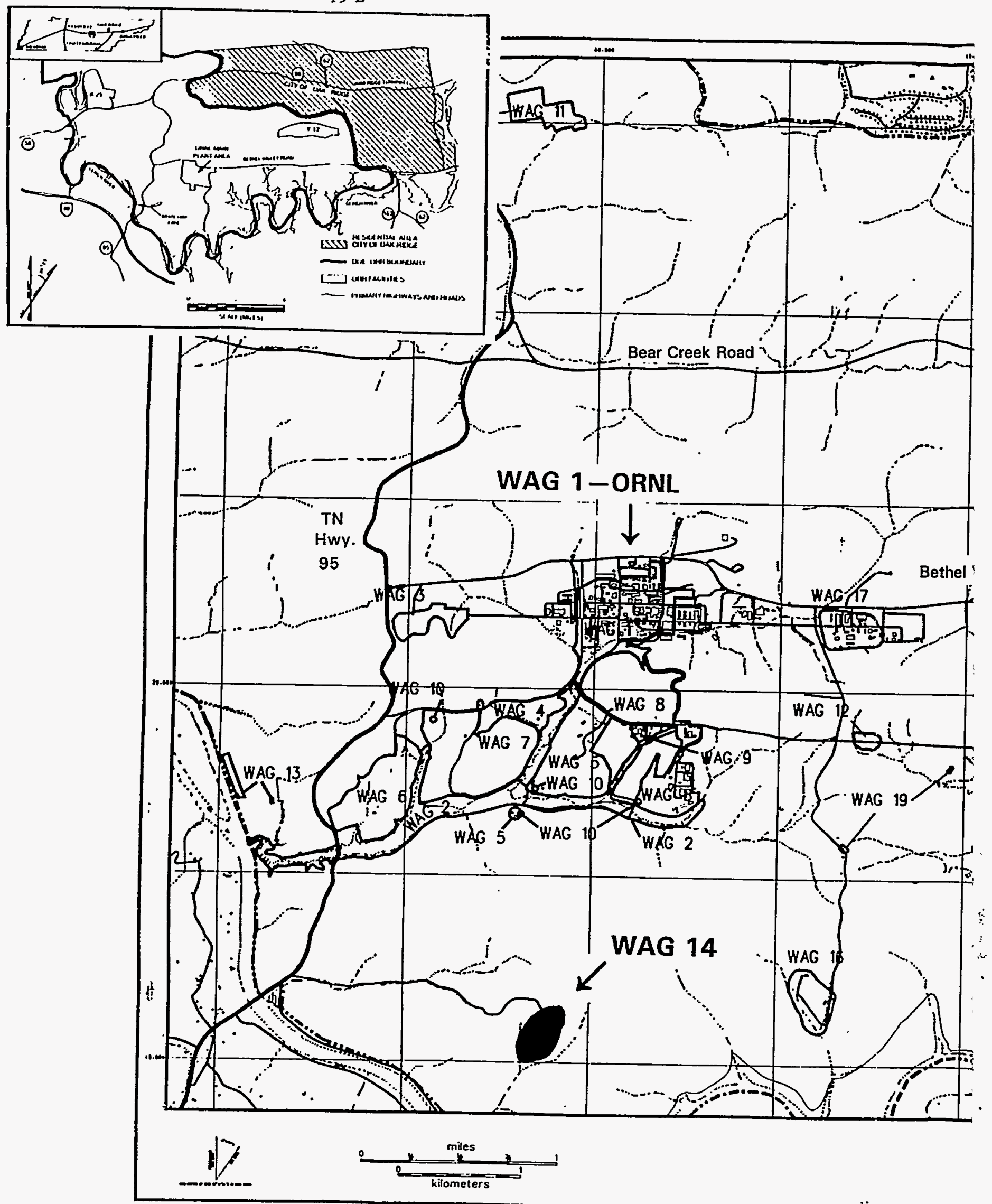

Fig. 19.1. Location of WAG 14, the Tower Shielding Facility. 


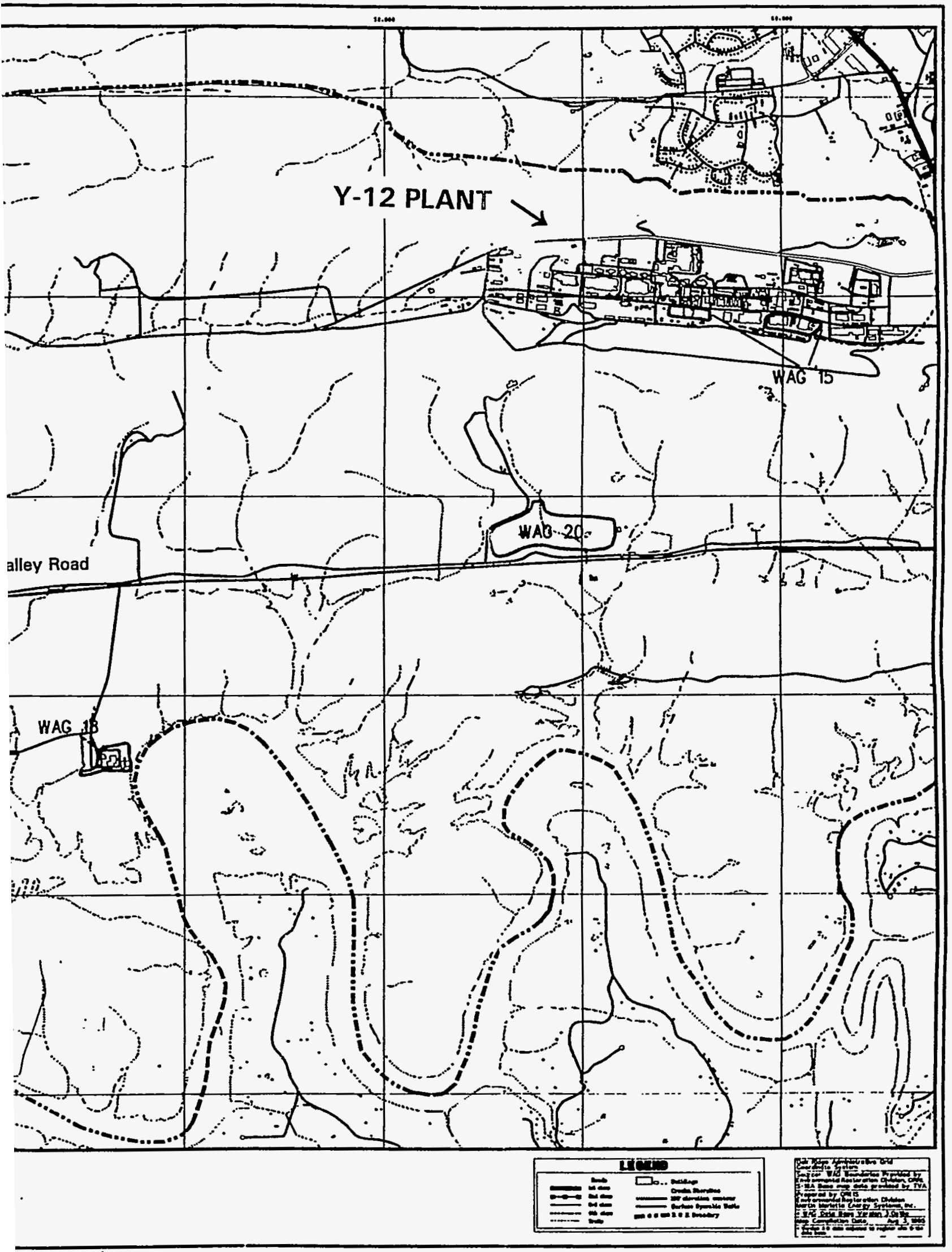


ORNL-OWG 87-836B

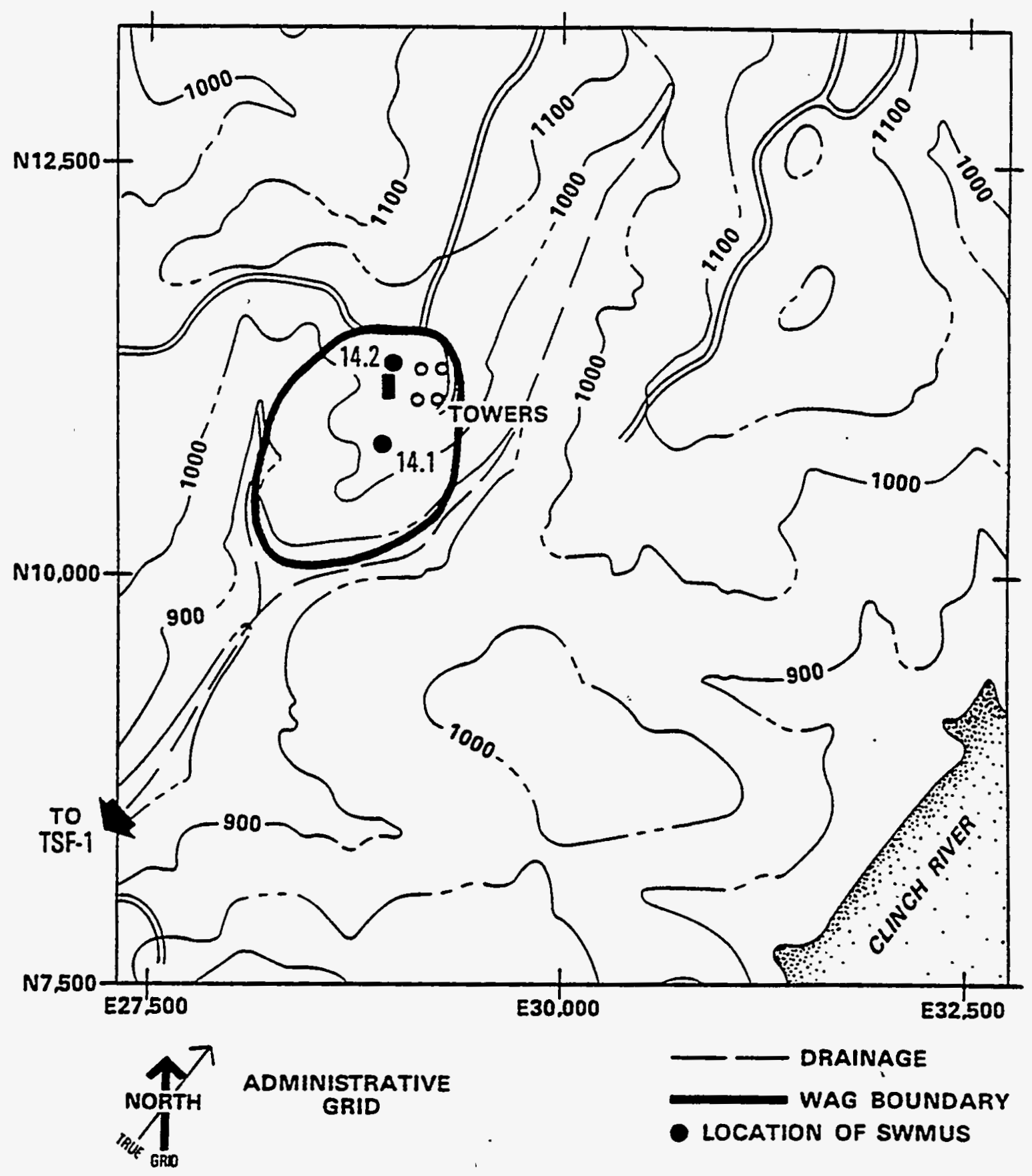

Fig. 19.2. Location of WAG 14 Solid Waste Management Units. Source: ORNL 1987 


\subsection{REGULATORY STATUS}

Based on results of the Surplus Contaminated Facilities Program contaminant scoping surveys and the WAG scoping surveys of Morrison and Cerling (1987), it appears that WAG 14 has not produced past releases of hazardous materials to the environment and does not presently represent a source of release. Furthermore, the cleanup operations planned for this facility under the Surplus Contaminated Facilities Program should eliminate the concern for future releases. ORNL suggests that WAG 14 be deleted from further consideration as a Resource Conservation and Recovery Act Section 3004(u) site and that action beyond cleanup of the site be terminated.

\subsection{REFERENCES}

Morrison, S. J. and T. E. Cerling 1987. Survey of Metal, Radionuclide and Organic Contamination at 20 Waste Area Groups (WAGs), ORNL Facilities, Oak Ridge, Tennessee, ORNL/RAP/Sub-87/27463/1, Oak Ridge Natl. Lab.

Oak Ridge Natl. Lab. 1987. RCRA Facilities Assessment (RFA)—Oak Ridge National Laboratory, ORNL/RAP-12/V1, Oak Ridge Natl. Lab.

\subsection{BIBLIOGRAPHY}

Boegly, W. J. 1988. "WAG 14 Data Package," Environmental Restoration Document Management Center Bar Code ER011354, Martin Marietta Energy Systems, Inc., Oak Ridge, Tenn.

Coobs, J. H., and J. R. Gissel 1986. History of Disposal of Radioactive Wastes into the Ground at Oak Ridge National Laboratory, ORNL/TM-10269, Oak Ridge Natl. Lab.

Oak Ridge Natl. Lab. 1990. ORNL Contaminated Site Summary Sheets, ORNL/M-2413, Oak Ridge Natl. Lab.

Stockdale, P. B. 1993. "Groundwater Conditions at the Tower Shielding Facility," Environmental Restoration Document Management Center Bar Code ER011382, Martin Marietta Energy Systems, Inc., Oak Ridge, Tenn.

Stockdale, P. B. 1993. "Geologic Conditions at the Tower Shielding Facility Site," Environmental Restoration Document Management Center Bar Code ER011381, Martin Marietta Energy Systems, Inc., Oak Ridge, Tenn. 


\title{
20. DESCRIPTION OF WAG 15
}

\begin{abstract}
Instructions to user
At this time there are no active projects at WAG 15. Full characterization of this WAG is therefore unwarranted, and a description of it [derived from the Resource Conservation and Recovery Act facilities assessment (ORNL 1987)] has been included in this document for general information purposes only.
\end{abstract}

\subsection{SITE DESCRIPTION}

A number of ORNL divisions occupy building space at the Oak Ridge Y-12 Plant. Waste resulting from these operations is handled by the Y-12 Plant waste handling systems; two Solid Waste Management Units (SWMUs), however, are the responsibility of ORNL. These are SWMU 15.1, cyclotron Z-oil storage at Building 9201-2, and SWMU 15.2, a number of transformer and capacitor storage sites (Figs. 20.1 and 20.2).

The Z-oil was used in the ORNL 86-inch cyclotron located in Building 9201-Z. This cyclotron was dedicated to the production of radionuclides used in medical diagnosis and treatment and for industrial applications. The cyclotron was taken out of service in 1983. The Z-oil is reported to contain $<50 \mathrm{ppm}$ polychlorinated biphenyls (PCBs) and may be contaminated with radionuclides. The inventory of $Z$-oil has been reduced from 15,000 to 7,000 gal $(56,780$ to $26,500 \mathrm{~L})$; this oil will remain until decommissioning activities for the cyclotron are initiated.

The transformers and capacitors located in Buildings 9201-2, 9204-1, 9204-3, and the SY 200 Scrap Yard were originally retained as spares for ORNL isotope production activities. These units contained oil having PCB concentrations ranging from 50 to $>500 \mathrm{ppm}$. Capacity of the units ranges from small transformers and capacitors [2 gal $(7.6 \mathrm{~L})]$ to five 2,200-gal $(8,328-\mathrm{L})$ transformers that were stored at the SY 200 Scrap Yard. During 1986, all of the surplus transformers and capacitors were removed from the ORNL areas at the Y-12 Plant and transferred to subcontractors for disposal.

In addition to the two SWMUs described above, there are 14 surplus facility sites (non-SWMUS) located within the Y-12 Plant. The cleanup of these sites will generate wastes that will require disposal at either ORNL or Y-12 Plant disposal facilities.

\subsection{KNOWN RELEASES}

The two SWMUs at the Y-12 Plant are (1) Building 9201-2, where ORNL operated a cyclotron using Z-oil as the coolant and (2) areas where surplus transformers and capacitors containing PCBs were located. There have been no reported releases of the $Z$-oil. Records indicate that PCB-contaminated oils from the transformers and capacitors have leaked from one transformer located at the SY 200 Scrap Yard. The oil from the transformers stored at the SY 200 Scrap Yard had PCB concentrations ranging from 2 to $17 \mathrm{ppm}$ and has been reclaimed. Thus, any spills of this oil should not result in gross $\mathrm{PCB}$ contamination. 


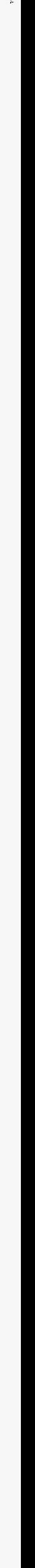




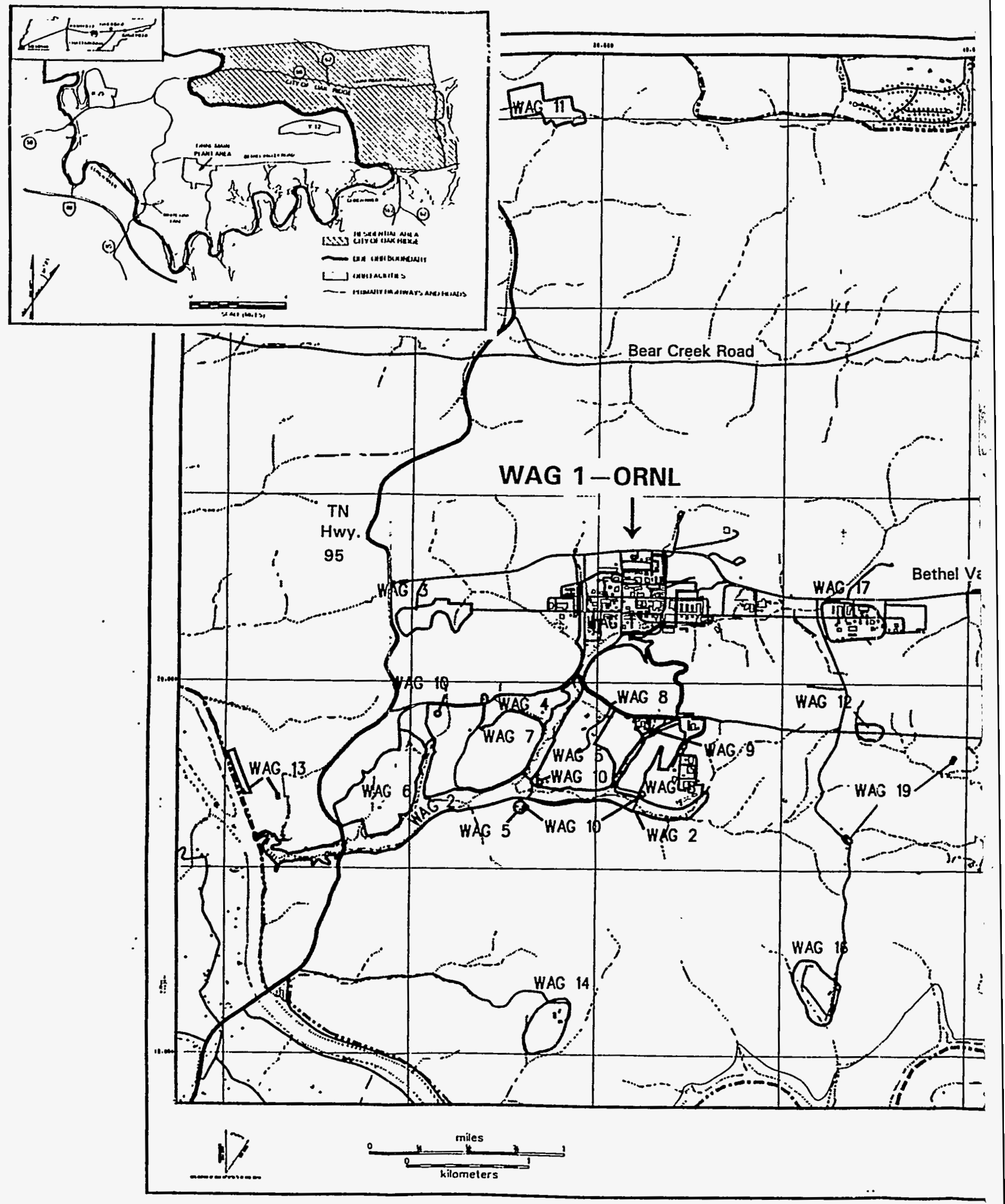

Fig. 20.1. Location of WAG 15,

ORNL Facilities at the Y-12 Plant. 


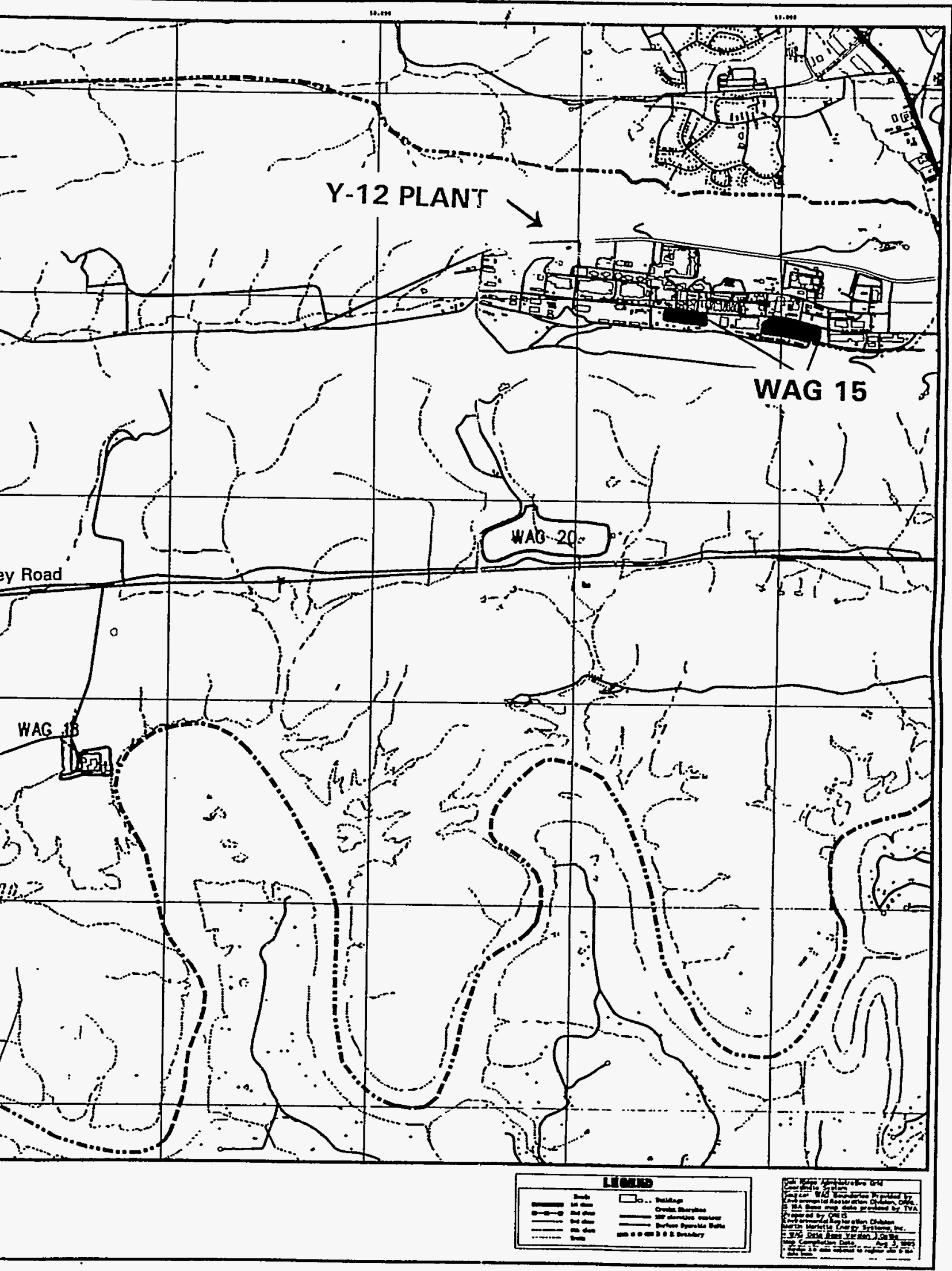




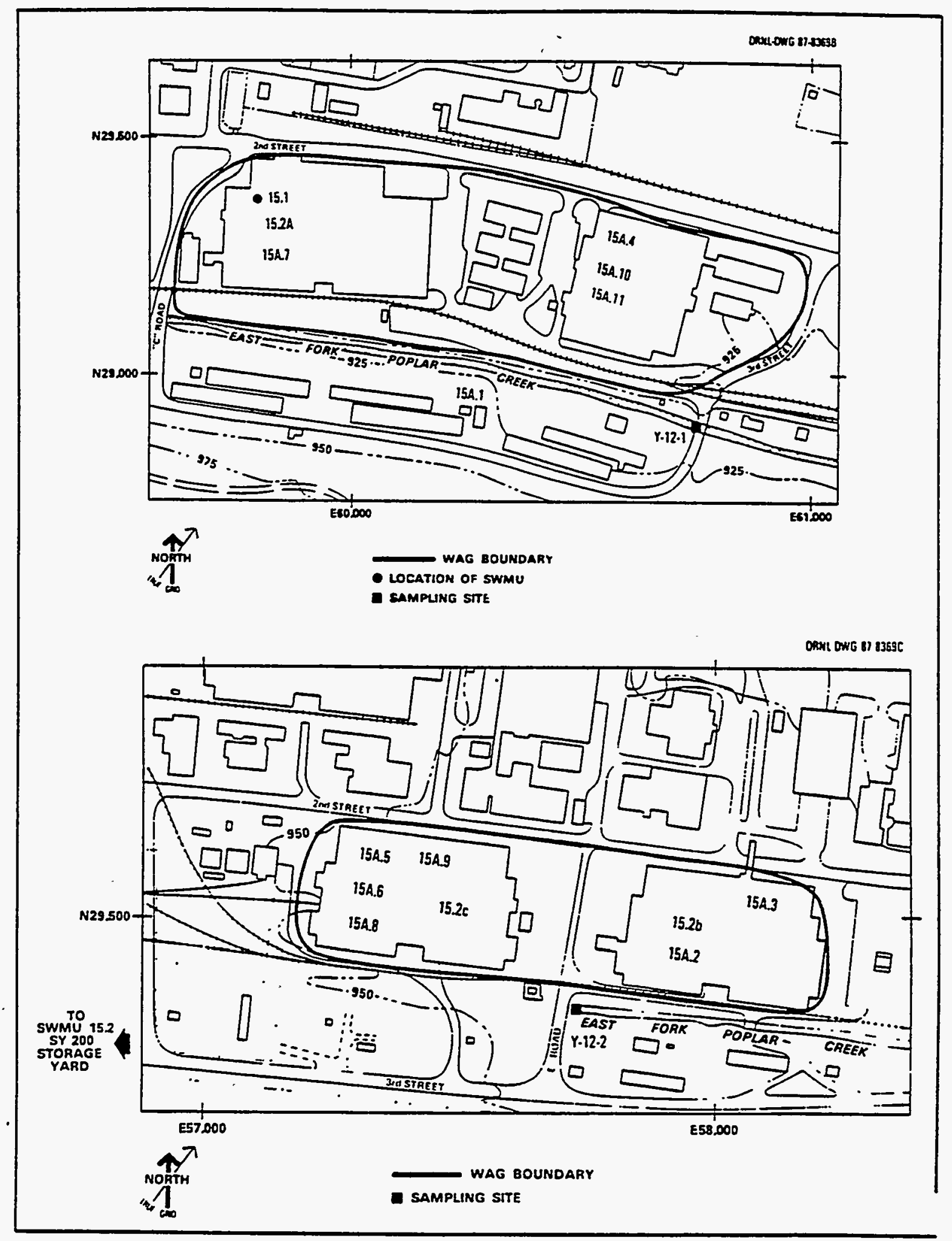

Fig. 20.2. Location of WAG 15 Solid Waste Management Units. Source: ORNL 1987 


\subsection{REGULATORY STATUS}

Before starting a remedial investigation plan for WAG 15, further surveys will be required to identify the potential for PCB release. As previously mentioned, all of the surplus transformers and capacitors have been removed and disposed of. Thus, the major source of PCB-contaminated oil has been removed. However, the fact that one transformer is reported to have leaked oil indicates that some soil sampling is warranted. Because the 86-inch cyclotron is no longer in use, the Z-oil inventory has been reduced. Once disposal of the remaining oil is completed, this source should be eliminated. A decision on the need for a remedial investigation plan for WAG 15 should be postponed pending further soil sampling and decontamination operations.

\subsection{REFERENCES}

ORNL (Oak Ridge Natl. Lab.) 1987. RCRA Facilities Assessment (RFA)—Oak Ridge National Laboratory, ORNL/RAP-12/V1, Oak Ridge Natl. Lab.

\subsection{BIBLIOGRAPHY}

Boegly, W. J. 1988. "WAG 15 Data Package," Environmental Restoration Document Management Center Bar Code ER011355, Martin Marietta Energy Systems, Inc., Oak Ridge, Tenn.

Coobs, J. H., and J. R. Gissel 1986. History of Disposal of Radioactive Wastes into the Ground at Oak Ridge National Laboratory, ORNL/TM-10269, Oak Ridge Natl. Lab.

Morrison, S. J. and T. E. Cerling 1987. Survey of Metal, Radionuclide and Organic Contamination at 20 Waste Area Groups (WAGs), ORNL Facilities, Oak Ridge, Tennessee, ORNL/RAP/Sub-87/27463/1, Oak Ridge Natl. Lab.

ORNL 1990. ORNL Contaminated Site Summary Sheets, ORNL/M-2413, Oak Ridge Natl. Lab. 


\section{DESCRIPTION OF WAG 16}

\section{Instructions to user}

At this time there are no active projects at WAG 16. Full characterization of this WAG is therefore unwarranted, and a description of it [derived from the Resource Conservation and Recovery Act facilities assessment (ORNL 1987)] has been included in this document for general information purposes only.

\subsection{SITE DESCRIPTION}

WAG 16, the Health Physics Research Reactor (HPRR) Area (also known as the Dosimetry Applications Research Facility) is located about 2 miles $(3.2 \mathrm{~km}$ ) south-southwest of the main ORNL plant area (Fig. 21.1). The HPRR consists of two buildings, one a combination laboratory-control building and the other the structure housing the unshielded reactor. WAG 16 includes two Solid Waste Management Units (SWMUs): the cesium forest (SWMU 16.1), and the HPRR retention pond (SWMU 16.2).

The cesium forest is a small forest ecosystem contaminated with ${ }^{137} \mathrm{Cs}$. Thirty trees, ranging up to $100 \mathrm{ft}(30 \mathrm{~m})$ tall, were inoculated with ${ }^{137} \mathrm{Cs}$ to determine the movement of this nuclide and to act as an analog to the essential element, potassium. A total of $467 \mathrm{mCi}\left(1.72 \times 10^{10} \mathrm{~Bq}\right)$ of ${ }^{137} \mathrm{Cs}$ was introduced into the transpiration system of a number of yellow poplar trees. The site is a 66- by $82-\mathrm{ft}$ $\left(5,380 \mathrm{fl}^{2}\right)$ plot [20- by $25-\mathrm{m}$ plot $\left.\left(500 \mathrm{~m}^{2}\right)\right]$. The site is just north of a patrol road leading from HPRR to the Tower Shielding Facility (WAG 14). The isotope was injected into the tree stems (trunks) over a three-day period (May 20-23, 1962). Correcting for radiological decay, approximately $270 \mathrm{mCi}$ $\left(1.0 \times 10^{10} \mathrm{~Bq}\right)$ remains since the isotope was injected. However, the amount on site has probably been decreased even more by wind distribution of leaves, movement through soil, and runoff.

SWMU 16.2 is a retention pond installed to collect groundwater that may have entered the concrete-lined pits in the reactor building used to store the reactor core. There are no records to indicate that the pond ever received any drainage from the storage pits or that any other liquids were added to the pond other than water discharged during testing of the fire protection sprinkler system. Some contamination in the pond might result from precipitation collecting in the pond.

\subsection{KNOWN RELEASES}

There have been no reported releases of contaminants (radioactive or hazardous chemicals) from either of the SWMUs in WAG 16. Research reports on the cesium forest (SWMU 16.1) indicate that some of the cesium injected into the trees has been translocated to the leaves of the trees, which have then fallen outside of the boundary of the forest. However, this is reported to be a fraction of the original activity injected. No groundwater or surface water sampling was performed as a part of the ecological studies on the forest. 
 


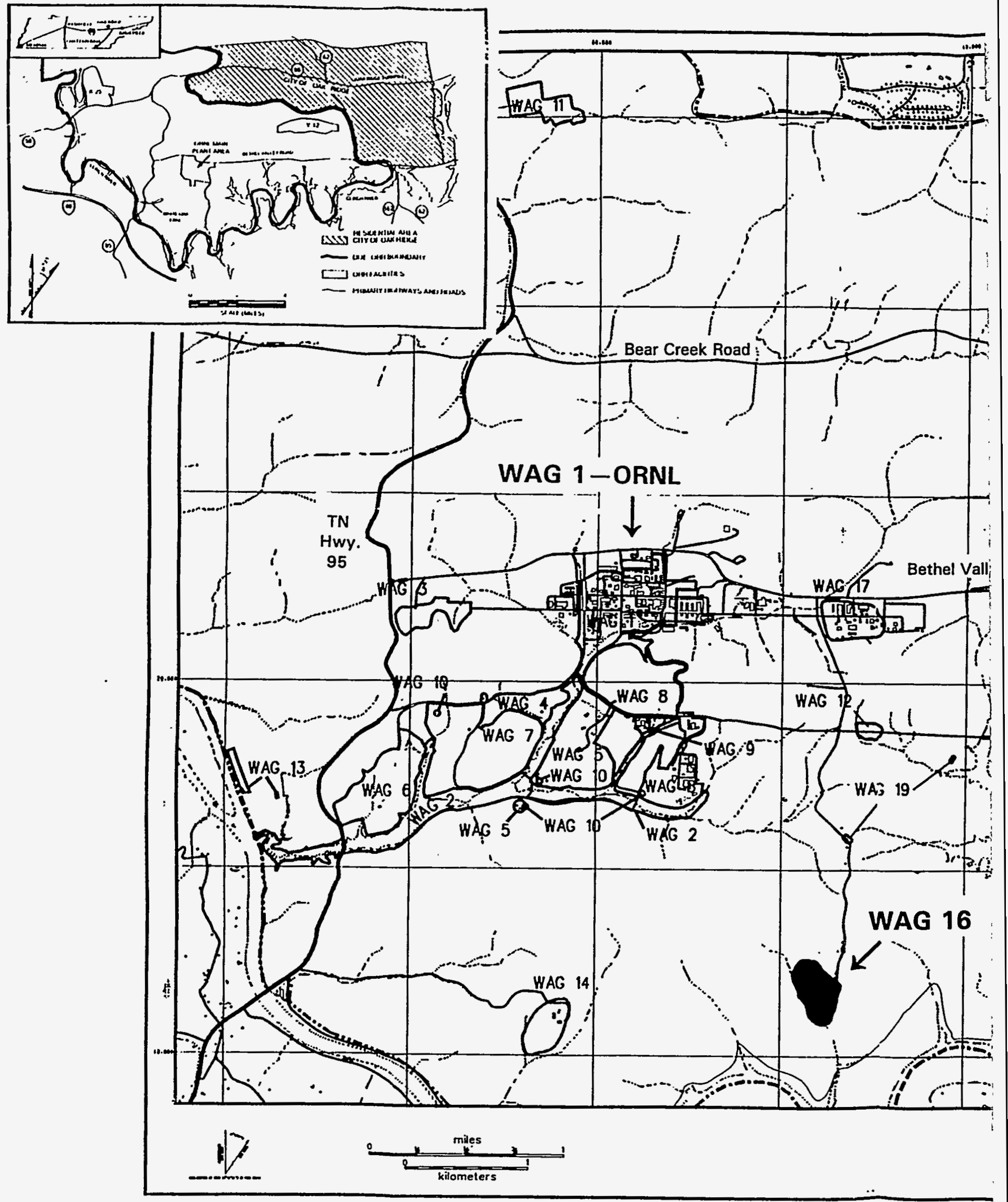

Fig. 21.1. Location of WAG 16,

Health Physics Research Reactor Area. 


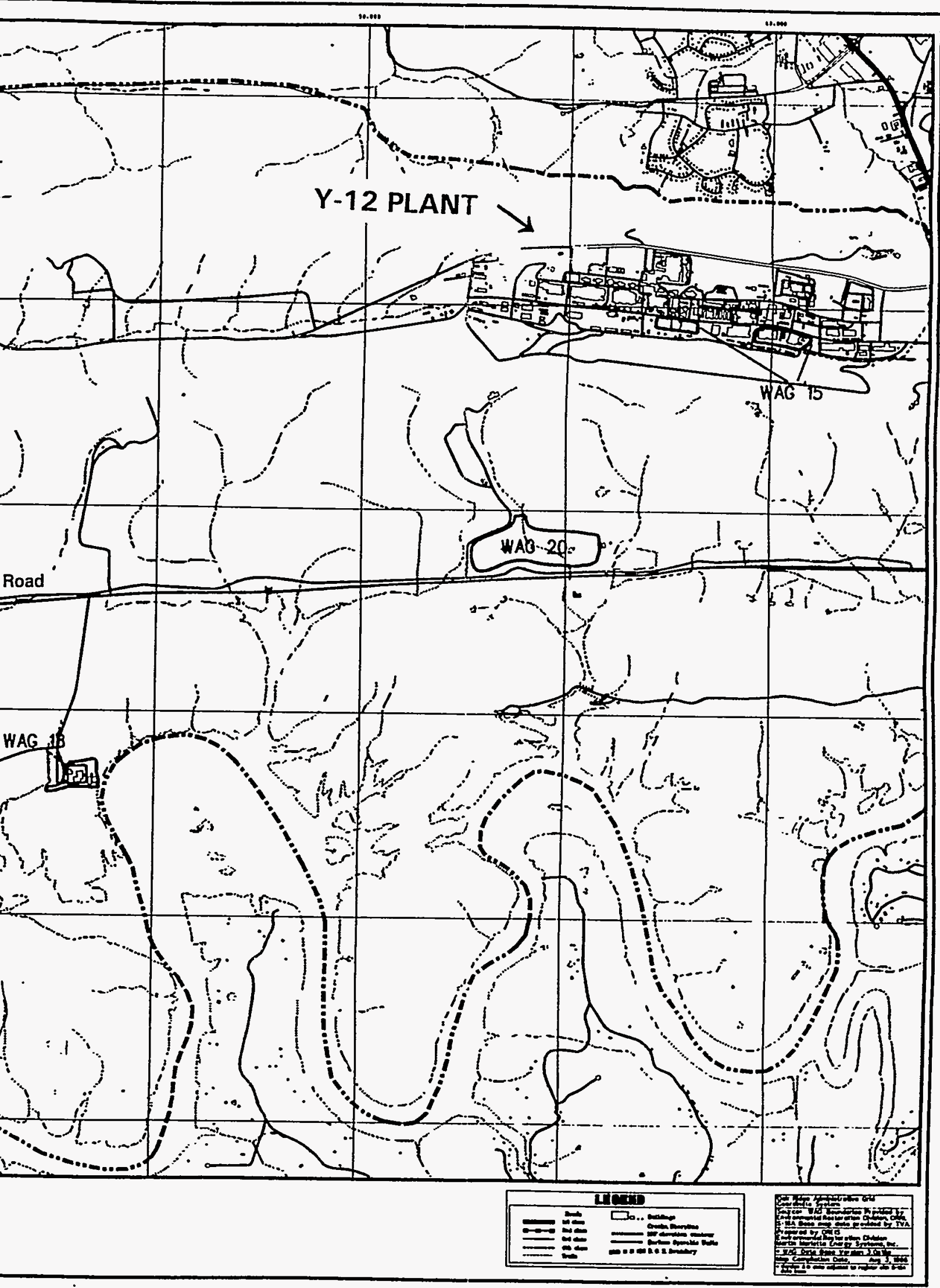




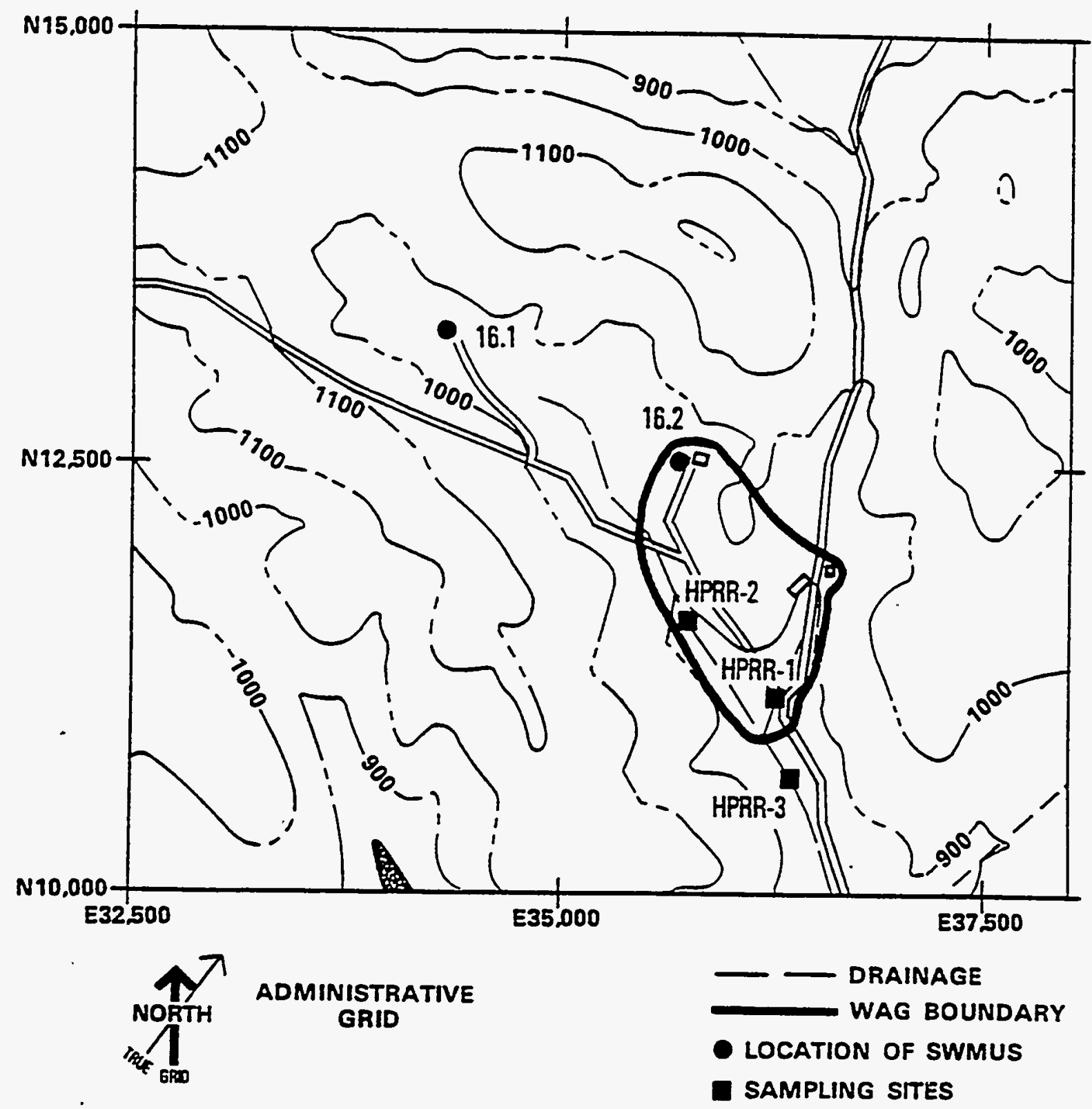

Fig. 21.2. Location of WAG 16 Solid Waste Management Units. Source: ORNL 1987

\subsection{REGULATORY STATUS}

WAG 16 and its two SWMUs do not appear to be a source of release of radionuclides and hazardous chemicals. The preliminary survey confirmed that there was no evidence of past releases. Because the amount of radioactivity present in the cesium forest is small [calculated to be about $270 \mathrm{mCi}\left(1.0 \times 10^{10} \mathrm{~Bq}\right)$ maximum] and the ability of local soils to retain cesium is relatively high, it appears that any releases from this SWMU would be minor. No hazardous chemicals have been added to either of the SWMUs, and it is recommended that WAG 16 be deleted from further consideration as a RCRA Section 3004(u) site. 


\subsection{REFERENCES}

ORNL (Oak Ridge Natl. Lab.) 1987. RCRA Facilities Assessment (RFA)-Oak Ridge National Laboratory, ORNL/RAP-12/V1, Oak Ridge Natl. Lab.

\subsection{BIBLIOGRAPHY}

Boegly, W. J. 1988. "WAG 16 Data Package," Environmental Restoration Document Management Center Bar Code ER011356, Martin Marietta Energy Systems, Inc., Oak Ridge, Tenn.

Coobs, J. H., and J. R. Gissel 1986. History of Disposal of Radioactive Wastes into the Ground at Oak Ridge National Laboratory, ORNL/TM-10269, Oak Ridge Natl. Lab.

Morrison, S. J. and T. E. Cerling 1987. Survey of Metal, Radionuclide and Organic Contamination at 20 Waste Area Groups (WAGs), ORNL Facilities, Oak Ridge, Tennessee, ORNL/RAP/Sub-87/27463/1, Oak Ridge Natl. Lab.

ORNL 1990. ORNL Contaminated Site Summary Sheets, ORNL/M-2413, Oak Ridge Natl. Lab. 


\title{
22. DESCRIPTION OF WAG 17
}

\begin{abstract}
Instructions to user
At this time there are no active projects at WAG 17. Full characterization of this WAG is therefore unwarranted, and a description of it [derived from the Resource Conservation and Recovery Act facilities assessment (ORNL 1987)] has been included in this document for general information purposes only.
\end{abstract}

\subsection{SITE DESCRIPTION}

WAG 17, the ORNL Services Area (Fig. 22.1), is located about 1 mile (1.6 km) directly east of the ORNL main plant area. WAG 17 is the major craft and machine shop area for ORNL. It includes the receiving and shipping departments, machine shops, carpenter shops, paint shops, lead burning facilities, garage facilities, welding facilities, and material storage area required to support ORNL routine and experimental operations.

Eight SWMUs are included within the boundaries of WAG 17 (Fig. 22.2). Of these, one is a former septic tank now converted for use as a sewage pumping station clearwell for buildings in the area, five tanks are used for waste oil storage (one of which is mounted on a vehicle), and two tanks are used for storage of photographic wastes.

The septic tank-pumping station services rest rooms only and should not have had radioactive or hazardous chemical wastes added. In the case of the oil storage tanks (two are underground and three aboveground), one of the underground tanks (SWMU 17.2c) is known to contain radioactivity; the other tanks (above- and underground) collect waste oils from vehicle maintenance and cutting oils from machining operations. The two aboveground photographic waste tanks are used to store wastes prior to transport to the silver recovery unit (SWMU 8.10). No leaks or spills of oil or hazardous materials from any of the tanks have been reported. Most of the aboveground tanks are diked to contain leakage.

\subsection{KNOWN RELEASES}

Abandoned, underground waste oil storage tank 7002A was uncovered in October 1989 in an attempt to determine whether it had been permanently closed. It was then discovered that the tank contained on oily/sludge water mixture. However, visual observations of the tank suggested that the level of material fluctuated, which, in turn, suggested that the tank was not tight and that the contents could have been a source of continuing release to the environment. During an attempt to remove the tank, all material in it (estimated at $148 \mathrm{gal}$ ) was released through existing corrosion holes on the sides of the tank into the pit. Cleanup of the site has been completed. Notifications of a release of PCB-contaminated material were made to DOE-Oak Ridge Operations; DOE-Headquarters; the Environmental Protection Agency, Region IV; and the National Response Center. The tank was wrapped in plastic and moved to a secured, diked location (ORNL 1990). There are no other reports of releases of hazardous materials or radionuclides from WAG 17. However, because this area has been in use since ORNL operations began in 1943, some spills or leaks of waste oils and solvents have probably occurred but have not been documented (ORNL 1987). 



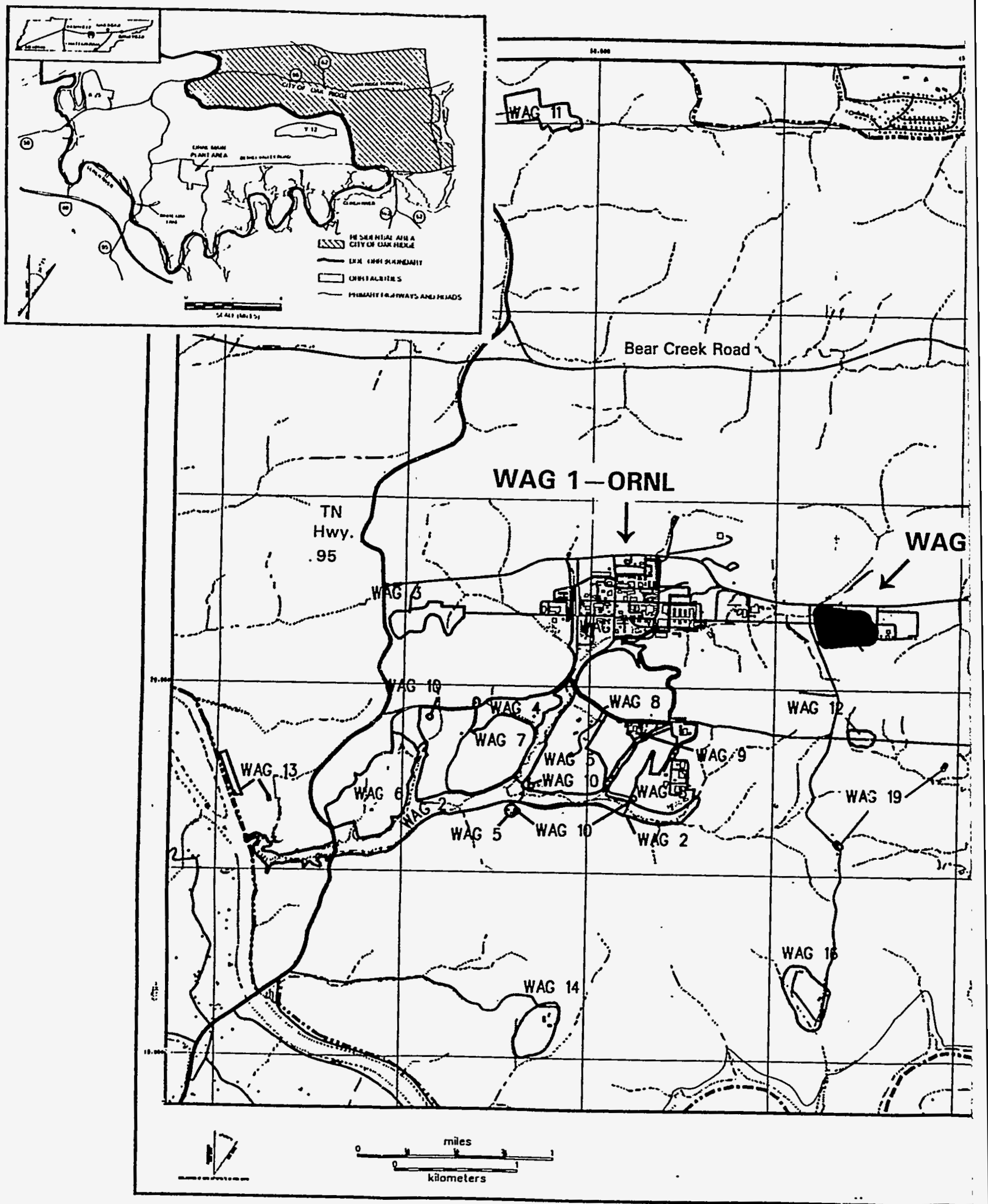

Fig. 22.1. Location of WAG 17, ORNL Services Area. 


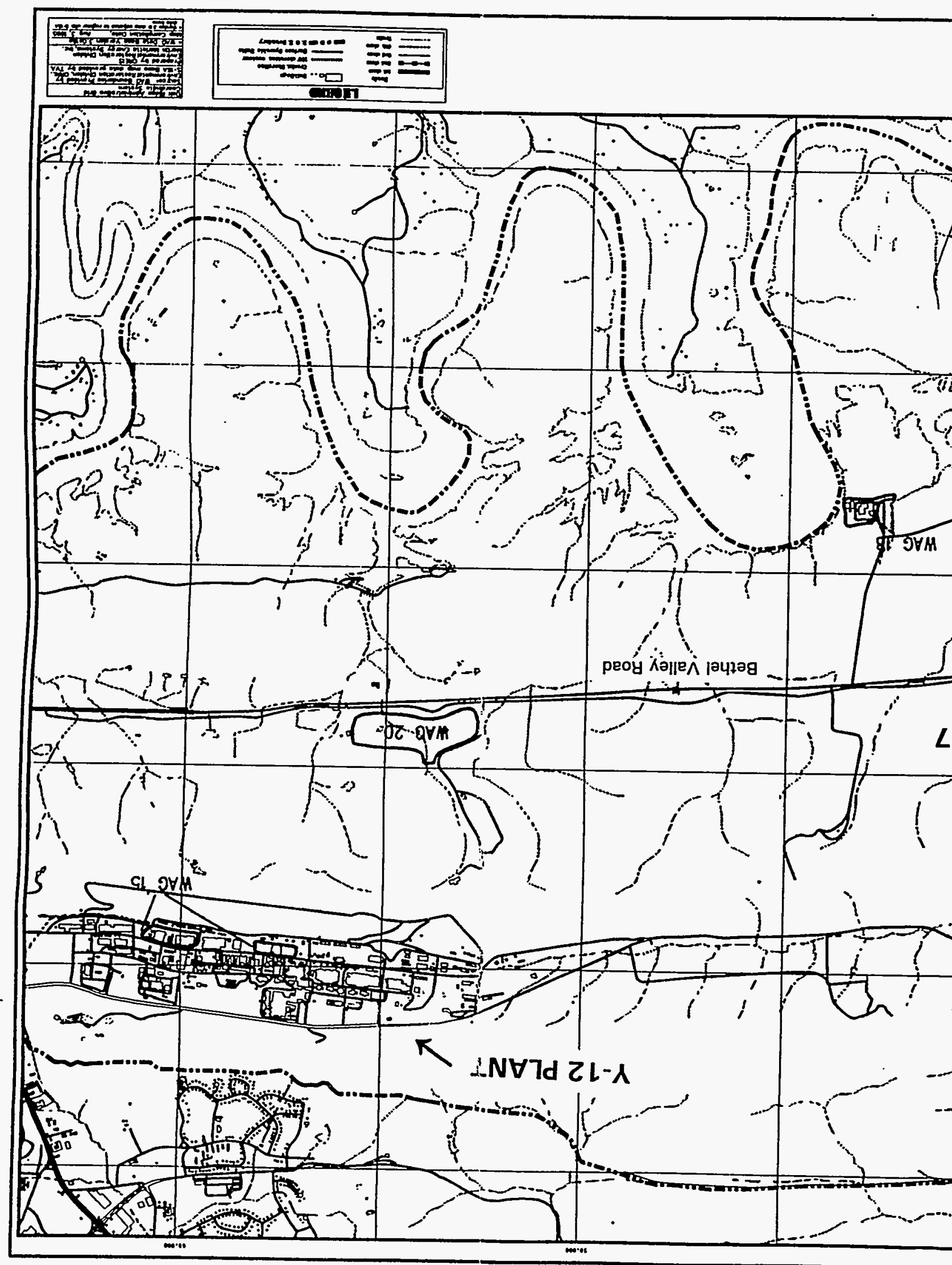




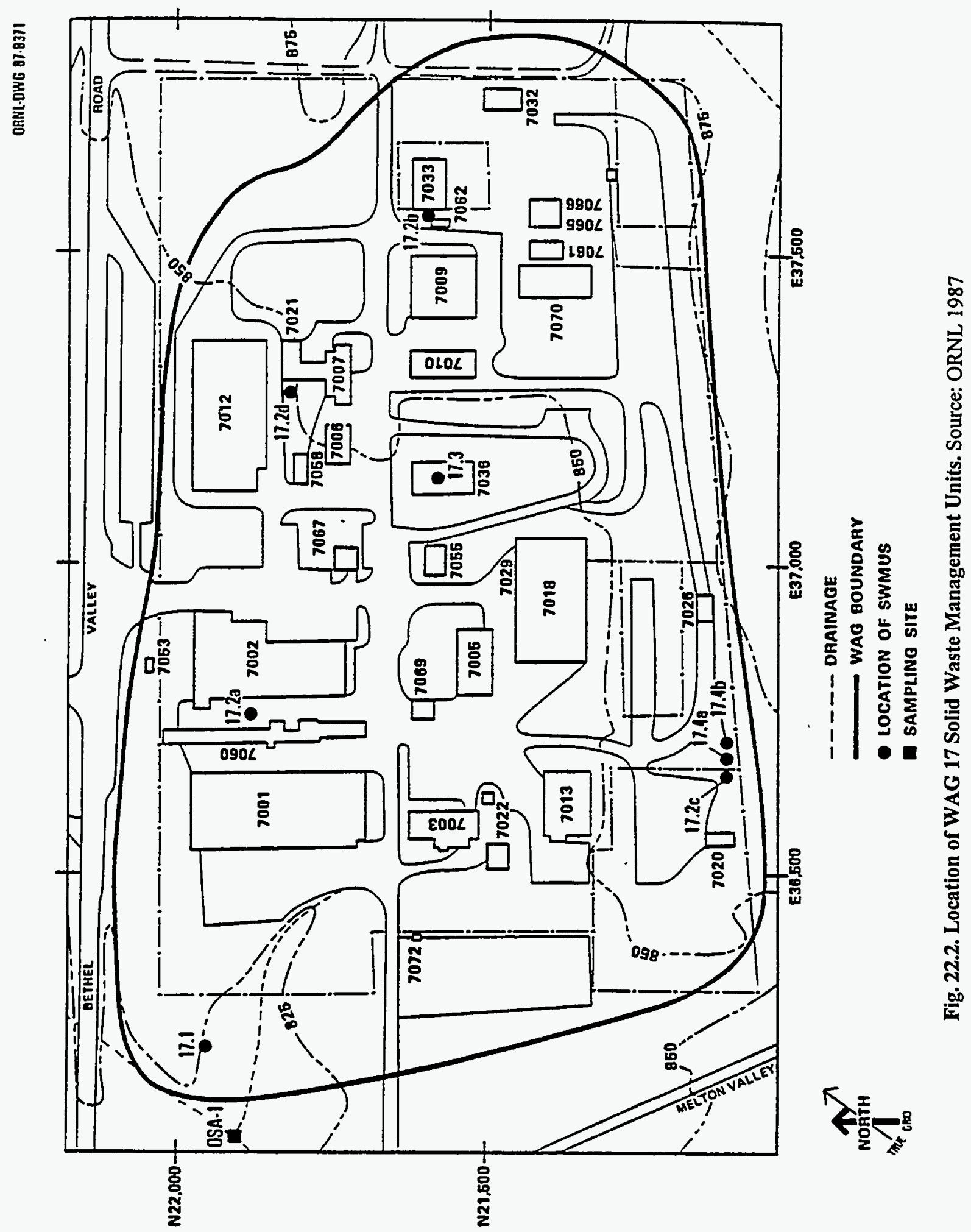




\subsection{REGULATORY STATUS}

The scoping survey indicates that $\mathrm{Cd}$ and organic contamination exists at WAG 17. Although there was some indication from the gravel sampling that there may have been contamination by ${ }^{137} \mathrm{Cs}$, the water sample taken indicates radionuclides are below detection levels at this time.

Evidence indicates that WAG 17 will require the preparation of a remedial investigation plan and some form of remedial action. However, it is suggested that further sampling (using the stream gravel and water sampling technique) be conducted to attempt to determine the source of the organic compounds and the Cd. At the present time, plans are being formulated to install hydrostatic head well clusters at the WAG boundary. Once these wells have been installed, it should be possible to locate monitoring wells and identify sources of contamination in WAG 17 . The need for remedial action can be determined once additional sampling and analysis is conducted.

\subsection{REFERENCES}

ORNL (Oak Ridge Natl. Lab.) 1987. RCRA Facilities Assessment (RFA)—Oak Ridge National Laboratory, ORNL/RAP-12/V1, Oak Ridge Natl. Lab.

ORNL 1990. ORNL Contaminated Site Summary Sheets, ORNL/M-2413, Oak Ridge Natl. Lab.

\subsection{BIBLIOGRAPHY}

Bechtel National Inc. 1988. Remedial Investigation Plan for Waste Area Grouping 17, ORNL/RAP/Sub-87/99053/20, Oak Ridge Natl. Lab.

Boegly, W. J., and G. K. Moore 1988. Environmental Sciences Division Environmental Data Package for the ORNL Services Area (WAG 17), ORNL/RAP-43, Oak Ridge Natl. Lab.

Coobs, J. H., and J. R. Gissel 1986. History of Disposal of Radioactive Wastes into the Ground at Oak Ridge National Laboratory, ORNL/TM-10269, Oak Ridge Natl. Lab.

EDGE 1988. Preliminary Geohydrologic Site Characterization and Proposed Water Quality Well Locations for WAG 17 and Lower WAG 2, ORNL/RAP/Sub-87/SB189/2, Oak Ridge Natl. Lab.

Mortimore, J. A., and M. L. Ebers 1994. Groundwater Quality Monitoring Well Installation for Waste Area Grouping 17 at Oak Ridge National Laboratory, Oak Ridge, Tennessee, ORNL/ER-74, Oak Ridge Natl. Lab.

Morrison, S. J. and T. E. Cerling 1987. Survey of Metal, Radionuclide and Organic Contamination at 20 Waste Area Groups (WAGs), ORNL Facilities, Oak Ridge, Tennessee, ORNL/RAP/Sub-87/27463/1, Oak Ridge Natl. Lab.

SAIC (Science Applications International Corp.) 1994. Remedial Investigation Work Plan for the Groundwater Operable Unit at Oak Ridge National Laboratory, Oak Ridge, Tennessee, DOE/OR/01-1252\&D1 (ORNL/ER-221\&D1), Martin Marietta Energy Systems, Inc., Oak Ridge, Tenn 


\section{DESCRIPTION OF WAG 18}

\section{Instructions to user}

At this time there are no active projects at WAG 18. Full characterization of this WAG is therefore unwarranted, and a description of it [derived from the Resource Conservation and Recovery Act facilities assessment (ORNL 1987)] has been included in this document for general information purposes only.

\subsection{SITE DESCRIPTION}

WAG 18, the Consolidated Fuel Reprocessing (CFR) Area, is located south of Bethel Valley Road, about 2.3 miles east of the ORNL main plant area (Fig. 23.1). Originally, this area was designated as the site of the Experimental Gas Cooled Reactor Project. This reactor was canceled before operation but after most of the facilities were constructed. The existing facilities were later converted for use by ORNL's CFR Division.

A total of nine Solid Waste Management Units (SWMUs) have been identified in WAG 18 (Fig. 23.2). SWMUs 18.la and b are retention basins used to collect storm water runoff; SWMU 18.2 is a tank used to store paint solvents; SWMU 18.3 is the septic tank system used to handle domestic sewage produced at the CFR; SWMUs $18.4 \mathrm{a}-\mathrm{d}$ are acidic process waste storage tanks; and SWMU 18.5 is an unused retention basin.

\subsection{KNOWN RELEASES}

There have been no reported releases of hazardous materials from any of the SWMUs located in WAG 18.

\subsection{REGULATORY STATUS}

Based on available information and the results obtained in the scoping studies, there does not appear to be evidence of past releases of hazardous materials from WAG 18. Because current operations do not involve greater than trace amounts of radionuclides, it appears that WAG 18 will not require the preparation of a remedial investigation plan for remedial action under Section 3004(u).

The only SWMUs in WAG 18 that involve hazardous wastes are the waste acid storage tanks (both stationary and mobile) and the paint solvent storage tank. These tanks are included in ORNL's tank inventory program and are inspected on a regular basis.

\subsection{REFERENCES}

ORNL (Oak Ridge Natl. Lab.) 1987. RCRA Facilities Assessment (RFA)—Oak Ridge National Laboratory, ORNL/RAP-12/V1, Oak Ridge Natl. Lab. 


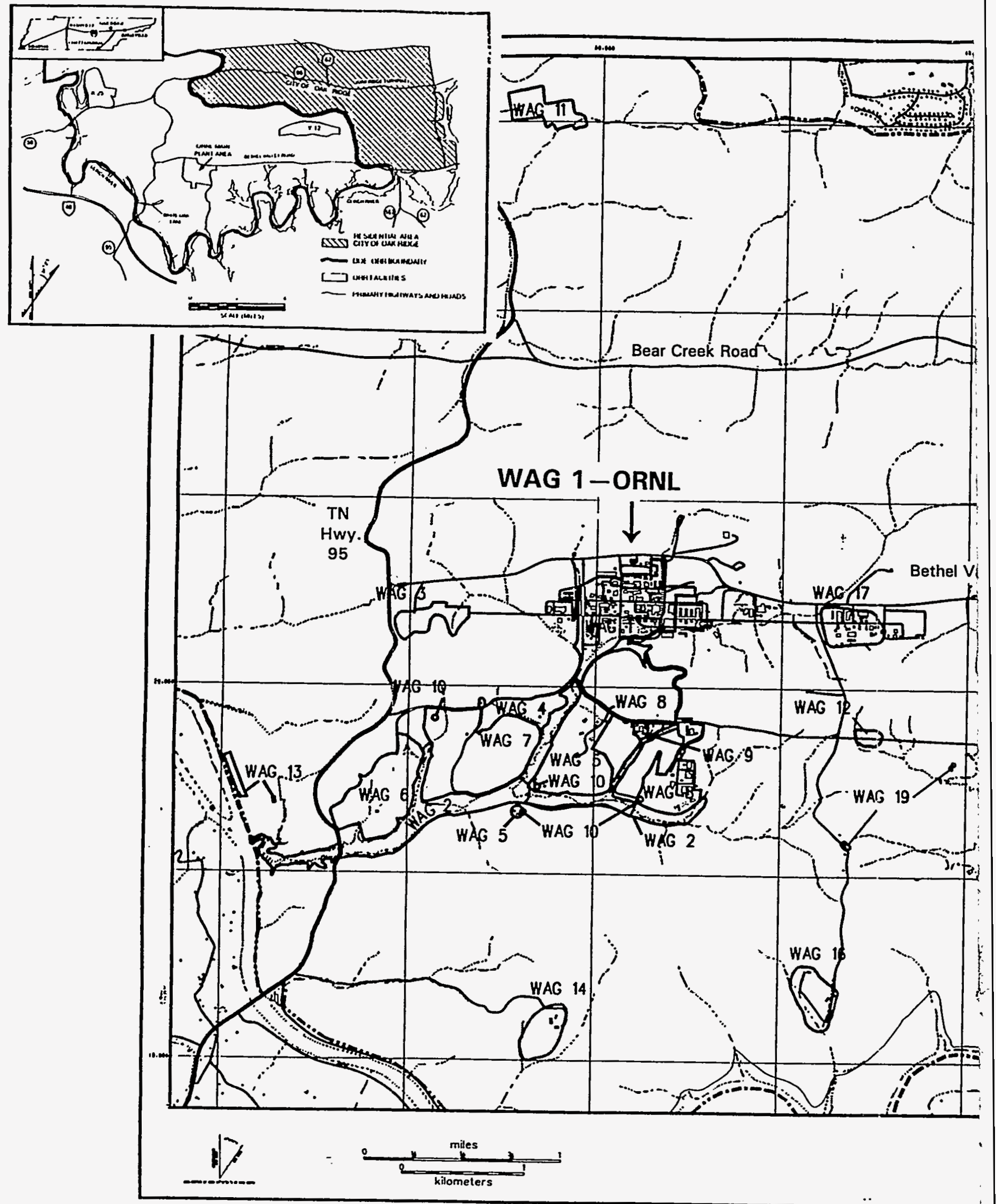

Fig. 23.1. Location of WAG 18,

Consolidated Fuel Reprocessing Area. 


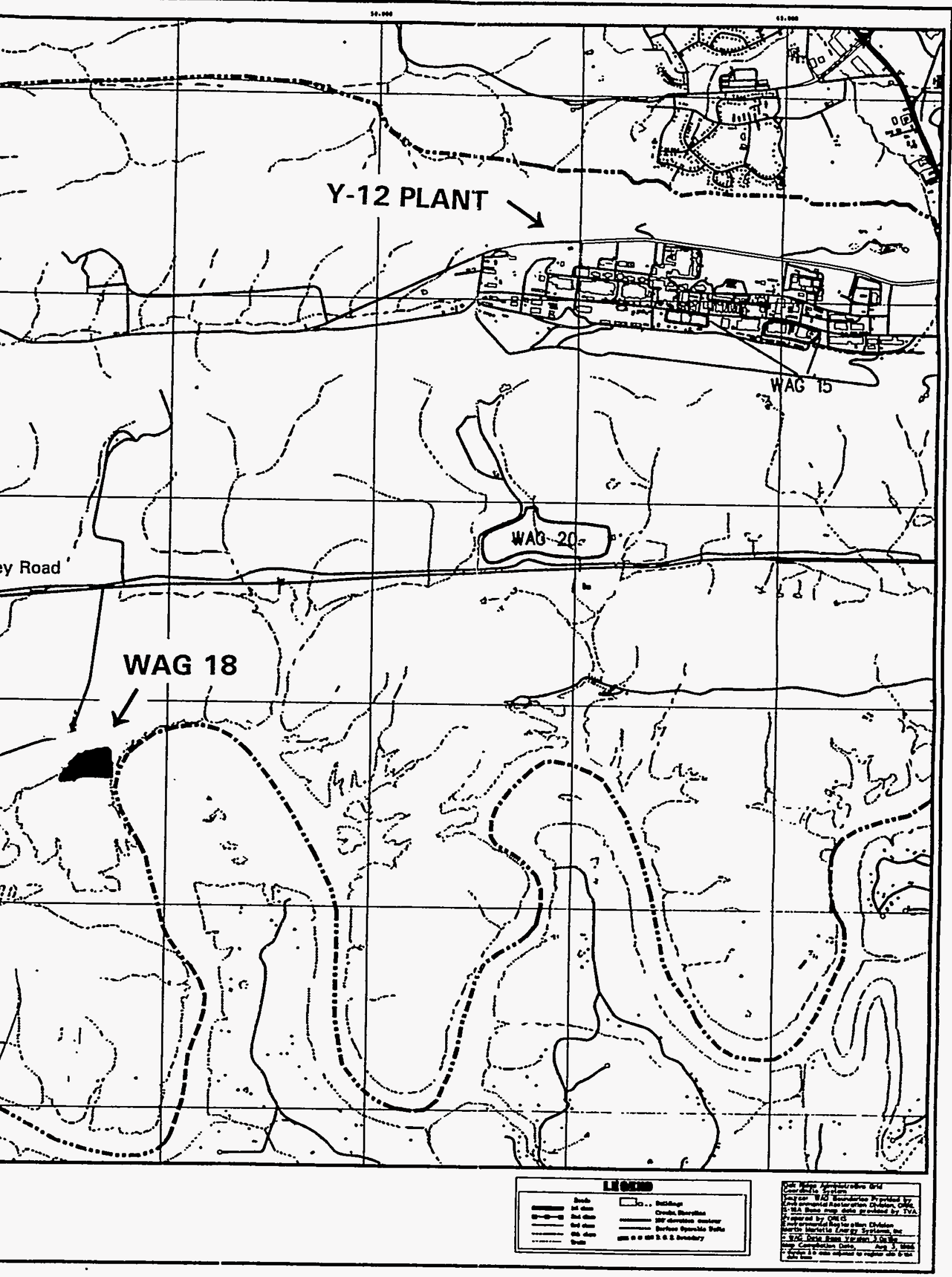




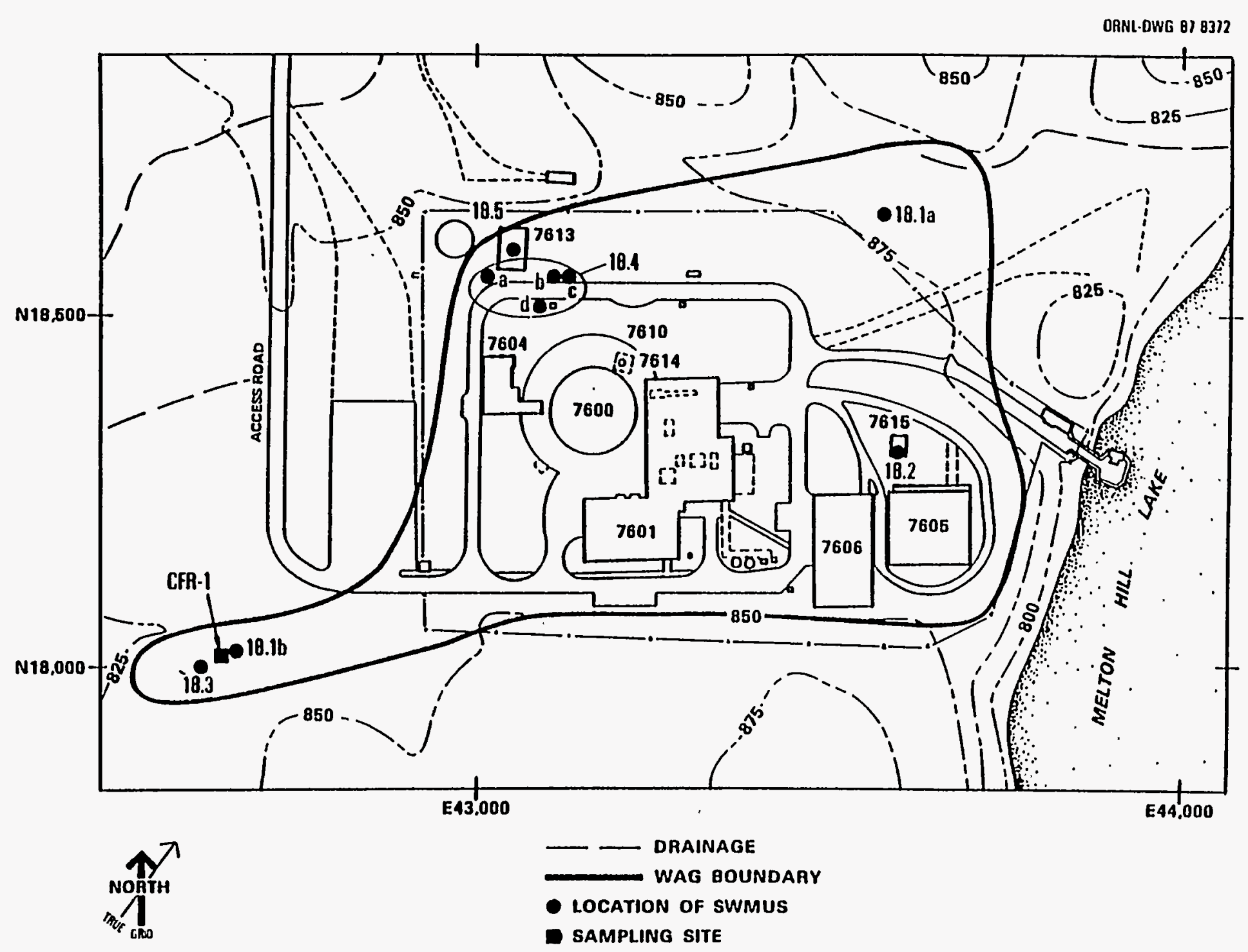

Fig. 23.2. Location of WAG 18 Solid Waste Management Units. Source: ORNL 1987 


\subsection{BIBLIOGRAPHY}

Boegly, W. J. 1988. "WAG 18 Data Package," Environmental Restoration Document Management Center Bar Code ER011359, Martin Marietta Energy Systems, Inc., Oak Ridge, Tenn.

Coobs, J. H., and J. R. Gissel 1986. History of Disposal of Radioactive Wastes into the Ground at Oak Ridge National Laboratory, ORNL/TM-10269, Oak Ridge Natl. Lab.

Morrison, S. J. and T. E. Cerling 1987. Survey of Metal, Radionuclide and Organic Contamination at 20 Waste Area Groups (WAGs), ORNL Facilities, Oak Ridge, Tennessee, ORNL/RAP/Sub-87/27463/1, Oak Ridge Natl. Lab.

ORNL 1990. ORNL Contaminated Site Summary Sheets, ORNL/M-2413, Oak Ridge Natl. Lab. 


\section{DESCRIPTION OF WAG 19}

\section{Instructions to user}

At this time there are no active projects at WAG 19. Full characterization of this WAG is therefore unwarranted, and a description of it [derived from the Resource Conservation and Recovery Act facilities assessment (ORNL 1987)] has been included in this document for general information purposes only.

\subsection{SITE DESCRIPTION}

WAG 19 is located southeast of the ORNL main plant area (Fig. 24.1). Contained in WAG 19 are the six Solid Waste Management Units (SWMUs) that represent ORNL's hazardous waste treatment and storage facilities (Fig. 24.2). Also included in this WAG is the new facility that has been permitted for the storage of hazardous wastes (SWMU 19.1).

This WAG contains two separate clusters of SWMUs: the first cluster includes the permitted hazardous and mixed waste storage units (SWMUs 19.1, 19.2, 19.3, and 19.4), and the second cluster includes two interim status SWMUs that treat and/or dispose of reactive or gaseous hazardous wastes (i.e., SWMUs 19.5 and 19.6). For purposes of defining the WAG boundaries, it did not appear necessary to connect the two clusters because the geohydrologic setting was not exactly the same, and the functions performed within the clusters were different. Also, because no other SWMUs exist in the immediate area, the two separate clusters are handled as one WAG rather than two WAGs. All of the SWMUs in WAG 19 have been permitted by the Tennessee Department of Environment and Conservation or are operated under interim status.

\subsection{KNOWN RELEASES}

There are no recorded spills or leaks at any of the sites in WAG 19. All of the facilities have been designed to contain any spills or leaks that occur in the waste containers handled or stored.

\subsection{REGULATORY STATUS}

No release of hazardous materials (chemical or radionuclide) has been reported for any of the SWMUs in WAG 19. Preliminary surveys appear to suggest that no releases of hazardous metals have occurred. It appears that this WAG (and its associated SWMUs) could be removed from the list of sites to be covered in future remedial investigations; however, it is suggested that additional sampling for organic contaminants be conducted before making a final determination of status.

\subsection{REFERENCES}

ORNL (Oak Ridge Natl. Lab.) 1987. RCRA Facilities Assessment (RFA)—Oak Ridge National Laboratory, ORNL/RAP-12/V1, Oak Ridge Natl. Lab. 

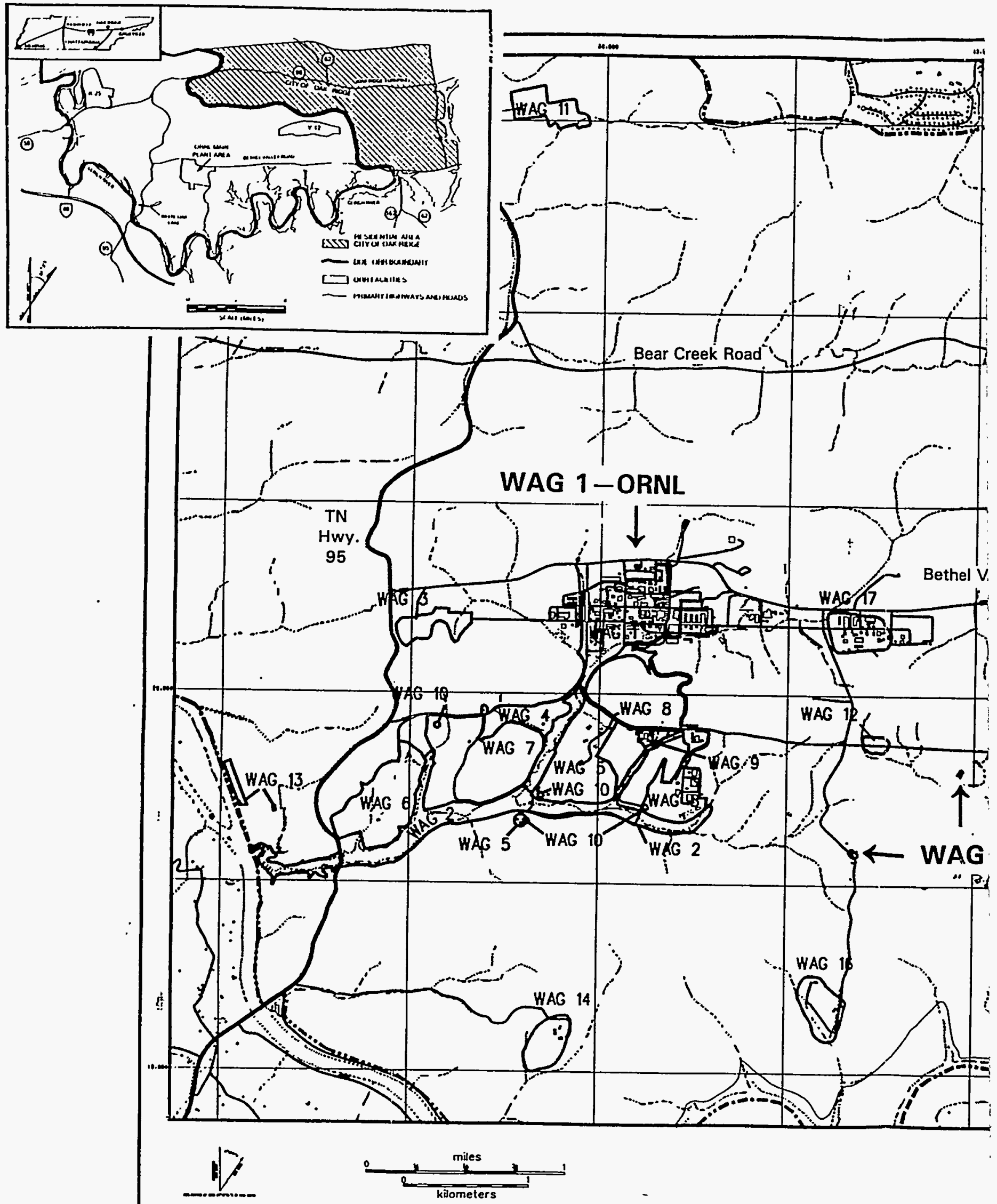

Fig. 24.1. Location of WAG 19, Hazardous

Waste Treatment and Storage Facilities. 


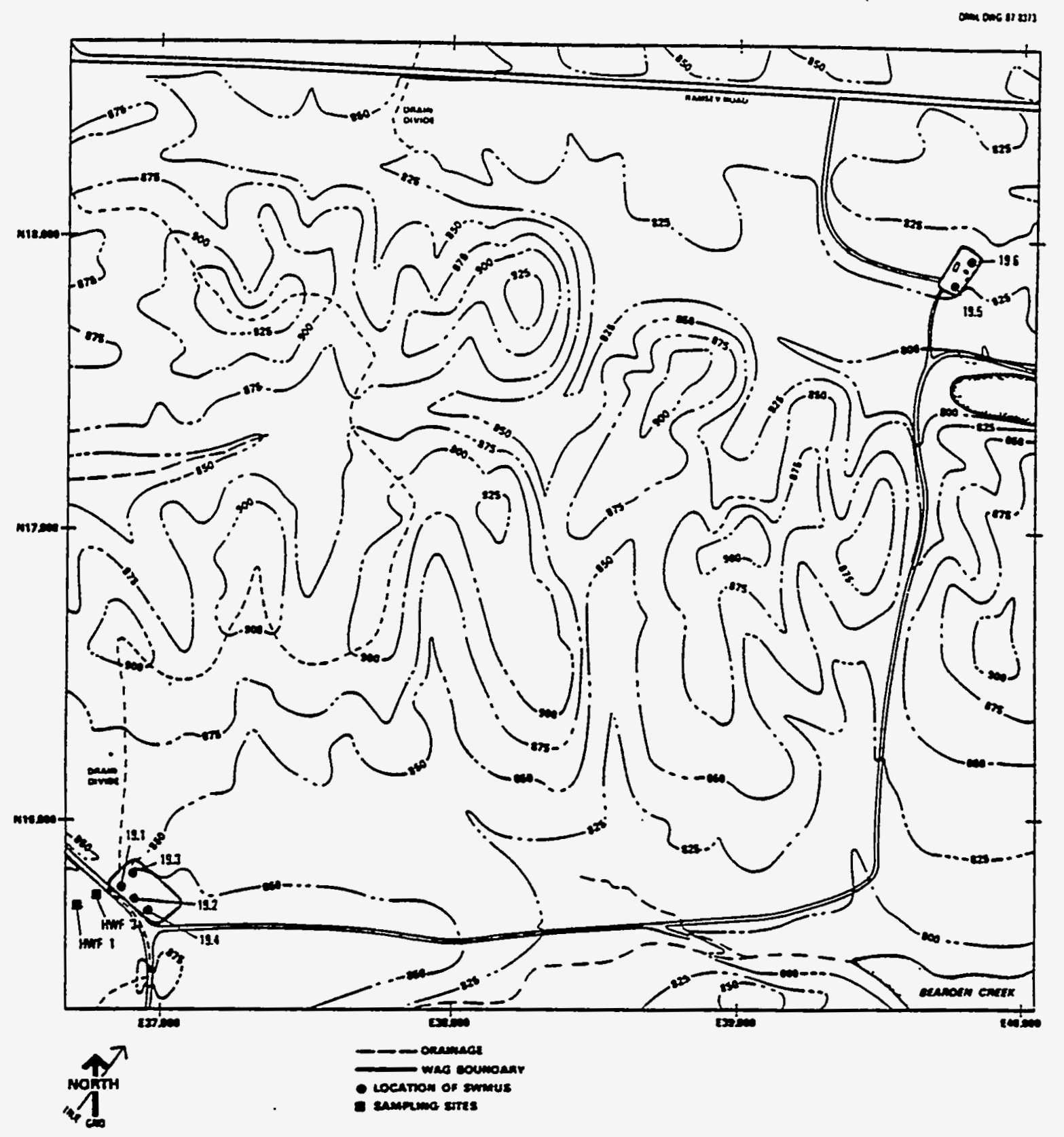

Fig. 24.2. Location of WAG 19 Solid Waste Management Units. Source: ORNL 1987

\subsection{BIBLIOGRAPHY}

Boegly, W. J. 1988. "WAG 19 Data Package," Environmental Restoration Document Management Center Bar Code ER011360, Martin Marietta Energy Systems, Inc., Oak Ridge, Tenn.

Coobs, J. H., and J. R. Gissel 1986. History of Disposal of Radioactive Wastes into the Ground at Oak Ridge National Laboratory, ORNL/TM-10269, Oak Ridge Natl. Lab. 
Morrison, S. J. and T. E. Cerling 1987. Survey of Metal, Radionuclide and Organic Contamination at 20 Waste Area Groups (WAGs), ORNL Facilities, Oak Ridge, Tennessee, ORNL/RAP/Sub-87/27463/1, Oak Ridge Natl. Lab.

ORNL 1990. ORNL Contaminated Site Summary Sheets, ORNL/M-2413, Oak Ridge Natl. Lab.

SAIC (Science Applications International Corp.) 1994. Remedial Investigation Work Plan for the Groundwater Operable Unit at Oak Ridge National Laboratory, Oak Ridge, Tennessee, DOE/OR/01-1252\&D1 (ORNL/ER-221\&D1), Martin Marietta Energy Systems, Inc., Oak Ridge Natl. Lab. 


\section{DESCRIPTION OF WAG 20}

Instructions to user
At this time there are no active projects at WAG 20. Full characterization of this WAG
is therefore unwarranted, and a description of it [derived from the Resource
Conservation and Recovery Act facilities assessment (ORNL 1987)] has been included
in this document for general information purposes only.

\subsection{SITE DESCRIPTION}

WAG 20 (Fig. 25.1) includes the Sewage Sludge Land Farm for the city of Oak Ridge. There is only one Solid Waste Management Unit in WAG 20. The site is located on the southeast side of Chestnut Ridge and north of Bethel Valley Road, about 5 miles $(8 \mathrm{~km})$ east of the ORNL main plant area (Fig. 25.2). The site is bounded on the west by Mount Vernon Road.

Sludge spreading at the site was initiated in November 1983; however, in March 1984 it was learned that some of the deposited sludge had been contaminated with various radionuclides, primarily ${ }^{137} \mathrm{Cs}$ and ${ }^{60} \mathrm{Co}$. As a result, for a short period of time the disposal operation was halted until the source of the contamination could be eliminated. Disposal of sludge at the site is currently in progress, and it is estimated that over $6 \mathrm{M}$ gal $\left(2.27 \times 10^{7} \mathrm{~L}\right)$ has been applied. The site contains 65 acres (26 ha).

\subsection{KNOWN RELEASES}

In granting approval for operation of the Land Farm, the Tennessee Department of Environment and Conservation restricted application rates to control nitrogen application rates. It specified application of sludge at a rate of no more than 6.24 tons/acre. In 1984 it was learned that some of the deposited sludge had been contaminated with various radionuclides, primarily ${ }^{60} \mathrm{Co}$ and ${ }^{137} \mathrm{Cs}$. A comprehensive program followed by a pathways analysis was conducted. The results of the analysis indicate that the yearly dose commitment to the total body would be $1.1 \mathrm{mrem} / \mathrm{yr}$ from the landfill.

\subsection{REGULATORY STATUS}

Based on the results of the earlier data collected as a part of the 1984 pathways analysis and the preliminary survey, WAG 20 does not appear to represent a source of release of hazardous constituents. Although the sewage sludge applied in past operations contained trace amounts of radioactivity and heavy metals, sampling does not indicate that these materials are being released in significant quantities. This facility is operated as a land disposal site by the city of Oak Ridge with the approval of the Tennessee Department of Environment and Conservation and is subject to regulation under the Clean Water Act. ORNL does not feel that additional remedial action studies are justified for this WAG and recommends that it be removed from further Section 3004(u) remedial action consideration. 


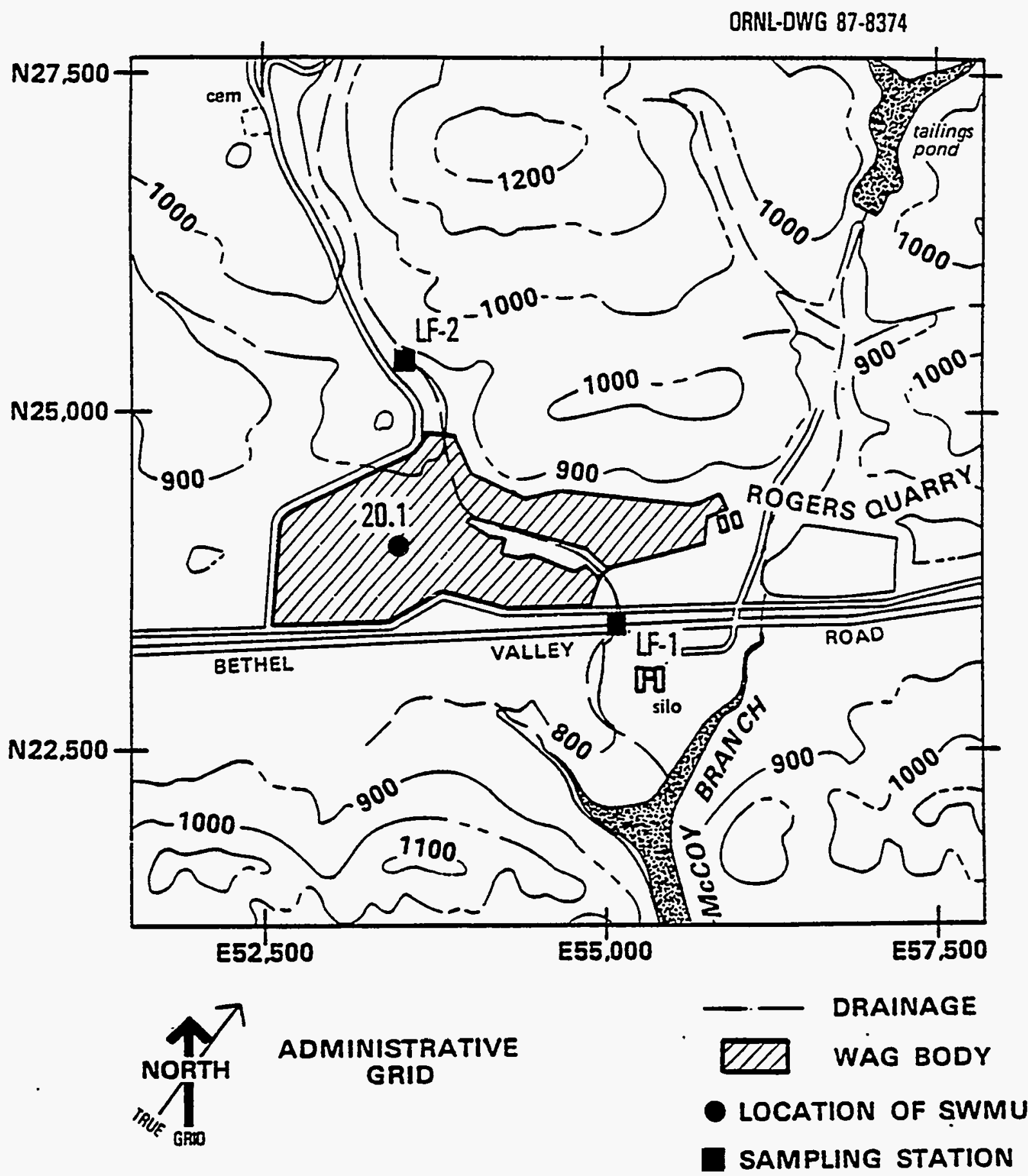

Fig. 25.2. Location of WAG 20 Solid Waste Management Unit. Source: ORNL 1987

\subsection{REFERENCES}

ORNL (Oak Ridge Natl. Lab.) 1987. RCRA Facilities Assessment (RFA)—Oak Ridge National Laboratory, ORNL/RAP-12/V1, Oak Ridge Natl. Lab. 


\subsection{BIBLIOGRAPHY}

Coobs, J. H., and J. R. Gissel 1986. History of Disposal of Radioactive Wastes into the Ground at Oak Ridge National Laboratory, ORNL/TM-10269, Oak Ridge Natl. Lab.

Iglar, A. F., and Boegly, W. J. 1987. Environmental Data for the Oak Ridge Sewage Sludge Land Treatment Facility (WAG 20), ORNL/RAP/LTR-87, Oak Ridge Natl. Lab.

Morrison, S. J. and T. E. Cerling 1987. Survey of Metal, Radionuclide and Organic Contamination at 20 Waste Area Groups (WAGs), ORNL Facilities, Oak Ridge, Tennessee, ORNL/RAP/Sub-87/27463/1, Oak Ridge Natl. Lab.

ORNL 1990. ORNL Contaminated Site Summary Sheets, ORNL/M-2413, Oak Ridge Natl. Lab. 


\section{DISTRIBUTION}

1. L. V. Asplund

2. K. W. Cook

3. L. L. Kaiser

4-5. A. J. Kuhaida, Jr. (2)

6. D. M. Matteo

7-9. P. L. Osborne (3)

10. P. T. Owen

11. P. A. Schrandt

12. A. S. Will III

13. Central Research Library

14. ER Doc. Mgmt. Center-RC

15-16. Office of Scientific and Technical Information, P.O. Box 62, Oak Ridge, TN 37831 (2)

17. Advances Sciences, Inc., 800 Oak Ridge Tumpike, Oak Ridge, TN 37830

18. Bechtel National, Inc., 151 Lafayette Drive, Oak Ridge, TN 37830

19. CDM Federal Programs Corp., 800 Oak Ridge Turnpike, Oak Ridge, TN 37830

20. MACTEC, 189 Layafette Drive, Oak Ridge, TN 37830 